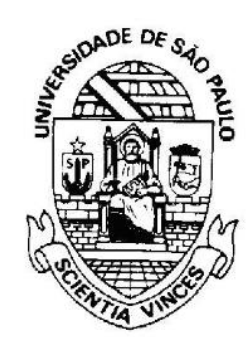

\author{
UNIVERSIDADE DE SÃo PAULO \\ FACULDADE DE EDUCAÇÃO DA USP - FEUSP \\ Programa de Pós-Graduação em Educação \\ CURSO DE DOUTORADO
}

\begin{abstract}
A EDUCAÇÃO DE CRIANÇAS EM HOSPITAIS: A experiência da cidade de Curitiba na Associação de Proteção à Infância Dr. Raul Carneiro, PR, 1988 - 2002
\end{abstract}

Doutoranda: Claudinéia Maria Vischi Avanzini Orientadora: Maurilane de Souza Biccas

SÃO PAULO - SP

2019 
Claudinéia Maria Vischi Avanzini

\section{A EDUCAÇÃO DE CRIANÇAS EM HOSPITAIS: A experiência da cidade de Curitiba na Associação de Proteção à Infância Dr. Raul Carneiro, PR, 1988 - 2002}

Tese apresentada à Faculdade de Educação da Universidade de São Paulo para a obtenção do título de Doutora em Educação.

Área de Concentração: História da Educação e Historiografia

Orientadora: Prof. ${ }^{a}$ Dr..$^{\underline{a}}$ Maurilane de Souza Biccas

SÃO PAULO - SP

2019 
Autorizo a reproduçäo e divulgaçäo total ou parcial deste trabalho, por qualquer meio convencional ou eletrônico, para fins de estudo e pesquisa, desde que citada a fonte.

Catalogação da Publicação

Ficha elaborada pelo Sistema de Geracão Automática a partir de dados fornecidos pelo(a) autor(a) Bibliotecária da FE/USP: Nicolly Soares Leite - CRB-8/B204

A946e

Avanzini, Claudineia Maria Viach

A Educaçĩo de criançaa em houpitaia: a experiencia da cidade de Curitiba na Amaociação de Proteção a

Infincia Dr. Raul Carneiro, PR, 198g - 2002 /

Claudineia Maria Viachi Avanzini; orientador

Maurilane de Souza Biccas. - - Sä Paulo, 2019. 293 P.

Tease (Doutorado - Programa de P6a-Graduaçio Cultura, Pilonofia e Hint6ria da Bducaç⿰氵㔾) -. Faculdade de Bducação, Univeraidade de São Paulo, 2019.

1. Historia Bducação. 2. Educaç̃̃o Hoapitalar. 3 Saude, 4. Becolarizaço, 5. InfAncia. I. Biccas, Maurilane de Souza, orient. II. Titulo. 
Nome: Claudinéia Maria Vischi Avanzini

Título: A Educação de crianças em hospitais: a experiência da cidade de Curitiba na Associação de Proteção à Infância Dr. Raul Carneiro, PR, 1988 - 2002

Orientadora: Prof. ${ }^{a}$ Dr. ${ }^{\underline{a}}$ Maurilane de Souza Biccas

Tese apresentada à Faculdade de Educação da Universidade de São Paulo para a obtenção do título de Doutora em Educação.

Aprovada em:

\section{Banca Examinadora}

Prof. ${ }^{\text {a }}$ Dr. ${ }^{\text {a }}$ Maurilane de Souza Biccas. Universidade de São Paulo Julgamento: Assinatura:

Prof. ${ }^{\text {a }}$ Dr. ${ }^{\text {a }}$ Amália Neide Covic. Universidade Federal de São Paulo Julgamento: Assinatura:

Prof. ${ }^{a}$ Dr. ${ }^{a}$ Armando de Castro Cerqueira Arosa. Universidade Federal do Rio de Janeiro Julgamento: Assinatura:

Prof. ${ }^{a}$ Dr. ${ }^{a}$ Eneida Simões da Fonseca. Universidade do Estado do Rio de Janeiro Julgamento: Assinatura:

Prof. ${ }^{\text {a }}$ Dr. ${ }^{\text {a }}$ Ana Luíza Jesus da Costa. Universidade de São Paulo Julgamento: Assinatura: 
Dedico esse trabalho às minhas "flores do dia" Sophia e Clara que como eu sofreram as ausências de tantos momentos por conta da dedicação árdua a esse outro objeto de amor que não eram elas...

Da mesma forma, dedico ao Rubens que diuturnamente me incentivou, acolheu e apoiou para a concretização desse meu sonho a tanto tempo desejado.

Dedico, finalmente à minha grande amiga e orientadora que além de continuar me direcionando no universo da História da Educação me acolheu, ajudou, acompanhou, nunca me abandonou e me deixou abandonar as verdadeiras razões para viver. 


\section{Agradecimentos}

Ao finalizar a escrita da tese há tantas pessoas especiais a agradecer, principalmente porque tenho plena noção de que a escrita pode até parecer solitária, mas nela esta imbricada uma infinidade de pessoas, intenções e compartilhamentos que, com certeza, não só favoreceram, mas foram essenciais para que eu conseguisse chegar ao que nomeio de fim da escrita.

Em primeiro lugar, quero agradecer imensamente minha amiga e orientadora Maurilane de Souza Biccas por confiar em mim e me acolher entre seus orientados, em sua casa, em sua vida, em sua história e me ajudar a continuar caminhando, crescendo e evoluindo nos caminhos historiográficos da História da Educação. Não tenho palavras para agradecer seu companheirismo e partilha até me acompanhando nas muitas idas e vindas nos hospitais paulistanos. Serei imensamente e eternamente grata aos seus ensinamentos. Poder conviver com você me proporcionou um crescimento intelectual, pessoal e emocional que eu não sabia poder alcançar! Muitíssimo obrigada por ser esta professora dedicada, generosa e companheira que você foi por todo o meu doutorado.

Agradeço imensamente aos professores da banca de qualificação e defesa Liane Maria Bertucci, Amália Neide Covic, Armando de Castro Cerqueira Arosa, Eneida Simões da Fonseca e Ana Luiza Jesus da Costa que me deram orientações tão valiosas. Obrigada pela contribuição acadêmica e pessoal.

Aos professores da Linha de História da Educação e Historiografia da USP, Diana Gonçalves Vidal, Maria Ângela Borges Salvadori e Ana Luiza Jesus da Costa pelas aulas, contribuições e convívio que aprofundaram minha formação.

Agradeço aos funcionários da Biblioteca Pública do Paraná, do Arquivo Público do Paraná, da Biblioteca do Hospital Pequeno Príncipe, da Casa de Memória de Curitiba e do Museu Paranaense por me auxiliarem e permitirem acesso as fontes pesquisadas e me dedicarem tempos tão preciosos de convívio.

Agradeço aos funcionários do Programa de Pós-graduação em Educação, por me ajudarem de forma muito profissional e respeitosa nos momentos que precisei.

Aos meus queridos amigos Cristina Megumi Hada, Hiroshi Hada, Sérgio Fonseca e Adalberto Ferreira por me acolherem em suas casas, me oferecerem um espaço e muito carinho e amor em muitos momentos de aulas e necessidades. 
Pelo apoio, pelas sugestões e pelo carinho, agradeço aos meus colegas do Núcleo Interdisciplinar de Estudos e Pesquisas em História da Educação - NIEPHE Alexandre Ribeiro e Silva, Angélica Borges, Angélica Pall Oriane, Denise Peixoto, Daniela Cristina Lopes de Abreu, Fabiana Garcia Munhoz, Fernanda Franchini, Fernanda Mendes Resende, Fernanda Moraes dos Santos, Milen Schramm, Miriam Fernandes, Rachel Duarte Abdala, Rafaela França, Rafaela Silva Rabelo, Sandra Maria Caldeira Machado, Surya Aaronovich Pombo de Barros e à Wiara Rosa Rios Alcântara e, em especial à Nadjalena de Araújo Souza, Bruno Geraldo Alves, Felipe Tavares de Moraes, Ariadne Lopes Ecar, Alexandra Naima Machado Rudakoff e Pedro de Souza Santos que tornaram a convivência acadêmica muito mais alegre e animada na USP e em São Paulo, além de alguns congressos e eventos.

Às colegas do grupo de pesquisa Mulheres e inovação docente (São Paulo e França, nas décadas de 1860 a 1960) Diana Gonçalves Vidal, Rebecca Rogers, Angélica Pall Oriani, Ariadne Lopes Ecar, Beatriz von Lasperg Careli, Dislane Zerbinatti Moraes, Fabiana Garcia Munhoz, Fernanda Franchini, Josiane Marques, Katiene Nogueira da Silva, Marcela Barbosa Calvo Vega, Paula Vicentini, Rachel Duarte Abdala, Rafaela Silva Rabelo, Rita de Cassia Gallego, Vivian Batista da Silva, Wiara Rosa Rios Alcântara, Emanuelle Picard, Gabrielle Houbre, Geneviève Hunyadi, Geneviève Pezeu, Laurent Gutierrez, Marianne Thivend, Sébastien-Akira Alix, Sévrerine Depoilly e Vera Léon agradeço pela possibilidade de enriquecimento intelectual, pela acolhida e principalmente pelo convívio alegre e incentivador também nas conferências internacionais e encontro que participamos.

Aos meus colegas de mestrado da Universidade Federal do Paraná Juarez José Tuchinski dos Anjos, Ernando Brito Gonçalves Junior, Wanessa Margotti Ramos Storti, Danielle Gross de Freitas, Jordana Stela Botelho Della Vechia e Gisele Gutstein Guttschow que me introduziram nas discussões de História e Historiografia da Educação e me despertaram essa paixão que nunca mais me abandonou!

À Dorotéa Pascnuki Szenczuk pela revisão do meu texto sugerindo importantíssimas contribuições que somente seu olhar apurado detectaria.

Ao Mario Marcari Filho pela revisão do texto e do abstract. Sem a sua ajuda seria impossível a legibilidade de meu trabalho. Muito obrigada meu amigo!

Agradeço especialmente minhas amigas e amigos mais distantes e mais de perto, que fizeram parte de minha história e acabaram influenciando minhas escolhas, Cleide Gomes Ferreira, Thais Gama da Silva, Márcia Cristiano Marciano, Sirlei Maria 
Ferreira, Dorotéa Pascnuki Szenczuk, Luciane do Rocio Souza, meus sinceros agradecimentos.

A toda a minha família, mãe, pai, Serginho, Paulinho, vó, cunhados, sobrinhos e primos, que mesmo de longe sofreram a tensão do trabalho e suportaram períodos tão distantes e escassos de convivência.

Aos meus colegas de trabalho queridos que me apoiaram sempre que eu precisava Márcia Patrícia Kuligovski, Mario Marcari Filho, Roberto Hideo Seima, Sheila Caroline Demochoski Persegona, Kelly Marise Chaves, Dorotéa Pascnuki Szenczuk, Elenilton Vieira Godoy, Emerson Rolkouski, Alessandra Hendi dos Santos, Elisandra Cecília Schwanka de Oliveira, Cristiane Lopuch Nogueira, Ana Lucia Maichak de Gois Santos, Rozane Marcelino de Barros, Marcia Regina Rezende Zanocini, Lilian de Medeiros, Luciane do Rocio dos Santos Souza, Claudinéia Santos, Rosana Faglioni Carrasco de Almeida, Cristiane Cardoso dos Santos obrigada pela compreensão e compartilhamentos!

Aos meus colegas conselheiros do Conselho Municipal de Educação de Araucária que dividiram comigo, neste percurso do doutorado, inúmeras reuniões e produções coletivas de normas e regras direcionadas ao Sistema Municipal de Ensino.

Aos Secretários de Educação do Estado do Paraná e do Município de Araucária que me possibilitaram a oportunidade de realizar os trabalhos necessários para a conclusão da pesquisa e me apoiaram sempre que eu precisava inclusive com liberação laboral concedida pelo Governo do Estado para efetivar os créditos e pesquisas necessários.

Ao Rubens que me apoiou, incentivou e esteve sempre do meu lado, mesmo que às vezes distante, favorecendo a efetividade deste trabalho, assim como minhas filhas Sophia e Clara que tiveram paciência comigo nos momentos em que fiquei ausente, impaciente e distante. Saibam que vocês são o grande motivo de minha existência. Obrigada por me ajudarem, compreenderem e dividirem comigo tanto amor! 
ataque a biblioteca

leia tudo

em que colocar

suas mãos

\& mais

alguma coisa

vá em frente,

colecione palavras

\& comece a poli-las

até que brilhem

como a luz das estrelas

na palma da

sua mão.

faça das palavras

a sua arma...

uma espada dourada

para lançar

seus inimigos

$\mathrm{p}$

0

$\mathrm{t}$

e

a.

- um tipo de plano de sobrevivência.

(LOVELACE, Amanda, 2017, p. 167). 


\section{RESUMO}

\section{A EDUCAÇÃO DE CRIANÇAS EM HOSPITAIS: A experiência da cidade de Curitiba na Associação de Proteção à Infância Dr. Raul Carneiro, PR, 1988 - 2002}

Neste trabalho são analisadas as motivações que auxiliaram a efetivação do convenio que cedeu professores a lecionar para crianças num hospital infantil em Curitiba - PR entre os anos de 1988 a 2002, e assim identificar o papel da educação para as crianças curitibanas num espaço totalmente diferenciado e paradoxal ao escolar, mas com objetivo educacional, o universo hospitalar. Além disto, a tese busca descrever o processo de efetivação dos atendimentos educacionais, analisar os objetivos e o modelo de educação para as crianças curitibanas internadas num hospital infantil e como esta prática de educação dentro de um hospital se desdobra. O ofício do Historiador dá elementos para tratar a temática pelas bordas, pois a pesquisa trata de algo que se encontra dentro de um hospital, sendo que a análise que se propõe com esse trabalho não é com o enaltecimento, mas sim a análise e produção de inteligibilidade, apontando as dificuldades do projeto. Ao falar do passado como diferença, a história mostra seu presente no qual é escrita, mostrando uma ausência no passado e um limite no interior do presente do qual é possível ultrapassar. Considera-se que 0 atendimento educacional hospitalar é relevante para a educação, pois com sua existência, crianças e jovens que estão impossibilitados de frequentar as escolas em decorrência de internamento hospitalar ou tratamento de saúde são beneficiadas e têm seus direitos garantidos, afinal, com as aulas durante seus internamentos, os alunos não interrompem seu processo de escolarização, o que é um direito previsto principalmente no Cap., IV, Artigos 53 e 54 do Estatuto da Criança e do Adolescente (BRASIL, 1990). Além disso, o direito à educação foi aceito internacionalmente a partir da Declaração dos Direitos da Criança feito pelas Nações Unidas em 1959 (com exceções da África do Sul) e significou igualdade de acesso para todos. A educação em hospitais vem procurando cumprir este direito, garantido em lei, para que a igualdade realmente se efetive. O recorte temporal é balizado pela realização do primeiro convênio entre a Secretaria de Estado da Educação para cessão de professores, que realizariam atendimentos educacionais às crianças internadas em um hospital infantil de Curitiba, no ano de 1988, ligado ao setor da assistência social, até o ano de 2002, quando é transferido o convênio para o setor de educação e cultura criado no hospital em questão. Com a cessão de professoras que iniciariam 0 atendimento educacional às crianças hospitalizadas, surgem alguns questionamentos, que serão respondidos com esse trabalho. Dentre eles destaco quais eram os espaços, tempos e práticas de educação que se desdobravam dentro do hospital? Neste sentido, as primeiras professoras do hospital destacaram que é possível identificar, por conta da especificidade do trabalho, necessidades das crianças ou até mesmo possibilidade de efetivação das atividades por conta do estado físico em virtude da doença, que elas precisaram se adaptar a uma educação diferenciada que acabava se distanciando da escola regular e do ensino tradicional, afinal a questão do tempo e espaço escolar era totalmente diferenciadas.

Palavras chave: Historia Educação, Educação Hospitalar, Saúde, Escolarização, Infância. 


\section{ABSTRACT \\ CHILDREN EDUCATION IN HOSPITALS: The experience of the city of Curitiba in an Association for Child Protection Dr. Raul Carneiro, PR, 1988 - 2002}

This paper will analyze the motivations that helped to implement the agreement that reallocated teachers to teach children in a children's hospital in Curitiba - PR between 1988 and 2002, thus identifying the importance of education for the children in Curitiba in a totally different and paradoxical to the school, but for educational purposes, the hospital universe. In addition, to understand the process of effecting educational care, to analyze the objectives and the model of education for the children in Curitiba, hospitalized in a children's hospital and to investigate how this practice of education within a hospital unfolds. The office of the Historian gives elements to deal with the issue by the edges, since the research deals with something that is found inside a hospital, and the analysis that is proposed with this work is not with the exaltation, but the analysis and production of intelligibility, pointing out the difficulties of the project. In speaking of the past as difference, history shows its present in which it is written, showing an absence in the past and a limit within the present from which it is possible to overcome. It is considered that the hospital pedagogical service is relevant for education, because with its existence, children and young people who are unable to attend schools due to hospital admission or health treatment are benefited and their rights are guaranteed, after all, with the classes during their hospitalizations, students do not interrupt their schooling process, which is a right foreseen mainly in Cap., IV, Articles 53 and 54 of the Statute of the Child and Adolescent (BRASIL, 1990). In addition, the right to education was accepted internationally on the basis of the United Nations Declaration of the Rights of the Child in 1959 (with the exceptions of South Africa) and meant equal access for all, education in hospitals has been seeking to fulfill this right, guaranteed by law, so that equality really takes effect. The temporal cut-off is marked by the first agreement between the State Secretariat of Education for the release of teachers, which would provide educational assistance to children admitted to a children's hospital in Curitiba in 1988, linked to the social assistance sector, until the year of 2002, when the agreement for the education and culture sector of the hospital in question is created. With the release of teachers who would initiate educational services to hospitalized children, some questions arise, which will be answered with this work: What were the spaces, times and practices of education that unfolded within the hospital? In this sense, the first teachers of the hospital emphasized that it is possible to identify, due to the specificity of the work, children's needs or even the possibility of carrying out the activities due to the physical state due to the disease, that they needed to adapt to an education differentiated from the regular school and traditional education, after all the question of time and school space was totally different.

Keywords: Education History, Hospital Education, Health, Schooling, Childhood. 


\section{Lista de llustrações}

Figura 1: Educação no hospital em Nova York - EUA 054

Figura 2: Início da Mobilização sobre direitos das crianças e adolescentes em 1988, Belo Horizonte, Minas Gerais

Figura 3: Fanfarra na Mobilização sobre direitos das crianças e adolescentes em 1988,

Belo Horizonte, MG

Figura 4: Imagem da Mobilização sobre direitos das crianças e adolescentes em 1988, Belo Horizonte, MG

Figura 5: Imagem mais centralizada da Mobilização sobre direitos das crianças e adolescentes em 1988, Belo Horizonte, MG

Figura 6: Imagem de aula no hospital em Curitiba, PR 145

Figura 7: Imagem de criança em hemodiálise e com aula no hospital em Curitiba, PR

Figura 8: Imagem de criança em hemodiálise e com aula no hospital em Curitiba, PR .153

Figura 9: As crianças doentes vão receber aulas nos próprios hospitais 163

Figura 10: Fotografia da professora 1 com estagiárias no hospital (Década de 90). 164 Figura 11: Carta parabenizando pelo trabalho de Hospitalização Escolarizada ...... 176

Figura 12: Carteiras utilizadas na Hospitalização Escolarizada 181

Figura 13: Croqui da sala de aula do Hospital utilizada até 1991 186

Figura 14: Fotografia de uma professora junto a um aluno ligado na máquina de hemodiálise 190

Figura 15: Fotografia do entrevistado em diálise peritoneal 206

Figura 16: Fotografia do entrevistado em hemodiálise sendo visitado por um piloto de corrida automobilística 209

Figura 17: Fotografia do entrevistado com Daniele Hypólito, ginasta brasileira que visitava o hospital onde ele fazia tratamento 211

Figura 18: Fotografia do entrevistado em sua formatura do Ensino Fundamental.. 216 Figura 19: Fotografia do entrevistado em sua formatura do Ensino Fundamental.. 218 Figura 20: Fotografia do entrevistado com sua professora hospitalar na formatura do Ensino Fundamental 219 
Figura 21: Fotografia do entrevistado com sua mãe em viagem para o litoral do Paraná, promovida pela equipe de nefrologia do hospital, logo após o segundo

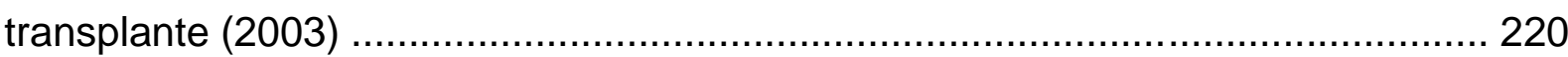

Figura 22: Fotografia da filha da entrevistada com 3 meses ................................. 228

Figura 23: Fotografia da filha da entrevistada com 4 anos numa Festa Junina (Junho/1986) 229

Figura 24: Formatura do Ensino Fundamental da filha da entrevistada com 10 anos 233

Figura 25: Fotografia da turma de Formação de Docentes do CE Prof. Lysímaco Ferreira da Costa onde estudava a filha da entrevistada [entre 1997 a 2001] 236 Figura 26: Fotografia da formatura da Formação de Docentes da filha da entrevistada 237

Figura 27: Fotografia da formatura da Formação de Docentes da filha da entrevistada 238 


\section{Lista de Quadro}

Quadro 1: Hospitais com Atendimento Educacional por regiões e estados brasileiros

Quadro 2: Matrícula inicial do Ensino Fundamental por dependência administrativa/PR $1978 / 2000$ 


\section{Lista de Siglas}

AJ Assessoria Jurídica

ASCJ Congregação Apóstolas do Sagrado Coração de Jesus

ASSINTECA Associação Interconfessional de Educação de Curitiba

CEEBJA Centro Estadual de Educação Básica para Jovens e Adultos

CEP Comitê de Ética e Pesquisa

CES Centro Estadual de Ensino Supletivo

CIME Cidade do Menor

CLT Consolidação das Leis do Trabalho

CNBB Conferência Nacional dos Bispos

CNE Conselho Nacional de Educação

CONANDA Conselho Nacional dos Direitos da Criança e do Adolescente

CONEP Comissão Nacional de Ética em Pesquisa

DCAD Defesa da Criança e do Adolescente

DCE Diretório Central dos Estudantes

ECA Estatuto da Criança e do Adolescente

EJA Educação de Jovens e Adultos

ENEM Exame Nacional do Ensino Médio

FEBEMs Fundações Estaduais do Bem-Estar do Menor

FIBGE Fundação Instituto Brasileiro de Geografia e Estatística

FUNABEM Fundação Nacional do Bem-Estar do Menor

FUNDEF Fundo de Manutenção e Desenvolvimento do Ensino Fundamental e de Valorização do Magistério

FUNDEPAR Fundação Educacional do Paraná

GRHS Grupo de Recursos Humanos Setorial da SEED

HPP Hospital Pequeno Príncipe

IBGE Instituto Brasileiro de Geografia e Estatística

INEP Instituto Nacional de Estudos e Pesquisas Educacionais Anísio Teixeira

LBA Legião Brasileira de Assistência

LDBEN Lei de Diretrizes e Bases da Educação Nacional

MEC Ministério da Educação

MNMMR Movimento Nacional de Meninos e Meninas de Rua

MPAS Ministério da Previdência e Assistência Social

MPMP Movimento Popular de Mulheres do Paraná

NRE Núcleos Regionais de Educação 


\begin{tabular}{ll} 
ONGs & Organizações Não Governamentais \\
ONU & Organização das Nações Unidas \\
PDT & Partido Democrático Trabalhista \\
PFL & Partido da Frente Liberal \\
PMDB & Partido do Movimento Democrático Brasileiro \\
PNBEM & Política Nacional de Bem-Estar do Menor \\
PNH & Política Nacional de Humanização \\
PSS & Processo Seletivo Simplificado \\
PT & Partido dos Trabalhadores \\
PUCPR & Pontifícia Universidade Católica do Paraná \\
QPM & Quadro Próprio do Magistério \\
SAREH & Serviço de Atendimento à Rede de Escolarização Hospitalar \\
SEAD & Secretaria de Estado de Administração \\
SEEC & Estadual de Cultura do Paraná \\
SEED & Secretaria de Estado da Educação do Paraná \\
SESA & Secretaria de Estado da Saúde do Paraná \\
SETI & Secretaria de Estado da Ciência, Tecnologia e Ensino Superior \\
SME & Secretaria Municipal de Educação de Curitiba \\
TCPE & Termo Cooperativo de Parceria Educacional - \\
UDR & União Democrática Ruralista \\
UFPR & Universidade Federal do Paraná \\
UNESCO & Organização das Nações Unidas para a Educação, a Ciência e a Cultura \\
Unicef & Fundo das Nações Unidas para a Infância \\
UNICEF & Fundo das Nações Unidas para a Infância \\
UPT & Universidade Popular do Trabalho \\
UNICAMP & Universidade de Campinas \\
USP & Universidade de São Paulo \\
UTI & Unidade de Terapia Intensiva \\
& \\
\hline
\end{tabular}




\section{SUMÁRIO}

INTRODUÇÃO 018

CAPÍTULO 1 - O DESENVOLVIMENTO DA EDUCAÇÃO HOSPITALAR NA EUROPA, ÁFRICA DO SUL, AMÉRICA E NO BRASIL ... 045

1.1 A EDUCAÇÃO HOSPITALAR NA EUROPA, ÁFRICA DO SUL, AMÉRICA E BRASIL .........046

1.2 A EDUCAÇÃO HOSPITALAR NOS DIFERENTES ESTADOS BRASILEIROS ……............. 065

1.3 A ESPECIFICIDADE LEGAL DA EDUCAÇÃO HOSPITALAR BRASILEIRA ....................... 079 CAPÍTULO 2 - A EDUCAÇÃO HOSPITALAR E EDUCAÇÃO, ONDE SE INSERE ESSA NOVIDADE?

2.1 EDUCAÇÃO HOSPITALAR E OS MOVIMENTOS, O ESTATUTO DA CRIANÇA E ADOLESCENTE (ECA) E A MUDANÇA NOS DIREITOS DAS CRIANÇAS E ADOLESCENTES 092

2.2 A MUNICIPALIZAÇÃO DO ENSINO E A LDBEN NA EDUCAÇÃO HOSPITALAR DO PARANÁ 119

2.2.1 Educação Hospitalar e Educação, aspectos legais pertinentes ao Estado do Paraná 130 CAPÍTULO 3 - SUJEITOS E AÇÕES EFETIVAS DA EDUCAÇÃO HOSPITALAR PARANAENSE 139

3.1 O PIONEIRISMO DA EDUCAÇÃO HOSPITALAR NUM HOSPITAL INFANTIL EM CURITIBA $-\mathrm{PR}$ 143

3.2 O "PROJETO MIRIM DE HOSPITALIZAÇÃO ESCOLARIZADA" E A IMPLANTAÇÃO DA

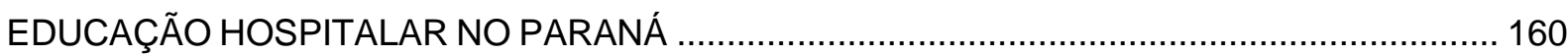

3.2.1 A Assistência Social e a escolarização no atendimento hospitalar ...................................... 169

3.2.1.1 Os lugares, os espaços e a materialidade da Educação Hospitalar ............................... 180

3.2.2 A efetivação do Projeto de Educação Hospitalar, seus professores, crianças e famílias 189

3.2.2.1 As primeiras professoras, seus vínculos e seus olhares para a Educação Hospitalar .... 193 3.2.2.2 As crianças, doentes, alunos/alunas da Educação Hospitalar: experiências entrelaçadas 202

3.2.2.3 O olhar da família da criança internada para a Educação Hospitalar 225 CAPÍTULO 4 - A EXPERIÊNCIA PARANAENSE EM EDUCAÇÃO HOSPITALAR: CAMINHOS E DESCAMINHOS 240

4.1 A CARACTERÍSTICA DO ATENDIMENTO NO ÂMBITO ESTADUAL E MUNICIPAL ........... 241 4.2 RUPTURAS E DESCAMINHOS NO ATENDIMENTO DA EDUCAÇÃO HOSPITALAR ........ 254

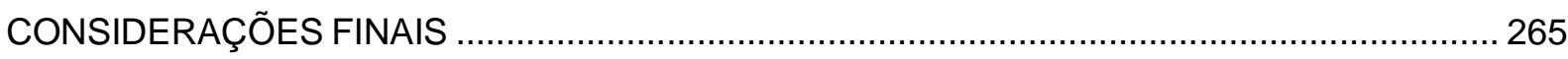

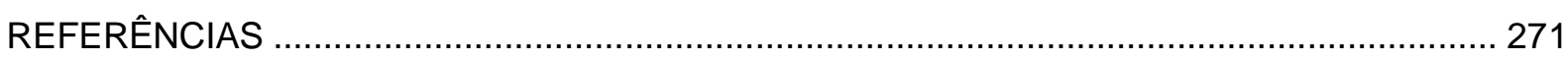

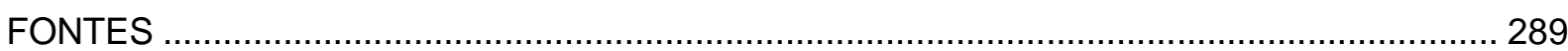

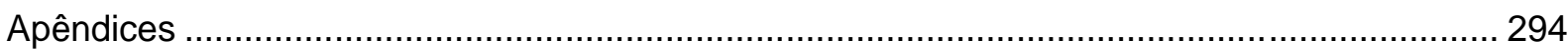

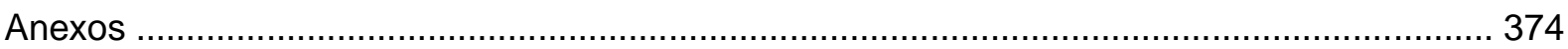




\title{
INTRODUÇÃO
}

\begin{abstract}
Suponho que no princípio dos princípios, antes de havermos inventado a fala, que é como sabemos, a suprema criadora de incertezas, não nos atormentaria nenhuma dúvida séria sobre quem fôssemos e sobre a nossa relação pessoal e colectiva com o lugar em que nos encontrávamos. O mundo, obviamente, só podia ser o que os nossos olhos viam em cada momento, e, também, como informação complementar importante, aquilo que os restantes sentidos - o ouvido, o tacto, o olfato, o gosto conseguissem perceber dele. [...] Hoje, porém, embora sabedores de que, desde o último vírus até o universo, não somos mais do que composições de átomos, e que no interior deles, além da massa que lhe é própria e os define, ainda sobra espaço para o vazio (o compacto absoluto não existe, tudo é penetrável), continuamos, tal como o haviam feito nossos antepassados das cavernas, a aprender, identificar e reconhecer o mundo segundo a aparência com que se nos apresente. (SARAMAGO, José, 2009, p. 34-35).
\end{abstract}

A produção científica é marcada por muita pesquisa e interesse em determinados pontos, que acabam fomentando o olhar dos pesquisadores para algumas temáticas em detrimento de outras. A trajetória desta pesquisa foi estruturada por conta do meu percurso pessoal, social, profissional e a curiosidade que me envolveram com a temática da Educação em diferentes contextos e finalmente da Educação Hospitalar. Os questionamentos e dúvidas que me motivaram a pesquisar esse assunto perpassa essa inquietação que Saramago apresenta num de seus escritos compilados para a produção do livro "O caderno" em que indica a raiz das incertezas que fomentam as pesquisas científicas e o desenvolvimento do conhecimento e da aprendizagem nos seres humanos e neste caso, em mim. Afinal, concordo com ele, pois, apesar de termos hoje uma quantidade enorme de informações disponíveis a todas as pessoas, há sempre novas dúvidas, novos conhecimentos que despertarão nossa curiosidade e nos farão formular outras questões para "reconhecer o mundo segundo a aparência com que se nos apresente", segundo nossas leituras, análises e interpretações.

A minha formação na área da educação teve um papel fundamental nas escolhas e desejos com relação a seleção da temática desta pesquisa. No Ensino Médio cursei concomitantemente o curso de Formação de Docentes e durante minha graduação em Pedagogia, realizada na Universidade de Campinas (Unicamp), me habilitei para atuar no ensino das séries iniciais do Ensino Fundamental, na Formação 
de Docentes no Ensino Médio, na administração e supervisão escolar. Em relação à formação de professores, o meu principal trabalho foi a comparação entre dois países (Brasil e Alemanha), para tanto realizei estágios em ambos os países, coletando dados, fazendo entrevistas e observações em sala de aula. Ainda na graduação, fui estagiaria na Secretaria de Educação e Cultura do Município de Paulínia - SP para aprofundar meus conhecimentos na área administrativa, o que resultou na monografia "A Educação e o Município de Paulínia". Fiz um curso de pós-graduação em Educação Social, produzindo a monografia intitulada "Exclusão Escolar no Ensino Fundamental", que foi apresentada em diversos congressos, encontros e seminários. Investi também numa especialização em Educação Especial produzindo o trabalho de conclusão de curso intitulado "Atendimento Pedagógico Hospitalar e Domiciliar no município de Araucária - PR".

Com relação à minha atuação profissional, trabalhei na área educacional desde 1991, lecionando em Escolas de Ensino Fundamental Estadual e na Educação Infantil municipal de Artur Nogueira, Engenheiro Coelho e Campinas - SP. Em 1996, aprovada num concurso público municipal de Paulínia - SP, passei a atuar como professora em escolas de Ensino Fundamental deste município. Em 2002 trabalhei como Professora de Psicologia da Educação e Didática na formação de professores do CEMEP - Centro Municipal de Ensino Médio e Profissionalizante de Paulínia "Osmar Passarelli Silveira" e em fevereiro de 2003, trabalhei concomitantemente como Professora Coordenadora do Ensino Médio e Educação de Jovens e Adultos da Escola Municipal Prof. "Flora Ap. Toledo Lima" no período noturno.

Desde 2004 atuei como Professora Pedagoga em Escolas de Curitiba, inicialmente por meio do Processo Seletivo Simplificado (PSS), um tipo de professor substituto e, a partir de 2005, após passar no concurso público para professores do Estado do Paraná ocorrido em 2004, vinculada ao Quadro Próprio do Magistério (QPM). Em 2007, participei de um processo seletivo para contratação de pedagogos para trabalhar na Educação Hospitalar em hospitais de Curitiba no Serviço de Atendimento à Rede de Escolarização Hospitalar (SAREH) ligado à Secretaria de Estado da Educação. Esse serviço, segundo seu documento orientador tinha por objetivo

[...] o atendimento educacional aos estudantes que se encontram impossibilitados de frequentar a escola, em virtude de situação de internamento hospitalar ou sob outras formas de tratamento de saúde, 
permitindo-Ihes a continuidade do processo de escolarização, a inserção ou a reinserção em seu ambiente escolar. (PARANÁ, 2007, p.6).

Ao ser selecionada, escolhi trabalhar no Hospital Pequeno Príncipe ${ }^{1}$ que atende crianças e adolescentes internados por longos períodos e que contava desde 1988 com atendimento pedagógico escolar para estas crianças e adolescentes. Neste hospital atuei por um ano e meio como pedagoga, onde minha principal função era a organização do trabalho pedagógico dos atendimentos ofertados por professores de diferentes disciplinas das séries finais do Ensino Fundamental e Médio aos estudantes hospitalizados. Além de coordenar, acompanhar e avaliar o trabalho dos professores da educação hospitalar, organizar os materiais e equipamentos para o seu desenvolvimento, observar se o aluno tinha liberação médica para ter aulas, auxiliar a integração entre os professores que atuava no hospital, ajudar na elaboração do Plano de Ação Pedagógica junto com os professores e profissionais do hospital, realizar o contato com a família e com a escola de origem dos alunos hospitalizados, planejar e garantir o cumprimento da hora-atividade dos professores e ao final dos atendimentos, ou na alta hospitalar do aluno, entregar aos seus pais ou responsáveis um relatório dos atendimentos pedagógicos realizados pelos professores no hospital com as atividades realizadas, orientando que fosse entregue na escola do estudante.

Como meu trabalho pedagógico se realizava no contexto de um hospital, que já atendia o público infantil desde o início do século $X X$, o interesse pela pesquisa histórica surgiu quando alguns questionamentos passaram a fazer parte do meu dia a dia. Comecei a me perguntar o porquê desta oferta de atendimento à saúde e à educação de crianças acabou desencadeando a construção de um hospital de crianças na cidade de Curitiba entre as primeiras décadas dos novecentos e ainda, como foi a implantação da educação hospitalar nas décadas de 1980 e $1990^{2}$ ? Quais seriam as motivações que tornou possível a efetivação do convênio que cedia

\footnotetext{
1 O Hospital Pequeno Príncipe inaugurado em 1971, em terreno anexo ao Hospital de Crianças César Pernetta, faz parte do Complexo Pequeno Príncipe, que conta com os dois hospitais que atendem prioritariamente crianças e adolescentes; as Faculdades Pequeno Príncipe, que desenvolve atividades acadêmicas, desde 2004, oferecendo atualmente graduação em Enfermagem, Biomedicina, Farmácia, Psicologia e Medicina, além de especializações, mestrado e doutorado na área da saúde; por último o Instituto de Pesquisa Pelé Pequeno Príncipe, criado em 2005, que tem entre seus objetivos desenvolver pesquisas da área básica e clínica em doenças complexas da infância. Todo o Complexo é mantido principalmente pela Associação Hospitalar de Proteção à Infância Dr. Raul Carneiro, fundada em 1956 por médicos e voluntários. Cf.: http://pequenoprincipe.org.br/hospital/ Acesso: 15/01/2017.

2 Nesse período o Brasil se encontra num processo de redemocratização do país com um movimento pelas Diretas Já e num debate que desencadeou a elaboração do Estatuto da Criança e do Adolescente - ECA que é promulgado em 13/07/1990. Maiores informações sobre esse assunto podem ser observadas no capítulo 2 .
} 
professores a lecionar para crianças num hospital infantil em Curitiba - PR no final do século XX e início do século XXI? Assim, passei a ter a necessidade de identificar o porquê da importância da educação para as crianças curitibanas do universo hospitalar no processo de efetivação dos atendimentos educacionais. Quais os objetivos e o modelo de educação para as crianças curitibanas internadas neste hospital infantil? Como esta prática de educação dentro de um hospital se desdobrou? Quem eram os sujeitos (estudantes e famílias) atendidos pela educação hospitalar? E finalmente, quem eram os professores do convênio que atuavam dentro do nosocômio? Todas estas questões acabaram culminando no ingresso em 2009 no mestrado em História e Historiografia da Educação na Universidade Federal do Paraná onde apresentei, em meados de 2011, a monografia intitulada: "As origens do Hospital de Crianças. Saúde e Educação em Curitiba, 1917-1932", orientado pelo Prof. Dra. Liane Maria Bertucci.

Esse trabalho respondeu em parte alguns dos questionamentos, mas o fato de continuar sem respostas para muitas dúvidas relacionadas diretamente às questões da Educação Hospitalar, me instigaram a fazer a inscrição em 2014, na seleção do doutorado, na área de História e Historiografia da Educação, da Universidade de São Paulo, com o projeto inicial intitulado: A Educação de crianças no Hospital de Crianças de Curitiba, 1932-1988.

Entre o mestrado e o doutorado, passei por problemas de saúde e tive que me afastar de todas as minhas atividades profissionais, pois meus rins pararam de funcionar e passei a fazer hemodiálises ${ }^{3}$ quatro vezes na semana. Esse tratamento durou dois anos, durante esse tempo, realizei diversas cirurgias, que me levaram a ficar longo tempo internada. Tive que usar fístula arteriovenosa (FAV) ${ }^{4}$, passar

\footnotetext{
3 Hemodiálise é um tratamento onde uma máquina filtra e limpa o sangue, portanto "faz parte do trabalho que o rim doente não pode fazer", liberando o corpo dos resíduos que prejudicam a saúde, como os líquidos e excesso de sal, auxilia o corpo a equilibrar o sódio, potássio, ureia, creatinina e controla a pressão arterial. (SOCIEDADE BRASILEIRA DE NEFROLOGIA, 2017). Disponível em: http://sbn.org.br/publico/tratatamentos/hemodialise/ Acesso em 14/01/2017.

${ }^{4}$ Fístula arteriovenosa (FAV), é realizada por uma cirurgia no braço ou perna, onde é feita "uma ligação entre uma pequena artéria e uma pequena veia, com a intenção de tornar a veia mais grossa e resistente, para que as punções com as agulhas de hemodiálise possam ocorrer sem complicações". (SOCIEDADE BRASILEIRA DE NEFROLOGIA, 2017). Disponível em: http://sbn.org.br/publico/tratatamentos/hemodialise/ Acesso em 14/01/2017.
} 
cateteres $^{5}$, fazer nefrectomia ${ }^{6}$ bilateral, por conta da doença que fez com que meus rins crescessem e impossibilitando o transplante e, posteriormente, me submeti a dois transplantes. O primeiro transplante não deu certo porque tive trombose na artéria renal logo após o procedimento, impossibilitando a perfusão do sangue para dentro o rim transplantado e o efetivo funcionamento deste. Somente o segundo transplante realizado em 12 de janeiro de 2016 funcionou, depois de uma intensa pesquisa junto a hematologistas e cuidados especiais para que não houvesse o mesmo problema de coagulação do primeiro.

Aqui vale a pena ressaltar que a menção aos problemas de saúde, não pode ser desconsiderada na definição da temática de pesquisa para o doutorado, mesmo que em princípio esta intencionalidade nunca esteve explícita ou relacionada diretamente com a experiência advinda com o problema de saúde. Entretanto, ela ampliou minha perspectiva e me auxiliou em um entendimento ainda melhor da problemática das crianças e adolescentes internados, principalmente aquelas que estudavam. Afinal, foi justamente durante meu tratamento que realizei a seleção para o doutorado e o iniciei em fevereiro de 2015, ficando praticamente mais de um ano estudando e realizando o tratamento de saúde, quase que vivenciando exatamente o que os alunos, sujeitos desta pesquisa, viviam diariamente.

Essa realidade trouxe outros elementos à minha trajetória enquanto pesquisadora, afinal a vivência enquanto estudante doente ampliou meu entendimento com relação ao que antes não era percebido ou mesmo experienciado por mim. Contudo, é importante destacar que esta experiência ampliou minha percepção sobre o tema, como também me mostrou que meu papel enquanto pesquisadora de uma área que parece tão ligada à minha realidade pessoal não poderia e nem deveria orientar negativamente as análises, afinal é fundamental que se tenha clareza das pretensões desta tese. O que se propõe é entender a Educação Hospitalar que foi implantada entre os anos de 1988 a 2002, em Curitiba, no Estado do Paraná, sua identidade e especificidade, algo muito distante da realidade por mim vivenciada. Tenho um entendimento muito claro sobre a questão do distanciamento

\footnotetext{
${ }^{5}$ Cateter de hemodiálise é um tubo colocado em uma veia do pescoço, tórax ou virilha que possibilita por meio de dois adaptadores a convecção com a linha da máquina de hemodiálise. (SOCIEDADE BRASILEIRA DE NEFROLOGIA, 2017). Disponível em: http://sbn.org.br/publico/tratatamentos/hemodialise/ Acesso em 14/01/2017.

6 Nefrectomia é um procedimento cirúrgico para retirada dos rins. Disponível em: http://infomidi.com.br/noticia/5921/o-que-e-nefrectomia. Acesso em: 14/01/2017.
} 
necessário para a realização de uma pesquisa histórica e científica, uma vez que não pretendo discutir a minha experiência enquanto estudante doente, mas sim, além da implantação da Educação Hospitalar, a experiência de outros sujeitos, no caso, crianças e adolescente que receberam esse atendimento no final do século XX. Há, portanto, uma clareza que o conhecimento sobre o tema é importante assim como o distanciamento da pesquisadora para que as análises sejam isentas de influências pessoais e fundamentando-se em Certeau (1982, p. 93) onde

a operação histórica consiste em recortar o dado segundo uma lei presente, que se distingue do seu 'outro' (passado), distanciando-se com relação a uma situação adquirida e marcando, assim, por um discurso, a mudança efetiva que permitiu este distanciamento.

Além disto, o ofício do Historiador também dá elementos para o tratamento da temática pelas bordas, pois a pesquisa trata de algo que se encontra dentro de um hospital. A análise que se propõe com esse trabalho não é com o enaltecimento, mas sim a análise e produção de inteligibilidade, apontando as possíveis dificuldades deste projeto de Educação Hospitalar. Desse modo, ao falar do passado como diferença, a história mostra seu presente no qual é escrita, mostrando uma ausência no passado e um limite no interior do presente do qual é possível ultrapassar. (CERTEAU, 1988, p. 40).

Nestas condições, considero que o atendimento educacional hospitalar é relevante para a educação, pois com sua existência, crianças, adolescentes e jovens que estão impossibilitados de frequentar as escolas em decorrência de internamento hospitalar ou tratamento de saúde são beneficiados e têm seus direitos garantidos. Afinal, com as aulas durante seus internamentos, os alunos não interrompem seu processo de escolarização, o que é um direito previsto principalmente no Cap. IV, Artigos 53 e 54 do Estatuto da Criança e do Adolescente (BRASIL, 1990).

Enfim, nesta tese analiso aspectos do processo social e cultural que resultou na estruturação do atendimento educacional hospitalar num Hospital de crianças, na cidade de Curitiba, nas últimas décadas dos Novecentos, do Século XX, a luz da teoria de E. P. Thompson (1981, 1984, 1987, 2002) e Certeau (1982, 1988, 2011). A opção pelo estudo das ideias e ações que resultaram na organização deste atendimento no Hospital (micro) acaba por auxiliar o entendimento do macrocosmo (sociedade curitibana) e, por sua vez, auxilia a compreensão da forma como a Educação das 
crianças e as próprias crianças eram percebidas, entendidas e valorizadas no final do século XX, na capital do Estado do Paraná.

Segundo Eric Hobsbawm:

Não há nada de novo em preferir olhar o mundo por meio de um microscópio em lugar de um telescópio. Na medida em que aceitamos que estamos estudando o mesmo cosmo, a escolha entre micro e macrocosmo é uma questão de selecionar a técnica apropriada. É significativo que atualmente mais historiadores achem útil o microscópio, mas isso não significa necessariamente que eles rejeitem os telescópios como antiquados (1998, p. 206).

O recorte temporal de 1988 a 2002 é balizado pela realização do primeiro convênio entre a Secretaria de Estado da Educação para liberação de professores que realizaram atendimentos educacionais às crianças internadas em um hospital infantil de Curitiba, no ano de 1988. O atendimento estava ligado ao setor da assistência social, até o ano de 2002, quando foi criado no hospital em questão, o Setor de Educação e Cultura que passou a acompanhar os convênios relacionados à educação, alterando significativamente o trabalho das professoras da prefeitura que assim passava a estar ligada a uma chefia direta dentro do hospital para a realização de atividades educacionais com as crianças doentes. Assim, por meio desta tese, se teve a intenção de investigar facetas dos múltiplos processos da organização do atendimento educacional hospitalar nos hospitais da Associação de Proteção à Infância Dr. Raul Carneiro, percebendo como se explicitava, entre 1988 e 2002, a preocupação (de médicos e outros membros da sociedade) com a educação das crianças, quais as ideias que permeavam os debates sobre o tema e que ações educacionais relacionadas ao cuidado com a saúde e educação marcaram esse processo, que contou com as participações das Secretaria de Estado da Educação do Estado do Paraná e Secretaria Municipal de Educação de Curitiba - PR.

Esta análise das discussões e empreendimentos que resultaram na estruturação da Educação Hospitalar em dois hospitais em Curitiba, Paraná é norteada pelos seguintes questionamentos: quais ações influenciaram e/ou contribuíram para a implantação da educação hospitalar para crianças em Curitiba no final do século XX? E qual o papel desta educação nesse processo de efetivação dos atendimentos educacionais às crianças doentes curitibanas?

Nesta tese, procura-se perceber como se explicitava, entre 1988 e 2002, a preocupação com a educação de crianças, como a organização da Educação Hospitalar foi implantada e ampliou seus atendimentos, quais os rumos que o 
tratamento da questão da educação das crianças em Curitiba acabou adotando e que ações educacionais dirigidas aos sujeitos do universo hospitalar relacionadas ao cuidado com a saúde de crianças marcaram esse processo.

Os pontos principais da pesquisa são a história do atendimento educacional hospitalar por meio da observação das políticas públicas estatais e municipais específicas para o atendimento ao direito à educação das crianças. A tese objetiva contribuir para a produção de conhecimento sobre o atendimento educacional à criança, compreendendo este atendimento como integrante de um processo histórico e cultural que envolve a produção de saberes e práticas educativas. Assim, têm-se a intenção de contribuir com uma análise da educação de maneira mais ampla, não apenas para o hospital estudado, e sugerir mudanças em suas produções e saberes. Esta temática é relevante, pois não foi abordada até o momento, portanto poderá contribuir para o campo da educação e da história da educação dando visibilidade a um assunto que historicamente vem sendo pautado e encaminhado até muito recentemente como uma prática assumida e realizada a partir de ações relacionadas à filantropia e à assistência social.

Como em 1988 é firmado um convênio entre a Associação Hospitalar Dr. Raul Carneiro e as Secretaria de Estado da Educação por intermédio do Secretário Belmiro Valverde Jobim Castor ${ }^{7}$ e Secretaria Municipal de Educação de Curitiba com a cessão de professoras que iniciaram o atendimento educacional às crianças hospitalizadas, surgem mais alguns questionamentos sobre esse assunto e que acabam por se integrar aos iniciais desta pesquisa: Quais eram os espaços, tempos e práticas de educação que se desdobravam dentro do hospital? Quem eram os sujeitos, estudantes, famílias e professores atendidos pela educação hospitalar, que atuavam ou se encontravam dentro dos nosocômios ligados à Associação? Como o atendimento educacional acontecia efetivamente?

A pesquisa tem por principal objetivo analisar as motivações que tornaram possível a efetivação do convênio que cede professores para que lecionem para as crianças em hospitais em Curitiba - PR entre os anos de 1988 a 2002. Dentre os objetivos específicos é possível considerar o papel da educação para as crianças curitibanas dentro do universo hospitalar no quer se refere ao processo de efetivação dos atendimentos educacionais, analisar os objetivos e os modelos de educação

\footnotetext{
7 PARANÁ, 2019b (Anexo 1), GAZETA DO POVO, 22/04/1988, p. 40.
} 
ofertado para as crianças curitibanas internadas, investigar como esta prática de educação se desdobra dentro do hospital e identificar quem eram os sujeitos, estudantes, famílias e professores do convênio encontrados no referido nosocômio.

O Hospital de Crianças, embrião dos hospitais onde a pesquisa se realiza, foi inaugurado em 2 de fevereiro de 1930, atendendo apenas ambulatoriamente nos seus dois primeiros anos de funcionamento (AVANZINI, 2011). Em 1932, foram inauguradas as três primeiras enfermarias iniciando efetivamente seu atendimento hospitalar, ou seja, com internamentos. Segundo Macedo, "no ano seguinte após a inauguração [destas enfermarias], registrava-se o internamento de 277 crianças" (MACEDO, 1978, p. 14). Em 1935, após três anos de funcionamento das enfermarias, o Hospital de Crianças foi cedido pela Cruz Vermelha Paranaense à Faculdade de Medicina do Paraná que o administrou até o ano de 1937. Em 1938, com o encerramento do contrato com a Faculdade de Medicina do Paraná, o Hospital foi doado ao Estado do Paraná. Anos depois, em 1951, por conta da Lei no 633, sancionada pelo governo do Estado do Paraná, o antigo Hospital de Crianças da Cruz Vermelha passou a se denominar Hospital de Crianças César Pernetta. Em junho de 1954 foi inaugurado o Centro de Estudos do Hospital de Crianças César Pernetta e em 1956 foi instalada e fundada a Associação Hospitalar de Proteção à Infância "Dr. Raul Carneiro", tendo por objetivo "promover meios para manutenção e aprimoramento do Hospital de Crianças César Pernetta" (GODOY, 1992), assim como proteger e assistir a "infância hospitalar, zelando pela saúde, o bem estar e as necessidades da criança" (ASSOCIAÇÃO HOSPITALAR DE PROTEÇÃO À INFÂNCIA DR. RAUL CARNEIRO, 1993, p. 04). A Associação Hospitalar de Proteção à Infância Dr. Raul Carneiro é uma entidade sem fins lucrativos, fundada por um grupo de voluntários e reinveste todo o resultado de sua arrecadação nas atividades de saúde, ensino e pesquisa mantendo uma organização não governamental que é o complexo hospitalar pediátrico Pequeno Príncipe, formado pelo Hospital Pequeno Príncipe e pelo Hospital de Crianças Dr. César Pernetta. A Associação vem, desde sua fundação, "viabilizando a existência e ampliação dos serviços de saúde por meio de uma permanente mobilização de pessoas, entidades e recursos para esse fim". Segundo o site do Hospital Pequeno Príncipe, a missão da Associação Hospitalar é "proteger a vida da criança e do adolescente, por meio da assistência em saúde, 
ensino, pesquisa e promover a mobilização social [...]" e, para tanto, conta com 2 mil pessoas, entre funcionários e voluntários ${ }^{8}$.

Com o passar dos anos aconteceu outra grande ampliação do hospital com a construção do Hospital Pequeno Príncipe, no terreno anexo ao Hospital de Crianças César Pernetta ${ }^{9}$, na Avenida Iguaçu. O terreno foi solicitado para a Secretaria da Saúde do Estado do Paraná e doado pelo Primeiro Secretário da Assembleia de Deputados, o senhor Anibal Khuri, em 1971. (ASSOCIAÇÃO HOSPITALAR DE PROTEÇÃO À INFÂNCIA DR. RAUL CARNEIRO, 1993, p. 05). Após oito anos, em 1979, o Hospital de Crianças César Pernetta foi cedido em comodato pelo governo estadual à Associação Hospitalar de Proteção à Infância Dr. Raul Carneiro, que desde então, administra os dois hospitais: Hospital Pequeno Príncipe e Hospital Infantil César Pernetta.

Segundo Certeau (1982, p. 31), a História é uma prática e um discurso, ao mesmo tempo um período (meados do século XX), um objeto (a história da educação hospitalar paranaense) e um lugar (os Hospitais da Associação de Proteção à Infância Dr. Raul Carneiro, Hospital César Pernetta e Hospital Pequeno Príncipe). "A evidenciação da particularidade deste lugar de onde falo, efetivamente prende-se ao assunto de que se vai tratar e ao ponto de vista por meio do qual me proponho a examiná-lo".

Desta forma os três "postulados" que Certeau descreve em seu texto "A escrita da História" são orientadores para a análise da história da educação no Hospital César Pernetta e Hospital Pequeno Príncipe de Curitiba. "Sem dúvida, a história é o nosso mito. Ela combina o "pensável" e a origem, de acordo com o modo através do qual uma sociedade se compreende". (CERTEAU, 1982, p. 32).

Atualmente, o Complexo Pequeno Príncipe, conta com 370 leitos de internação, dos quais 62 são de Unidade de Terapia Intensiva e semi-intensiva. Em 2015, foram mais de 23 mil internamentos com uma taxa de ocupação de leitos próxima dos $80 \%{ }^{10}$. Essa instituição sempre voltada ao atendimento da saúde, atendeu também, de maneira indireta às questões educacionais, educando as mães, formando médicos e difundindo as ideias higienistas e eugênicas no início do século XX.

\footnotetext{
${ }^{8}$ Cf. https://pequenoprincipe.org.br/hospital/a-mantenedora/

${ }^{9}$ Cesar Pernetta era pediatra, 11을 Professor Titular da cadeira de Pediatria da Universidade Federal do Paraná e muito trabalhou para a efetivação do funcionamento do Hospital de Crianças Cesar Pernetta (ASSOCIAÇÃO HOSPITALAR DE PROTEÇÃO À INFÂNCIA DR. RAUL CARNEIRO, 1993).

${ }^{10} \mathrm{Cf} .:$ http://pequenoprincipe.org.br/hospital/assistencia-a-saude-em-numeros/ Acesso: 15/01/2017.
} 
Bertucci (2015, p. 37) ao tratar da saúde da criança e a educação do trabalhador nas teses médicas e nos jornais operários em São Paulo, no início do século $X X$, indica a educação das mães como uma das preocupações frequentes nesse período, "pois apenas uma mulher educada tornaria efetivamente possível a reversão do quadro de doença e morte prematura de crianças que, muitas vezes, já nasciam debilitadas", tal argumento pode indicar que a educação destas mães estaria relacionada inclusive com a enfermidade infantil. Com relação aos dados de mortalidade das crianças de 0 a 1 ano, a autora descreve que segundo os dados estatísticos do Serviço Sanitário do Estado "de cada 1.000 crianças nascidas em São Paulo, no ano de 1924, apenas 832 atingiram 1 ano de idade e do total de 13.158 falecimentos na cidade no mesmo ano, 3.896, ou seja $29,60 \%$, eram de menores de 1 ano", sendo as doenças do aparelho digestivo as maiores causadoras da mortalidade das crianças $48,59 \%$, seguidas das "causas pré-natais, natais ou neonatais", $17,54 \%$ dessas mortes.

Em Curitiba, a mortalidade infantil nas primeiras décadas do século XX também é causada pela "falta de cuidados com os recém-nascidos e perturbações digestivas, além dos acidentes ou doenças relacionadas ao nascimento" (AVANZINI, 2011, p. 29). Essas perturbações digestivas ocorriam, muitas vezes, por conta do abandono precoce do aleitamento materno, pela falta de higiene relacionada ao aleitamento artificial ou alimentação das crianças. Por conta disto, os "preceitos da puericultura" (BERTUCCI, 2015, p. 37), se difundem no discurso médico, que também tinha o objetivo de educar as mães para que elas conseguissem criar seus filhos preservando a saúde e garantindo o "crescimento e desenvolvimento adequados" das crianças por meio de um grupo de técnicas científicas fundamentada no saber médico-científico. (FREIRE, 2008, p.160). A difusão de cursos de puericultura, o discurso médicocientífico e a preocupação com a saúde e educação das crianças foram algumas das justificativas para a criação do Hospital de Crianças de Curitiba nas primeiras décadas do século XX (AVANZINI, 2011, p. 113). Estudar uma instituição de saúde que tem como linha condutora inclusive a educação, me instigou a aprofundar a pesquisa para entender os motivos que levaram essa instituição a ofertar Educação para as crianças internadas na década de 1980 deste mesmo século.

Essa educação no hospital, inicialmente voltada para as mães, por meio dos cursos de puericultura, que abordavam os cuidados higiênicos e sanitários com as crianças se modifica e a partir da década de 1980 do século XX, com a implantação 
dos atendimentos ofertados diretamente às crianças e adolescente internados, a educação passou a ser muito mais experiencial, ou seja, aquela que se aprende em espaços que não são os escolares, propriamente ditos, mas ao se consolidar acaba se ampliando, porque levam em consideração os valores, as histórias de vida, a cultura (CAVACO, 2003, p. 129) e a própria cultura hospitalar.

No âmbito teórico metodológico, esta pesquisa se ancora na história social, na história cultural e na história do tempo presente. Esse trabalho pretende trabalhar com a ideia de uma história problema, onde seu objeto é construído, suas hipóteses devem ser explicitadas e seus procedimentos conhecidos (CHARTIER, 1996, p. 64).

A História do Tempo Presente iniciada na década de 1970 como uma abordagem recente no campo da História, segundo Pôrto (2007) apud Thiecker (2008) é assentada na História Contemporânea e seus "estudos, seja social ou político tomaram a história de um passado recente como base para suas interpretações". Pôrto ainda indica que não se sabe ao certo qual o início exato do marco temporal da história do tempo presente, que pode ter sido a queda do muro de Berlim ou as guerras coloniais, o que é certo é que ela é "escrita pela testemunhas dos acontecimentos ${ }^{11}$ ". (THIECKER, 2008).

De acordo com Mauad (2007), somente depois dos anos 1980 que os historiadores "passaram a consolidar o debate em torno da definição dos pressupostos teórico-metodológicos para o trabalho com o tempo presente" por meio da operação "no presente com a multiplicidade do tempo histórico" (THIECKER, 2008), e isso ocorreu somente neste período por conta da "preocupação com as denúncias das falsificações, desvios e ocultações, como princípios básicos da tradição disciplinar da história" causadas pela subjetividade e distorção observadas em alguns testemunhos dos sujeitos da história do tempo presente.

Segundo Fico (2012, p. 44) a única singularidade da história do tempo presente "é a pressão dos contemporâneos ou a coação pela verdade" com que é confrontada, ou seja, esse conhecimento histórico pode ser cotejado "pelo testemunho dos que viveram os fenômenos que busca narrar e/ou explicar". Entretanto, estas distorções e confrontos podem ser reincorporadas no estudo por meio do questionamento dessas "falsificações e dos usos políticos do passado e do presente". Além disto, a

11 Para maiores informações sobre história do tempo presente consultar: BEZERRA e LUCA, 2008; CHARTIER, 2010; DUTRA (org.), 2013; FERREIRA, PINSKY E LUCA, 2015 FICO, 2012; SAVIANI, 2015. 
contraprova também pode ser usada como mecanismo de legitimação dos "depoimentos orais" que corroboram para a produção da história do tempo presente. (FERREIRA, 2000, p. 122). Auxiliando na refutação dessas apreensões, Chartier indica a contemporaneidade do historiador com seus objetos entendida positivamente, pois na história do tempo presente

\begin{abstract}
o pesquisador é contemporâneo de seu objeto e divide com os que fazem a história, seus atores, as mesmas categorias e referências. Assim, a falta de distância, ao invés de um inconveniente, pode ser um instrumento de auxílio importante para um maior entendimento da realidade estudada, de maneira a superar a descontinuidade fundamental, que ordinariamente separa 0 instrumental intelectual, afetivo e psíquico do historiador e aqueles que fazem a história" (CHARTIER, 1993a, p.8).
\end{abstract}

Ao defender a história do tempo presente e concordando com Chartier (1993b), Ferreira destaca que esta compõe "um lugar privilegiado para uma reflexão sobre as modalidades e os mecanismos de incorporação do social pelos indivíduos de uma mesma formação social" (2000, p. 122), além de revelar aos historiadores novas abordagens e temáticas, como é o caso desta pesquisa que investiga a história da educação hospitalar. A história do tempo presente também é subsidiada com as contribuições da história oral.

Ao entender as possibilidades e os desafios colocados pelos relatos orais na escrita da história. De acordo com Fico (2012, p. 45), o estatuto do testemunho do historiador, desde a Antiguidade, "era a segurança de credibilidade para a história, especialmente o testemunho ocular, garantia de que se trabalhava com fatos que presenciáramos com "nossos próprio olhos" e não apenas de que "ouvíramos falar"'.

A diferença da história contemporânea para a história remota [...] é apenas uma questão de grau'. O remédio para ambas - além do caráter moral do historiador - era construir seu ponto de vista acima da perspectiva individual e identificar o objeto histórico com uma verdade mais geral. $\mathrm{O}$ historiador 'deve conquistar um ponto de vista independente a partir do qual a verdade objetiva, uma visão geral, torna-se cada vez mais confiável. ${ }^{12}$ (FICO, 2012, p. 46).

Por conta desta necessidade de a escrita histórica ser construída de forma confiável, descolada da individualidade e da verdade objetiva do historiador, além do seu caráter moral, me preocupei constantemente, durante a elaboração deste trabalho, em me apoiar numa variedade diferenciada de fontes que ao serem entrelaçadas e analisadas auxiliaram na tessitura da presente narrativa, assim como

12 Os trechos entre aspas simples são de Ranke apud KRIEGER, 1977, p. 271 e citados desta forma no texto de Fico, 2012. 
contribuíram para a análise de seus resultados, sendo os relatos orais mais uma dentre essas variadas fontes. No caso desta investigação, os relatos orais foram produzidos a partir de entrevistas com os diferentes sujeitos envolvidos na educação hospitalar paranaense na última década do novecentos do século $\mathrm{XX}$.

Efetivamente foram realizadas 6 entrevistas, sendo duas com a Assistente Social que implantou o projeto de Hospitalização Escolarizada em 1988. Outras, com duas professoras que atuaram na educação hospitalar, entre os anos de 1990 a 2002, uma das professoras estava ligada à Secretaria de Estado da Educação e a outra à Secretaria Municipal de Educação do município de Curitiba. Outra entrevista foi realizada com uma mãe de uma ex-aluna, que foi atendida entre os anos de 1991 e 1992. Entrevistei ainda uma professora da rede estadual e um ex-aluno que foi atendido nos anos de 2002 e 2003. As entrevistas estão disponibilizadas na íntegra dos apêndices $\mathrm{A}$ ao $\mathrm{K}$ deste trabalho.

As fontes orais também começaram a ser usadas metodologicamente nos meios acadêmicos mais amplamente na década de 1970 principalmente como história oral. Neste trabalho não utilizo a história oral em sua integralidade, mas me apoio em suas referências para produzir as fontes orais que foram utilizadas no entrelaçamento com outras fontes.

Essa opção metodológica não ignora as possíveis distorções observadas com o uso da história oral, mesmo que no caso deste trabalho seja utilizado especificamente as fontes orais, reconheço como cita Hall (1992, p. 157) que "a história oral está longe de ser uma história espontânea, não é a experiência vivida em estudo puro", além do que é evidente que "os relatos produzidos pela história oral devem estar sujeitos ao mesmo trabalho crítico das outras fontes que os historiadores costumam consultar". Dentre as distorções apontadas pelo autor, há o agravante da memória que demarca muito do que é revelado. Esta memória acaba sendo marcada subjetivamente também pelas experiências posteriores fazendo com que os entrevistados deixem de enfatizar ou destacar muitas das experiências efetivas ocorridas e questionadas nas entrevistas realizadas para a produção dos relatos orais. Além disto, ainda há as distorções intencionais que precisam ser consideradas nesse tipo de fonte, ou seja, o fato da maioria dos indivíduos não conseguir "avaliar claramente seu papel nos acontecimentos históricos", transferirem anacronicamente suas "opiniões atuais para o passado" e finalmente há o "entrevistado que já tem uma 
história pronta, o número ou uma linha sobre o passado" e nem percebe mais as omissões e simplificação que faz em sua versão do passado. (HALL, 1992, p. 158).

Apesar da memória ser considerada por alguns historiadores um risco para a produção histórica havendo uma oposição entre história e memória, por esta ser considerada incerta, aberta a lembranças, esquecimentos, vulnerável a manipulações e utilizações, suscetível a latência e revitalizações, é preciso lembrar que "a história é a reconstrução sempre problemática e incompleta do que não existe mais [...] uma representação do passado" normalmente crítica, problemática e conceitual. (DOSSE, 2012, p. 286). Desta forma, considero que ambas deixam de ser opostas por conta dos "recentes estudos de história social da memória" que a apresenta como um "objeto de história da mesma forma que a efetividade do acontecimento em seus estreitos limites temporais".

Considerados como uma problemática da pesquisa, também foram observados o próprio processo de produção das fontes orais. Para não invalidar as entrevistas e as transcrições realizadas para este trabalho, a produção foi isenta de opiniões e desejos. Mesmo estando envolvida com a pesquisa, me preocupei em não direcionar, além dos questionamentos pré-determinados, as diversas entrevistas que compõem o lócus nesta tese.

$\mathrm{Na}$ tentativa de evitar uma tendência em produzir análises unicamente com "explicações dominadas pelas histórias dos indivíduos envolvidos, suas personalidades, biografias, vontades e ações", considerei constantemente "o fato de que a memória é sempre uma reelaboração, socialmente determinada, e que a história oral corre o risco de fazer um uso extremamente inocente dos relatos por ela produzidos". Neste sentido utilizei outras fontes tais como os documentos oficiais, jornais, fotografias, cartas e, etc. Finalmente, para não ser envolvida na pretensa inocência proporcionada pela história oral, me concentrei nas características da "sensibilidade para as múltiplas determinações, sua preocupação com a contextualização e com as mudanças no decorrer do tempo" para a efetivação da produção histórica a que me proponho nesta tese. (HALL, 1992, p. 160).

Considero, como indica Vidal que as fontes orais são "um registro da humanidade, nem melhor, nem mais importante do que uma antiquíssima lasca de sílex, nem mais democrática do que uma carta ou uma obra de arte. Sua importância está no que o historiador faz com ela" (VIDAL, 1990, p. 82). Portanto, utilizo as fontes orais como fontes documentais para fazer história. 
A predispor-se a deixar falar o "oprimido", no caso desta pesquisa, os estudantes atendidos por professores enquanto estavam internados em hospitais infantis, assumo novamente, a postura da neutralidade; torna-se o instrumento por meio do qual as falas irão emergir (VIDAL, 1990).

Ainda sobre o estabelecimento das fontes, Certeau chama a atenção para o fato de que

não se trata apenas de fazer falar estes "imensos setores adormecidos da documentação" e dar voz a um silêncio, ou efetividade a um possível" a pesquisa histórica deve operar uma redistribuição do espaço, dando-se um lugar "[...] por uma ação instauradora e por técnicas transformadoras. (1982, p. 83).

Desta forma, a presente pesquisa

[...] não mais parte de "raridades" (restos do passado) para chegar a uma síntese (compreensão presente), mas [...] parte de uma formalização (um sistema presente) para dar lugar aos "restos" (indícios de limites, e portanto, de um passado que é produto do trabalho). (CERTEAU, 1982, 83).

Enfim, para a realização das entrevistas, gravadas em áudio, inicialmente foi preciso entrar em contato com a pessoa a ser entrevistada, explicar o objetivo da investigação, marcar um encontro para explicar melhor o projeto de pesquisa e a proposta metodológica, ou seja, a entrevista, assim este primeiro encontro também funcionava como um momento de familiarização do que seria feito, apresentar o termo de consentimento livre e entregar o roteiro com as perguntas elaboradas para a entrevista para que tomassem conhecimento, esta antecipação poderia ajuda-los a trazer algum material de suporte para auxiliar suas respostas e também para deixálos tranquilos durante o encontro.

Com a Assistente Social foram realizadas duas entrevistas, uma em 2010, período do meu mestrado ${ }^{13}$ (Apêndices A e F) e outra em 2016 (Apêndices B e G), esta última entrevista direcionou os questionamentos para a temática da educação no hospital. A Professora 1 cedeu as entrevistas (anexo $\mathrm{C} \mathrm{e} \mathrm{H}$ ) no intervalo das atividades de sala de aula, por isso, tivemos que realizar três sessões em três dias diferentes, no decorrer de um ano ${ }^{14}$. O contato com o ex-aluno, por morar no interior do Estado, foi praticamente todo a distância, com o uso de aplicativo de comunicação

\footnotetext{
${ }^{13}$ Essa entrevista não foi analisada na produção da dissertação, pois a opção na época não foi utilizar fontes orais no arcabouço de fontes no mestrado.

${ }^{14}$ As entrevistas com a Professora 1 aconteceram nos dias 24/08/2016, 09/03/2017 e 29/08/2017.
} 
ou e-mail, sendo que nos encontramos somente no dia da realização da entrevista (anexo D e K). As entrevistas, tanto com a mãe da ex-aluna (anexo E e J), como com a Professora 2 (anexo $\mathrm{C}$ e $\mathrm{I}$ ) foram realizadas num único encontro depois do contato inicial.

Após a finalização das entrevistas, estas foram transcritas e devolvida aos entrevistados que analisaram o conteúdo e depois devolveram com as indicações de correções. Todas as correções apontadas foram acatadas e alteradas de acordo com as solicitações, sendo que a Assistente Social e a mãe entrevistada foram as únicas que não solicitaram nenhuma adequação na transcrição. Finalmente, foi realizada uma última reunião para aprovação da transcrição com a assinatura do termo de autorização da entrevista, do uso do depoimento e imagem, para aqueles sujeitos da pesquisa que as disponibilizaram. No caso da autorização do uso de imagem, esta também foi assinada pela filha da mãe entrevistada, que foi ex-aluna da Educação Hospitalar do Hospital Pequeno Príncipe, pois sua imagem aparece em várias fotografias utilizadas na tessitura desta tese.

Para a realização da pesquisa e inclusive das entrevistas desta tese foi realizado o seu cadastro na Plataforma Brasil, sendo que a mesma consta como aprovada desde 16 de agosto de 2017. Esse cadastro é fundamental porque a Plataforma Brasil é uma base nacional e unificada de registros eletrônico de pesquisas criada pelo Governo Federal para sistematizar o recebimento dos projetos de pesquisa que envolvam seres humanos nos Comitês de Ética em todo o país. Ela permite que as pesquisas sejam acompanhadas em seus diferentes estágios - desde sua submissão até a aprovação final pelo Comitê de Ética e Pesquisa (CEP) e pela Comissão Nacional de Ética em Pesquisa (Conep), quando necessário. O registro da pesquisa na plataforma proporciona até o acompanhamento da fase de campo, o envio de relatórios parciais e dos relatórios finais das pesquisas que serão encaminhadas após sua conclusão, como o sistema também concede a apresentação de documentos em meio digital, proporciona inclusive que a sociedade possa acessar os dados públicos das pesquisas aprovadas ${ }^{15}$.

Segundo o Capítulo II, Art. 27, da Resolução n. 4.871 de 22/10/2001, os princípios éticos adotados para a produção científica e o desenvolvimento de atividade de pesquisa na Universidade de São Paulo (USP) asseguram que sejam utilizados

${ }^{15}$ Cf.: http://plataformabrasil.saude.gov.br/visao/publico/indexPublico.jsf Acesso em: 22/05/2019. 
métodos adequados e compatíveis com as normas éticas, os objetivos do projeto sejam cientificamente válidos, assim como a divulgação dos seus resultados sejam públicas, as conclusões sejam coerentes com os resultados, seja dado crédito a colaboradores e outros pesquisadores, assim como à USP, na apresentação e publicação dos resultados e conclusões e, em se tratando de pesquisa envolvendo pessoas, individuais ou coletivas, como foi o caso também desta pesquisa, sejam respeitados os princípios estabelecidos nas declarações e convenções sobre Direitos Humanos, na Constituição Federal e na legislação específica. (SÃO PAULO, 2001).

Além disto, foi realizado o levantamento, seleção e registros dos documentos oficiais relacionados ao campo educacional, direta ou indiretamente, que retratavam a discussão sobre a educação no período. Também houve a preocupação em diversificar as tipologias documentais de modo a perceber como a educação hospitalar era pensada e organizada a partir da atuação de profissionais ligados ao hospital, professores, médicos e autoridades públicas que estavam relacionados à problemática da educação hospitalar no final do século XX e início do XXI.

Com relação aos documentos históricos, Certeau (1982, p. 46) descreve duas problemáticas nas quais se fundamenta este projeto, a primeira

[...] examina sua capacidade de tornar pensáveis os documentos de que o historiador faz um inventário. [...] Esta perspectiva, cada vez mais comum hoje em dia, leva o historiador às hipóteses metodológicas de seu trabalho, à sua revisão através de intercâmbios pluridisciplinares, aos princípios de inteligibilidade suscetíveis de instaurar pertinências e de produzir "fatos" e, finalmente, à sua situação epistemológica presente no conjunto das pesquisas características da sociedade onde trabalha.

A segunda tendência privilegia "a relação do historiador com um vivido, quer dizer, a possibilidade de fazer reviver ou de "ressuscitar" um passado. Ela quer restaurar um esquecimento e encontrar os homens através dos traços que eles deixaram" (CERTEAU, 1982, 46).

Assim, fundada sobre o corte entre um passado, que é seu objeto, e um presente, que é o lugar de sua prática, a história não para de encontrar o presente no seu objeto, e o passado, nas suas práticas. Ela é habitada pela estranheza que procura, e impõe sua lei às regiões longínquas que conquista, acreditando dar-Ihes a vida. (CERTEAU, 1982, 46).

Nesta direção, Chartier (1996, p. 96) finaliza seu texto intitulado Escribir las práticas, chamando a atenção para o fato de que "a operação histórica, se trata de séries e indícios, assim como a realidade referencial que constituem os vestígios, a 
população de mortos - personagens, mentalidades ou preços - que a escrita historiadora pretende encenar" 16 .

Desta forma, o estudo da Educação na Associação de Proteção à Infância Dr. Raul Carneiro de Curitiba, busca em diversos documentos encontrar estes indícios ou vestígios que corroborem para trazer à vida essa "população de mortos" e auxiliem na produção historiográfica da temática e possam, a partir dos dois aspectos descritos por Certeau (1982, p. 107) para a escrita, exercer o papel de rito de sepultamento, exorcizando a morte, "introduzindo-a no discurso" como prerrogativa de seu sentido etnológico, assim como a sua função simbolizadora, que "permite a uma sociedade situar-se, dando-lhe na linguagem, um passado, abrindo assim, um espaço próprio para o presente", desta forma identificar os caminhos percorridos pelos hospitais infantis de Curitiba para a implantação de um atendimento educacional para as crianças hospitalizadas.

\footnotetext{
Certamente essa representação do fazer história [...] procede, incessantemente, à reparação das dilacerações entre o passado e o presente; assegura um "sentido" que supera as violências e as divisões do tempo; [...] Como afirmava Michelet, ela é o trabalho de vivos para "acalmar os mortos" e reunir toda uma espécie de aparatos em uma aparência de presença que é a própria representação. (CERTEAU, 2011, p. 51).
}

Assim, destaco dentre as quatro questões principais a serem observadas na produção historiográfica indicadas por Certeau, "uma historicidade da história, que implicava a ligação entre uma prática interpretativa e uma prática social" e que "a história oscila entre o real e o texto que organizava sua inteligibilidade". (VIDAL, 2011, p. 278).

Desta forma, o estudo sobre as ideias e ações que concorreram para a estruturação da educação hospitalar nos hospitais da Associação de Proteção à Infância Dr. Raul Carneiro e a influência da educação nas atividades desenvolvidas nos hospitais, além das fontes orais buscará suas fontes na Biblioteca Pública do Paraná e na biblioteca do próprio Hospital: relatórios de atividades (em tópicos e resumos), gráficos temporais/anuais das atividades desenvolvidas pelo Hospital; históricos da instituição; dados estatísticos de matrículas; legislação sobre educação hospitalar; relação de governadores e respectivos secretários de Estado da Educação do Paraná; livros comemorativos e memorialísticos; a dissertação de Muggiati (1989),

16 Tradução livre da autora. 
que descreve a implantação do Projeto Mirim de Hospitalização Escolarizada e carta à Assistente Social da Associação.

Também foram pesquisados os jornais curitibanos e nacionais que circularam de maneira mais constante no período estudado: Gazeta do Povo (1988-2003), Folha de Londrina (1988), Tribuna do Paraná (1988), Estado do Paraná (1988) e Livre Paraná (1994), Folha de São Paulo (1961), Última Hora do Rio de Janeiro (1961) e excerto do Diário Oficial do Estado do Paraná; além de leis e decretos da Secretaria de Estado da Educação do Paraná, do Ministério da Educação, dos Conselhos Nacional e Estadual de Educação, Convênio da Educação Hospitalar da Secretaria de Estado da Educação do Paraná e do Município de Curitiba, processos administrativos da Secretaria de Estado da Educação, bem como as revistas Vida Universitária - PUCPR (1988 e 1996) e da publicação dos Anais do 1 Encontro Nacional sobre o Atendimento Escolar Hospitalar (2000), assim como fontes secundárias que tratam da educação em outros estados e países.

Fonte amplamente utilizada pelos historiadores nas últimas décadas, o jornal é um locus privilegiado para os pesquisadores da educação perceber os meandros cotidianos dos processos educativos, educacionais ou escolares e no caso das questões relacionadas à saúde, isto se evidencia em vários estudos, entre outros os de Bertucci (2003, 2004), Ganz (1997), Marques (2003), Sigolo (1998). Como lembra Vieira, "o jornal - entendido como lugar de produção, veiculação e circulação dos discursos - assume uma função importante no processo de formação das representações sobre o mundo" (2007, p.16).

Segundo Pôrto (2007) apud Thiecker (2008), a partir de 1904, as fotografias começam a ser publicadas nos jornais diários, favorecendo que as notícias passem a ser propagadas em imagem, e, apesar, de algumas vezes, a fotojornalismo funcionar como ilustração, sua veiculação promoveu o aumento da tiragem da imprensa, assim como sua qualificação. Além disto, essas imagens contribuíram "para a construção de identidades sociais, raciais, políticas, étnicas, nacionais". Neste trabalho foram utilizadas imagens tanto da fotojornalismo, como componentes de álbuns de família dos sujeitos da pesquisa. A respeito dos álbuns de família, Kossoy (2014, p. 114) destaca que por meio deles "constata-se a ação inexorável do tempo e as marcas por ele deixadas" além de que "são estes fragmentos interrompidos da vida, que por vezes revemos, uma insuperável, por vezes constrangedora, fonte de recordação e emoção. 
São os documentos fotográficos também um insubstituível meio de informação". (KOSSOY, 2014, p. 115).

Foram ainda utilizados relatórios de atividades de professores que trabalharam nos hospitais pesquisados, dados estatísticos do censo escolar do Ministério da Educação (MEC) e da Secretaria de Estado da Educação do Paraná (SEED). Ainda foi realizado um estudo da materialidade da educação hospitalar, como as carteiras e outros materiais utilizados nos atendimentos pedagógicos nos hospitais.

A respeito da legislação, tento fundamentar a análise das leis, decretos e orientações legais na perspectiva indicada por E. P. Thompson $(1984 ; 1987)$ relacionando, algumas vezes, as leis com as relações sociais mais abrangente "nas quais elas estão inseridas", sendo que essas acabam colaborando em sua produção. (FARIA FILHO, 2011, p. 256), além do que "é verdade que, na história, pode se ver a lei a mediar e legitimar as relações de classes existentes" (THOMPSON, 1987, p. 358). Nas duas últimas décadas do século XX, alguns exemplos podem ser observados nas diversas mobilizações de diferentes grupos e movimentos sociais que participaram ativamente da elaboração e aprovação da Constituição Federal de 1988, do Estatuto da Criança e do Adolescente (ECA) aprovado no dia 13 de julho de 1990 e da Lei de Diretrizes e Bases da Educação Nacional (LDBEN) em 1996 ${ }^{17}$.

Com relação às categorias que sustentam os argumentos da tese, destaco a Escolarização, a Escolarização Hospitalar e a concepção de criança e infância.

Entendendo por Escolarização, como Faria Filho (2003), num duplo sentido, a instituição de procedimentos e políticas relacionadas "à "organização" de uma rede, ou redes, de instituições, mais ou menos formais, responsáveis seja pelo ensino elementar da leitura, da escrita, do cálculo e, no mais das vezes, da moral e da religião" e "o processo e a paulatina produção de referências sociais, tendo a escola, ou a forma escolar de socialização e transmissão de conhecimentos, como eixo articulador de seus sentidos e significados". (FARIA FILHO, 2003, p. 78).

A Escolarização pode ser relacionada aos "modos como o Estado quanto às maneiras como os grupos sociais organizam e produzem a escola como instituição social de controle das populações e de transmissão cultural”. Essa perspectiva perpassa a aceitação social da constituição do escolar como referência simbólica, "o que implica o jogo tenso de reinvenção das identidades sociais e das representações

\footnotetext{
17 Maiores informações sobre os movimentos sociais na busca dos direitos das crianças e adolescentes podem ser encontradas no Cap. 2.
} 
sobre o lugar social da escola". Desta forma, a escolarização do social, se liga à categoria cultura escolar porque concebe a descrição e análise "dos aspectos que caracterizam de maneira especial essas práticas educativas, tais como os tempos, os espaços, os sujeitos, os conhecimentos e as práticas escolares". (VIDAL \& BICCAS, 2008, p. 28).

Num sentido mais abrangente, o fenômeno da escolarização pode ser melhor entendido e dimensionado se considerarmos os dois últimos séculos da sociedade brasileira no que diz respeito aos "múltiplos significados e os diversos fatores intervenientes da radical mudança em nossa sociedade no que diz respeito à escola", afinal no início do oitocentos não existiam escolas e partimos de uma sociedade sem escolas para "a quase totalidade de nossas crianças na escola" no início do novecentos. (FARIA FILHO, 2003, p. 79).

Assim, parafraseando E. P. Thompson (1984.p.271) em seus estudos sobre
as transformações impostas à sociedade inglesa pela industrialização,
podemos dizer que, na transição de uma sociedade não escolarizada para
uma escolarizada, a tensão desta recai sobre a totalidade do social, não
deixando intocada nenhuma de suas diversas dimensões. Tal tensão pode
ser percebida não apenas naquilo que toca diretamente à escola e o entorno,
mas naquilo que de mais profundo há na cultura e nos processos sociais
como um todo: das formas de comunicação às formas de constituição dos
sujeitos, passando pelas inevitáveis dimensões materiais garantidoras da
vida humana e de sua reprodução, tudo isso modifica-se, mesmo que
lentamente, sob o impacto da escolarização. (FARIA FILHO, 2003, p. 81).

Concordo com Faria Filho, apoiado na fundamentação da história social, que o panorama da crescente valorização da escolarização e da escola ocorrem principalmente pela movimentação social que modifica a constituição do sujeito, sua vida e suas formas de conhecimento e aprendizagem, sendo que "a escola é tanto produtora quanto produto da sociedade como um todo", e a seleção do que interessa estudar "é como esse fenômeno se dá em suas múltiplas facetas em tempos e espaços determinados". (FARIA FILHO, 2003, p. 81).

Enfim, o que me interessa neste trabalho são as múltiplas realidades e envolvimentos da escolarização compreendida "a partir de uma história cultural"18 que quer lidar com as práticas e as representações dos sujeitos envolvidos nesse fenômeno" assim como "de uma história social preocupada com as consequências e as dinâmicas sociais" da escolarização observada nos últimos anos na sociedade brasileira. (FARIA FILHO, 2011, p. 252).

${ }^{18}$ Grifos do autor. 
Neste sentido, destaco que a categoria da Escolarização Hospitalar se insere numa dessas facetas onde tempo e espaço de aprendizagem são múltiplos e variados, pois passam a assumir a "produção de referências sociais", tendo na "forma escolar de socialização e transmissão de conhecimento" o "eixo articulador dos seus sentidos e significados" (VIDAL \& BICCAS, 2008, p. 28), afinal as Classes Hospitalares, a Educação Hospitalar, a Escola no hospital, o atendimento pedagógicoeducacional, a Hospitalização Escolarizada ou a Escolarização Hospitalar ${ }^{19}$ estão relacionadas a organização de redes mais ou menos formais de ensino e aprendizagem, ao mesmo tempo são produtoras de referências sociais que consideram a socialização e transmissão de conhecimentos como articuladoras de sentidos e significados (FARIA FILHO, 2003, p. 78).

A "segunda conotação de escolarização remete-nos à configuração e definitiva afirmação, entre nós, daquilo que Vincent, Lahire e Thin (2001) chamam de forma escolar, ou seja, de uma forma especificamente escolar de socialização da infância e da juventude". De acordo com esses autores, a disposição e a propagação da instituição escolar no século XIX ocorre inclusive com o aumento constante de seu prestígio para fora dos prédios escolares. (FARIA FILHO, 2003, p. 78).

Corroborando com essas afirmações, Faria Filho ainda destaca que "os tempos escolares são múltiplos e, tanto quanto a ordenação do espaço, fazem parte da ordem social e escolar", bem como são "pessoais e institucionais, individuais e coletivos". Na Escolarização Hospitalar tanto o tempo como o espaço também são abertos, múltiplos e variáveis, dependendo da especificidade e possibilidade dos estudantes e do hospital, com a possibilidade real de subversão à delimitação, controle, classificação em quadros de anos/séries, horários, relógios, campainhas, etc. Sendo, portanto, a "força educativa e sua centralidade no aparato escolar" (FARIA FILHO, 2003, p. 85) considerados mutáveis.

No caso das concepções de criança e infância, é importante entender que são variáveis e foram sendo modificadas ao longo do tempo. Portanto, é necessário diferenciar criança e infância, afinal os termos não são sinônimos, infância é uma

\footnotetext{
19 Há várias nomenclaturas com que diversos autores se posicionam quando tratam da Educação
} oferecida em hospitais. Maiores informações sobre esse assunto podem ser encontradas no Cap. 1. 
construção social, definida por critérios instituídos socialmente e criança é entendida como um ser biológico, representado por suas necessidades ${ }^{20}$.

De acordo com Gilberto Freyre, citado por Gouveia (2003, p. 195),

um projeto de construção de uma história da criança brasileira [é] marcada pela compreensão da existência de infância diversas, definidas pelos diferentes pertencimentos sociais, étnicos, redes familiares, religiosos, que Ihe fazem traçar um projeto marcado pelo caráter plural de infância e não falar da infância no singular. [...] Freyre revela que seu projeto tem em vista não a criança em sua singularidade, mas ao que ela anuncia e prenuncia do adulto, 0 adulto brasileiro, sua identidade.

De acordo com Martins, a partir da segunda metade do século XIX, existia uma preocupação crescente com a criança, por conta da "onda de humanitarismo e a formulação da crítica social pelo movimento filantrópico e pelos movimentos políticos de cunho socialista, mais atuantes na segunda metade do século" (2008, p. 138). No caso do Brasil, o início do novecentos do século XX foi marcado pelo cuidado com a saúde da criança, principalmente nos primeiros anos de vida, sobretudo pelos médicos brasileiros, "que reivindicavam um novo papel social como promotores da higienização, da boa formação física e mental das crianças" e, portanto, a educação das mães no cuidado higiênico de seus filhos passou a ser um projeto social fomentado pelos médicos brasileiros deste período. (AVANZINI, 2011, p. 13).

Segundo Souza (1998), no final do oitocentos e início do novecentos do século $\mathrm{XX}$, as atenções dirigidas à infância brasileira eram norteadas pelo projeto de modernização do Brasil, com o intuito de higienizar, sanear, urbanizar e industrializar na perspectiva do favorecimento do progresso nacional, sendo que o papel da família, no caso a mãe, é considerada fundamental para chegar a esse objetivo. De acordo com Camara (2004, p. 163), nas primeiras décadas do século XX, há diferentes representações de infância consideradas desejadas para a formação do "novo cidadão" 21 , sendo "associada ao referencial de criança saudável, ajustada e em consonância com a perspectiva de civilização pretendida para o país" o principal desejo desse período. Enfim, o padrão de infância pretendido deveria se conformar "aos princípios de higiene e aos referenciais científicos que definiram pelos vieses da psicologia e da puericultura, os parâmetros a partir dos quais se forjaram as

${ }^{20}$ Maiores informações sobre a história da criança e infância veja ARIÈS, 1981; DEL PRIORE, 2000; DEMARTINI, 2001; FERREIRA e GONDRA, 2007; GOUVÊA, 2003; HEYWOOD, 2010; KUHLMANN JR., 2000; 2004; VENÂNCIO, 2010.

${ }^{21}$ Grifos da autora. 
idealizações mental, física e pedagógica para a infância do país em mudança". (CAMARA, 2004, p. 171). Essa infância desejada e idealizada seria "a criança/aluno disciplinado", principalmente no universo escolar que teria o objetivo de "encaminhar, moldar e construir hábitos saudáveis" (CAMARA, 2004, p. 172). Neste sentido, a autora identifica a "dimensão de infância escolarizada", como aquela onde "as "crianças" seriam pensadas, escutadas, prescritas e silenciadas no espaço da escola", que por sua vez, desempenharia a prevenção vedando os perigos originados dos vícios diários a que as crianças estariam submetidas caso ficassem nas ruas ou sem supervisão escolar. (CAMARA, 2004, p. 173).

Desta forma, surge a ideia de uma infância "desprezada", "doente", "estigmatizada", "triste", totalmente contraditória ao pressuposto desejado "da criança protegida, saudável, assistida, alegre, robusta" e educada pela escolarização. (CAMARA, 2004, p. 179). Para essa criança desvalida e excluída do universo escolar emerge a filantropia e o assistencialismo ${ }^{22}$ que norteiam as concepções de infância e criança a partir da década de 30 do novecentos.

No texto da primeira Convenção dos Direitos da Criança de 1924, o foco era dado à proteção da criança e aos deveres do adulto em relação a sua proteção física e moral. Em 1959, à posse de direitos foi aprovada na segunda Convenção e aprovada pela Organização das Nações Unidas, explicitamente nos artigos referentes aos "direitos de proteção, em nome de um desenvolvimento saudável de seres "imaturos"”. (REDE MARISTA DE SOLIDARIEDADE, 2012, p. 32). No Brasil, a validação dos princípios da Convenção ocorreu somente trinta anos depois, em 1990, ano da promulgação do Estatuto da Criança e do Adolescente (ECA), que mudou o paradigma do conceito de criança e infância, compreendendo não somente a criança, mas também o adolescente como sujeitos de direitos, assim como propagado na Convenção de 1959.

\footnotetext{
Ancorada a princípios constitucionais como a democracia participativa e a descentralização político-administrativa e consonante com o conjunto de documentos internacionais da época, o Estatuto da Criança e do Adolescente, Lei 8.069 de 1990, emerge com uma radical mudança de concepção sócio-jurídica da infância e da juventude: a afirmação histórica de crianças e adolescentes como sujeitos de direitos. (REDE MARISTA DE SOLIDARIEDADE, 2012, p. 48).
}

\footnotetext{
22 Para maiores informações sobre filantropia e assistencialismo veja: KUHLMANN JR., 2004 e LEVY, 1996; MARCÍLIO, 2006.
} 
De acordo com o artigo 6ำ do Estatuto serão considerados os "fins sociais a que [o ECA] se dirige, as exigências do bem comum, os direitos e deveres individuais e coletivos, e a condição peculiar da criança e do adolescente como pessoas em desenvolvimento". (BRASIL, 1990). Esse reconhecimento da criança e do adolescente como indivíduos em desenvolvimento indica a valorização propalada também no artigo 227, da Constituição brasileira, promulgada em 1988 e que assegura

à criança, ao adolescente e ao jovem, com absoluta prioridade, o direito à
vida, à saúde, à alimentação, à educação, ao lazer, à profissionalização, à
cultura, à dignidade, ao respeito, à liberdade e à convivência familiar e
comunitária, além de colocá-los a salvo de toda forma de negligência,
discriminação, exploração, violência, crueldade e opressão. (BRASIL, 1988).

Desta forma, a política de atendimento passa a ser concebida com base nos princípios constitucionais, considerando esses indivíduos como sujeito de direitos garantidos juridicamente, legalmente, portanto, passando a ter acesso a um conjunto de políticas públicas articuladas a um sistema de atendimento. Dentre essas políticas e atendimentos, da Educação em hospitais passou a ser assegurada.

A tese foi estruturada em quatro capítulos, o primeiro intitulado "O desenvolvimento da Educação Hospitalar na Europa, África do Sul, América e no Brasil”, tem por objetivo apresentar e analisar a história da Educação Hospitalar na Europa, África do Sul, América e no Brasil. Ao realizar a historicidade das instituições hospitalares de vários países, no que se refere ao atendimento e experiências educativas voltadas para as crianças, por eles criadas e empreendidas, visou construir um mapa para ajudar a compreender quando, onde e como vem sendo empreendido este tipo de preocupação com as crianças que ficavam hospitalizadas e sem terem condições de frequentar a escola.

No segundo capítulo, com o título "A Educação Hospitalar e a Educação, onde se insere essa novidade?", são apresentados os movimentos, o Estatuto da Criança e Adolescente (ECA), a mudança nos direitos das crianças e adolescentes. Discute ainda o processo de municipalização do Ensino no Paraná e as implicações para a Educação Hospitalar, sendo que esta parte se desdobra nas discussões sobre a Educação Hospitalar e Educação a respeito dos aspectos legais pertinentes ao Estado do Paraná, tentando responder onde se insere essa novidade.

O capítulo três, intitulado "Sujeitos e ações efetivas da Educação Hospitalar paranaense", busca compreender e analisar a implantação, efetivação e o funcionamento do projeto de Educação Hospitalar tentando entender a questão do 
pioneirismo da Educação Hospitalar num hospital infantil em Curitiba - PR e o "Projeto Mirim de Hospitalização Escolarizada" por meio dos sujeitos, professores, crianças e família. Focaliza o trabalho da Assistente Social e a escolarização no atendimento hospitalar apresentando os lugares, espaços e a materialidade da Educação Hospitalar. Busca apresentar a efetivação do projeto de Educação Hospitalar, seus professores, crianças e famílias, traz os olhares das primeiras professoras em relação a Educação Hospitalar e encerra dando visibilidade aos estudantes e famílias, assim como evidenciando as experiências destes sujeitos na Educação Hospitalar.

Finalmente o quarto capítulo, com o título "A experiência paranaense em Educação Hospitalar: caminhos e descaminhos", apresenta e analisa as características do atendimento no âmbito estadual e municipal, bem como as rupturas e os descaminhos no atendimento da Educação Hospitalar. 


\section{CAPÍTULO 1 - O DESENVOLVIMENTO DA EDUCAÇÃO HOSPITALAR NA EUROPA, ÁFRICA DO SUL, AMÉRICA E NO BRASIL}

Como historiador, não tenho como definir o que é a "verdade histórica", mas posso estimular a reflexão sobre a multiplicidade de interpretações possíveis. (FICO, 2012, p. 48).

O objetivo deste capítulo é conhecer e compreender os processos de desenvolvimento da Educação Hospitalar na Europa, África do Sul, América e no Brasil, buscando identificar onde se apresentam estas experiências, quais as concepções dos atendimentos implementados. Aborda também a historicidade da Educação Hospitalar no Brasil, levando em consideração as especificidades dos diferentes estados da federação brasileira.

Para este capítulo foram utilizados dois recortes temporais: o primeiro aborda a Educação Hospitalar na Europa e nas Américas, a partir de finais do século XIX e início do século $X X$, período em que são registradas as primeiras experiências de Educação em hospitais. Barros (2011), Polaino-Lorente e Lizasoáin (1992) inferem sobre a possibilidade da existência de um tipo de atendimento de escolarização iniciado no Coast Hospital da Dinamarca em 1875 e no Hospício Nacional de Alienados no Rio de Janeiro em 1902. Há ainda registros que de no período de 1902 a 1950 ocorreu a implantação de atendimentos de Educação Hospitalar em São Paulo, Rio de Janeiro, Viena, Johannesburg e Paris; o segundo recorte temporal toma a especificidade da Educação Hospitalar brasileira, entre 1950 e 1988, balizado pela fundação da Educação Hospitalar, reconhecida como a mais antiga ainda em funcionamento, no Hospital Jesus, no Rio de Janeiro, em 1950. Em 1988, é o período do ano da implantação da Educação Hospitalar no Estado do Paraná, que é o objeto de análise desta tese.

A apresentação do desenvolvimento da educação hospitalar na Europa, África do Sul, América e no Brasil foi norteada pelo seguinte questionamento: quais os modelos educacionais propostos no atendimento das crianças e dos adolescentes? Os modelos educacionais internacionais circularam e/ou foram implementados no Brasil? Se sim, em que estados brasileiros? Os modelos educacionais criados e implementados em hospitais traz algum tipo de inovação para a educação regular nos países da Europa, África do Sul, América e no Brasil? Quais as questões políticas e pedagógicas que podem ser observadas na Educação Hospitalar na Europa, África 
do Sul, América e nos diferentes estados brasileiros? Existe algum trabalho da equipe multidisciplinar/interdisciplinar na Educação Hospitalar? Caso positivo, como é o trabalho desta equipe? Quais as relações e entrelaçamentos entre seus diferentes membros? Quais os materiais educacionais e pedagógicos utilizados na Europa, África do Sul, América e nos diferentes estados do Brasil na Educação Hospitalar? De que modo se apresenta a história da Educação Hospitalar no Brasil? Quais são os diferentes estados brasileiros que iniciam a Educação Hospitalar? E finalmente, quando a Educação Hospitalar surge nesses estados brasileiros?

O capítulo está dividido em três partes: A Educação Hospitalar na Europa, África do Sul, América e Brasil; a Educação Hospitalar nos diferentes estados brasileiros; e a especificidade legal da Educação Hospitalar brasileira.

\subsection{A EDUCAÇÃO HOSPITALAR NA EUROPA, ÁFRICA DO SUL, AMÉRICA E BRASIL}

O início do século $X X$ se caracterizou por intensas alterações no mundo ocidental. A Primeira Guerra Mundial (1914-1918), associada a crises econômicas, uma nova ordem colonial, reestruturações territoriais e políticas das nações europeias e a grande depressão de 1929 demarcaram algumas das mudanças do período (HOBSBAWM, 1995). A Educação Hospitalar surge em vários países europeus e do mundo nestes contextos de guerras e de reorganizações de fronteiras.

Para apresentar a Educação Hospitalar na Europa no que se refere a história, a especificidade deste atendimento e algumas experiências de práticas pedagógicas, utilizo os trabalhos dos autores: Vasconcelos (2006); Polaino-Lorente e Lizasoáin (1992); Garcés (2008); Barros (2009); Ibarra, Guimarães e Dias (2008) e Araújo (2017).

Segundo Polaino-Lorente e Lizasoáin (1992, p. 55) e Araújo (2017, p. 80), a Dinamarca se destacou como o primeiro país europeu a investir na educação de crianças hospitalizadas, isto teve início no Coast Hospital, que implantaram o atendimento em 1875 para as tuberculosas. O professor contratado foi financiado pelo próprio hospital, pois foi apenas em 1965, que o Ministério da Educação estabeleceu que todas as crianças em hospitais deveriam receber educação escolar. $\mathrm{Na}$ bibliografia consultada há pouca referência sobre este trabalho, mas certamente é muito importante pela inovação. $O$ fato da Dinamarca ter iniciado este tipo de 
atendimento de educação em hospitais no século XIX e ter dado continuidade nas décadas posterior, contribuiu para que em 1992 Dinamarca contasse, com professores regulares em 80 hospitais, assim como com pedagogo responsável por realizar atividades lúdicas com crianças dos 20 departamentos de pediatria existentes no país.

Depois de mais de 40 anos, em 1917 foi registrada outra experiência em Educação em hospitais na Áustria, que de acordo com Polaino-Lorente e Lizasoáin (1992, p. 53), foi o primeiro país da Europa a implantar uma Escola Hospitalar por intermédio de iniciativa de pediatras e pedagogos, que estabeleceram a necessidade da cooperação médico-pedagógica para ajudar as crianças e adolescentes internados na Clínica Universitária Infantil de Viena. A experiência acabou se espalhando por vários outros hospitais e em 1992, havia treze filiais da Escola Hospitalar de Viena em diversos hospitais com mais de 60 professores que seguiam os currículos oficiais e ofertavam educação para crianças entre 6 e 15 anos no país.

Em 1923 foi implantado na Johannesburg Hospital School na África do Sul o atendimento de Educação Hospitalar. Segundo dados da instituição ${ }^{23}$, esse atendimento começou quando um grupo de voluntários que visitavam crianças doentes nas enfermarias, reconheceram que essas crianças precisavam continuar sua educação, o que marcou a direção informal realizada por voluntários durante muitos anos na escola deste hospital, sendo que, em 1960, o Departamento de Educação de Johannesburg assumiu a escola e nomeou professores qualificados. Carstens (2004) indica que a escola fica no 9a andar do bloco amarelo do Charlotte Maxeke Hospital, sendo que atualmente permite que mais de 100 crianças completem sua escolaridade, de acordo com o currículo nacional.

Apesar dessas três experiências relatadas na Dinamarca, Áustria e África do Sul, segundo diversos autores, dentre eles Vasconcelos (2006), Oliveira (2010, p. 24), Ibarra, Guimarães e Dias (2008, p. 2), Ferreira (2015, p. 63), 1935 é considerado como o marco inicial do atendimento em escolarização de crianças com doenças contagiosas e inadaptadas por Henri Sellier em Paris, França. Esse serviço tinha o objetivo de "suprir as dificuldades escolares de crianças tuberculosas". Em 1939 foi criado o Centro Nacional de Estudos e de Formação para a infância inadaptada em Suresnes-Paris com o objetivo de formar professores para o atendimento hospitalar,

${ }^{23}$ Disponível em: http://www.johannesburghospitalschool.co.za/meet-the-team/ Acesso em 04/11/2017. 
assim como o cargo de professor hospitalar pelo Ministério da Educação francês. De acordo com Polaino-Lorente e Lizasoáin (1992, p. 55), a atividade de ensino de crianças internadas desde a década de 1950 está bem desenvolvida na França, sendo que, para os professores atuar neste contexto, precisam realizar uma formação especializada geral e específica de 3 anos.

As atividades pedagógicas nos hospitais franceses se dividem em aprendizagens escolares no período da manhã e atividades lúdicas no período da tarde (desenhos, leituras e filmes). O atendimento pedagógico é individual, e para isso é preciso que os professores elaborem uma ficha com o objetivo de avaliar o nível das crianças, a aferição é também sempre feita pelo professor. Entretanto, se a criança ficar mais de um mês internada é preciso realizar um contato mais frequente entre o colégio da criança e a escola do hospital. É solicitado ao colégio o programa curricular, o nível de conhecimento da criança, as dificuldades que o aluno apresenta, etc. e assim que a criança receber alta, a escola do hospital encaminha ao colégio o programa seguido durante a hospitalização e os resultados alcançados, assim como outras observações importantes (POLAINO-LORENTE e LIZADOÁIN, 1992, p. 56).

Após a II Guerra Mundial, a partir de 1947 ocorreu uma expansão da Educação Hospitalar na Europa, podemos citar o exemplo da Espanha, em que experiências de educação em hospitais ocorreram nas cidades de Madri, Barcelona, Manresa, Sevilla, Valência, Albacete, Murcia e Navarra. (GARCÉS, 2008; POLAINO-LORENTE e LIZADOÁIN, 1992). Os atendimentos nos hospitais nestas diversas cidades atenderam ora em classes hospitalares, ora em salas de jogos. Em Madri o foco do atendimento eram as atividades manuais realizadas por meio de jogos ou recortes, em Barcelona, a Educação no hospital era responsabilidade da Educação Especial, sendo o objetivo deste atendimento levar em consideração o ponto de vista humano, social e psicológico do alunado. Em Manresa, além das atividades lúdicas, havia atendimentos voltados aos conteúdos escolares com atendimento individualizado dos estudantes. Em contrapartida, o foco das aulas de saúde do hospital de Sevilha era direcionado (o foco) para pais e crianças. Em Valência e Albacete ocorriam atividades lúdico-recreativas, como animação sociocultural para crianças com internamentos curtos $^{24}$, enquanto que para a hospitalização em períodos maiores, os professores voluntários davam aulas dentro do hospital. Em Murcia, o destaque ficava para a

24 São consideradas internações de curta duração as que duram menos de 07 dias. (LIZASOÁIN RUMEU; OCHOA LINACERO; SOBRINO MORRÁS, 1999, p. 369). 
formação dos professores que em sua maioria eram formados no Ensino Geral Básico seguidos pelos formados em Pedagogia. O tempo de efetivo trabalho nos hospitais era de 6 a 7 horas por dia e a relação era de 20 estudantes por professor. Finalmente, em Navarra a educação hospitalar era em tempo integral tanto para crianças como para adultos, mas não era centrada no ensino, as atividades tinham por objetivo orientar, dialogar, ocupar e fazer companhia.

De acordo com Zapata, Arboleda e Bustamante (2014), são poucos os hospitais da Espanha que ainda não implantaram o atendimento escolar em suas instalações. Somente na província de Andalucia, em 2014, já havia 43 classes hospitalares implantadas, para atender crianças de 3 a 16 anos. Outras classes também foram implementadas em várias outras cidades da Espanha. (ARAÚJO, 2017, p. 85).

Segundo Menezes (2018, p. 298) essa difusão expressiva do atendimento educacional aos estudantes em tratamento de saúde na Espanha se fundamenta "em leis e regulamentos nacionais e supranacionais, vigentes naquele país" que garante "a continuidade da escolarização dos estudantes em tratamento de saúde nos hospitais" vinculado à escolarização obrigatória.

Em Belgrado, na lugoslávia, havia escolas nos hospitais desde 1950, e lá os professores do hospital se preocupavam com o desenvolvimento psicológico, emocional e social das crianças hospitalizadas, sendo que muito hospitais do país ofereciam educação pré-escolar e escolar para as crianças. Os professores da préescola eram os principais responsáveis pelas atividades recreativas dos hospitais, enquanto os professores de educação básica ${ }^{25}$ ensinavam de acordo com uma adaptação do currículo regular dos colégios, levando em consideração as necessidades de cada estudante (POLAINO-LORENTE e LIZADOÁIN, 1992, p. 62).

No Reino Unido, a partir de 1959 as crianças internadas receberam atividades educativas e lúdicas (POLAINO-LORENTE e LIZADOÁIN, 1992, p. 57). Em 1961 foi fundada a National Association for the Welfare of Children in Hospital (NAWCH), que durante 25 anos investiu neste tipo de atendimento, o que a habilitou, em 1984, encaminhar uma carta abordando questões importantes sobre as crianças hospitalizadas ao Parlamento Europeu. Esta carta, após debates e inclusões tornouse em maio de 1986 a Carta Europeia de Direitos das Crianças Hospitalizadas

25 Essa educação básica do texto do Polaino-Lorente e Lizadoáin (1992) deve ser entendida como Ensino Fundamental e não como entendemos a Educação Básica no Brasil que segundo a LDBEN nº 9 394/1996 inciso I do art. 4º é organizada da seguinte forma: a) pré-escola; b) ensino fundamental; e c) ensino médio. 
(POLAINO-LORENTE e LIZADOÁIN, 1992, p. 57 e 58). Em 1988, em Leiden, foi também aprovada pela Associação Europeia para as Crianças Hospitalizadas (EACH) (LEVY, 1996, p. 1).

Apesar da educação hospitalar ser um direito garantido a todas as crianças britânicas, em idades entre 5 e 16 anos, menos da metade das internadas recebiam algum tipo de atendimento recreativo e somente $30 \%$ destas eram realizadas por profissionais devidamente formados e remunerados. Possivelmente, este pode ser um dos motivos que levou, em 1985, a criação, em Newcastle, de um serviço para coordenar todas as atividades de educação hospitalar existentes. Vários problemas foram encontrados, dentre os principais, se destacam as diferenças nas idades das crianças atendidas, a capacidade e o período de permanência das hospitalizadas, o que levou à categorização dos atendimentos aos estudantes, entre os que ficam por tempo internados e ou com internações recorrentes; os que ficam por uma curta estadia; e, as saudáveis que ingressam por alguma intercorrência e ou urgência.

Em 1992, nos hospitais ingleses, havia três professores encarregados pela educação de 24 crianças sendo que, normalmente, cada professor ficava responsável por pacientes de uma mesma faixa etária e ensinavam uma mesma matéria, com um trabalho semelhante ao realizado na escola de origem. (POLAINO-LORENTE e LIZADOÁIN, 1992, p. 59). Segundo Barros (2009, p. 285) tinham 30 escolas hospitalares no Reino Unido em 2008.

Com relação à Alemanha, no início da década de 1920, um grupo de pediatras já apontavam a necessidade de investir na educação e na escolaridade dos pacientes pediátricos. No entanto, somente no final da década de 1960, que alguns pediatras e professores conseguiram implantar escolas hospitalares. A expansão nas décadas seguintes foi grande, em 1992, a maioria dos 400 hospitais infantis já contava com um adequado sistema escolar vinculado ao sistema de escolas especiais. Na maioria das vezes, essas escolas hospitalares são independentes do hospital, entretanto, tem sempre a obrigação de colaborar intensamente com médicos e enfermeiras. Normalmente as aulas aconteciam em grupos, o currículo escolar da escola de origem crianças era o foco principal das atividades desenvolvidas, abordavam as matérias básicas, assim como jogos organizados e terapêuticos. (POLAINO-LORENTE e LIZADOÁIN, 1992, p. 53).

Na Alemanha a educação hospitalar é dividida, o Estado assume o pagamento dos profissionais e as localidades devem assegurar os espaços físicos, ou seja, a 
infraestrutura e os materiais pedagógicos para o desenvolvimento das atividades. $O$ Método de ensino na Educação Infantil Hospitalar é o Montessori, indicando as especificidades tanto da materialidade física quanto pedagógica para a implantação nestas instituições de saúde.

Na Noruega, a educação hospitalar está regulada por uma série de leis. As responsabilidades são compartilhadas entre os Ministérios da Educação e o da Saúde. A partir de 1969, as atividades educacionais nos hospitais noruegueses aumentaram tanto quantitativamente quanto qualitativamente. Dentre as diretrizes governamentais favoráveis às crianças hospitalizadas destaca-se "que los hospitales están obligados a disponer y facilitar espacios y materiales para a estimulación de las actividades y los aprendizajes de los niños de diferentes edades"26" (POLAINOLORENTE e LIZADOÁIN, 1992, p. 60). Por conta disto, em 1992, havia 177 hospitais com 50 professores de pré-escola e 155 da educação básica trabalhando em tempo integral.

Polaino-Lorente e Lizasoáin (1992, p. 57) indicam que na Hungria, desde a década de 1970, as atividades pedagógicas aconteciam nos 650 leitos do Hospital Infantil Miskole. A formação dos pedagogos que trabalhavam neste hospital era da educação pré-escolar e ou da educação especial, o que se destaca em relação aos outros países. Somando-se a essa questão, um dos objetivos da Educação Hospitalar para as crianças que ficavam um grande tempo internadas seria o ensino das matérias escolares.

A partir de 1975 há discussões sobre a Educação Hospitalar tanto na Suíça como na Turquia. Na Suíça, ocorreu o primeiro curso anual de pedagogos hospitalares, visando à preparação para a atuação educacional no hospital. Esta formação era oferecida por uma associação de pedagogos hospitalares. Em 1992, havia aproximadamente 60 professores e dependendo da vinculação do profissional poderia haver variação no período e horário de trabalho, bem como a remuneração. As instituições responsáveis por esses profissionais eram o Departamento da Educação, a Saúde e/ou instituições privadas. Os professores hospitalares na Suíça são considerados membros do hospital e em equipe com os médicos, assistentes sociais e psicólogos recebem informações sobre as crianças hospitalizadas em reuniões organizadas para este fim. $\mathrm{Na}$ educação pré-escolar eram realizados

26 - Que os hospitais estão obrigados a dispor e facilitar espaços e materiais para a estimulação das atividades e as aprendizagens das crianças de diferentes idades (Tradução livre da autora). 
trabalhos manuais e jogos. Na educação básica, os professores trabalhavam principalmente as matérias escolares mais importantes.

$\mathrm{Na}$ Turquia, a avaliação dos atendimentos em educação hospitalar não chegou a um nível satisfatório, mas progressos eram observados a cada ano, sendo que no Departamento de Pediatria da Universidade de Hacetteppe, em Ankara, havia em 1992, um estudo piloto sobre um programa educativo de preparação para a hospitalização infantil.

Na Suécia, uma lei promulgada em 1977, estabeleceu o direito para todas as crianças hospitalizadas a ter acesso a jogos terapêuticos. As atividades pré-escolares e recreativas dos hospitais recebem o nome de Terapia Recreativa, assim o trabalho educativo e sociológico dos professores deveria ter uma meta terapêutica. (POLAINOLORENTE e LIZADOÁIN, 1992, p. 60).

Somente na década de 1980 se implantou ou se recomendou a Educação Hospitalar em outros países europeus, como na Itália, que estabeleceu inicialmente no Bambino Gesú Hospital, em Roma, que tinha por objetivo estabelecer entretenimento e formação específica às crianças hospitalizadas (POLAINOLORENTE e LIZADOÁIN, 1992, p. 59). Depois de dez anos de implantação do serviço, o tempo dos atendimentos passou a acontecer em período integral.

Em 1984, foi recomendado um programa educacional para as crianças hospitalizadas por meio da sociedade "Our Children" na República da Croácia. (ARAÚJO, 2017, p. 82). Em 1988, em Leiden, na Holanda, foi realizada a reunião da “European Association for Children in Hospital', onde ocorreu a reformulação da Carta Europeia dos Direitos da Criança Hospitalizada, que passou também a assegurar que a Educação Hospitalar deveria ser realizada por uma equipe de profissionais capacitados. Também em 1988, aconteceu na Eslovênia, o 1ํ Seminário Europeu de Educação e Ensino de Crianças Hospitalizadas, onde despontou a ideia a respeito da criação de uma associação europeia de pedagogos hospitalares, a "Hospital Organisation of Pedagogues in Europe (HOPE)", com os objetivos gerais de

promover o desenvolvimento da pedagogia hospitalar através da cooperação entre os países europeus, atuar como mediadora entre os profissionais da pedagogia hospitalar, promover investigações e publicações relacionadas à pedagogia hospitalar, oferecer e trocar informações através de cartas e organização de seminários e congressos, e unir esforços de todos os países europeus para a propagação da pedagogia hospitalar. (ARAÚJO, 2017, p. 84). 
Dentre as ações desenvolvidas pela Associação, em 2000, num dos congressos organizados pela própria HOPE em Barcelona, "foi apresentada a Carta Europeia sobre o Direito à Atenção Educativa das crianças e adolescentes enfermos". (ARAÚJO, 2017, p. 84). Finalmente, na Finlândia, por meio de trabalhos apresentados no 6th Congresso of HOPE on Hospital Education, realizado em Tampere, em junho de 2008, foi possível evidenciar que no país havia naquele ano 33 escolas hospitalares. (BARROS, 2009, p. 280).

O surgimento da Educação Hospitalar nos países da América ocorre mais tardiamente que nos outros países do mundo, sendo que é possível identificar a existência de educação hospitalar em países como Brasil, EUA, Peru, Chile, Colômbia, Argentina, México, Costa Rica, Guatemala, El Salvador, Honduras e Venezuela. Na maioria dos casos, os objetivos dessa escolarização era contribuir com o processo de hospitalização, favorecer o internamento com momentos alegres e proveitosos e finalmente, proporcionar a continuidade dos estudos escolares (FERREIRA, 2015, p. 76).

No caso dos EUA, o sistema educacional inseriu em 1961 na cidade de Nova York "um grupo de professoras encarregadas de ensinar hospitalizados, de seis a 18 anos e que estejam seriamente doentes", de acordo com dois jornais brasileiros, as atividades dessas professoras seriam aplicar provas semanais e exames no final do ano, os estudantes, por sua vez se iam para as aulas em "cadeiras ou camas de rodas”. (ÚLTIMA HORA, 25/09/1961, p. 9; ÚLTIMA HORA, 26/09/1961, p. 10; DIÁRIO DO PARANÁ, 28/09/1961, p. 2).

A fotografia da figura 1 aparece no Jornal Última Hora, de 1961 e registra o atendimento pedagógico oferecido pelas professoras às crianças de Nova York. Na fotografia, há uma mulher, que ao que parece é a professora, vestida com uma roupa clara, com uma tiara na cabeça e segurando uma folha. Ela está em pé com uma folha nas mãos, que pode ser uma atividade e a frente de um grupo de seis crianças que estão em leitos, sendo que três dessas crianças estão com as mãos levantadas, talvez esperando para se posicionarem. Outras três crianças observam. A expressão das duas únicas crianças voltadas para o fotógrafo que registra a imagem é reflexiva, como se estivessem tentando assimilar, compreender ou entender o que lhes estava sendo apresentado, talvez algum conteúdo, conhecimento ou questionamento. 
Figura 1 - Educação no hospital em Nova York - EUA.

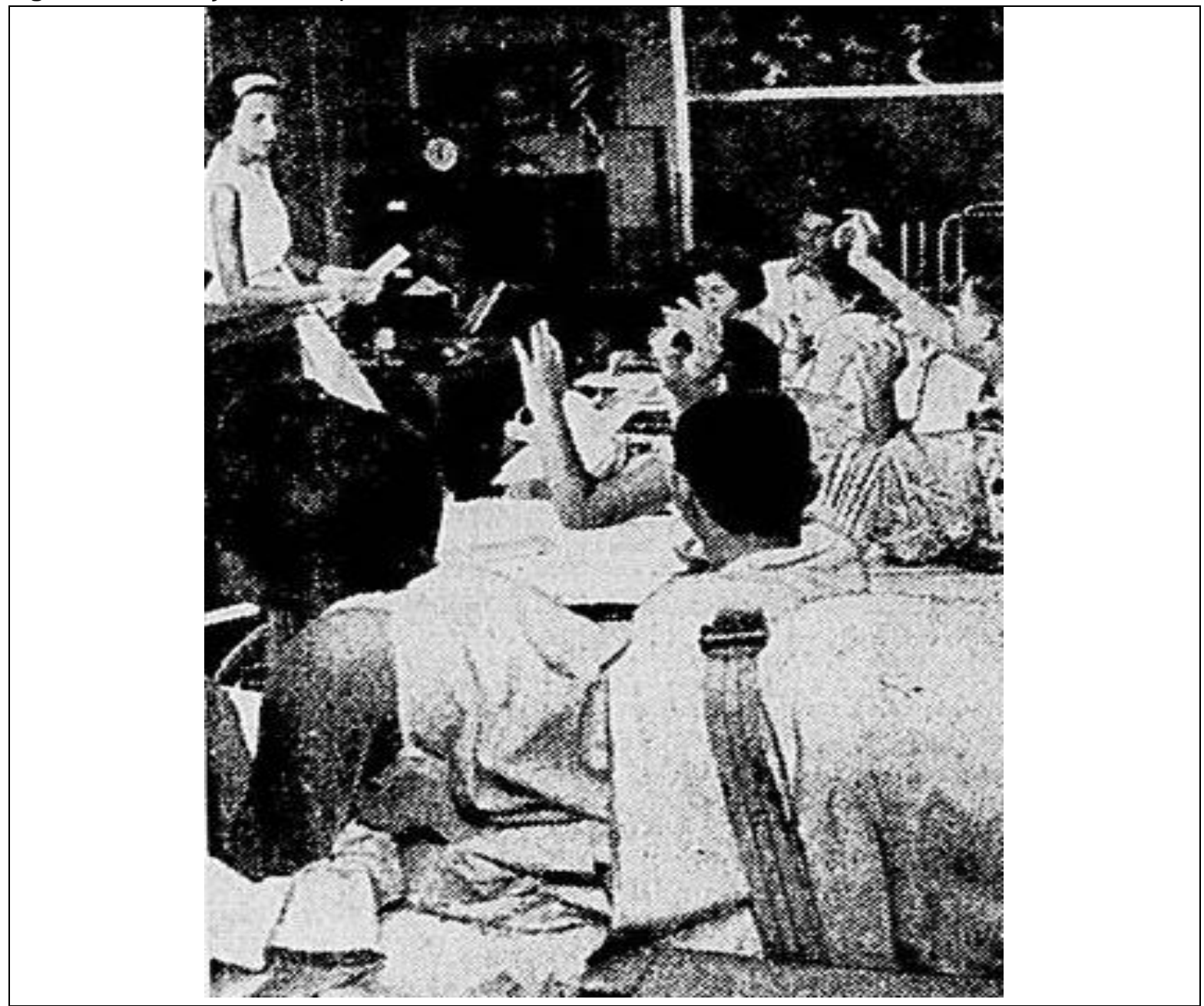

Fonte: ÚLTIMA HORA, 25/09/1961, p. 9.

A professora está olhando para as crianças e parece falar algo pelo posicionamento de sua boca que está entreaberta. Por falta de nitidez na imagem não é possível distinguir aspectos do quarto, mas ao que parece é uma enfermaria ou espaço grande, pois coube uma quantidade razoável de leitos onde as crianças estão sentadas ou deitadas, é possível observar que logo no primeiro plano da imagem há uma criança que está de bruços, coberta até a cintura e olhando fixamente para algo bem a sua frente e não para a professora. Ao fundo da imagem, há outro adulto sentado, não sendo possível distinguir seu sexo ou função, poderia ser um médico, (uma) outra professora ou ainda um estudante maior, visto que na matéria do Jornal há a indicação do atendimento ser ofertado até para "os hospitalizados" com 18 anos.

O fato da mesma imagem e matéria se repetirem e dois jornais diferentes, um do Rio de Janeiro e outro de Curitiba, também em dias muito próximos, 25 e 28, no final do mês de setembro de 1961, é algo que instiga a curiosidade em relação à 
intencionalidade da notícia que foi internacionalmente divulgada. Infelizmente não conseguimos elucidar esta questão. No entanto chama a atenção que estes tipos de informação sobre a efetivação do atendimento da educação hospitalar só tiveram divulgação e visibilidade nos Estados Unidos da América, na década de 1970 quando é publicada a lei que se ocupa com a educação para as crianças em tratamento de saúde.

A lei 94-142, em questão, denominada "The Education for All Handicapped Children Act', era ligada à Educação Especial e tinha três fundamentos conceituais que indicavam a gratuidade e adequação da educação pública com um "programa de educação individualizado" realizado em "ambiente educacional menos restritivo possível". Esses fundamentos efetivaram legalmente que as escolas americanas deveriam também ofertar "uma educação apropriada para as crianças em tratamento de saúde", pois "a educação especial inclui também a instrução em hospitais e instituições para atender as necessidades das crianças que delas necessitam". (ARAÚJO, 2017, p. 82).

Após essa determinação legal, somente em 2000, a Academia Americana de Pediatras se manifestou por meio do Comitê de Saúde Escolar e indicou três possibilidades para a efetivação e acessibilidade da educação para as crianças e adolescentes que estavam incapacitadas de frequentarem as escolas regulares por conta de tratamentos de saúde. Segundo eles, as crianças e adolescentes podiam receber configurações alternativas de educação desenvolvidas em centros de reabilitação, hospitais ou até mesmo em casa, sendo que era de responsabilidade da escola de origem da criança/adolescente organizar os programas adaptados às suas possibilidades e necessidades durante o tempo de seu afastamento, considerando que eles deveriam retornar o quanto antes às escolas de origem. (PEDIATRICS, 2000, p. 1155).

Com relação aos países da América do Sul, além do Brasil que conta com atendimentos relacionados à Educação Hospitalar desde o início e meados do século XX, em $1950^{27}$ é possível observar articulações políticas para a implantação de uma escola num hospital no Chile. O Diretor Provincial de Educação solicitou que a professora Norma Decarli Cid criasse uma escola no Hospital de Niños Leonor Mascayano. Em 1960, foi emitida uma resolução pelo Ministério da Educação criando

27 Tratarei deste assunto ainda neste capítulo. 


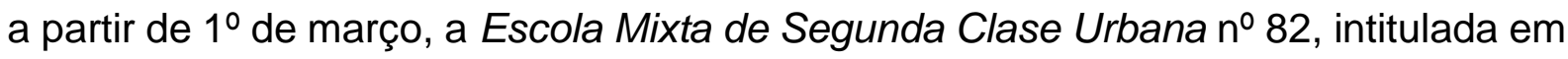
2007 de Escola G-545 do Hospital Regional de Concepción (GARCÉS, 2008, p. 06; FERREIRA, 2015, p .76).

A oficialização e o reconhecimento das aulas hospitalares no Chile se concretizaram somente em 1999, ano em que o Ministério da Educação do país emitiu o Decreto Supremo de Educação n 374/99 que criou uma escola básica especial no hospital com oferta de aula hospitalar de educação básica especial vinculada a um estabelecimento de educação próximo ao hospital onde as aulas eram ministradas. $O$ financiamento da educação hospitalar chilena foi instituído pelo Decreto Supremo de Educação $n^{\circ}$ 375/99, que indicou as corporações, fundações e a municipalidade como as entidades que poderiam iniciar a implantação de aulas em diferentes hospitais (GARCÉS, 2008, p. 07; FERREIRA, 2015, p .77). Apesar das dificuldades, em 2007, existiam 25 instituições com aulas particulares, o que evidencia um grande crescimento, efetivado especialmente, por conta do interesse coletivo dos Ministérios da Educação e Saúde, das instituições apoiadoras e dos profissionais da educação hospitalar. As aulas hospitalares se concentraram principalmente na zona central do país, na região de Valparaíso e na capital, Santiago, assim como na zona sul, já que na zona norte era onde havia os menores índices de atendimento do país. (GARCÉS, 2008, p. 08).

No Peru, a "Fundación Telefónica Perú Aulas Educativas en Hospitales", criou a partir de 1994, um programa educativo e multidimensional intitulado Programa Aprendo Contigo, com o objetivo de oferecer o atendimento escolar para as crianças hospitalizadas. (ARAÚJO, 2017, p. 84).

Na Colômbia, o plano de ação "Hospital amigo", implantou programas de apoio escolar em alguns hospitais da cidade de Manizales (Caldas) e no ano de 2000, o Programa "Aula Lúdico-pedagógica" foi estabelecido no Hospital Pablo Tobón Uribe em Medellín. (ZAPATA, ARBOLEDA; BUSTAMANTE, 2014, p. 60; ARAÚJO, 2017, p. 85).

Em 2004, na Argentina, surgiu a associação civil "Semillas del Corazón por los derechos educativos del nino enfermo", com o intuito de promover e difundir os direitos das crianças doentes, aumentar o número de atendimentos pedagógicos em hospitais. "Além disso, a associação desenvolveu alguns programas para atendimento escolar em ambiente hospitalar, na cidade de Córdoba". (ARAÚJO, 2017, p. 86; MÉXICO, 2009, p. 25). 
No México, "foram identificados 47 hospitais que contam com o Programa "Sigamos aprendiendo en el hospital', da Secretaria de Educação Pública e da Secretaria de Saúde, iniciado em 2005". Chama a atenção o fato de que durante o século $X X$, várias iniciativas surgiram "com o objetivo de dar continuidade escolar a população pediátrica hospitalizada". (ARAÚJO, 2017, p. 86; MÉXICO, 2009, p. 29).

Em 2006 foi criada a Rede Latinoamericana e do Caribe pela Educação de crianças e jovens hospitalizados ou em tratamento ${ }^{28}$ (REDLACEH) "uma organização sem fins lucrativos, que tem como objetivo o desenvolvimento da Pedagogia Hospitalar na América Latina e Caribe", por meio "da promoção do direito à educação das crianças e adolescentes hospitalizados". Fazem parte como membros desta Rede os seguintes países: Argentina, Brasil, Chile, Colômbia, Costa Rica, Equador, Guatemala, México, Peru e Venezuela os países membros da Rede. (REDLACEH, 2019).

Apesar das dificuldades econômicas da maioria dos países, a educação hospitalar se encontrava em desenvolvimento na América Central, sendo que em 2007 já era possível identificar atendimentos pedagógicos em hospitais na Costa Rica, Guatemala, El Salvador e Honduras (Apêndice L).

Com relação ao Brasil, considero equivocada a indicação descrita em algumas publicações, baseadas na história da Educação Especial, que apresentam o ano de 1600, como o ano do primeiro atendimento escolar da Santa Casa de Misericórdia de São Paulo, realizado às pessoas com deficiência física (CAIADO, 2003; JANUZZI, 2004; OLIVEIRA; CAVALCANTE, 2011, p. 102; OLIVEIRA, Et. al, 2010, p. 76; DARELA, 2007, p. 22; FERREIRA, 2015, p. 79; ARAÚJO, 2017, p. 107), é importante destacar que a data de criação da Santa Casa de Misericórdia ${ }^{29}$ é 24 de abril de 1715. Apesar dessas contradições há registros de atendimentos educacionais nos hospitais brasileiros no começo dos novecentos.

No Brasil após a proclamação da República houve um crescimento e reordenamento de muitas cidades, como aconteceu com a capital do país, o Rio de Janeiro, bem como em São Paulo, Porto Alegre, Recife e Curitiba, principalmente por conta do aumento da imigração, e do quantitativo de oficinas e fábricas, gerando

\footnotetext{
28 Maiores informações sobre a REDLACEH podem ser visualizadas em http://www.redlaceh.org/ Acesso em: 11/05/2019.

29 SANTA CASA DE MISERICÓRDIA DE SÃO PAULO. Irmandade da Santa Casa de Misericórdia de São Paulo: excelência na assistência, ensino e pesquisa. Disponível em: https://www.santacasasp.org.br/portal/site/quemsomos/historico Acesso em: 06/05/2019.
} 
enriquecimento urbano. No entanto, a infraestrutura básica, água tratada, esgoto e etc. não acompanhou o crescimento das cidades e da população. (BERTUCCI, 2015, p. 28; AVANZINI, 2011, p. 01; TELAROLLI JUNIOR, 1996, p. 270). De acordo com Gondra (2002, p. 315), o reordenamento econômico, cultural e político que aconteceu no Brasil desde o final do século XIX, criou "novos signos, como a ideia de progresso, que marcariam o país no início do Novecentos". (AVANZINI, 2011, p. 13). Aos poucos, um conjunto de "intelectuais de diferentes áreas como médicos, "sociólogos", filantropos e juristas" se agregou e uniu esforços para "instaurar a ordem civilizatória brasileira" (MARQUES, 1994, p. 18).

A construção da identidade do cidadão brasileiro republicano foi um desejo e ao mesmo tempo trouxe uma grande inquietação que perpassava diversos segmentos sociais em distintos lugares do Brasil, principalmente por parte dos sanitaristas, assim como os ideais eugênicos. ${ }^{30}$ Assim, no final do século XIX e na primeira metade do século XX, as políticas públicas de saneamento foram marcadas pelas concepções eugênicas divulgadas de forma alterada e "com metodologia estruturada na perspectiva higiênica". (BERTUCCI, 2015, p. 29; AVANZINI, 2011, p. 18; PELICCIONI; PELICCIONI, 2007, p. 323; MOTA, 2003). Segundo Pandini (2006, p. 20), "os médicos higienistas disseminaram a preponderância da educação na regeneração da raça, no aperfeiçoamento do espírito e na conformação do corpo infantil, elementos esses indispensáveis à constituição de uma nação civilizada".

Preocupados com a formação da população brasileira, em meio ao movimento sanitarista ${ }^{31}$, ações da Fundação Rockefeller ${ }^{32}$ e a difusão de ideias eugênicas, os médicos estavam atentos à saúde da criança operária e realizavam propostas, várias delas imbricadas com indicações educativas, que abrangiam da gestação e aleitamento materno à jornada de trabalho dos menores nas fábricas, como exemplificavam teses defendidas no início dos anos 1920 na Faculdade de Medicina e Cirurgia de São Paulo. (BERTUCCI, 2015, p. 29).

\footnotetext{
30 Segundo Mota (2003, p. 44), a eugenia pode acontecer "por ação negativa ou restritiva e por ação positiva ou construtiva". A eugenia restritiva possui entre suas medidas "a regulamentação do casamento, a segregação e a esterilização", porque desta forma se impediria o nascimento de indivíduos julgados "anormais e deficientes". Por outro lado, a eugenia construtiva se fundamentava na "educação higiênica e na propaganda dos princípios de eugenia e da hereditariedade".

${ }^{31}$ O movimento sanitarista tinha o objetivo de elaborar e realizar políticas de saúde pública no país (incluindo a educação para a saúde, que, por sua vez, não é atendimento escolar hospitalar). Maiores informações podem ser encontradas em HOCHMAN, 1998. (BERTUCCI, 2015, p. 29).

s Sobre a atuação da Fundação Rockefeller em São Paulo, veja: FARIA, 2007. Sobre a parceria Fundação Rockefeller e Faculdade de Medicina e Cirurgia de São Paulo: MARINHO, 2003. (BERTUCCI, 2015, p. 29).
} 
Segundo Martins (2008, p. 138), desde a segunda metade do século XIX havia uma preocupação com a saúde da criança, principalmente nos seus primeiros anos de vida, que se estendeu até o início do século $X X$, especialmente no meio médico brasileiro. Este por sua vez, "reivindicavam um novo papel social como promotores da higienização, da boa formação física e mental das crianças". Assim, se destacam programas com o objetivo de educar essas crianças. Em 1919, Moncorvo Filho fundou o Departamento da Criança no Brasil, o que favoreceu a difusão do ideário "de que a assistência poderia ser científica, portanto, resolver problemas ligados à pobreza com base no conjunto de conhecimentos mais adiantados que circulavam naquele contexto". (LOPES; MENDES; FARIA, 2005, p. 20).

No início do século XX surgem no Brasil algumas instituições para cuidar de crianças e jovens entendidos como "desvalidos" 33 , pois, segundo a sociedade da época, estes indivíduos precisavam "de assistência para não degenerarem ou para serem recuperados" (AVANZINI, 2011, p. 04; NEGRÃO, 2004; PANDINI, 2006; MARCÍlIO, 2006; TURINA, 2010). Além disto, instituições que cuidassem particularmente da saúde de crianças e, analogamente, da educação higiênica delas começaram também a ser implantadas no país ${ }^{34}$.

A nova nação republicana, progressista e ordeira construída e estruturada nas primeiras décadas do século XX estava estreitamente ligada aos princípios de educação e saúde da população. Neste sentido, é possível entender o porquê da implantação de uma proposta educacional diferenciada dentro de hospitais nas maiores cidades do país.

De acordo com Saldanha e Simões (2013, p. 447), o início das ações de Educação em ambientes diferenciados não foi amplamente explorada e expôs diversas lacunas. Entretanto, as autoras apontam, a possível existência "de um serviço de escolarização em ambiente hospitalar" no Hospício Nacional de Alienados, no Rio de Janeiro, fundado em 1902 e extinto em 1942, que segundo Barros (2011, p. 19) acontecia no Pavilhão-escola Bourneville. Conforme relata Lobo (2008, p. 405), o Pavilhão era composto por duas salas separadas entre meninos e meninas, outra

33 "Desvalido" era a criança sem riqueza ou sorte, enjeitado, menino de rua, etc. Criança no limite: vítima do abandono, possível transgressor da ordem no final do século XIX e início do século XX. (SILVA, 2010, p. 14).

${ }^{34}$ Entre as iniciativas mais implantadas, embasadas nas ideias de Moncorvo Filho, estavam: estudos sobre a vida de crianças pobres que pretendiam apontar diferentes práticas para sua proteção; inspeção escolar e iniciativas para fiscalização do trabalho fabril de mulheres e crianças (WADSWORTH, 1999). 
sala da escola e o jardim. "A escola [...] dispunha também de material didático específico, como objetos de formas geométricas, tecidos e outros materiais de várias texturas e cores, além de instrumentos de percussão".

Barros (2011, p. 20) pontua ainda, que essa experiência de educação em ambiente hospitalar do Hospital de Alienados do Rio de Janeiro, anacronicamente não pode ser considerada uma escola hospitalar, por conta de não ser possível justificar as questões tanto de universalização da Educação, como dos atendimentos de saúde na perspectiva de assistência e tratamento que caracterizam os hospitais na atualidade, ou autor considera ainda, que essa experiência estaria ligada muito mais ao surgimento dos atendimentos em classes especiais às crianças com deficiências do que a um atendimento de Educação Hospitalar, propriamente dito, pois muito do que temos no Brasil e em outros países não é escolar, é educativo recreacional e/ou terapêutico.

Em 1931, aproximadamente trinta anos depois do início da primeira experiência no Rio de Janeiro, alguns autores indicam a existência de atividades pedagógicas no Pavilhão Fernandinho e no Pavilhão Condessa Penteado, da Santa Casa de Misericórdia de São Paulo, que ocorreu em parceria com a Escola Estadual Arthur Guimarães. (BARROS, 2011, P. 21; MAZZOTA, 2003, p. 39; SALDANHA; SIMÕES, 2013, p. 448; ZOMBINI, 2011, p. 46). Os registros do movimento escolar de 01/08/1931 a 10/12/1932 indicaram que essas classes funcionavam tecnicamente "como classes hospitalares ou, ainda, configurando a modalidade "ensino hospitalar", isto é, não compondo grupo-classe", além disto, cada professora tinha "sua programação de atendimento individualizado aos alunos" que eram pacientes do hospital. (MAZZOTA, 2003, p. 39).

Apesar destas evidências, Barros (2008, p. 34) aponta que no Brasil, a oferta institucionalizada de aulas a crianças e adolescentes hospitalizados data efetivamente da década de 1950, quando começou a funcionar o atendimento escolar aos estudantes hospitalizados, no Hospital Municipal Jesus, no Rio de Janeiro. Este atendimento se diferencia dos outros dois anteriormente apresentados, segundo Araújo (2017, p. 107), pelo fato de ser primeiro direcionado para alunos não deficientes. Além disto, o que pode também justificar a informação, largamente difundida, de que esse seria o mais antigo atendimento em Educação Hospitalar do Brasil, porque continua ininterruptamente até os dias atuais. De acordo com Oliveira (2015, p. 07), o Hospital Barata Ribeiro, também no Rio de Janeiro, "disponibilizou 
instalações escolares no Centro Cirúrgico e Ortopédico, desde 1948" dois anos antes da liberação para o Hospital Jesus e até 1960 ambos os hospitais, "Hospital Barata Ribeiro e o Hospital Jesus funcionavam com classes hospitalares sem que um soubesse da existência do outro". (OLIVEIRA, 2015, p. 07; MEIRA, 1971, p. 243).

No que diz respeito a nomenclatura, há vários pesquisadores brasileiros, dentre eles Fonseca (1999b, p. 07) ${ }^{35}$, que, baseados na legislação, tanto do Conselho Nacional de Educação, como do Ministério da Educação, utilizaram, em algum momento, a conceituação de Classes Hospitalares ${ }^{36}$ para descrever "o atendimento escolar no ambiente hospitalar", ofertado aos "alunos impossibilitados de frequentar as aulas em razão de tratamento de saúde que implique internação hospitalar, atendimento ambulatorial ou permanência prolongada em domicílio"37. (BRASIL, 2001, p. 04). Entretanto, de acordo com o documento da Secretaria de Educação Especial do MEC, a classe hospitalar é entendida como "o atendimento pedagógicoeducacional que ocorre em ambientes de tratamento de saúde", com estudantes internados, assim como em atendimento no "hospital-dia e hospital-semana ou em serviços de atenção integral à saúde mental”. (BRASIL, 2002, p. 13).

A classe hospitalar trabalha com os processos de desenvolvimento e de aprendizagem e é classe hospitalar na medida em que, sistematicamente, detém um espaço e cumpre seu papel pedagógico-educacional que, sem dúvida alguma pode e deve: a) ser permeado por atividades lúdicas; b) envolver familiares e acompanhantes bem como os profissionais de saúde do hospital; e, c) contar com a participação de estudantes e pesquisadores de áreas diversas do conhecimento. E para que isso aconteça, o professor deve estar à frente dessa estrutura, gerenciando com maestria o desenvolvimento das atividades planejadas e propostas as crianças na sala de aula no ambiente hospitalar. (FONSECA, 2002, p. 212).

A autora evidencia a importância dos professores como mediadores das aprendizagens ofertadas às crianças, do gerenciamento das classes hospitalares, 0 papel pedagógico-educacional, na perspectiva de para tal se valer de atividades mais

\footnotetext{
35 Sobre a nomenclatura classe hospitalar veja: ARAÚJO, 2017, p. 87; BARROS, 1999; BARROS, 2009; CECCIM, 1999; FONSECA, 2002, p. 205; FONSECA, 2011, p. 82; FONTES, 2002; FREITAS, 2001; FREITAS, 2005; FUNGHETTO; GONÇALVES, 2008; IBARRA, GUIMARÃES; DIAS, 2008, p. 01; INVERNIZZI, 2008; MELO, 2007; MENEZES, 2018, p. 23; ORTIZ; OLIVEIRA, SOUZA FILHO; PIRES JÚNIOR, 1997; OLIVEIRA, 2005; OLIVEIRA, Et. al, 2010, p. 76; OLIVEIRA, 2015, p. 02; ORTIZ, 2010; ROSA; XAVIER, 2007; SANDRONI, 2008; ROCHA; SOARES, 2003; PASSEGGI, 2010; ZARDO, 2004, p. 93; ZARDO; FREITAS, 2007, p. 13; ZOMBINI, 2011.

${ }^{36}$ Classe Hospitalar, Pedagogia Hospitalar, Escola Hospitalar são algumas das terminologias utilizadas para designar o atendimento escolar para crianças hospitalizadas. (ARAÚJO, 2017, p. 87).

${ }^{37}$ Cf.: http://portal.mec.gov.br/cne/arquivos/pdf/CEB0201.pdf Acesso em: 08/05/2019.
} 
lúdicas, que pudessem envolver os diferentes sujeitos presentes no processo de hospitalização.

No entanto, a discussão em relação a nomenclatura deste serviço de educação em hospitais é controversa. Em 2003, Fonseca, após refletir "sobre o que consta no paradigma de inclusão e nas iniciativas oficiais em relação à promoção de uma escola para todos", indica que escola hospitalar ou atendimento escolar no ambiente do hospital sejam termos mais abrangente do que classe hospitalar, estabelecido pelo MEC/SEESP. Apesar de indicar certo desconforto com relação ao uso dos dois termos, por conta do "atendimento escolar que se dá no hospital", sugerir uma certa segregação, "como se a escola para as pessoas doentes tivesse que ser essencialmente diferente da escola que qualquer indivíduo frequenta", o significado da palavra classe é diversificado, pois pode ser um espaço específico para atender grupos de alunos, "turma ou mesmo um grupo determinado por sua condição socioeconômica ou pela atuação profissional na área de saúde". A autora considera escola hospitalar mais adequado ao contexto da primeira década dos anos 2000 em determinadas regiões do país, afinal, o que se deseja enfatizar é que "a pessoa precisa de uma escola" e esta precisa se ajustar as necessidades e interesses independentemente do local onde se encontrar, seja no hospital ou qualquer outro. Desta forma, efetivamente a escola será "para todos como preconiza a legislação" nacional. (FONSECA, 2003, p. 07).

Neste sentido Paula (2005, p. 02) relata que, apesar da grande aceitação do termo classe hospitalar na área de saúde e do uso nos documentos do Ministério da Educação e Cultura (MEC), os estudiosos que participaram das edições do Encontro Nacional sobre Atendimento Escolar Hospitalar no Brasil, defendem a alteração da nomenclatura para "escola hospitalar", argumentando que este "é um termo mais abrangente". Corroborando com esse posicionamento, Arosa (2007, p. 28) destaca que o uso de escola, no espaço hospitalar, precisa ser entendido não "como uma edificação, como estrutura física somente, mas uma escola com a amplitude que o processo educacional necessita". Quando se pensa na Educação é necessário, portanto, romper com os limites arquitetônicos e efetivar suas práticas em todos os espaços do hospital, desde os corredores, refeitórios, leitos, enfermarias, salas de esperas, assim como nas UTIs, etc. "É preciso conceber a educação como um processo que ultrapassa os limites físicos, paredes e territórios; impostos por hierarquizações reveladas e veladas". 
Neste trabalho utilizo várias nomenclaturas para tratar do atendimento educacional nos hospitais, pois, na maioria das vezes, reproduzo o que é apresentado nas fontes pesquisadas, além de considerar essas diferentes nomenclaturas em seu sentido epistemológico. Apesar disto, por vezes o termo ao qual mais faço referência é Educação Hospitalar, por conceber que, tanto classe como escola, são menos amplos que a Educação em si, esta engloba não somente o espaço onde o ato educacional acontece, que no caso do hospital é variável e dinâmico, mas também seus princípios, normas, regras, métodos, etc., assim como sugere Arosa (2007, p. 28).

Fonseca (2002, p. 212) indica que, na maioria das vezes, esses atendimentos são relacionados “ao conceito de educação não-formal ${ }^{38 ”, ~ e n q u a n t o ~ A r o s a ~(2007, ~}$ p.25) argumenta que eles não podem ser identificados "nem como educação informal, nem com a [...] não formal, pois seus pressupostos teóricos, sua organização, intencionalidade e regulamentação ganham cunho de formalidade". Neste sentido, acrescento e concordo com $\operatorname{Cavaco}^{39}$ (2003, p. 130) que entende "a educação numa perspectiva global, em que as três modalidades, educação formal, não-formal e informal se apresentam como complementares entre si". Desta maneira, considero que isso se reflete na Educação Hospitalar, entendendo que estas formas de educação concebidas de maneira isoladas não conseguem "responder às necessidades formativas dos indivíduos".

Segundo Gelpi (1991, p. 71), “a educação será permanente, não se conhecerão mais lugares, nem tempos privilegiados, cada um será educando e educador, não haverá fronteiras entre a educação formal e não formal, a educação inicial e permanente", analogamente a educação no hospital é tanto inicial como permanente, acontece de forma estendida por todo o espaço hospitalar, em qualquer tempo, ora se apresenta como formal, pois segue as regras e os procedimentos determinados

38 A Educação não-formal é entendida como "[...] qualquer tentativa educacional organizada e sistemática que se realiza fora dos quadros do sistema formal (de ensino), para fornecer determinados tipos selecionados de aprendizagem a subgrupos específicos da população [...]". (FÁVERO, 1980, p. 23).

39 A autora apresenta no texto "Fora da escola também se aprende", a síntese de uma investigação que teve como principal objetivo compreender o processo formativo de adultos não escolarizados, residentes no meio rural. Apesar do público alvo do estudo diferir do deste trabalho e considerando que a autora escreve a partir da cultura portuguesa, que difere em questões educacionais do que acontece no Brasil, considero que as contribuições a respeito das modalidades formal, não-formal e informal de educação, assim como a formação experiencial explorada no artigo (CAVACO, 2003) se aplicam igualmente à educação em hospitais, até porque, esse é um local exterior à escola e onde comprovadamente ocorrem aprendizagens. 
pelas escolas nas quais os estudantes estão matriculados e, ora não formal, por estar organizada e ser sistemática, mas realizada fora das escolas do sistema formal de ensino e ainda pode ser considerada informal, porque as aprendizagens realizadas no contexto hospitalar podem ser desorganizadas e assistemáticas, entretanto envolve as crianças que estão internadas num "[...] processo permanente pelo qual qualquer pessoa adquire e acumula conhecimentos, habilidades, atitudes e perspicácia, através de experiência diária e contato com o meio ambiente em casa, no trabalho e no lazer" (FÁVERO, 1980, p. 23) e porque não entender o hospital como esse ambiente no qual as crianças que frequentemente estão hospitalizadas não seja o local onde eles cotidianamente estão aprendendo?

Segundo Fávero (1980, p. 23) na educação informal o indivíduo está constantemente em processo de aprendizagem "através do exemplo e das atitudes dos parentes e amigos; [...], leitura de jornais e livros; ou ouvindo rádio, vendo filmes e televisão", todos passíveis de ocorrer no universo hospitalar, inclusive com ampliação dos contatos, além de parentes e amigos, também com profissionais da saúde e educação.

De acordo com Cavaco (2003, p. 143) o "nível do saber, saber-fazer e do saberser, tendo sido adquiridos com base na multiplicidade de experiências vividas nos vários contextos", podem ser gerados principalmente por meio da aprendizagem experiencial, afinal, como preconiza Freire (2000, p. 71) "não podemos duvidar de que a nossa prática nos ensina", o que fundamenta a percepção de que a aquisição desses saberes resulta também "de processos muito complexos e diversificados, baseados na experiência" (CAVACO, 2003, p. 143). Ainda segundo Cavaco (2003, p. 143 apud GELPI, 1989, p. 93), "o processo de aprendizagem experiencial "não é restritivo no espaço e no tempo, não conhece limites nem fronteiras", portanto a aprendizagem acontece continuamente ao longo da vida das pessoas, sendo possível observar "a aplicação e aperfeiçoamento dos saberes adquiridos nos vários contextos em que se movimentam e, registrando-se por vezes, a mobilização de conhecimentos anteriores para realização de novas aprendizagens". (CAVACO, 2003, p. 143-144). Dentre esses vários contextos, destaco o ambiente hospitalar como um espaço privilegiado para o desenvolvimento de novas aprendizagens e saberes.

Conforme defende Dominicé (1988, p. 56) sublinha-se "a capacidade formadora das confrontações da vida quotidiana, das contrariedades sofridas [ ], das exigências e desafios. A formação influenciada pelas pessoas com as quais se cruzaram ao longo da sua vida e pelos contextos em que se 
inseriram, foi também um processo marcado pelas suas características individuais. Ou seja, "a formação enraíza-se na articulação do espaço pessoal com o espaço socializado; progride com o sentido que a pessoa lhe dá [ ]“. As características e atitudes apresentadas foram fundamentais para capitalizar as experiências que tiveram ao longo da vida, construindo e enriquecendo assim o seu percurso formativo. (CAVACO, 2003, p. 146).

Considerando Cavaco, os autores citados por ela e o conceito de educação experiencial, percebe-se o hospital como um dos espaços onde as pessoas, na maioria das vezes, se deparam com contrariedades, confrontações da vida cotidiana, desafios, até mesmo de sobrevivência, e também, onde se relacionam socialmente com diversificados indivíduos que enriquecem suas experiências para, por meio de suas características pessoais, ampliar seu percurso formativo, o que possibilita inclusive um ambiente educacional que favorece a aprendizagem desse indivíduos hospitalizados. Desta forma, concluo que o atendimento da Educação Hospitalar, além de amplas possibilidades de aprendizagens, diz respeito inclusive aos conteúdos escolares.

\subsection{A EDUCAÇÃO HOSPITALAR NOS DIFERENTES ESTADOS BRASILEIROS}

A respeito da Educação Hospitalar no Brasil, Fonseca (2002, p. 208) afirma que no período de 1950 a 1990, foram implantadas e se mantinham em funcionamento somente 10 classes hospitalares no país, sendo que a partir de 1990 a Educação para crianças hospitalizadas apresentou maior expansão. Segundo Saldanha e Simões (2013, p. 448) isso ocorreu por conta do avanço das pesquisas e pode ser observada em diferentes localidades e estados brasileiros. Além disso, a década de 1990, foi amplamente marcada "pela implantação de documentos legais que vieram legitimar o direito à educação para crianças e adolescentes e motivaram a implantação do atendimento escolar nos hospitais em todo país" ${ }^{\prime 0}$. (SALDANHA; SIMÕES, 2013, p. 451).

Segundo Hobsbawm (1995, p. 402) após 1973, o ritmo de desenvolvimento econômico entrou em declínio e a inércia do sistema podia ser observada fazendo com que a ideia de um período esplêndido que se aguardava se desestruturasse.

\footnotetext{
40 Uma discussão mais detalhada sobre a fundamentação legal da Educação Hospitalar é realizada no final deste capítulo e início do Cap. 2.
} 
No Brasil, a década 1980 foi marcada por um crescimento econômico irrisório. Desmantelava-se o sistema político baseado na ditadura militar que propagava o crescimento econômico e os novos tempos, juntamente com o que acontecia em âmbito mundial, [trazia] insegurança para os brasileiros. (SILVA, 2011, p. 59).

As novas configurações no contexto nacional tornavam os problemas das décadas de 1970 e 1980 mais perturbadores, combinando com oscilações estruturais, tanto na economia quanto na circulação da informação e também nas mudanças sociais e culturais (Hobsbawm, 1995). Além disso, a recessão econômica que marcou o início dos anos 1980 coincidiu com o início da hiperinflação, entre 1980 a 1983, levando a recessão interna na política econômica nacional e mundial. O Produto Interno Bruto (PIB), a queda dos investimentos, o aumento do déficit público, as dívidas interna e externa assim como a inflação marcaram o período. (LACERDA, 2010).

Apesar disto, o final dos anos 80 do século $X X$, no Brasil, ficou conhecido como o período da Abertura Política com o fim do período militar que durou mais que 20 anos, de 1964 a 1985. Foram muitas as transformações na estrutura política, como a reconstrução de um país mais democrático, as mudanças de paradigma institucional levaram a anistia, que permitiu a volta dos exilados, o fim do regime bipartidário e da censura à imprensa. Enfim, as liberdades civis foram reconstituídas gradualmente pela população brasileira. Entre 1979 e 1985, o Brasil era governado pelo general João Batista de Oliveira Figueiredo, último presidente do Regime Militar. No início da década de 1980, a política econômica pretendia alcançar o crescimento econômico de qualquer forma, com medidas como maior indexação salarial e de preços, com reajuste semestral e por faixas e controle de juros. (SANTOS, 2014, p. 31-33).

\footnotetext{
Nesse processo, a sociedade como um todo estava reconstituindo ideais democráticos que haviam sido reprimidos. [...] Uma sociedade que ensaiava os primeiros passos para a redemocratização não poderia conviver, na formação de seus cidadãos, com vestígios de um ambiente repressor, que restringisse a liberdade de pensamento; ou pressupostos autoritários, que impusessem projetos de cima para baixo, sem a participação das comunidades e dos próprios segmentos que compõem essa sociedade como um todo. (COSTA, 2010, p. 6).
}

A conjuntura sociopolítica dos anos 1980 auxiliou o surgimento dos movimentos sociais organizados, que lutavam pela redemocratização por meio da mudança política, principalmente com o apoio às eleições diretas para os governos, em oposição ao regime militar. Esse foi um período bastante profícuo com grande idealismo, entretanto, o crescimento do êxodo rural com a concentração dessa 
população migratória nas periferias das grandes cidades trouxe novas configurações sociais e econômicas para a sociedade brasileira.

Em 1985, José Sarney iniciou seu governo como Presidente da República, tentou retomar o crescimento econômico, apesar da crise fiscal que assaltava o país. $\mathrm{Na}$ tentativa de controlar a inflação houve o congelamento dos preços dos produtos e mercadorias, esta estratégia não deu certo dando ainda mais força a inflação com a explosão dos preços dos alimentos, dentre eles a carne. (LACERDA, 2010).

Segundo Trintin (2005, p.9), a década de 1980, reflete "a perda de capacidade do setor público em realizar investimentos no setor produtivo", por conta da "crise da dívida externa, da crise financeira do Estado, e do aumento das taxas de inflação" e, portanto, do esgotamento de financiamentos ao setor público. As políticas econômicas foram determinadas por estratégias de curto prazo, com o objetivo principal de resolver os "problemas da crise da dívida externa e controle do processo inflacionário", não havendo nenhuma medida direcionada à política industrial de longo prazo, com possibilidade de favorecimento da modernização do setor produtivo, o que o tornaria mais competitivo no mercado internacional.

Em conseqüência, a década de oitenta caracteriza-se por dois movimentos
da indústria brasileira, a profunda crise iniciada em 1981, que se prolongou
até meados de 1984 , fruto de uma política econômica ortodoxa recessiva
implementada pelo governo federal e monitorada pelo Fundo Monetário
Internacional, que atingiu mais fortemente os setores produtores de bens de
consumo duráveis e bens de capital, notadamente, os que comandaram o
crescimento no período anterior e, o período de recuperação econômica,
iniciado a partir do segundo semestre de 1984, que foi amplamente
sustentado pelos setores mais ligados às exportações, notadamente, bens
intermediários. (TRINTIN, 2005, p.9).

Desta forma, "as taxas de crescimento do Produto Interno Bruto da indústria de transformação do país", foram de somente 2,2\% ao ano em média, enquanto na década de 1970 a taxa era de 8,7\%. A partir da década de 1990, houve uma diminuição no ritmo de crescimento industrial, observada na alteração da inserção da indústria na economia nacional, com as vendas e compras industriais passando "a depender mais fortemente do mercado nacional". (TRINTIN, 2005, p.9,10).

Apesar destas questões complexas na economia nacional, a década de 1990 foi marcada pelo aumento no número de atendimentos da Educação Hospitalar nos diferentes estados brasileiros, informação observada, principalmente nos textos de Fonseca que desde 1999 estuda essa evolução. Em seu primeiro trabalho que trata o assunto e também apresentado no $1^{\circ}$ Encontro Nacional sobre o Atendimento Escolar 
Hospitalar $^{41}$ a autora destaca que em 1998 havia 30 hospitais, distribuídos em 11 Unidades Federativas, com atendimento escolar hospitalar, sendo que aproximadamente 1500 crianças eram atendidas mensalmente por 80 professores. (FONSECA, 1999a, p. 123, 124, 126).

Nos anais do $1^{\circ}$ Encontro Nacional sobre o Atendimento Escolar Hospitalar realizado entre os dias 19 e 21 de julho de 2000, na Universidade do Estado do Rio de Janeiro - RJ, Ceccim e Fonseca (2000) atualizaram os dados do mapeamento nacional de classes hospitalares apresentados em 1999, sendo que já no ano seguinte do levantamento inicial, esse número de hospitais com Educação Hospitalar havia mais que duplicado no último ano do século XX, alcançando 113\%, com 64 hospitais com atendimento escolar hospitalar em 15 Unidades Federativas. Em 2002, a autora realiza nova atualização dos dados, que indicou um crescimento quantitativo das Classes Hospitalares no Brasil com 74 hospitais com algum tipo de "atendimento escolar para seus pacientes". (FONSECA, 2002, p. 207; SALDANHA; SIMÕES, 2013, p. 456).

No mapeamento de 2007, a quantidade de Classes Hospitalares nos hospitais aumentou para 101 hospitais, 16 infantis, pertencente a 17 estados e no Distrito Federal. "Desse total, $45 \%$ dos alunos cursam a educação infantil e 51\% frequentam o ensino fundamental". Além disso, 18 estabelecimentos, em 11 estados, ofereciam atendimento pedagógico domiciliar aos estudantes que estavam realizando tratamento oncológico. Os estados com o maior número de atendimentos são os estados de São Paulo com 21 hospitais, Rio de Janeiro com 13, Bahia com 10 hospitais, Distrito Federal com 9 hospitais, e Santa Catarina com 8 instituições que oferecendo atendimento escolar no ambiente hospitalar. (BARROS, 2008, p. 34-35).

Em 2011 um novo levantamento foi realizado e o número de hospitais com escolas mais do que quadruplicou em relação ao primeiro levantamento de 1998, alcançando 128 classes hospitalares no país (FONSECA, 2011, p. 82), distribuídas nas diversas regiões brasileiras, sendo a região sudeste com maior número, 52 classes, seguida da região centro-oeste com 24, nordeste com 23, 19 na região sul com 19 e 10 na região norte. Além disto, a autora acrescenta os dados com relação aos atendimentos realizados em casas de apoio, abrigos e residências de estudantes em tratamento de saúde que estavam impossibilitados de frequentar as escolas, 32

${ }^{41}$ Cf.: http://www.escolahospitalar.uerj.br/anais.htm Acesso 29/09/2015 Acesso em 11/05/2019. 
instituições que oferecem esse serviço chamado de atendimento escolar domiciliar. (FONSECA, 2011, p. 86).

O 1ํ Encontro que aconteceu em 2000, no Rio de Janeiro, coincidiu com a comemoração do aniversário de 50 anos da criação da Classe Hospitalar no Hospital Jesus, o que favoreceu os depoimentos de três profissionais que trabalharam neste espaço a apresentar o seguinte texto: "Classe Hospitalar Jesus: trajetória do jubileu de ouro (1950-2000)", Lecy Rittmeyer, primeira professora da Classe Hospitalar Jesus, Rachel Perrone da Silva, diretora da Classe Hospitalar Jesus de março de 1978 à agosto de 1986 e Leila Ozon Imbrosio, diretora de abril de 1986 a janeiro de 1992 apresentando a trajetória de cada uma no atendimento, assim como as especificidades, a evolução e o crescimento do atendimento escolar hospitalar no Hospital Municipal Jesus e em consequência, no Estado do Rio de Janeiro.

Lecy Rittmeyer cursava a faculdade de Serviço Social, em 14 de agosto de 1950, quando Dr. David Pilar, diretor do Hospital Jesus a convidou para trabalhar no atendimento escolar voltado as crianças internadas. Foi designada para esse serviço, por meio da Portaria 634. A professora relatou que na época o hospital tinha aproximadamente 200 leitos e 80 crianças em idade escolar, não havia salas específicas para a realização do acompanhamento educacional, por isso as atividades ocorriam individualmente nas enfermarias, com atividades de biblioteca, por meio de empréstimos sistemáticos de livros aos pacientes do hospital.

Em 1958, mais uma professora foi cedida para o hospital, o que oportunizou uma distribuição melhor do trabalho, assim como "maior rendimento escolar por parte das crianças hospitalizadas". (RITTMEYER; SILVA; IMBROSIO, 2000). Em 1960, Lecy Rittmeyer e Ester Lemos Zaboroviski, do Hospital Jesus; Marly Fróes Peixoto, do Hospital Barata Ribeiro e Lola Sanches Aratanha, da Seção de Convalescentes do Hospital Jesus eram as professoras em exercício nos hospitais.

No final do ano de 1960, as professoras dos Hospital Jesus e do Barata Ribeiro foram apresentadas por conhecidos em comuns e perceberam que realizavam 0 serviço escolar nos dois hospitais sem qualquer normatização, regulamentação ou vínculo oficial com a Secretaria de Educação, existia somente um acordo com os diretores dos hospitais. Com a necessidade da unificação e de uma regulamentação do trabalho, encaminharam ao Professor Álvaro Palmeira, Diretor do Departamento de Educação Primária, reivindicações e começaram a defender "a regulamentação do 
serviço, a assistência ao deficiente físico nos hospitais do estado nas escolas públicas primárias e, finalmente, no domicílio". (RITTMEYER; SILVA; IMBROSIO, 2000).

As instalações da Educação Hospitalar no Hospital Jesus aconteceram na gestão do Diretor Dr. Issac Fares Abraão, que cedeu 5 salas que eram da radiologia, que não estavam sendo utilizadas, possibilitando a realização das "atividades extracurriculares como teatro, bandinha, canto e atividades manuais chegando até a um artesanato com bazar permanente no hospital". Com a ampliação do espaço ocorreu também a ampliação do número de professoras que, em 1963, somava $6 . \mathrm{Na}$ gestão do Dr. Deyler Goulart Meira ocorreu uma remodelação do setor médico e as salas da Radiologia foram reincorporada ao hospital, com a promessa da criação do setor escolar nos planos de melhorias do hospital. Entretanto, após dois anos, mesmo com o fim da remodelação, o setor não foi criado e as professoras perceberam o "prejuízo da realização do trabalho e consequente baixa do rendimento escolar" por conta da falta de lugar específico para a realização dos atendimentos e também pela falta de conhecimento dos objetivos do trabalho do atendimento escolar hospitalar, que "não são apenas levar aos deficientes conhecimentos escolares fundamentais, mas contribuir para sua recuperação integral, educando-os e preparando-os para a vida em comunidade". A justificativa do diretor do hospital para a não efetivação do setor escolar foi por conta de os internamentos prolongados terem diminuído consideravelmente. Informação que, pelo relato das professoras, não foi possível confirmar.

Segundo a ex-diretora da Classe Hospitalar Jesus, Rachel Perrone da Silva, do início de 1965 ao final de 1973, os estudantes atendidos tinham de 6 a 14 anos, estudavam da Classe de Alfabetização até a $4^{\text {a }}$ série do $1^{\circ}$ grau e ficavam internados em diferentes clínicas do hospital, com problemas como: sequela de poliomielite, deficiências congênitas, problemas clínicos, neurológicos, cirúrgicos, com períodos longos de internação ou internações repetitivas. Neste período, o tipo de atendimento pedagógico curricular era realizado "de acordo com as necessidades dos alunos e adaptados às suas limitações". As atividades eram realizadas nas salas de aula, que ficavam "em dependências adaptadas do prédio do ambulatório e nos leitos para os alunos que não podiam se locomover". Além das atividades curriculares, também havia aulas de religião, oferecida "por uma catequista da paróquia da comunidade, de música" ofertada por uma recreadora, "atividades de biblioteca e auditório [como] 
leitura de histórias e atividades decorrentes, pesquisas, teatro, além de empréstimo de livros". (RITTMEYER; SILVA; IMBROSIO, 2000).

No final da década de 1970 e início de 1980, o Hospital Jesus ficou 2 anos em obras, tendo sido contemplado na reforma um projeto para as instalações da escola que além dos atendimentos às turmas da Educação Hospitalar, em 1982 criou o PROJETO BARRAM ${ }^{42}$, que dividia a responsabilidade das seis atividades implantadas: Biblioteca, Artes, Recreação, Religião, Artesanato e Música entre as professoras que atendiam as diversas turmas. Além disto, havia a oferta de atividades comemorativas do Calendário Cívico Escolar, apresentação de Teatro Infantil, Mágicos, Palhaços e passeios ao Jardim Zoológico, Parque da Cidade, Passeio de Metrô, etc. A partir de 1984, segundo a ex-diretora Rachel Perrone da Silva, começou um atendimento que elas denominaram de precoce, que consistia no atendimento da Educação Infantil, para as crianças entre 0 a 4 anos.

Em 1986, a classe funcionava como Escola Hospital Jesus e era ligada administrativamente ao $14^{\circ}$ Distrito de Educação e, pedagogicamente ao Instituto Helena Antipoff, órgão da Secretaria Municipal de Educação. Nesse período a equipe de profissional da Escola Hospitalar era composta de uma diretora-adjunta, uma secretária, dez professoras e um funcionário de apoio, havia 4 salas de aula e 6 enfermarias onde a equipe atuava, dentre elas a Ortopedia, Neurologia, Cirurgia e Clínica Médica, por conta dos estudantes estarem impossibilitados de se locomover e para os bebês de 0 a 2 anos e 11 meses ainda ocorria o Atendimento Precoce ${ }^{43}$.

A Escola se preocupava em realizar atendimentos mais humanizados, envolvendo, sempre que possível, pequenos grupos para fomentar a socialização, o desenvolvimento do Projeto BARRAM, tentava favorecer a aprendizagem "de forma dinâmica, rica, viva e cheia de oportunidades de novas vivências" para enriquecimento das potencialidades dos estudantes. O trabalho realizado "pela escola era estudado, avaliado, documentado", sendo que cada estudante tinha sua Ficha de Avaliação que era analisada para detectar se os objetivos relacionados para cada estudante haviam

\footnotetext{
$42 \mathrm{O}$ nome Projeto BARRAM foi escolhido por conta das atividades que eram desenvolvidas com ele: $\mathrm{B}$ - Biblioteca, A - Artes, R - Recreação, R - Religião, A - Artesanato e M - Música, seu planejamento acontecia em conjunto pela equipe semanalmente, tentando acompanhar o Calendário Cívico Escolar e inserindo atividades decorrentes no desenvolvimento do conteúdo curricular comum. (RITTMEYER; SILVA; IMBROSIO, 2000).

43 No Atendimento Precoce as professoras tentavam envolver os pais, indicando "a maneira educacional de minimizar os problemas ocorridos no desenvolvimento, devido aos períodos prolongados de internação, à ausência de estímulos ou até mesmo à desnutrição". (RITTMEYER; SILVA; IMBROSIO, 2000).
} 
sido atingidos ao final do período de internação. Essa ficha era retomada caso o estudante voltasse a ser internado e assim seriam inseridos novos objetivos. (RITTMEYER; SILVA; IMBROSIO, 2000).

Apesar de todo esse trabalho estruturado descrito pelas funcionárias da Educação Hospitalar, no Hospital Municipal Jesus, que acontecia desde 1950, somente em 2005, a Secretaria Municipal de Educação e a Secretaria Municipal de Saúde do Rio de Janeiro efetivaram um convênio que dispõe sobre o funcionamento das classes hospitalares no município. (ARAÚJO, 2017, p. 107; OLIVEIRA, 2015, p. 09).

Com relação as outras localidades, há registros do início da primeira classe hospitalar no Distrito Federal no ano de 1964, que segundo Araújo (2017, p. 107) foi "uma experiência pioneira no estabelecimento de convênio entre as Secretarias de Estado de Educação e Saúde no país".

Na década de 1970, em Ribeirão Preto, cidade no interior de São Paulo, há registros da criação da classe hospitalar do Hospital das Clínicas. Chama a atenção este fato, pois esta classe foi aberta antes da "publicação da legislação que cria as classes hospitalares no país". (ARAÚJO, 2017, p. 108). Até a década de 1990, as professoras eram voluntárias e em 1997 as aulas passaram a ser realizadas por pedagogas da rede estadual de ensino, que atendiam principalmente crianças de 6 a 14 anos.

Em 2006, o Hospital das Clínicas da Faculdade de Medicina de Ribeirão Preto, da Universidade de São Paulo (USP), contava com três atendimentos visando a escolarização da clientela doente, com um grupo pela manhã e dois à tarde, que atendiam crianças e jovens da Pediatria, Ortopedia e Traumatologia, Neuropediatria, Cirurgia Pediátrica, Oftalmologia, Otorrinolaringologia e Clínica Médica. As salas de atendimento pedagógico eram coloridas, decoradas com desenhos, com muitos "livros infantis, jogos educativos e brinquedos, onde o estudo é mesclado com o lúdico. Também existem recursos audiovisuais, como televisão e videocassete" e quando a criança tinha problemas de mobilidade, as aulas podiam também ser realizadas nos leitos. Os atendimentos aconteciam da pré-escola ao ensino fundamental, apesar de também terem "recebido pedidos para alfabetização de adultos". (OLANDA, 2006, p. 52).

O fortalecimento das ações de Educação Hospitalar no Estado de São Paulo ocorre principalmente com os avanços legais observado na aprovação da Lei n. 
10.685, 30 de novembro de 2000 (SÃO PAULO, 2000), que dispõe sobre o acompanhamento educacional da criança e do adolescente internados para tratamento de saúde, que de acordo com Mazzotta (2003, p.39 apud ARAÚJO, 2017, p. 107) é a primeira legislação publicada encontrada "na esfera estadual, especificamente, sobre esse tipo de atendimento".

A implantação do Projeto Mirim de Hospitalização Escolarizada no Hospital Infantil Pequeno Príncipe, em Curitiba no Paraná, oficializada a partir de 1988, foi estruturada mediante convênio com as redes Estadual e Municipal de Educação. Este projeto foi amplamente divulgado em jornais do Estado, em entrevistas, nos processos administrativos das Secretarias de Educação, livros memorialísticos, etc. Também teve destaque na publicação dos anais do $1^{\circ}$ Encontro Nacional sobre o Atendimento Escolar Hospitalar, realizado no ano de 2000 no Rio de Janeiro, em trabalho intitulado: "Pedagogia hospitalar" apresentado pelas professoras da Pontifícia Universidade Católica do Paraná (PUC/PR), Elizete Lúcia Moreira Matos e Margarida M. T. de Freitas Muggiati. Estas professoras também são autoras do livro "Pedagogia Hospitalar. A humanização integrando educação e saúde” publicado em 2006.

Na apresentação das autoras no Encontro no Rio de Janeiro elas informam que o objetivo do Projeto Mirim de Hospitalização Escolarizada era "a continuidade da escolarização para crianças/jovens em idade escolar que, por enfermidade, necessitam ficar longos períodos afastados da escola, gerando atrasos no aprendizado e ou abandono da escolaridade". Indicaram ainda, que junto ao projeto foi realizado um levantamento de dados teóricos para fundamentar a preparação acadêmica do pedagogo na PUC/PR ${ }^{44}$ para que, após essa formação específica, pudesse atuar no ambiente hospitalar por meio de "um novo processo alternativo de ensino e ludicidade que ultrapasse o contexto formal da escola"45. (MATOS; MUGGIATI, 2000).

No Rio Grande do Sul, em 1989, foi estabelecido um protocolo de intenções entre a Secretaria de Estado da Educação e o Hospital das Clínicas de Porto Alegre, proporcionando o desenvolvimento do Programa de Apoio Pedagógico (PAP), que aconteceu a partir de 1990. O objetivo deste programa era realizar o atendimento escolar hospitalar para as crianças internadas por longos períodos. "Em 2002, o

\footnotetext{
${ }^{44}$ Sobre formação de professores, veja: COVIC, 2003; COVIC, 2008.

45 Para acesso de maiores informações publicadas nos anais acessar: http://www.escolahospitalar.uerj.br/anais.htm Acesso 29/09/2015 Acesso em 11/05/2019.
} 
programa foi reestruturado, possibilitando a sistematização e registro dos atendimentos às crianças hospitalizadas". (ARAÚJO, 2017, p. 108).

Em 1991, foi criado Curso de Educação Especial da Universidade Federal de Santa Maria, no Hospital Universitário de Santa Maria (RS) fruto de um projeto de pesquisa, que tinha por objetivo encontrar diferentes soluções às propostas do MEC. Neste sentido, "criaram um currículo alternativo para atender à classe hospitalar multisseriada composta de adolescentes, crianças inseridas na escola, e crianças que nunca frequentaram uma escola", onde a flexibilização curricular era valorizada, sendo que nem todos os estudantes seriam obrigados a atingir "o mesmo grau de conhecimento num tempo determinado"46. (OLANDA, 2006, p. 50).

Em 1997, começa o atendimento escolar hospitalar voltados aos pacientes de todas as idades, no Hospital Sarah Kubitschek, na cidade de Belo Horizonte, em Minas Gerais. A proposta era desenvolver as atividades, em parceria com as escolas de origem dos pacientes/estudantes, nos leitos ou no refeitório, depois de uma semana de internação.

Também no Estado de Minas Gerais, em 2010, o município de Juiz de Fora "elaborou um projeto de implantação de classes hospitalares", que envolveu a "Secretaria de Educação, gestores e professores das escolas, profissionais da área da saúde, além de conselheiros tutelares, escolas, pais e responsáveis, entre outros" o que facilitou a sua implantação. (ARAÚJO, 2017, p. 108).

Com relação ao Hospital Sarah Kubitschek acredito ser importante destacar que é um hospital que reconhece e valoriza a ação docente, principalmente do Pedagogo ${ }^{47}$. Neste sentido foi realiza a contratação deste profissional, por meio de concurso público em suas unidades de: Brasília (DF), São Luís (MA), Salvador (BA), Belo Horizonte (MG) e Rio de Janeiro (RJ). O pedagogo fazia parte do quadro de funcionários do hospital, compondo com Pediatras, Enfermeiros, Fisioterapeutas, Fonoaudiólogos, Psicólogos e Professores de Educação Física, uma equipe multidisciplinar, que visava atender as crianças e os adolescentes internados em sua integralidade, realizando a discussão, acompanhamento e avaliação da recuperação deles.

\footnotetext{
${ }^{46}$ Vale ressaltar que isso deveria acontecer em qualquer escola, no hospital ou fora dele.

${ }^{47}$ Essa ação docente a que me refino relacionada ao curso de Pedagogia, dentre suas habilitações, também prepara o estudante para atuar como professor na Educação Infantil e nos anos iniciais do Ensino Fundamental.
} 
No Hospital Sarah, de São Luís, no Estado do Maranhão, o atendimento escolar ocorria na Enfermaria Pediátrica, aos pacientes que ficavam internados por um tempo mínimo de internação. O trabalho do professor tem início a partir da coleta de dados e informações sobre a escolarização das crianças ou adolescentes. $\mathrm{Na}$ sequência era realizado um contato com a escola destes estudantes para solicitar os conteúdos escolares. Quando as crianças não frequentavam a escola ou não se conseguia o contato com a escola de origem era realizada uma avaliação pedagógica, para descobrir as dificuldades dos estudantes em idade escolar "para possibilitar a implementação de um programa que, embora tente seguir a educação formal, modifica-se no cotidiano trabalhado com a inserção de vídeos, computador e jogos pedagógicos". (OLANDA, 2006, p. 53).

Em 1999, foi instituído no Estado de Goiás o "Projeto Hoje", direcionado ao atendimento escolar das crianças hospitalizadas. O Projeto chegou a ter 22 classes hospitalares e atendia aproximadamente duzentos estudantes por dia. (ARAÚJO, 2017, p. 108).

Em 2002, o Núcleo de Educação Popular (NEP), da Universidade Estadual do Pará (UEPA) começou um atendimento pedagógico com as crianças em tratamento oncológico na Associação Voluntariado de Apoio à Oncologia (AVAO) ${ }^{48}$, sendo que dentre as atividades realizadas com as crianças estavam os desenhos, pinturas com guache, recortes, colagens, leituras de histórias infantis, atividades de alfabetização com produção "de fichas de descobertas das famílias silábicas a partir das palavras que tenham significância" para os estudantes, além das atividades ofertadas no projeto pedagógico "Árvore da Vida ou da felicidade"49. (OLANDA, 2006, p. 58).

Todas as experiências destacadas em relação aos atendimentos educacionais em hospitais em diversos Estados do Brasil, apontam para uma grande expansão que

\footnotetext{
48 A Associação Voluntariado de Apoio à Oncologia (AVAO) é uma entidade filantrópica de direito privado, fundada em 1999, sem fins lucrativos, que se mantém através de doações e que tem como objetivo prestar apoio aos pacientes portadores de câncer atendidos no município de Belém no Hospital Ofhir Loyola, com sede própria localizada na Travessa 14 de abril, ao lado do Hospital Ofhir Loyola. (OLANDA, 2006, p. 57).

49 O projeto pedagógico denominado "Árvore da Vida ou da felicidade" consiste em uma atividade realizada por meio de um desenho de árvore, em que seus ramos são formados por folhas compostas de desenhos e micro-textos de cada criança. Essa atividade auxilia a identificação de quais conhecimentos foram trabalhados durante o projeto no retorno do estudante para seu universo escolar, como estratégia que favorece, tanto para o educador, como para o educando, o reencontro na ação educativa, assim como possibilita a identificação e alegria desses estudantes que se identificam por meio de seus trabalhos expostos, ocorrendo assim, o reconhecimento da preservação de seu lugar naquele espaço educativo diferenciado. (OLANDA, 2006, p. 58).
} 
ocorreu até o ano de 2011. De acordo com Fonseca (2011), podemos também apontar para os atendimentos realizados em várias regiões do país.

\section{Quadro 1 - Hospitais com Atendimento Educacional por regiões e estados brasileiros}

\begin{tabular}{|c|c|}
\hline \multicolumn{2}{|r|}{ Região Norte } \\
\hline Acre & $\begin{array}{l}\text { Hospital de Saúde Mental do Estado do Acre } \\
\text { Fundação Hospitalar do Acre } \\
\text { Hospital Infantil Yolanda Costa e Silva }\end{array}$ \\
\hline Pará & $\begin{array}{l}\text { Hospital Ophir Loyola (oncologia) } \\
\text { Fundação Santa Casa de Misericórdia do Pará } \\
\text { Hospital Metropolitano de Urgência e Emergência } \\
\text { Fundação Hospital de Clínicas Gaspar Viana } \\
\text { Hospital Universitário João de Barros Barreto }\end{array}$ \\
\hline Roraima & Hospital da Criança Santo Antônio em Boa Vista; \\
\hline Tocantins & Hospital de Referência de Gurupi (UNIRG). \\
\hline \multicolumn{2}{|r|}{ Região Nordeste } \\
\hline Bahia & $\begin{array}{l}\text { Hospital Sarah de Salvador } \\
\text { Hospital da Criança (Obras Assistenciais Irmã Dulce) } \\
\text { Hospital Infantil Martagão Gesteira } \\
\text { Hospital Roberto Santos } \\
\text { Hospital Santa Isabel } \\
\text { Hospital Couto Maia } \\
\text { Hospital Eládio Lassferre } \\
\text { Hospital Anna Nery } \\
\text { Hospital São Rafael } \\
\text { Hospital Otávio Mangabeira } \\
\text { Hospital Manuel Novaes em Itabuna } \\
\text { Hospital São Marcos } \\
\text { Hospital Aristides Maltez } \\
\text { Hospital Subúrbio }\end{array}$ \\
\hline Ceará & $\begin{array}{l}\text { Hospital Infantil Albert Sabin } \\
\text { Instituto do Rim e Hospital do Coração }\end{array}$ \\
\hline Maranhão & Hospital Sarah São Luís \\
\hline $\begin{array}{l}\text { Rio Grande do } \\
\text { Norte }\end{array}$ & $\begin{array}{l}\text { Hospital Varela Santiago } \\
\text { Hospital do Seridó em Caicó (Escola Sulivan Medeiros) } \\
\text { Hospital Maria Alice }\end{array}$ \\
\hline Sergipe & Hospital João Alves Filho \\
\hline Aracaju & Hospital Universitário de Aracajú. \\
\hline \multicolumn{2}{|r|}{ Região Centro Oeste } \\
\hline Distrito Federal & $\begin{array}{l}\text { Hospital de Base de Brasília } \\
\text { Hospital Regional Materno Infantil Asa Sul } \\
\text { Hospital de Reabilitação Asa Norte } \\
\text { Hospital de Apoio (Oncologia) } \\
\text { Hospital Gama } \\
\text { Hospital Regional de Brasilândia } \\
\text { Hospital Regional da Gama } \\
\text { Hospital Regional de Ceilândia } \\
\text { Hospital da Cidade de Taguatinga }\end{array}$ \\
\hline
\end{tabular}




\begin{tabular}{|c|c|}
\hline & $\begin{array}{l}\text { Hospital Sarah de Brasília } \\
\text { Hospital Regional de Sobradinho } \\
\text { Hospital Regional de Samambaia } \\
\text { Hospital Universitário de Brasília }\end{array}$ \\
\hline Goiás & $\begin{array}{l}\text { Hospital Materno-Infantil de Goiânia } \\
\text { Hospital de Clínicas (UFG) } \\
\text { Hospital Araújo Jorge em Goiânia } \\
\text { Hospital de Doenças Tropicais de Goiânia } \\
\text { Centro Integrado de Saúde Mental Emanuel }\end{array}$ \\
\hline Mato Grosso & Hospital Universitário Júlio Muller (UFMT) em Cuiabá \\
\hline $\begin{array}{l}\text { Mato Grosso } \\
\text { do Sul }\end{array}$ & $\begin{array}{l}\text { Assoc. Beneficente Santa Casa da Cidade de Campo Grande } \\
\text { Hospital Universitário de Campo Grande (Be-a-Ba) } \\
\text { Hospital Regional de Mato Grosso do Sul Rosa Pedrossian } \\
\text { Hospital São Julião (hanseníase) } \\
\text { Hospital Universitário de Dourados } \\
\text { Hospital do Câncer Alfredo Abrão }\end{array}$ \\
\hline \multicolumn{2}{|r|}{ Região Sudeste } \\
\hline Espirito Santo & Hospital Infantil Nossa Senhora da Glória \\
\hline Minas Gerais & $\begin{array}{l}\text { Hospital Sarah Kubitschek de Belo Horizonte } \\
\text { Hospital João Paulo II (Fundação Hospitalar de MG - Fleming) } \\
\text { Fundação Hemominas em Belo Horizonte } \\
\text { Santa Casa de Misericórdia de Belo Horizonte } \\
\text { Hospital Universitário de Juiz de Fora } \\
\text { Hospital Municipal de Governador Valadares } \\
\text { Hospital Vital Brasil em Timóteo } \\
\text { Hospital Márcio Cunha em Ipatinga } \\
\text { Santa Casa de Misericórdia de Montes Claros } \\
\text { Hospital Universitário Clemente de Faria (UNIMONTES) }\end{array}$ \\
\hline São Paulo & $\begin{array}{l}\text { Hospital da Santa Casa de Misericórdia } \\
\text { Hospital São Paulo (UNIFESP) } \\
\text { Hospital do Câncer (A.C. Camargo) } \\
\text { Centro de Atenção Integral a Saúde Clemente Ferreira em Lins } \\
\text { Hospital das Clínicas (FMUSP) } \\
\text { Instituto do Coração } \\
\text { Instituto da Criança } \\
\text { Instituto de Traumato-Ortopedia } \\
\text { Hospital Emílio Ribas, Instituto de Psiquiatria } \\
\text { Hospital Estadual Infantil Darcy Vargas } \\
\text { Hospital Infantil Cândido Fontoura } \\
\text { Hospital de Clínicas de Ribeirão Preto } \\
\text { Hospital da SOBRAPAR (anomalias craniofaciais) } \\
\text { Hospital do Servidor Público Municipal da Cidade de São Paulo } \\
\text { Hospital do Servidor Público de São Paulo } \\
\text { Centro Infantil Boldrini em Campinas } \\
\text { Hospital de Clínicas de Campinas } \\
\text { Hospital Mário Gatti em Campinas } \\
\text { Hospital de Clínicas e Hemocentro de Marília } \\
\text { Hospital de Base de São José do Rio Preto } \\
\text { Hospital Municipal de Paulínia } \\
\text { Hospital do Câncer de Barretos }\end{array}$ \\
\hline
\end{tabular}




\begin{tabular}{|c|c|}
\hline & $\begin{array}{l}\text { Hospital GRENDAC em Jundiaí } \\
\text { Hospital Mun. Ver. José Storópolli na Vila Maria (UNICAPITAL) }\end{array}$ \\
\hline Rio de Janeiro & $\begin{array}{l}\text { Hospital Municipal Jesus } \\
\text { Hospital São Zacarias } \\
\text { Hospital Marcílio Dias } \\
\text { Hospital Cardoso Fontes } \\
\text { Hospital dos Servidores do Estado } \\
\text { Hospital Geral de Bonsucesso } \\
\text { Instituto Nacional do Câncer } \\
\text { Instituto Estadual de Hematologia Arthur de Siqueira Cavalcanti } \\
\text { Instituto de Puericultura e Pediatria Martagão Gesteira (UFRJ) } \\
\text { Hospital Universitário Pedro Ernesto (UFRJ) } \\
\text { Hospital Geral de Nova Iguaçu (Hospital da Posse) } \\
\text { Hospital Universitário Antônio Pedro (UFF) em Niterói } \\
\text { Hospital Getúlio Vargas Filho em Niterói } \\
\text { Hospital Municipal Desembargador Leal Junior em Itaboraí } \\
\text { Hospital Alcides Carneiro em Petrópolis } \\
\text { Hospital Infantil Ismélia da Silveira em Duque de Caxias }\end{array}$ \\
\hline \multicolumn{2}{|r|}{ Região Sul } \\
\hline Paraná & $\begin{array}{l}\text { Hospital Infantil Pequeno Príncipe } \\
\text { Hospital Erasto Gaertner } \\
\text { Hospital Universitário Evangélico de Curitiba } \\
\text { Hospital de Clínicas (UFPR) } \\
\text { Fundação Criança Renal } \\
\text { Hospital Santa Casa de Cornélio Procópio }\end{array}$ \\
\hline Santa Catarina & $\begin{array}{l}\text { Hospital Infantil Joana de Gusmão em Florianópolis } \\
\text { Hospital Hélio Anjos Ortiz em Curitibanos } \\
\text { Hospital Regional Lenoir Vargas Ferreira em Chapecó } \\
\text { Hospital Nossa Senhora da Conceição em Tubarão } \\
\text { Hospital Bom Jesus em Ituporanga } \\
\text { Hospital Santa Terezinha em Joaçaba } \\
\text { Hospital São Francisco em Concórdia } \\
\text { Hospital Regional São Paulo em Xanxerê } \\
\text { Hospital Santo Antônio em Blumenau }\end{array}$ \\
\hline $\begin{array}{l}\text { Rio Grande do } \\
\text { Sul }\end{array}$ & $\begin{array}{l}\text { Hospital de Clínicas de Porto Alegre } \\
\text { Hospital da Criança Santo Antônio } \\
\text { Hospital Universitário de Santa Maria (UFSM) } \\
\text { Hospital Santa Terezinha em Erechim. }\end{array}$ \\
\hline
\end{tabular}

Fonte: Fonseca (2011, p.82-85).

Pelo levantamento de Fonseca (2011, p. 83, 84), em 2011 havia hospitais que ofereciam atendimento escolar para os estudantes hospitalizados em todos os estados das regiões Sul, Sudeste e Centro-Oeste. Todavia, nas regiões Nordeste não houve informações sobre esse tipo de atendimento nos Estados do: Piauí, Paraíba, Pernambuco e Alagoas. Na Região Norte, não foi identificado educação hospitalar nos Estados do: Amazonas, Rondônia e Amapá. Araújo (2017, p. 110), endossa as informações apontadas por Fonseca (2011) e ainda destaca que nos Estados de São 
Paulo, Rio de Janeiro, Paraná, Bahia e Distrito Federal possuem a maior concentração de hospitais com atendimento escolar, o que não corresponde aos Estados onde ocorrem os maiores índices de internamentos:

Comparando os dados da quantidade de escolas no hospital e da quantidade de internações anuais por estado, observa-se que os estados que mais ofertam escolas ou classes para este tipo de atendimento são: São Paulo (18\%), Rio de Janeiro (12\%) e Paraná (11\%). E os estados da Bahia e de Minas Gerais possuem um número maior de internações, (104486 e 98830, respectivamente), que os estados do Rio de Janeiro (73208) e do Paraná (60484), por exemplo. Contudo, oferecem um número menor de estabelecimentos que proporcionam o atendimento escolar à crianças e adolescentes hospitalizados. A Bahia conta com $9 \%$ do número total de hospitais com atendimento escolar e Minas Gerais conta com apenas 7\%. (ARAÚJO, 2017, p. 113).

Mesmo com todo o incentivo e a implantação de Educação em hospitais na maioria dos Estados brasileiros, os dados apresentados por Araújo (2017, p. 109-112) "justificam que, para que se concretize o atendimento às legislações" relativas à Educação Hospitalar das crianças hospitalizadas em classes hospitalares ou escolas hospitalares, é "necessário a criação de políticas públicas para esse fim". Neste sentido Fonseca (1999c, p. 33) corrobora argumentando ser necessário fomentar a garantia do direito à educação aos estudantes hospitalizados por meio de uma política pública voltada para as necessidades pedagógico-educacionais e os direitos à educação e a saúde desta população "que se encontra em particular estágio de vida, tanto em relação ao crescimento e desenvolvimento, quanto em relação à construção de estratégias sócio interativas para o viver individual e em coletividade" (ARAÚJO, 2017, p. 113) e desta forma favorecer o aumento deste tipo de atendimento, principalmente nos locais onde ocorre o maior número de internados.

\subsection{A ESPECIFICIDADE LEGAL DA EDUCAÇÃO HOSPITALAR BRASILEIRA}

A Declaração Universal dos Direitos da Criança, aprovada em 1959 pela Organização das Nações Unidas tem entre suas prioridades a defesa ao direito à educação, ao brincar e ao convívio social. Segundo Bellinghausen (2003, p. 28; ONU, 1959), o 5ำ princípio desta declaração destaca que deverá ser oferecida à "criança incapacitada física, mental ou socialmente [...] o tratamento, a educação e os cuidados especiais exigidos pela sua condição peculiar". 
No Brasil, a Lei 꾸 1.044/69 é a primeira normativa, explicitamente voltada ao atendimento das crianças e adolescentes afastados da escola por motivos de saúde. Esta lei estabelece o direito do aluno portador de afecções congênitas ou adquiridas a continuar seus estudos, principalmente se os alunos se encontrarem em condições de aprendizagem. (BRASIL, 1969).

Em 1988, a Constituição da República Federativa do Brasil estabeleceu a obrigatoriedade de educação para todos e a declarou um direito de todos e um dever do Estado, assim como a universalização do atendimento escolar, em seus Artigos 205 e 214. (BRASIL, 1988).

A Conferência Mundial sobre "Educação para Todos", realizada em 1990, em Jomtien, na Tailândia, voltou sua atenção à satisfação das necessidades básicas de aprendizagem e para tanto, elaborou um documento que tratava das necessidades básicas de aprendizagem. Apresentava as metas a serem atingidas relacionadas à educação básica. Com relação aos sujeitos que apresentam necessidades especiais o Artigo $3^{\circ}$ deste documento de diretrizes e metas, elaborado pela UNESCO, destacou a questão da universalização do acesso e a promoção da equidade na Educação para os sujeitos com deficiência. (UNESCO, 1998, p. 4):

Art. 3 UNIVERSALIZAR O ACESSO À EDUCAÇÃO E PROMOVER A EQUIDADE [...] 5. As necessidades básicas de aprendizagem das pessoas portadoras de deficiências requerem atenção especial. É preciso tomar medidas que garantam a igualdade de acesso à educação aos portadores de todo e qualquer tipo de deficiência, como parte integrante do sistema educativo.

Voltando ao Brasil, neste mesmo ano foi aprovada a Lei ํo. 8069/1990, o Estatuto da Criança e do Adolescente (ECA), que dispõe sobre a proteção integral à criança e ao adolescente como cidadão e sujeito de Direito. Neste Estatuto que expõe as garantias de direitos para a criança e adolescente, também é considerada a situação especial de escolarização a seguir.

Art. 5o Nenhuma criança ou adolescente será objeto de qualquer forma de negligência, discriminação, exploração, violência, crueldade e opressão, punido na forma da lei qualquer atentado, por ação ou omissão, aos seus direitos fundamentais. [...]

[...]Art. 53. A criança e o adolescente têm direito à educação, visando ao pleno desenvolvimento de sua pessoa, preparo para o exercício da cidadania e qualificação para o trabalho, assegurando-se-lhes:

I - igualdade de condições para o acesso e permanência na escola;

Art. 54. É dever do Estado assegurar à criança e ao adolescente:

I - ensino fundamental, obrigatório e gratuito, inclusive para os que a ele não tiveram acesso na idade própria; (BRASIL, 1990). 
Em 1994, realizada em Salamanca, na Espanha, a Conferência Mundial sobre "Necessidades Educativas Especiais: acesso e qualidade" comprometeu-se com a garantia do acesso à escola regular às crianças e adolescentes com deficiência, discutindo também sobre as escolas inclusivas para todos. Na conferência foi elaborado um documento que ressalta a Política e a Prática em Educação Especial.

No Brasil, foi promulgada as Diretrizes e Bases da Educação Nacional (LDB), Lei no 9.394/96, que em seu título II, Artigo 3ㅜㅗ inciso I, dispõe sobre a garantia do acesso e permanência na escola, retomando a ideia de educação para todos, igualdade de condições de cidadãos e seus direitos, já prevista na Constituição Federal de 1988. O atendimento pedagógico educacional hospitalar e domiciliar também podem ser observados no Capítulo V, Artigo 58, da LDB, que dispõe sobre a Educação Especial aos portadores de necessidades especiais. Nestes artigos podemos entender as crianças e adolescentes, como sujeitos de direitos, tendo as suas necessidades e interesses atendidos até mesmo quando estão com a saúde comprometida.

Colaborando com essa perspectiva, em 2001, o Conselho Nacional de Educação institui as Diretrizes Nacionais para a Educação Especial na Educação Básica, com a publicação da Resolução do Conselho Nacional de Educação/CEB n. 02/01. Essa resolução, dentre seus objetivos visava o retorno e reintegração da criança e/ou do adolescente às escolas regulares após alta da internação, dispunha, ainda em seu Artigo 13, da necessidade de oferta de classes hospitalares, e o atendimento pedagógico em ambiente domiciliar, visando à continuidade do processo de desenvolvimento e de aprendizagem de alunos matriculados na Educação Básica. Isto evidencia a preocupação e o respeito com a situação de adoecimento e hospitalização da criança, como já referenciamos, a classe hospitalar surgiu "como uma modalidade de ensino da Educação Especial, regulamentada por legislação específica, que visa atender pedagógico-educacionalmente crianças e adolescentes hospitalizados". (HOLANDA; COLLET, 2011, p. 382).

Em 2002, esse contexto e em atendimento a LDB, o Ministério da Educação (MEC) publicou o documento orientador intitulado "Classe Hospitalar e Atendimento Pedagógico Domiciliar: estratégias e orientações":

Na impossibilidade de freqüência à escola, durante o período sob tratamento de saúde ou de assistência psicossocial, as pessoas necessitam de formas alternativas de organização e oferta de ensino de modo a cumprir com os 
direitos à educação e à saúde, tal como definidos na Lei e demandados pelo direito à vida em sociedade. (BRASIL, 2002, p. 11).

Entre os objetivos apontados no documento pode-se destacar que as classes hospitalares deveriam:

\begin{abstract}
elaborar estratégias e orientações para possibilitar o acompanhamento pedagógico-educacional do processo de desenvolvimento e construção do conhecimento de crianças, jovens e adultos matriculados ou não nos sistemas de ensino regular, no âmbito da educação básica e que encontramse impossibilitados de freqüentar escola, temporária ou permanentemente e, garantir a manutenção do vínculo com as escolas por meio de um currículo flexibilizado e/ou adaptado, favorecendo seu ingresso, retorno ou adequada integração ao seu grupo escolar correspondente, como parte do direito de atenção integral. (BRASIL, 2002, p. 13).
\end{abstract}

Esse documento orientador do MEC vincula nitidamente a classe hospitalar com o ensino da Educação Especial, afinal, além da regulamentação legal específica, o direcionamento das ações e estratégias orientadas pelo MEC explicitam o objetivo do atendimento pedagógico-educacional das crianças e adolescentes hospitalizados considerando os princípios básicos da Educação Especial, por exemplo a flexibilização e adaptação curricular. Segundo Holanda e Collet, (2011, p. 382), esses estudantes ao ficarem afastados do universo escolar e impedidos do convívio social com os semelhantes, convivem com o "risco de fracasso escolar e de possíveis transtornos ao desenvolvimento", portanto, os professores precisam "adequar a programação ao conteúdo em andamento nas classes originais dos alunos, a fim de ajudá-los na reintegração escolar após a alta hospitalar".

Segundo o inciso III, do Art. $8^{\circ}$ da Resolução CNE/CEB nº 02/2001, que instituiu as Diretrizes Nacionais para a Educação Especial na Educação Básica, as escolas da rede regular de ensino devem prever e dispor, na organização de suas classes comuns de

flexibilização e adaptações curriculares, que considerem o significado prático e instrumental dos conteúdos básicos, metodologias de ensino e recursos didáticos diferenciados e processo de avaliação adequados ao desenvolvimento dos alunos que apresentam necessidades educacionais especiais, em consonância com o projeto pedagógico da escola, respeitada a freqüência obrigatória. (BRASIL, CNE/CEB 2001).

Ao se tratar de flexibilização curricular o volume V, do Projeto Escola Viva, que trata das Adaptações Curriculares de Grande Porte, indica que a flexibilização pode ocorrer nas adaptações curriculares no que diz respeito aos objetivos, conteúdos, método de ensino, estratégias de avaliação, temporalidade e organização. (BRASIL, 
2000a, p. 10). Com relação à adaptação curricular, o MEC informa que existem as de grande porte que "compreendem ações que são da competência e atribuição das instâncias político-administrativas superiores, já que exigem modificações que envolvem ações de natureza política, administrativa, financeira, burocrática, etc". e as de pequeno porte que "compreendem modificações menores, de competência específica do professor. Elas constituem pequenos ajustes nas ações planejadas a serem desenvolvidas no contexto da sala de aula". (BRASIL, 2000a, p. 09). Essas adaptações de pequeno porte são relacionadas exclusivamente à especificidade do trabalho do professor não necessitando de autorização, "nem dependendo de ação de qualquer outra instância superior, nas áreas política, administrativa e/ou técnica". (BRASIL, 2000b, p. 08).

Neste sentido, é importante pensar nas adaptações que seriam necessárias, tanto dos recursos e instrumentos didático-pedagógicos, como dos aspectos pedagógicos. Entre os recursos e instrumentos didático-pedagógicos estavam indicados: os "jogos e materiais de apoio pedagógico disponibilizados ao educando pelo professor e que possam ser manuseados e transportados com facilidade"; pranchas com presilhas e "suporte para lápis e papel; teclados de computador adaptados; softwares educativos; pesquisas orientadas via internet; vídeos educativos, etc". (BRASIL, 2002, p. 17). Nas adaptações dos aspectos pedagógicos pode-se destacar que:

O atendimento pedagógico deverá ser orientado pelo processo de desenvolvimento e construção do conhecimento correspondentes à educação básica, exercido numa ação integrada com os serviços de saúde. A oferta curricular ou didático-pedagógica deverá ser flexibilizada, de forma que contribua com a promoção de saúde e ao melhor retorno e/ou continuidade dos estudos pelos educandos envolvidos. (BRASIL, 2002, p. 17).

Com relação à competência do atendimento educacional hospitalar descrito no documento do MEC, que indica estratégias e dá orientações para a implementação de Classe hospitalar, vinculada "aos sistemas de educação como uma unidade de trabalho pedagógico das Secretarias Estaduais, do Distrito Federal e Municipais de Educação, como também às direções clínicas dos sistemas e serviços de saúde em que se localizam". Assim as Secretarias de Educação devem acatar as solicitações dos hospitais para a oferta do serviço de atendimento educacional hospitalar, contratar e capacitar os professores, dispor dos recursos financeiros e materiais para esses atendimentos. (BRASIL, 2002, p. 15). 
O documento do MEC indica ainda, que os aspectos físicos do espaço, as instalações, os equipamentos dos ambientes das classes hospitalares devem ser projetados com o intuito de "favorecer o desenvolvimento e a construção do conhecimento para crianças, jovens e adultos, no âmbito da educação básica, respeitando suas capacidades e necessidades educacionais especiais individuais". Essa classe hospitalar deve ter uma sala com mobiliário adequado, para o desenvolvimento das atividades educacionais. Além disto, há uma exigência de se ter uma bancada com pia no local, "instalações sanitárias próprias, completas, suficientes e adaptadas [...] e espaço ao ar livre adequado para atividades físicas e ludopedagógicas". O documento aponta ainda que o atendimento poderá acontecer "na enfermaria, no leito ou no quarto de isolamento, uma vez que restrições impostas ao educando por sua condição clínica ou de tratamento assim requeiram", como também no ambulatório do hospital onde "poderá ser organizada uma sala específica da classe hospitalar ou utilizar-se os espaços para atendimento educacional". (BRASIL, 2002, p. 16).

Dentre os materiais e equipamentos necessários para a classe hospitalar o documento indica que

[...] sempre que possível, devem estar disponibilizados recursos audiovisuais, como computador em rede, televisão, vídeo-cassete, máquina fotográfica, filmadora, videokê, antena parabólica digital e aparelho de som com CD e k7, bem como telefone, com chamada a ramal e linha externa.

A justificativa para a liberação desses materiais e equipamentos deveriam ocorrer porque são considerados essenciais para "o planejamento, desenvolvimento e avaliação do trabalho pedagógico", assim como no contato da classe hospitalar, tanto com a escola de origem do estudante, como com "o sistema de ensino responsável por prover e garantir seu acesso escolar" e também com dos estudantes atendidos com os docentes e amigos da escola de origem se desejar ou precisar. (BRASIL, 2002, p. 16).

Com relação às condições clínicas que impossibilitam o uso da classe hospitalar pelos estudantes internados se destacam entre as principais causas: dificuldades de locomoção; imobilização parcial ou total; obrigação de horários para administração de medicamentos; efeitos colaterais de determinados medicamentos; restrições na alimentação; procedimentos invasivos; dores localizadas ou generalizadas; e, indisposição geral decorrente de doenças variadas. Dentre as 
especificidades individuais que impossibilitam aos estudantes a realização das atividades educacionais nas classes hospitalares se destacam, principalmente, 0 repouso relativo ou absoluto, a necessidade de permanecer na cama ou a exigência do uso constante de equipamentos de suporte à vida. Nestas condições e limitações especiais, é de responsabilidade do

\begin{abstract}
sistema educacional e serviços de saúde, oferecerem assessoramento permanente ao professor, bem como inseri-lo na equipe de saúde que coordena o projeto terapêutico individual. O professor deve ter acesso aos prontuários dos usuários das ações e serviços de saúde sob atendimento pedagógico, seja para obter informações, seja para prestá-las do ponto de vista de sua intervenção e avaliação educacional. (BRASIL, 2002, p. 18).
\end{abstract}

Ainda segundo o documento orientador do MEC, os recursos humanos para a implantação do serviço devem contar com um professor coordenador para "coordenar a proposta pedagógica em classe hospitalar", tendo entre suas atribuições "conhecer a dinâmica e o funcionamento peculiar dessas modalidades, assim como conhecer as técnicas e terapêuticas que dela fazem parte ou as rotinas da enfermaria ou dos serviços ambulatoriais e das estruturas de assistência social", quando for o caso. Administrativamente, precisa estar articulado com "a equipe de saúde do hospital, com a Secretaria de Educação e com a escola de origem do educando" e ainda realizar a orientação dos professores da classe hospitalar "em suas atividades e definir demandas de aquisição de bens de consumo e de manutenção e renovação de bens permanentes". (BRASIL, 2002, p. 21).

O professor é outro integrante da equipe de recursos humanos e deve atuar na classe hospitalar trabalhando "com a diversidade humana e diferentes vivências culturais, identificando as necessidades educacionais especiais dos educandos impedidos de frequentar a escola, definindo e implantando estratégias de flexibilização e adaptação curriculares". Precisa também:

propor procedimentos didático-pedagógicos e as práticas alternativas necessárias ao processo ensino-aprendizagem dos alunos, bem como ter disponibilidade para o trabalho em equipe e o assessoramento às escolas quanto à inclusão dos educandos que estiverem afastados do sistema educacional, seja no seu retorno, seja para o seu ingresso. (BRASIL, 2002, p. 21).

O professor precisa ainda "fazer parte da equipe de assistência ao educando", para auxiliar nos cuidados da saúde, assim como no aperfeiçoamento do planejamento de ensino", consultando o prontuário e as informações ali registradas, sua formação deve ser preferencialmente em Educação Especial, Pedagogia ou 
licenciaturas, precisa "ter noções sobre as doenças e condições psicossociais vivenciadas pelos educandos e as características delas decorrentes" e finalmente, é de sua competência "adequar e adaptar o ambiente às atividades e os materiais, planejar o dia-a-dia da turma, registrar e avaliar o trabalho pedagógico desenvolvido". (BRASIL, 2002, p. 21).

Além do professor responsável pela classe, o documento ainda indica um profissional de apoio para trabalhar como assistente das classes hospitalares, podendo ser um profissional "de nível médio ou estudantes universitários das áreas da saúde e educação", sendo sua função auxiliar o professor na organização do espaço e controle da frequência dos estudantes, ajudar na manutenção da "higiene do ambiente e dos materiais, a desinfecção concorrente e terminal dos mesmos e o acompanhamento dos educandos para uso do banheiro e na alimentação em classe". (BRASIL, 2002, p. 22).

Nas considerações finais do documento orientador, são publicadas algumas orientações relativas à necessidade do Poder Público em identificar os estabelecimentos de saúde que ofertam Educação para crianças e adolescente. Parece que o objetivo é reforçar orientações legais em relação à obrigatoriedade das classes hospitalares. Segundo a Lei de Diretrizes e Bases da Educação e as Diretrizes Nacionais da Educação Especial na Educação Básica, a necessidade de os sistemas de ensino ofertar formação continuada aos professores das classes hospitalares com o objetivo de que este atendimento trabalhe de acordo com os princípios e orientações da educação básica, assim como sendo comprometido com o sucesso do estudante e a proposta de atenção integral. (BRASIL, 2002, p. 25).

Por fim, dentre as recomendações finais do documento se destacam a indicação de ação conjunta entre os Sistemas de Educação e de Saúde, Estaduais, Municipais e do Distrito Federal, dada "a complexidade do atendimento pedagógicoeducacional realizado em ambientes hospitalares e domiciliares", fomento de debates, formações e jornadas com o intuito de "sensibilizar os gestores educacionais, professores [e instituições parceiras] no que se refere às necessidades e especificidades do atendimento hospitalar e domiciliar" para favorecer sua institucionalização, assim como para a elaboração de "um plano de trabalho que oriente e acompanhe o trabalho pedagógico" e favoreça "a articulação das classes hospitalares [...] com os Sistemas de Educação e de Saúde" e comunicar a rede de ensino e aos órgãos representativos médicos em âmbito municipal, estadual e federal 
para favorecer a continuidade do atendimento em domicílio ou novas implantações de classes hospitalares para atender o direito dos estudantes em tratamento de saúde à continuidade da escolarização. (BRASIL, 2002, p. 27).

Considerando que a produção destes documentos legais, publicados na década de 1990 são frutos de debates, tensões, disputas, concordo com Arosa (2007) no que tange a perspectiva de que toda essa questão legal acabou demonstrando que o processo de consolidação da classe hospitalar e da Educação Hospitalar ocorreu "num contexto de lutas dos movimentos sociais em favor dos direitos da criança, como parte da redemocratização do país, em que a educação se torna um direito de todos". (ARAÚJO, 2017, p. 97). Passo a discutir a partir deste ponto a função desses movimentos sociais na busca dos direitos das crianças e adolescente, principalmente na garantia do direito à educação sem distinção de espaço, local, tempo e, inclusive, volto a abordar no item 2.2.1 aspectos legais pertinentes ao atendimento educacional hospitalar. 


\title{
CAPÍTULO 2 - A EDUCAÇÃO HOSPITALAR E EDUCAÇÃO, ONDE SE INSERE ESSA NOVIDADE?
}

\author{
...venha cá, venha cá! \\ Não tenha medo... \\ Vem dançar a \\ Dança da peneira... \\ Tô na peneira... \\ Tô peneirando \\ Tô no namoro... \\ Tô namorando \\ Tô no movimento... \\ Tô movimentando!! \\ (Tirado da edição extra do "Pé-de-Moleque" \\ - MNMMR ${ }^{50}, 1995$, VALLAURI, 2007, p.459).
}

O objetivo do capítulo é realizar uma análise das discussões pedagógicas sobre a Educação Hospitalar no Paraná, procurando entender quais ações contribuíram para a estruturação da Educação Hospitalar para crianças em Curitiba, no final do século XX. Aqui se busca identificar o papel da municipalização do ensino para a educação e apontar quais as questões políticas pedagógicas da Educação nas décadas de 1980 e 1990 que contribuíram para a Educação Hospitalar no Paraná.

A discussão norteadora deste capítulo é o discurso político e pedagógico observado na Educação Hospitalar do Paraná, analisando o seu pretenso pioneirismo na Educação Hospitalar em um hospital infantil de Curitiba - PR, identificando onde se insere a Educação Hospitalar na Educação de forma mais ampla e, então, contextualizar a Educação Hospitalar no que se refere aos movimentos sociais e políticos pelos direitos das crianças e adolescentes favorecendo a aprovação do ECA. Dentre esses movimentos destaco os movimentos de mulheres e de meninos e meninas de rua, que contribuíram para fomentar a movimentação social com o envolvimento desses sujeitos nas propostas, assim como nas lutas sociais. Apresento ainda um extrato do poema publicado num dos jornais do MNMMR, que demonstra a clareza do engajamento desses sujeitos na luta pelos seus direitos. O recorte temporal deste capítulo situa-se entre a década de 1980 até aproximadamente os anos 2000.

Essa análise das discussões pedagógicas sobre a Educação Hospitalar no Paraná será norteada pelo seguinte questionamento: quais ações contribuíram para a implantação de um serviço de educação num hospital para crianças em Curitiba no

50 "Pé de Moleque" era o nome de um jornal que começou a ser vinculado em 1992 e era organizado pelo Movimento Nacional de Meninos e Meninas de Rua (MNMMR). 
final do século XX? Qual a importância da municipalização do ensino para a educação? E quais as questões políticas pedagógicas da Educação, nas décadas de 1980 e 1990, que contribuíram para a Educação Hospitalar no Paraná? Tais questionamentos fundamentam-se em Chartier, pretendem trabalhar com a ideia de uma história problema, onde seu objeto é construído, suas hipóteses devem ser explicitadas e seus procedimentos conhecidos (1996, p. 64).

Portanto, neste capítulo, procuro perceber como se apresentava, nas décadas de 1980 e 1990, a preocupação com a educação de crianças, como e quando foi criado e implementado a Educação Hospitalar em Curitiba, de que modo se apresenta a história da Educação Hospitalar em Curitiba, qual a importância da educação nesse processo de efetivação dos atendimentos educacionais às crianças curitibanas, como e quando foi realizada a municipalização da Educação Básica no Paraná, como a Municipalização da Educação Básica no Paraná é fundamentada pela legislação educacional nacional e paranaense, quais as contribuições da municipalização do Ensino na Educação Hospitalar do Paraná, onde a Educação Hospitalar se insere no âmbito da Educação e quais os aspectos legais pertinentes ao Estado do Paraná. Quais os materiais educacionais e pedagógicos utilizados na Educação que também são utilizados na Educação Hospitalar paranaense?

Com relação ao desenvolvimento econômico, no Paraná, posteriormente ao ciclo do café, na década de 1970, a concentração fundiária encerrou a democratização do acesso à terra, fortalecendo o crescimento dos núcleos urbanos (OLIVEIRA, 2001, p. 34). Com a queda da produção de café, a cultura da soja foi adotada pela maioria dos grandes proprietários rurais como a alternativa que pareceu mais atraente. Neste sentido, o Paraná teve um dos crescimentos econômicos mais expressivos na produção de soja do país na década de 1970.

\footnotetext{
Os efeitos da cultura da soja sobre a urbanização e a industrialização paranaenses foram enormes. A intensa mecanização do cultivo e a colheita do produto levou à dispensa de um número enorme de trabalhadores rurais. [...] O resultado foi a expansão do número de desempregados na área rural. (OLIVEIRA, 2001, p. 37).
}

Esses desempregados da área rural migravam para outras fronteiras agrícolas ou para as cidades, o que fez aumentar o número de favelas e cortiços no Paraná, assim como de outros Estados, isso acabou favorecendo, no final dos anos 1970, a transposição da população urbana sob a rural. 
A industrialização se desenvolveu, inicialmente para atender as necessidades e demandas do beneficiamento da soja, como a produção de óleo e farelo de soja (OLIVEIRA, 2001, p. 37), posteriormente para se adequar às necessidades capitalistas que visava o crescimento econômico permanente e "a prosperidade material da sociedade". (OLIVEIRA, 2001, p. 39).

Nos anos finais do período do regime militar, em 1982, o governador eleito para a gestão 1983-87 foi José Richa do PMDB. Assim como outros governadores no Brasil, tentou buscar "novas saídas, não comprometidas com o projeto de sociedade ainda defendido pelo governo federal, que não sofreram mudanças". (COSTA, 2010, p. 5). Em Curitiba, capital do Estado, a migração da população rural ocorrida neste período, ocupou a região sul da cidade, fazendo com que houvesse uma preocupação do governo, tanto do ponto de vista social como habitacional para esta região.

De acordo com os censos do IBGE (2010), a população paranaense sofreu um acréscimo de aproximadamente 368\%, entre os anos de 1991 até 2010. Em 1991, o Paraná contava com 2.229.872 habitantes, em 2000 com 9.564 .643 e em 2010 eram 10.444.526 habitantes.

De acordo com Paiva (1990 p. 7-8), a expansão do sistema de educação pode ser verificada nos anos do primeiro século republicano, onde o país contava com 14 milhões de habitantes e 250000 alunos nas escolas primárias, ou seja, 1 aluno para cada 56 habitantes. Trinta anos depois, tínhamos um aluno para cada 30 habitantes, após um século de República, um aluno para cada 5 habitantes.

\begin{abstract}
Além disso, apesar das imensas críticas que merece o nosso sistema de ensino nesse final de século [...] há que se reconhecer que, ao longo dos últimos 100 anos, observou-se uma notável diferenciação do sistema aliada a uma radical modificação em sua qualidade [...]. A impressionante ampliação do sistema de educação, capaz de justificar a afirmação de que nossa história educacional é fundamentalmente uma história republicana, esconde, porém, uma evolução complexa. (PAIVA, 1990, p. 7-8).
\end{abstract}

No Brasil, a década de 1980 foi marcada por acontecimentos como a transição entre o regime autoritário, a Ditadura Militar, e o regime democrático. A partir de 1979, ainda no contexto da ditadura, observava-se que o processo de democratização começava a se estabelecer (ZANARDINI; BLUM; MICHELLON, 2013, p. 119), desencadeado principalmente, pela greve dos metalúrgicos do ABC paulista, o fim da censura oficial em 1980. A volta dos exiliados começa a ocorrer a partir de 1981, foram realizadas e eleições diretas para governadores, em 1982. Destacamos ainda a emenda apresentada pelo deputado Dante de Oliveira, emenda das eleições diretas 
para presidência - derrotada em 25 de abril de 1984. (FRIGOTTO, 2006, p. 36).

No Paraná, o processo de "democratização" do país se refletiu na década de 1980 com a eleição direta para Governador José Richa eleito pelo do Partido do Movimento Democrático Brasileiro (PMDB), governou no período de 1983-1986, o mote da gestão foi "democracia patrocinada pelo Estado". Além disto, essa gestão instaurou algumas "políticas de impacto" tais como: "eleições diretas para diretor de escola, a não obrigatoriedade do uniforme escolar e a descentralização administrativa da Secretaria de Estado da Educação". (NOGUEIRA,1994, p. 10).

No período de 1987-1990, o Estado foi governado por Álvaro Dias, do PMDB, a plataforma da gestão foi "a redefinição da democratização pelo Estado". Roberto Requião, também eleito pelo PMDB, sucedeu o governo, no período de 1991-1994, com a plataforma de uma "nova era na Educação". Entre os anos de 1995 a 2003, Jaime Lerner, do Partido Democrático Trabalhista (PDT) e posteriormente filiado ao Partido da Frente Liberal (PFL), governou o Estado do Paraná, tendo por ideal "a excelência na Educação". (ZANARDINI; BLUM; MICHELLON, 2013, p. 121; LIMA; VIRIATO, 2000, p. 6).

Toda essa efervescência que rodeia a participação e a descentralização no que diz respeito a educação no Estado do Paraná, está presente no documento do Governo Federal de João Figueiredo III Plano Setorial de Educação, Cultura e Desporto 1980/1985, que definiu estratégias de ação específicas e prioritárias comuns nacionais e também para cada região. (ZANARDINI; BLUM; MICHELLON, 2013, p. 121).

No caso da Região Sul, a descentralização se evidenciou no estímulo à municipalização do ensino de $1^{\circ}$ grau, que era disciplinada pelo planejamento participativo.

Nas próximas partes deste capítulo abordo a Educação Hospitalar e os movimentos, o Estatuto da Criança e Adolescente (ECA) e a mudança nos direitos das crianças e adolescentes e a municipalização do Ensino e a LDBEN na Educação Hospitalar do Paraná, sendo que esta parte se desdobra nas discussões sobre a Educação Hospitalar e Educação a respeito dos aspectos legais pertinentes ao Estado do Paraná, tentando responder onde se insere a Educação Hospitalar no âmbito educacional. 


\subsection{EDUCAÇÃO HOSPITALAR E OS MOVIMENTOS, O ESTATUTO DA CRIANÇA E ADOLESCENTE (ECA) E A MUDANÇA NOS DIREITOS DAS CRIANÇAS E ADOLESCENTES}

A educação hospitalar está respaldada em diversos documentos, dentre eles há os legais, que visam, dentre outras questões, assegurar também o direito e acesso à educação para crianças e adolescentes, o que se estende as que são afastadas da escola por motivos de saúde. Entretanto, apesar da Declaração Universal dos Direitos Humanos (UNESCO, 1948) dispor sobre a garantia da não violação e o exercício pelo cidadão de um elenco de direitos considerados básicos a vida digna, a escolarização de crianças e adolescentes hospitalizados demorou para ser efetivada e ser garantida em nosso país, como foi abordado anteriormente.

Precisamente com relação ao atendimento às crianças e estudantes afastados da escola por motivos de saúde, a primeira normativa legal que prevê um atendimento escolar direcionado a elas é a Lei no 1.044/69, que dispõe sobre o tratamento excepcional para alunos com afecções, estabelecendo o direito do aluno com afecções congênitas ou adquiridas à continuidade de seus estudos, principalmente se os alunos se encontrarem em condições de aprendizagem.

O Estado Democrático Brasileiro é instituído em 1988 com a promulgação da Constituição da República Federativa do Brasil, que em seus artigos 205 e 214, estabelece a obrigatoriedade de educação para todos. A educação é encarada, a partir deste marco, como um direito de todos e dever do Estado e o foco na universalização do atendimento escolar passa a ser efetivo.

A Conferência Mundial sobre "Educação para Todos", que ocorreu em 1990, já anunciada anteriormente, produziu o documento sobre as necessidades básicas de aprendizagem e as metas a serem atingidas relacionadas à educação básica. Deste documento de diretrizes e metas, destaco o art. 3 que pretende universalizar o acesso à educação e promover a equidade, que no item 4 define:

Um compromisso efetivo para superar as disparidades educacionais deve ser assumido. Os grupos excluídos - os pobres; os meninos e meninas de rua ou trabalhadores; as populações das periferias urbanas e zonas rurais; os nômades e os trabalhadores migrantes; os povos indígenas; as minorias étnicas, raciais e lingüísticas; os refugiados; os deslocados pela guerra; e os povos submetidos a um regime de ocupação - não devem sofrer qualquer tipo de discriminação no acesso às oportunidades educacionais. (UNICEF, 1991). 
Nesta direção foi aprovado no Brasil, o Estatuto da Criança e do Adolescente ECA, Lei no. 8069/1990, que dispõe sobre a proteção integral à criança e ao adolescente como cidadão e sujeito de Direito, garantindo-lhes direitos inclusive relacionado à situação especial de escolarização. Segundo o art. 5ำ, nenhuma criança ou adolescente poderá sofrer "qualquer forma de negligência, discriminação, exploração, violência, crueldade e opressão, punido na forma da lei qualquer atentado, por ação ou omissão, aos seus direitos fundamentais". Além disso, o art. 53. indica que "a criança e o adolescente têm direito à educação, visando ao pleno desenvolvimento de sua pessoa, preparo para o exercício da cidadania e qualificação para o trabalho", para tanto, é assegurado a ambos, "igualdade de condições para o acesso e permanência na escola". (BRASIL, 1990). O Estado deve assegurar para a criança e ao adolescente a "educação básica obrigatória e gratuita dos 4 (quatro) aos 17 (dezessete) anos de idade, assegurada inclusive sua oferta gratuita para todos os que a ela não tiveram acesso na idade própria”. (BRASIL, 1988). Desta forma, é direito de todas as crianças e adolescentes ter acesso à educação, independentemente de seu estado de saúde, desenvolvimento ou local onde se encontrem.

Com a promulgação do ECA, as crianças e adolescentes passaram a ser encarados como "sujeitos de direito, portadores de todos os direitos fundamentais e sociais, inclusive o de responderem pelos seus atos" e deixam de ser vistos como portadores de necessidades e objetos de tutela, pois

A falta de atenção à saúde; à educação; o desrespeito à liberdade, à
dignidade e à convivência familiar e comunitária; o descaso pela educação,
pela cultura, pela profissionalização, pelo esporte e pelo lazer; obrigam uma
elaboração de normas capazes de garantir coercivamente os direitos de
nossa maior riqueza, as crianças. (AMARAL e SILVA, 1999, p. 16).

Todavia, essa percepção de crianças e adolescentes como sujeitos de direito previsto no Estatuto da Criança e do Adolescente e legalmente foi constituído após muita mobilização social. No Brasil, advogados que defendiam a causa da criança e do adolescente contavam com a contribuição de alguns setores da Igreja Católica, e ambos reclamavam por mudanças de paradigmas, pois o crescimento da pobreza e a derrocada das redes de proteção social, dos serviços públicos colaboraram para "o crescente aumento e maior visibilidade dos 'meninos de rua' nas pequenas e grandes cidades. O sistema de proteção ao menor estava falido, sem estratégia, sem criatividade, sem possibilidade de solução". (OLIVEIRA, 2007, p. 142). Assim, a 
promulgação do ECA acabou oportunizando uma nova perspectiva no entendimento da infância brasileira.

De acordo com Cirqueira (2007, p. 17), a elaboração do ECA aconteceu após, pelo menos uma década (1980), de luta da sociedade brasileira, que se mobilizou pela redemocratização do país e pela defesa dos direitos da criança e do adolescente. Havia movimentos da sociedade lutando pelo direito ao voto, pelo retorno dos exilados políticos, ou seja, pela efetivação dos direitos políticos, civis e sociais o que centralizava as reivindicações, mesmo com a diferença dos temas centrais, pois o objetivo comum era a instalação da democracia e o reconhecimento dos indivíduos como cidadãos.

A publicização da questão social que envolvia a infância e a adolescência no país (pobreza, situação de rua, abandono, violência institucional) e o paradigma tutelar (paternalista) do Código de Menor de 1979 foram eixos de denúncias na década de 1980. (CIRQUEIRA, 2007, p. 17).

O Código de Menores de 1927, foi o primeiro instrumento de regulação de políticas públicas para crianças e adolescentes no Brasil, que culpabilizava as famílias pelo não provimento da subsistência e desenvolvimento de seus filhos. Por isso, indicava a "institucionalização das crianças e adolescentes órfãos ou filhos de "pais irresponsáveis", visando educá-los e discipliná-los dos pontos de vista físico, moral e civil". (OLIVEIRA, 2007, p. 138). Apesar do Código de Menores ser "declaradamente voltado à regulamentação das ações do Estado em relação aos "menores abandonados e delinqüentes", foi duramente atacado, principalmente por limitar as ações dos responsáveis, especialmente no que se refere as punições físicas, ao sustento dos filhos e por reforçar as leis que regulamentavam o emprego de crianças como mão-de-obra em diferentes atividades. (MORELLI, SILVESTRE e GOMES, 2000, p. 66).

\footnotetext{
A destituição do pátrio poder foi criada como um recurso para ser aplicado quando os responsáveis não atuavam satisfatoriamente, ou seja, quando deixavam o filho passar necessidades, aplicando castigos mais severos, agredindo ou violentando física ou moralmente a criança, sendo este um dos pontos mais relevantes na garantia dos direitos individuais das crianças brasileiras. (MORELLI, SILVESTRE e GOMES, 2000, p. 66).
} 
Essa lei desponta "com o objetivo de regulamentar a assistência ao chamado menor ${ }^{51 "}$ e traz à tona a conexão entre os discursos dos médicos higienistas e dos juristas da época, que se diziam preocupados com "o grande número de crianças que perambulavam pelas ruas, inquietos com o aumento da chamada criminalidade infantil" e outros interessados na prevenção e "produção de novas formas de controle da sociedade." (LAZZAROTTO e NASCIMENTO, 2016, p. 262).

Com o golpe militar de 1964 e o agravamento da violência nas grandes cidades, o "menor" passou a ser sempre encarado como um "menor infrator", esta concepção circulou por quase um século, "a questão da criança e do adolescente no Brasil é marcada pela negligência do Estado e pela violência da sociedade". (MORELLI, SILVESTRE e GOMES, 2000, p. 68).

Tal lógica perdura por mais de 50 anos, até que em 1979, em pleno período de ditadura, os militares propõem uma reformulação no Código, nele incluindo o que foi intitulado de infância em situação irregular. É bom lembrar que a ditadura civil-militar de 1984 decreta que crianças e adolescentes são um problema de segurança nacional e para regular tal questão é implantada a Política Nacional de Bem-Estar do Menor - PNBEM (BRASIL, 1964), seguindo o parâmetro de ordem, desenvolvimento e segurança imposto pela Lei de Segurança Nacional, vigente no país à época. (LAZZAROTTO e NASCIMENTO, 2016, p. 263).

Em 1984, foi incluído no Código de Menor, que as crianças e adolescentes em situação de risco eram um problema de segurança nacional. Para tanto, o Código continha diretrizes severas e repressivas direcionadas às crianças e aos adolescentes considerados em "situação irregular", aqueles que, na maioria das vezes, eram entendidos como um perigo à sociedade e, portanto, precisavam ser recolhidos e disciplinados em institucionalizações asilares, locais onde essas crianças e adolescentes estariam protegidos e seguros, sendo este último o discurso que se difundia para a aceitação social de tal prática. (CIRQUEIRA, 2007, p. 17).

Resumidamente é possível perceber que desde a época imperial até os dias atuais, são produzidas políticas públicas voltadas para a infância e a juventude que retratam o período histórico de sua produção, sendo que a primeira lei publicada sobre esse assunto ocorre no período da República e as principais diferenças seriam: a metodologia ser voltada para a pedagogia do trabalho aos jovens em conflito com a lei no Código Penal da República; a questão da vigilância pública sobre a infância

\footnotetext{
${ }^{51}$ Os menores fazem parte de uma "infância específica, a infância pobre, que não deveria circular pela cidade, não deveria fazer parte da paisagem urbana" e recebiam essa denominação em diferenciação aos que são chamados crianças. (LAZZAROTTO e NASCIMENTO, 2016, p. 262).
} 
estava presente no Código de Menores de 1927; o tratamento da pobreza como patologia ficava evidente no Código de Menores de 1979. (Lei Federal n 8.069/1990)". (ALVES e SIQUEIRA, 2014, p. 584).

O Código do Menor de 1979 foi alvo de inúmeras críticas, realizadas pela sociedade civil organizada, por profissionais, entre eles, ex-administradores ou extrabalhadores das Fundações Estaduais do Bem-Estar do Menor (FEBEMs), Organizações Não Governamentais (ONGs) e instituições religiosas, que assistiam crianças e adolescentes infratoras em liberdade condicional, se engajaram e formaram uma rede intensamente contrária à ideologia correcional, defendendo a "transformação das FEBEMs e do sistema de bem-estar do menor como um todo, mexendo com a base ideológica e social que norteava as estruturas de serviços." (OLIVEIRA, 2007, p. 141).

O movimento social pelos direitos da cidadania florescia com força
inimaginada. Uma nova sensibilidade social gerava turbulência política e
congregava grupos diversos e, até, historicamente antagônicos, como
trabalhadores e intelectuais, cristãos e marxistas, profissionais liberais e
líderes comunitários. Projetavam-se os desejos de uma massa que
necessitava de uma bandeira viva. E não havia bandeira mais legítima e
inquestionável que as crianças e adolescentes de rua - os mais oprimidos,
as maiores vítimas da injustiça, filhos das favelas, a prole dos deserdados.
(OLIVEIRA, 2007, p. 142).

Assim, os ativistas que lutavam pela libertação dos oprimidos, sentindo-se também oprimidos, explorados, perseguidos e empobrecidos, se uniram aos estudantes, pensadores, líderes intelectuais, defensores da cidadania, organizadores, facilitadores e executores do trabalho comunitário, integrante do movimento político e profissional de resistência, educadores que defendiam os direitos das crianças e dos adolescentes, especialmente os maiores oprimidos, os de rua (OLIVEIRA, 2007, p. 142; LAZAROTTO e NASCIMENTO, 2016, p. 263) na participação e organização dos movimentos a favor dos direitos das crianças e dos adolescentes.

Os primeiros educadores sociais de rua, os agentes de pastoral, conseguiram garantir sua presença significativa e sua disponibilidade incondicional para as crianças, mas o projeto de desenvolver a consciência crítica das crianças e da comunidade falhava dadas as demandas assistenciais - crianças com fome, frio e doentes. Eles precisavam de alianças para concretizar o projeto político que não estavam conseguindo realizar. (OLIVEIRA, 2007, p. 150).

Neste contexto de mobilização e luta destaca-se o Movimento Nacional de Meninos e Meninas de Rua - MNMMR. Criado em 1985 foi "um dos principais movimentos em defesa da infância e da adolescência, naquele período" (CIRQUEIRA, 
2007, p. 18), se caracterizou como uma organização popular, não governamental autônoma, constituída por um conjunto de educadores, ativistas, colaboradores e voluntários que participaram de programas de educação social que pretendiam junto com as crianças e adolescentes de camadas populares, lutar pela conquista e a defesa de seus direitos. De forma mais abrangente, foi concebido como "um movimento popular de defesa dos direitos humanos e de cidadania", tendo como um princípio básico o fortalecimento das práticas libertárias que consideravam "meninos e meninas de rua como agentes de suas próprias vidas, promotores de uma nova sociedade justa, fraternal e participativa, em conjunto com todos os segmentos oprimidos" que lutam por sua liberdade. (OLIVEIRA, 2007, p. 151), além de entender as "crianças e adolescentes como seres humanos em condição peculiar de desenvolvimento; cidadãos, sujeitos de direitos legítimos". (VALLAURI, 2007, p. 395).

Posteriormente, o MNMMR se firmou "como uma organização de luta pelos direitos de crianças e adolescentes, prioritariamente meninos e meninas de rua" (VALLAURI, 2007, p. 400) e em conjunto com o Fundo das Nações Unidas para a Infância (UNICEF), a Fundação Nacional do Bem-Estar do Menor (FUNABEM), a Pastoral do Menor, o Ministério Público de São Paulo, entre outros, foram responsáveis por diversas manifestações em defesa da criança e adolescentes, principalmente aqueles que viviam nas ruas. (CIRQUEIRA, 2007, p. 18; PANSARDI, 2015, p. 12).

Segundo Pansardi (2015, p. 11), em meados da década de 1980, psicólogos, pedagogos, educadores, assistentes sociais, movimentos religiosos, juristas, entre outros, ligados à infância saíram às ruas de todo o Brasil, principalmente das grandes capitais, tais como São Paulo, Rio de Janeiro, Porto Alegre, Recife, foi "pela primeira vez, falava-se em direitos de crianças e adolescentes - extensivos a todos, sem discernimento de classe social". (MORELLI, SILVESTRE e GOMES, 2000, p. 66). Esse debate público apresentava novas ideias que questionava a lógica punitiva e repressora do Código de Menores.

Também eles, meninos e meninas, acompanhavam as passeatas que ocupavam vias de grandes cidades. Negros, a maioria deles. Pobres, marginalizados, garotos de rua. As mobilizações evidenciavam a carência de políticas públicas e deixavam claro quem eram os principais afetados por uma legislação que considerava a pobreza uma ameaça à ordem vigente. "Menores em situação irregular" (como a eles se referia a legislação vigente à época), queriam tornar-se sujeitos. Antes considerados meros seres tutelados (pelo Estado, pelas famílias...), garotas e garotos então assumiam protagonismo, demonstravam ter voz e vez. (PANSARDI, 2015, p. 11). 
Essas mobilizações nas ruas, envolviam defensores da causa da criança e do adolescente de rua, pobres, negros e abandonados e acabou auxiliando na construção de argumentos convincentes para romper paradigmas, enfrentar disputas jurídicas e apoiar a opinião popular na luta pela garantia de prioridade no que diz respeito aos direitos às crianças e adolescentes.

No começo dos anos 1980, com a Comissão Pró-Meninos de Rua no Paraná, o MNMMR realizou uma primeira manifestação (VALLAURI, 2007, p. 415). O primeiro grupo deste movimento no Estado se efetivou em 1982, por meio do Projeto Alternativas Comunitárias de Atendimento a Meninos de Rua (Unicef e MPAS). (VALLAURI, 2007, p. 398).

Foi realizado na cidade de Brasília, em 1985, o Encontro Nacional de Grupos Locais, considerado como uma "verdadeira assembleia de Constituição do MNMMR". (VALLAURI, 2007, p. 399). Este evento foi um desdobramento de uma reunião nacional e um Seminário Latino-Americano de Alternativas Comunitárias de Atendimento a Meninos de Rua, ocorrida nos anos de 1983 e 1984.

Em 1986, aconteceu também em Brasília o primeiro Encontro Nacional de Meninos e Meninas de Rua, que contou com a participação de aproximadamente 500 crianças e adolescentes do país. Nele foram discutidos assuntos como: educação, família, saúde, trabalho, violência e organização. O documento final deste encontro apontou os elementos básicos que acabaram constituindo as propostas de emendas populares para a Constituição promulgada em 1988, proporcionando, portanto, toda uma organização de muitos Estados em torno do processo constituinte.

É importante destacar que a capital do país, Brasília foi um importante palco para dar visibilidade as inúmeras pautas e agendas que marcaram o processo de elaboração da constituição de 1988.

A partir de 1985, na cidade de Curitiba, Paraná a Comissão Pró-Meninos de Rua procurou a Comunidade Profeta Elias, na Vila Lindóia, que realizava um trabalho de prevenção, com atividades que permitiam a permanência das crianças na comunidade. Em 1986, membros da Comunidade e alguns meninos começaram a participar das reuniões, que eram realizadas na Biblioteca Pública, o que possibilitou o "início do processo de diálogo e aproximação entre educadores e meninos e meninas". (VALLAURI, 2007, p. 416).

Em 1988, foi realizada a Primeira Assembleia Estadual do MNMMR, com a participação dos meninos e meninas de comunidade e de rua, neste mesmo ano o 
MNMMR já incluía a comissão local de Londrina, primeira cidade do interior do Estado, com membros de Ibiporã. A Pastoral do Menor ${ }^{52}$ e a Fundação Fé e Alegria ${ }^{53}$ eram parceiras voluntárias no trabalho realizado pelo Movimento. (VALLAURI, 2007, p. 417).

Em 1989, da mesma forma que atuavam no processo constituinte Federal, o Movimento atuou na Assembleia Constituinte Estadual, por meio da participação dos meninos e meninas diretamente na Assembleia Legislativa, apresentando emendas populares. (VALLAURI, 2007, p. 417). Com relação às ações desenvolvidas pelo MNMMR destaca-se o Primeiro Encontro Estadual de Meninos e Meninas de Rua, realizado em Curitiba, o objetivo foi "discutir e preparar a participação do Paraná no Segundo Encontro Nacional de Meninos e Meninas de Rua". Os temas do encontro foram violência, direitos básicos, Estatuto da Criança e do Adolescente (ECA) e teve a participação de 80 meninos e meninas de rua e comunidades. (VALLAURI, 2007, p. 418).

O Segundo Encontro Nacional ocorreu no mês de setembro de 1989, em Brasília, o foco do evento foi pressionar o Congresso Nacional pela aprovação do ECA, além de discutir sobre violência e a organização dos meninos e das meninas. Os grupos do Paraná participaram deste encontro coordenando as oficinas de música e vídeo. (VALLAURI, 2007, p. 418).

Em 1990, aconteceu a Segunda Assembleia Estadual do MNMMR, em Londrina, interior do Estado do Paraná, contou com a participação das comissões locais de Pinhais, Londrina, Curitiba, São José do Caiuá e Santo Antônio da Platina. Essa Assembleia serviu para avaliar a atuação do Movimento em 1990, programar as

\footnotetext{
${ }^{52}$ A Pastoral do Menor, baseada na ação evangelizadora da Igreja no Brasil e norteada pelas Diretrizes Gerais da Conferência Nacional dos Bispos (CNBB) foi implantada na Arquidiocese do Rio de Janeiro em 1984 com o objetivo de buscar a promoção e defesa da criança e do adolescente desrespeitados em seus direitos humanos, tem por missão a promoção e defesa "da vida das crianças e dos adolescentes empobrecidos e em situação de risco pessoal e/ou social desrespeitados em seus direitos fundamentais" (CNBB - Pastoral do Menor Nacional, Princípios, Diretrizes e Organização, Artigo 12, 2014). Cf. https://www. pastoraldomenor.com.br/ Acesso em 09/02/21019.

${ }^{53}$ A Fundação Fé e Alegria é uma organização da sociedade civil, sem fins lucrativos, que promove no Brasil processos educativos integrais, inclusivos e de qualidade e ações de promoção social. Fazem parte da Federação Internacional de Fé e Alegria e acreditam que, por meio da Educação Popular, contribuirão para a construção de uma sociedade democrática, justa e solidária. Iniciaram ações educacionais em 1955 na Venezuela e, em 1964, após tornar-se compromisso da Companhia de Jesus foi difundida em outros países da América Latina. No Brasil, começaram a atuar com a Educação Infantil em 1981, em uma pequena creche em Mauá, região metropolitana de São Paulo. Atualmente, mais de 13 mil pessoas, entre crianças, jovens e adultos, em 20 cidades de 14 estados, são beneficiadas pelas ações de Educação e Promoção Social da Fundação. Cf. https://fealegria.org.br/ Acesso em 09/02/21019.
} 
atividades para 1991 e eleger o coordenador estadual. Além disto, o estatuto do MNMMR foi discutido e foram apresentadas algumas teses e propostas para a Assembleia Nacional. (VALLAURI, 2007, p. 419).

Em 1991, foi aprovado o Estatuto da Criança e do Adolescente, a criação dos Conselhos de Direitos ${ }^{54}$ e Tutelar, foi realizado em Curitiba uma reunião da Comissão Estadual, que teve por objetivo elaborar e divulgar os objetivos que passariam a orientar. (VALLAURI, 2007, p. 419). Neste mesmo ano, em maio, foi divulgado o resultado da primeira pesquisa realizada pelo MNMMR sobre os índices de mortes violentas no Paraná. Foi também realizado um estudo sobre a marginalização da criança e adolescente.

Em agosto de 1991, em Ponta Grossa, aconteceu o Encontro Estadual de Meninos e Meninas de Rua, e a partir deste momento o Paraná contou com a figura do "articulador", que era uma pessoa liberada e "paga pela coordenação nacional para desenvolver o trabalho de fortalecimento e interiorização". (VALLAURI, 2007, p. 422). Em setembro, foi cedido pelo Diretório Central dos Estudantes (DCE), da Universidade Federal do Paraná (UFPR), um espaço para implantação do escritório Estadual do Movimento. Foram realizadas campanhas de arrecadação de materiais de limpeza, eletricidade, tintas, de construção para reforma do espaço. "Nesta época surgem contatos em Pato Branco e Ponta Grossa e em junho, é efetivada Comissão Local de Pinhais". (VALLAURI, 2007, p. 423). O MNMMR ficou no espaço do DCE até o início de 1994, quando foi obrigado a sair do prédio, por que a nova direção eleita era ligada a União Democrática Ruralista (UDR), portanto contrária ao Movimento. (VALLAURI, 2007, p. 428).

Em 1992, no terceiro Encontro Nacional em Brasília, o Paraná participou com 23 meninos e meninas, 06 educadores e 29 colaboradores de diversas entidades. (VALLAURI, 2007, p. 424). Em 2000, um dos últimos trabalhos da Comissão Paranaense do MNMMR foi no Projeto "Malandro, Sem Camisinha Não Dá“, realizando em parceria com o Ministério da Saúde, a proposta de formação era em módulos para educadores em saúde. O Estado foi um dos selecionados para fazer o

54 O CONANDA é um órgão colegiado permanente de caráter deliberativo e composição paritária, previsto no Artigo 88 da Lei no 8.069, de 13 de julho de 1990 (ECA), criado pela Lei no 8.242, de 12 de outubro de 1991, e regulamentado pelo Decreto no 5.089, de 20 de maio de 2004. Disponível em: http://www.crianca.mppr.mp.br/modules/conteudo/conteudo.php?conteudo=1564 Acesso em: 24/04/2019. 
Projeto, que "contou com a produção de materiais específicos para atividades de rua - vídeo, cartilha, manual, jogos”. (VALLAURI, 2007, p. 431).

As Comissões Locais foram se enfraquecendo enquanto movimento, principalmente porque as pessoas que delas participavam foram se envolvendo e acabaram por deslocar a atuação para o interior dos Conselhos de Direitos ou o Tutelar. Contudo, há duas hipóteses para o encerramento do Movimento. Alguns consideravam que "os principais objetivos, implantação do Conselho e do ECA foram conquistados e o movimento perdeu seu sentido de ser; outros acham que houve um refluxo como de todos os movimentos urbanos em geral”. (VALLAURI, 2007, p. 432).

Com relação a história da Comissão Local de Curitiba do MNMMR, esta se confunde com a da Comissão Estadual, pois ambas têm a mesma trajetória da organização Nacional. Em Curitiba e no Estado do Paraná, "o embrião do que veio a ser o Movimento Nacional de Meninos e Meninas de Rua surgiu no início dos anos 80, com o Projeto Alternativas de Atendimento aos Meninos de Rua". (VALLAURI, 2007, p. 435).

\begin{abstract}
A preocupação das crianças das comunidades foi se ampliando para a realidade daquelas que se encontravam nas ruas de Curitiba, principalmente no anel central. Elas eram crianças de periferia que, por diversos e extremados motivos, foram buscar sua sobrevivência nas ruas, à mercê ora da solidariedade das pessoas, ora de pequenos delitos. Foi assim que se iniciou o trabalho de "abordagem de rua", até então inexistente em Curitiba, desenvolvendo uma nova proposta pedagógica, de educação popular. (VALLAURI, 2007, p. 437).
\end{abstract}

No começo, os educadores iam para as ruas para "conhecer a realidade e descobrir formas educativas de trabalhos com eles...", com isso, a capoeira, música, brincadeiras, festas de Natal e comemorações mensais dos aniversários, atividade na qual toda a Comunidade se envolvia, foram as formas encontradas para manter contato com as crianças de rua. (VALLAURI, 2007, p. 437).

Em 1987, aconteceu o Primeiro Encontro de Crianças de Rua e Comunidade na capital do Estado paranaense. Foi também nesta data o início das atividades da Assembleia Nacional Constituinte e a Comissão Local do MNMMR, que participaram na elaboração de propostas de emendas populares e as encaminhavam à Assembleia Legislativa, assim como, organizaram uma passeata na Vila Lindóia, em outubro com a temática: "Garantia dos direitos básicos". (VALLAURI, 2007, p. 438).

De 1987 a 1997, foram muitas e intensas as atividades desenvolvidas pelo MNMMR, muitas delas fruto de militância e em condições muito adversas, as 
dificuldades de ordem financeira, talvez tenha sido a mais significativa, pois os educadores, muitas vezes não tinham vale transporte para se locomoverem, prejudicando os acompanhamentos de abordagens e as atividades "foram se restringindo a grupos de meninos da Comunidade Profeta Elias e à Chácara Quatro Pinheiros", apesar de outros membros do Movimento continuarem tentando manter os contatos. (VALLAURI, 2007, p. 455).

Apesar de todo o descaso com o Movimento, no ano 2000, o Núcleo da Vila Torres, que continuava ainda atuante, conseguiu aprovar o projeto "A arte para um mundo melhor" que comprou instrumentos musicais para o grupo de Rap. "Aos poucos o Movimento, agora já sem um local fixo de encontro, sem liberados e sem recursos financeiros, vai se dissolvendo". Apesar disto, algumas comunidades ainda mantiveram suas atividades, mas não mais como MNMMR. (VALLAURI, 2007, p. 455).

Paralelamente aos movimentos do MNMMR, o Movimento Popular de Mulheres do Paraná (MPMP) foi um outro movimento que atuou entre os anos de 1981 a 1993. (KNAPIK, 2005, p. 7). O objetivo era construir uma sociedade igualitária por meio de um trabalho de formação e conscientização de mulheres, resgatando a autoestima e a cidadania, fortalecendo o protagonismo e participação no "processo de elaboração de um novo projeto político de sociedade". (KNAPIK, 2005, p. 7).

No Brasil as mobilizações das mulheres ressurgiram apenas no início dos anos de 1970 e foram influenciadas principalmente pelas lutas femininas nos Estados Unidos, que oportunizaram diversas conquistas e modificações nas vidas das mulheres, como o que aconteceu por meio da "Revolução Sexual", com o desenvolvimento da pílula anticoncepcional que propiciou à mulher ter mais controle sobre sua sexualidade e seu corpo. Além disto, o ano de 1975 foi instituído pela Organização das Nações Unidas (ONU) como o Ano Internacional da Mulher, o que favoreceu o começo do movimento feminista no Brasil, marcado intensamente pela luta política contra o regime militar. (KNAPIK, 2005, p. 32). O aparecimento do MPMP ocorreu unido à história das Comunidades Eclesiais de Base - CEBs, na década de 1970, período de uma intensa atividade das pastorais, das comunidades de base, movimentos populares e sindical. As bandeiras de luta das mulheres neste período eram por "melhores condições de vida e luta pela terra, em geral, os Clubes de Mães", [onde] estudavam a Bíblia, discutiam os problemas das comunidades e faziam artesanato". (KNAPIK, 2005, p. 81). Dos Clubes de Mães passaram a se organizar 
também nas Pastorais e, por meio dessas experiências de base, o movimento foi aumentando até se integrar às reivindicações políticas e econômicas. (KNAPIK, 2005, p. 83).

Em 1981, ocorreu em Francisco Beltrão o 1ํEcontro de Mulheres do Paraná, reunindo representantes da região Sul, Oeste, Região Metropolitana, Sudoeste e Região Central do Estado, inclusive de Castro, Medianeira, Curitiba, Capanema e Turvo, para discutir a metodologia e a problemática do trabalho com mulheres. (KNAPIK, 2005, p. 85). O principal objetivo deste encontro do MPMP foi conscientizar as mulheres do seu valor e as estimular a participar da luta por uma sociedade mais justa e igualitária. O MPMP acabou se tornando a base dos outros movimentos de mulheres no Paraná, sendo que todos eles sempre conservaram algumas conexões, tanto no campo quanto na cidade. (KNAPIK, 2005, p. 89).

No caso do Paraná, as contribuições partiram de Medianeira, Palmas e Foz do Iguaçu, a contribuição mais significativa a ser considerada nesta tese, partiu de Foz do Iguaçu, pois com a necessidade de creches na cidade, "as mulheres se reuniam para tentar fazer algo pelas crianças, além de promoverem cursos financiados pela Legião Brasileira de Assistência (LBA) ${ }^{55 ", ~ a s ~ a t i v i d a d e s ~ e r a m ~ r e a l i z a d a s ~ n o ~ c e n t r o ~}$ comunitário de uma associação de moradores. (KNAPIK, 2005, p. 90).

As diferentes bandeiras de luta do MPMP, visavam fortalecer a "libertação da mulher", as temáticas em pauta eram: Mulher e Bíblia; Mulher e Sindicato; Mulher e Constituinte e Política; Mulher e Saúde; Mulher e Educação; Mulher e Meio-Ambiente; Mulher e Auto Sustento. (KNAPIK, 2005, p. 100).

Com relação à temática Mulher e Educação pode-se destacar que seu objetivo era elaborar uma metodologia própria, na perspectiva da mulher, habilitando-a dentro do MPMP. O Plano de Ação disposto nesta bandeira era:

\footnotetext{
${ }^{55}$ Legião Brasileira de Assistência, órgão assistencial público brasileiro, fundado em 28 de agosto de 1942, pela então primeira-dama Darcy Vargas, com o objetivo de ajudar as famílias dos soldados enviados à Segunda Guerra Mundial. Por meio do Decreto-lei no 593, de 27 de maio de 1969, transforma a sociedade civil em fundação, como o nome de Fundação Legião Brasileira de Assistência, mantendo a mesma sigla LBA, vinculado ao Ministério do Trabalho e Previdência Social. Com a aprovação da Lei oㅜ 6.439, de 1ำ de setembro de 1977, fica vinculado ao Ministério da Previdência e Assistência Social. Pelo art. 252 do Decreto no 99.244, de 10 de maio de 1990, passa a ser vinculado ao Ministério da Ação Social. Em 1991, sob a gestão de Rosane Collor, foram feitas diversas denúncias de esquemas de desvios de verbas da LBA, como uma compra fraudulenta de 1,6 milhão de quilos de leite em pó, sendo extinta por meio do art. 19, inciso I, da Medida Provisória ํㅡㄹ 813, de $1^{\circ}$ de janeiro de 1995, publicada no primeiro dia de governo do Presidente Fernando Henrique Cardoso. Na época da sua extinção estava vinculado ao Ministério do Bem-Estar do Menor. Disponível em: http://fonte.ufsm.br/index.php/legiao-brasileira-de-assistencia-lba Acesso em: 02/05/2019.
} 
- $\quad$ organizar a equipe em nível de Estado, região e Municípios;

- $\quad$ elaborar cursos de alfabetização para mulheres, com material didático e metodologia apropriada e sob a ótica da mulher, usando o Método Paulo Freire;

- $\quad$ capacitar membros da equipe para desenvolver um trabalho adaptado; - fazer alianças com outras entidades de conhecer experiências desenvolvidas por elas;

- $\quad$ conhecer o projeto de educação de cada escola. Acompanhar através dos filhos e controlar o conteúdo da educação (por um conteúdo nãomachista);

- lutar por creches na área urbana e rural (0 - 6 anos), com equipe multidisciplinar;

- lutar por uma participação dos pais no ensino municipal, para que possam questionar, reformular e dirigir a política municipal de ensino;

- lutar para que a educação seja formadora de cidadãos emancipados, com consciência crítica e sem discriminação;

- desenvolver campanhas de alfabetização de mulheres a partir do próprio conhecimento do seu corpo;

- $\quad$ propor novas formas de educação dos filhos mudando valores do cotidiano, sociedade e movimentos sociais. (KNAPIK, 2005, p. 149).

Em 1993, o I Congresso Estadual do MPMP marcou os 10 anos de história do Movimento e foi realizado na Universidade Popular do Trabalho (UPT), em Curitiba. O objetivo era comemorar "os 10 anos de história do Movimento", assim como analisar o trabalho desenvolvido naquela década de existência e traçar metas para os próximos anos. Neste evento, participaram 120 delegadas das 7 regiões do Paraná: Sudoeste, Oeste, Sul, Noroeste, Norte, Centro e Curitiba e foi realizado um levantamento das ações de maior destaque desenvolvidas pelo Movimento. Dentre essas ações destacou-se:

- $\quad$ formação das Bandeiras de Luta (1983);

- constituição da articulação dos movimentos e organizações das mulheres dos segmentos populares do Paraná (1984);

- $\quad$ criação das coordenações Municipal, Regional e Estadual (1985);

- $\quad$ participação intensa com encaminhamento de proposta à Assembleia Nacional Constituinte (1986);

- $\quad$ participação relevante da fundação de sindicatos, compondo comissões e direções em todos âmbitos (local, estadual e nacional);

- criação de uma Comissão Nacional sobre a questão da Mulher Trabalhadora (1988);

- $\quad$ presença constante nas ocupações, grandes caminhadas e romarias na luta pela reforma agrária (de 1985 a 1988);

- $\quad$ caravana a Brasília com propostas sobre aposentadoria da mulher trabalhadora rural (1992);

- $\quad$ produção do vídeo "Marias do Povo", produzido e gravado pelas próprias mulheres do MPMP para comemorar os 10 anos de existência do Movimento (o vídeo foi traduzido publicado na Bélgica pela AVIMO, entidade de divulgadora de vídeos na área de lutas populares em questões religiosas). (KNAPIK, 2005, p. 168). 
Além disto, também se definiu novas orientações para atividades do MPMP, como a criação de novas bandeiras de luta com a Auto Sustentação, Educação e Meio-Ambiente. (KNAPIK, 2005, p. 169).

Em 1995, foi realizado o II Congresso Estadual do MPMP, com a temática Avaliação e Crise, este evento não teve as mesmas características e empolgação do primeiro encontro, demonstrando que o movimento já estava desgastado e dividido. Os sinais iniciais de crise apareceram "com os resultados da campanha de participação popular no processo constituinte do país", pois se desejava que a nova Constituição acabasse com o controle político da transição e com o autoritarismo militar. Na realidade, a Constituição garantiu "mecanismos de participação popular, como o referendo e o plebiscito, uma forma de se participar das decisões e fiscalizações do poder público" para determinados segmentos da sociedade civil, como operários, mulheres, crianças e idosos. (KNAPIK, 2005, p. 172). Contudo, "a maior derrota sentida foi a negação do projeto da reforma agrária", demonstração de que a democracia não se estendeu para toda a sociedade. Assim como a campanha presidencial de 1989, cuja derrota foi uma grande frustração para esquerda, para as forças democráticas, que não conseguiram eleger o candidato a presidente pelo voto. E finalmente, começava a ser estabelecido um projeto neoliberal, que gerava "mais e mais excluídos".

Isto influenciou e questionou os movimentos populares e o movimento
específico de mulheres. Foi um período de descrença, perplexidade e
desencanto. Culminando com a crise moral do governo, impelindo os
movimentos organizados para irem às ruas, pedir o impeachment do
presidente.
A Igreja Católica, grande incentivadora dos movimentos populares, diminuiu
sua participação junto ao povo. (KNAPIK, 2005, p. 173).

Além disto, de 80 a 90\% das mulheres do MPMP eram provenientes das CEBs, que apoiava materialmente e oferecendo estímulo organizacional. Com o enfraquecimento das CEBs o Movimento acabou também se enfraquecimento. (KNAPIK, 2005, p. 173).

Nos anos 90, os antigos militantes envelheceram ou cansaram-se, ou tornaram-se dirigentes de organizações, parlamentares, etc. E não se formaram novos quadros de militantes. Os poucos novos que surgiram passaram a atuar de forma radicalmente diferente. [...] Ninguém quer mais sobrepor os interesses do movimento aos de sua vida pessoal, particular. (GOHN, 2003, apud KNAPIK, 2005, p. 174). 
Apesar de seu enfraquecimento é interessante destacar as conquistas do MPMP, como por exemplo o desenvolvimento de atividades com mulheres das classes populares, especialmente a rural, com o objetivo de criar uma "metodologia da mulher", por meio de uma tarefa multiplicadora de repasse diferente dos modelos masculinos. (KNAPIK, 2005, p. 181).

Um dos resultados mais importantes para as participantes do Movimento está relacionado "com relação a conscientização, compreensão de si mesma, e de sua capacidade de agir sobre a realidade", assim como a atuação das mulheres em diversos espaços como "na família, na igreja, nos sindicatos, nos partidos políticos, na comunidade, onde elas foram abrindo novos caminhos partindo de suas experiências". As atividades coletivas também auxiliaram no empoderamento dessas mulheres na luta contra a opressão e a injustiça social. A luta sem medo acabou mostrando saídas para que essas mulheres pudessem romper os limites aos quais foram educadas desde muito cedo e oportunizou que se posicionassem contra 0 universo machista e hegemônico. (KNAPIK, 2005, p. 183). Enfim, o MPMP arquitetou uma nova sociedade, sem discriminação, sem desigualdade, sem opressão, além dos direitos, em particular para as trabalhadoras rurais, ter sido uma conquista notável. (KNAPIK, 2005, p. 184).

Dentre as metas do Plano de Ação do MPMP, a questão da luta para que a educação fosse formadora de cidadãos emancipados, com consciência crítica e sem discriminação foi o foco de campanhas de alfabetização de mulheres, visando discutir propostas de novas formas de educação aos filhos, alterando valores da sociedade, do cotidiano e movimentos sociais. (KNAPIK, 2005, p. 203).

Além destas demandas do MPMP, a mobilização das mulheres ocorreu também, e principalmente, no que diz respeito à luta por creches e pré-escola para crianças de zero a seis anos. Essas mobilizações ocorreram nos bairros, nos sindicatos e no Estado. (CAMPOS, 1985, p. 17).

Discutindo o papel social da pré-escola, Sônia Kramer ${ }^{56}$ aponta que deveria ser um direito da criança, fruto de lutas explicitadas nos movimentos que aturam no

56 Sônia Kramer é uma renomada pesquisadora da temática da Educação Infantil, atua, além da educação infantil com os primeiros anos do ensino fundamental, infância, formação de professores, políticas públicas e educação, alfabetização, leitura e escrita e estudos judaicos. Tem graduação em Pedagogia, mestrado e doutorado em Educação e pós-doutorado realizado na New York University. É professora da Pontifícia Universidade Católica do Rio de Janeiro e coordena o curso de especialização em Educação Infantil, o curso de pós-graduação em Estudos Judaicos, o grupo de pesquisa sobre 
processo de elaboração da Constituição de 1988 e posteriormente pelo ECA. A legislação passou a reconhecer "a obrigatoriedade por parte do estado em oferecer creches e pré-escolas para criança de 0 a 6 anos, de todas as classes sociais, garantindo que seja da família a decisão de efetivar ou não a matrícula”. Segundo a autora, a creche, direcionada a crianças de 0 a 3 anos com "horário integral", caráter médico ou assistencial representava uma alternativa concreta que permitia a mulher se inserir no mundo do trabalho, enquanto a pré-escola para crianças de 4 a 6 anos, ofertada em período parcial deveria ser vinculada administrativamente ao sistema educacional público. (KRAMER, 1985, p. 20).

A principal igualdade nos dois tipos de atendimento seria a necessidade de que o trabalho realizado por ambos não tivesse somente "um caráter assistencial, como também educativo", com "garantia do atendimento nutricional, de saúde e da segurança”. Kramer (1985, p. 21) defende a ideia de que a pré-escola desempenha um papel social importante no contexto da luta pela democratização da educação brasileira, analisado principalmente o papel social da pré-escola pública na década de 80 e "que contribuições específicas a pré-escola pode dar, discutindo seus limites e possibilidades".

\begin{abstract}
A expansão das creches se deu: com o programa de creches da segunda guerra mundial; no final da década de 60 início da de 70, inclusive com revisão do seu significado - resultado dos movimentos sociais urbanos; na França, após o movimento de 1968 e por pressão dos pais e técnicos, as creches públicas passaram por uma revisão de sua orientação higienista e medicalizada, procurando uma interação mais intensa com a família; na Itália o significado dessa instituição é revisto, sendo reivindicada, no contexto de sociedades urbanas, como um local alternativo para a socialização de crianças pequenas. (ROSEMBERG, 1984, p. 92 e 93).
\end{abstract}

Na década de 1920 foram criadas as primeiras creches de empresa por industriais paulistas, estas serviram como referências para a inserção na legislação trabalhista de 1943 de uma regulamentação sobre creche. A Consolidação das Leis do Trabalho $^{57}$ (CLT) foi o primeiro texto legal que apresenta a obrigação de oferta de creches no país, logicamente vinculado às empresas privadas que utilizava "mão-deobra feminina em idade fértil, e extensiva apenas a seus filhos até seis meses de

Infância, Formação e Cultura (INFOC), o Curso Trajetórias Judaicas no Rio de Janeiro e Museu de Arte do Rio/MAR; o Projeto Yiddish como Resistência e experiência identitária.

${ }^{57}$ A Consolidação das Leis do Trabalho (CLT) regulamenta as relações trabalhistas e foi decretada por meio do Decreto-Lei $n^{\circ} 5.452$ de $1^{\circ}$ de maio de 1943, com o objetivo de proteger o trabalhador regular as relações de trabalho e criar o direito processual do trabalho. Disponível em: http://www.planalto.gov.br/ccivil 03/Decreto-Lei/Del5452.htm Acesso em 07/04/2019. (BRASIL, 1943). 
idade". Neste período, essa obrigatoriedade do direito às creches estava relacionada somente com o período da amamentação do bebê, sendo que não havia nenhuma indicação de um estabelecimento destinado à educação da criança pequena. (ROSEMBERG, 1984, p. 94).

A partir de 1970, mesmo com o golpe militar implantado no Brasil em 1964, as manifestações de organização da sociedade civil e as mulheres participavam intensamente dos movimentos que foram surgindo nas grandes cidades por meio de diversas meios como os clubes de mães, ligado ou não à Igreja Católica ou em associações para todos como Sociedade Amigos de Bairro. Depois de 1985, com a instituição do Ano Internacional da Mulher pela ONU, vão surgindo núcleos de organização feministas no Brasil. Desta forma, as mulheres também se engajam em movimento feminista: que lutam por questões gerais e também voltadas ao objetivo da emancipação feminina. (O MOVIMENTO DE MULHERES NO BRASIL, 1979, p. 67). Em ambos os movimentos, de mulheres ou feminista, surge rapidamente a reivindicação por creche e em 1975 foi realizado o primeiro ato público de mulheres em São Paulo e na sua carta programática é possível encontrar as seguintes indicações:

É necessário que todas as mulheres, os representantes das sociedades amigos de bairro, clube de mães e interessados em geral, desenvolvam juntos um programa que venha a resolver o problema de creches na cidade de São Paulo. (ROSEMBERG, 1984, p. 96).

Dentre as manifestações que aconteceram em 1975, destaco o movimento de funcionários, alunos e professores (homens e mulheres) da Universidade de São Paulo que realizaram pela primeira vez uma manifestação pública estruturada pela reivindicação por creche. Além disto, segundo a imprensa divulgou a época, a pressão de mulheres trabalhadoras de um bairro da periferia de São Paulo que reivindicavam creches em frente à prefeitura para secretários e ao próprio prefeito ou ainda as construções de creches em sistema de mutirão por grupos organizados de moradores de um bairro, principalmente mulheres, demonstrava que em diversos lugares eram observadas diferentes formas de luta por creche. Inicialmente estes são movimentos isolados, mas que desencadeiam na cidade o movimento unitário intitulado Movimento de Luta por Creches, sendo que a partir deste ano a reivindicação por creche estava presente em quase todo ato público feminista, publicação ou evento. "O jornal de esquerda Movimento consagrou em 1976 um número especial sobre as mulheres 
(inteiramente vetado pela censura) que continha uma longa reportagem sobre creches". (ROSEMBERG, 1984, p. 97).

Esse movimento integrou feministas de diferentes orientações, grupos de mulheres associados ou não à Igreja Católica, aos diferentes partidos políticos (legais ou clandestinos) e grupos independentes, além de unir grupos espalhados de moradores, que solicitavam creche em seus bairros.

O Movimento de Luta por Creches foi criado em 1979 e foi uma resolução do Primeiro Congresso da Mulher Paulista, tendo como proposta central a reivindicação por creche. Na década de 1980, a expansão da rede de creches é incluída nas plataformas dos diversos partidos políticos, de situação e oposição. Então, esse Movimento cresceu e se desenvolveu obtendo da Prefeitura a promessa de construção de 830 creches em três anos. O Movimento reivindicava e também zelava pela qualidade do equipamento como a exigência de "certos padrões da construção" o funcionamento da creche, a participação na seleção de funcionários, inclusive das diretoras das creches e desta forma foram instaladas 120 creches na cidade São Paulo.

Entretanto, questões negativas começam a surgir e em 1983 a Câmara Municipal de São Paulo cria uma Comissão Especial de Inquérito sobre creche, pois a construção era muito cara, os custos de manutenção altos e defendiam o incentivo à participação de setores privados. A indicação era que o Estado deveria colaborar somente indiretamente por meio de convênios. (ROSEMBERG, 1984, p. 98). Corroborando com a desmobilização, o Movimento de Luta de Creches deixou de existir enquanto movimento unitário, pois seus membros se espalharam nos partidos políticos (PMDB e PT) e apenas ações isoladas nos bairros é que continuaram a existir.

Naquele momento, reivindicar por creche era consenso, entretanto,

A participação de grupos feministas no Movimento de Luta por Creches foi,
na verdade, episódica, tendo cessado logo. Apesar de a questão da creche
continuar sendo levantada em vários encontros feministas, os antigos e
mesmo os novos grupos que vão se formando priorizam outros temas, como
a violência, a saúde, a descriminalização do aborto, o planejamento familiar.
(ROSEMBERG, 1984, p. 99).

A reorganização dos partidos políticos e a "abertura política" desagregou as alianças entre as feministas e o Estado e respondendo a pressão do Movimento de Luta por Creches foram construídas novas creches, entretanto seu objetivo passou a 
ser o combater a miséria com a destinação de suas vagas à população que recebia até dois salários mínimos, assim, "as mães dos Clubes de Mães, que foram aquelas mulheres que realmente participavam da luta, ficaram fora da possibilidade de ser atendidas pelas creches existentes“. (ROSEMBERG, 1984, p. 100). Além disso, em conformidade com a proposta de participação do Movimento no funcionamento das creches, um grupo expressivo da liderança é integrado à instituição como contratados como funcionários públicos da rede de creche municipal e também por isso o momento perde a força de reivindicação.

Finalmente, a percepção de que o número limitado de vagas nas creches, com um quadro grande de funcionários justificava o argumento do poder público ao destacar os altos custos desse modelo de creche em funcionamento, o que deteve a sua expansão ou favoreceu a indicação de programas emergenciais como a creche domiciliar. (ROSEMBERG, 1984, p. 101).

De acordo com Franco (1984, p. 179), a situação da criança pobre brasileira entre 1970 a 1977 era catastrófica, apesar do número de matrícula na pré-escola ter mais do que duplicado, em 1980 ela correspondia a somente 5,6\% da população préescolar, 1.335.817 crianças. (MEC/SEEC, 1980; FIBGE, 1982). Além disto, e concebendo a desnutrição da população infantil brasileira neste período como sendo uma das mais altas da América Latina, é bastante importante que tanto pré-escolas, como creches alimentem as crianças durante o período de atendimento. (FRANCO, 1984 , p. 181). Esses problemas de desnutrição e pobreza atingia " 12.000 .000 crianças brasileiras entre um e cinco anos de idade, ou seja, 53\% delas" (FIBGE/UNICEF, 1982, p.7).

A situação da criança no Brasil não é unicamente por conta da carência ${ }^{58}$ de recursos, mas por opções políticas que desprezavam as pessoas mais pobres e favoreciam os grandes investimentos. (FRANCO, 1984, p. 206). Neste contexto, a educação compensatória desempenhou um argumento positivo na preparação da criança para o sucesso no processo inicial de escolarização.

De acordo com Rosemberg (1986, p. 217), uma alternativa para expandir o número de vagas nas creches na década de 80 seriam as creches domiciliares, mãe crecheira, creche familiar ou lar vicinal, diferentes nomenclaturas para o mesmo tipo de atendimento onde a criança pequena ficaria sob a guarda de uma mulher que

58 O termo "carente" é compreendido como "privação sócio econômica básica e não de privação cultural" segundo Franco (1984, p. 179). 
cuidaria da sua casa e dos filhos de outras famílias, com o auxílio de pagamento. Essa modalidade de atendimento foi inclusive estimulada por organismos internacionais como a OMEP e UNICEF, pois, além de proporcionar a guarda da criança para países subdesenvolvidos, também coincidia com "baixo custo, baixa tecnologia e participação da comunidade". Desta forma, o foco educacional recaiu novamente sobre a educação compensatória.

Contrariando o preceito compensatório e considerando a inclusão dos preceitos constitucionais de uma proposta para a educação da criança de zero a seis anos, Campos (1986) aponta que "a educação da criança pequena está ligada tanto ao campo educacional como à questão da família, da maternidade e, por consequência, aos direitos da mulher". Por conta disto, a questão da creche e outras formas de apoio à maternidade têm sido uma das centrais preocupações dos movimentos de mulheres.

\begin{abstract}
Embora, no caso, seja a creche ser o objetivo principal de preocupação, a pré-escola também é reivindicada pelas mulheres, dentro de uma posição que defende a necessidade de uma política integrada de educação da criança de zero a seis anos, assim como a posição que prioriza a dimensão educativa da creche, opondo-se à concepção puramente assistencialista adotada geralmente pelos órgãos oficiais, nas várias instâncias administrativas. (CAMPOS, 1986, p. 238).
\end{abstract}

Desta forma, a oferta de creches e pré-escolas públicas atendia duplamente, tanto garantindo o direito da mulher à igualdade na sociedade, como também ao direito das crianças à educação. Esses argumentos foram utilizados para incluir a demanda de creche e pré-escola na parte da Constituição que tratava da educação. Antes da promulgação da constituição, essa luta era controversa no meio educacional brasileiro, pois até aquele momento o país não tinha ainda conseguido garantir o acesso aos oito anos de escolaridade obrigatória a todos e havia um receio que a luta pela Educação Infantil pudesse esvaziar a ênfase no Ensino Fundamental.

Com relação ao Ensino Fundamental, o direito à educação seria uma obrigação para o Estado e para o cidadão. No caso da Educação Infantil, esta seria obrigação do Estado como contrapartida ao direito da criança. A creche precisaria estar disponível para as famílias, mas esta não era obrigada a utilizar esse serviço se não tivesse interesse. Entretanto, a universalização da pré-escola para crianças a partir dos cinco anos já era defendida na década de 80, principalmente por conta do ponto de vista educacional. (CAMPOS, 1986, p. 239).

Com isso, no período constituinte, havia um consenso com relação à inclusão da criança pequena no artigo constitucional relativo à educação, seria necessário, 
portanto, definir a questão da fonte de recursos para a efetivação desta necessidade. (CAMPOS, 1986, p. 240). A luta era para que houvesse a inclusão da pré-escola entre as modalidades de ensino: Ensino Fundamental, Ensino Médio, Ensino Superior (de graduação e pós-graduação), Ensino Supletivo, Ensino pré-escolar e Educação de excepcionais. (CAMPOS, 1986, p. 241).

\begin{abstract}
A divisão interna das suas verbas, nas três instâncias administrativas, seria feita de acordo com as prioridades da política educacional adotado em cada caso.

As verbas disponíveis para educação não são apenas as vinculadas pela Constituição. O Finsocial, $0,5 \%$ do faturamento das empresas, responsável por aportes de verbas significativas, nos últimos anos, para esse nível de ensino. (CAMPOS, 1986, p. 242).
\end{abstract}

A questão da divisão das verbas seria, portanto, mais uma dentre tantas dificuldades e resistências encontradas, tanto na definição da creche como uma "modalidade de ensino", como também na disputa com outros níveis de ensino, como o Ensino Superior, pelas mesmas verbas e recursos. Para minimizar essa questão, foi proposto à criação de um imposto similar ao salário-educação destinado para programas de creche, entretanto, por enfrentar alguns problemas, essa proposta foi descartada. (CAMPOS, 1986, p. 242).

Nacionalmente, todas essas lutas intensas da sociedade civil organizada resultaram na promulgação da Constituição de 1988, a mais democrática e cidadã já aprovada no Brasil e também na aprovação do Estatuto da Criança e do Adolescente (ECA).

O Estatuto da Criança e do Adolescente - ECA, Lei no 8069/90 - revogou o Código de Menores, instituindo uma nova referência à infância e à adolescência no nosso país, a Doutrina de Proteção Integral. Essa Doutrina foi aprovada e difundida através da Convenção Internacional dos Direitos da Criança de 1989. Assim, o ECA é baseado numa concepção educativa, voltado para a garantia dos direitos de cidadania a essa população, em detrimento da antiga visão repressiva, punitiva e assistencialista imposta pelo Código de Menores. (MORELLI, SILVESTRE e GOMES, 2000, p. 69).

Em 2015, ocorreu a comemoração aos 25 anos do Estatuto da Criança e do Adolescente, Bárbara Pansardi publica na Revista Rolimã ${ }^{59}$ um artigo intitulado "Mobilizar para garantir: 25 anos do ECA", fazendo uma retomada do período, as mobilizações sociais que aconteceram nos anos 1980 e que foram decisivas para o apoio da sociedade e a para a aprovação do Estatuto. O artigo publicado na edição

59 Disponível em: http://oficinadeimagens.org.br/mobilizar-para-garantir-25-anos-do-eca/ Acesso em 28/10/2018. 
de junho de 2015 da revista tem a ilustração de imagens que ajudam a compreender a força das mobilizações e nos apresentam um repertório interessante de questões a serem analisadas. Essas imagens retratam uma passeata de 1987 na Avenida Afonso Pena em Belo Horizonte com aproximadamente 1,5 mil crianças empunhando cartazes que questionavam, reivindicavam ou tratavam de seus direitos.

Nas imagens 2, 3, 4 e 5 apresentadas na sequência, nas próximas páginas estão publicadas no artigo Bárbara Pansardi e também no arquivo da Pastoral do Menor Nacional, tiradas de uma mobilização realizada no centro da cidade de Belo Horizonte, em 1988.

Figura 2 - Início da Mobilização sobre direitos das crianças e adolescentes em 1988, Belo Horizonte, Minas Gerais.

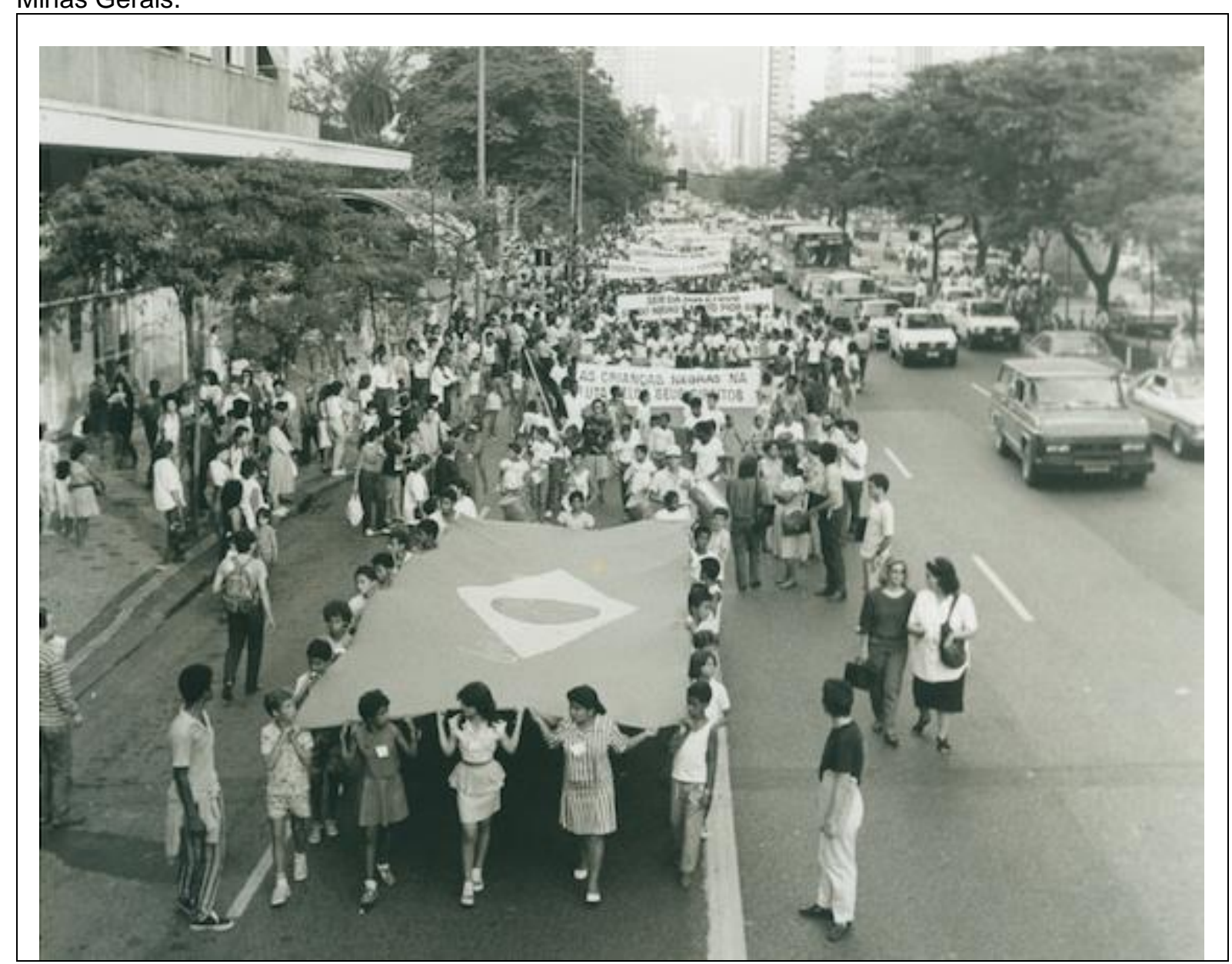

Fonte: Arquivo Pastoral do Menor Nacional.

A imagem 2, mostra um registro da passeata dando apresentando uma visão global. A cena que está em destaca e que abre a passeata são crianças, meninos e meninas carregando uma bandeira do brasil aberta. As meninas estão vestidas com vestidos e ou saias; os meninos com camisetas, calças e ou shorts; todos estão calçados e alguns usam crachás. Logo à frente, ao lado da bandeira estão dois 
adultos, uma mulher à direita da imagem e um rapaz do lado esquerdo, os dois estão olhando para trás, na direção das outras crianças e adolescentes da manifestação, muito provavelmente observando se todos estão acompanhando o mesmo ritmo da caminhada. As crianças e adolescentes que podem ser observados, quase em sua totalidade, é composta por negros e muito provavelmente, meninos de rua ou acolhidos em institucionalizações asilares existentes na época.

A imagem 3 mostra uma outra cena da passeata, o destaque desta fotografia são crianças da fanfarra tocando instrumentos, dando possivelmente uma musicalidade e ritmo para que as pessoas possam se movimentar durante o trajeto na avenida. As crianças e adolescentes estão vestidos com a camiseta da "CIMEAMAS - Cidade do Menor AMAS60".

Figura 3 - Fanfarra na Mobilização sobre direitos das crianças e adolescentes em 1988, Belo Horizonte, MG.

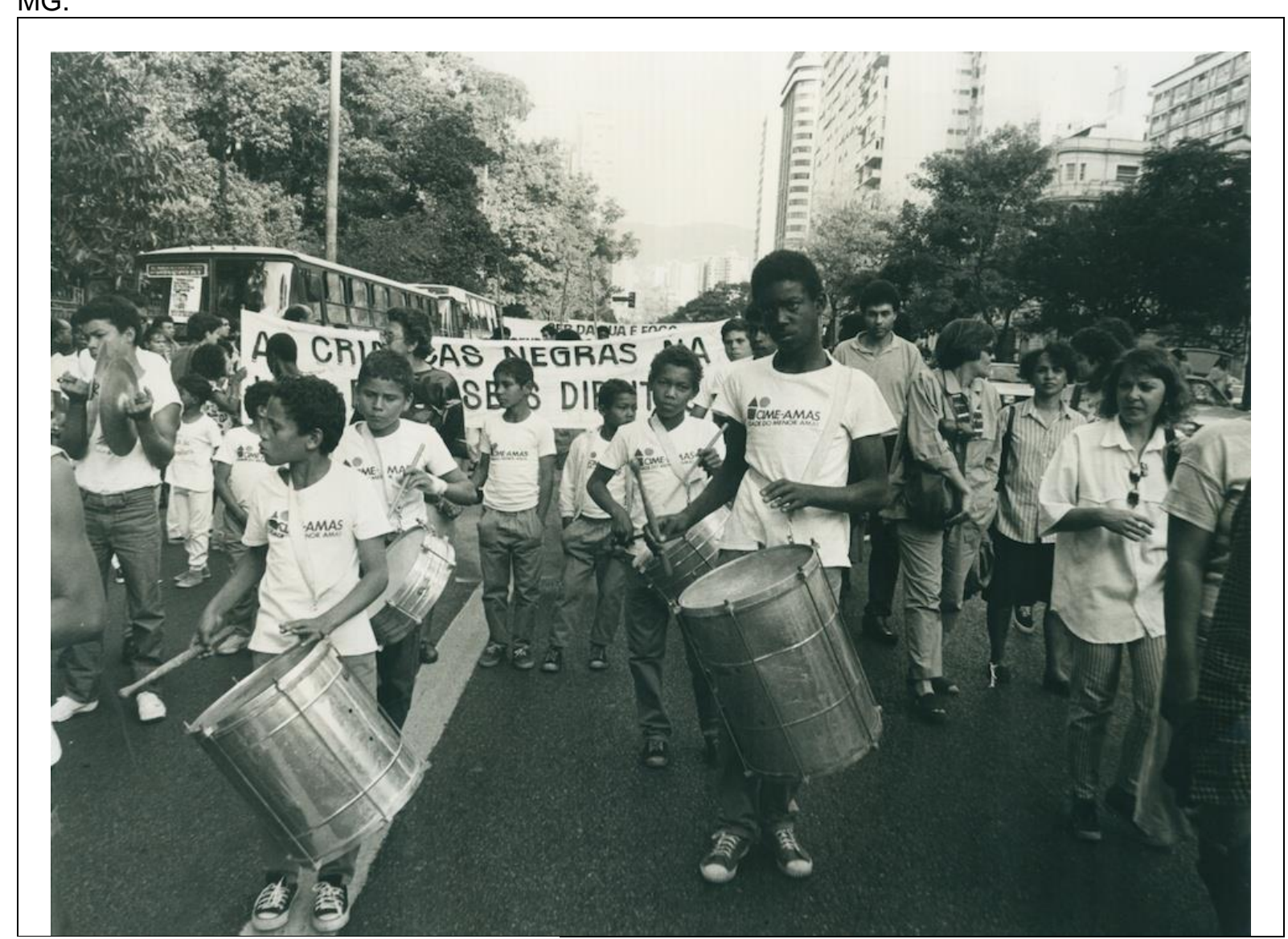

Fonte: Arquivo Pastoral do Menor Nacional.

60 Cidades do Menor foram instituições criadas para atender e amparar menores em situação de abandono ou maus tratos e que recebiam apoio financeiro de outras instituições sociais e religiosas, sendo que algumas existem até hoje, como é o caso da Fundação Comunitária Fabricianense de Coronel

Fabriciano,

MG.

Disponível em: https://www.diariodoaco.com.br/ler noticia. $p h p ? i d=33256 \& t=c i d a d e-d o-m e n o r-c o m p l e t a-40-a n o s-$ Acesso em: 01/11/2018. 
Atrás da banda da fanfarra começa a aparecer outra cena na passeata crianças e adolescentes carregando várias faixas. Na primeira esta escrito: "As crianças negras na luta pelos seus direitos", que parece ser a principal demanda desta manifestação retratada.

Além dos manifestantes, é possível observar pessoas paradas nas calçadas, olhando a manifestação passar, outras estão ajudando a organizar a passeata.

$\mathrm{Na}$ fotografia que figura na imagem 4 , o destaque são as diversas faixas que compõem uma certa ala da passeata, algumas inscrições registradas são possíveis de serem lidas, outras não: "Ser da rua é fogo, sendo negro é muito pior ainda", "Por que não posso ser criança?" e "Somos cidadãos de qual país?". Essas questões indicam as reivindicações destes sujeitos que praticamente enchem a avenida. Podemos inferir que o movimento negro talvez tivesse junto nas reivindicações dos direitos das crianças e adolescente, uma vez, que estudos do período indicavam que uma grande parte das crianças que estavam nas ruas eram pretas e pardas.

Figura 4 - Imagem da Mobilização sobre direitos das crianças e adolescentes em 1988, Belo Horizonte, MG.

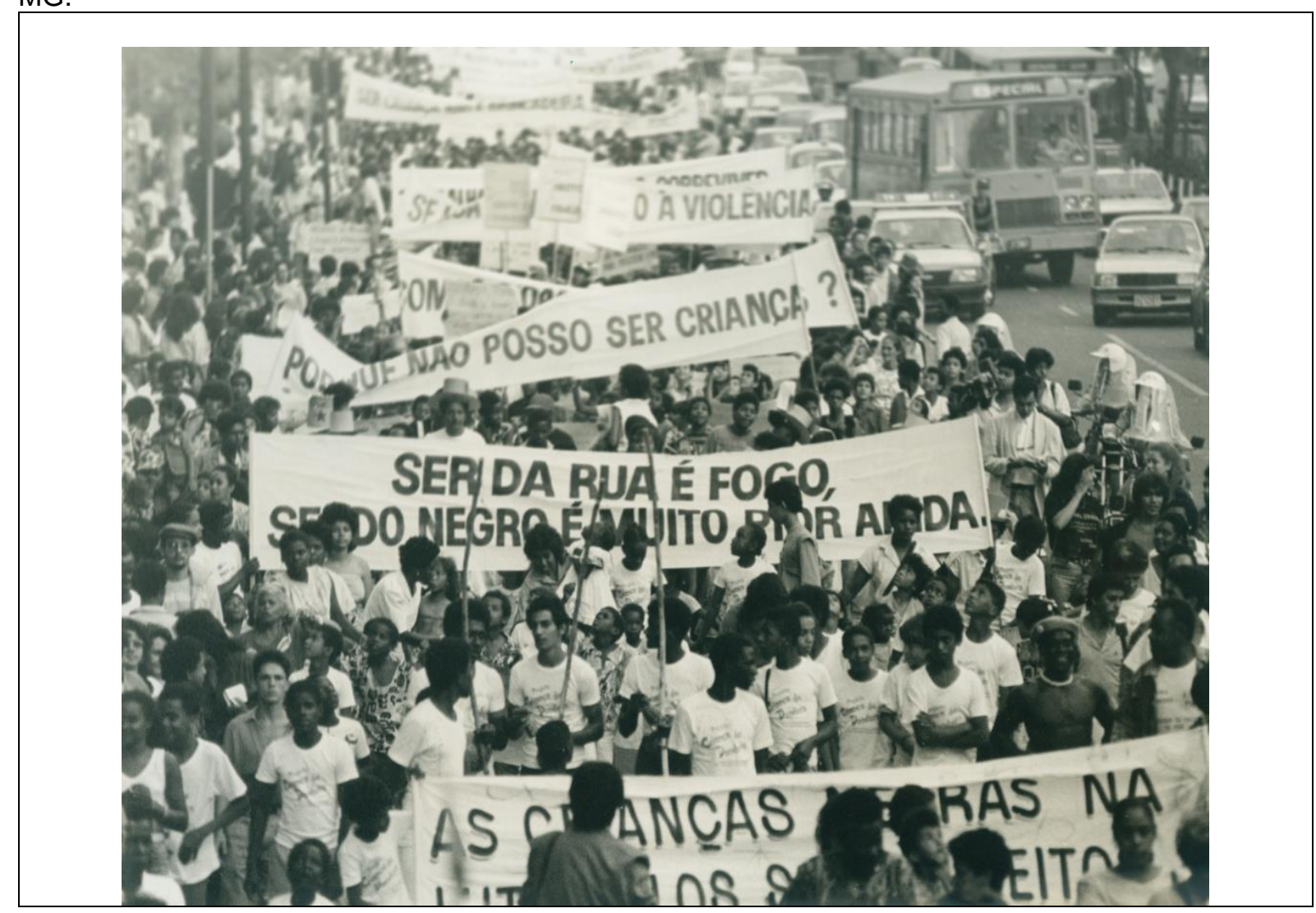

Fonte: Arquivo Pastoral do Menor Nacional. 
Ainda na imagem 4 é possível reconhecer três motocicletas com policiais acompanhando ao lado da manifestação, entre o corredor de manifestantes e os carros.

Figura 5 - Imagem mais centralizada da Mobilização sobre direitos das crianças e adolescentes em 1988, Belo Horizonte, MG.

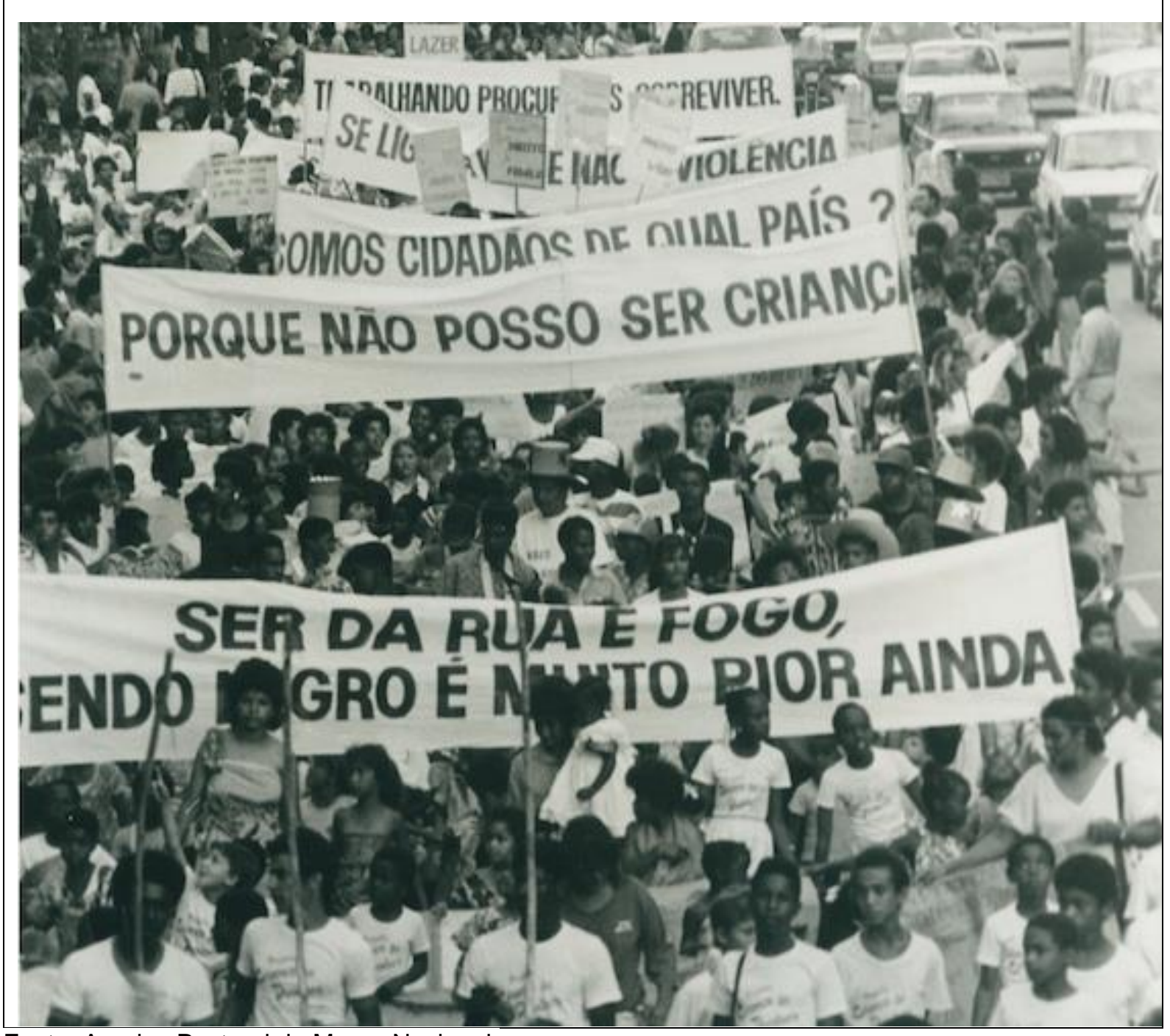

Fonte: Arquivo Pastoral do Menor Nacional.

O primeiro grupo que pode ser observado nas imagens 4 e 5 é de alguns adolescentes, dentre eles, há alguns tocando berimbaus, instrumento de percussão característico do Brasil, indispensável em rodas de capoeira ${ }^{61}$ ou outros contextos,

\footnotetext{
${ }^{61} \mathrm{~A}$ capoeira é uma expressão cultural caracterizada por seus movimentos ágeis e harmoniosos, em ritmo de música e aspectos coreográficos. Na capoeira os praticantes utilizam mais os movimentos com os pés e a cabeça e menos os movimentos com as mãos. A capoeira surgiu no Brasil, como uma forma de resistência dos escravos trazidos da África na época colonial. Além de ser utilizada para defesa física, a capoeira foi uma forma de resguardar a identidade dos escravos africanos. Atualmente, fala-se em "jogo de capoeira" ou em "roda de capoeira", pois normalmente os movimentos são apenas simulações de ataque, defesa e esquiva entre dois capoeiristas. Disponível em: https://www.infoescola.com/artes-marciais/capoeira/ Acesso em: 20/10/2018.
} 
como celebrações de candomblé de caboclo. Nesse grupo é possível ver um único adolescente sem camisa, com uma calça branca, colar de contas brancas no pescoço e uma boina na cabeça sorrindo e parecendo bem satisfeito, ao que tudo indica, ele estaria jogando capoeira.

No período, as reivindicações eram vistas como utopia ou aspiração que posicionava "a infância como portadora de direitos, onde se criticava o descaso, a omissão. Condenava-se a violência, os internatos, e colocavam-nos em marcha na construção da cidadania". (BAZÍLIO, 2001, p. 19). Entretanto, essas reivindicações podem ser consideradas essenciais para a efetivação de mudanças sociais e legais principalmente com relação à aprovação do ECA.

No contexto das grandes mobilizações ocorridas em 1988, é criado pelo MNMMR, outros movimentos de luta pelos direitos da infância e adolescência e entidades não governamentais com membros da sociedade civil, o Fórum Nacional Permanente em Defesa da Criança e do Adolescente (DCA). Entre seus objetivos estava o combate da violência contra a criança e ao adolescente e a mediação entre essas entidades, que defendiam os interesses das crianças e adolescentes e a Assembleia Constituinte, apresentando "propostas de regulamentação dos artigos 227 e 228 da Constituição Federal de 1988". Essas propostas originaram o "projeto de lei "Normas Gerais de Proteção à Infância e à Juventude", aprovado na Câmara de Deputados em 1989, [...] um ensaio para a construção do Estatuto", que foi aprovado em 1990. (CIRQUEIRA, 2007, p. 20; OLIVEIRA, 2007, p. 154).

\footnotetext{
Pensando na redação do ECA, o Fórum compôs um grupo denominado "Grupo de Redação do Estatuto", cujo corpo foi composto por representantes dos movimentos de defesa da criança e do adolescente, em destaque 0 MNMMR, a UNICEF, a FUNABEM, SAS e órgãos estaduais inscritos no FONACRIAD (Fórum Nacional dos Dirigentes de Políticas Estaduais para Criança e Adolescente). Tratava-se de um grupo heterogêneo e com divergências no que se referia à metodologia de trabalho com a criança e o adolescente, cujas formas educativas a serem adotadas e a filosofia de ação proveniente do projeto ético-político de cada ator desse corpo de redação, apesar de diferenciadas, eram motivadas por um interesse comum, ou seja, o de elaborar um documento amplo e abrangente para a nova legislação. (CIRQUEIRA, 2007, p. 20).
}

A consequência desse trabalho foi à aprovação do estatuto em forma de lei, cujo conteúdo representou "a materialização de uma luta histórica pelo reconhecimento da criança e do adolescente como cidadãos, pessoas em condição particular de desenvolvimento" e, portanto, carente de proteção integral e universal. (CIRQUEIRA, 2007, p. 20). 
Estatuto da Criança e do Adolescente representa um avanço na legislação brasileira, por ter sido fruto de um amplo processo de participação e discussão de organizações da sociedade civil e dos movimentos sociais e, principalmente por oferecer "uma nova orientação na relação do adulto com as crianças e os adolescentes". (MORELLI, SILVESTRE e GOMES, 2000, p. 65 e 66).

Segundo Piloltti e Rizzini (1995), conforme citado por Bazílio (2001) e Cirqueira (2007), o Estatuto traz sete principais mudanças:

1. A criança e o adolescente sujeitos de direitos, 2. A falta de renda familiar não deve ser motivo relevante para a perda do pátrio poder, 3 . A privação de liberdade somente com o flagrante do ato infracional e com a fundamentação da autoridade judiciária competente, 4 . $O$ direito de defesa pode ser exercido por outros indivíduos no decorrer do processo legal e não somente pelo Curador de Menor ou pelo Ministério Público, 5. A internação da criança e do adolescente deverá possuir tempo determinado, 6. O Magistrado não tem mais decisão absoluta, 7. A participação da sociedade civil através de Conselhos de Direitos e do Conselho Tutelar na promoção e proteção dos direitos da Criança e do Adolescente. (CIRQUEIRA, 2007, p. 21).

Sem dúvida, a Constituição Federal de 1988 e o ECA significaram um avanço em termos de reivindicações e conquista dos direitos políticos, civis e sociais pela sociedade civil, no entanto há um distanciamento entre o direito conquistado e a proteção desses direitos, em face dos objetivos neoliberais. Um dos objetivos do projeto societário hegemônico (neoliberal), consiste no desmonte dos direitos sociais, direitos esses conquistados na Constituição de 1988, o que acontece em nome do progresso e da convocação da participação social da sociedade, que significa assumir a responsabilidade do Estado em atender as demandas e privatizar os problemas sociais. Então, é possível concluir que os direitos conquistados não significaram unicamente uma ação prática de reconhecimento das reivindicações do povo pela efetivação de sua cidadania, na medida em que acabaram sendo utilizados pelo Estado como um mecanismo de efetivação dos objetivos hegemônicos. (CIRQUEIRA, 2007, p. 27).

Apesar de trazer inovações no trato da criança e do adolescente, o ECA está norteado pelo neoliberalismo do período, que acaba limitando o preconizado pela legislação, pois o Estado possui intervenções minimizadas no enfrentamento às múltiplas expressões da questão social que vitimiza milhões de crianças e adolescentes brasileiros, cujas políticas públicas, direcionadas a este segmento etário, possuem como eixo a participação popular, a descentralização, a democratização da coisa pública e a "comunitarização". (CIRQUEIRA, 2007, p. 27). 
Desta forma, o Estatuto além de garantir os direitos por meio de conquistas sociais geradas nas muitas lutas da sociedade, também fixa responsabilidades para crianças e adolescentes, funcionando como um importante instrumento de pedagogia social. (AMARAL e SILVA, 1999, p. 16).

Além dos ganhos com relação à aprovação do ECA, próximo a esse período de sua publicação aconteceu uma outra mobilização que movimentou todo o universo educacional e legislativo brasileiro, também com um envolvimento social expressivo iniciado logo após a promulgação da constituição de 1988, que se refere à organização e aprovação da Lei de Diretrizes e Bases da Educação Nacional em 1996 e que será melhor explorado a partir de agora neste trabalho.

\subsection{A MUNICIPALIZAÇÃO DO ENSINO E A LDBEN NA EDUCAÇÃO HOSPITALAR DO PARANÁ}

O início do processo de Municipalização do Ensino Fundamental do Estado do Paraná ocorre em 1983 com a criação de termos de cooperação entre as prefeituras municipais e o Estado. Nesse termo de cooperação o foco seria a contratação de professores, pessoal técnico-administrativo e serviços gerais, sendo o Estado responsável pelo pagamento de um salário mínimo para esses profissionais e as prefeituras responsáveis pelas obrigações contratuais, administração dos recursos e do pessoal. Esse tipo de convênio era renovado anualmente e aconteceu até meados de 1991. (ZANARDINI; BLUM; MICHELLON, 2013, p. 121; LIMA; VIRIATO, 2000, p. 6). Por meio desses termos de cooperação a

Fundação Educacional do Paraná62 (FUNDEPAR), que construía escolas em terrenos municipais, cabendo ao município zelar pela sua manutenção. Este procedimento propiciou uma economia em torno de $40 \%$ na expansão da rede pública. Ao mesmo tempo, elevou o percentual de matrículas de $1^{\underline{a}}$ a $4^{\underline{a}}$ séries da rede municipal. (EVANGELISTA; SCHMIDT, 1992, p. 282).

Ainda nesse processo "democrático", o documento Projeto Pedagógico 19871990 é organizado na gestão do Governador Álvaro Dias (1987-1990), do PMDB, no Estado do Paraná. Esse documento era norteador das ações da Secretaria de Estado da Educação - SEED/PR e se concentrava na "democratização" da escola em todas as suas dimensões. Nessa gestão, a prioridade no campo pedagógico seriam "as

62 Criada em 1962 com o objetivo de "apoiar a Secretaria Estadual de Educação em áreas como construção, reforma e reparo de prédios escolares" (CUNHA, 1991, p. 232). 
duas séries iniciais do $1^{\circ}$ grau com a implantação do Ciclo Básico de alfabetização e o fortalecimento e aperfeiçoamento de docentes". (ZANARDINI; BLUM; MICHELLON, 2013, p. 122). Além disto, neste governo ainda se defendia a continuidade do processo de Municipalização do Ensino Fundamental e a desconcentração dos Núcleos Regionais de Ensino. (LIMA; VIRIATO, 2000, p. 7).

No "Projeto Pedagógico" desta gestão o conceito de descentralização, se estabelece somente como a atribuição de funções para a comunidade, porque na tentativa de integração com as Associações de Pais e Mestres, a descentralização é evidenciada somente no atendimento aos serviços de limpeza, conservação e guarda dos prédios escolares, aumento no grau de responsabilidade de todos em relação à escola e no compromisso para com ela. Desta forma, a "participação instrumental é a forma de colaboração e de responsabilização da comunidade escolar pela manutenção do espaço físico, da falta de recursos, da falta de segurança, entre outras danações". (LIMA; VIRIATO, 2000, p. 7). A questão da autonomia da Escola é outro conceito apresentado no Documento que conclama a comunidade para a participação mais efetiva na escola, em festas, mutirões de limpeza, apoio aos movimentos grevistas de professores e funcionários, assim como para decidir. Desta forma, na tentativa de reduzir os gastos públicos, o Governo Álvaro Dias implanta nesta gestão o Projeto Mutirão, e fomenta a aquisição de materiais de conservação e manutenção, como mecanismo de participação da comunidade escolar na manutenção das escolas e a descentralização dos recursos da FUNDEPAR.

Apesar do Projeto Pedagógico 1987-1990 ter antecedido ao documento do governo federal, este já mostra bem delineada a questão da racionalização dos recursos públicos, contando com o apoio da comunidade escolar. (ZANARDINI; BLUM; MICHELLON, 2013, p. 123).

Ainda na gestão de Álvaro Dias ocorre uma reordenação nos termos de cooperação Estado/Município relacionado à municipalização das escolas estaduais, sendo que o "Protocolo de Intenções" existente no termo passa a indicar:

[...] a transferência gradativa do patrimônio do Estado para o Município; a manutenção da folha de pagamento dos recursos humanos com vínculo empregatício estadual, mas com exercício na futura escola municipal; apoio técnico para adequação da administração municipal e o repasse da diferença de custo que o município tiver acima dos gastos indicados constitucionalmente. (EVANGELISTA; SCHMIDT, 1992, p. 287).

A aceleração do processo de municipalização, implantação do Conselho Escolar, do Regimento Escolar Único e a institucionalização do Projeto Político 
Pedagógico da Escola foram os programas do governo de Roberto Requião, próximo governador eleito entre os anos de 1991 a 1994. (LIMA; VIRIATO, 2000, p. 8).

O processo de municipalização do ensino das séries iniciais do Ensino Fundamental no Estado do Paraná se efetivou, portanto, no início dos anos 90, anteriormente a constituição do Fundo de Manutenção e Desenvolvimento do Ensino Fundamental e de Valorização do Magistério (FUNDEF) 63, revelando que a transferência "de tal responsabilidade aos municípios paranaenses antecede a criação do referido Fundo", mesmo que "a intensificação da municipalização, tenha sido uma das suas principais finalidades". (SANTOS, 2003, p. 257). Tal situação indica a real intenção do poder público federal que era o (re) partilhamento das responsabilidades diretas de financiamento do Ensino Fundamental, explícito também no "balanço do primeiro ano" de vigência do referido fundo.

O FUNDEF foi sendo encarado "como um fundo mais de manutenção do que desenvolvimento", afinal não dispunha novos recursos para a educação, mas prescrevia "temporariamente, um rearranjo dos recursos disponíveis de forma a realizar, de fato, a ampliação do atendimento educacional por parte dos municípios". (SANTOS, 2003, p. 261).

Com relação ao avanço do processo de municipalização de escolas do Ensino Fundamental, uma pesquisa realizada pelo MEC indicou que pelo Censo Escolar de 1998, 28,1\% dos municípios declararam ter assumido escolas estaduais ao longo do último ano, sendo que este "movimento de municipalização foi mais intenso na região Sudeste onde se constatou que $57,6 \%$ dos municípios assumiram escolas de Ensino Fundamental" que antes pertenciam à rede estadual. (BRASIL, 1999, p. 24). Ainda com base nos dados do mesmo Censo Escolar, entre os anos de 1997 e 1998, o número de matrículas da rede pública de Ensino Fundamental cresceu 6\%, passando de 30.535.072 alunos em 1997, para 32.380.024 em 1998. O maior incremento ocorreu no crescimento de $21,5 \%$ nas matrículas do conjunto dos municípios brasileiros, sendo que as redes estaduais tiveram uma redução de 4,6\%, o que evidencia o aceleramento no processo de municipalização. (BRASIL, 1999, p. 21).

No Paraná, a municipalização do ensino da Educação Infantil (pré-escola), do Ensino Fundamental (séries iniciais), Educação de Jovens e Adultos (supletivo) e da Educação Especial se efetivou, especialmente, a partir de 1990, praticamente uma

${ }^{63}$ FUNDEF - Fundo de Manutenção e Desenvolvimento do Ensino Fundamental e de Valorização do Magistério de vigência obrigatória a partir de 1ํ de janeiro de 1998. (SANTOS, 2003, p. 258). 
década antes da implantação do FUNDEF. Apesar das primeiras iniciativas de transferência de responsabilidades quanto à oferta de ensino para os municípios datarem da década de 60 do século passado.

De acordo com diferentes autores ${ }^{64}$, o processo de municipalização no Paraná ocorre em três momentos:

O primeiro, associado ao processo de constituição e de reestruturação do
sistema estadual de ensino, implicadas pelas leis e reformas nacionais de
educação (1961 e 1971); o segundo desenvolve-se associado a projetos
nacional (1975-1981) e regional, com financiamento internacional, voltados à
educação no meio rural e o terceiro, inicia-se com os estudos nacionais de
custo aluno que, com as mudanças tributárias definidas na Constituição de
1988 , passarão a funcionar como parâmetro para o "modelo" paranaense que
vigora de 90 a 97. (SANTOS, 2003, p. 263-264).

Segundo dados apresentados pela FUNDEPAR/Secretaria de Educação relativos à matrícula inicial do Ensino Fundamental por zona e dependência administrativa de 1978 a 1987, a oferta de ensino fundamental urbano municipal cresceu, passando de 139.070, em 1978, para 225.771, em 1987, enquanto a oferta de educação municipal rural declinou, passando de 453.536, em 1978, para 271.359 em 1987.

No total a tendência também se apresentou constantemente declinante passando, entre 1978 e 1987, de 592.606 para 497.130, respectivamente. Tais dados permitem verificar que os movimentos migratórios, para fora do Estado, intensos nos anos 70, e das regiões rurais para as urbanas dentro do mesmo município ou entre municípios, predominantes nos anos 80 , aliados ao arrefecimento do ritmo de crescimento da população, reconfiguraram completamente o perfil do atendimento educacional municipal no Paraná no período analisado e que os projetos nacionais e locais voltados a compensar os efeitos dos processos transformadores do meio rural, pouca efetividade tiveram, se é que tiveram qualquer efetividade. (SANTOS, 2003, p. 264).

No início do segundo governo do PMDB pós-ditadura militar, entre os anos de 1987 a 1990, ocorre o terceiro momento do processo de municipalização do ensino no Paraná que se intensifica entre 1991 a 1994, por conta de duas razões unicamente de ordem financeira, o déficit cada vez maior das contas da administração estadual e o virtual aumento das receitas municipais por conta da alterações de ordem tributária

\footnotetext{
${ }^{64}$ Maiores informações podem ser encontradas em LOCCO, Leila de Almeida; ZABOT, Nircélio. Política de municipalização do ensino de 1 o grau no Paraná. Curitiba, s/d. (mimeo). EVANGELISTA, Olinda; SCHMIDT, Maria Auxiliadora. Relação Estado/Município no Paraná: construção ou desconstrução da escola pública de qualidade. In: Estado e educação. Campinas, SP, Papirus: Cedes: São Paulo: Ande: Anped, 1992, p. 279 -297, (coletânea C.B.E.). SANTOS, Jussara Maria T. Puglielli. As políticas governamentais para o ensino fundamental no Estado do Paraná diante dos preceitos da Constituição. São Paulo, 1998, Tese (Doutorado em Educação) Faculdade de Educação da Universidade de São Paulo.
} 
contidas na Constituição de 1988, que seria de "31,1\% nos municípios menores, de 25,2\% nos maiores e de 29\% nos intermediários". (SANTOS, 2003, p. 265).

Entretanto, as expectativas não se efetivam e a

greve dos professores de 1988 representava o primeiro alerta do impasse do sistema de ensino de $1^{\circ}$ grau, pois enquanto a participação do ensino de $1^{\circ}$ grau no orçamento estadual caía de 56,1\%, em 1987, para 52,2\%, em 1988, havia um incremento no número de alunos, passando de 927.612, em 1987, para 975.870 , em 1988. Contudo a greve de 1990 não foi mais um indício de impasse, mas um sintoma de colapso do sistema de ensino de $1^{\circ}$ grau, pois a participação dos recursos destinados ao ensino de 1ㅇa grau no orçamento estadual havia sido rebaixada para $45 \%$, naquele ano, e a matrícula, nesse grau de ensino, atingiria 1.023.143 alunos. (SANTOS, 2003, p. 266).

De acordo com Santos (2003, p. 266), os profissionais da educação foram excluídos do processo de definição da política de municipalização do ensino das séries iniciais do Ensino Fundamental, implantada a partir de 1991, principalmente por conta dos conflitos entre eles e o governo estadual causado pelo arrocho salarial e precarização das condições de trabalho. Assim, "definição dos mecanismos por meios dos quais se definiu o processo de municipalização implicou na condução unilateral e autoritária do governo estadual", pois houve uma certa oposição da comunidade educacional e também dos municípios envolvidos no processo, motivados pelas "relações conflituosas entre os profissionais da educação e a administração estadual" e a "redução de gastos para a administração estadual".

Para o governo estadual, os repasses de recursos financeiros aos municípios apresentaram, ao longo do tempo, uma redução significativa, dada a sua representatividade em relação ao total das despesas as SEED, passando de 14\%, antes do início do processo de municipalização para 3\% em 1995. (SANTOS, 2003, p. 267).

A regulamentação da municipalização do ensino foi sendo alterada, parece que para se "ajustar às dificuldades interpostas no processo de sua implementação" e assumiu três versões. A primeira, de 1991, implementada nos dois primeiros meses do ano, "ainda antes da posse do terceiro governador peemedebista", requeria a assinatura dos municípios junto ao Poder Público Estadual no "Protocolo de Intenções" que efetuava a "parceria" entre o Estado/Município na oferta do ensino préescolar e fundamental na rede pública, com o objetivo de dividir os serviços e encargos entre os dois entes públicos, Estado e Município, para a efetivação da universalização do Ensino Fundamental. (SANTOS, 2003, p. 268). 
o modelo empregado visava exclusivamente a dimensão financeira. Os municípios "parceiros" passaram a assumir os encargos e o custeio e o Estado que definiu a forma e arbitrou sua aplicação, teve reduzido o montante de recursos repassados aos municípios [...]. (SANTOS, 2003, p. 268).

Desta forma, o processo de municipalização continuou, assim como a exclusão de um debate mais amplo com a comunidade escolar e toda a sociedade civil, até que em 1994, o Termo Cooperativo de Parceria Educacional (TCPE) traz a seguinte ampliação do processo de municipalização que obriga os municípios paranaenses, além do atendimento da Educação Infantil, das séries iniciais do Ensino Fundamental, também realizar o atendimento da Educação Especial e do ensino supletivo fase I, pontos que não eram previstos na versão 1991.

[...] a ação de parceria educacional entre a SEED-PR e o Município Parceiro, visando o desenvolvimento do ensino fundamental, prioritariamente no que se refere às quatro séries iniciais, ao pré-escolar, à educação especial e ao ensino supletivo fase I, atendendo ao disposto no artigo 211 da Constituição Federal. (SANTOS, 2003, p. 269).

Apesar desta alteração, "o teor do TCPE não difere substancialmente daquele expresso no Protocolo de Intenções SEED-PR (1991), pois o que está efetivamente regulado se refere ao repasse de recursos financeiros". Desta forma, no final de 1993, dos 371 municípios existentes no Paraná, 315 municípios (84,9\%) haviam assinado o Termo Cooperativo de Parceria Educacional, provavelmente por conta das alterações incorporadas com relação à oferta de "estímulos financeiros aos municípios parceiros". (SANTOS, 2003, p. 270-271).

Entretanto, os valores definidos para o custo/aluno variam bastante, tanto que em 1992 e 1993 "observa-se uma redução acentuada desses valores em termos reais". Além disto, entre 1993 e 1994, também foi incorporada, no Termo Cooperativo de Parceria Educacional, a cláusula de aceitação da "municipalização parcial" pela SEED-PR. (SANTOS, 2003, p. 271).

Com relação ao processo de municipalização nos anos de 1992 e 1993, a Fundação Educacional do Paraná - FUNDEPAR realiza um balanço do conjunto de informações relativas à educação municipais e estaduais para o período e chega às seguintes conclusões: Confirma que os municípios de pequeno porte e com maior dependência financeira dos repasses governamentais foram os primeiros a aderir ao processo de municipalização do ensino, por conta de serem "mais frágeis do ponto de vista econômico e, portanto, os mais dependentes financeiramente das demais instâncias governamentais." (SANTOS, 2003, p. 272); indica que os municípios, ao 
aderirem ao processo de municipalização, não realizaram uma avaliação prévia "de suas próprias condições financeiras e mesmo gerenciais" e, por conta disto, esperando ter ganho financeiro, "alguns deles [...] ao se darem conta de que estes não se efetivaram conforme suas expectativas, tentavam devolver ao Estado as responsabilidades que caberiam a eles". (SANTOS, 2003, p. 273).

Os municípios passaram a ter dificuldades em atender os critérios exigidos pelo Estado "em relação à documentação financeira, [...] de comprovação trimestral dos gastos municipais com programas de educação", na vulnerabilidade de implantação do Ciclo Básico de Alfabetização, por conta da falta de "orientação pedagógica às equipes dos municípios que assumiram a parceria educacional", e ainda a exclusão de muitos professores municipais dos cursos de formação promovidos pelo Estado, demonstrando "que o Estado não possui uma proposta concreta de apoio aos municípios em programas da capacitação" aos professores municipais. (SANTOS, 2003, p. 274). Não houve ainda uma "adequada mudança organizacional nas estruturas municipais de ensino" e "os professores e funcionários técnicoadministrativos estaduais, lotados nas escolas que foram municipalizadas, buscaram delas sair". Essa movimentação de profissionais sobrecarregou financeiramente os municípios que tiveram que assumir o quadro de funcionários das escolas e 0 resultado foi a oferta de salários mais baixos oferecidos pelas prefeituras, falta de planos de carreira para o magistério, assim como "baixa qualificação dos candidatos que se apresentam aos concursos públicos ou aos testes seletivos realizados para a reposição do pessoal do Estado que se evadiu da rede municipalizada". (SANTOS, 2003, p. 275).

Tais indicações reforçam as considerações, já feitas, relativamente ao fato de o processo de municipalização do ensino representar uma estratégia de desresponsabilização do Estado para com o ensino fundamental e a transferência de custeamento para os municípios, frente à crescente precarização das condições de financiamento do Estado.

Em 2001, a Lei Estadual no 13.116 de 08 de março, dispõe sobre a destinação da quota estadual do salário educação e estabelece a redistribuição de $50 \%$ da mesma ao Estado e municípios tendo como referência o número de alunos matriculados nas respectivas redes de ensino. Entretanto, a referida lei, no $2^{\circ}$ parágrafo do artigo $2^{\circ}$, condiciona a participação dos municípios nessa redistribuição à totalização do processo de municipalização. 
Os Municípios que ainda não tiveram implantado a totalidade do processo de municipalização das quatro séries iniciais do Ensino Fundamental, até 360 dias após a promulgação desta Lei, deverão apresentar, à apreciação da Secretaria de Estado da Educação, projeto de totalização da municipalização, incluindo termos e cronograma de implementação. (PARANÁ, 2001, p.1).

Por meio da reprodução dos dados relativos ao período 1978 - 2000 das matrículas iniciais do Ensino Fundamental por dependência administrativa retirados do Relatório Final da Pesquisa "Implantação e Impactos do FUNDEF no Estado do Paraná" (2002, p. 26) é possível perceber a redução de matrículas em todas as dependências administrativas, menos na municipal que tem um incremento de $29,7 \%$ no período.

Quadro 2 - Matrícula inicial do Ensino Fundamental por dependência administrativa/PR - 1978/2000

\begin{tabular}{|c|c|c|c|c|c|}
\hline Ano & Total & \multicolumn{4}{|c|}{ Dependência Administrativa } \\
\hline & & Federal & Estadual & Municipal & Particular \\
\hline 1978 & 1.528 .171 & 484 & 837.518 & 592.606 & 97.563 \\
\hline 1983 & 1.520 .559 & 988 & 854.928 & 515.767 & 148.876 \\
\hline 1988 & 1.630 .890 & 779 & 975.870 & 500.585 & 153.656 \\
\hline 1991 & 1.734 .836 & 1.161 & 988.398 & 597.618 & 147.659 \\
\hline 1995 & 1.772 .823 & 1.101 & 868.432 & 754.726 & 148.564 \\
\hline 1998 & 1.808 .149 & 440 & 873.881 & 794.477 & 136.351 \\
\hline 2000 & 1.692 .648 & 439 & 787.308 & 775.183 & 129.718 \\
\hline $\begin{array}{c}\text { Taxa de } \\
\text { Crescimento } \\
\%\end{array}$ & $-2,4 \%$ & $-62,2 \%$ & $-20,3 \%$ & $29,7 \%$ & $-12,2 \%$ \\
$(91 / 00)$ & & & & & \\
\hline
\end{tabular}

Fonte: SIE-SEED/PR-FUNDEPAR; MEC/INEP/SEEC - CENSO ESCOLAR. (SANTOS, 2003, p. 277).

Em contrapartida, o Censo Escolar de 2002, constata que houve redução de matrícula de $0,2 \%$ no Ensino Fundamental nos anos seguintes aos demonstrados no Quadro 1. (GAZETA DO POVO, 30/08/02, online - 'Resultados do Censo de 2002').

Apesar do documento "Inovando nas Escolas Públicas do Paraná65" avaliar a municipalização como algo tranquilo, pois na maioria das vezes há uma "aproximação

65 PARANÁ. Secretaria de Estado da Educação. Inovando nas Escolas do Paraná. Brasília: Instituto Nacional de Estudos e Pesquisas Educacionais, 1994. 
das escolas estaduais com as municipais", afinal muitas escolas das quatro primeiras séries do Ensino Fundamental eram da rede estadual e com a municipalização do ensino, em várias localidades existe uma "ação coletiva, um único Conselho Escolar", professores do estado dirigindo as escolas municipais, sendo que em alguns outros locais "há a mesma direção para escolas estaduais e municipais; a mesma biblioteca e a mesma videoteca são utilizadas pelos professores e alunos de todas as redes de ensino." (PARANÁ, 1994, p. 23), essa não é a realidade evidenciada pelo desagrado observado não somente no Paraná, mas também em outros estados brasileiros com relação aos convênios entre Estado e Município. No Paraná, os municípios reclamavam por conta dos repasses dos recursos serem insuficientes, além dos frequentes atrasos que aconteciam. "Assim, os projetos, convênios e parcerias efetivados com o Município acabavam sendo uma forma de o Estado descarregar no município o ônus das obrigações que deveriam ser respondidas por ambos". (LIMA; VIRIATO, 2000, p. 9).

O movimento de municipalização que precede o FUNDEF é, com certeza, marcado pelas tentativas de "forçar" o município a cumprir com os preceitos legais e assumir sua responsabilidade com o Ensino Fundamental. O Estado se coloca como parceiro, embora, nem sempre corresponda às obrigações de contrapartida. O que fundamenta o movimento gerado a partir de 1995 é - cunho mercadológico, fundamentado num racionalismo tacanho que direciona o papel do Estado para a desresponsabilização em relação à educação. (LIMA; VIRIATO, 2000, p. 9).

A abundância "de estratégias de participação, descentralização, autonomia e ênfase na gestão de recursos escolares", que acontecem no desenrolar dos governos que se sucedem no Paraná após a "democratização", acaba por implantar pressupostos do neoliberalismo. Desta forma, apesar da participação plena nas decisões, a descentralização e a autonomia financeira das escolas observadas na década de 1980 e 1990 insere a educação

[...] num contexto de rearticulação do modo capitalista de produção, o qual em meio aos conceitos de globalização, pós-modernidade e acumulação flexível, dentre outros, celebra o mercado e as estratégias que garantam o seu "caráter democrático". (ZANARDINI; BLUM; MICHELLON, 2013, p. 124).

Assim, a década de 1990, revela um novo padrão de Estado e de políticas sociais, que se apoia nos princípios do neoliberalismo e no "discurso de "ineficiência" do Estado e das instituições a ele relacionadas, dentre elas, a escola". (ZANARDINI; BLUM; MICHELLON, 2013, p. 125). Desta forma, é implantada, com orientações da esfera federal, sobretudo no governo do Presidente Fernando Henrique Cardoso, mas 
também nas gestões dos Presidentes Fernando Collor de Mello e Itamar Franco, uma proposta de gestão ajustada aos valores do mercado e sua propagada democracia, implementando, portanto nesta década uma reforma da gestão escolar disposta com os mesmos princípios que nortearam a reforma da educação básica e do Estado. Desta forma, "a participação, a descentralização e a autonomia, propaladas na década de 1980, permanecem evidentes, mas agora, digamos que "despidas", de seu "caráter popular e de esquerda"' (ZANARDINI; BLUM; MICHELLON, 2013, p. 125) divulgado na época, e

\begin{abstract}
"trajadas" com as cores da moderna administração pública gerencial, capaz de superar a rigidez e a centralização da administração pública burocrática e "democratizar/descentralizar" para construir o consenso necessário à sobrevivência do capital. (ZANARDINI; BLUM; MICHELLON, 2013, p. 125).
\end{abstract}

Em 1993, durante o governo Itamar Franco, foi assinado o Plano Decenal de Educação para Todos, que tinha como argumento a ineficiência das escolas que se demonstraram incapazes de manter os alunos no ambiente escolar, pois:

O sistema educacional tem-se caracterizado por elevado coeficiente de inércia que constrange a disposição para melhorar, agir cooperativamente, adotar inovações e incorporar avanços significativos e tecnológicos nos processos de ensino e de gestão escolar. (BRASIL, MEC, 1993).

Para reverter esse cenário, o Plano Decenal propôs uma reforma da educação básica com o estabelecimento de padrões basilares para a rede pública, como a fixação de conteúdos mínimos determinados pela constituição, valorização do magistério, estímulo às inovações, desenvolvimento de novos padrões de gestão educacional, eliminação das desigualdades educacionais, melhoria do acesso e permanência escolar e sistematização da educação continuada de jovens e adultos. (ZANARDINI, 2006).

[...] materialização das categorias, descentralização, participação e autonomia em sua acepção liberal, é bem ilustrada pela proposta de gestão compartilhada implementada no Estado do Paraná, na década de 1990, de modo particular a partir de 1995 quando se inicia a primeira gestão do governo Jaime Lerner (1995-2002). Esta proposta é implementada a partir das orientações financeiras, técnicas, políticas e pedagógicas do Banco Mundial, sob o pretexto de que os países periféricos seriam ineficientes para administrar suas políticas públicas. (ZANARDINI; BLUM; MICHELLON, 2013, p. 127).

No governo de Jaime Lerner, a gestão escolar foi definida como uma ação especialmente liderada pelo diretor da escola, devendo resultar na unidade de ação 
do estabelecimento de ensino, "construção da excelência, em torno de seus objetivos, passando por princípios básicos", como superação de limitações e dificuldades, criatividade no desenvolvimento de "seu projeto de excelência, inserção da vida e força da comunidade na vida da escola, envolvimento coletivo de todos os seus participantes." (PARANÁ, 1995, p. 1; ZANARDINI; BLUM; MICHELLON, 2013, p. 128).

Desta forma, tanto na primeira gestão (1995-1998) e início da segunda (19992002), desse governo,

[...] teremos o Projeto Qualidade do Ensino Básico do Paraná, o Programa Expansão, Melhoria e Inovação do Ensino Médio do Paraná, o Programa Correção de Fluxo, a implantação da Universidade do Professor e a continuidade do processo de Municipalização do Ensino Fundamental. (LIMA; VIRIATO, 2000, p. 10).

O contexto político de "democratização da sociedade brasileira" na década de 1980 foi essencial na incorporação das categorias autonomia, descentralização e participação, assim como as políticas de gestão escolar nas instituições auxiliares da escola, mas foi na década de 1990 "que tais políticas receberam ênfase e as categorias acima apontadas materializam-se em Projetos e Programas que tiveram por fim articular a reforma da gestão escolar à reforma econômica do Estado, isso principalmente com o intuito de que as políticas de gestão implementadas no Paraná e no Brasil acelerasse a desburocratização da gestão dos estabelecimentos de ensino. (ZANARDINI; BLUM; MICHELLON, 2013, p. 133).

Assim, é importante confirmar que nas décadas de 1980, 1990 e início dos anos 2000 os conceitos de descentralização, autonomia e participação foram usados "como estratégia política para transferir a responsabilidade pela Educação para instituições não estatais". (LIMA; VIRIATO, 2000, p. 13). Entretanto, é essencial que entendamos que a descentralização não deve significar a desobrigação do Estado em seu papel de mantenedor da Educação Pública, mas deve oportunizar que a comunidade local tenha autonomia nas decisões acerca dos aspectos financeiros, administrativos e pedagógicos, sendo o Estado obrigado a fornecer os recursos financeiros e apoio técnico-administrativo para manter a Escola Pública com qualidade e para todos. (LIMA; VIRIATO, 2000, p. 14).

[...] o movimento iniciado na década de 1980, toma forma nos anos 1990, com o governo $\mathrm{FHC}$ e a implementação de políticas que visavam, dentre outros aspectos, atingir a redefinição do papel da Escola, e de sua organização, na sociedade brasileira. O governo "LULA", porém, encontrou 
um projeto em andamento, com o qual teve limitadas possibilidades de ruptura, e continuou então, o favorecimento, a implementação dos interesses do capital mundial. (ZANARDINI; BLUM; MICHELLON, 2013, p. 132).

Após esses apontamentos, vale ressaltar que "a inspiração para constituição de um meio de desresponsabilização do poder público com a educação das massas é inconteste". (SANTOS, 2003, p. 278). Em 2006, é reeleito o governador Roberto Requião, no Estado do Paraná, que anunciou os seguintes princípios da política educacional: "a) educação como direito do cidadão, b) universalização do ensino, c) escola pública, gratuita e de qualidade, d) combate ao analfabetismo, e) apoio à diversidade cultural, f) organização coletiva do trabalho e g) gestão democrática66". (ZANARDINI; BLUM; MICHELLON, 2013, p. 132).

\subsubsection{Educação Hospitalar e Educação, aspectos legais pertinentes ao Estado do Paraná}

Nesse contexto de democratização da educação para todos, a Educação Hospitalar passa a ser implantada principalmente para atender uma demanda legal. Ainda no Regime Militar é instituído o Decreto-Lei oㅜ 1.044/69 que dispõe sobre tratamento excepcional para os alunos portadores de afecções e a Lei Federal no 6.202/75 que atribui à estudante em estado de gestação o regime de exercícios domiciliares instituído pelo Decreto-Lei 1.044/69.

O Decreto-Lei ํㅜ 1.044, de 21 de outubro de 1969, apresentou uma lista de doenças que justificavam o atendimento educacional diferenciado aos estudantes acometidos por elas. Indicava ainda a oferta de exercícios domiciliares com acompanhamento da escola, como compensação da ausência às aulas, com base em laudo médico e com a autorização do regime de exceção ${ }^{67}$ como competência do Diretor do estabelecimento. (BRASIL, 1969).

A Lei Federal № 6.202, sancionada em 1975, atribuiu em seu Artigo 1ํㅡㄹ à estudante gestante o regime de exercícios domiciliares instituído pelo Decreto-lei oㅜ

\footnotetext{
66 De acordo com a Lei de Diretrizes e Bases da Educação Nacional a gestão democrática do ensino público é um dos princípios da Educação Nacional, sendo que, segundo o art. 14, os sistemas de ensino definirão as normas da gestão democrática do ensino público na educação básica, de acordo com as suas peculiaridades e considerado a participação dos profissionais da educação na elaboração do projeto pedagógico da escola e a participação das comunidades escolar e local em conselhos escolares ou equivalentes. (BRASIL, 1996).

67 O regime de exceção tratado no art. 3o desse Decreto-lei se refere a atribuição de exercício domiciliares com acompanhamento da escola aos estudantes que por condições de saúde nem sempre possam frequentar a escola, na proporção mínima exigida em lei, como compensação da ausência às aulas.
} 
1.044/69, isto a partir do oitavo mês de gestação e durante três meses. O início do período em que é permitido o afastamento é determinado por atestado médico que deve ser apresentado à direção da escola, com a flexibilidade, inclusive do aumento do período de repouso, antes e depois do parto (Art. $2^{\circ}$ ). (BRASIL, 1975).

Depois destas leis e sobre esse assunto, somente após vinte anos, em 1995 foi publicada a Resolução no 41/1995 - CONANDA que evidenciava a necessidade e o direito da criança e do adolescente quanto ao atendimento pedagógico quando hospitalizados:

09-Direito de desfrutar de alguma forma de recreação, programas de educação para a saúde, acompanhamento do currículo escolar durante sua permanência hospitalar; [...]

19-Direito a ter seus direitos constitucionais e os contidos no Estatuto da Criança e do Adolescente respeitados pelos hospitais integralmente.

Nesta mesma década, com relação à proposta de educação no Paraná, em 1992 é implantado o Currículo Básico para a escola pública do Estado. No discurso da abertura do documento datado de outubro de 1990, a secretária de Educação, senhora Gilda Poli Rocha Loures ${ }^{68}$, declara em carta aos professores que a melhoria da qualidade do ensino é o foco de todos os envolvidos na educação paranaense e portanto, a implantação do currículo básico, construído coletivamente por todos os professores paranaenses, tem como "meta uma sociedade mais justa, onde todos tenham acesso aos conhecimentos e dele possam se apropriar". (PARANÁ, 1992, p. 7).

Com início a partir de 1987, a reestruturação do currículo da Pré-escola até a 8 a série envolveu desde os educadores das escolas, as equipes de ensino dos Núcleos Regionais de Educação69 (NRE) e do Departamento de Ensino de 1arau da Secretaria de Estado da Educação do Paraná. De acordo com a Diretora do Departamento de Ensino de 1ํ Grau, Cleusa Maria Richter e a Assessora TécnicaPedagógica, Carmen Lúcia Gabardo, essa revisão dos conteúdos básicos das disciplinas no Paraná ocorreu por meio de um extenso percurso com contínuas

\footnotetext{
68 Gilda Poli Rocha Loures foi Secretária de Estado da Educação em dois momentos, de 16/03/1983 a 13/03/1987 no governo de José Richa e José Elísio Ferraz de Campos e de 11/01/1989 a 15/08/1991 no governo de Álvaro Fernandes Dias (Anexo 1).

${ }^{69}$ A Secretaria de Estado da Educação do Paraná é representada em diversas cidades do Estado pelos Núcleos Regionais de Educação (NREs). Ao todo são 32 NREs que têm a função de orientar, acompanhar e avaliar o funcionamento da Educação Básica e suas Modalidades. Disponível em: http://www.comunidade.diaadia.pr.gov.br/modules/conteudo/conteudo.php?conteudo=112 Acesso em 23/03/2018.
} 
discussões e reflexões entre os educadores do estado, com relação aos aspectos teórico-metodológicos de cada área do conhecimento. A concepção, os conteúdos, o encaminhamento metodológico e a avaliação de cada disciplina foram discutidas e aprofundadas por meio de muitos assessoramentos, cursos e estudos, sendo a fundamentação teórica do documento, declaradamente, a pedagogia histórico-crítica. (PARANÁ, 1992, p. 13).

Em 1988, o Ciclo Básico de Alfabetização foi implantado no Paraná num número significativo de escolas paranaenses, sendo o ponto de partida para a reestruturação do currículo. O Ciclo Básico de Alfabetização permitia que o processo de aprendizagem não fosse sistematicamente interrompido para um número maior de alunos excluindo a reprovação da $1^{\text {a }}$ série. No Ciclo Básico de Alfabetização o processo de apropriação da língua escrita é proposto segundo uma nova proposta de alfabetização compreendida "além do simples domínio do sistema gráfico". (PARANÁ, 1992, p. 13).

A proposta oficial do Currículo Básico do Paraná foi preliminarmente reestruturada e publicada em novembro de 1989 e rediscutida na semana pedagógica de 1990 por todos os professores estaduais, sendo que as sugestões desses debates contribuíram na sistematização da redação final da proposta curricular do Paraná realizada pelas equipes de ensino.

O Currículo Básico para a Escola Pública do Paraná, expressa o grau de consciência político-pedagógico atingida pelos educadores paranaenses. As preocupações com a democratização da educação, tanto no que se refere ao atendimento a todas as crianças em idade escolar, quanto à produção de um ensino de boa qualidade, explicitam-se nesta sistematização. (PARANÁ, 1992, p. 14).

O documento faz uma fundamentação geral e uma específica de cada área do conhecimento apresentando além da teoria que fundamenta cada componente curricular, os embasamentos pedagógicos, o encaminhamento metodológico, a relação de conteúdos e a avaliação. No documento são publicados textos de renomados teóricos brasileiros e paranaenses como Jussara Maria T. Puglielli Santos e Odilon Carlos Nunes que escrevem sobre o "Ensino de $1^{\circ} \mathrm{Grau}$ ", Elvira Cristina de Souza Lima que publica "Algumas questões sobre o desenvolvimento do ser humano e a aquisição de conhecimentos na escola", Ana Maria Bento, Beatriz Müller, Maria do Rocio V. Torres, Sônia de F. Schwantes que escrevem sobre "Pré-Escola", Lígia Regina Klein e Rosiclér Schafaschek sobre "Alfabetização”, Elisisane Vitória Tiopolo, 
Marcia Flamia Porto, Reny M. Gregolin Guindaste e Sônia Monciaro Virmont sobre "Língua Portuguesa", Carlos Roberto Vianna, Maria Tereza Carneiro Soares, Regina Luzia Cório de Buriasco e Regina Maria Michelotto sobre "Matemática", Judite Marai Barbosa Trindade e Maria Auxiliadora M. Santos Schmidt sobre "História", Hatsue Misima Jecohti e Roberto Filizola sobre "Geografia", Carlos Petronzelli e Sidinei Tarcizo Pinheiro sobre "Ciências", Carlos Alberto de Paula, Consuelo Alcioni Borba Duarte Schlichta, Elmarina Samways e Rose Meri Trojan sobre "Educação Artística", Valda M. Tolkmitt sobre "Educação Física", Beatriz Maria Moro Zétola Bez e Lúcia Cherem sobre "Língua Estrangeira Moderna", Maria do Carmo Marcondes e Brandão Rolim sobre "Organização Social e Política Brasileira (OSPB)". E por fim, praticamente em um Currículo anexo e a parte ao final do Currículo Básico do Paraná consta a disciplina de "Ensino Religioso" que foi construída em parceria entre a Secretaria de Estado da Educação e a Associação Interconfessional de Educação de Curitiba ASSINTEC ${ }^{70}$.

Todos esses artigos indicam como deveria ser o trabalho efetivo em sala de aula com as diferentes disciplinas do Currículo do Ensino Fundamental, e de acordo com as entrevistas com as professoras da Educação Hospitalar, muitas vezes elas baseavam os seus planejamentos de aula nos documentos emitidos pela Secretaria de Educação.

\begin{abstract}
Baseada nos planejamentos da própria Secretaria de Educação que separava os conteúdos para cada série. Então eu seguia um roteiro como se fosse em uma escola, como se fosse em uma sala de aula. Eu sabia que aquela criança, se estivesse em sala de aula, estaria estudando alguns conteúdos pertinentes ao nível, a série e ao bimestre na qual estava. (PROFESSORA 1, 2016) ${ }^{71}$.
\end{abstract}

Apesar das formações sobre a implantação do Currículo Básico terem sido ofertadas para os profissionais que se encontravam em efetivo exercício nas unidades escolares e as professoras da Educação Hospitalar não se sentirem incluídas por argumentarem que "[...] toda aquela parte pedagógica que estava sendo trabalhado no município, a parte de atualizações pedagógicas a gente não tinha, porque a gente

\footnotetext{
${ }^{70}$ A Associação Interconfessional de Educação de Curitiba (ASSINTEC) foi constituída em 20 de junho de 1973 e era uma entidade formada por representantes de diferentes confissões religiosas (católicas, metodista, presbiteriana, luterana, evangélica reformada) e aberta às demais que dela quisessem participar. Tinha o objetivo de implantar e implementar a Educação Religiosa nas Escolas Públicas do Estado do Paraná. (PARANÁ, 1992, p. 227).

71 Entrevista concedida pela PROFESSORA 1. Entrevista I. [ago. 2016]. Entrevistador: Claudinéia Maria Vischi Avanzini. Curitiba, 2016. 1 arquivo.mp3 (60min.). A entrevista na íntegra encontra-se transcrita nos Apêndices $\mathrm{C}$ e $\mathrm{H}$ desta tese.
} 
não participava de curso"72, percebo que mesmo assim elas desenvolviam o trabalho pedagógico na unidade hospitalar com os estudantes e esse trabalho acabava refletindo exatamente o que era apregoado no documento do Currículo Básico, principalmente com relação ao foco do trabalho com conteúdo escolares baseados nos conhecimentos científicos.

Para esta compreensão pedagógica cabe à escola dosar e sequenciar 0 saber sistematizado, o conhecimento científico, tendo em vista o processo de sua transmissão-assimilação. A tarefa que se impõe é organizar o saber escolar, ou seja, tomar como elemento norteador das atividades da escola a socialização do conhecimento sistematizado. (SANTOS; NUNES, 1992, p. 16).

Assim como na metodologia de trabalho desenvolvida dentro do hospital que segundo as professoras e aluno entrevistados considerava a individualidade de cada estudante e suas necessidades: "As atividades eram escolhidas e selecionadas por mim [...]. Eu levava os livros para as enfermarias, mostrava figuras nos livros, as ilustrações, dava as explicações e as crianças desenvolviam atividades"73.

\begin{abstract}
Ela tinha uma didática pedagógica bacana, [...] vendo que estava tudo bem, [...] ela vinha com o conteúdo, cada dia de diálise, cada sessão nós trabalhávamos uma coisa. Numa sessão da segunda-feira nós vamos trabalhar Ciências, na sessão da quarta a gente pega Matemática, na sessão da sexta-feira vamos ver Geografia, ah, mas se você tem prova de Geografia na outra segunda, então nas três sessões de diálise vamos trabalhar só Geografia, [...]. Então o conteúdo era trabalhado, mais ou menos dessa forma. [...] Eu acho que a dinâmica, o ensino principalmente da Ciência era muito lúdico, falava de algumas coisas que não tinha nada a ver com a Ciência, mas que ao mesmo tempo trabalhava Ciência. [...] Ela conseguia fazer com que a gente não ficasse preocupado com as intercorrências e prendia a minha atenção naquele conteúdo que estava sendo explicado, a Matemática mesmo era trabalhado com questões de remédios [...]. Então, o trabalho lúdico dela e trazendo para a minha realidade daquele momento foi algo que me marcou. (Informação verbal Ex-Aluno 1) ${ }^{74}$.
\end{abstract}

Isso demonstra que o trabalho pedagógico com estudantes hospitalizados, como também estava sendo apregoado por Lima no documento do Currículo Básico do Paraná considerava que o ser humano se caracteriza como uma espécie social pela construção de sua individualidade por meio da relação com outro. "O sujeito se

72 Entrevista concedida pela PROFESSORA 2. Entrevista I. [ago. 2017]. Entrevistador: Claudinéia Maria Vischi Avanzini. Curitiba, 2016. 1 arquivo.mp3 (1h35min.41seg.). A entrevista na íntegra encontra-se transcrita nos Apêndices C e I desta tese.

73 Entrevista concedida pela PROFESSORA 1. Entrevista I. [ago. 2016]. Entrevistador: Claudinéia Maria Vischi Avanzini. Curitiba, 2016. 1 arquivo.mp3 (60min.). A entrevista na íntegra encontra-se transcrita nos Apêndices $\mathrm{C}$ e $\mathrm{H}$ desta tese.

${ }^{74}$ Entrevista concedida pelo EX ALUNO. Entrevista I. [abril. 2018]. Entrevistador: Claudinéia Maria Vischi Avanzini. Curitiba, 2018. 1 arquivo.mp3 (41min.27seg.). A entrevista na íntegra encontra-se transcrita nos Apêndices D e K desta tese. 
constitui, assim, em virtude de processos múltiplos de interação com o meio sociocultural, pela presença de outros indivíduos e/ou objetivo culturalmente inserido e definidos" (1992, p. 19). E a relação do estudante com o adulto, na escola ou no universo educacional, é mediada pelo conhecimento formal. Assim, é possível "dizer que a ação do professor é uma ação específica e apresenta, portanto, características que a distinguem da ação dos outros adultos com quem a criança convive". Esta relação não pode ser reduzida a uma atitude autoritária de quem detém o conhecimento e o transmite. Deve ser, antes, atitude criativa de quem detém o conhecimento formal e possibilita a formulação deste conhecimento pelo aluno. (LIMA, 1992, p. 22).

Ainda com relação a fundamentação legal que insere a Educação Hospitalar na Educação brasileira e paranaense, o art. $2^{\circ}$ da LDBEN - Lei n. ํ 9394/96 - Lei de Diretrizes e Bases da Educação Nacional, convalida que a educação é direito de todos e dever do Estado e da família. No título II, Artigo 3ํ, inciso I, a lei destaca a garantia do acesso e permanência na escola, retomando a ideia de educação para todos, igualdade de condições de cidadãos e seus direitos, já previsto na Constituição Federal de 1988, que em seu no parágrafo 5ํ do Artigo 5oo obriga o Poder Público a criar formas alternativas de acesso aos diferentes níveis de ensino e no Artigo 23 evidencia que a Educação Básica pode ser organizada de diversas formas para garantir a aprendizagem dos estudantes. Desta forma, crianças e adolescentes considerados sujeitos de direito, precisam ter suas necessidades e interesses educacionais atendidos até mesmo quando estão com a saúde comprometida e não conseguem acompanhar as aulas na escola regular.

Em 2001, o Conselho Nacional de Educação (CNE) aprova a Resolução no 02/2001 que institui as Diretrizes Nacionais para a Educação Especial na Educação Básica, que orienta, dentre outras questões, a organização do atendimento educacional especializado a alunos impossibilitados de estar em sala de aula, por conta de tratamento de saúde que implique em internação hospitalar, atendimento ambulatorial ou permanência prolongada em domicílio. O artigo 13 dispõe sobre a necessidade de oferta de classes hospitalares e o atendimento em ambiente domiciliar para dar continuidade ao processo de desenvolvimento e de aprendizagem dos alunos matriculados na Educação Básica, contribuindo para o seu retorno e reintegração ao universo escolar. Além disto, o documento aponta que o professor que atende o aluno deve elaborar um relatório com a certificação de frequência dos alunos atendidos pela 
educação hospitalar, isso indica a preocupação e o respeito pela situação de adoecimento e hospitalização da criança adjacente ao seu direito de receber educação.

O Ministério da Educação (MEC) publica em 2002 o documento orientador "Classe Hospitalar e Atendimento Pedagógico Domiciliar: estratégias e orientações". A justificativa para a elaboração desse documento é a necessidade de estruturação de "ações políticas de organização do sistema de atendimento educacional em ambientes e instituições outros que não a escola" e a orientação da promoção de "oferta do atendimento pedagógico em ambientes hospitalares e domiciliares" (BRASIL, 2002, p. 7).

Os princípios e fundamentos do documento evidenciam que durante o período de tratamento de saúde ou psicossocial e na impossibilidade da continuidade na frequência à escola, todos precisam "de formas alternativas de organização e oferta de ensino de modo a cumprir com os direitos à educação e à saúde" (BRASIL, 2002, p. 11). A terceira parte do documento apresenta os objetivos das Classes hospitalares e do atendimento pedagógico domiciliar:

[...] elaborar estratégias e orientações para possibilitar o acompanhamento pedagógico-educacional do processo de desenvolvimento e construção do conhecimento de crianças, jovens e adultos matriculados ou não nos sistemas de ensino regular, no âmbito da educação básica e que encontramse impossibilitado de frequentar a escola, temporária ou permanente e, garantir a manutenção do vínculo com as escolas por meio de um currículo flexibilizado e/ou adaptado, favorecendo o seu ingresso, retorno ou adequada integração ao seu grupo escolar correspondente, como parte do direito de atenção integral. (BRASIL, 2002, p. 13).

Em 2003 o Conselho Estadual de Educação do Paraná fixa normas para a Educação Especial para o Sistema de Ensino do Estado aprovando a Deliberação no 02/03 que em seu Artigo 14, Inciso III, classifica as Classes Hospitalares e o atendimento pedagógico domiciliar como alguns dos serviços especializados que deverão ser assegurados pelo Estado, por meio de parcerias ou convênios com as áreas de educação, saúde, assistência social, entre outros. (PARANÁ, 2003).

Após 4 anos, em 2007 foi institucionalizado no Paraná o Serviço de Atendimento à Rede de Escolarização Hospitalar - SAREH ${ }^{75}$, mediante Resolução

${ }^{75} \mathrm{O}$ Serviço de Atendimento à Rede de Escolarização Hospitalar (SAREH) objetiva o atendimento educacional aos estudantes que se encontram impossibilitados de frequentar a escola, em virtude de situação de internamento hospitalar ou tratamento de saúde, permitindo-lhes a continuidade do processo de escolarização, a inserção ou a reinserção em seu ambiente escolar. Disponível em 
Secretaria de ํㅜ 2527/2007 com o objetivo de oferecer atendimento aos alunos impossibilitados de frequentar as aulas por conta de tratamento de saúde. (PARANÁ, 2007). Assim foram formalizados convênios de parceria entre as Secretaria de Estado da Educação (SEED), da Saúde (SESA) e da Ciência, Tecnologia e Ensino Superior (SETI), para que por meio do SAREH, as unidades conveniadas, uma casa de apoio e dez hospitais espalhados pelo estado, oferecessem atendimento pedagógico que garantissem a continuidade da escolarização formal aos estudantes temporariamente impossibilitados de frequentar a escola regular.

Após a instituição da Resolução Secretarial ํo 2527/2007 o número de hospitais com classes hospitalares no Paraná foi ampliado significativamente, sendo que em 2019, de acordo com o Edital de contratação havia 21 unidades hospitalares ou de tratamento de saúde ofertando Educação Hospitalar no estado. (PARANÁ, 2019a).

Entretanto, dentre as ações que contribuíram para a implantação de um serviço de educação num hospital para crianças em Curitiba no final do século XX destaco toda essa exigência legal que foi se efetivando por conta de muita movimentação social e política na garantia do direito das crianças à educação e saúde que se delineia não somente em âmbito mundial, mas também nacional e estadual e que é destaque deste capítulo.

A Hospitalização Escolarizada é criada e implementada em Curitiba efetivamente em 1988, ano da efetivação do convênio entre o Hospital Pequeno Príncipe e o Estado do Paraná (GAZETA DO POVO, 22/04/1988, p. 40; GAZETA DO POVO, 28/04/1988, p. 02; GAZETA DO POVO, 01/11/1990, p. 56; TRIBUNA DO PARANÁ, 22/04/1988, p. 02; ESTADO DO PARANÁ, 22/04/1988, p. 08; 01/11/1990, p. 07; Revista Vida Universitária, jun./jul., 1988, p.5). Entretanto, essa implementação ocorre muito por conta da movimentação e do interesse educacional da assistente social que trabalhava nesse hospital desde 1974. Segundo depoimento dela, seu trabalho no hospital começou com a supervisão de duas alunas que estavam fazendo um trabalho de conclusão de curso dentro do hospital e precisavam de supervisão ${ }^{76}$, como ela também atuava na universidade, lecionando no curso de Serviço Social, foi

http://www.gestaoescolar.diaadia.pr.gov.br/modules/conteudo/conteudo.php?conteudo=68 Acesso em 27/05/2018.

${ }^{76}$ Entrevista concedida pela ASSISTENTE SOCIAL. Entrevista I. [ago. 2010]. Entrevistador: Claudinéia Maria Vischi Avanzini. Curitiba, 2010. 1 arquivo.mp3 (14min.19seg.). A entrevista na íntegra encontrase transcrita nos Apêndices A e F desta tese. 
contratada para assumir a chefia do Serviço Social do hospital e também auxiliar nesses trabalhos educacionais. Com o tempo de experiência, foi percebendo que as crianças hospitalizadas abandonavam sua escolarização durante o período de internamento e com todo o debate nacional de democratização, abertura política e efetivação de direitos foi se movimentando dentro do próprio hospital e na esfera política para conseguir implementar o serviço de escolarização das crianças hospitalizadas ${ }^{77}$.

O processo de efetivação do atendimentos educacional às crianças doentes curitibanas ocorreu de forma gradativa, mas efetiva, pois em dois anos, em 1990, duas professoras efetivamente realizavam esse atendimento e a educação assumiu um papel muito importante dentro do próprio hospital com ampliação gradual de sua valorização, não somente pelos estudantes, pais, professores, assistente social, como também pela equipe médica e terapêutica que percebe a melhoria do quadro geral das crianças internadas ${ }^{78}$.

\footnotetext{
${ }^{77}$ Entrevista concedida pela ASSISTENTE SOCIAL. Entrevista II. [ago. 2016]. Entrevistador: Claudinéia Maria Vischi Avanzini. Curitiba, 2016. 1 arquivo.mp3 (24min.48seg.). A entrevista na íntegra encontrase transcrita nos Apêndices $B$ e G desta tese.

78 Entrevista concedida pela PROFESSORA 2. Entrevista I. [ago. 2017]. Entrevistador: Claudinéia Maria Vischi Avanzini. Curitiba, 2016. 1 arquivo.mp3 (1h35min.41seg.). A entrevista na íntegra encontra-se transcrita nos Apêndices $\mathrm{C}$ e I desta tese. Maiores informações sobre esse assunto foram trabalhadas no Cap. 4.
} 


\section{CAPÍTULO 3 - SUJEITOS E AÇÕES EFETIVAS DA EDUCAÇÃO HOSPITALAR PARANAENSE}

É do conhecimento de todos, e eu o aceito como coisa natural, que uma pessoa atormentada por dor e mal-estar orgânico deixa de se interessar pelas coisas do mundo externo, na medida em que não dizem respeito a seu sofrimento. Uma observação mais detida nos ensina que ela também retira o interesse libidinal de seus objetos amorosos: enquanto sofre, deixa de amar. (FREUD, 1914, "Sobre o narcisismo - Uma introdução", vol. XIV, pg. 98).

Tratar das experiências dos sujeitos envolvidos no universo da Educação Hospitalar paranaense nos primórdios da implantação do serviço no Paraná, ouvir suas histórias, suas dores e suas vitórias, trouxe à tona informações sobre sofrimentos e mazelas psicológicas sentidas por esses sujeitos, o que justifica a epígrafe do capítulo que traz uma citação de Freud de 1914 sobre seus estudos do narcisismo e onde o autor sugere a normalidade e aceitação com relação ao desinteresse aos "objetos amorosos" pelas pessoas atormentadas pela doença. Essas questões serão melhor exploradas no decorrer deste capítulo, principalmente nos depoimentos tanto da mãe, como do ex-aluno da Educação Hospitalar do Paraná entrevistados para a produção desta tese.

Segundo Burke (2004, p. 17), "imagens, assim como textos e testemunhos orais, constituem-se numa forma importante de evidências históricas. Elas registram atos de testemunho ocular". Neste sentido, este capítulo se constitui basicamente com fontes imagéticas, textuais e resultado de entrevistas obtidas com 5 (cinco) sujeitos envolvidos com a educação hospitalar no estado do Paraná na década de 1990. As imagens, registros pessoais de álbuns de família, foram disponibilizadas por alguns dos entrevistados para serem utilizadas como fontes de informações e registro de um determinado e específico instante do passado, o período que estavam dentro do universo hospitalar com atendimento educacional. "Nunca ficamos passivos diante de uma fotografia: ela incita nossa imaginação, nos faz pensar sobre o passado, a partir do dado de materialidade que persiste na imagem". (MAUAD, 2004, p. 35)

Como é imóvel e estática, representa um tempo presente, um agora diante do qual o pesquisador é levado a reconstruir o que levou aqueles sujeitos a estarem ali, assim, daquele jeito, naquele momento, para poder prever o desenlace, os momentos 
seguintes que podem vir a ser encontrados em outros instantes isolados, em outras fotografias. (LEITE, 2001, p.37). Por meio da sensibilidade, do conhecimento multidisciplinar do momento histórico retratado de forma fracionada e o esforço sucessivo no entendimento aos documentos é que pode ultrapassar o plano iconográfico na tentativa de compreensão do entorno, a decodificação do ausente, descongelando o documento a partir de um anima com o objetivo de "intuir sobre seus significados ocultos", pois o imaterial "pertence ao domínio da imaginação e dos sentimentos". Situando-nos "no nível do iconológico: o iconográfico carregado de sentido", método proposto por Kossoy (1998, 2001, p. 43).

Para interpretar tais representações, as fotografias são exploradas em busca
de formas de comunicação não-verbal, registradas através de gestos, poses,
olhares, expressões faciais, orientações do corpo, posturas, distância e
distribuição espacial entre os indivíduos, organização e disposição dos
objetos. Essas poses são analisadas em suas interações com três recursos
expressivos nelas presentes: as vestimentas (verdadeiros prolongamentos
do corpo), os objetos simbólicos e a ambientação (STANCIK, 2009, p. 447).

Desse modo, após sua inclusão e em contrapartida ao contexto histórico em que foram elaboradas, por meio do enfrentamento entre o total e os detalhes (LEITE, 2001, p.158), entre os vestígios e seu contexto mais amplo, "entre o privado (o retrato de família) e a esfera pública", as fotografias escolhidas serão analisadas por meio de procedimentos com a intenção de torná-las historicamente significativas, não para contar a história de certas famílias (STANCIK, 2009, p. 448), mas para pensar o impacto na Educação e na Educação Hospitalar sobre a vida familiar e demonstração da forma como esses registros demarcaram as questões pedagógicas dentro do hospital no Paraná, na última década do novecentos.

Segundo Leite (2001, p. 23) "tanto o documento escrito quanto as imagens iconográficas ou fotográficas são representações que aguardam um leitor que as decifre", Stancik completa destacando que o historiador é forçado, a sempre que se defrontar com uma fotografia, ou qualquer outro documento, se questionar sobre quem, o que, de que forma, por que, para quem e em que contexto foi produzido o documento/fotografia. "Porque ela não apenas registra um instante com uma imensa aparência de realidade, mas, possibilitando uma interpretação subjetiva, suscita reflexões, e sua leitura é sempre histórica". (STANCIK, 2009, p. 462).

Neste sentido é importante perceber que as fotografias utilizadas neste capítulo da tese foram produzidas num determinado momento e registram somente um pequeno instante do passado e a intenção de determinados sujeitos em registrar 
esses momentos. Segundo Borges (2003, p. 73) é preciso "compreender as vozes dos homens e mulheres de ontem" para que se conheçam os sentidos de "suas produções simbólicas". E para tanto, é oportunizado que alguns sujeitos que vivenciaram essa experiência de Educação Hospitalar nos anos de sua implantação tenham direito a expor suas vozes, imagens e opiniões sobre o assunto e sobre suas vidas.

Entre os documentos escritos utilizados neste capítulo considero importante destacar os jornais, que de acordo com Vieira, quando "entendido como lugar de produção, veiculação e circulação dos discursos - assume uma função importante no processo de formação das representações sobre o mundo" (2007, p.16).

Apresentar as experiências dos sujeitos envolvidos no universo da Educação Hospitalar paranaense apresentando quem são esses sujeitos, dentre estes, descobrir quem eram as primeiras professoras, quais seus vínculos empregatícios e seus olhares com relação à Educação Hospitalar, quem eram os alunos da Educação Hospitalar deste período estudado e quais as experiências que eles relatam com relação à Educação Hospitalar na qual tiveram aula nos período de internamento, quais as ações efetivas que desencadearam a Educação Hospitalar paranaense, de que modo se estabelece as especificidades da Educação Hospitalar curitibana, em que medida 0 projeto de Educação Hospitalar, seus professores, alunos e atendimentos se efetiva neste universo tentando entender como a Assistente Social que implantou o projeto da "Escolarização Hospitalizada" efetivou esse implantação, quais os modelos educacionais direcionados ao atendimento das crianças e dos adolescentes que podem ser observados nos atendimentos educacional no hospital infantil de Curitiba, de que modo se apresentam os progressos no atendimento da Educação Hospitalar em Curitiba, quais as questões político pedagógicas podem ser observadas no atendimento da Educação Hospitalar no município, se existiu um trabalho da equipe multidisciplinar na Educação Hospitalar de Curitiba e como era o trabalho desta equipe multidisciplinar, caso tenha existido, assim como quais as relações e entrelaçamentos entre os diferentes membros desta equipe e por último evidenciar quais materiais educacionais e pedagógicos foram utilizados no hospital de Curitiba na Educação Hospitalar são as questões que norteiam esta parte do trabalho.

Finalmente, o objetivo do capítulo é apresentar os sujeitos e as ações efetivas da Educação Hospitalar paranaense, levando em consideração a efetivação do projeto "Hospitalização Escolarizada" e a implantação da Educação Hospitalar no 
Paraná, seus professores, alunos e atendimentos, a Assistente Social e as mazelas no atendimento hospitalar x escolarização, as primeiras professoras, seus vínculos e seus olhares para a Educação Hospitalar, assim como os alunos e suas experiências na Educação Hospitalar. Essas informações são encontradas em diferentes fontes, como no "Projeto Mirim de Hospitalização Humanizada", notícias de jornais diários, fotografias, publicações diversas, assim como em livros memorialísticos e, principalmente nas fontes orais obtidas por meio de entrevistas com a Assistente social que implantou o serviço no hospital infantil em Curitiba, algumas professoras que realizavam o atendimento no período de sua implantação e posteriormente, um ex-aluno que foi atendido educacionalmente no projeto Educação Hospitalar e a mãe de uma ex-aluna que foi atendido na educação hospitalar no período pesquisado. $O$ recorte temporal deste capítulo vai de 1988, ano da implantação da Educação Hospitalar no Estado do Paraná, a 2002, momento em que o hospital cria um setor de Educação que passa a gerir o que diz respeito às questões de educação, escolarização e cultura dentro dos hospitais geridos pela Associação Hospitalar de Proteção à Infância Dr. Raul Carneiro (CARREIRA, 2016, p. 33).

$O$ capítulo foi dividido em duas partes. A primeira parte trabalha a questão do pioneirismo da Educação Hospitalar num hospital infantil em Curitiba - PR. Na segunda parte foi apresentado o "Projeto Mirim de Hospitalização Escolarizada" e a implantação da Educação Hospitalar no Paraná, detalhando efetivamente sobre os sujeitos e ações efetivas da Educação Hospitalar paranaense com a discussão sobre a Assistência Social e a escolarização no atendimento hospitalar, que se desdobra apresentado os lugares, os espaços e a materialidade da Educação Hospitalar. A segunda parte do capítulo ainda trata da efetivação do projeto de Educação Hospitalar, seus professores, crianças e famílias se subdividindo em outros três itens: As primeiras professoras, vínculos e olhares para a Educação Hospitalar; as crianças, doentes, alunos/alunas da Educação Hospitalar: experiências entrelaçadas; e o olhar da família da criança internada para a Educação Hospitalar. 


\title{
3.1 O PIONEIRISMO DA EDUCAÇÃO HOSPITALAR NUM HOSPITAL INFANTIL EM CURITIBA - PR
}

\begin{abstract}
A historiografia [...] consiste em fazer com que o discurso seja dotado de referencialidade, em levá-lo a funcionar como "expressivo" em autorizá-lo pelo viés do "real" e, enfim, em instituí-lo como suposto saber. Sua lei é ocultar o nada, preencher os vazios. O discurso não deve aparecer separado das coisas, nem deve ser revelada a ausência ou a perda a partir da qual ele se constrói. (CERTEAU, 2011, p. 111).
\end{abstract}

A Educação Hospitalar em Curitiba é apontada como pioneira nos jornais e nos depoimentos dos entrevistados para essa pesquisa, isso suscita a percepção de que esse discurso de pioneirismo corrente entre os envolvidos com a temática foi amplamente difundido, sendo que para a historiografia e segundo a citação de Certeau que inicia o presente subtítulo, o discurso deve ser dotado de referencialidade, retratar a realidade e, portanto, estabelecer um "suposto saber". Desta forma, o entrelaçamento das fontes aparece como essencial por conta de que este discurso precisa estar também presente em fontes diversas e diferenciadas, mesmo que o oculto também seja percebido.

Neste sentido, são encontradas em diferentes fontes as informações que auxiliam na elaboração deste capítulo e, essas fontes diversas integram um saber que referencia uma proposta de educação para as crianças paranaenses distinta da educação formal escolar ${ }^{79}$. Considerando, como destaca Certeau, que as coisas precisam se integrar aos discursos, inicio esse capítulo situando o espaço onde acontece essa educação, o Hospital de Crianças, posteriormente denominado Hospital César Pernetta, situado na Rua Silva Jardim, entre as ruas Desembargador Motta e Brigadeiro Franco, é inaugurado oficialmente em Curitiba no início de 1930 (FACULDADE DE MEDICINA DO PARANÁ, 1929, p. 42; HOSPITAL PEQUENO PRÍNCIPE, 2018; ASSOCIAÇÃO HOSPITALAR DE PROTEÇÃO À INFÂNCIA DR. RAUL CARNEIRO, 1993, p. 4; AVANZINI, 2011, p. 04), com a estreita parceria entre a Cruz Vermelha Paranaense e a Faculdade de Medicina do Paraná, o número de pacientes aumentou, assim como a complexidade dos tratamentos, o que concorreu para que seções/consultórios diferenciadas de atendimento especializado fossem organizadas no Hospital. Em 1951 é o ano da troca do nome do hospital para Hospital

\footnotetext{
${ }^{79}$ A educação formal escolar entendida como aquela em que o estudante adquire num ambiente escolar tradicional.
} 
de Crianças César Pernetta, em 1956 médicos e voluntários fundam a Associação Hospitalar de Proteção à Infância Dr. Raul Carneiro para ajudar na manutenção do Hospital e em 1971 a Associação constrói mais um complexo hospitalar em terreno anexo ao Hospital César Pernetta que recebe o nome de Hospital Pequeno Príncipe ${ }^{80 .}$

A Educação Hospitalar se inicia somente depois de aproximadamente 15 anos, em 1988, quando é firmado um convênio entre a Associação Hospitalar de Proteção à Infância Dr. Raul Carneiro e a Secretaria de Estado da Educação por intermédio do Secretário Belmiro Valverde Jobim Castor ${ }^{81}$ e a Secretaria Municipal de Educação de Curitiba com a liberação de uma professora que iniciaria o atendimento educacional à criança hospitalizada. A informação é amplamente divulgada inclusive com matéria publicada num dos principais jornais paranaenses com o seguinte título de chamada: Criança em hospital não perderá aula82.

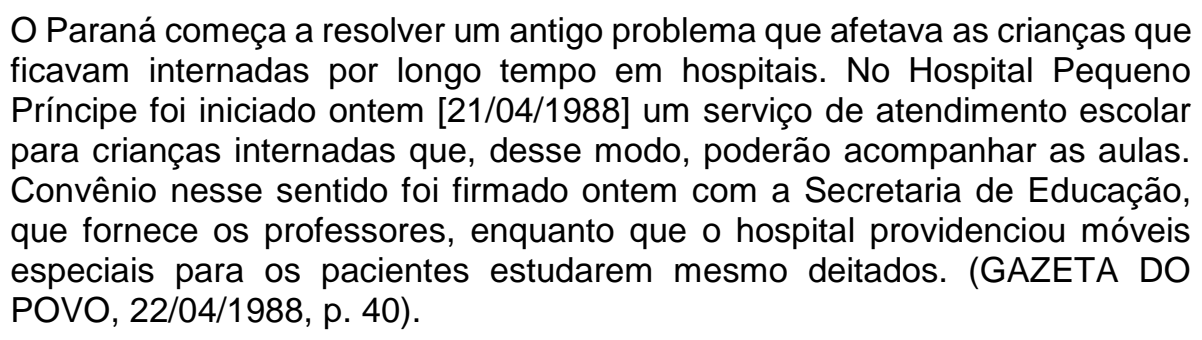

Além desta matéria, na semana seguinte o jornal também publica uma chamada logo abaixo da imagem disponibilizada a seguir, onde destaca a questão de que os estudantes que se encontravam "por prazos relativamente longos em hospitais" em Curitiba deixariam de "perder o ano letivo" por conta de "uma iniciativa inédita e de grande alcance" que seria o convênio entre "a Secretaria de Educação e o Hospital Pequeno Príncipe". A nota, como a matéria anterior, esclarece novamente a contrapartida de cada um dos envolvidos no convênio, a Secretaria liberaria os professores e o hospital, os equipamentos necessários e adequados aos estudantes para que eles realizassem as tarefas da escola.

80 Cf.: http://pequenoprincipe.org.br/hospital/historia/ Acesso em 12/08/2018 (HOSPITAL PEQUENO PRÍNCIPE, 2018; ASSOCIAÇÃO HOSPITALAR DE PROTEÇÃO À INFÂNCIA DR. RAUL CARNEIRO, 1993, p. 4; AVANZINI, 2011, p. 04).

81 Anexo 1; PARANÁ, 2019b; GAZETA DO POVO, 22/04/1988, p. 40.

82 É importante levar em consideração que não se pode perder aula e, portanto, não deveria haver tempo mínimo de hospitalização para que o atendimento educacional hospitalar começasse, como foi publicado no jornal destacando o atendimento para "as crianças que ficavam internadas por longo tempo". 
Figura 6 - Imagem de aula no hospital em Curitiba, PR.

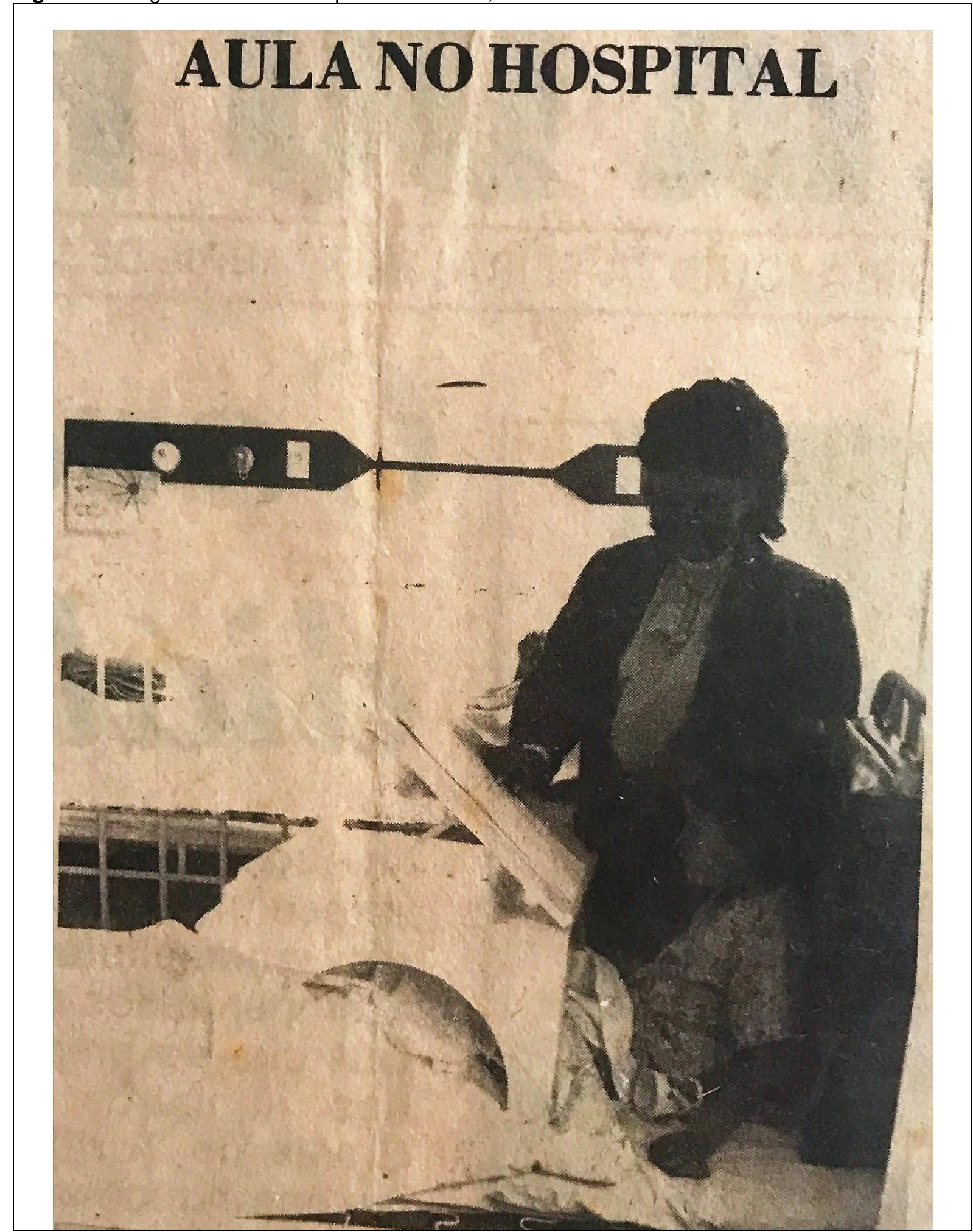

Fonte: (GAZETA DO POVO, 28/04/1988, p. 02).

Essa adequação dos equipamentos pode ser observada na figura 6 que mostra uma criança no leito hospitalar com uma pessoa ao seu lado, muito possivelmente uma professora, que utilizando um equipamento adaptado, provavelmente uma 
carteira $^{83}$, parece apresentar alguma atividade ou leitura para a criança, que olha atentamente para o que lhe está sendo apresentado à sua frente. $\mathrm{Na}$ imagem, ainda é possível observar que ao fundo há outro leito hospitalar, na parede há um cartaz com desenho de sol, logo abaixo de uma faixa escura com tomadas e talvez saída de oxigênio, o que indica que essa imagem foi registrada numa enfermaria ou leito duplo do hospital. A criança vestindo um pijama hospitalar está sentada no leito com o colo e pernas cobertos com lençóis e a mulher da imagem está vestida com uma camisa clara e um blazer de manga longa escuro, tem cabelos curtos e se encontra com as mãos segurando alguma coisa na parte da "carteira" que está com o tampo inclinado em $45^{\circ}$ à frente da criança. Não é possível distinguir o rosto dela e nem da criança na imagem, mas se percebe que ambos olham na direção desse instrumento que a mulher segura e com o título e a publicação na imagem é possível concluir que se trata efetivamente de um exemplo de aula em desenvolvimento dentro do hospital já no mês de abril de 1988.

Entretanto, considero importante destacar que para a efetivação desta implantação da Educação Hospitalar houve toda uma movimentação política e social que aconteceu anteriormente à efetivação do convênio que ocorre no primeiro semestre de 1988. Nesse caso, é interessante observar que antes da notícia anterior ser divulgada, Muggiati apresenta em um livro memorialístico publicado por ela, que

[...] buscando a solução conciliadora e com o devido respaldo do hospital, procurei a Secretaria Estadual de Educação, cujo então secretário, Prof. Belmiro Jobim Valverde Castor ofereceu a melhor acolhida à ideia do enfrentamento desse complexo problema, em termos de discussão e busca de solução. Na sequência, o Senhor Secretário disponibilizou o empréstimo de uma professora, para a experiência, pelo prazo de dois bimestres. (MUGGIATI, 2012, p. 50).

O problema ao qual o próprio secretário se refere e que justifica a implantação da Educação Hospitalar é algo que aparece em diversas fontes pesquisadas (jornais, entrevistas, dissertações, etc.), como por exemplo a entrevista cedida no dia 12 de agosto de 2016 pela Assistente Social que destaca "a incompatibilidade do tratamento e da escola", fala constantemente repetida por ela e bastante destacada como o principal motivo para a implantação do serviço educacional no hospital. Além disto, na dissertação de mestrado de Muggiati (1989, p. 10) que trata do mesmo assunto, há um levantamento de pressupostos teóricos, e dentre estes pressupostos, "o

\footnotetext{
${ }^{83}$ Retomarei a discussão sobre esses equipamentos no capítulo 4.
} 
tratamento, em hospitalização prolongada e a frequência escolar" eram considerados "processos antagônicos" antes da implantação da Educação Hospitalar. Mais adiante na mesma dissertação, a pesquisadora destaca que "esta prática [da Educação Hospitalar] tem por objetivo conciliar os interesses do tratamento e da escola, prevenindo possíveis rupturas, de ambas as partes”. (MUGGIATI, 1989, p. 12). Colaborando com esses posicionamentos, a Professora 1 em entrevista cedida em agosto de 2016 destaca que

[...] no período de atuação como assistente social no hospital [...] [a Assistente Social] percebeu que havia uma lacuna entre o tratamento de saúde das crianças internadas no hospital e a defasagem que esse tratamento gerava em relação à escolarização dessas crianças. Essas crianças ficavam com um vácuo naquele período de tratamento e isso gerava nas famílias e nas próprias crianças uma instabilidade emocional, porque as crianças vinham muitas vezes de outras cidades e largavam o estudo em virtude do tratamento [...], e a [Assistente Social] percebeu que havia a possibilidade de conciliar o tratamento de saúde com a escolarização desde que houvesse a implantação de um projeto. (Informação verbal Professora 1).

Essas informações demonstram que a Assistente Social percebe o valor da escola no hospital e a primeira professora ao ir ao hospital, acabou agindo com Psicóloga ou Assistente Social.

Ainda na dissertação, Muggiati (1989, p. 21 e 22) discute sobre as questões de Direitos das Crianças observadas principalmente na Declaração de Direitos da Criança, da Organização Mundial da Saúde, onde há um destaque a sua proteção especial. Neste sentido, considero importante destacar que há alguns documentos que também tratam desta questão e serão discutidos neste capítulo. Tais documentos procuram assegurar atenção especial ao reconhecimento da criança e adolescente como sujeitos de direito, dentre estes documentos está a Deliberação no 02/03 do Conselho Estadual de Educação do Paraná e a Resolução Secretarial nº 2527/2007 do SAREH no Paraná, etc. ${ }^{84}$.

Ainda segundo Muggiati (1989, p. 22), são considerados direitos inalienáveis que requerem a máxima proteção, "todas as forças facilitadoras do seu bem-estar, o livre acesso à saúde e à educação".

$\mathrm{Na}$ situação de necessidade de hospitalização prolongadas ou de atendimento múltiplos da criança em idade escolar, tais direitos essenciais contraditoriamente se encontram na mais plena desproteção, diante do impasse com que se deparam: ou o tratamento, ou a escola, ou, então,

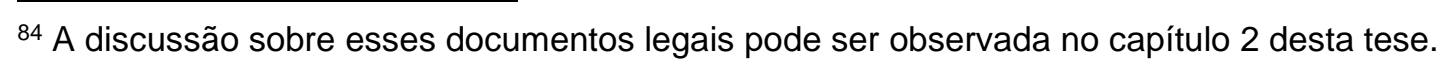


prejuízo a ambos; ou ainda acomodação ou conformismo. (MUGGIATI, 1989, p. 22).

Portanto, se justifica a movimentação pela implantação da Educação no Paraná para que as crianças em atendimento hospitalar tivessem garantido tanto o direito à saúde como o da educação. Além disto, é interessante perceber que essa movimentação ocorre no mesmo período histórico em que a sociedade também se mobiliza pela garantia de direitos a todos os cidadão, pela defesa da constituinte, pela movimentação em defesa da criança e seus direitos com a elaboração e promulgação do Estatuto da Criança e do Adolescente e com a defesa da educação para todos com a aprovação, não somente da Constituição Federal, como também posteriormente da Lei de Diretrizes e Bases da Educação Nacional.

Com toda essa indicação legal, o atendimento educacional hospitalar assume um papel importante na garantia dos direitos das crianças e, levanto a hipótese de que acaba sendo liberado por conta dessas exigências legais. Assim, uma professora é disponibilizada pela Secretaria de Estado da Educação ${ }^{85}$ para realizar o atendimento temporário por praticamente seis meses, ou seja, dois bimestres em 1988. (MUGGIATI, 1988, p. 4; MUGGIATI, 2012, p. 50; PROFESSORA 1, 2016; PACHECO, 2017, p. 154).

Pela análise das publicações nos jornais paranaenses na dissertação, no livro memorialístico da assistente social e nas entrevistas das duas professoras com relação a assinatura do convênio entre a Secretaria de Estado e Municipal da Educação do Paraná e a Associação Hospitalar de Proteção à Infância Dr. Raul Carneiro, é possível perceber que o hospital já realizava um tipo de atendimento educacional para os estudantes que ficavam internados por longo tempo. Segundo Pacheco (2017, p. 34), "os primeiros passos relativos aos atendimentos pedagógicos às crianças em tratamento de saúde" datam de 1987, ano do início das observações da Assistente Social da Associação sobre o assunto que desencadearam na dissertação apresentada por ela em 1989, "onde constam suas considerações sobre os fatos ocorridos neste período".

\footnotetext{
${ }^{85}$ A relação entre o setor público x privado, com a cedência das professoras com vínculo público ligado ora com o governo estadual, ora com o municipal para trabalhar num ambiente hospitalar que, apesar de ser gerido por uma Associação, envolve o setor privado, que acaba recebendo as professoras que efetivam o atendimento hospitalar, não foi amplamente discutida no trabalho, pois este não é o foco desta tese.
} 
As matérias de dois jornais do dia 22/04/1988 evidenciam praticamente as mesmas informações com relação a esse assunto. No jornal Tribuna do Paraná o título da reportagem é "Pequeno Príncipe faz escola" e no jornal O Estado do Paraná é "Hospitais vão dar atendimento para escolares". Nestas matérias está descrito que o secretário de Educação à época, Belmiro Valverde, observou "os primeiros resultados de um trabalho iniciado há um ano pelo Hospital Pequeno Príncipe, de Curitiba com seus pacientes". (TRIBUNA DO PARANÁ, 22/04/1988, p. 02; O ESTADO DO PARANÁ, 22/04/1988, p. 08). Esse trabalho seria a efetivação do Projeto Mirim de Hospitalização Escolarizada planejado pelos médicos e assistentes sociais do hospital, com o intuito de evitar a evasão escolar das crianças que permaneciam por longo tempo no hospital, além de impedir que as crianças ficassem deprimidas ou revoltadas por conta do "excesso de tempo longe dos pais" causado pelos internamentos ${ }^{86}$.

Ainda segundo as reportagens, os recursos utilizados para montar uma sala de aula e as carteiras especiais constituídas eram do próprio hospital. Segundo Ivan Fontoura, diretor clínico do hospital,

[...] a escola é personalizada e funciona nos mesmos moldes das antigas. Duas professoras, auxiliadas pelas assistentes sociais, instruem as crianças de forma a que não passem o dia sem terem pelo menos uma atividade. Para comprovar a seriedade do trabalho, ao final de um período são realizados inclusive testes visando checar se os ensinamentos foram bem assimilados. (O ESTADO DO PARANÁ, 22/04/1988, p. 08).

A assistente social comenta ainda que "os resultados do primeiro ano de funcionamento do Projeto Mirim de Hospitalização Escolarizada são bastante positivos", pois muitos cumprimentos foram recebidos, até mesmo de outros Estados que constataram a "reintegração perfeita" nas turmas de origem de seus estudantes após permanecerem um grande tempo hospitalizados. (O ESTADO DO PARANÁ, 22/04/1988, p. 08).

Entretanto, contradizendo a informação do diretor clínico do hospital publicada nos jornais de que havia duas professoras trabalhando no hospital, Muggiati (1988, p. 4; MUGGIATI, 1989, p. 40; MUGGIATI, 2012, p. 50), explica que nesse período experimental do projeto, somente uma professora auxiliada por seis estagiárias do

86 O Estatuto da Criança e Adolescente aprovado somente em 1990 que garantiu em seu art. 12 que as crianças e adolescentes tivessem o direito da permanência em tempo integral de um dos pais ou responsável nos casos de internação. (Redação dada pela Lei no 13.257, de 2016). Disponível em http://www.planalto.gov.br/ccivil 03/LEIS/L8069.htm Acesso em: 06/04/2019. (BRASIL, 1990). 
curso de magistério atuavam com os estudantes internados na cardiologia, ortopedia, hematologia, oncologia, nefrologia e no atendimento à febre reumática. Apesar da discrepância nas informações publicadas em alguns jornais, o entusiasmo do Secretário de Educação do Estado do Paraná é destacado em várias publicações, assim como o dos estudantes atendidos, "suas famílias e o próprio pessoal do hospital". Isso colabora para que o convênio entre a Secretaria de Estado da Educação e a Associação mantenedora dos hospitais seja firmado e renovado no final de 1988, depois de avaliação qualitativa, além de ser divulgada, pelo Secretário de Educação a ampliação do mesmo serviço em outros hospitais com grande quantidade de crianças internadas. (GAZETA DO POVO, 22/04/1988, p. 40).

Segundo o secretário da Educação, Belmiro Valverde, o sistema deverá ser estendido a outros hospitais onde ocorra grande concentração de crianças, e chegando também ao interior do estado. Muitas das crianças atendidas já estão internadas a seis meses ou mais, e recomeçam agora a estudar depois de já ter perdido as esperanças de acompanhar as aulas, com suas antigas turmas de amigos. (GAZETA DO POVO, 22/04/1988, p. 40).

Após essa euforia inicial, informações sobre o atendimento educacional em hospitais voltam a frequentar as páginas de jornais somente em 1990, ano também da contratação por Regime CLT da professora 1 entrevistada para a produção desta tese.

No final de 1990, duas reportagens e em distintos jornais disseminaram a informação de que a experiência em educação hospitalar havia iniciado efetivamente durante três meses, de agosto a novembro de 1987 em Curitiba, com o atendimento pedagógico mensal beneficiando, desde então, cerca de 30 crianças. Além disto, várias destas crianças hospitalizadas em 1987, "apesar de serem obrigadas a passar por um longo período de hospitalização" não foram prejudicadas em seus estudos, pois conseguiram a aprovação em suas turmas de origem. Essas informações serviram para ampliar o interesse de "outras unidades de saúde e de educação e pesquisa brasileiros" sobre o assunto. (O ESTADO DO PARANÁ, 01/11/1990 p. 7; GAZETA DO POVO, 01/11/90 p. 56; PACHECO, 2017, p. 36).

De acordo com Pacheco (2017, p. 36), uma professora da Secretaria Municipal de Educação de Curitiba - SME é cedida em 1989 para desempenhar suas funções junto a estudantes internados, desenvolvendo "atividades no atendimento pedagógico escolar". Entretanto, no apêndice F de sua pesquisa, Pacheco (2017, p. 154) indica três professoras municipais que desempenharam suas funções no Hospital Pequeno 
Príncipe em 1988 e 1989, muito possivelmente as duas primeiras foram cedidas sem a efetivação do convênio, mas durante o período de negociação da Associação Hospitalar junto à Secretaria Municipal de Educação, assim como aconteceu com a Secretaria de Estado da Educação. É interessante observar no apêndice que a terceira professora cedida trabalhou de 1989 até 1992 no Hospital mantido pela Associação e que depois dela, até 2002 outras quatro professoras assumiram esse trabalho, sendo que uma delas começa a trabalhar em 2002 e permanece até hoje. Além das professoras que trabalham diretamente no Hospital Pequeno Príncipe, durante o período desta pesquisa, há outras três professoras que foram cedidas pela Secretaria Municipal de Educação para trabalhar na Associação Criança Renal que funcionava dentro de um dos Hospitais mantidos pela Associação Hospitalar de Proteção à Infância Dr. Raul Carneiro e onde as crianças realizavam o tratamento de hemodiálise.

O convênio entre a Associação Criança Renal e o município começou em 1996, e consistia na cessão de uma professora para trabalhar dentro do setor de hemodiálise, que ficava no Hospital Pequeno Príncipe, quase 10 anos depois dos convênios do Hospital com as secretarias estadual e municipal, que cediam professora para o atendimento nos outros espaços do hospital e não somente na hemodiálise. A figura 7 retrata o espaço ocupado pela Associação Criança Renal e uma criança estudando enquanto realizava seu tratamento.

O registro fotográfico foi publicado no Jornal $O$ Estado do Paraná em 01/11/1990 e apresenta um estudante de 14 anos chamado Luiz José Padilha Pereira e que no dia anterior "fez uma prova de ciências enquanto realizava uma [sessão de] hemodiálise no Hospital Pequeno Príncipe". Segundo a matéria no jornal, Luiz "está participando do projeto desde 1988, quando começou seu tratamento de hemodiálise no" hospital. Morador da cidade de São Mateus do Sul, que fica a $143 \mathrm{~km}$ da capital do Estado, "vem todas as segundas, quartas e sextas-feiras a Curitiba" para realizar o tratamento, sendo que conseguia frequentar a escola somente nas terças e quintasfeiras. Segundo Vânia Regina Prado, a professora que o acompanhava no hospital, apesar disso, o estudante tinha "um bom aproveitamento pedagógico". (O ESTADO DO PARANÁ, 01/11/1990, p. 07). 
Figura 7 - Imagem de criança em hemodiálise e com aula no hospital em Curitiba, PR.

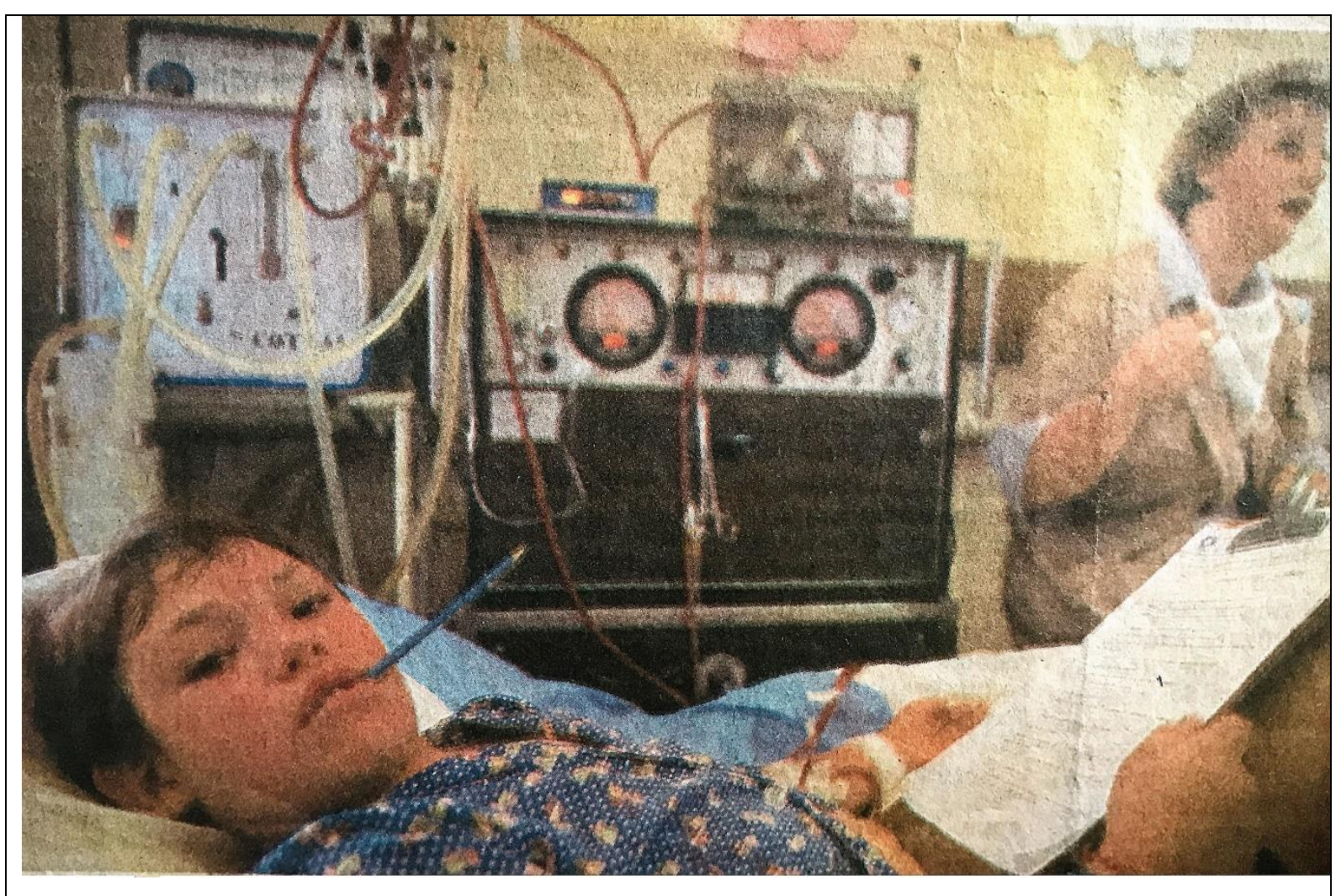

Fonte: (O ESTADO DO PARANÁ, 01/11/1990, p. 07).

Na imagem é possível ver que Luiz está com um lápis azul no canto esquerdo da boca, estava deitado com um olhar fixo no fotógrafo que registrava a imagem, apesar de não estar posando para o registro da fotografia, vestia uma camisa do pijama fechada somente com dois botões e entreaberta na barriga que se cobria parcialmente com a prancheta que ele segurava com a mão direita. Na prancheta havia uma folha de atividade, que possivelmente poderia ser a prova de ciências descrita na reportagem. Seu braço direito estava prostrado imóvel ao seu lado por estar pulsionado e ligado à máquina da hemodiálise com as linhas de sangue preenchidas. Ao fundo havia a máquina de hemodiálise em funcionamento e outros aparelhos que pareciam ligados à máquina. Ao lado da máquina de hemodiálise havia uma mulher sentada, com a boca semiaberta e olhando atentamente para outra direção, como se estivesse conversando com alguém que não aparece no registro da imagem. Essa mulher poderia ser uma enfermeira ou a própria professora, parecia explicar algo, pois a mão estava levantada como se estivesse gesticulando. Está vestida com uma camisa branca por baixo de algo que parecia ser um jaleco bege de mangas $3 / 4$. 
Figura 8 - Imagem de criança em hemodiálise e com aula no hospital em Curitiba, PR.

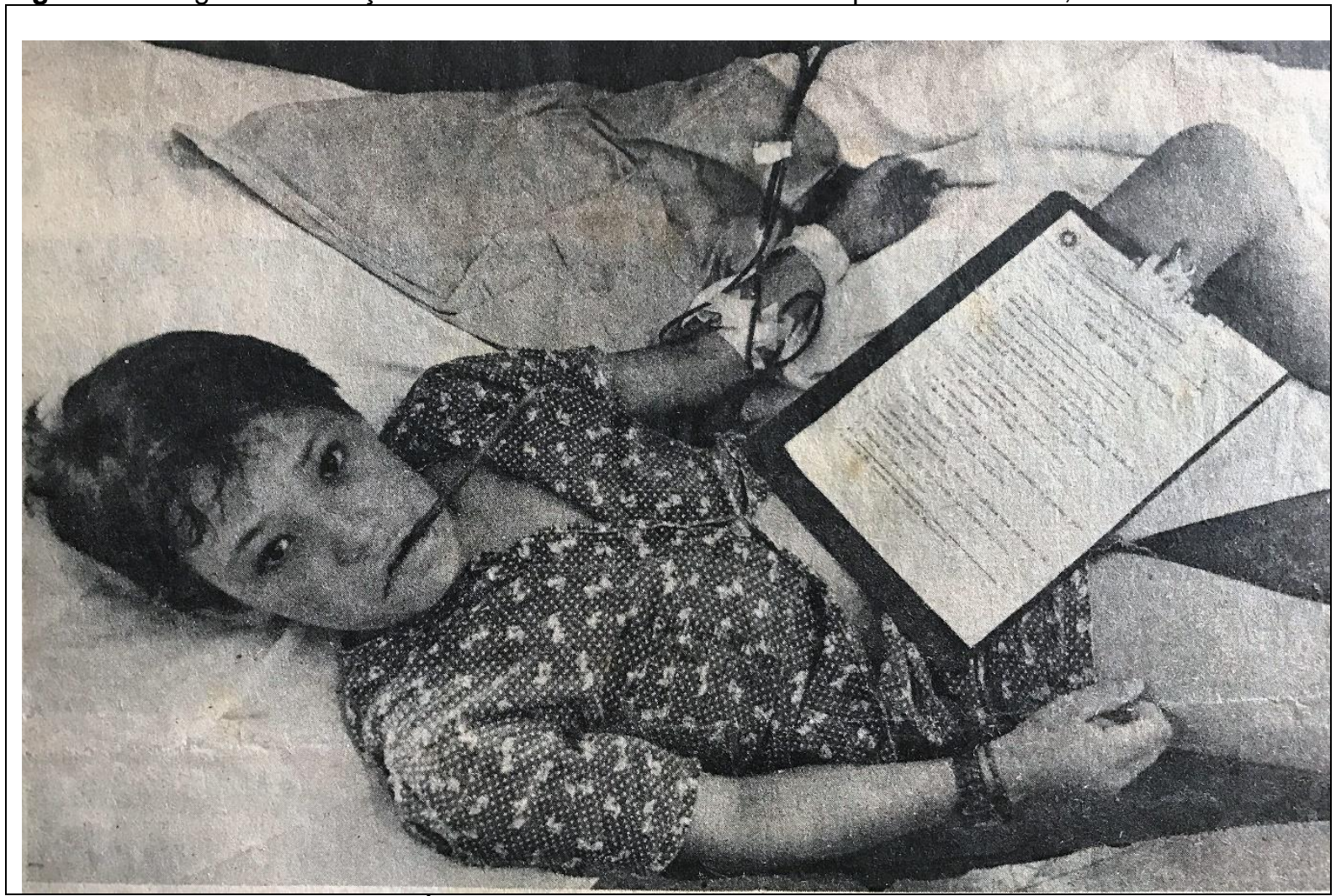

Fonte: (O ESTADO DO PARANÁ, 01/11/1990, p. 07).

Na publicação há um outro registro fotográfico em branco e preto de um outro ângulo, que pode auxiliar a análise da imagem colorida. Neste registro disposto na figura 8 é possível distinguir que Luiz tinha, possivelmente um relógio e uma pequena pulseira no braço direito e a folha timbrada presa à prancheta em seu colo estava completamente preenchida com as atividades.

Segundo a publicação no jornal, naquele período havia "15 crianças em idade escolar, internadas no Hospital Pequeno Príncipe, em Curitiba" e, estas, estariam "desenvolvendo normalmente seus estudos graças ao Projeto de Hospitalização Escolarizada". De acordo com a Assistente Social responsável pela escolarização no hospital, "uma equipe interdisciplinar, formada por assistentes sociais, psicólogos e pedagogos acompanham o desenvolvimento do projeto", que era considerado pelos pais e escolas como uma iniciativa "excelente". (O ESTADO DO PARANÁ, 01/11/1990, p. 07).

As aulas eram ministradas individualmente para as crianças por "duas professoras, uma da rede estadual e outra da rede municipal", elas consideravam o programa curricular da escola de origem de cada criança, para isso entravam "em contato com a família e com a escola para se inteirar do programa pedagógico". Além 
disto, elas aplicavam também as provas, que tinham "validade para efeito de notas e boletins das escolas". O projeto era implantado automaticamente para as crianças oriundas da rede pública de ensino, entretanto, era opcional para os estudantes das instituições particulares. (O ESTADO DO PARANÁ, 01/11/1990 p. 7; PRADO, 1990c, p. 1).

Com relação a contratação da professora, a Secretaria de Estado da Educação do Paraná, por meio do Grupo de Recursos Humanos Setorial - GRHS celebrou em 19 de fevereiro de 1990 um contrato de trabalho de Professores de $5^{\mathbf{a}}$ a $8^{\mathrm{a}}$ séries com a professora que, segundo a cláusula 1a , ministraria aulas semanais no Projeto Hospitalar Pequeno Príncipe. Sua remuneração fixada na cláusula $3^{\underline{a}}$ seria em hora/aula, ela receberia em função do número de aulas semanais trabalhadas e seu pagamento seria efetuado mensalmente. O tempo de validade do contrato, que inicialmente, na cláusula $5^{\text {a }}$, é de experiência, portanto 90 dias, é prorrogado por tempo indeterminado na cláusula $6^{\underline{a}}$ por conta de o contrato não ser rescindido. $A$ professora fica contratada em Regime CLT até março de 1995, quando foi efetivada por realizar um concurso público. (PARANÁ, 1990; ASSOCIAÇÃO HOSPITALAR DE PROTEÇÃO À INFÂNCIA DR. RAUL CARNEIRO, 1995). Em junho de 1995, a chefe do GRHS/SEED encaminha o ofício no $341 / 95$ para a Associação Hospitalar de Proteção à Infância Dr. Raul Carneiro informando que as 16 aulas extraordinárias da professora cedida pela SEED seriam canceladas a partir de 10/06/95, porque a professora passou "a ocupar um cargo de 20 (vinte) horas semanais do Quadro Próprio do Magistério". De acordo com o Art. 16 do Decreto n 3.007/94, é proibido "a atribuição de aulas extraordinárias aos professores colocados à disposição de entidades" conveniadas à SEED. (PARANÁ, 1995c).

Em oito de novembro de 1990, a professora que estava em exercício na Associação Hospitalar pela Secretaria de Estado da Educação fez um requerimento solicitando a implantação do adicional de insalubridade retroativamente, pois o pedido inicial dela ocorreu em maio e a autorização da secretaria aconteceu em agosto. (ASSOCIAÇÃO HOSPITALAR DE PROTEÇÃO À INFÂNCIA DR. RAUL CARNEIRO, 1990). Não há informações de quando esse pedido foi atendido, entretanto é possível deduzir que esse adicional foi implantado, pois, quase 5 anos depois, em 29 de maio de 1995 ela encaminha nova solicitação para Ramiro Wahrhaftig, Secretário de Estado da Educação da época (PARANÁ, 2019b), pedindo a reimplantação do adicional de insalubridade por conta de sua efetivação em março e, portanto, alteração 
do regime de trabalho. Neste documento, a professora informa que as condições e o local de trabalho não se alteraram e que o convênio entre a Secretaria de Estado e a Associação Hospitalar é renovado anualmente. Reiterando esse pedido, a professora anexa na última página do Protocolo Integrado de Documentos nº 2.467.379-0, aberto no dia 18 de março de 1996, que trata da prestação de serviços da professora na Associação Hospitalar, uma nova solicitação de reavaliação do processo para a reimplantação do adicional de insalubridade que, segundo seu documento, a resolução publicada sobre o assunto "não foi suficientemente satisfatória". (PARANÁ, 1996b).

A resposta positiva para a reimplantação da gratificação de insalubridade para a professora do estado foi publicado somente com o Parecer no 3325, de 16/12/1996, divulgado na Informação nº 053/97 - AJ87/SEED de 19 de fevereiro de 1997, disponível nas páginas 29 e 30 do Protocolado Integrado n² 2.321.204-8 que define o valor máximo em "40\% (quarenta por cento) do inicial do Quadro Geral do Estado, conforme Art. 10 da Lei n ${ }^{\circ} 10.692 / 93 "$, a informação ainda utiliza os artigos $3^{\circ}$ e $13^{\circ}$ da referida lei e os artigos $7^{\circ}$ e 70 da Constituição Federal para fundamentar. A última parte da solicitação indica que a partir de março de 1995 até novembro de 1996 foi o período em que a professora ficou sem receber a gratificação, por conta da alteração do Regime de trabalho e que a Divisão de Medicina e Saúde Ocupacional/SEAD ${ }^{88}$, por meio da Informação $n$ ํ 032/96 esclareceu que nada mudou com relação às condições de trabalho da professora no hospital. (PARANÁ, 1995b; PARANÁ, 1997, p. 30).

Com relação aos convênios, foi possível encontrar o inicial, assinado em 19 de abril de 1989, pela professora Gilda Poli Rocha Loures, representando a Secretaria de Estado da Educação do Paraná e por Ety Gonçalves Forte, presidente da Associação Hospitalar De Proteção à Infância Dr. Raul Carneiro, e o Termo de Colaboração Técnica de renovação do convênio assinado em 26 de abril de 1995 e que consta no Protocolo Integrado SEED no 2.135.689-1 aberto em 07/02/1995 (PARANÁ, 1995a). Além destes dois Termos, foram encontrados o Protocolo Integrado SEED no 1.832.867-4 de 11/03/1994 que trata da renovação do convênio, apesar de não constar o convênio dentro desse protocolo e o Protocolo Integrado SEED no 2.467.379-0 de 18/03/1996 que tem como assunto a permanência da

\footnotetext{
87 Assessoria Jurídica.

88 Secretaria de Estado de Administração.
} 
prestação de serviços da professora que está designada desde 1990 para prestar serviços na Associação Hospitalar.

O Termo de Convênio de 1989 é composto de sete cláusulas, sendo que o objetivo do convênio, descrito na primeira, seria a promoção de "assistência escolar às crianças internadas nos Hospitais Pequeno Príncipe e Cezar Perneta oferecendo atendimento individualizado" e contato com a escola de origem da criança. Para tanto, seriam liberadas duas professoras (cláusula $2^{\underline{a}}$ ), a terceira e quarta cláusulas indicam que as professoras trabalharam junto ao Serviço Social e Psicologia do hospital e apresentaram relatório anual para a SEED, que por meio do Núcleo Regional de Educação realizaram fiscalizações para garantir o efetivo cumprimento do convênio, este, na quinta cláusula poderia ser rescindido com retirada dos professores cedidos caso a Associação não providenciasse a renovação do convênio antes de sessenta dias antes do término de vigência do Termo. A vigência do Termo de Convênio era até o dia 31 de dezembro de 1989, "podendo ser prorrogado e modificado, com inclusão e exclusão de cláusulas, mediante Termo Aditivo em comum acordo entre as partes". Por fim, o Termo se encerra, na cláusula sétima, indicando que casos omissos seriam resolvidos em acordo entre as partes, sendo o foro de Curitiba o responsável em resolver qualquer conflito. (PARANÁ, 1989).

Em 11 de março de 1994 a Associação Hospitalar de Proteção à Infância Dr. Raul Carneiro abriu o Protocolo Integrado no 1.832.867-4, que solicita à Secretaria de Estado da Educação do Paraná a renovação do Termo de Cooperação Técnica, protocolado sob o no 1.343.198-2/1993 para o ano de 1994 e aproveita para solicitar que as professora e psicóloga que estão cedidas continuem os trabalhos que, segundo a solicitação "tem sido de grande importância para a melhoria da qualidade de assistência prestada" na instituição. Os estudantes atendidos se encontravam internados, em ambulatório, com hidrocefalia, ambulatório de paralisia cerebral e mielomeningocele. (PARANÁ, 1994, p. 02). O protocolo traz ainda uma relação com o nome completo de 24 crianças internadas em atendimento com a professora em 1993. (PARANÁ, 1994, p. 04). Finalmente, a última página do protocolo é a cópia da Portaria n 304/94 de designação da professora para continuar prestando serviços na Associação Hospitalar de Proteção à Infância Dr. Raul Carneiro. A referida portaria foi assinada por Daesy Maria Nogueira Bientinez, Chefe do Grupo de Recursos Humanos Setorial da Secretaria de Estado da Educação (GRHS/SEED) em 1994. 
Em fevereiro de 1995 foi aberto novo protocolo № 2.135.689-1 solicitando à Secretaria de Estado da Educação do Paraná a renovação do Termo de Cooperação Técnica nos mesmos termos do protocolo do ano anterior, a solicitação inicial faz referência ao nome das profissionais que estão liberadas para trabalhar no hospital, a importância do trabalho e quais as clínicas ou ambulatórios dos pacientes atendidos, que são exatamente os mesmos citados no ano anterior. A grande diferença neste protocolo é que não é apresentada a relação de crianças atendidas, nem a portaria de liberação da professora, entretanto, das páginas 03 a 06, é anexado o Termo de Cooperação Técnica celebrado entre o Governo do Estado e a Associação Hospitalar de Proteção à Infância Dr. Raul Carneiro. Esse termo é bem mais abrangente que o primeiro, apresentando dez cláusulas.

Segundo o Termo de Cooperação de 1995, o objetivo que justifica a colaboração entre os dois órgãos para a efetivação do Projeto Mirim de "Hospitalização Escolarizada" deixa de ser somente as intenções de ambos os órgãos de oferecer assistência escolar com atendimento individualizado e entrosamento com a escola de origem e passa a ser principalmente uma obrigação legal disposta no "Título VIII - Capítulo III - Seção I - da Constituição Federal e no Título VI - Capítulo II - Seção I - da Constituição Estadual", que tratam da temática da educação.

As cláusulas segunda e quarta delimitam o atendimento para as "crianças em idade escolar própria para o Ensino Fundamental", no caso matriculadas de $1^{\text {a }}$ a $4^{\text {a }}$ série e que se encontravam "internadas, por motivos de saúde nos Hospitais pertencentes à Associação". (PARANÁ, 1995a, p. 03). A cada grupo de 30 crianças seria designado pela SEED um professor para garantir o atendimento delas, sendo que o parágrafo único da cláusula quarta determina que a SEED designará em 1995 dois servidores por conta da relação, anteriormente encaminhada pela Associação. (PARANÁ, 1995a, p. 04).

As competências da Secretaria de Estado da Educação e da Associação Hospitalar são descritas na cláusula terceira, sendo que a SEED ficou somente com a responsabilidade de designar servidor(es) habilitado(s), de seu quadro funcional para atender as crianças descritas na cláusula anterior, enquanto a Associação Hospitalar era responsável em "ceder dependências devidamente instaladas [...] arcar com o pagamento das despesas de consumo de água, luz e de limpeza" e não cobrar qualquer "taxa, contribuição ou mensalidade" pelos serviços prestados aos estudantes atendidos. Além disto, o parágrafo único desta cláusula indica que a SEED não 
assumiria nenhuma outra despesa que não fosse o pagamento e os encargos sociais dos servidores por ela designados e a Associação Hospitalar não assumiria nenhum vínculo empregatício desses servidores com exercício nas dependências do Hospital. (PARANÁ, 1995a, p. 04).

As informações sobre o controle da frequência dos designados ficavam sobre a responsabilidade da Associação que tinha um prazo mensal para informar a SEED, o desligamento, substituição e revisão do número de servidor designados ficavam a cargo da SEED, a rescisão do contrato por qualquer uma das partes, o prazo de vigência até 31 de dezembro de 1995 e a data de solicitação de prorrogação do Termo de Cooperação pela Associação em 30 de setembro com o pronunciamento da SEED até o dia 31 de outubro de 1995 estavam dispostos nas cláusulas quinta até a nona. Caso a SEED não se manifestasse favoravelmente à prorrogação do Termo de Cooperação até o dia 31 de outubro de 1995, significaria que não haveria interesse na prorrogação da "Cooperação Técnica ou efetivação de novo Convênio de Cooperação Técnica”. (PARANÁ, 1995a, p. 06).

O foro da Comarca de Curitiba foi o escolhido para dirimir as controvérsias que pudessem surgir do Termo de Cooperação Técnica que foi assinada em três vias no dia 26 de abril de 1995 pela Secretaria de Estado da Educação em exercício, Miriam de Fátima Zaninelle Wellner e Ety Forte, presidente da Associação Hospitalar. O presente Termo de Cooperação Técnica foi publicado no Diário Oficial do Estado sob no 4.520 em 31/05/1995. (PARANÁ, 1995d).

Após esse período não foi possível encontrar nenhuma outra renovação do convênio, mas segundo relatos nos jornais, dissertações, livro memorialístico e entrevistas das professoras, assistente social, mães e estudantes atendidos, esse atendimento continua até 2002, mas foi interrompido por conta do desinteresse da SEED em renovar o Termo de Cooperação na gestão do Governador Jaime Lerner do PSDB. De acordo com o depoimento da Professora 1, o Termo de Cooperação Técnica não foi renovado porque a secretaria de educação da época não considerou aquele trabalho "como algo relevante" 89 .

A minha saída do hospital deu-se em janeiro de 99, por uma determinação da Secretária de Educação na época, Alcione Saliba. Tendo em vista que havia um déficit de professores, uma defasagem, havia a necessidade de

${ }^{89}$ Entrevista concedida pela PROFESSORA 1. Entrevista I. [ago. 2016]. Entrevistador: Claudinéia Maria Vischi Avanzini. Curitiba, 2016. 1 arquivo.mp3 (60min.). A entrevista na íntegra encontra-se transcrita nos Apêndices $\mathrm{C}$ e $\mathrm{H}$ desta tese. 
professores nas escolas e o governo não tinha feito concurso, foi determinado que todos os professores em convênio retornassem para as salas de aula, para suas funções de origem e que cada convênio seria analisado individualmente e que se houvesse a necessidade, seria reativado o Termo de Cooperação Técnico e haveria o chamamento posterior. (Informação verbal Professora 1).

A professora 1 é informada sobre a determinação da Secretaria para que retornasse à escola de origem, se posiciona contrariamente à sua saída do hospital e argumenta que a justificativa foi também a falta de professores nas escolas por conta de ausência de concursos públicos para suprir essa demanda crescente. Comenta ainda que "por alguns anos o convênio ficou interrompido devido a SEED não julgar necessária a atuação de professores na área hospitalar" e que essa saída da Educação Hospitalar não foi uma escolha, mas uma determinação da SEED. Desta forma, conclui-se que não é possível faltar professores nas escolas comuns, entretanto, essa falta é encarada com naturalidade na Educação Hospitalar.

Depois de quatro anos da falta de professores estaduais nos hospitais paranaenses, em 2003 o Conselho Estadual de Educação do Paraná fixa normas para a Educação Especial para o Sistema de Ensino do Estado aprovando a Deliberação no 02/03 que em seu Artigo 14, Inciso III classifica as Classes Hospitalares e o atendimento pedagógico domiciliar como alguns dos serviços especializados que deverão ser assegurados pelo Estado, por meio de parcerias ou convênios com as áreas de educação, saúde, assistência social, entre outros. (PARANÁ, 2003). Portanto, neste ano, o reconhecimento legal da Educação Hospitalar no Paraná se efetiva, o que estimula a Secretaria de Estado da Educação a retomar em 2007 a educação em hospital, interrompida desde 1999, afinal esta passa a ser um direito de todo educando hospitalizado.

Assim, a publicação no Paraná em 2007 da Resolução Secretarial ํo 2.527/2007 que institui o Serviço de Atendimento à Rede de Escolarização Hospitalar - SAREH retoma o atendimento que foi interrompido por cinco anos e amplia gradativamente o número de hospitais com classes hospitalares (PARANÁ, 2007a). No documento base inicial do Serviço é possível evidenciar a "relação entre o significativo interesse na implantação de classes hospitalares devido às mudanças políticas e os avanços científicos nas áreas: pediátrica, pedagógica, de educação básica e de saúde coletiva" (PARANÁ, 2007b). 


\title{
3.2 O "PROJETO MIRIM DE HOSPITALIZAÇÃO ESCOLARIZADA" E A IMPLANTAÇÃO DA EDUCAÇÃO HOSPITALAR NO PARANÁ
}

Segundo as notícias nos jornais já destacadas na primeira parte deste capítulo, em 1988 fazia um ano que o Projeto Mirim de Hospitalização Escolarizada estava em efetivo funcionamento atendendo crianças hospitalizadas com professores no hospital infantil em Curitiba por meio de iniciativa do próprio hospital. (TRIBUNA DO PARANÁ, 22/04/1988, p. 02; O ESTADO DO PARANÁ, 22/04/1988, p. 08).

\begin{abstract}
O secretário de Educação, Belmiro Valverde, viu de perto ontem os primeiros resultados de um trabalho iniciado há um ano pelo Hospital Pequeno Príncipe de Curitiba com seus pacientes. Trata-se do Projeto Mirim de Hospitalização Escolarizada, idealizado pelos próprios médicos e assistente social do hospital[...]. (TRIBUNA DO PARANÁ, 22/04/1988, p. 02).
\end{abstract}

Corroborando com essa informação, uma das professoras que atuou a partir de 1990 informou na entrevista cedida por ela, que

O projeto tinha como nome Projeto Mirim de Hospitalização Escolarizada, de autoria da professora [...], que na ocasião era assistente social do Hospital Pequeno Príncipe e professora da Pontifícia Universidade Católica no Curso de Serviço Social. (Informação verbal Professora 1).

Esse Projeto Mirim de Hospitalização Escolarizada elaborado pela Assistente Social do Hospital inicia o planejamento da Educação Hospitalar que seria implantada, assim como seus objetivos, metas e especificidade. Na introdução do projeto, constatado também em artigo de jornal paranaense, pode-se observar que o motivo principal apontado para a organização da hospitalização escolarizada, seria o fato das crianças internadas perderem 0 ano letivo por conta da incompatibilidade do tratamento, que muitas vezes acontecia em internamentos prolongados, e a frequência escolar. A página inicial do projeto ainda apresenta os hospitais onde este problema persistia e onde foi implantado inicialmente o Projeto de Escolarização Hospitalizada, o Hospital Pequeno Príncipe e César Pernetta, em Curitiba. Além disso, indica a mantenedora desses hospitais, a Associação Hospitalar de Proteção à Infância Dr. Raul Carneiro e os profissionais que já atuavam na equipe interdisciplinar dentro dos hospitais. (GAZETA DO POVO, 22/04/1988, O ESTADO DO PARANÁ, 22/04/88 p. 08; p. 40; MUGGIATI, 1988, p. 1).

A justificativa para a implantação do Projeto seria o "expressivo número de crianças", em idade escolar, com problemas de saúde e "com sério comprometimento, em significativa defasagem" escolar. Para que esse problema fosse superado, o 
projeto precisaria ser efetivado para que o tratamento de saúde conseguisse alcançar o resultado esperado, e o processo de escolaridade não fosse "quantitativamente e qualitativamente prejudicado em situação contrária", porque isso poderia prejudicar muito o tratamento, segundo o Projeto Mirim de Escolarização Hospitalizada. (MUGGIATI, 1988, p. 2).

\begin{abstract}
Diversas foram as oportunidades em que os pais, com relativa razão, tentavam abreviar a duração do tratamento, em virtude das necessidades escolares, quando não, por completo, o abandonavam. Situações ainda houve em que alguns pacientes, nessas condições, nem chegavam a se matricular, atingindo a fase da pré-adolescência ou mesmo adolescência em estado de analfabetismo ou nas primeiras séries escolares. (MUGGIATI, 1988, p. 2).
\end{abstract}

Como o documento indicava que sempre acontecia alguma ruptura, "com o tratamento, ou com o processo de escolaridade", o que desencadeou, no caso da educação, a "evasão escolar, analfabetismo, significativos atrasos de escolaridade, repetências", além do abandono, falta de cuidados e comprometimento com os tratamentos de saúde, gerando constantemente angústia, preocupação e frustração. O Projeto de Hospitalização Escolarizada se apresentava como a "solução ao problema levantado" servindo como "medida conciliatória entre os interesses do tratamento e da escola", além de possivelmente considerar que "intrinsecamente [...] poderia contribuir na "redução do Índice de repetência escolar" nacional. (MUGGIATI, 1988, p. 2).

O projeto ainda aponta os benefícios ocupacionais relacionado ao fato das atividades propostas na hospitalização escolarizada representar potencialmente uma terapia, além do principal objetivo que era conciliar os "interesses relacionados à plena efetivação do tratamento, sem prejuízos à escolaridade”. (MUGGIATI, 1988, p. 2).

Entre os objetivos específicos do Projeto Mirim de Hospitalização Escolarizada encontram-se:

- manter estreito entrosamento com a escola a qual pertence a criança em acompanhamento;

[...] - motivar as crianças favorecidas pelo projeto, no sentido de que venham a valorizar a oportunidade de aproveitamento do espaço hospitalar, para manter em dia suas obrigações escolares;

- incentivar as famílias, no tocante à necessária participação nos processos, como elos de ligação com a escola;

- vivenciar o projeto, também, como útil terapia ocupacional e ainda com eficaz contribuição ao bom termo do tratamento;

- manter registrado o seguimento do processo, com vistas a um efetivo controle. (MUGGIATI, 1988, p. 3). 
O Projeto Mirim aponta que para a efetivação dos objetivos apresentados foi preciso fomentar uma parceria com a Secretaria de Estado da Educação do Paraná, junto ao Secretário Belmiro Valverde Jobim Castor, sendo que sua escrita ocorreu depois que houve esse primeiro contato, pois, essa informação é apresentada no interior do documento do projeto, assim como a informação da efetivação da assinatura do convênio firmado entre as partes interessadas.

Com relação aos profissionais que realizaram 0 atendimento às crianças internadas com oferecimento de hospitalização escolarizada, o projeto indica que duas professoras foram colocadas à disposição dos hospitais para atender aproximadamente 20 crianças, com idade entre 7 a 14 anos. Além destas professoras, "quatro alunas do curso de magistério do Colégio Sagrado Coração de Jesus" (MUGGIATI, 1988, p. 3; PROFESSORA 1; O ESTADO DO PARANÁ, 01/11/1990 p. 7; GAZETA DO POVO, 01/11/90 p. 56; PACHECO, 2017, p. 36) realizavam estágio junto às atividades do projeto. Apesar das fontes confirmarem a liberação de somente uma professora, a informação com relação a existência de estagiárias também é confirmada na entrevista da Professora 1 e em algumas imagens publicadas nos jornais de 1988, afinal as professoras que apareciam atendendo os alunos naquela ocasião pareciam ser bem jovens para serem profissionais de magistério formadas, como na figura 9 a seguir.

Essa imagem corrobora com as informações apresentadas no início deste capítulo e fundamentadas pelas notícias nos jornais que informava fazer um ano da existência do Projeto Mirim de Hospitalização Escolarizada em 1988. Além disto, em 22 de abril de 1988 o secretário de Educação do Estado viu de perto o trabalho iniciado há um ano pelo Hospital Pequeno Príncipe de Curitiba com seus pacientes com relação à escolarização, teceu elogios ao trabalho e efetivou o convênio com a liberação efetiva de professores (TRIBUNA DO PARANÁ, 22/04/1988, p. 02; O ESTADO DO PARANÁ, 22/04/1988, p. 08). Desta forma, suponho que essa adolescente que segura o livro e ao que parece esta explicando algo para a criança da imagem, possa ser uma das seis estagiárias que atuavam no projeto em seu período experimental em 1987, visto que nas notícias dos jornais o Secretário de Educação libera a professora e efetiva o convênio a partir desta visita. Além disto, a informação da efetivação do projeto a um ano como ação do hospital é bem explicita na matéria jornalística. (MUGGIATI, 1988, p. 4; MUGGIATI, 1989, p. 40; MUGGIATI, 2012, p. 50). 
Figura 9: As crianças doentes vão receber aulas nos próprios hospitais.

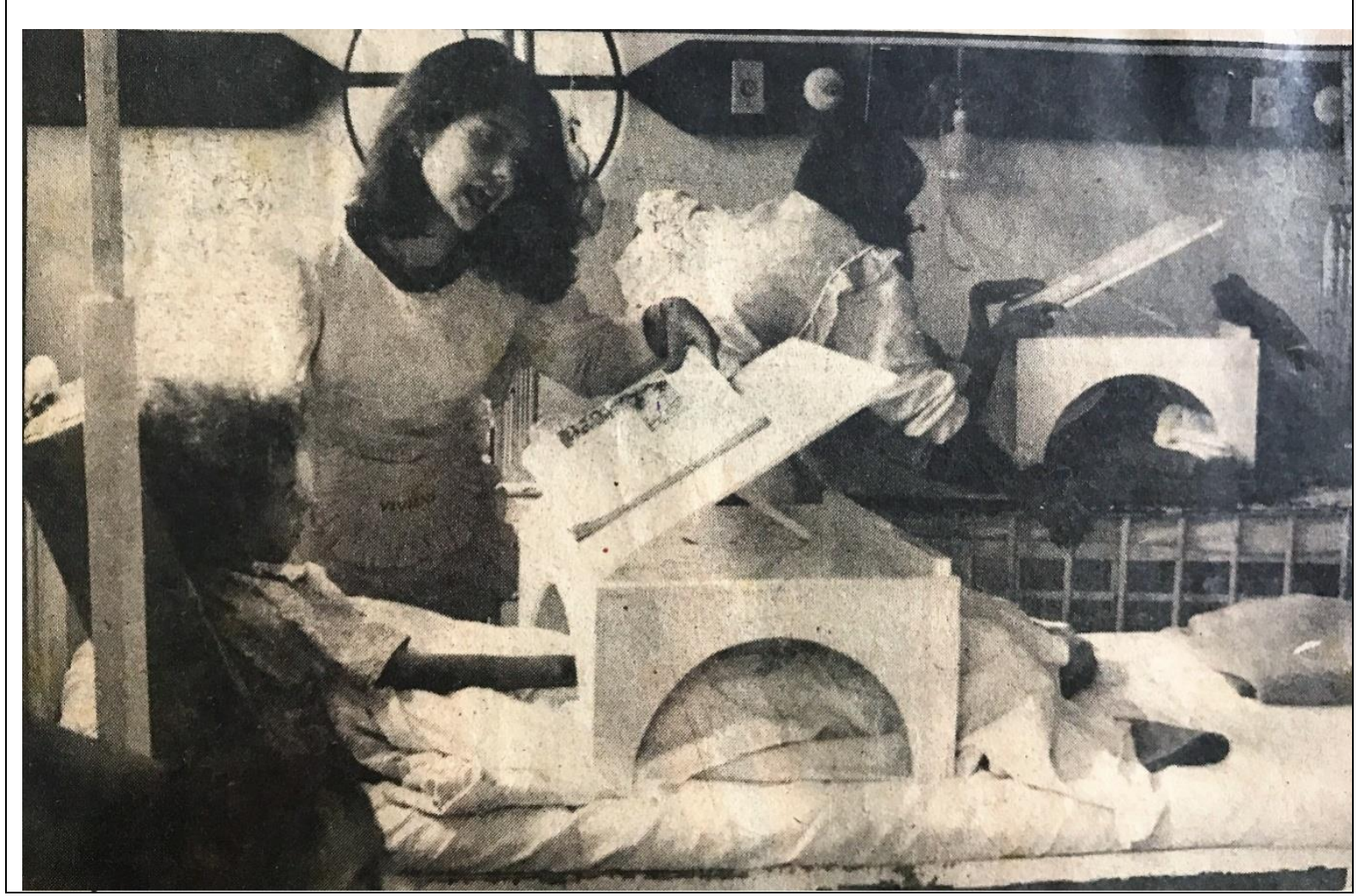

Fonte: GAZETA DO POVO, 22/04/1988, p. 4090.

Anos mais tarde, essa parceria com o Colégio Sagrado Coração de Jesus ${ }^{91}$ se evidencia com as informações prestadas pela Professor 1 na entrevista cedida por ela para a produção deste trabalho.

A atuação das estagiárias dentro do Hospital Pequeno Príncipe ocorreu quando, por parte do Colégio Sagrado Coração de Jesus, a então Coordenadora do Magistério [...] procurou a [...] a chefe do Serviço Social, pedindo o espaço do Hospital Pequeno Príncipe como campo de estágio para as estudantes do Magistério". ${ }^{92}$ (PROFESSORA 1, 2016).

Essas estagiárias, por sinal, em depoimento das duas professoras nas entrevistas, continuaram presentes no hospital mesmo depois do projeto ser implantado experimentalmente. "[...] se eu fizer magistério, você deixa eu fazer estágio aqui dentro da hemodiálise?" (PROFESSORA 2, 2017), esse foi um dos questionamentos de uma estudante acompanhada pedagogicamente pela Professora 2 enquanto fazia tratamento de hemodiálise no hospital. O interessante é que,

\footnotetext{
90 Maiores discussões sobre essa figura serão realizadas no Cap. 4.

91 Maiores informações sobre o Colégio Sagrado Coração de Jesus podem ser encontradas no site: http://www.redesagradosul.com.br/ Acesso em 11/04/2019.

${ }_{92}$ Entrevista concedida pela PROFESSORA 1. Entrevista I. [ago. 2016]. Entrevistador: Claudinéia Maria Vischi Avanzini. Curitiba, 2016. 1 arquivo.mp3 (60min.). A entrevista na íntegra encontra-se transcrita nos Apêndices $\mathrm{C}$ e $\mathrm{H}$ desta tese.
} 
segundo a entrevista da professora, essa estudante efetivamente fez a Formação de Professores, realizou o estágio junto com a Professora 2 e acabou sendo contratada pelo hospital para realizar um trabalho administrativo e em 2018 estava cursando Pedagogia na Universidade Federal do Paraná.

a [Assistente Social] me chamou e perguntou sobre minha disponibilidade para supervisionar o estágio dentro do hospital, [...] por acreditar que aquilo iria contribuir muito no cotidiano das crianças, porque daria uma abertura maior, uma possibilidade maior quanto ao volume de atendimento. [...] eu selecionava as atividades e distribuía o que era possível para as estagiárias. Elas não elaboravam nada, elas apenas aplicavam, eu separava as atividades e elas aplicavam e trabalhavam com as crianças. (PROFESSORA 1, 2016).

Com os depoimentos das duas professoras é possível perceber que o atendimento delas não ficava restrito à formação das séries finais do Ensino Fundamental, como apregoava o projeto inicial, como também se expandia para a formação profissional de futuros professores. Além de ser ampliado para um número maior de crianças, visto que as estagiárias também atendiam pedagogicamente as crianças sob a orientação da professora da Educação Hospitalar que trabalhava no hospital.

Figura 10: Fotografia da professora 1 com estagiárias no hospital (Década de 90).

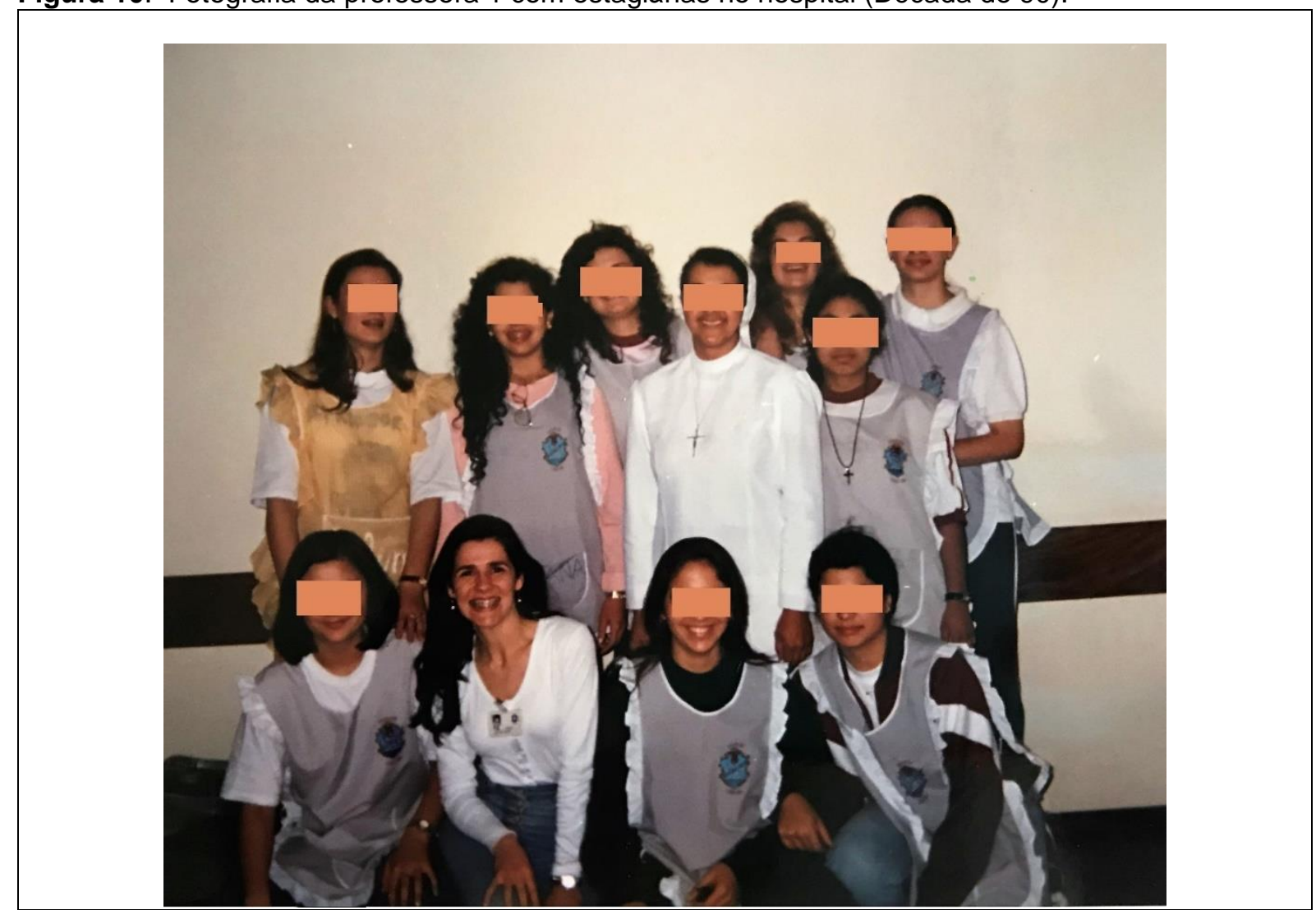

Fonte: Acervo Arquivo pessoal Professora 1. 
Na figura 10, pertencente ao arquivo pessoal da Professora 1, é possível observar a professora rodeada por nove estagiárias, muito provavelmente do Colégio Sagrado Coração de Jesus, pois com exceção de uma, todas usam o mesmo jaleco cinza com babados brancos nas bordas e com o emblema utilizado no colégio na década de 90. Além disto, a participação da freira vestida completamente de branco da Congregação Apóstolas do Sagrado Coração de Jesus (ASCJ) ${ }^{93}$ na figura, reforça a ideia de que essas são as estagiárias que a Professora 1 se refere em seu depoimento para essa pesquisa. As tarjas da figura foram necessárias, pois nem a professora que registrou a imagem e a cedeu para essa pesquisa conseguia se lembrar quem eram essas estagiárias para que pudéssemos conseguir suas autorizações de uso de imagem. A única estagiária sem o jaleco padrão cinza está com outro jaleco marrom, o que indica que para a realização do estágio no hospital havia a exigência do uso do jaleco, muito provavelmente por conta de proteção higiênica para as crianças hospitalizadas, assim como para as estagiárias.

Pelo aspecto físico das estagiárias é possível perceber que são adolescentes, com exceção de uma, todas têm cabelo comprido e somente duas os mantêm presos. Além disto, é possível observar que quatro estão com camisetas de manga curta por baixo do jaleco cinza, além da professora e da freira há mais quatro com camisetas ou blusas de mangas longas, sendo que de duas estagiárias não é possível detectar as roupas que utilizam, devido a posição que ocupam na figura, atrás das colegas ou da freira. As que estão à frente utilizam calças escuras ou jeans, cinco pessoas da imagem estão usando relógio, uma das estagiárias que está ao lado da freira tem um óculo pendurado na gola da camiseta e a do outro lado porta uma corrente com um crucifixo, um pouco menor do que está sendo utilizado pela freira.

A professora tem pendurado na gola de sua camisa um crachá de identificação funcional com sua fotografia num dos lados e um timbre, possivelmente do hospital,

\footnotetext{
93 Três religiosas Missionárias Zelosas do Sagrado Coração de Jesus, posteriormente Apóstolas do Sagrado Coração de Jesus, que residiam no Colégio na frente do Hospital durante 3 anos na década de 1930 iam diariamente "ao hospital para dar assistência espiritual às crianças, cuidar da sua alimentação e recreação". Em 1937, Dr. Victor do Amaral convidou as irmãs a se instalarem no Hospital para poderem dedicar todo seu tempo às crianças. Essas passaram a morar no hospital e, a pedido dos administradores do nosocômio, posteriormente passaram a atender "na assistência e cuidados de enfermagem", além de realizarem o trabalho de evangelização junto às famílias e crianças hospitalizadas e promoção humana dos funcionários por meio de formações de conscientização da vida cristã. (ASSOCIAÇẨO HOSPITALAR DE PROTEÇÃO À INFÂNCIA DR. RAUL CARNEIRO, 1993, p. 05, 06, 07 e 10; HOSPITAL INFANTIL, 1987, p. 2). Em 1969, as Irmãs Apóstolas do Sagrado Coração de Jesus gerenciavam os serviços do Hospital das Crianças César Pernetta como um todo. (cf. http://pequenoprincipe.org.br/hospital/enfermagem/ Acesso em 11/04/2019).
} 
no outro que, por conta da imagem não estar muito nítida, não é possível distinguir exatamente a qual instituição pertence. Durante a entrevista, a Professora 1 fez questão de mostrar essa fotografia para comprovar a presença das estagiárias no hospital e comprovar o que estava relatando.

Com relação às estagiárias, a Professora 1 destacou na entrevista, que um grupo de aproximadamente dez estagiárias iam duas vezes por semana realizar o estágio junto a ela no hospital. As estagiárias estudavam pela manhã e iam ao hospital para realizar as atividades de estágio no período da tarde quantas vezes fossem necessárias até cumprirem a carga horária total do estágio ${ }^{94}$. Então, após cumprir a carga horária, o estágio se encerrava e abriam vaga para outros grupos repetirem o procedimento de estágio no hospital. O controle de frequência das estagiárias e a avaliação do andamento do estágio no hospital ficava sob a responsabilidade da Professora 1 que em reuniões programadas repassava para a, professora do colégio das estagiárias, coordenadora e responsável pelo estágio. Nessas reuniões que ocorriam os repasses tanto da professora do hospital como da coordenadora do estágio com relação ao que estava acontecendo no estágio e "as intervenções necessárias em relação à cada estagiária". (PROFESSORA 1, 2016).

Ainda com relação ao período experimental de efetivação do Projeto Mirim de Hospitalização Escolarizada, este aconteceu de agosto a novembro de 1987, e teve resultados considerados satisfatórios, pois, de acordo com várias fontes, com a sua efetivação, mesmo somente por aproximadamente 4 meses, houve a aprovação escolar das crianças que participaram desta fase do projeto. (O ESTADO DO PARANÁ, 01/11/1990 p. 7; GAZETA DO POVO, 01/11/90 p. 56; PACHECO, 2017, p. 36; MUGGIATI, 1988, p. 3; MUGGIATI, 1989, p. 40; MUGGIATI, 2012, p. 50).

Segundo o Projeto, as crianças que recebiam este atendimento pedagógico tinham idade escolar e indicação de longa duração de internamento, eram principalmente aquelas crianças "acometidas de problemas ortopédicos, hematológicos, oncológicos, nefrológicos e cardíacos, destes, em especial com febre reumática" como já destacado anteriormente. (MUGGIATI, 1988, p. 4; MUGGIATI, 1989, p. 40; MUGGIATI, 2012, p. 50).

A respeito do trabalho das professoras, destaca-se o imediato contato com a escola onde a criança estaria matriculada, que poderia ser pessoalmente no caso das

${ }^{94} \mathrm{~A}$ professora não conseguiu lembrar qual era a carga horária que as estagiárias cumpriam nos seus estágios. (PROFESSORA 1, 2016). 
escolas de Curitiba, ou por meio de telefone ou carta com as escolas do interior com o objetivo de solicitar "dados da vida escolar, currículo e material do paciente-aluno". (MUGGIATI, 1988, p. 4; PRADO, 1990a, p.1).

O atendimento a partir de então oferecido às crianças enquadradas no projeto é de natureza individualizada, integradamente com o Serviço Social e, se necessário, com o Serviço de Psicologia e demais técnicos. Ao final do bimestre, são aplicados os testes encaminhados pelas escolas, os quais são devidamente devolvidos àqueles estabelecimentos que os avaliará. (MUGGIATI, 1988, p. 4).

O projeto ainda trata da questão dos materiais disponibilizados aos alunos ou aos professores para a efetivação dos atendimentos, mencionando a FUNDEPAR pelo fornecimento do material didático e indica as carteiras especiais adaptadas aos atendimentos nos leitos com tampas graduáveis para auxiliar o atendimento de crianças com "gesso, tração ou outras espécies de dificuldades". (MUGGIATI, 1988, p. 4).

Com relação à avaliação dos resultados do projeto, houve a previsão de uma pesquisa, com "o objetivo de auferir subsídios, com vistas ao aperfeiçoamento do próprio projeto e realimentação dos objetivos e da dinâmica interdisciplinar". Além disto, a assistente social comenta sobre uma pesquisa de mestrado e por conta da relevância do projeto, este seria incluído na dissertação. (MUGGIATI, 1988, p. 4).

É interessante observar que outros hospitais da capital acabam utilizando o mesmo projeto para justificar as solicitações de implantação de educação hospitalar em suas dependências, como por exemplo o Hospital Erasto Gaertner que em 1991 efetiva o convênio com a Secretaria de Estado do Paraná para a implantação do "Projeto Mirim de Hospitalização Escolar" (PACHECO, 2017, p. 45) e o Hospital de Clínicas da Universidade Federal do Paraná que por meio do Protocolo Integrado no 903.242-8 de 08/01/1991, solicita a aprovação do Convênio sobre a "Hospitalização Escolarizada para Crianças" seguindo o "exemplo do que já vem ocorrendo no Hospital Pequeno Príncipe/César Pernetta ." (PARANÁ, 1991, p. 02).

Neste protocolo integrado, o Hospital de Clínicas além de anexar a relação de crianças em idade escolar internadas naquele momento no Departamento de Pediatria do Hospital de Clínicas da Universidade Federal do Paraná, informou que essas crianças ficavam internadas por um período longo por conta das "características peculiares de tratamento que geralmente envolvem situações de maior complexidade" e por elas estarem em período de escolarização e necessitarem de assistência 
pedagógica utilizaram quatro argumentos para justificar a implantação do proposta educativa naquele hospital. Primeiro, essas crianças em faixa etária escolar hospitalizadas tinham disponibilidade de tempo, com tardes ociosas e poderiam aproveitar para receber atendimento escolar individualizado. Segundo, pela maioria das crianças internadas no hospital terem "baixo poder aquisitivo" e algumas vezes nunca terem frequentado a escola, poderiam ser alfabetizadas ou terem um acompanhamento das tarefas escolares, principalmente para aquelas crianças que comprometessem seu ano letivo por estarem "submetidas a longo período de hospitalização, ou em atendimento múltiplo a nível externo". A prevenção de abandono do tratamento ou da educação com a necessidade de conciliação de ambos foi outra justificativa do documento e finalmente a indicação de que o "acompanhamento escolar além de suprir a falta da família" auxiliaria o aprendizado, impedindo os atrasos escolares e as repetências. (PARANÁ, 1991, p. 09). A justificativa é encerrada com a indicação da implantação naquele hospital do "modelo de assistência pedagógica a crianças hospitalizadas considerado padrão da Secretaria de Educação do Estado" já adotado no Hospital Pequeno Príncipe/Cezar Perneta e Hospital Erasto Gaertner, principalmente porque responderia a demanda do atendimento educacional e hospitalar das crianças preenchendo "a lacuna existente nos hospitais".

Corroborando com o argumento dos atendimentos serem direcionados aos pacientes com longos períodos de internamento e tratamentos extremos, o Jornal Gazeta do Povo publica a informação de que após ser o protagonista do $3^{\circ}$ transplante renal realizado no Hospital Pequeno Príncipe no final de 1990, Luciano tem alta e sua imagem foi estampada no jornal inclusive com a divulgação da informação de sua alegria em voltar para casa. A reportagem foi finalizada chamando a atenção para o "Programa de Hospitalização Escolarizada que atende crianças obrigadas a permanecer por longos períodos internadas" e que inclusive auxiliou a aluno a "concluir no hospital a $4^{a}$ série do $1^{\circ}$ grau". Assim, Luciano "vai pra casa com duas certezas: passou para $5^{\text {a }}$ série e pode a partir de agora levar uma vida normal". (GAZETA DO POVO, 02/12/90, p. 26).

Na perspectiva de justificar e comparar o possível atendimento a ser ofertado no Hospital de Clínicas com o que estava sendo ofertado nos Hospitais Pequeno Príncipe e César Pernetta, nas páginas seguintes, o protocolado anexa na íntegra a dissertação de Muggiati que apresenta os motivos e como implantar o projeto, alguns 
recortes de jornais que tratam do Projeto nos hospitais da Associação Hospitalar de Proteção à Infância Dr. Raul Carneiro e cópia do Projeto Mirim de Hospitalização Escolarizada. Esses documentos auxiliavam na evidenciação e disseminação do projeto inicial da Associação Hospitalar e indicava a necessidade de implantação também em outros hospitais. As últimas páginas do processo traz o Termo de Convênio de amparo Técnico celebrado entre a Secretaria de Estado da Educação e o Hospital de Clínicas da Universidade Federal do Paraná que tinha "como objetivo promover assistência escolar a crianças internadas no Hospital de Clínicas oferecendo atendimento individualizado, mantendo entrosamento com a escola de origem à qual pertence a criança", assim como acontecia desde o final da década de 80 em outros hospitais que oportunizaram o atendimento pedagógico para as crianças internadas na capital paranaense.

\subsubsection{A Assistência Social e a escolarização no atendimento hospitalar}

A escolarização dentro do hospital em Curitiba se inicia vinculada à Assistência Social, pois quem percebe a necessidade da implantação de um serviço de escolarização no hospital na década de 1980 e se movimenta para que o serviço seja implantado é a Assistente Social chefe do hospital de crianças da cidade que acaba acompanhando esse serviço até sua aposentadoria em $2012^{95}$. O Serviço Social é implantado no hospital pesquisado em 1968, com "uma certa rotatividade de Assistentes Sociais no cargo até 1974" (MUGGIATI, 1989, p. 15), ano em que segundo dados colhidos nas entrevistas cedida pela Assistente Social, ela começa a trabalhar como assistente social no hospital.

A ideia em criar um serviço de escolarização para as crianças internadas surgiu pela "incompatibilidade do tratamento e da escola" que a Assistente Social observava frequentemente entre as crianças que faziam tratamento de saúde no hospital. Assim, a Hospitalização Escolarizada no hospital que ela trabalhava foi implantada em 1988 depois que ela conseguiu sensibilizar a direção do hospital para essa problemática ${ }^{96}$. Corroborando com esta informação é possível encontrar na dissertação intitulada

\footnotetext{
${ }^{95}$ Informações colhidas em entrevista concedida pela ASSISTENTE SOCIAL. Entrevista II. [ago. 2016]. Entrevistador: Claudinéia Maria Vischi Avanzini. Curitiba, 2016. 1 arquivo.mp3 (24min.48seg.). A entrevista na íntegra encontra-se transcrita nos Apêndices B e G desta tese.

${ }^{96}$ Informação colhida na entrevista concedida pela ASSISTENTE SOCIAL. Entrevista II. [ago. 2016]. Entrevistador: Claudinéia Maria Vischi Avanzini. Curitiba, 2016. 1 arquivo.mp3 (24min.48seg.). A entrevista na íntegra encontra-se transcrita nos Apêndices B e G desta tese.
} 
"Hospitalização Escolarizada: uma nova alternativa para o escolar-doente" a indicação sobre o problema observado no hospital antes da implantação da escolarização e que acabou desencadeando toda a movimentação para sua efetivação.

O problema, portanto, é evidente: existe uma nítida contradição entre o necessário tratamento hospitalar e a necessária frequência escolar, de vez que ambos exigem o mesmo espaço temporal.

Se por um lado o tratamento logra êxito, pelo outro, o processo de escolaridade é quantitativa e qualitativamente prejudicado; em situação contrária, o tratamento entra em colapso, com envolvimento de gravidade muitas vezes irreversíveis. É o entrecruzamento de duas necessidades essenciais: ou a saúde, ou a educação, esta é a contradição.

Rupturas do tratamento ou evasões escolares representam uma constância, ou ainda sérios prejuízos a ambos, neste caso culminando com perdas do ano letivo e agravamento da enfermidade. (MUGGIATI, 1989, p. 07 e 08).

Com base inclusive na Declaração dos Direitos da Criança, da Organização Mundial da Saúde, considera-se direito inalienável que requer extrema proteção o bem-estar, o livre acesso à saúde e à educação das crianças. (MUGGIATI, 1989, p. 22). Assim, caso ocorra uma hospitalização prolongada ou múltiplos atendimentos hospitalares da criança em idade escolar, ambos, direitos indispensáveis estariam em risco, pois "diante do impasse com que se deparam: ou o tratamento, ou a escola, ou, então, prejuízo a ambos; ou ainda acomodação ou conformismo". (MUGGIATI, 1989, p. 22).

[...] o entrecruzamento das duas necessidades essenciais básicas, saúde e educação, absurdamente passam a se projetar sob a imagem de agressores, com recíprocas ameaças, à eficácia do tratamento ou à integridade do ano letivo. (MUGGIATI, 1989, p. 22).

Em outro trecho da dissertação, a autora insiste neste argumento classificando a "situação dos escolares-doentes" como sendo de crianças "tolhidas do exercício de seus legítimos direitos, pelo simples fato de serem doentes" (MUGGIATI, 1989, p. 24). A autora ainda levanta algumas contradições encontradas que bloqueavam tanto 0 tratamento de saúde, como o processo de escolaridade, sendo os principais abaixo discriminados:

Quanto ao tratamento: preocupação dos pais em abreviar o tratamento;

- falhas relacionadas aos retornos marcados (desarticulação do esquema de tratamento);

- participação deficitária dos familiares no tratamento;

- angústia da criança motivada pela falta às aulas, com reflexo no tratamento; 


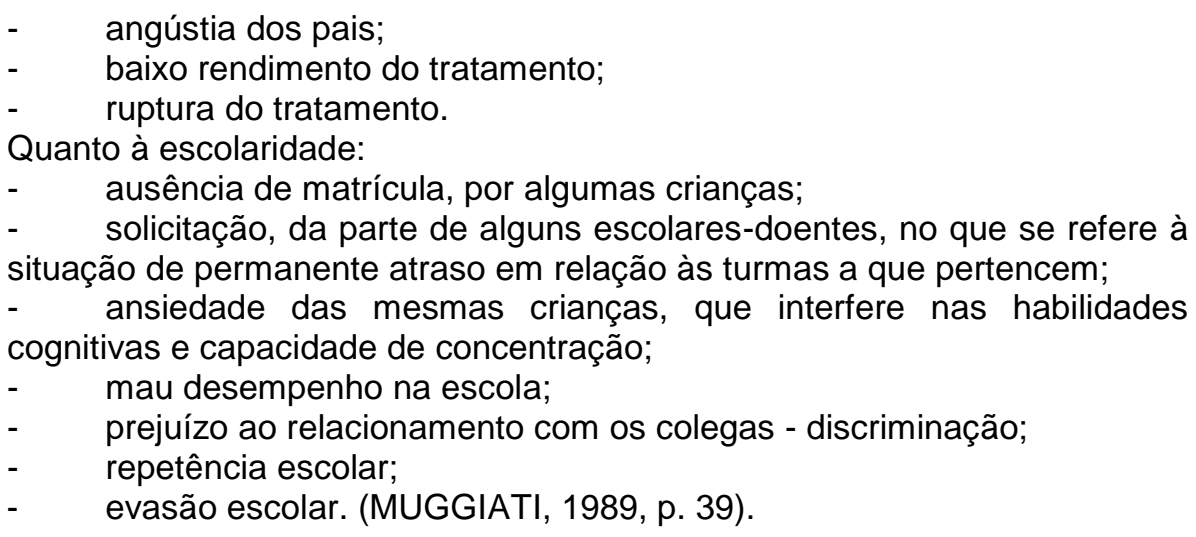

Com certeza, essas contradições prejudicava as crianças, algumas vezes, num dos atendimentos, mas também em alguns casos, em ambos. Afinal, para uma criança doente o tratamento é essencial, assim como sua vida escolar e sua aprendizagem. Coibir um desses universos afetava diretamente a evolução, progresso e até mesmo a sobrevivência dessas crianças.

Esse argumento da Assistente Social das crianças terem tolhido os seus direitos à educação e à saúde também foi utilizado pelas professoras entrevistadas sobre as causas que levaram a implantação do serviço de Hospitalização Escolarizada em Curitiba. A respeito da efetivação dessa implantação da Hospitalização Escolarizada no Hospital em 1988, a Professora 1 (2016) destaca que o projeto chamado inicialmente de "Projeto Mirim de Hospitalização Escolarizada", de autoria da assistente social do hospital e professora da Pontifícia Universidade Católica no Curso de Serviço Social ocorreu porque ela enquanto Assistente Social no hospital e pesquisadora na Universidade, "percebeu que havia uma lacuna entre o tratamento de saúde das crianças internadas naquele hospital". Essa lacuna era observada na defasagem com relação à escolarização daquelas crianças que precisavam realizar tratamentos no hospital, porque durante o período do tratamento ocorria um vácuo tanto nas crianças, como em suas famílias gerando o abandono na escolarização regular das crianças. Isso acabava favorecendo também uma instabilidade emocional, afinal, muitas vezes as crianças vinham de outras cidades e acabavam abandonando a escola, o que provocava em consequência, uma desestrutura emocional, pois para que o tratamento fosse garantido, muitas vezes seria necessário o abandono da escola. Esse abandono por sua vez era considerado também um problema para as famílias. Nesse contexto, a Assistente Social percebeu 
a necessidade "de implantar um projeto dentro do hospital, [...] onde ela propõe o atendimento pedagógico às crianças hospitalizadas"97.

Segundo o depoimento da Professora 2 (2017), a Assistente Social que implantou o projeto da Hospitalização Escolarizada o fez por conta de perceber que muitas crianças, ou deixavam a escola por conta do tratamento ou deixavam o tratamento por conta da escola. Segundo a professora, há vários relatos a esse respeito também na dissertação de mestrado de Muggiati (1989) que trata do assunto "Ela dizia: "Puxa, não é possível que a criança não estude por conta do tratamento". Essa inquietação a levou a fazer a pesquisa que desencadeou na dissertação em 1989 intitulada Hospitalização Escolarizada: uma nova alternativa para o escolardoente. Com relação à Assistente Social do hospital onde foi implantada a primeira experiência de Hospitalização Escolarizada em Curitiba

[...] ela vai atrás do Governo do Estado por conta de uma parceria, porque ela queria implantar esse projeto que chamava na época, Projeto Mirim de Hospitalização Escolarização. Esse era o nome que a [Assistente Social] ${ }^{98}$ utilizava, Projeto Mirim. Ela vai atrás do Governo do Estado para pôr um professor dentro do hospital e o Governo do Estado, na época o secretário empresta, ele dá uma professora para a [Assistente Social], para que essa professora desenvolvesse todo um trabalho dentro do hospital, porque era uma coisa que era viável. Essa professora fica por 3 meses dentro do hospital, acho que foi $87 . .$. (PROFESSORA 2, 2017).

Mesmo observando uma forte admiração por parte das professoras entrevistadas pela Assistente Social que implantou o serviço de escolarização, talvez por conta de se sentirem agradecidas, pois se não fosse essa implantação da Hospitalização Escolarizada realizada pela Assistente Social, elas não teriam todo o seu histórico profissional tão destacado e diferenciado, sua vida profissional reconhecida, sua experiência com um trabalho tão diferenciado e inovador para a época e seu reconhecimento social. Entretanto, é impossível desvalorizar a importância do trabalho realizado pela Assistente Social, pois realmente é possível perceber sua capacidade de argumentação, assim como a importância de sua movimentação e envolvimento, talvez até mesmo político, com a diretoria do hospital, o governo do estado e municipal, para a efetivação da implantação e desenvolvimento da escolarização no hospital. Talvez, sem essa articulação da Assistente Social, esse

97 Entrevista concedida pela PROFESSORA 1. Entrevista I. [ago. 2016]. Entrevistador: Claudinéia Maria Vischi Avanzini. Curitiba, 2016. 1 arquivo.mp3 (60min.). A entrevista na íntegra encontra-se transcrita nos Apêndices $\mathrm{C}$ e $\mathrm{H}$ desta tese.

${ }_{98}$ Para preservar a identidade da Assistente Social, o seu nome foi substituído pela sua função em todos os trechos que aparecem nas entrevistas e neste trabalho. 
atendimento pedagógico em hospitais poderia não ter acontecido, ou ter demorado muito mais para ser implantado na cidade de Curitiba, no Paraná.

Com relação ao questionamento sobre a existência de um convênio entre o hospital e o Estado, após um silêncio prolongado, a Assistente Social responde:

Olha, esse convênio havia sim, porque imediatamente eu fui conversar com a direção do hospital e também com o secretário da educação e ao mesmo tempo ele achava que era possível sim, essa estadualização ao mesmo tempo do tratamento. (ASSISTENTE SOCIAL, 2016).

Desta forma, houve a indicação de uma professora, liberada pela Secretaria de Estado da Educação (SEED), que realizou os atendimentos por um período experimental, de quatro meses com aprovação de $100 \%$ dos alunos atendidos (MUGGIATI, 1989, p. 40; MUGGIATI, 2012, p. 50). Esse convênio foi assinado pelo hospital e SEED somente em abril de 1989, depois deste período experimental, o Secretário de Educação da SEED Paraná e que assinou o convênio inicial foi o professor Belmiro Jobim Valverde Castro. Segundo o depoimento da Professora 10 convênio era realmente documentado e assinado.

Desde o primeiro momento, eu já entrei no hospital com esse convênio assinado ${ }^{99}$. O Termo de Cooperação Técnica ficava no Departamento Jurídico da SEED e na diretoria do Hospital Infantil Pequeno Príncipe, do hospital quem o assinava eram os diretores, o diretor clínico, quando eu entrei, era o diretor Dr. Ivan Fontoura, Dona Ety Forte. Eles assinaram a parte do... (PROFESSORA 1, 2016).

No período experimental do projeto houve a atuação de uma professora auxiliada por seis estagiárias do curso de magistério, sendo que inicialmente, apesar da flutuação do número de alunos, houve o registro de 30 casos. "Em abril de 1988, já com resultados positivos e comprovada a necessidade da professora no ambiente hospitalar" que já atuava na época na cardiologia, febre reumática, ortopedia, hematologia, oncologia e nefrologia, "foi firmado convênio entre a Secretaria de Educação e a Associação mantenedora dos hospitais", convênio que foi renovado no final de 1988, depois de avaliação qualitativa. (MUGGIATI, 1989, p. 40; MUGGIATI, 2012, p. 50).

Cabe, aqui, a observação, de que o fato suscitou uma enorme ressonância na comunidade, cujas mídias se fizeram presentes no dia da assinatura do citado Convênio, com interessantes publicações a seu respeito e aplausos pela inusitada iniciativa. É também digno de nota que esse interesse

\footnotetext{
${ }^{99}$ Vale destacar que essa professora começa a trabalhar no hospital em 1990, portanto, realmente com o convênio assinado.
} 
permanece até os dias de hoje, com repetidas reportagens sobre a evolução "deste tão importante projeto", como tem sido classificado. (MUGGIATI, 2012, p. 51).

Segundo depoimento da Assistente Social (2016), o serviço da Hospitalização Escolarizada acontecia com a frequência à escola e ao mesmo tempo o tratamento de saúde das crianças. Ao ser questionada se a partir da implantação da escolarização o tratamento do hospital e a frequência à escola eram compatíveis, ela respondeu que as crianças faziam tudo ao mesmo tempo, enquanto elas estavam no hospital iam fazendo a escolarização.

A Assistente Social relata que não encontrou dificuldade nenhuma para implantar a escolarização no hospital, porque tanto médicos como direção do hospital queriam o projeto, assim como houve o apoio da Secretaria de Estado da Educação na realidade ela informou que encontrou facilidade para implantar esse projeto, dentre essas facilidades destacou "[...] as professoras da escola mandavam os projetos para o hospital e ao mesmo tempo eu fazia as provas para os alunos. E passava para as professoras. A nota é dada pelas professoras" ${ }^{100}$. Segundo ela, resumidamente 0 trabalho se desenrolou da seguinte forma: a escola passava as provas, a Assistente Social repassava para as professoras que trabalhavam no hospital, essas professoras davam para os alunos e depois de realizadas as provas ou atividades, estas eram devolvidas para a escola aferir as notas aos alunos que não podiam frequentar as aulas normalmente por estarem em tratamento hospitalar.

Ela destaca que o Dr. Ivan Fontoura ${ }^{101}$, em 1988 Diretor Clínico do hospital, a ajudou muito nesta implantação, sendo que ele destaca no Jornal Tribuna do Paraná que "[...] a escola é personalizada e funciona nos mesmo moldes das antigas. Duas professoras, auxiliadas pelas assistentes sociais instruem as crianças de forma a que

100 Entrevista concedida pela ASSISTENTE SOCIAL. Entrevista II. [ago. 2016]. Entrevistador: Claudinéia Maria Vischi Avanzini. Curitiba, 2016. 1 arquivo.mp3 (24min.48seg.). A entrevista na íntegra encontra-se transcrita nos Apêndices B e G desta tese.

101 Dr. Ivan Beira Fontoura nascido em 1926 na cidade de Curitiba, formou-se em 1951 em Medicina pela Universidade Federal do Paraná, fez pós-graduação em Puericultura e Nutrição, Mestrado na Universidade da Califórnia e Doutorado em Sourbone, Universidade Paris. Foi professor assistente da PUC- PR em Pediatria e Puericultura e atuou por 54 anos com clínica pediátrica, dirigindo diversos hospitais, inclusive o Hospital Pequeno Príncipe, onde trabalhou por 30 anos. Entre 1971 a 1975 foi Secretário Estadual de Saúde. Atualmente aposentado, desenvolve vários trabalhos voluntários no litoral paranaense, região onde reside. https://portal.cfm.org.br/index.php?option=com content\&view=article\&id=1080:\&catid=3 
não passem o dia sem terem pelo menos uma atividade". (TRIBUNA DO PARANÁ, 22/04/1988, p. 02).

As primeiras professoras a realizar este serviço no hospital eram profissionais cedidas pelo Estado que, além de aplicar as provas, "ajudavam as crianças... Esclarecia os termos..." (ASSISTENTE SOCIAL, 2016). As crianças, após realizarem as avaliações, entregavam para as professoras, que por sua vez devolviam para a escola. Segundo a Assistente social, as professoras chegavam às 8hrs, ficavam até a hora do almoço ou vinham em rotinas alternadas, às vezes pela manhã, outras vezes à tarde. Ao chegar no hospital, essas professoras passavam primeiro na secretaria para registrar sua presença ao trabalho, sendo que a frequência ao trabalho delas era de segunda a sexta-feira.

Os atendimentos às crianças no início se desenvolvia numa sala especial, mas também aconteciam diretamente no leito de cada criança internada. Essas aulas não podiam acontecer em todo o hospital, pois nem sempre as salas podiam ser reservadas para esse tipo de trabalho de educação, então na maioria das vezes acontecia nos leitos, onde as professoras faziam questionamentos aos alunos internados que as respondiam e assim se desenrolava a maioria do processo educacional. (ASSISTENTE SOCIAL, 2016).

Com relação a essa dinâmica do processo sócio pedagógico, Muggiati (1989) relata que

\begin{abstract}
A partir do momento em que é, pelo médico ou pela equipe, caracterizada a necessidade de participação do escolar-doente no Projeto, de imediato, por prévio entendimento, os pais ou responsáveis são encaminhados ao Serviço Social, onde é iniciado, juntamente com a professora, um amplo processo, a nível de diálogo, de tomada de consciência, de forma crítica e reflexiva da situação. (MUGGIATI, 1989, p. 41).
\end{abstract}

A partir desta conversa inicial, os pais eram incluídos nesse processo, pois eles seriam o elo entre o hospital e a escola de origem da criança, assim como deveriam participar ativamente também do processo educativo. A professora então, entrava em contato com a escola de origem, pessoalmente, se a escola fosse em Curitiba, ou por telefone ou carta para escolas de outras localidades, nestes casos, os pais ficavam responsáveis em levar em mãos todos os documentos necessários para essas escolas (MUGGIATI, 1989, p. 41), que algumas vezes, se manifestavam por meio de carta elogiando e apoiando a ideia destes atendimentos que as professoras faziam no hospital, "[...] elas diziam assim, que a criança nem parecia que estava em tratamento, 
porque ela ficava internada"102 e quando retornava para a escola era como se não tivesse ficado internada.

Figura 11 - Carta parabenizando pelo trabalho de Hospitalização Escolarizada.

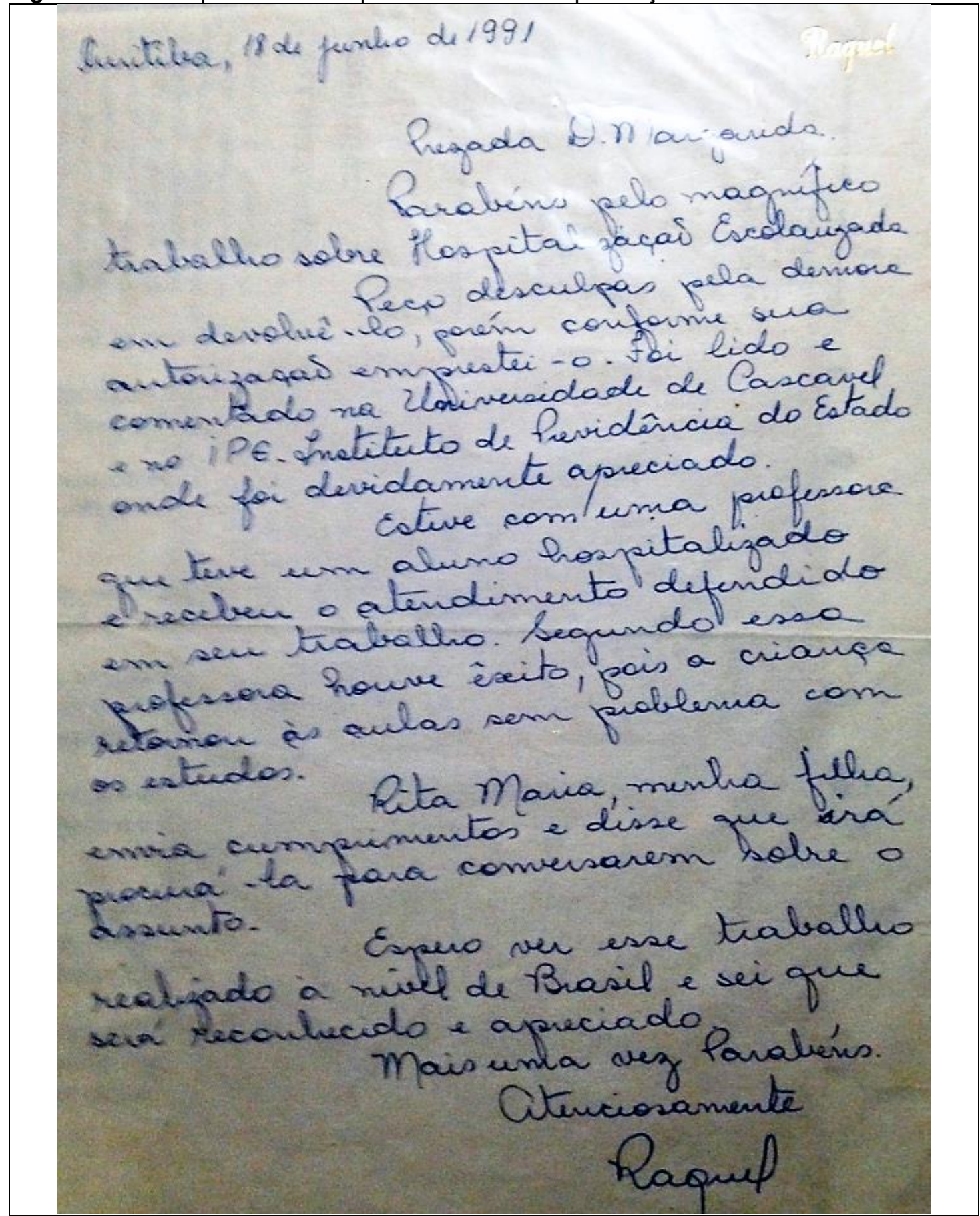

Fonte: Acervo pessoal Assistente Social. (18/06/1991).

102 Entrevista concedida pela ASSISTENTE SOCIAL. Entrevista II. [ago. 2016]. Entrevistador: Claudinéia Maria Vischi Avanzini. Curitiba, 2016. 1 arquivo.mp3 (24min.48seg.). A entrevista na íntegra encontra-se transcrita nos Apêndices B e G desta tese. 
Além das informações das escolas das crianças atendidas havia manifestações de diferentes pessoas que acabavam tendo contato com o trabalho de Hospitalização Escolarizada, como na carta apresentada pela senhora Raquel na figura 11, que em junho de 1991 agradece a Muggiati pela disponibilização de sua monografia sobre o assunto que foi apreciado tanto na Universidade de Cascavel como no Instituto de Previdência do Estado - IPE. Considero interessante destacar a parte da carta que traz a informação do contato da remetente com uma professora que teve um aluno que recebeu atendimento educacional enquanto esteve internado e também obteve êxito no retorno às suas aulas que ocorreram sem problemas.

Os mesmos aplausos podiam ser observados provenientes dos médicos e demais funcionários do hospital, eles aceitavam essas aulas, "ficavam assim..., agradecidos, porque o aluno colaborava com o tratamento. [...] Ele aceitava o tratamento". (ASSISTENTE SOCIAL, 2016). Quando os médicos e demais funcionários do hospital chegavam e encontravam a professora dando aula, eles colaboravam e "sempre diziam assim, que a hora que precisar, ele estava à disposição" ${ }^{103}$. Considero que nestes casos, de aceitação e agradecimento da equipe médica para as atividades propostas pelas professoras, talvez isso ocorresse muito mais pela colaboração das crianças com o tratamento, que acabava facilitando o trabalho da equipe médica, do que por conta da percepção da garantia do direito à educação ou pela necessidade da oferta de educação para essas crianças.

Segundo Muggiati (1989, p. 42), nos casos em que a criança em idade escolar, se encontrasse fora da escola, sem nunca ter estudado por conta de problemas de saúde, a professora junto com os pais da criança procedia a efetivação da matrícula dessa criança para depois realizarem a inclusão dela no projeto de escolarização no hospital.

$\mathrm{Na}$ entrevista, a Assistente Social ainda destaca que os alunos gostavam das aulas recebidas no hospital, inclusive destaca que nos finais de semana, que as professoras não trabalhavam, os alunos torciam para que os dias passassem rápido para eles terem as aulas, assim como seus pais ou responsáveis, que "davam graças

103 Entrevista concedida pela ASSISTENTE SOCIAL. Entrevista II. [ago. 2016]. Entrevistador: Claudinéia Maria Vischi Avanzini. Curitiba, 2016. 1 arquivo.mp3 (24min.48seg.). A entrevista na íntegra encontra-se transcrita nos Apêndices B e G desta tese. 
a Deus! Porque sempre eles encontravam essa incompatibilidade do tratamento com a escola, a frequência à escola"104.

A Assistente Social entrevistada ainda confirma que depois da implantação da Hospitalização escolarizada, pode observar melhoras na criança, principalmente na colaboração com o tratamento. Além disto, havia uma preocupação com o retorno da criança para a escola regular após a alta hospitalar, sendo que havia todo um trabalho realizado pelas professoras para minimizar essa ruptura com a escolarização regular.

Concomitante às atividades acima relatadas, como parte do processo, é precedido, pelas equipes, um trabalho de preparação do retorno à normalidade, correspondente à fase extra hospitalar, tanto em relação ao doente, quanto à família, através de diálogos a respeito das possíveis implicações no enfrentamento da nova realidade; deixando sempre transparecer o carater de emergência do processo de escolaridade no hospital. (MUGGIATI, 1989, p. 43).

Ainda com relação aos elogios, também são encontrados vários deles publicados nos jornais paranaenses e publicados no livro memorialístico de Muggiati (2012, p. 55).

O Projeto Mirim de Hospitalização Escolarizada, primeiramente implantado
nos Hospitais Pequeno Príncipe e César Pernetta, responde à necessidade
de conciliação entre tratamento e educação escolar. Acrescentando "que é
muito importante motivar as crianças no sentido de que venham a valorizar a
oportunidade de aproveitamento do espaço hospitalar para manter em dia as
suas obrigações escolares". Com uma sala equipada e a orientação
pedagógica de uma professora especializada, "vamos incentivar este
projeto", destacou um dos médicos do Hospital Erasto Gaertner. (GAZETA
DO POVO, 15/12/1991, s/p).

As melhores recordações que a Assistente Social tem deste período é a sensação de que ela contribuiu.

Eu sou feliz, porque eu contribui com alguma coisa para a escolarização da criança. É! [...], hoje eu estou realizada, em parte também por, pelo projeto. Eu estou realizada! [...] Eles achavam o projeto muito importante. E a mídia veio ao hospital e fez entrevistas. Eles diziam assim, que o projeto era importantíssimo para a criança. [...] Vou te dizer uma coisa, me realizei! [...], como assistente social, isso fez parte de minha realização, porque eu contribui com alguma coisa, e algo assim, importantíssimo! (ASSISTENTE SOCIAL, 2016).

O reconhecimento pelo trabalho da assistente social no atendimento educacional de crianças hospitalizadas é amplamente manifestado tanto em jornais,

104 Entrevista concedida pela ASSISTENTE SOCIAL. Entrevista II. [ago. 2016]. Entrevistador: Claudinéia Maria Vischi Avanzini. Curitiba, 2016. 1 arquivo.mp3 (24min.48seg.). A entrevista na íntegra encontra-se transcrita nos Apêndices B e G desta tese. 
livros memorialísticos da própria instituição e também pelas professoras entrevistadas. Numas das entrevistas fornecidas a professora destaca que

A base de todo o trabalho hospitalar é a tese, o projeto da Prof. a. /Assistente Social [...]. Não existe outra referência, se não houvesse uma cabeça pensante que percebesse aquela lacuna existente, e que havia a necessidade de implantar aquele trabalho, ele não teria surgido. A base toda é o projeto. (PROFESSORA 1, 2016).

A Professora 1 ainda destaca que quando foi convidada "pela Superintendente da Educação da SEED", Ihe foi esclarecido que o projeto já existia, havia sido "defendido em forma de tese na Pontifícia Universidade Católica de Porto Alegre". Na verdade, o projeto fora apresentado na forma de dissertação para a obtenção do título de mestre por Muggiati. A função da professora seria, portanto

[...] desenvolvê-lo sem ter sobre ele quaisquer responsabilidades de base, porque ele já estava pronto e acabado. Cabia a mim, sim, desenvolvê-lo dentro dos padrões e sempre que necessário fosse levar quaisquer tipos de dúvidas à [Assistente Social], [...]. [A Assistente Social] foi minha supervisora e chefe imediata durante todos os anos que estive no Pequeno Príncipe. Então, quaisquer dúvidas que houvessem em relação ao projeto eram com ela, ela tinha plena responsabilidade, assinava, eu apenas desenvolvia, cumpria a parte pedagógica. Então, quando iniciei minha atuação me foi esclarecido isso, que eu não teria coparticipação e coautoria. Não poderia falar em nome do projeto sem citar a origem dele, que era da [Assistente Social]. (PROFESSORA 1, 2016).

Considero importante destacar novamente que o depoimento da professora acaba indicando a admiração dela pelo trabalho desenvolvido pela Assistente Social, admiração essa que parece extrapolar o campo profissional, há uma clara admiração pela concepção pela qual a Assistente Social fundamenta seu trabalho e também a implantação de um atendimento pedagógico para as crianças internadas num hospital. Essa concepção parece ser também a concepção pela qual o trabalho da professora é fundamentado.

A Professora 2 (2017) também vincula a existência da educação no hospital à mesma assistente social, segundo seu depoimento foi ela que negociou junto ao governo do estado para que um professor fosse emprestado para desenvolver o trabalho dentro do hospital, porque segundo os dois, governo e assistência social, isso era algo viável. A professora destaca que uma fala frequente da assistente social era: "Puxa, não é possível que a criança não estuda por conta do tratamento"105.

105 Entrevista concedida pela PROFESSORA 2. Entrevista I. [ago. 2017]. Entrevistador: Claudinéia Maria Vischi Avanzini. Curitiba, 2016. 1 arquivo.mp3 (1h35min.41seg.). A entrevista na íntegra encontra-se transcrita nos Apêndices C e I desta tese. 
A Assistente Social ministrava aula no curso de Serviço Social na PUCPR no período que começou a trabalhar na Associação Hospitalar de Proteção à Infância Dr. Raul Carneiro e onde implantou a Hospitalização escolarizada, sendo que trabalhou nesta universidade por 20 anos, começando quando se mudou para Arapongas em 1951, depois de se casar.

\subsubsection{Os lugares, os espaços e a materialidade da Educação Hospitalar}

Com relação à materialidade da Educação Hospitalar vários sujeitos envolvidos cotidianamente com o projeto indicam algumas possibilidades concretas, além disto, algumas notícias de jornais colaboraram para iluminar ainda mais essa questão.

A Assistente Social destacou em sua entrevista que, dentre os materiais utilizados na hospitalização escolarizada havia os quadros negros que eram utilizados pelas professoras em suas aulas com os alunos hospitalizados. (ASSISTENTE SOCIAL, 2016). De acordo com Muggiati (1989, p. 42), os quadros de giz que as professoras utilizavam eram "assentados em cavaletes, com pequenas rodas, deslocáveis pelas diversas enfermarias", além disso, havia um quadro menor para atender as crianças com alguma situação de tração e que ficaria próximo a ela. (GAZETA DO POVO, 1988, p. 40).

Além disto, para as atividades realizadas no leito, eram usadas "pequenas carteiras especiais, confeccionadas no hospital, com tampas graduáveis, correspondentes às necessidades específicas de cada criança" que poderiam escrever mesmo que precisassem ficar "deitadas, ou sentadas, sem mínima interferência ou interrupção do tratamento". Segundo várias notícias de jornal, tais carteiras foram desenhadas pelo diretor clínico do hospital, ex-secretário da saúde, Ivan Beira Fontoura. (MUGGIATI, 1989, p. 42; GAZETA DO POVO, 1988, p. 40; FOLHA DE LONDRINA, 1988, s/p).

Em sua entrevista, a Professoras 1 (2016) destacou as seguintes informações sobre esta carteira especial existente no momento em que ela começou a trabalhar no hospital:

Nós tínhamos aquelas carteiras adaptáveis. Eram de um material fino, uma espécie de MDF, não sei especificar, eram de madeira leve, elas foram recortadas, uma espécie de caixotes que se encaixavam ao corpo, uma mesinha que se encaixava ao corpo das crianças nas laterais e uma prancheta que dava para encaixar algo na altura do rosto. E nelas, apoiando o material as crianças escreviam, principalmente as crianças da clínica de Ortopedia, elas ficavam imóveis, não podiam se mexer, não podiam sair das 
enfermarias, não saiam nem da cama. Então, pensando naquelas crianças, principalmente, foi que a [Assistente Social] conseguiu encontrar a solução para assegurar o atendimento. Quando cheguei elas já estavam lá. E realmente eram grandes, mas eu as levava uma a uma para as enfermarias e era com elas que eu trabalhava. Elas não podiam ficar nas enfermarias, tinham que voltar para a sala, eram pintadas de branco, com tinta à base de óleo, porque precisavam ser higienizadas depois, era necessário passar um pano para fazer a assepsia. Então aquelas carteiras já estavam lá. E depois disso, nada mais sugestivo foi inventado. (PROFESSORA 1, 2016).

Figura 12: Carteiras utilizadas na Hospitalização Escolarizada.

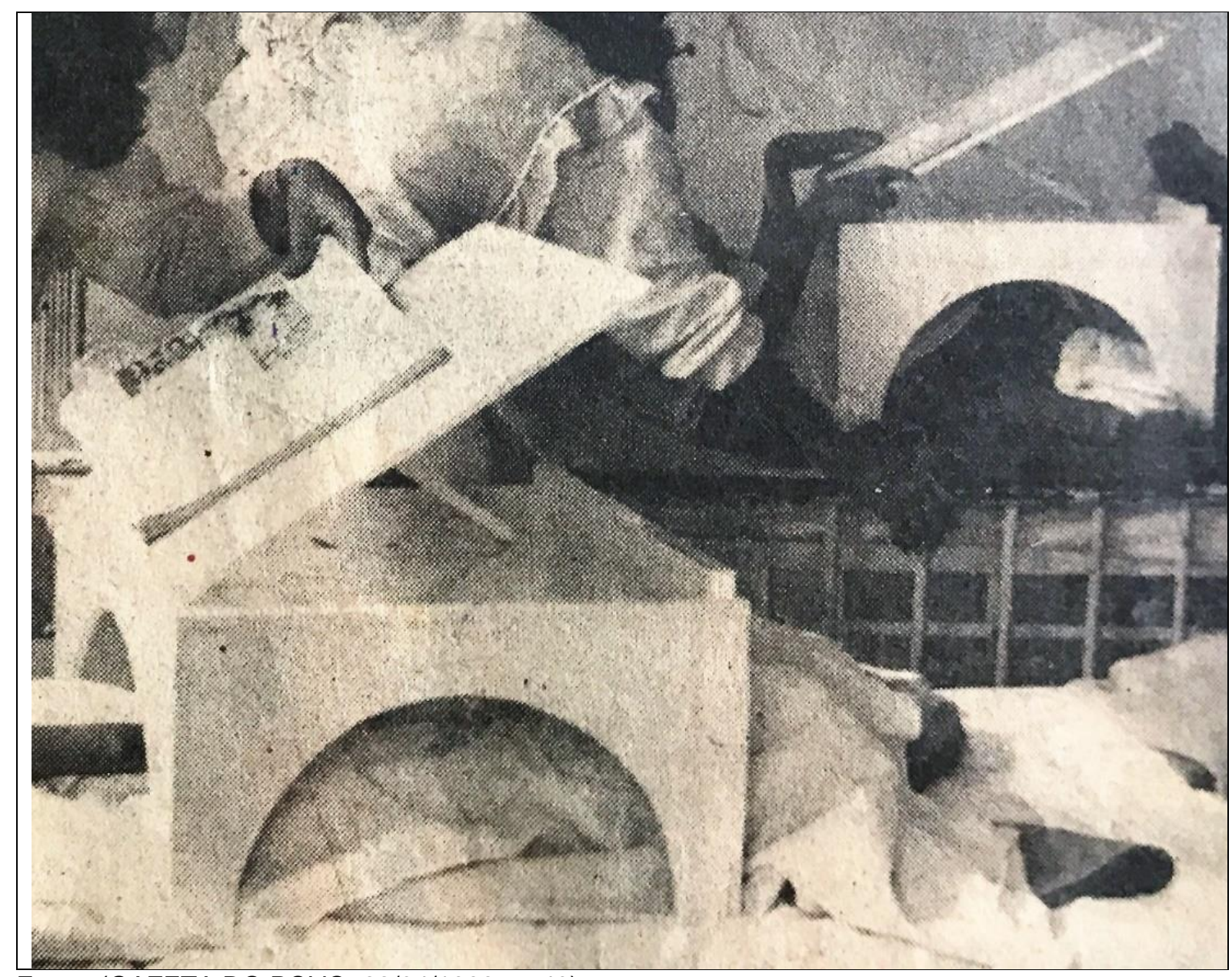

Fonte: (GAZETA DO POVO, 22/04/1988, p. 40).

No jornal diário Gazeta do Povo é possível observar imagens destas carteiras adaptadas em pleno uso com as crianças internadas e nos leitos na figura $12 . \mathrm{Na}$ imagem retratada na página do jornal é possível ver duas carteiras adaptáveis ao corpo de duas crianças nos próprios leitos de cada uma delas, essas carteiras adaptadas, confeccionadas pelo diretor clínico do hospital na época, Dr. Ivan tinham o tampo, tipo prancheta móveis para que as crianças pudessem escrever. Segundo depoimento de uma das professoras entrevistadas, 
[...] essas caixinhas eram muito utilizadas, principalmente na Ortopedia, onde as crianças ficavam no leito, elas não se locomoviam. [...] Era uma carteira que se adaptava ao corpo e tinha uma pranchetinha. Então ali a criança conseguia colocar a atividade, escrever, bem como servia de suporte para um livro, para uma leitura. (PROFESSORA 1, 2016).

O material escolar, tanto permanente como o de consumo, era fornecido pela Fundação Educacional do Paraná (FUNDEPAR) ou pela Associação Hospitalar que administrava o hospital e ficava à disposição do projeto de Hospitalização Escolarizada, sendo que uma das professoras entrevistadas destaca que ela utilizava ainda folhas, livros, lápis de cor, lápis, apontador, que eram levados dentro de uma caixa organizadora, assim como um volume de atividades. Enfim, o que seria necessário durante o dia de trabalho.

Nós usávamos também, pranchetas normais, levávamos dentro de uma caixa
os materiais: lápis, lápis de cor, as folhas destacadas, os cadernos, os livros
que nós tirávamos as atividades para as crianças olharem, alguns livrinhos
de historinha. Enfim, isso tinha uma caixa. Era um transporte constante, na
época não havia ainda cestinha de supermercado, carrinho, hoje seria bem
mais fácil transportar, na época não, perdia-se algum tempo, perdia-se ou
ganhava-se levando esses materiais para as enfermarias. (PROFESSORA 1,
2016).

Além disto, havia momentos que as professoras aplicavam as provas/avaliação, apesar desta não ser a função primordial do projeto, elas deveriam apenas dar suporte no desenvolvimento de atividades pedagógicas, entretanto, as avaliações precisavam ser aplicadas às crianças atendidas, segundo o depoimento delas. A avaliação era responsabilidade da escola, que deveria avaliar a criança quando esta retornava para o ambiente escolar após alta hospitalar. Entretanto, em alguns momentos, algumas escolas solicitavam e enviavam as avaliações, que eram aplicadas pelas professoras no hospital e depois eram enviadas para a escola para serem corrigidas, porque a questão da avaliação específica, as notas, enfim, esse controle era realizado pelas professoras das escolas de origem das crianças atendidas no hospital ${ }^{106}$.

Segundo a Professora 2 (2017), que atendia somente na hemodiálise, não havia um lugar específico para fazer os atendimentos/aulas, as aulas aconteciam naquele setor mesmo, não havendo uma sala específica, principalmente porque os alunos não saiam da máquina. Então, as aulas aconteciam com a professora sentando

\footnotetext{
106 Entrevista concedida pela PROFESSORA 1. Entrevista I. [ago. 2016]. Entrevistador: Claudinéia Maria Vischi Avanzini. Curitiba, 2016. 1 arquivo.mp3 (60min.). A entrevista na íntegra encontra-se transcrita nos Apêndices $\mathrm{C}$ e $\mathrm{H}$ desta tese.
} 
num banco plástico ao lado da máquina onde a criança fazia o tratamento. Com relação à prática de trabalho, estas também eram adequadas a esta realidade.

\begin{abstract}
As atividades eram sempre feitas em pranchetas, por conta da posição da criança, porque não tinha uma mesa. E uma coisa que eu utilizei e que achava bem legal na época, eu fui num Calheiro e pedi para ele fazer uma placa de zinco um pouquinho maior que o A4, utilizava alfabeto móvel, figuras, atividades que eu colocava aquelas plaquinhas de imã. Hoje se acha isso para vender, mas antigamente não tinha. Então a gente utilizava aqueles imãs de propaganda de gás, da panificadora... Quando ia fazer uma atividade com o alfabeto móvel ou qualquer outra atividade, eu colava o imã nestes materiais para utilizar nessa placa. Assim conseguia trabalhar no concreto. (PROFESSORA 2, 2017).
\end{abstract}

A professora ainda destaca que no início de seu trabalho em 1998, os materiais que utilizava eram oferecidos pela própria instituição, a Associação Criança Renal. A partir de 2005, o município começou a mandar material como lápis, borracha, pranchetas, livros, jogos pedagógicos, material dourado, que segundo ela, na época estava começando a ser bastante usado no município. Dentro da sala da hemodiálise, tinha um armário onde todo esse material era guardado. Além disso, tinham as fichas das crianças, utilizadas para registrar os relatos das professoras com relação aos atendimentos, os dados da escola, com quem era falado no contato com a escola, porque além do papel do professor, era também as professoras que faziam o papel do pedagogo, do diretor, de tudo o que fosse preciso. (PROFESSORA 2, 2017).

A Professora 1 (2016), em sua entrevista explicou que as atividades e os materiais que utilizava com os alunos nas aulas no hospital eram baseados nos planejamentos da própria Secretaria de Educação que separava os conteúdos para cada série, ela seguia um roteiro como se fosse em uma escola, como se estivesse em uma sala de aula regular, porque ela sabia que se aquela criança estivesse em sala de aula, estaria estudando determinados conteúdos pertinentes ao nível, a série e ao bimestre no qual estavam. O contato com a escola de origem das crianças era feito quando ela tinha oportunidade e conseguia. Nestes casos, a escola fornecia a orientação, a programação, o planejamento da turma do aluno que ela estaria atendendo. Ela deixou bem claro que era somente o planejamento, pois as atividades eram escolhidas e selecionadas pela própria professora, ela mesmo que organizava segundo os livros que ela levava para as enfermarias. Nesses livros, ela mostrava figuras, ilustrações, dava as explicações e as crianças desenvolviam as atividades propostas pela professora. 
Quando eram crianças que ficavam internadas em longa permanência eu preparava um caderno e as atividades ficavam no caderno. Quando eram de internamento de curta duração eu fazia em folhas separadas, sempre arquivava isso em envelopes e quando as crianças voltavam para as escolas, elas levavam as produções, por isso não ficavam no hospital. Raramente ficava uma ou outra produção de criança. As crianças voltavam e mostravam para as professoras de origem, para as escolas de origem o que elas produziram enquanto estiveram internadas. Até para que as professoras pudessem sim, elaborar avaliações partindo dos conteúdos que foram trabalhados. (PROFESSORA 1, 2016).

Como destacado pela professora, as atividades poderiam ser feitas em cadernos ou folhas avulsas que sempre eram encaminhadas pelas crianças para as suas escolas de origem no momento de suas altas, desta forma seus professores podiam acompanhar o que havia sido realizado pedagogicamente pela professora do hospital.

Ao ser questionada sobre seus conhecimentos a respeito do currículo implantado pelo Estado, afinal seus planejamentos eram embasados nos documentos oficiais do Estado do Paraná, ela argumentou que quando ingressou no hospital já tinha uma bagagem como professora, já havia sido estagiária da SEED por dois anos, em 87 e 88, já atuava em escolas estaduais como estagiária de $1^{\underline{a}}$ ao $4^{\underline{a}}$ série e em 89 foi professora regente numa escola da Rede Estadual, então, por já ter esse contato, sabia como funcionava. Ainda destacou que na época não havia essa flexibilidade de conteúdos que hoje a educação propõe, "era uma sistematização e era algo mais rígido. Não havia muita variação de conteúdo". Os conteúdos eram separados por turma e em bimestres, sendo bastante claro o que seria necessário trabalhar com cada uma das turmas desde a $1^{\text {a }}$ até a $4^{\underline{a}}$ série. Segundo a professora, ela seguia roteiros, retirava propostas de atividades dos livros, "mas seguia roteiros preestabelecidos pela própria Secretaria de Educação"107.

Muggiati (1989, p. 42) chama a atenção para a precariedade das condições físicas no que tange o funcionamento do projeto, afinal, por conta de um remodelamento das alas hospitalares as atividades estavam prejudicadas. Esse remodelamento também é destacado pela Professora 1 (2016) entrevistada como a causa da perda da sala utilizada nos primeiros anos do convênio para a realização das aulas dentro do hospital.

107 Entrevista concedida pela PROFESSORA 1. Entrevista I. [ago. 2016]. Entrevistador: Claudinéia Maria Vischi Avanzini. Curitiba, 2016. 1 arquivo.mp3 (60min.). A entrevista na íntegra encontra-se transcrita nos Apêndices $\mathrm{C}$ e H desta tese. 
No ano de 1990 havia sim uma sala pequena com uma mesa e quatro cadeiras, onde de maneira agendada nós poderíamos levar crianças para o atendimento, porém isso tinha que ser feito de uma maneira organizada, porque eu não poderia atender uma criança de 4⿳亠丷a série e a minha colega de trabalho atender uma criança de $1^{\underline{a}}$ série, onde ela estaria alfabetizando no mesmo momento que eu estaria trabalhando outro conteúdo, isso iria interferir e atrapalhar no desenvolvimento da atividade. Então nós combinávamos um período de tempo para que cada qual fizesse uso da sala com as crianças, para os alunos que poderiam sair das enfermarias. Isso era benéfico emocionalmente, as crianças se locomoviam, saiam da cama e não se sentiam tão aprisionadas ao leito. Então isso era bom pra crianças que podiam. As crianças que não podiam sair do leito, os atendimentos eram feitos também dentro de uma organização, havia um cronograma de atendimento. $\mathrm{E}$ mais ou menos em um período de uma ou duas horas para cada criança no próprio leito. Depois de 1990, essa sala deixou de existir por uma questão de reforma e não mais a resgatamos, passamos sim a planejar e fazer a nossa organização junto ao Serviço Social, na mesma sala e atendimento somente nas enfermarias. (PROFESSORA 1, 2016).

A Professora 1 deixa bem claro em sua entrevista que, mesmo quando elas tinham a sala a disposição da Educação, os atendimentos educacionais poderiam acontecer na sala de aula ou nos leitos. Os motivos que levavam a essa diversidade de atendimento se dava por conta da organização para o uso da sala, pela mobilidade/imobilidade das crianças que seriam atendidas e pela impossibilidade do atendimento de crianças das diferentes séries conjuntamente. Segundo a professora, seria muito complicado o atendimento concomitantemente de uma criança de $4^{\mathrm{a}}$ e outra de $1^{\text {a }}$ série, mesmo que com professoras diferentes, pois isso iria interferir e atrapalhar no desenvolvimento das atividades de alfabetização com a criança da $1^{\text {a }}$ série ou no trabalho com outro conteúdo com a criança de $4^{\underline{a}}$ série. Por conta disto, as diferentes professoras tinham horários diferenciados para o uso da sala por dia, tinham um cronograma de atendimento.

O benefício emocional, a possibilidade da locomoção das crianças que saiam da cama e não se sentiam tão aprisionadas ao leito foram os pontos positivos indicados pela professora para que os alunos pudessem sair das enfermarias e irem para a sala terem aulas. Entretanto, para as crianças que não podiam sair do leito também havia uma organização dos atendimentos para que cada um tivesse uma ou duas horas de aulas no próprio leito. 
Figura 13: Croqui da sala de aula do Hospital utilizada até 1991

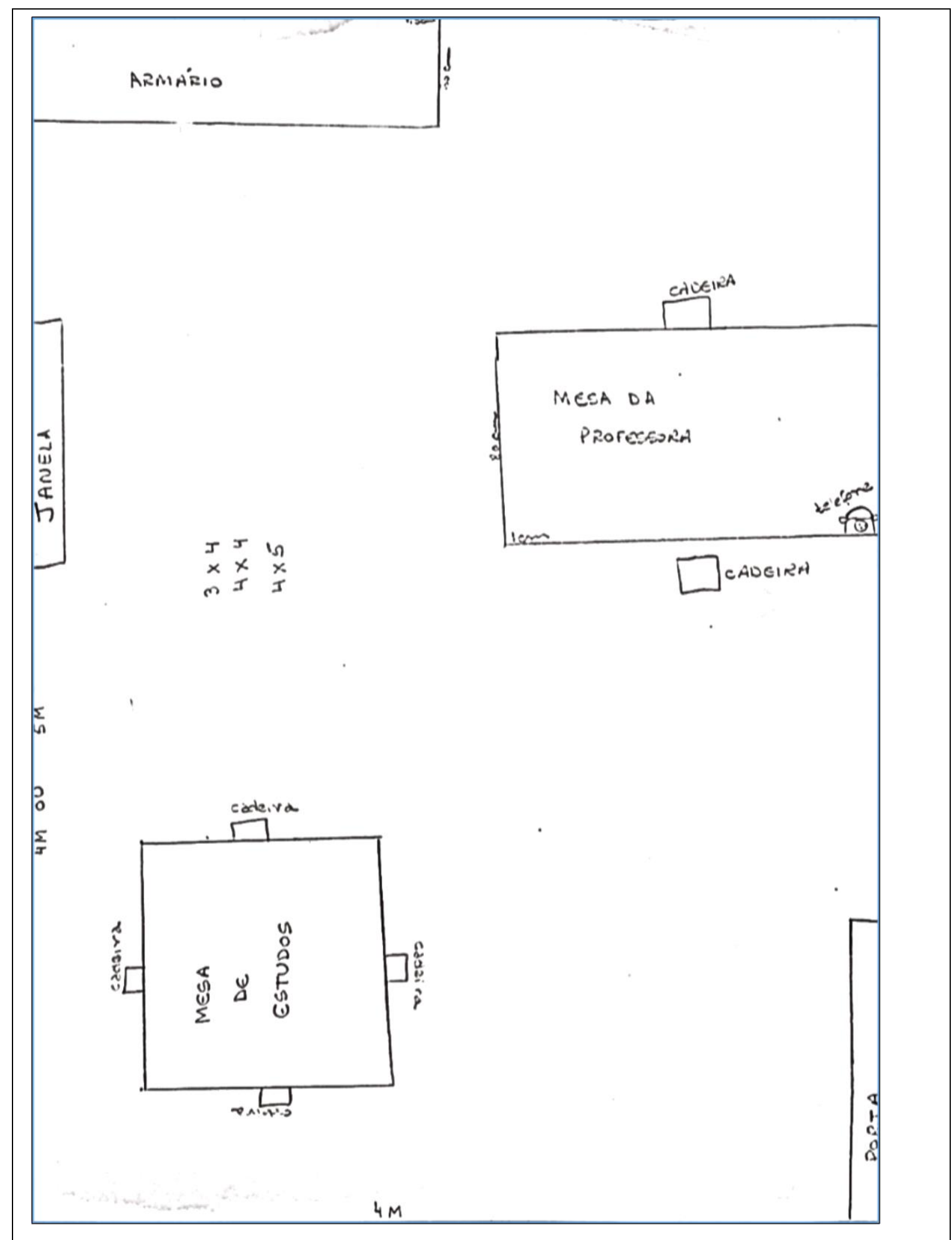

Fonte: Desenho cedido pela Professora 1.

Com relação a sala de aula utilizada até o ano de 1990, uma das professoras entrevistadas fez um esboço desta sala. No croqui, desenhado pela Professora 1, exposto na figura 13, não é possível ter certeza da real metragem da sala, pois a 
professora não se lembrava exatamente do tamanho, entretanto, deixou as possíveis medidas da mesma registrada no centro do desenho e nas paredes. Ela indicou que a sala poderia ser de $3 \times 4 \mathrm{~m}^{2}, 4 \times 4 \mathrm{~m}^{2}$ ou ainda $4 \times 5 \mathrm{~m}^{2}$. No desenho, a professora destacou os locais onde ficavam porta, canto inferior do esboço, e janela, praticamente no meio da parede paralela à porta. Na sala havia um armário que media em torno de $1,5 \mathrm{~m} \times 0,6 \mathrm{~m}$ e uma mesa de professora que media em torno de $1 \mathrm{~m} \times$ 0,8m com duas cadeiras, sobre essa mesa é possível observar a presença de um telefone e para completar o mobiliário da sala da Hospitalização Escolarizada havia ainda uma mesa de estudos com quatro cadeiras, na qual não foi feita nenhuma menção sobre o tamanho destes móveis.

Tal representação nos indica que neste ambiente não seria possível levar um grande número de alunos, pois além do local ser bastante reduzido, havia somente cinco cadeiras para alunos na sala. A professora entrevistada destacou como era a sala e que esta foi destinada por um período bem curto ao trabalho de Educação Hospitalar de alguns alunos que podiam sair dos leitos.

Além dos dados apresentados no croqui, a Professora 1 descreve em sua entrevista como era essa sala da Hospitalização Escolarizada.

No período também curto quando eu entrei no Pequeno Príncipe havia uma
sala pequena. Ela tinha uma mesa, umas 4 cadeiras, uma mesa de professor,
uma mesa de escritório, um telefone, um armário. Inicialmente era uma sala
só para as professoras, mas isso não perdurou por muito tempo, porque o
hospital estava sempre em reforma e modificações e houve a necessidade
de absorver aquela sala para algum setor. Então logo após o uso daquela
sala, ela foi absorvida, nunca mais nós obtivemos um espaço específico para
levar as crianças. Aí sim, o atendimento era só nas enfermarias. Foi um
período bem curto, um ano mais ou menos. (PROFESSORA 1,2016).

Apesar da sala não ser mais disponibilizada para a educação, as atividades educacionais não deixaram de acontecer. As professoras passaram a utilizar a sala do Serviço Social para planejar e se organizar antes de suas aulas e os atendimentos passaram a ser realizados exclusivamente nos leitos, nas próprias enfermarias do hospital. Para essas aulas nos leitos, a Professora 1 (2016) destaca que ela utilizava as carteiras adaptadas e uma outra caixa organizadora onde levava os materiais educacionais e pedagógicos que usaria nas aulas. Com relação aos jogos, destacou que na época havia bem poucos jogos, pois não havia nem produção destes materiais, muito menos o uso como se observa na atualidade. Segundo ela, "hoje se tem uma gama muito intensa de materiais, [...] trabalha-se jogos dentro da sala de aula, isso faz parte da rotina do professor, na época isso era algo inacessível, poucas pessoas 
tinham acesso a isso", além disso, também não se percebia "que jogos fosse algo tão importante", sendo que seu uso estava mais ligado à recreação. Entretanto, com relação aos livros, a Professora 1 (2016) informou que buscava esses volumes de livros nas editoras e os usava como base na organização de suas atividades, porque não tinha livros para distribuir para as crianças visto que cada uma delas pertencia a "uma escola diferente com escolhas de materiais pedagógicos também distintos"108. Enfim, com esses materiais educacionais a professora oferecia o suporte no desenvolvimento de atividades pedagógicas de cada criança atendida na educação hospitalar.

Os atendimentos nas enfermarias eram realizados quase sempre com até duas crianças de forma bastante individualizada, pois as professoras normalmente explicavam as atividades diferenciadamente para cada criança, enquanto uma desenvolvia a sua tarefa a professora ia alternando as explicações para a outra criança. Desta forma, era dando tempo para que cada uma fizesse as tentativas de desenvolvimento, de resolução da atividade com retorno da professora junto aos alunos somente para conferência e correção das atividades repassadas nas aulas.

Ao ser questionada sobre o progresso observados nas crianças que eram atendidas, a Professora 1 (2016) destacou que as próprias crianças manifestavam o quanto era importante para elas serem atendidas. Além disto, a professora comentou que quando chegava nas enfermarias, as crianças estavam aguardando a sua chegada. "A aula, para elas, fazia parte do tratamento hospitalar, elas aguardavam o momento de serem atendidas. O atendimento da professora para elas era muito importante"109.

A organização da professora para esses atendimentos nas enfermarias também acontecia nas diferentes clínicas onde ela atendia. Como a professora em questão atendia nas Clínicas da Nefrologia e da Ortopedia, ela se organizava para ficar metade do período numa clínica e a outra metade em outra, com alternância de horário nos diferentes dias da semana para poder atender os diferentes alunos que

\footnotetext{
108 Entrevista concedida pela PROFESSORA 1. Entrevista I. [ago. 2016]. Entrevistador: Claudinéia Maria Vischi Avanzini. Curitiba, 2016. 1 arquivo.mp3 (60min.). A entrevista na íntegra encontra-se transcrita nos Apêndices $\mathrm{C}$ e $\mathrm{H}$ desta tese.

109 Entrevista concedida pela PROFESSORA 1. Entrevista I. [ago. 2016]. Entrevistador: Claudinéia Maria Vischi Avanzini. Curitiba, 2016. 1 arquivo.mp3 (60min.). A entrevista na íntegra encontra-se transcrita nos Apêndices $\mathrm{C}$ e $\mathrm{H}$ desta tese.
} 
pudessem estar nestes locais. "Eu tinha um cronograma, tinha uma divisão que eu previa os atendimentos para equilibrar isso, e deixar justo" 110 .

\subsubsection{A efetivação do Projeto de Educação Hospitalar, seus professores, crianças e famílias}

O Projeto de Educação Hospitalar tem seu marco inicial em Curitiba, Paraná em 1988 quando o Projeto Mirim de Hospitalização Escolarizada começa os seus atendimentos. Segundo Pacheco (2017, p. 154), nove professoras municipais trabalharam neste hospital entre 1988 e 2002 . Após este ano, outras treze professoras também trabalharam neste local, sendo que dessas treze, 6 ainda trabalhavam até o final de 2017. Segundo a Professora 1 entrevistada para a produção deste trabalho, além da professora cedida experimentalmente em 1988, somente ela trabalhou pela Secretaria do Estado de Educação no hospital entre 1990 a 1999, quando o convênio com a Secretaria do Estado do Paraná é interrompido. O Estado retoma esses atendimentos somente depois de sete anos quando é implantado um outro serviço de atendimento hospitalar para atender estudantes impossibilitados de frequentar a escola por conta de internamentos ou tratamentos de saúde, o SAREH.

Os sujeitos da Educação Hospitalar paranaense são professores, alunos, assistente social, estagiários de magistério e pais dos alunos que eram atendidos nos hospitais, além de implicitamente também serem os médicos, enfermeiros, auxiliares de enfermagem, psicólogas, enfim, a maioria dos profissionais do hospital que tinham contato direto ou indireto com as crianças e adolescentes em tratamento e que recebiam a escolarização neste mesmo período e local. Para esta pesquisa restringi o olhar e esforços para colher informações, experiências e memórias dos professores, ex-alunos, assistente social e mãe de uma ex-aluna da Educação Hospitalar por meio de entrevistas, fotografias, registros escritos ou publicações em jornais diários da capital e do estado.

A escolha das professoras considerou o fato delas terem trabalhado com a Educação Hospitalar no período do recorte proposto para a pesquisa, sendo que a professora com o vínculo estadual oficialmente, foi a primeira professora disponibilizada pela Secretaria de Estado da Educação para fazer esse trabalho, a

110 Entrevista concedida pela PROFESSORA 1. Entrevista I. [ago. 2016]. Entrevistador: Claudinéia Maria Vischi Avanzini. Curitiba, 2016. 1 arquivo.mp3 (60min.). A entrevista na íntegra encontra-se transcrita nos Apêndices $\mathrm{C}$ e $\mathrm{H}$ desta tese. 
professora liberada antes que ela começasse a trabalhar no hospital com Educação Hospitalar ficou provisoriamente durante quatro meses experimentais para que fosse realizada uma avaliação dos resultados considerados positivos para que o convênio realmente se efetivasse junto a rede estadual. A professora do município trabalhou do ano de 1998 até 2005 com a Educação Hospitalar "num espaço que era arrendado para a Associação Criança Renal, [posteriormente Fundação Criança Renal] e que ficava dentro do Hospital Pequeno Príncipe". Ela começa a trabalhar no local após ter trabalhado por praticamente 10 anos em escolas de Educação Especial e já estar por dois anos concursada na rede municipal de Educação de Curitiba.

A figura 14, retirada da capa do Jornal diário Gazeta do Povo em meados de março de 1998 foi fotografada por Edson Silva e consistia na chamada para a reportagem da página 05 intitulada "Criança vai estudar durante hemodiálise". Logo abaixo da imagem na capa do jornal é possível encontrar a seguinte descrição: "Aula durante Hemodiálise. Parceria com a Secretaria Municipal de Educação permite que as crianças submetidas a sessões de hemodiálise, que duram quatro horas, possam estudar enquanto estão ligadas ao aparelho".

Figura 14: Fotografia de uma professora junto a um aluno ligado na máquina de hemodiálise.

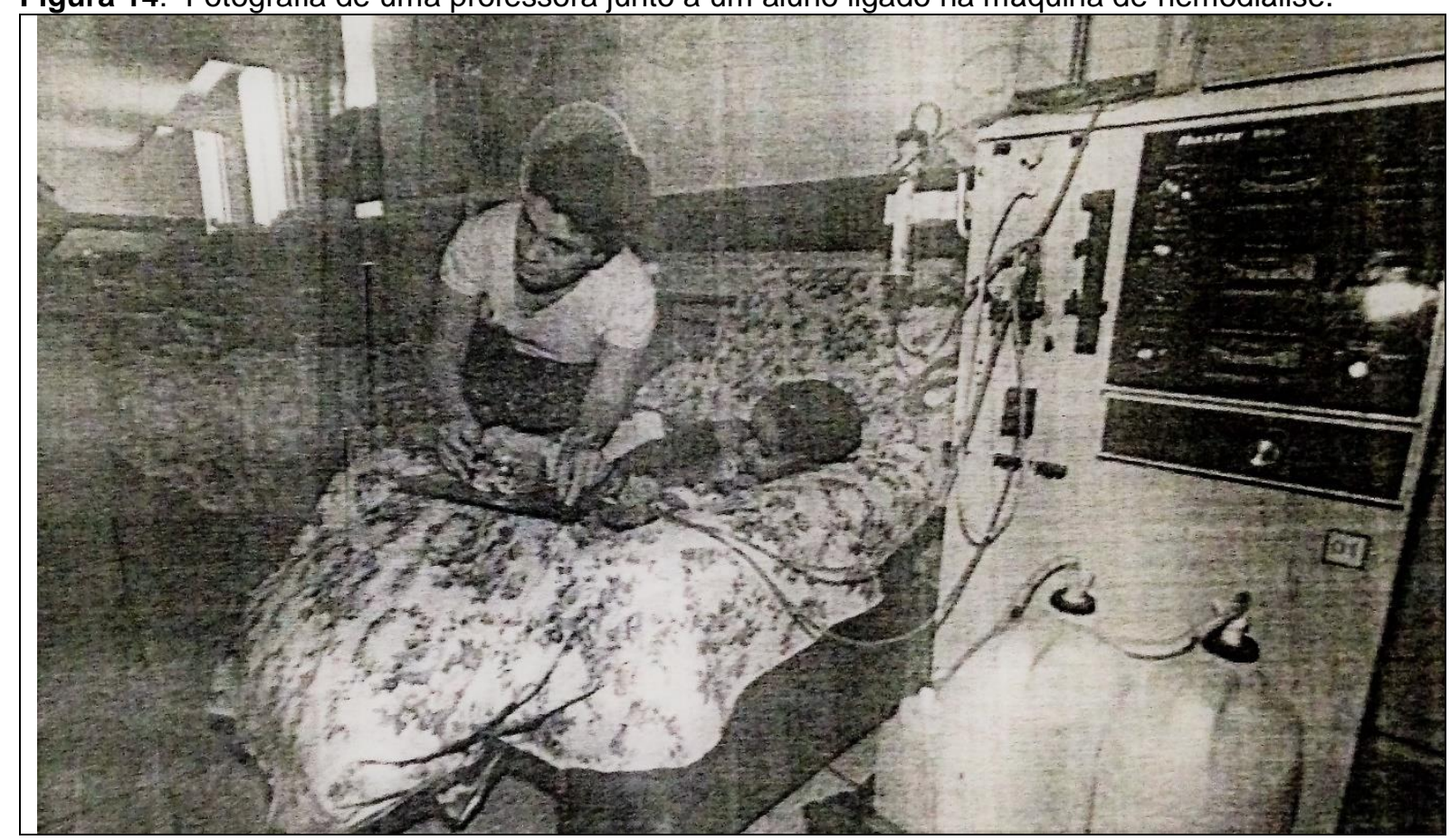

Fonte: GAZETA DO POVO, 14/03/1998, p. 01.

A fotografia retrata uma professora curvada sob a criança que está conectada por dois cateteres numa máquina de hemodiálise, que parecia estar ligada, o que indica que a sessão de hemodiálise daquela criança estava em andamento. Ao que 
parece, a professora está com uma prancheta nas mãos, olhando para a frente e organizando alguma atividade que seria repassada para a criança, que, por sua vez, olha interessada para o material organizado pela professora. No artigo há a informação de que 22 crianças estariam recebendo há seis meses aulas ofertadas por duas professoras cedidas pelo Secretaria Municipal de Educação para a Associação Criança Renal no Hospital Pequeno Príncipe. "Segundo a professora Juliana Bley, que dá aulas no período da manhã, muitas crianças que não sabiam sequer reconhecer uma vogal, em pouco tempo já estavam lendo". (GAZETA DO POVO, 14/03/1998, p. 05).

A mãe entrevistada, mais um sujeito da Educação Hospitalar paranaense, tem uma filha que foi atendida pela Educação Hospitalar entre os anos de 1991 e 1993, período em que fazia hemodiálise no hospital. Em 25 de agosto de 1993 a ex-aluna realizou o transplante e, segundo a mãe (2016), sua filha ficou em tratamento neste hospital de 1991 a 2001, quando ela perdeu o rim transplantado e teve que voltar a fazer hemodiálise num outro hospital de adulto, pois já estava com 18 anos e não tinha mais idade para continuar o acompanhamento no hospital infantil ${ }^{111}$. A mãe entrevistada se intitula uma pessoa do interior, sem muitos recursos ou conhecimentos médicos, chegando a resistir ao tratamento da filha quando as questões de saúde foram se agravando. Ela é auxiliar de serviços gerais num Colégio Estadual em Curitiba no Paraná e já trabalhava em escolas quando a filha passou a frequentar o universo escolar e hospitalar. Entretanto, destaco que ela, como uma boa parte de familiares com filhos em atendimento no hospital são pessoas bem simples, carentes e com baixo índice de escolarização. Esse tipo de informações é observado no discurso da Assistente Social entrevistada ${ }^{112}$ e também encontrado no site do hospital ao descrever as políticas de humanização direcionadas "para crianças e adolescentes de famílias em sua maioria de baixa renda e baixo nível de escolarização"113 e também, no início da página que trata do voluntariado no hospital, que

\footnotetext{
${ }^{111}$ A informação de que os adolescentes maiores de 18 anos deixavam de ser atendidos na Associação Hospitalar de Proteção à Infância Dr. Raul Carneiro é confirmada na entrevista da Assistente Social cedida no ano de 2010.

112 Entrevista concedida pela ASSISTENTE SOCIAL. Entrevista I. [ago. 2010]. Entrevistador: Claudinéia Maria Vischi Avanzini. Curitiba, 2010. 1 arquivo.mp3 (14min.19seg). A entrevista na íntegra encontra-se transcrita nos Apêndices A e F desta tese.

113 Disponível em http://pequenoprincipe.org.br/hospital/politicas-de-humanizacao/. Acesso em 27/07/2018.
} 
Desde 1919, [...] conhece bem a importância do voluntariado e da solidariedade, pois é fruto da iniciativa voluntária de um grupo de mulheres da comunidade curitibana que decidiu viabilizar um inédito atendimento em saúde para a população carente da cidade, primordialmente as crianças ${ }^{114}$.

Essa informação com relação às crianças atendidas nos hospitais da Associação Hospitalar de Proteção à Infância Dr. Raul Carneiro de que pertenciam a níveis mais baixos de renda e escolarização se repete em outras fontes pesquisadas, como por exemplo na entrevista do ex-aluno que se declarou pertencente a classe menos favorecida econômica e socialmente. Segundo suas palavras fazia parte de uma "família humilde", seu pai era funcionário público de nível médio, sua mãe dona de casa analfabeta e os irmãos mais velhos trabalhavam como boias-frias no interior do Paraná ${ }^{115}$. A Assistente Social (2010) em entrevistada destacou que as profissões dos pais das crianças atendidas no hospital em sua maioria eram de domésticas, pedreiros, carpinteiros, pessoal de uma renda econômica mais baixa. Contudo, a Assistente Social informou que com o passar do tempo o hospital começou a atender convênios e particulares no ambulatório e internamentos o que trouxe um outro público para o hospital. Apesar disso, a maioria dos atendidos continuou sendo para pessoas "com poucos recursos financeiros"116.

De acordo com informações prestadas pelas professoras entrevistadas, as crianças atendidas na Educação Hospitalar na década de 90 em sua maioria oriundas do interior do estado e eram as que estudavam nas quatro primeiras séries do Ensino Fundamental. Todavia, percebendo que muitas dessas crianças do universo hospitalar tinham desistido da escola por conta da doença ou do tratamento, as professoras acabaram auxiliando também os adolescentes que evadiram da escola a retornar para os bancos escolares, algumas vezes recorrendo à Educação de Jovens e Adultos.

[...] a professora Juliana Bley, que dá aulas no período da manhã [na hemodiálise do hospital] [...] lembrou que as crianças que têm que passar por sessões de hemodiálise costumam ficar deprimidas e uma das principais consequências dessa depressão é o abandono da

\footnotetext{
114 Disponível em http://pequenoprincipe.org.br/hospital/voluntarios/. Acesso em 27/07/2018.

115 Entrevista concedida pelo EX-ALUNO. Entrevista I. [abril. 2018]. Entrevistador: Claudinéia Maria Vischi Avanzini. Curitiba, 2018. 1 arquivo.mp3 (41min.27seg.). A entrevista na íntegra encontra-se transcrita nos Apêndices $\mathrm{D}$ e $\mathrm{K}$ desta tese.

116 Entrevista concedida pela ASSISTENTE SOCIAL. Entrevista I. [ago. 2010]. Entrevistador: Claudinéia Maria Vischi Avanzini. Curitiba, 2010. 1 arquivo.mp3 (14min.19seg.). A entrevista na íntegra encontra-se transcrita nos Apêndices A e F desta tese.
} 
escola. O trabalho das professoras, disse ela, também é incentivar essas crianças a voltar a estudar. (GAZETA DO POVO, 14/03/1998, p. 05).

Finalmente, a efetivação do projeto de Educação Hospitalar no universo paranaense se dá pela continuidade dos atendimentos pedagógicos ininterruptamente até os dias atuais, apesar de sabermos que o Estado se retirou do hospital entre os anos de 1999 a 2007, o hospital continuou oferecendo o atendimento com as professoras municipais, informação inclusive confirmada no site do hospital, que ao destacar entre os trabalhos de humanização pertencentes ao universo hospitalar informa que

[...] garante, há quase 30 anos, o direito à educação e cultura durante a internação, com o atendimento escolar vinculado ao colégio do paciente. Além disso, os pacientes têm a oportunidade de acesso à cultura por meio de oficinas e projetos que desenvolvem atividades artísticas, de leitura, prática de jogos, entre outras ${ }^{117}$.

Neste sentido, além de manter convênios com o Estado do Paraná e com a prefeitura do município de Curitiba para a cessão de professoras destes dois órgãos para atuar com a Educação Hospitalar, a própria Associação Hospitalar tem em seu quadro funcional, profissionais de educação que prestam serviços no Setor de Educação e Cultura em funcionamento desde 2002 (CARREIRA, 2016, p. 36).

\subsubsection{As primeiras professoras, seus vínculos e seus olhares para a Educação Hospitalar}

Entre as professoras que trabalharam no hospital onde a Hospitalização Escolarizada inicia no Paraná, foram entrevistadas duas professoras, uma vinculada à Educação Estadual e outra à Educação Municipal.

A professora estadual destacou que atuou como professora no hospital entre 1990 a 1998, sendo convidada pela Superintendência da SEED a trabalhar como professora no ensino de $1^{\underline{a}}$ à $4^{\underline{a}}$ série no hospital. Atualmente é do Quadro Próprio do Magistério (QPM) no Estado do Paraná trabalhando com a Educação de Jovens e Adultos, lecionando Português e Literatura. Ela começou a trabalhar em 1989 como professora da rede estadual de Educação do Paraná, tendo, portanto, vínculo há 30

\footnotetext{
117 Disponível em: http://pequenoprincipe.org.br/hospital/nossos-servicos/ Acesso em 27/07/2018.
} 
anos, é formada em Letras, Língua Portuguesa, tem especialização em Interdisciplinaridade na Educação Básica118.

A Professora 2, vinculada à Educação Municipal desde 1996, informou que sua formação é Normal Superior, especialista em Educação Especial, Educação Especial Inclusiva com ênfase em Avaliação Diagnóstica Escolar e mestre em Educação, trabalhando desde 1987 no magistério, sendo que em 1998 começa a trabalhar no hospital como professora e fica ali até 2016, se afastando por conta do mestrado. Ao ser questionada até quando trabalhou no hospital pesquisado, responde que não trabalhou neste hospital e sim "num espaço que era arrendado para a Associação Criança Renal e que ficava dentro do Hospital”, explica que o convênio onde trabalhava era entre o município e a Associação Criança Renal que posteriormente passou a ser Fundação Criança Renal. Portanto começou neste trabalho na Associação Criança Renal em 1998 ficando até agosto de 2005. Essa possibilidade de trabalho na Fundação surgiu por conta de um remanejamento logo no início da carreira, com poucos anos de rede foi remanejada para uma escola bastante distante de sua casa, como tinha dois filhos pequenos, em torno de 2 anos e meio, e sem condições de ir para essa escola distante foi lhe apresentado o convênio com a Associação, caso ela quisesse, pois era próximo da casa dela. Apesar de não saber nem do que se tratava acabou aceitando.

[...] quando cheguei no endereço que me deram era de um consultório médico. Pensei na hora, até comentei com meu marido: "Acho que me deram o endereço errado, porque não tem escola aqui, não tem nada". Aí meu marido disse: "Então bata no consultório para ver o que é, e aí você volta na Secretaria". Quando fui falar com a pessoa desse consultório, ela me disse: "Não, é pra cá mesmo", eu falei: "Como assim?" Ela falou: "É pra você trabalhar, é um convênio que nós temos com o município. O município cede professora. Era cessão de um profissional para trabalhar dentro do setor de hemodiálise, que ficava no Hospital Pequeno Príncipe, era um convênio com a Associação Criança Renal junto com a prefeitura. Foi assim que surgiu. (PROFESSORA 2, 2017).

Ao ser questionada sobre os motivos que a levaram a iniciar esse trabalho, a Professora respondeu que iniciou sua vida profissional, na Educação Especial e sentiu que aquele seria um trabalho diferenciado, não como a Educação Especial que estava acostumada, mas uma educação diferenciada, pois não seriam crianças com deficiência, público alvo da Educação Especial, entretanto essas crianças também

118 Entrevista concedida pela PROFESSORA 1. Entrevista I. [ago. 2016]. Entrevistador: Claudinéia Maria Vischi Avanzini. Curitiba, 2016. 1 arquivo.mp3 (60min.). A entrevista na íntegra encontra-se transcrita nos Apêndices $\mathrm{C}$ e $\mathrm{H}$ desta tese. 
estavam passando por um momento diferente, por um "momento especial de vida". Por considerar que seria um novo desafio e por ser mais fácil, porque estaria próximo da sua casa e dos seus filhos, aceitou. Apesar de não ser a primeira professora a trabalhar na hemodiálise do hospital, pois o convênio com a Associação havia começado em 1996 com uma professora no período da manhã e outra professora no período da tarde, esta do período da tarde, não conseguiu se adaptar, a Associação Hospitalar acabou solicitando a troca desta profissional, então a Professora 2 foi a terceira profissional cedida para trabalhar nesse convênio em substituição desta que pediu desligamento. A professora 2 passou a trabalhar no período da tarde, enquanto a professora municipal que continuou trabalhando permaneceu no período da manhã. (Informação verbal Professora 2) ${ }^{119}$.

A respeito da efetivação da implantação da Hospitalização Escolarizada no Hospital em 1988, a Professora 1 destaca que quando foi convidada para trabalhar no Hospital a escolarização já estava completamente implantada, assim como já existia o Termo de Cooperação Técnica, sendo que ela somente foi designada e a partir daquele momento, prestava serviço mensalmente, assinava o ponto e levava à SEED ou ao NRE. Destacou que anteriormente à sua entrada no trabalho na Hospitalização Escolarizada houve outra professora que trabalhou no hospital de forma experimental, com uma atuação voltada para a recreação, sendo que nada oficial foi registrado durante esse período inicial com o trabalho desta outra professora, não houve relatórios, nenhuma anotação, nada "que configurasse um trabalho efetivamente pedagógico", mesmo com o afastamento dela do trabalho, o Convênio seguiu os trâmites normais e na época já encontrava-se no Departamento Jurídico.

A Professora 1 (2016) ainda destaca que quando foi convidada "pela Superintendente da Educação da SEED”, após indicação de seu nome pela diretora com quem trabalhou em 1989, indicação realizada pela identificação nela de um perfil coerente para atuar com as crianças hospitalizadas, com características julgadas como necessárias para o desenvolvimento deste trabalho. A função da professora seria desenvolver a parte pedagógica do Projeto de Hospitalização Escolarizada não tendo "sobre ele quaisquer responsabilidades de base", sendo que para o

119 Entrevista concedida pela PROFESSORA 2. Entrevista I. [ago. 2017]. Entrevistador: Claudinéia Maria Vischi Avanzini. Curitiba, 2017. 1 arquivo.mp3 (1h35min.41seg.). A entrevista na íntegra encontra-se transcrita nos Apêndices C e I desta tese. 
esclarecimento de quaisquer tipos de dúvidas, deveria ocorrer junto a sua supervisora e chefe imediata, a Assistente Social no Pequeno Príncipe ${ }^{120}$.

Ao serem questionadas sobre a valorização e o reconhecimento da Educação Hospitalar e tentando responder em que medida esse projeto de educação, seus professores, alunos e atendimentos se efetivou no universo paranaense, as professoras entrevistadas indicaram as dificuldades com relação ao reconhecimento do trabalho delas na década de 1990, momento em que começaram a trabalhar dentro do hospital. A Professora 1 (2016) destacou que atualmente existe uma estrutura específica para esse projeto, tanto no município (SME) como no estado (SEED), sendo que esse atendimento é reconhecido, todos os profissionais dentro da área hospitalar o conhece, tanto com os profissionais da SME, quanto com os profissionais da SEED. Entretanto, na época que elas iniciaram o trabalho no hospital havia profissionais que nem imaginava sobre a existência daquele projeto, só as conhecendo no momento em que as viam atuando ou quando observavam as estagiárias trabalhando com as crianças hospitalizadas, pois, segundo ela, não era algo regulamentado, não era algo tão formal, nem reconhecido. Neste sentido, a Professora 2 (2017) destacou que no momento que iniciou o trabalho no Setor de Hemodiálise tanto a equipe de saúde, quanto a família valorizavam muito mais a questão da saúde que a escolarização, essa, muitas vezes era descartada no momento que a criança ficava doente. Segundo ela, isso acontecia porque a própria família direcionava toda a preocupação para a doença da criança, o foco seria a cura. No entanto, quando a possibilidade da escolarização começa a aparecer dentro do universo hospitalar, o foco se divide também para o viés educacional, que passa a se tornar importante para as crianças e suas famílias, pois com os atendimentos pedagógicos direcionados pelas professoras o resgate da escola acabava acontecendo.

[...] muitas vezes a gente percebia que quando chega de início eles tem um certo: "não, agora não. A gente vai pensar no transplante, vamos pensar no problema de saúde", mas à medida que eles vão vendo que a coisa acontece, que de repente esse transplante pode ser que não seja tão rápido assim, ele pode demorar um pouco mais, não vai sair em 6 meses, em 1 ano... às vezes demora mais tempo, no caso ali do setor ele dependia de um transplante ou de um doador da própria família que fosse compatível, ou de um rim de cadáver, então às vezes essa espera de meses passam-se anos. Então tá...

120 Entrevista concedida pela PROFESSORA 1. Entrevista I. [ago. 2016]. Entrevistador: Claudinéia Maria Vischi Avanzini. Curitiba, 2016. 1 arquivo.mp3 (60min.). A entrevista na íntegra encontra-se transcrita nos Apêndices $\mathrm{C}$ e H desta tese. 
E a gente vai ficar esperando, esperando a vida passar? E era uma coisa que eu colocava muito para as famílias, eu dizia: "vamos aproveitar o tempo, enquanto está tratando a doença vamos focar em outras coisas, porque, de repente ele vai sair daqui e daí? Se a coisa demorar um pouco mais para passar. O que eu vou fazer da minha vida agora?" Com os adolescentes foi nesse sentido que eu consegui resgatar a escola, eu dizia: "Tá, vocês vão transplantar e daí? O que vai ser sua vida? Você não estudou. Você esqueceu disso. Você foi vivendo a sua hemodiálise. Você ficou doente, vivendo um tratamento..." Claro que a gente ia colocando em outra linguagem, tentando mostrar didaticamente, pedagogicamente de uma outra maneira. "Mas o que vai ser da sua vida a hora que você transplantar, porque sua vida é casa, hemodiálise, casa, hemodiálise. E a hora que transplantar. O que vai ser? Ah, é né! É, então vamos estudar". (PROFESSORA 2, 2017).

A professora demonstrava por meio de argumentos que a educação poderia acontecer concomitantemente ao tratamento de saúde que estava sendo realizado, e que também acabava auxiliando na divisão do foco que ficava compartimentado entre a doença e outras questões consideradas. Segundo ela, há ex-alunos que eram atendidos por ela quando crianças e que hoje estão fazendo mestrado, graduação, trabalhando, seguiram a vida. Segundo ela, eles comentam: "Puxa vida, ainda bem que você apareceu e que eu não fiquei parado esperando as coisas acontecerem".

Então, é legal, quando você vê essas histórias assim de que no momento da doença a gente tem uma outra questão que a gente pode ver também, que a gente não fica parado pensando que é só doença, porque a coisa acontece de focar muito na doença, no momento que você tira o foco também tem uma questão de que a vida é mais do que só doença, tem outras coisas que a gente pode viver. (PROFESSORA 2, 2017).

Apesar de toda essa valorização, de acordo com a entrevista desta mesma professora $^{121}$, o projeto de Hospitalização Escolarizada se efetiva no âmbito municipal somente em 2005, quando a Secretaria Municipal de Educação de Curitiba reconhece a existência de professores dentro de hospitais. Anteriormente, os convênios da educação junto aos hospitais não eram vinculados a um departamento pedagógico como o Ensino Fundamental ou a Educação Especial, mas ao departamento jurídico da Secretaria.

Segundo a entrevistada, o trabalho delas consistia em contatar as escolas, explicar a importância do trabalho educacional no hospital, como este acontecia e solicitar atividades para serem desenvolvidas com as crianças hospitalizadas. No início as escolas tinham certa dificuldade para entender como esse trabalho acontecia, chegando em alguns momentos a fazer o seguinte comentário: "Ah, tá, vamos ver de

${ }^{121}$ Entrevista concedida pela PROFESSORA 2. Entrevista I. [ago. 2017]. Entrevistador: Claudinéia Maria Vischi Avanzini. Curitiba, 2016. 1 arquivo.mp3 (1h35min.41seg.). A entrevista na íntegra encontra-se transcrita nos Apêndices C e I desta tese. 
mandar", sendo que a professora, às vezes, precisava ser mais incisiva, chegando a informar as pedagogas das escolas que a chefia de ambas era a mesma do Ensino Fundamental e que esta seria informada se o material das crianças não fossem encaminhados para o hospital ${ }^{122}$.

Com relação aos modelos educacionais que eram utilizados no atendimento das crianças e dos adolescentes na Hospitalização Escolarizada em Curitiba da década de 1990 se destaca na fala das duas professoras o ensino tradicional. Entretanto, ao mesmo tempo em que elas se reconhecem como professoras tradicionais, principalmente por realizar um trabalho mais mecânico de explicação dos conteúdos, realização de exercícios e aplicação de provas encaminhadas pelas escolas, realizando atividades onde a sistematização dos conteúdos era mais rígida, não priorizando a flexibilização e não havendo a possibilidade de muita variação de conteúdo. No discurso da Professora 1 ela destacou:

Sabia-se o que o primeiro ano iria trabalhar no decorrer do ano, os conteúdos eram separados em bimestres, sabia-se o que era conteúdo de $2^{2}$ série, de $3^{\mathrm{a}}$ e de $4^{\mathrm{a}}$. Na realidade eu seguia roteiros. Buscava atividades dentro dos livros, mas seguia roteiros preestabelecidos pela própria Secretaria de Educação. (PROFESSORA 1, 2016).

Elas deixam claro que, por conta da especificidade do trabalho, necessidades das crianças ou até mesmo possibilidade de efetivação das atividades por conta do estado físico de cada criança em virtude da doença, tinham que se adaptar a uma educação diferenciada que acabava se distanciando da escola regular e do ensino tradicional, afinal a questão do tempo e espaço escolar era totalmente diferenciada e como esse distanciamento aconteceu também com relação ao acompanhamento das secretarias, elas acabavam trabalhando conforme acreditavam ser o certo e o melhor para a criança. Tanto que a Professora 2 descreve que

Então, você ia meio no escuro, vou fazendo como dava certo, vai
acontecendo, era muito mais uma visão do que dá certo com Fulano, com o
aluno $\mathrm{A}$, e o que dá certo com o aluno $\mathrm{B}$, vamos indo no escuro, porque a
gente não tinha uma orientação até 2005 . [...] A partir de 2005 a gente
consegue seguir uma linha pedagógica e ir compreendendo o que acontece,
mas de 98 até 2005 eu fiz como eu achava que tinha que ser e como
funcionava. Se você fosse trabalhar alfabetização e você visse que tinha que
trabalhar com o $\mathrm{BA}-\mathrm{BE}-\mathrm{BI}-\mathrm{BO}-\mathrm{BU}$ você ia trabalhar com o $\mathrm{BA}-\mathrm{BE}-$
$\mathrm{BI}-\mathrm{BO}-\mathrm{BU}$, se você via que dava para começar a trabalhar com a

122 Entrevista concedida pela PROFESSORA 1. Entrevista I. [ago. 2016]. Entrevistador: Claudinéia Maria Vischi Avanzini. Curitiba, 2016. 1 arquivo.mp3 (60min.). A entrevista na íntegra encontra-se transcrita nos Apêndices $\mathrm{C}$ e H desta tese. 
articulação dentro de um texto, você ia fazendo. Então, era meio que nas escuras. (PROFESSORA 2, 2017).

Além disto, a Professora 1 (2016) destacou que o atendimento era praticamente individualizado, pois ela explicava as atividades e enquanto um dos alunos as desenvolvia ela alternava as explicações com outras crianças. Esse tipo de atendimento pedagógico, apesar de ter traços tradicionais, já se apresentava como uma inovação no ensino, onde o aluno era visto em sua individualidade e especificidade.

Os avanços, reconhecimento e aceitação por parte do corpo clínico são os elementos descritos pela Professora 1 (2016) como progressos no atendimento da Educação Hospitalar no hospital infantil de Curitiba. Segundo ela, à medida que todo o corpo clínico ia tomando conhecimento do que estava acontecendo, percebiam a importância do trabalho e permitiam uma abertura maior para a atuação, não havendo mais uma resistência por parte dos médicos. Então, as professoras iam tendo mais liberdade para trabalhar com as crianças e a escolarização no hospital avançava.

Pouco a pouco eles foram permitindo o uso de aparelho que produzisse som,
os lápis coloridos para pintura, eles foram dando um pouco mais de abertura
por perceberem que as crianças demonstravam interesse, se animavam. As
psicólogas também, em reuniões manifestavam que aquilo produzia nas
crianças uma segurança, um bem-estar. Então o corpo clínico foi aceitando
mais a atuação do projeto, de quem trabalhava no projeto, no caso eu e uma
outra professora. (PROFESSORA 1, 2016).

A Professora 2 (2017) descreveu uma situação muito parecida a essa quando, logo após começar a trabalhar no hospital, solicitando ajuda a uma enfermeira para trocar o horário de atendimento médico da criança para que ela pudesse ser matriculada neste horário do tratamento, recebeu a informação de que primeiro viria a saúde e depois a escola, mas com o passar do tempo, à medida que as professoras mostraram a prática e que a educação funcionava auxiliando também as questões da saúde, pois as crianças conseguiam viver a questão da saúde concomitantemente com outras questões da vida, essa mesma profissional começou a informar a professora que determinadas crianças ou adolescentes não estavam indo para a escola, chegando a cobrar da professora que ela visse o que estava acontecendo.

Somando-se a isso e apesar das professoras entrevistadas dizerem que inicialmente também ficavam afastadas das decisões das respectivas secretarias, tanto municipal como estadual, por trabalharem sem muito suporte, formação ou acompanhamento, esse distanciamento seria uma das principais questões político 
pedagógicas que podem ser levadas em consideração no atendimento da Educação Hospitalar no hospital infantil de Curitiba, afinal a disponibilização dessas professoras para realizar um trabalho tão diferenciado e alheio ao que estava acontecendo nas unidades educacionais, a autonomia que lhes era oferecida para entrar em contato com as escolas, que quase sempre valorizava o trabalho por ser tão raro e diferenciado e o fato das duas secretarias demonstrarem interesse na continuidade do projeto que se manteve por vários anos, a Secretaria de Estado da Educação, nesta fase inicial deixou que a professora atuasse no hospital durante 9 anos, indica a valorização política e pedagógica deste atendimento educacional ofertado no hospital. Segundo a Professora 1, o Termo de Cooperação Técnica não foi renovado, porque a Secretária de Estado da Educação no último ano da década de 1990 "não avaliou aquilo como algo relevante, por isso houve a interrupção do trabalho, que anos mais tarde retornou mais institucionalizado como o SAREH"123.

Com relação à existência de um trabalho da equipe multidisciplinar na Educação Hospitalar no hospital infantil de Curitiba, as duas professoras destacam o trabalho efetivado pela equipe multidisciplinar na Educação Hospitalar no hospital de Curitiba. Segundo elas o trabalho desta equipe multidisciplinar consistiria em, principalmente compreender a criança como um todo, que precisava ser atendida em todas as suas necessidades, tanto física, psicológica, como educacional, também por isso, as professoras passam a compor essa equipe multidisciplinar que era constituída por médicos, enfermeiros, auxiliares de enfermagem, psicólogos, assistentes sociais e pelas próprias professoras que passaram a além de compor a equipe, decidir junto aos demais profissionais do hospital os rumos do tratamento das crianças. Essas decisões aconteciam em reuniões frequentes, algumas vezes semanais, de todos os envolvidos no atendimento das diversas crianças do hospital, assim, as relações e entrelaçamentos entre os diferentes membros da equipe multidisciplinar do hospital, inicialmente conflituosa, passou com o tempo a ficar fortalecida.

De início não, porque eles reconheciam que a parte mais importante para a criança era a saúde e que a escola podia ficar em segundo plano. No momento em que a gente começou a mostrar a evolução dessas crianças pedagogicamente eles nos incluíram na equipe e daí a gente começou a participar até de reuniões deles. Às vezes, na consulta com a médica, ela nos

${ }^{123}$ Entrevista concedida pela PROFESSORA 1. Entrevista I. [ago. 2016]. Entrevistador: Claudinéia Maria Vischi Avanzini. Curitiba, 2016. 1 arquivo.mp3 (60min.). A entrevista na íntegra encontra-se transcrita nos Apêndices $\mathrm{C}$ e $\mathrm{H}$ desta tese. 
chamava para conversar sobre a escola com a família. (PROFESSORA 2, 2017).

A vinculação das professoras no universo hospitalar se fortalece de tal forma que além da participação nas reuniões da equipe multidisciplinar, as professoras passam, em alguns casos, a ser convidadas a participar das consultas médicas das crianças e até a última página do prontuário médico das crianças passa a incluir um tipo de "histórico escolar", para que quando o médico fizesse a consulta, pudesse olhar na última folha e acompanhar os registros escolares. Segundo a Professora 1 (2016) algumas vezes o médico, após olhar a última página dizia para a criança ou adolescente em atendimento: "Ah, você estuda em tal escola, está fazendo tal ano. Como é que está a escola? Está indo ou não está? Está dando certo?" Por esse motivo e por essa valorização, as professoras mantinham essas informações do acompanhamento pedagógico na última página do prontuário.

A gente tinha uma documentação nossa, que nós desenvolvemos e ficava dentro do prontuário. Qualquer modificação, por exemplo, no começo do ano a criança foi do $1^{\circ}$ para o $2^{\circ}$ ano, a gente atualizava. Quando elas mudavam da escola, ou alguma coisa, a gente atualizava também. (PROFESSORA 2, 2017).

A valorização do trabalho desenvolvido pelas professoras dentro do hospital naquele período é evidente ao perceber nas entrevistas que elas comentam que quando eram cedidas para a instituição de saúde, era esta que se responsabilizava e delineava o trabalho realizado por elas. A Professora 2 (2017) destaca em sua entrevista que as únicas duas cláusulas do convênio da Educação Hospitalar entre a Associação Hospitalar de Proteção à Infância Dr. Raul Carneiro e o município de Curitiba eram: "Manter entrosamento com a escola de origem do aluno e trabalhar conteúdo escolar". Afinal, segundo ela, a função dela "enquanto professora, era trabalhar conteúdo escolar"124. E, segundo ela, esse foi o trabalho que ela fez durante todo o tempo que ficou cedida para a Educação Hospitalar. Segundo a mesma professora, esse trabalho se delineou em sua vida por meio de muita sensibilidade em perceber qual seria o canal de diálogo com as crianças em tratamento de saúde, apesar deste trabalho não ser de recreação, ser focado no conteúdo escolar, a intencionalidade pedagógica é fundamental para que o trabalhar do conteúdo

124 Entrevista concedida pela PROFESSORA 2. Entrevista I. [ago. 2017]. Entrevistador: Claudinéia Maria Vischi Avanzini. Curitiba, 2016. 1 arquivo.mp3 (1h35min.41seg.). A entrevista na íntegra encontra-se transcrita nos Apêndices C e I desta tese. 
acontecesse de forma lúdica, principalmente porque eles são crianças e brincando vão aprendendo.

\begin{abstract}
Eu não vou ler uma história por uma história, não vou fazer um jogo pelo jogo, eu tenho uma intencionalidade com isso. Então, eu vou trabalhar sempre amarrando com o pedagógico escolar. E eu acho que a gente tem que aliar, eu vejo que dá resultado isso, o quanto é importante, o quanto essas crianças... Você tira ela daquela coisa da doença, só daquele mundo que ela está vivendo da doença, você consegue mostrar outros caminhos, outras vertentes de vida para ela. (PROFESSORA 2, 2017).
\end{abstract}

Apesar de as duas professoras destacarem que o trabalho era bastante tradicional no início, com a efetivação dele, elas percebem que a forma de trabalhar tinha que ser diferente, tinha que respeitar, principalmente a individualidade de cada criança, que era necessário fazer sentido tudo que estivesse sendo trabalhado. Enfim, a realidade ia mostrando o que funcionava e o trabalho foi ficando muito mais funcional, coerente e criativo para as crianças doentes, alunos da Educação Hospitalar.

\title{
3.2.2.2 As crianças, doentes, alunos/alunas da Educação Hospitalar: experiências entrelaçadas
}

Com relação às crianças, doentes e alunos da Educação Hospitalar destaco que um dos grandes objetivos e metas neste trabalho era possibilitar que os maiores envolvidos com a escolarização no hospital tivessem vez e voz. Oportunizar a participação efetiva aos principais protagonistas da Educação Hospitalar e que muitas vezes nunca seriam ouvidos, passou a ser uma necessidade, principalmente pela valorização da História vista de baixo fundamentada na teoria da história social (THOMPSON, 2002). Somando-se a isto, explicitar as experiências desses protagonistas, os alunos da educação hospitalar do Paraná, solidifica a perspectiva teórica em que "a experiência surge espontaneamente no ser social, mas não surge sem pensamento. Surge porque homens e mulheres (e não apenas filósofos) são racionais, e refletem sobre o que acontece a eles e ao seu mundo" (THOMPSON, 1981, p. 15) teoria a qual tanto me identifico enquanto pesquisadora da História da Educação.

Não foi o objetivo, contudo, relatar "experiências" com um fim em si mesmas. Trabalhando com as balizas dadas ao termo por E. P. Thompson, elas participaram desta análise, não de forma condescendente aos seres sociais, especialmente às pessoas comuns. Puderam imprimir dinâmica ao olhar histórico quando afirmada a capacidade da luta popular em transformar uma 
educação doada ao povo em um direito social. Tal formulação não foi um slogan teórico, mas sim um movimento, ou conjunto de movimentos que deixaram marcas no tempo e indícios na documentação. (COSTA, 2012, p. 258).

Entendendo que a Educação Hospitalar ofertada aos estudantes hospitalizados ou com problemas crônicos de saúde seria uma forma de engajamento popular para tornar a educação oferecida a eles em um direito social, trabalho nesta parte do trabalho com uma entrevista realizada com um ex-aluno da Educação Hospitalar que foi atendido entre os anos de 1990 e 2002, exatamente o final do recorte temporal deste trabalho. A entrevista foi cedida no dia 28/04/2018, no final de uma tarde quente em Curitiba, onde o entrevistado, que mora em Cascavel, no interior do Paraná, a 506 $\mathrm{km}^{125}$ da capital, se encontrava para participar de um congresso de Nefrologia, ao qual havia sido convidado para compor uma mesa que tinha por objetivo discutir a transição entre o tratamento nefrológico pediátrico e adultos.

Em 2018 com 31 anos, o ex-aluno do hospital que desde $1990 \mathrm{fez}$ acompanhamento com nefrologista, por conta de doença renal, segundo entrevista cedida em abril, esse problema renal não era congênito, seu problema era neurológico de acometimento da espinha, ele nasceu com mielomeningocele ${ }^{126}$. Doença que gerou a bexiga neurogênica ${ }^{127}$, que por sua vez, causou um problema de refluxo vesico urinário ${ }^{128}$, que produziu infecções urinárias repetidas, que desencadeou a pielonefrite ${ }^{129}$ e esta destruiu o rim do entrevistado, tudo isso aconteceu nos três primeiros anos de vida do ex-aluno e por demorar no diagnóstico da bexiga neurogênica em decorrência da mielomeningocele ele perdeu um rim, sendo que com

125 Disponível em https://www.google.com.br/maps/dir/ Acesso em 27/05/2018.

${ }^{126}$ A mielomeningocele, também conhecida como espinha bífida aberta, é uma malformação congênita da coluna vertebral da criança em que as meninges, a medula e as raízes nervosas estão expostas. Disponível em http://www.minhavida.com.br/saude/temas/mielomeningocele Acesso em 12/05/2018.

${ }^{127} \mathrm{~A}$ bexiga neurogênica é a incapacidade de controlar $\mathrm{O}$ ato de urinar devido a uma disfunção na bexiga ou esfíncter urinário. Disponível em https:/www.tuasaude.com/bexiga-neurogenica/ Acesso em $12 / 05 / 2018$.

$128 \mathrm{O}$ refluxo vesico ureteral é uma condição anormal que está relacionada à origem de infecções urinárias. A urina que vem dos rins e segue pelos ureteres até a bexiga normalmente não retorna para os ureteres, por ação de um "mecanismo valvular". O não funcionamento desta "válvula anatômica" permite o refluxo da urina e favorece o transporte de bactérias para os ureteres ou até os rins, chamado de refluxo vesico ureteral. Disponível em https://www.hospitalsiriolibanes.org.br/hospital/especialidades/nucleo-avancadourologia/Paginas/refluxo-vesicoureteral.aspx Acesso em 12/05/2018.

${ }_{129}$ Pielonefrite é uma doença inflamatória infecciosa, potencialmente grave, causada por bactérias. Ela acomete o parênquima renal, onde se localizam as estruturas funcionais produtoras de urina, e o bacinete (ou pelve renal), porção dilatada do rim, com o formato aproximado de um funil, cuja função é facilitar o fluxo da urina pelos ureteres, a fim de que seja armazenada na bexiga e depois eliminada pela uretra. Disponível em https://drauziovarella.uol.com.br/doencas-e-sintomas/pielonefrite/ Acesso em 12/05/2018. 
apenas 3 anos o seu único rim funcionava com $60 \%$ de função renal. Foi então que começou o tratamento com os nefropediatras no Hospital Pequeno Príncipe. Desde que iniciou o tratamento, ele passou por várias cirurgias para correção do problema na bexiga neurogênica, fez ampliação da mesma, fez cirurgia para corrigir o pé torto ${ }^{130}$ equinovaros bilateral, um dos sintomas causado pela mielomeningocele.

\begin{abstract}
Quando eu entrei no Pequeno Príncipe, no início dos anos 90, eu já fiz a cirurgia de correção ortopédica nos pés, fiz a correção dos pés e também fiz ampliação na bexiga e daí eu iniciei o tratamento com o nefrologista pediátrico no Pequeno Príncipe. A partir do momento que eu fiz essa ampliação da bexiga e que se identificou qual era o problema que estava causando 0 problema renal, foi tratado o problema da bexiga, mas aí o problema renal continuou, como eu já tinha perdido o rim, eu fiz uma cirurgia para retirar [esse] rim que não estava funcionando e fiquei em acompanhamento com o que eles chamam de tratamento conservador, fiquei em acompanhamento para ver a função, monitorar a função do outro rim. (Informação verbal Exaluno 1) ${ }^{131}$.
\end{abstract}

Segundo o ex-aluno, esse tratamento conservador durou de junho de 1990 até 2000, ano em que o único rim dele entrou em falência renal basal e ele precisou fazer diálise peritoneal ${ }^{132}$. Os médicos sugeriram esse tratamento, pois o tratamento hospitalar seria na capital do Paraná, em Curitiba, e como ele era de Toledo, interior do estado, de início se cogitou a possibilidade de ele fazer a diálise peritoneal, assim ele poderia ir para casa, não precisando residir em Curitiba. Com isso, em 2000, ao perder o funcionamento renal, realizou uma nefrectomia deste último rim e iniciou o tratamento dialítico, por meio da diálise peritoneal. Entretanto teve que ficar internado por um longo tempo, se preparando para os procedimentos, colocando e tirando

130 O Pé Torto Congênito é definido como uma deformidade caracterizada por mau alinhamento complexo do pé que envolve partes moles e ósseas, com deformidade em equino e varo do retro pé, cavo e adução do médio e ante pé. Maranho DA, Volpon JB. Pé torto congênito. Acta Ortop Bras. [online]. 2011;19(3):163-9. Disponível em: http://www.scielo.br/pdf/aob/v19n3/a10v19n3.pdf Acesso em: 13/05/2018.

131 Entrevista concedida pelo EX-ALUNO. Entrevista I. [abril. 2018]. Entrevistador: Claudinéia Maria Vischi Avanzini. Curitiba, 2018. 1 arquivo.mp3 (41min.27seg.). A entrevista na íntegra encontra-se transcrita nos Apêndices $\mathrm{D}$ e $\mathrm{K}$ desta tese.

132 Diálise peritoneal é uma das opções de tratamento para a Insuficiência Renal Crónica Terminal, sendo uma técnica fisiológica que utiliza a membrana peritoneal (membrana que envolve os órgãos abdominais), como um filtro do sangue, imitando a ação do rim, removendo excesso de água e toxinas do corpo. A técnica funciona com a introdução do dialisante na cavidade peritoneal através de um cateter colocado na parte inferior do abdômen, pois a cavidade peritoneal pode frequentemente reter mais de 3 litros, sendo que na prática clínica é mais usual utilizar de 1,5 a 2 litros de dialisante. A diálise peritoneal (DP) acontece por meio da osmose, onde é realizada a adição de glucose, que é uma grande molécula, ao líquido da diálise peritoneal, a molécula de "glucose arrasta a água do lado do sangue para o lado do líquido da DP, tentando diluir a elevada concentração de glucose e chegar ao equilíbrio. [...] Os produtos residuais, como a ureia e a creatinina, são removidos por difusão. [...] O conteúdo do dialisante da DP pode ser dividido em eletrólitos, solução tampão e agentes osmóticos, estando disponíveis muitas composições diferentes". Disponível em https://www.portaldadialise.com/portal/oque-e-dialise-peritoneal Acesso em 24/06/2018. 
cateteres, porque somente depois de três procedimentos cirúrgicos para colocação do cateter, que o último funcionou, um deu rejeição, outro infeccionou, segundo relatório médico, o peritônio do ex-aluno era inviável. Nesse meio tempo fizeram o treinamento de sua mãe, responsável pela diálise domiciliar que no início era manual e depois foi disponibilizado à família uma máquina para fazer uma diálise automática. Com isso, ele ganhou alta e foi para casa realizando a diálise peritoneal por 8 meses.

Além do relato do aluno, essas informações podem ser visualizadas em algumas fotografias disponibilizadas por ele. A seleção de uma pequena parte dos registros que compõem o álbum apresentado pelo aluno foi realizada de forma arbitrária, mas presa aos desígnios de trazer à luz um breve relato de sua vida no período em que ele recebeu o atendimento pedagógico no hospital. O uso da fotografia não tem por pressuposto ser apenas uma forma de expressão, como também um meio de comunicação e informação, principalmente por conta dos indícios nela presentes.

Os registros fotográficos foram tomados não apenas como uma imagem com a qual se procurou captar a realidade, mas como sua construção e/ou leitura, como meio de comunicação através de mensagens de caráter não-verbal e forma de mostrar-se para si e para os outros (STANCIK, 2009, p. 446).

Neste sentido, apresento algumas fotografias que entrelaçadas com os testemunhos orais, colhidos na entrevista, detectam importantes vestígios históricos que auxiliam na produção dessa história. Neste sentido, na figura 15 há a imagem do entrevistado realizando uma das sessões de diálise peritoneal que fazia em sua casa e que foi descrita por ele na entrevista.

Ao que parece, o local onde ele está seria o quarto dele, pois é possível ver que ele está sentado num móvel que parece uma cama. Na imagem há também uma mesa onde se encontra a máquina cicladora, que é o aparelho que infunde e drena o líquido, fazendo as trocas necessárias, dentro do abdômen do entrevistado e três bolsas, duas com o líquido dialisante, uma delas está conectada à máquina e outra sobre a mesa, ao lado da máquina aguardado para ser utilizada assim que a primeira bolsa fosse totalmente introduzida no abdômen do entrevistado e uma bolsa de drenagem, que é a que está ligada ao aparelho por um tubo com uma conexão em vermelho. Esses equipamentos de diálise estão ligados a uma tomada que, ao que parece, foi instalada tardiamente, pois o fio dela encontra-se oculto por uma canaleta. Esse tipo de instalação indica que anteriormente naquele local não existia uma 
tomada, portanto houve uma instalação tardia, muito provavelmente para que a máquina de diálise pudesse ser ligada naquele local, possibilitando um pouco de conforto para o entrevistado durante o tempo em que deveria ficar aguardando a realização do tratamento, de 8 a 10 horas. No caso, esse era o período que ele cita em sua entrevista, que fazia a Diálise Peritoneal Automatizada (DPA). Nesse tipo de diálise, a máquina cicladora é fornecida ao paciente que antes de dormir se conecta a ela, que por sua vez, faz as trocas automaticamente segundo a prescrição médica. "A drenagem é realizada conectando a linha de saída a um ralo sanitário e/ou recipiente rígido para grandes volumes", sendo que, se necessário, durante o dia ainda podem ser programadas "trocas manuais". Na imagem, o entrevistado está conectado por meio do cateter que se encontra no seu abdômen à máquina cicladora por um tubo que termina numa conexão azul próxima da máquina de diálise.

Figura 15: Fotografia do entrevistado em diálise peritoneal.

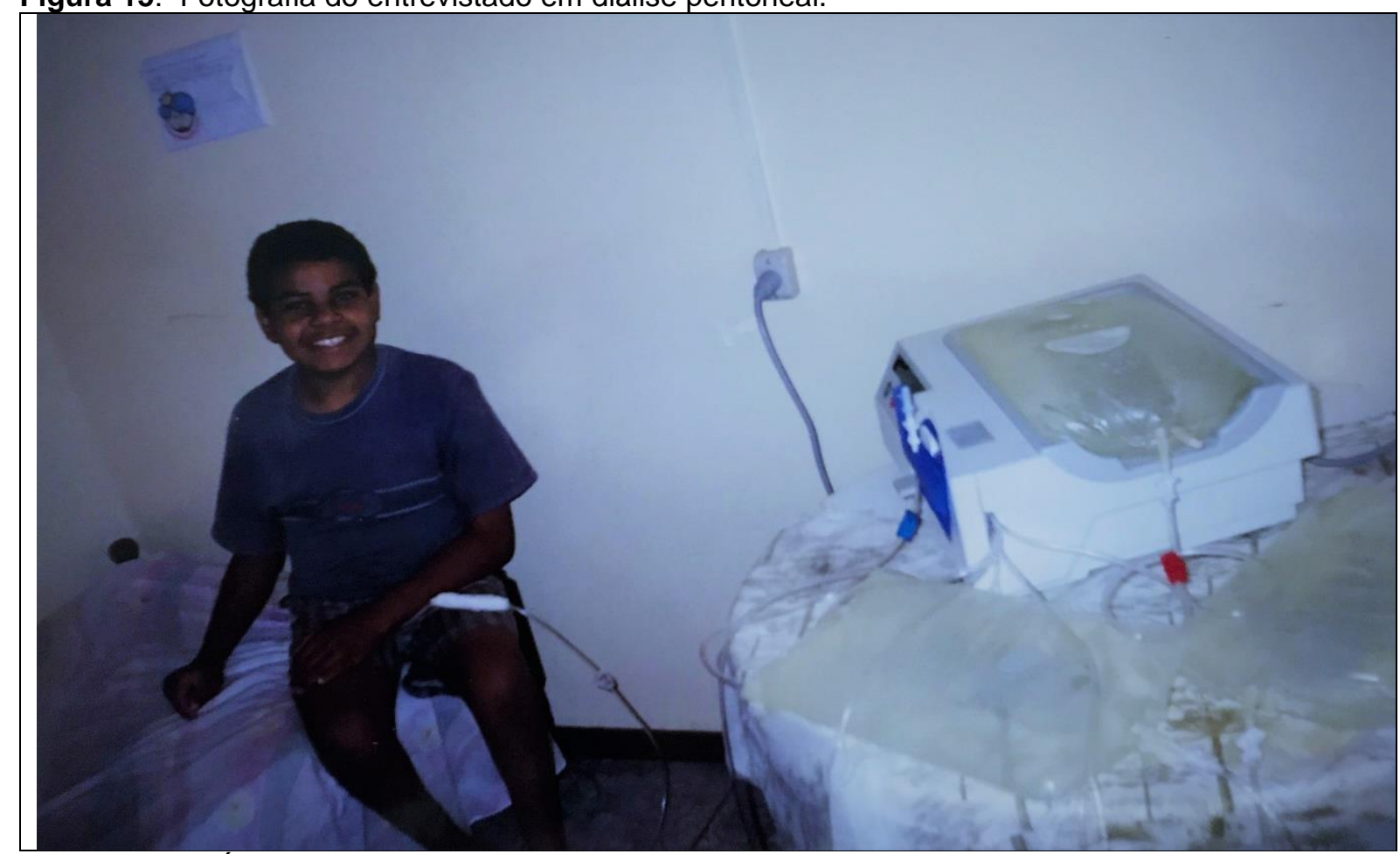

Fonte: Acervo Álbum de Família do ex-aluno. (1º semestre/2000).

Segundo o entrevistado, após os 8 meses que realizou diálises desta forma, ele teve peritonite ${ }^{133}$ por infecção fúngica, pegou cândida extremamente severa. Segundo ele, "foi o único momento ao longo dos meus trinta anos que eu achei que

133 A Peritonite é inflamação do peritônio, tipicamente devido à infecção pelas bactérias ou pelos fungos. (CHOW, 2018). Disponível em: https://www.news-medical.net/health/What-is-Peritonitis(Portuguese).aspx. Acesso em 29/04/2019. 
realmente ia morrer, eu fazia picos de 40, 41, 42 graus de febre, e assim, parado eu tremia, tremia, tremia, tremia, muito"134. Com isso, em dezembro de 2000, voltou ao hospital, retirou o cateter, tratou a infecção fúngica e iniciou o tratamento hemodialítico já realizando exames para o transplante renal, pois a mãe doaria o rim para ele.

Nesse momento, o ex-aluno considerou importante destacar que ele é adotivo, foi abandonado quando tinha 3 meses de idade, sua mãe biológica o colocou numa creche domiciliar, que, segundo ele, existiam naquela época em Toledo, e foi embora. Hoje ele sabe que ela foi para Curitiba, mas na época ninguém sabia o paradeiro dela, só que o abandonou naquela creche por 3 anos. Segundo ele, nesse período, dos 3 meses até os 3 anos de idade, foi o período que ele mais sofreu por conta dos problemas de saúde e por estar sem a mãe biológica. O pais adotivos que fizeram todo esse processo de viagens para Curitiba e para se apresentarem como pais perante os serviços médicos tiveram que fazer todo o procedimento legal para adoção, sendo que ele foi registrado no nome dos pais adotivos que o acompanhavam sempre que preciso para os tratamentos na capital do estado. Somente depois que ele estava com 10 anos de idade, a minha mãe biológica apareceu e se apresentou como sua mãe.

O trauma do abandono se traduziu como algo muito triste e marcante em sua vida. A volta da mãe biológica, num momento tão difícil significou situações conflitantes de um desgaste bastante evidente na entrevista do ex-aluno. Em suas palavras, o primeiro contato com a mãe biológica foi marcado por uma mágoa acumulada por 10 anos de abandono. Ao aparecer e se apresentar como "Sou sua mãe", a resposta que a mãe biológica recebeu dele foi:

Não, minha mãe está aqui do meu lado, sempre esteve, essa é minha mãe, esse é meu pai e vão continuar sendo, você pode ser a pessoa que me colocou no mundo, mas não se apresente como minha mãe, porque tu não é, pode ser qualquer outra pessoa, talvez no máximo quem me colocou no mundo, ou qualquer outra coisa que tu queiras, menos ser minha mãe, porque minha mãe é essa que está aqui do meu lado e esteve todos os meus anos de vida. (EX-ALUNO, 2018).

Ele fazia hemodiálise, porque havia perdido o cateter da diálise peritoneal quando a mãe biológica se aproximou dele. Então, ela acabou se disponibilizando a doar um rim a ele justificando da seguinte forma: "Como eu já te abandonei lá atrás,

\footnotetext{
${ }^{134}$ Entrevista concedida pelo EX-ALUNO. Entrevista I. [abril. 2018]. Entrevistador: Claudinéia Maria Vischi Avanzini. Curitiba, 2018. 1 arquivo.mp3 (41min.27seg.). A entrevista na íntegra encontra-se transcrita nos Apêndices D e K desta tese.
} 
por questões adversas. [...] Então eu vou doar o rim para você, vou te trazer a vida novamente". Na entrevista o ex-aluno faz questão de reproduzir as palavras da mãe, e ironizando agradece a ela da seguinte forma: “Nooossa! Que lindo, né?! Que lindo! Muito obrigado! Tá bom, se você quer. Eu não estou te pedindo, mas já que você quer, vamos lá". Esse "eu não estou lhe pedindo" ele repete várias vezes na entrevista, acredito que ele queria evidenciar que nunca pediu para isso, mas como a mãe biológica se dispôs a fazer a doação em vida a ele, que segundo seu sarcasmo, parecia uma forma dela se redimir por tê-lo abandonado quando ainda era um bebê.

Então, em dezembro de 2000, enquanto ele começa as sessões de hemodiálise, sua mãe biológica estava fazendo toda a bateria de exames de histocompatibilidade para transplantarem. Depois de três meses de hemodiálise, em fevereiro ele transplantou com o rim da minha mãe biológica. Entretanto, segundo o ex-aluno:

Deus já deixa as coisas todas certinhas, não basta você querer e aparecer 10 anos de novo e depois dizer: "Oi, eu sou sua mãe e vou lhe trazer a vida". Deus já sabe como funciona as coisas e ele faz caminhos certos por linhas tortas, como dizem. Rejeitei o rim. "Não te quero, rim, porque tu não faz parte de mim, nunca fez e não vai ser agora”. Rejeitei o rim. (EX-ALUNO, 2018).

Segundo o entrevistado, a explicação médica foi que nenhum exame mostrou que a mãe dele tinha uma artéria a mais e no momento de fazer a ligação desta segunda artéria em seu rim houve um rompimento da sua artéria, houve um sangramento moderado no rim, que foi controlado e que depois, quando eles fizeram a ligação da artéria estava tudo certo, mas não ia sangue suficiente. Então, o rim ficou "hipoperfundido, hipooxigenado e essa hipoxigenação, essa hipoperfusão acabou fazendo com que eu tivesse uma rejeição aguda imediata, não durou uma semana, meu rim estava necrosado"135. Pelas palavras do entrevistado,

[...] não basta você querer consertar o inconsertável. Não teve jeito, rejeitei o rim, sofri um monte, transplantei em fevereiro sai em abril do hospital, ou seja, fiquei 2 meses ali sofrendo, indo para o centro cirúrgico revisando o rim, fazendo enxurrada de volume, muito soro, muito soro, muito soro e o soro não saia, porque o rim não estava funcionando, o líquido entrava, mas não saia, então eu ia inchando, a pressão ia aumentando, até que o médico um dia falou para mim, eu fiz o transplante, se não me engano, [...] dia 3 de fevereiro, dia 20 de março o médico falou para mim: "Ou nós tiramos esse rim, ou ele acaba com a vida do seu filho." Falou para minha mãe, que eu considero como mãe, e falou para a pessoa que doou, que é a minha mãe

\footnotetext{
135 Entrevista concedida pelo EX-ALUNO. Entrevista I. [abril. 2018]. Entrevistador: Claudinéia Maria Vischi Avanzini. Curitiba, 2018. 1 arquivo.mp3 (41min.27seg.). A entrevista na íntegra encontra-se transcrita nos Apêndices $\mathrm{D}$ e K desta tese.
} 
biológica também. "Não teve jeito, ou nós tiramos ou ele morre, porque ele está ficando inchado, está ficando com a pressão alta, o rim está necrosando e vai necrosar os outros órgãos do abdômen, então não dá, nós vamos ter que tirar". "Tá, e tirar e daí fazer o quê?" "Não tem o que fazer, é o que você já sabe, é tirar e voltar para a hemodiálise". Aí falei: "Ah, não, está com zoação com a minha cara". "Não, não estou brincando, nós vamos tirar e você vai voltar para a hemodiálise". Aí teve todo aquele momento de negação, porque é cinco fases do luto, não é?! Foi literalmente um momento de luto, aí vencemos todo aquele momento tenebroso, horrível, mas enfim, está bom, né! Antes sem um rim vivo e com um rim morto. Então, vamos tirar o rim. Tiramos o rim e eu fiquei melhor. Então, não teve... aquilo não fazia parte de mim e nunca fez e não ia ser naquele momento. Tiramos o rim, foi passando os dias e eu fui melhorando clinicamente, aí saí do hospital, mas já saí do hospital dialisando, hemodialisando, fazendo hemodiálise, isso já era março de 2001. (EX-ALUNO, 2018).

Figura 16: Fotografia do entrevistado em hemodiálise sendo visitado por um piloto ${ }^{136}$ de corrida automobilística.

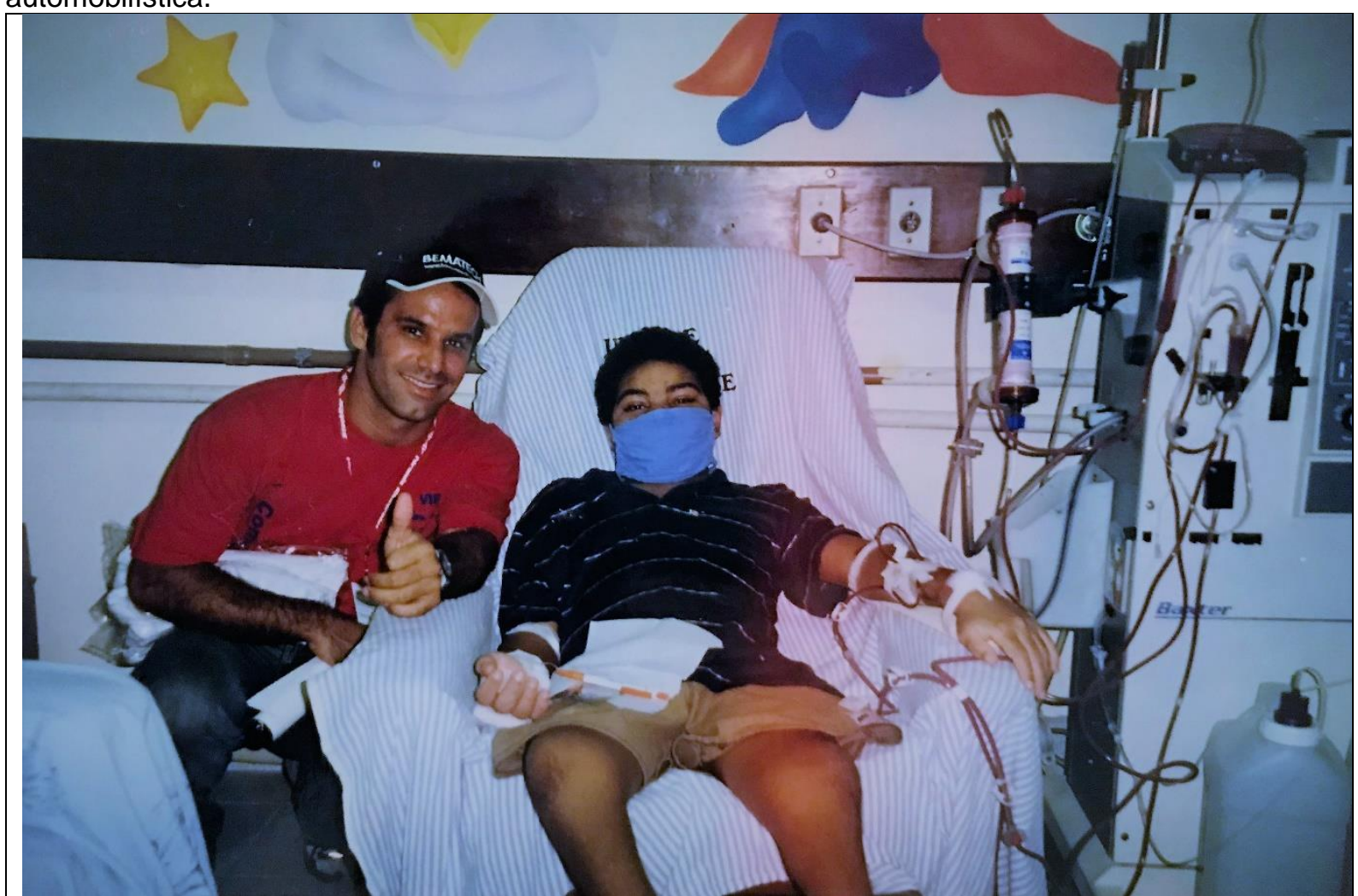

Fonte: Acervo Álbum de Família do ex-aluno. (1º semestre 2001).

Essas sessões de hemodiálise que ele passou a fazer foram registradas em imagens fotográficas. Segundo KOSSOY (1998, p. 46) essas imagens têm múltiplas faces da realidade, a primeira realidade é a aquela mais visível, é fixa, imutável, irreversível e a segunda realidade seria exterior, o testemunho, o conteúdo da imagem fotográfica, ela também é fixa e imutável, mas sujeita a múltiplas interpretações. Em ambas as etapas, na elaboração das imagens e na sua interpretação, haverá sempre

${ }^{136}$ Frequentemente figuras ilustres frequentam o hospital de crianças para conhecer o trabalho desenvolvido no local e visitar pacientes. 
um complexo e fascinante processo, sucessivo e interminável, de criação/construção de realidades, ou novas realidades. Essas múltiplas faces da realidade descrita na entrevista e demarcada com a figura 16 fica evidente quando o entrevistado descreve todo o processo de perda do transplante e apresenta a imagem estando numa sessão de hemodiálise usando uma máscara que indica a proximidade com o transplante.

O uso de máscaras pós transplante é necessário visto a questão da baixa imunidade do paciente que faz uso de medicamentos imunossupressores numa dosagem muito alta durante os primeiros dias após o transplante. Esse uso de altas doses de fármacos imunossupressores tem o intuito de inibir a rejeição do rim transplantado. Entretanto, a utilização dos imunossupressores torna a pessoa transplantada mais suscetível ao aparecimento de infecções e para prevenir essas infecções utilizam-se antibióticos de amplo espectro por via endovenosa ou oral, entretanto também deve usar máscara de proteção durante o primeiro mês e sempre que a pessoa que passou por uso de imunossupressores for a uma instituição de saúde ${ }^{137}$, pois ali normalmente a proliferação de infecções é maior, por conta do alto número de pessoas infectadas por vírus ou bactérias que encontram-se naquele ambiente. Desta forma, a imagem indica que o primeiro transplante, que não funcionou, havia acontecido, afinal o entrevistado estava numa sessão de hemodiálise, indicativo de que seus rins não funcionavam, utilizando máscara e com um dos braços pulsionado para o recebimento de medicamento intravenoso, indicativo que ele ainda se encontrava internado no momento do registro da imagem.

Além da máquina de hemodiálise, a poltrona reclinável, o lençol do hospital, a instalação da água que é obrigatória para o funcionamento da máquina e é visível por estar fora da parede, a própria parede com a faixa de madeira deixam claro que a imagem foi registrada dentro do setor de hemodiálise. O hospital onde ficava o setor de hemodiálise que o entrevistado fazia o tratamento quando criança é todo revestido com essas faixas de madeira nessa mesma altura. O entrevistado encontra-se sentado numa poltrona hospitalar reclinável para hemodiálise, coberta com um lençol e está conectado à essa máquina de hemodiálise que se encontra logo ao seu lado, esta, por sua vez está funcionando, pois, os dois tubos que ligam o braço esquerdo do entrevistado à máquina estão todos vermelhos com seu sangue que está sendo filtrado e devolvido ao seu corpo por um desses tubos.

137 Disponível em https://www.portaldadialise.com/articles/e-depois-do-transplante Acesso em 24/06/2018. 
$\mathrm{Na}$ fotografia o entrevistado recebe a visita de um piloto de corrida automobilística, que ele não se lembra quem é, mas comenta que ele se encontrava em Curitiba no período por conta da temporada do campeonato daquele ano. Frequentemente os pacientes do hospital infantil recebem visita de pessoas famosas, conhecidas ou ilustres que vão até o hospital para conhecer o trabalho desenvolvido na instituição, ajudando na divulgação e angariando fundos para a manutenção das atividades de saúde desenvolvidas no local. Neste sentido, a figura 17 também é de um destes momentos onde o entrevistado está com a ginasta Daniele Hypólito que compete em provas de ginástica artística e é bastante conhecida por participar de vários eventos olímpicos representando o Brasil.

Figura 17: Fotografia do entrevistado com Daniele Hypólito, ginasta brasileira que visitava o hospital onde ele fazia tratamento.

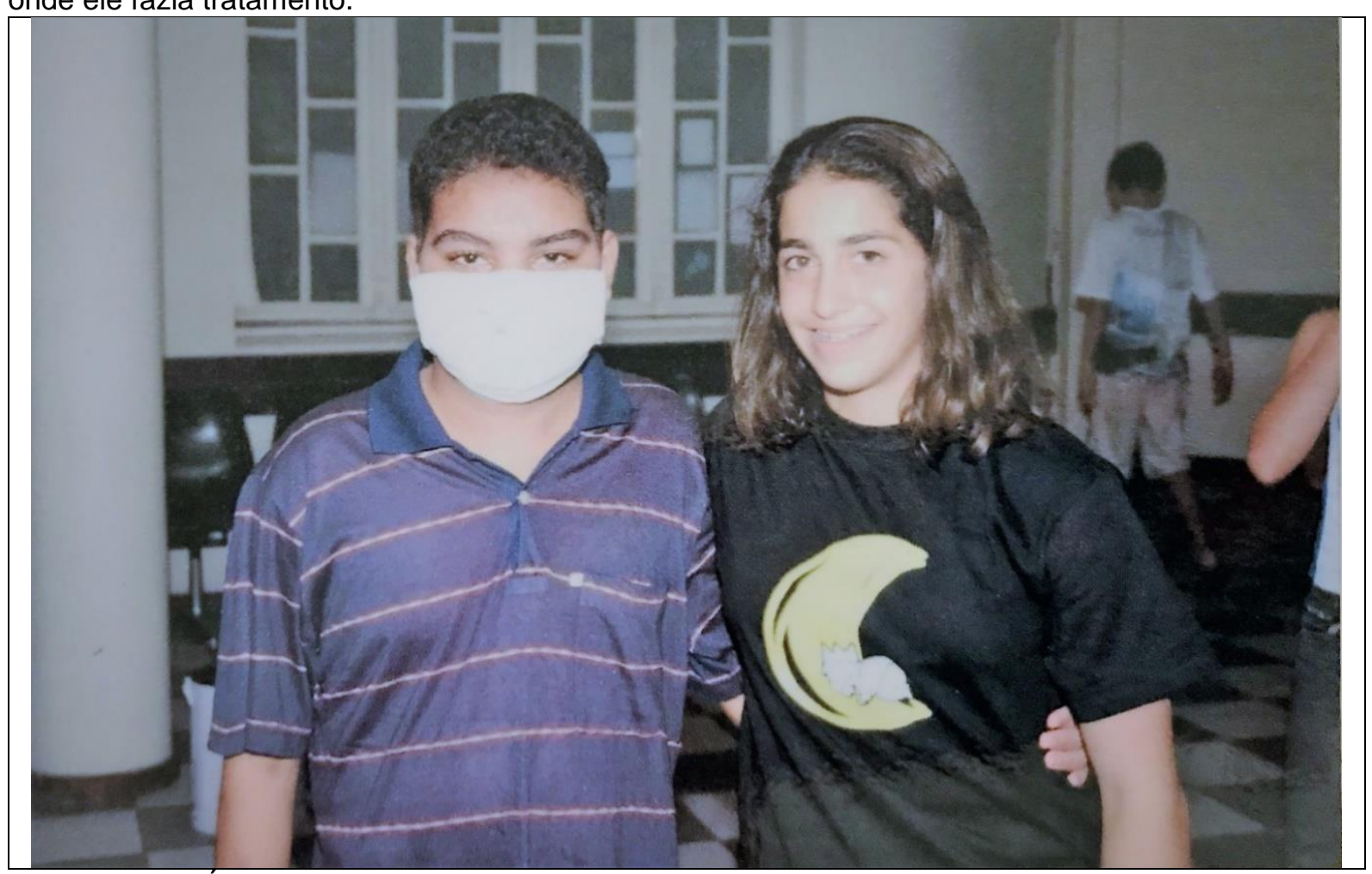

Fonte: Acervo Álbum de Família do ex-aluno. (2001/2002).

Entretanto, nesta imagem somente é possível perceber que seu registro foi feito depois do transplante e na Praça do Bibinha ${ }^{138}$, pois o entrevistado usa uma máscara para se proteger de possíveis infecções e a janela, coluna e pisos observados na fotografia indica que eles estão nessa praça, ambiente que se localiza logo após a

\footnotetext{
${ }^{138}$ Maiores informações e imagens disponíveis em http://pequenoprincipe.org.br/noticia/pacientes-dohospital-pequeno-principe-sao-surpreendidos-com-visita-do-bope/ Acesso em 24/06/2018.
} 
entrada principal do prédio histórico do hospital e que é um espaço cultural e de eventos.

Depois desse primeiro transplante, entre março de 2001 até dezembro de 2002 ele ficou um ano e 9 meses exclusivamente em hemodiálise. $E$ foi nesse período que a Educação Hospitalar o "acolheu", segundo ele. A justificativa foi que não teria mais jeito, eles teriam que vir para Curitiba, largar a vida, os amigos, a família e inclusive a escola em Toledo para mudar para a capital e cuidar da saúde,

[...] porque sem vida não existe mais nada, ou você está bem, você tem saúde
para viver todo o resto, gozar da vida, ou você não tem mais nada, do que
adianta você estudar, querer viver com sua família, seus amigos, se você não
tem vida. Então, largamos tudo lá, viemos eu e minha mãe para Curitiba,
vamos mudar para cá. Mudar como, de que jeito? O único lugar que, eu que
era criança, a minha mãe é analfabeta, não sabe ler nem escrever, ela
escreve o primeiro e o segundo nome, porque aprendeu em casa com a mãe
dela, mas aí ela vai tudo por cor, ela sabe... a gente cria... mecanismos
secundários para se virar. (EX-ALUNO, 2018).

Ele relata que foi difícil toda essa adaptação, afinal morar em Curitiba seria bem diferente de vir somente para fazer um tratamento e voltar, pois além de toda a questão de adaptação numa cidade diferente, havia toda a logística em alugar uma casa, manter e cuidar de duas famílias, etc. Segundo o aluno entrevistado, eles eram uma "família humilde" e tiveram que vir para Curitiba, somente ele e a mãe, o restante da família ficou em Toledo, o "pai era assalariado, funcionário público de Ensino Médio [...], os irmãos mais velhos trabalhavam na lavoura, eram o que chamavam naquela época de boias-frias" ${ }^{139}$ e eles tiveram que largar tudo e vir para Curitiba para iniciar o tratamento da hemodiálise no hospital.

Ainda segundo ele, 2001 foi um ano de hospital e mais nada, não houve um ano escolar, em dezembro de 2000 ele já tinha iniciado a hemodiálise e também os exames para a realização do transplante. Em termos escolares, "o ano letivo de 2001 não existiu, e depois então, menos ainda, porque 2001 foi um ano de adaptação, de morar em Curitiba, de se adaptar a hemodiálise e de reconstituir uma vida de acordo com o que a gente tinha naquele momento"140.

\footnotetext{
139 Entrevista concedida pelo EX-ALUNO. Entrevista I. [abril. 2018]. Entrevistador: Claudinéia Maria Vischi Avanzini. Curitiba, 2018. 1 arquivo.mp3 (41min.27seg.). A entrevista na íntegra encontra-se transcrita nos Apêndices $\mathrm{D}$ e $\mathrm{K}$ desta tese.

140 Entrevista concedida pelo EX-ALUNO. Entrevista I. [abril. 2018]. Entrevistador: Claudinéia Maria Vischi Avanzini. Curitiba, 2018. 1 arquivo.mp3 (41min.27seg.). A entrevista na íntegra encontra-se transcrita nos Apêndices D e K desta tese.
} 
Até o final de 2000 ele frequentou a escola em Toledo, sendo que em 2001 estava no $7^{\circ}$ ano. Desde as séries iniciais, até o $6^{\circ}$ ano das séries finais do Ensino Fundamental ele frequentou em Toledo enquanto fazia tratamento em Curitiba, pois ao voltar das intervenções médicas na capital, retomava os estudos na própria escola que estudava. Entretanto, 2001 foi esse período da mudança, pois ficou fora do colégio só voltando a estudar em 2002, por conta de o tratamento na hemodiálise terminar em dezembro de 2002, ano do segundo transplante realizado com doador cadáver.

\begin{abstract}
Aí Deus me abençoou com um doador cadáver em dezembro de 2002, 11 de dezembro de 2002, uma data de nascimento, de renascimento. 11 de dezembro de 2002 eu fiz um segundo transplante e estou com ele, graças a Deus, até hoje, 2018. Vivendo lindo e maravilhoso, belo e feliz, estudando. (EX-ALUNO, 2018).
\end{abstract}

Interessante observar o destaque que ele dá em seu depoimento com relação ao fato de estar "vivendo lindo e maravilhoso, belo e feliz, estudando", o fato de estar estudando tem um valor muito expressivo em sua colocação. Ao introduzir o assunto educação na entrevista, foi possível iniciar uma conversa sobre o universo escolar e como esse universo havia o influenciado ou o ajudado de alguma forma. Ao ser questionado sobre seu histórico escolar ele destaca que em 2001 iniciaria o $7^{\circ}$ ano, mas como teve alta do hospital em março/abril e já iniciou as hemodiálises, depois de passar os meses iniciais de adaptação, acabou ficando fora da escola e perdeu o ano letivo. Contudo, no final deste ano foi "abordado pela professora que trabalhava a questão da pedagogia hospitalar" que foi conhecê-lo, "porque ela fazia um trabalho de conhecer todos os pacientes novos que entravam na hemodiálise, coletar o histórico escolar, saber como estavam, como que era a vivência escolar e fazia um acompanhamento dali em diante". Então, no final de 2001 a professora conversou com ele, se apresentou, informou que trabalhava com a Educação Hospitalar e queria saber qual a série que ele estava, o que estava fazendo, como estudava, se estudava ou não. Depois deste contato inicial, eles combinaram que a partir do início do ano de 2002 o aluno faria Educação de Jovens e Adultos num Centro Estadual de Ensino Supletivo (CES), hoje Centro Estadual de Educação Básica para Jovens e Adultos (CEEBJA), para que concluísse o Ensino Fundamental, no caso o $7^{\circ}$ e $8^{\circ}$ ano para que depois em 2003, frequentasse uma escola de Ensino Médio regular. A professora esclareceu que acompanharia o aluno durante o tempo em que ele estivesse na hemodiálise. Entretanto, com relação ao ano de 2003, a professora comentou com o 
entrevistado que iriam "aguardar para ver [...] Vamos esperar para chegar, mas agora como você parou no Ensino Fundamental, vamos concluir o seu Ensino Fundamental por meio do CEEBJA"141.

E foi o que fizeram, no início de 2002 ele fazia hemodiálise três vezes na semana, três horas por dia e iniciou logo no início do ano "o supletivo para concluir o Ensino Fundamental. Aí eu fiz CEEBJA, em um ano eu fiz o $7^{\circ}$ e o $8^{\circ}$ ano"142. Essas aulas do CEEBJA aconteciam com a ajuda da professora hospitalar que buscava as atividades e as entregava para que ele as realizasse. Segundo ele, a professora "correu atrás dos trâmites burocráticos, ligou na minha escola lá em Toledo, viu como que era, o que precisava de documentação..."143. O matriculou no CEEBJA Paulo Freire, que ficava próximo do hospital onde ele fazia tratamento e no qual, segundo informações cedidas pela própria professora, já tinha um contato com a direção do Colégio.

\begin{abstract}
A parte escolar burocrática ela que resolveu, já veio me dizer que você já está matriculado, está tudo ok, nós só demos a informação e as fontes, os contatos com quem ela precisava falar, mas ela que fez todo os contatos, ligou e foi atrás de documentação. Aí, quando eu entrei no CEEBJA aqui, ela que também ia até lá, buscava no CEEBJA os materiais, os conteúdos escolares para eu estudar e trabalhava na hemodiálise, eu ia para o CEEBJA somente para fazer as provas. (EX-ALUNO, 2018).
\end{abstract}

Durante esse ano de estudo, o entrevistado deixou claro que estudava tanto nas sessões de hemodiálise com a ajuda da professora, como em casa. As avaliações, após agendamento prévio, eram realizadas diretamente no CEEBJA. Ao ser questionado se gostava dessas aulas que tinha no hospital ele respondeu que no início ele não estava muito animado, pois havia toda a questão psicológica de não aceitação por conta do tratamento, segundo ele, sua vida escolar e seus amigos de escola estavam em Toledo e ele acreditava que quando acabasse o tratamento voltaria para lá e poderia continuar os estudos em sua cidade natal. Então, quando as aulas do CEEBJA começaram, ele estava desanimado e também porque existia a insegurança em não saber até quando esse tratamento seria necessário. Ele relata

\footnotetext{
141 Entrevista concedida pelo EX-ALUNO. Entrevista I. [abril. 2018]. Entrevistador: Claudinéia Maria Vischi Avanzini. Curitiba, 2018. 1 arquivo.mp3 (41min.27seg.). A entrevista na íntegra encontra-se transcrita nos Apêndices D e K desta tese.

142 Entrevista concedida pelo EX-ALUNO. Entrevista I. [abril. 2018]. Entrevistador: Claudinéia Maria Vischi Avanzini. Curitiba, 2018. 1 arquivo.mp3 (41min.27seg.). A entrevista na íntegra encontra-se transcrita nos Apêndices $D$ e $K$ desta tese.

${ }^{143}$ Entrevista concedida pelo EX-ALUNO. Entrevista I. [abril. 2018]. Entrevistador: Claudinéia Maria Vischi Avanzini. Curitiba, 2018. 1 arquivo.mp3 (41min.27seg.). A entrevista na íntegra encontra-se transcrita nos Apêndices D e K desta tese.
} 
que tinha receio de ficar daquela forma pelo resto da vida. Todavia, a insistência da professora foi decisiva para que ele retomasse os estudos durante o tratamento, pois, segundo o ex-aluno, ela argumentava da seguinte forma: "Não! Vamos, porque quando acabar você pode voltar e continuar lá, mas aí você não perdeu [...]. Vamos estudar". Ele destaca que não conseguia perceber isso e dizia: "Não, eu não vou perder, eu estou querendo me tratar agora". Mas a professora insistiu muito para que ele resgatasse os estudos de onde havia parado e acabou o convencendo.

O detalhe significativo que pode ser constatado agora, é que se ele não retornasse para sua vida escolar como foi proposto pela professora, ele não voltaria a estudar com os amigos quando retornasse à Toledo, porque em 2002 eles já estariam no $8^{\circ}$ ano, caso ele deixasse para fazer $07^{\circ}$ ano regular somente neste ano, ficaria atrasado com relação à sua turma de origem. Então, fazendo o CEEBJA, conseguiu acoplar os dois anos escolares num só e quando voltou para Toledo, depois do transplante que funcionou e foi encerrada a hemodiálise, pôde retomar os estudos com a própria turma. Lógico que isso só é possível concluir porque o histórico escolar dele é conhecido hoje, mas a proposta da Hospitalização Escolarizada perpassa esse objetivo. Essa questão chama a atenção para a imprevisibilidade do tratamento, pois no caso dele, quando se começa a fazer hemodiálise e é necessário um transplante de rim doado por cadáver, nada é previsível, não dá para programar nada, tudo dependerá dos rumos que o tratamento adquire e não é passível de planejamento.

Com relação às aulas que ele recebia no hospital, ele as descreve como sendo boas, pois além de distrair durante o período do tratamento, a professora "tinha uma didática pedagógica bacana" ${ }^{144}$,

[...] ela aguardava eles me conectarem na máquina, eu era pulsionado, tinha fístula, ela aguardava eu me conectar na máquina e eu vendo que estava tudo bem, que não tinha passado mal, nem nada, aí ela vinha com o conteúdo, cada dia de diálise, cada sessão nós trabalhávamos uma coisa. Numa sessão da segunda-feira nós vamos trabalhar Ciências, na sessão da quarta a gente pega Matemática, na sessão da sexta-feira vamos ver Geografia, ah, mas se você tem prova de Geografia na outra segunda, então nas três sessões de diálise vamos trabalhar só Geografia, porque na semana que vem você vai ter prova. Então o conteúdo era trabalhado, mais ou menos dessa forma. Ela trabalhava o conteúdo de prova na semana anterior comigo nas diálises, mas sem dizer... "Olha, em casa você estuda as outras disciplinas, as outras matérias". E era assim que a gente ia levando. (EXALUNO, 2018).

\footnotetext{
144 Entrevista concedida pelo EX-ALUNO. Entrevista I. [abril. 2018]. Entrevistador: Claudinéia Maria Vischi Avanzini. Curitiba, 2018. 1 arquivo.mp3 (41min.27seg.). A entrevista na íntegra encontra-se transcrita nos Apêndices D e K desta tese.
} 
Apesar de no início considerar as aulas chatas, por medo de nunca mais voltar a sua vida normal, ele foi percebendo que foram essas aulas que o ajudaram a continuar os estudos, chegando a realizar a formatura do Ensino Fundamental. $\mathrm{Na}$ cerimônia de formatura foram realizados diversos registros fotográficos, esses registros tinham por finalidade documentar o andamento da formatura dos alunos do CEEBJA Paulo Freire no final do ano de 2002. Segundo Kossoy (2014, p. 51), toda fotografia é realizada "com uma certa finalidade. [...] esses registros - que foram produzidos com uma finalidade documental ${ }^{145}$ - representarão sempre um meio de informação, um meio de conhecimento, e contarão sempre seu valor documental, iconográfico". Neste sentido, as próximas três fotografias selecionadas do álbum da formatura do ex-aluno, além de apresentar o registro do momento final de um determinado ciclo escolar, representam diversas informações e conhecimentos sobre o entrevistado, seu círculo de convívio e parte de sua história escolar.

Figura 18: Fotografia do entrevistado em sua formatura do Ensino Fundamental.

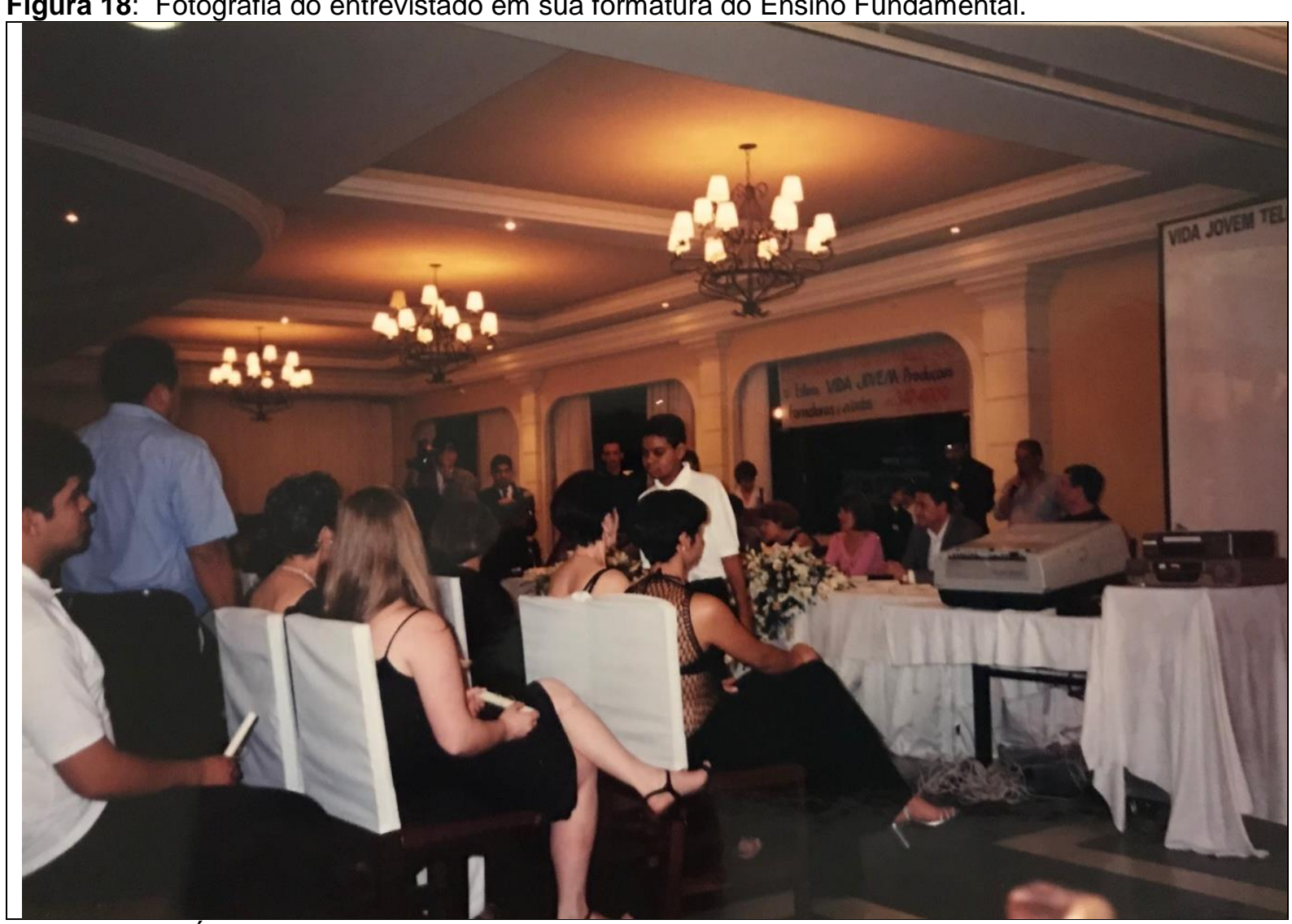

Fonte: Acervo Álbum de Família do ex-aluno. (Dezembro/2002).

\footnotetext{
${ }^{145}$ Grifo do autor.
} 
Na figura 18 podemos ver o local da formatura, muito provavelmente um clube da cidade, percebe-se que é um salão de festas bem requintado por conta dos três lustres com 12 lâmpadas pendurados no teto, os detalhes da arquitetura do local com rebaixamentos de gesso no teto e o piso, muito possivelmente revestido com porcelanato, com motivos geométricos. A organização do local para a formatura se deu com uma mesa diretiva para os membros do corpo docente a frente que contava com toalhas brancas que as cobriam até o chão e dois enfeites com arranjos de flores também brancas, as cadeiras dos formandos prostradas e viradas para a mesa diretiva foi organizada de duas a duas com um corredor de passagem no meio de cada dupla de cadeiras. No canto direito da fotografia há duas mesas, uma com um aparelho projetor e outra com dois aparelhos que parecem ser reprodutores de vídeo que estava sendo projetado no telão da empresa Vida Jovem Telões na parede logo a frente. A propaganda da empresa que forneceu o telão para o evento aparece não somente no próprio telão, como também numa faixa que está estendida num dos vãos, que podem ser janelas ou portas logo atrás da mesa diretiva. Além deste espaço de janela ou porta com a faixa de propaganda do telão é possível ver mais dois espaços iguais a esse nos fundos da sala.

Na fotografia há um homem com camisa social azul e calça preta em pé, no meio do corredor dos alunos e de costas para o fotógrafo, não é possível deduzir quem era e o que fazia ali, poderia ser um aluno que estava indo para a mesa diretiva ou ainda alguém da instituição que ficou naquele lugar para organizar os alunos em seus lugares adequados. Além dele, há pelo menos seis formandos sentados, todos com roupas sociais, as mulheres com vestidos pretos e sandálias com salto alto, os homens com camisas sociais brancas e calças pretas, todos estão sentados de frente para a mesa diretiva, onde também se observa pelo menos cinco pessoas sentadas, que muito provavelmente eram professores, direção e equipe pedagógica do CEEBJA Paulo Freire, instituição onde o entrevistado estudou a $7^{a}$ e $8^{\underline{a}}$ série naquele ano. Atrás da mesa diretiva também há outras sete pessoas em pé, provavelmente, analisando as roupas que estavam vestindo ou equipamentos que estavam portando, eram seguranças, fotógrafos ou funcionários de apoio do CEEBJA ou do próprio clube.

O entrevistado aparece na fotografia voltando da mesa diretiva em direção às cadeiras destinadas aos formandos, não é possível saber se esse momento era o início do evento ou algum outro em que ele foi chamado para ir à mesa, mas percebese pela expressão de seu rosto que ele está bastante sério, indicando que estava 
nervoso ou apreensivo. Entretanto, na figura 19, fica evidente que ele está voltando para seu lugar depois de receber o canudo de formatura que representa o certificado. Ele apresenta todo feliz e orgulhoso esse canudo e posa para o fotógrafo registrar antes de se sentar em seu lugar.

Figura 19: Fotografia do entrevistado em sua formatura do Ensino Fundamental.

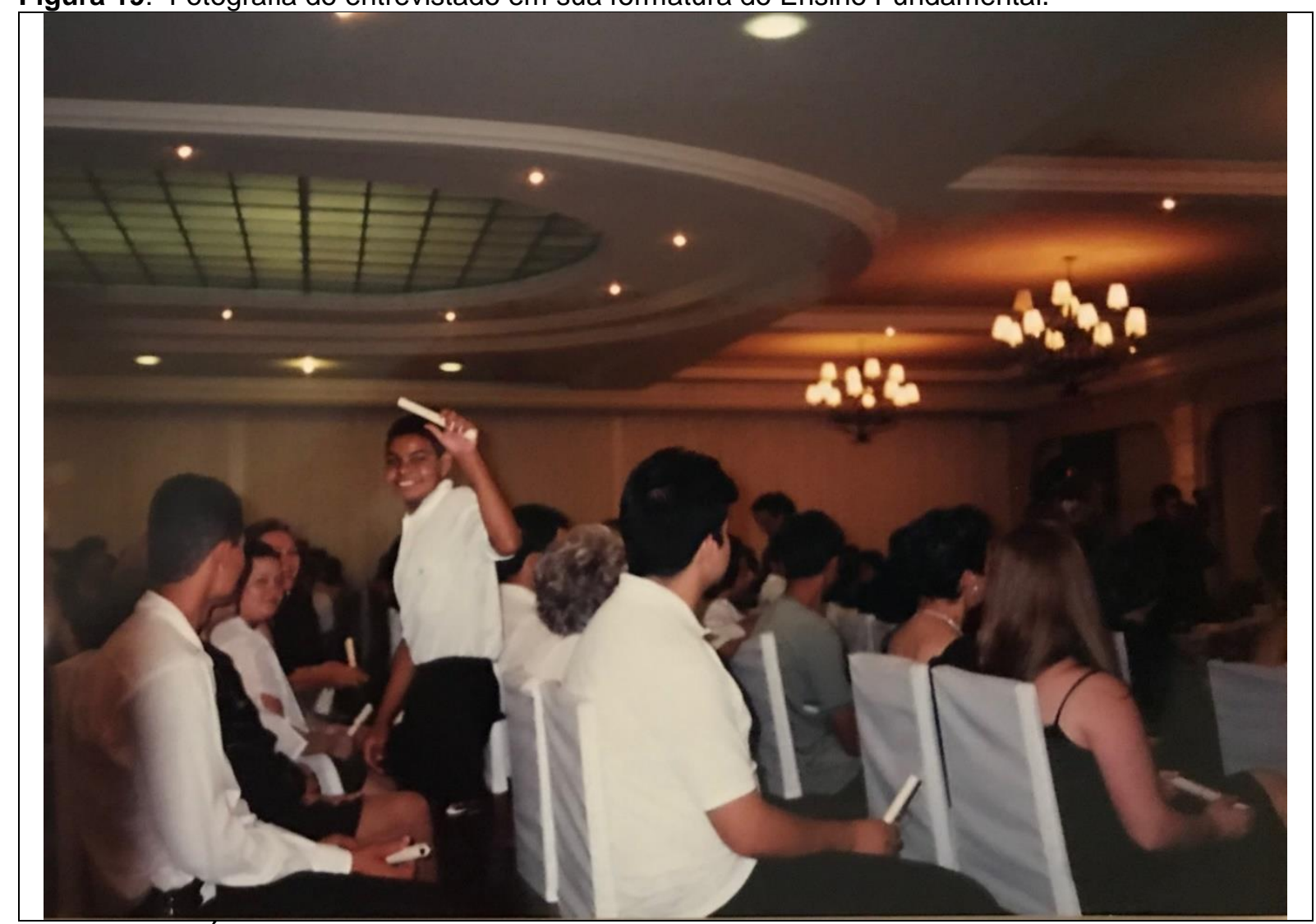

Fonte: Acervo Álbum de Família do ex-aluno. (Dezembro/2002).

Na imagem há mais alunos sentados nas cadeiras destinadas aos formandos, a maioria deles está com o canudo nas mãos e as únicas duas formandas que estão voltadas para a fotografia estão sentadas nas duas últimas cadeiras que aparece na imagem no canto superior esquerdo e parecem estar felizes, pois sorriem ao olhar para o entrevistado enquanto ele posa para o fotógrafo. Entre todos os formandos observados na fotografia, somente um deles está vestido de forma diferente dos demais, está sentado no terceiro lugar da segunda fileira da fotografia e está com uma camiseta cinza, destoando do restante dos formandos que estão todos com roupas sociais nas cores preto ou branco, o que sugere que essa roupa foi padronizada para os estudantes utilizarem na formatura. Ao fundo da imagem, ainda é possível perceber que há um grande número de pessoas, que seriam os convidados, familiares ou ainda formandos de outras turmas. 
A figura 20, ainda no dia da formatura, apresenta o entrevistado e a professora que o auxiliou durante todo esse processo de escolarização até a realização do evento no qual estão retratados. Ela está vestida com uma blusa social vermelha com mangas, uma saia e sapatos pretos, está com o cabelo amarrado e parece estar falando alguma coisa para ele no momento em que a fotografia foi registrada.

Figura 20: Fotografia do entrevistado com sua professora hospitalar na formatura do Ensino Fundamental.

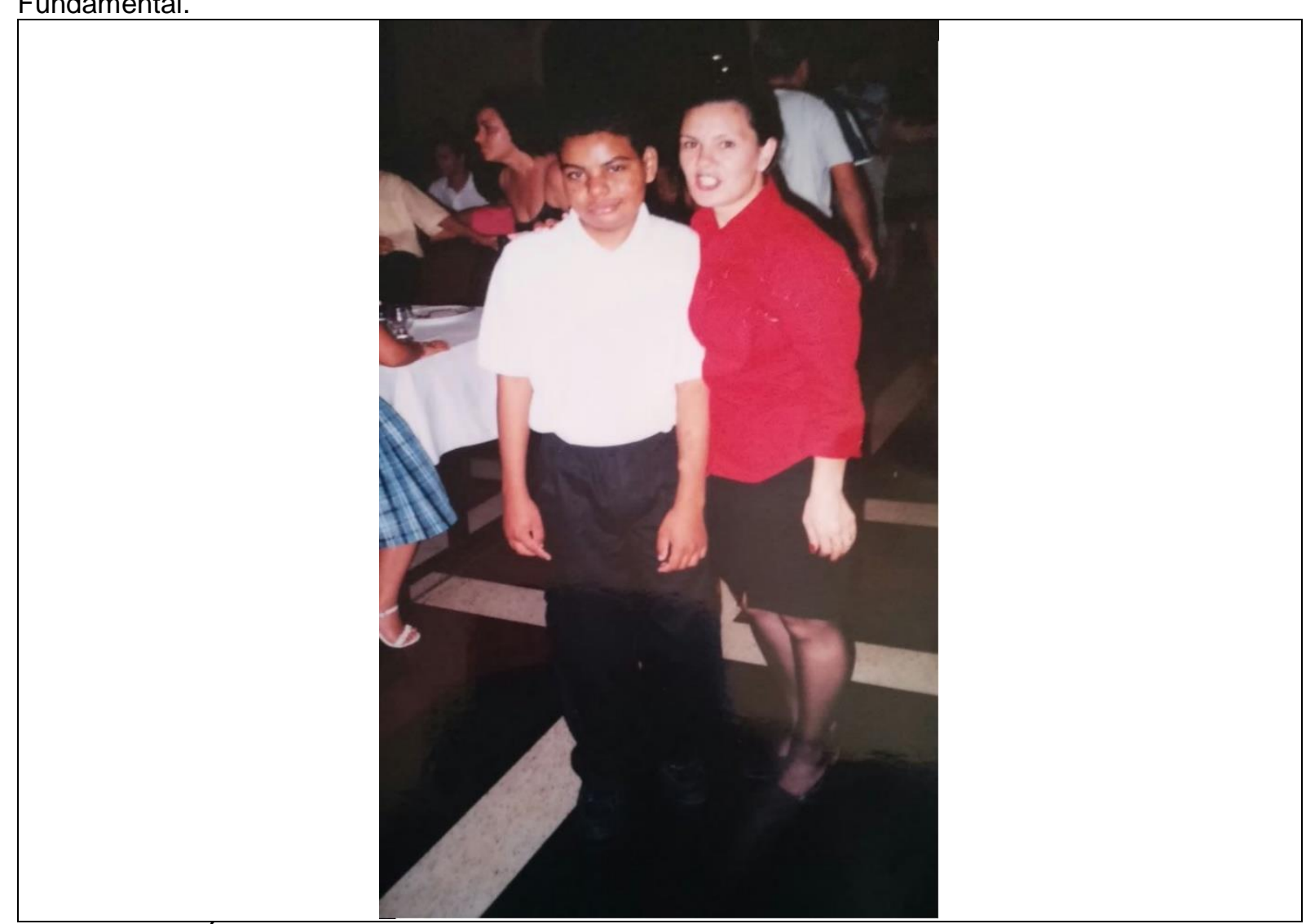

Fonte: Acervo Álbum de Família do ex-aluno. (Dezembro/2002).

Ao que parece pelos pratos e copos distribuídos nas mesas observadas ao fundo da imagem dos dois, as outras pessoas que participavam da formatura se preparavam para um jantar. A Formatura, segundo o entrevistado foi organizada e promovida pelo pessoal da Nefrologia Pediátrica e Hemodiálise do Hospital, pois além dele havia outros colegas de hemodiálise que também finalizaram o Ensino Fundamental no CEEBJA e fizeram a formatura deste nível de ensino no final de 2002.

Logo depois disso, o entrevistado fez um novo transplante com um rim doado pela fila de transplantes e em 2003 começou o Ensino Médio numa escola regular em 
Curitiba, porque ficou em acompanhamento na cidade até 2008 , sendo que voltou a morar em Toledo no final do ano de $2003^{146}$.

Figura 21: Fotografia do entrevistado com sua mãe em viagem para o litoral do Paraná, promovida pela equipe de nefrologia do hospital, logo após o segundo transplante.

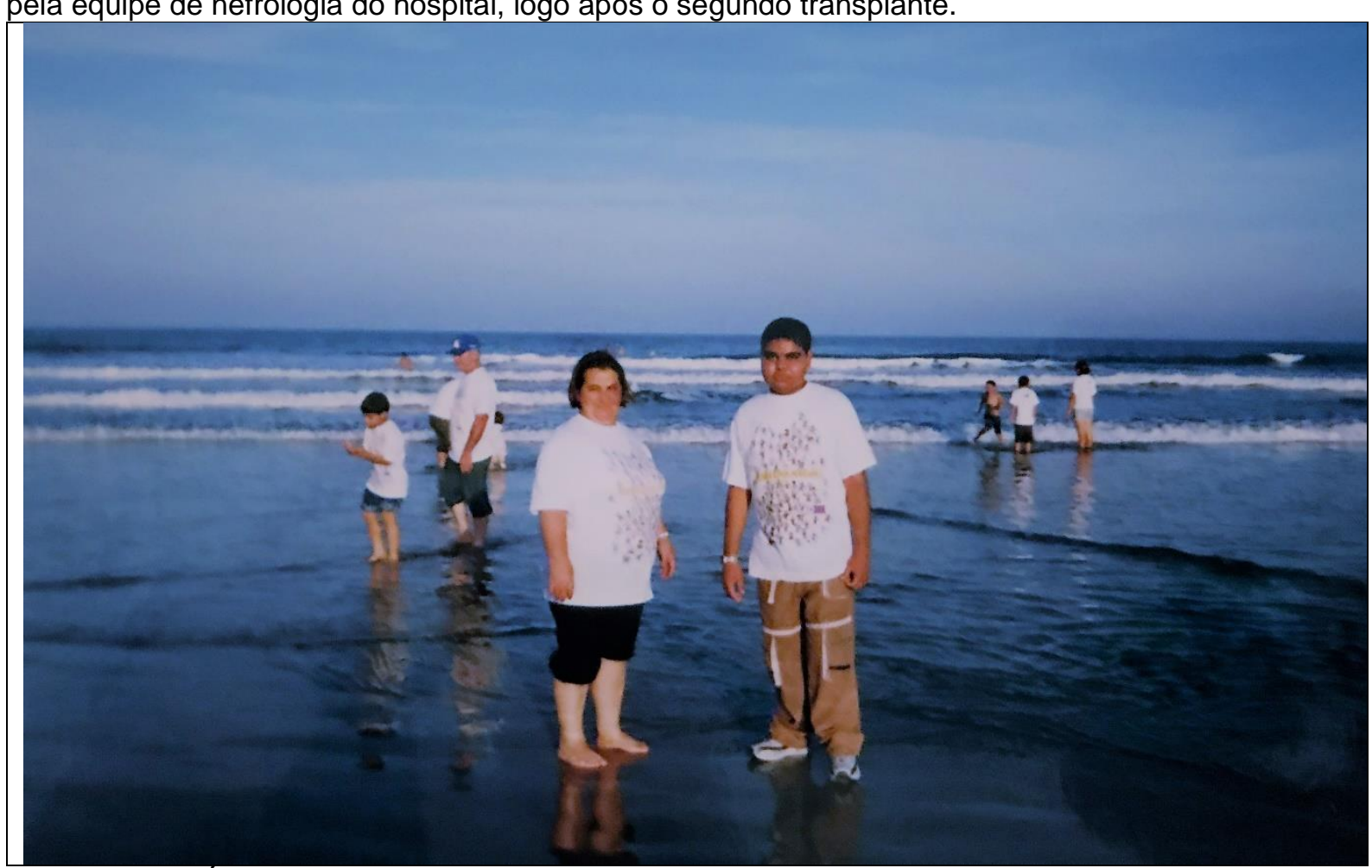

Fonte: Acervo Álbum de Família do ex-aluno. (2003).

Na figura 21 há o registro da primeira viagem ao litoral para conhecer o mar do entrevistado. Essa viagem aconteceu depois de um tempo do segundo transplante, evidência observada por conta de ele estar bem mais inchado, possivelmente consequência das doses altas de corticoides, um dos remédios utilizados no póstransplante e pelo fato de não estar utilizando a máscara de proteção para evitar possíveis infecções, normalmente somente dispensam do uso da máscara depois dos 3 ou 6 primeiros meses do transplante. Ao seu lado está sua mãe que ainda morava com ele em Curitiba por conta do tratamento pós transplante. Eles registram o seu contato com o mar, mas não entram na água, ficam com roupas, sendo que ele até está usando tênis, calça comprida e uma camiseta que parece ter sido cedida pelo hospital para as pessoas que estariam no passeio, afinal sua mãe, assim como as algumas outras pessoas ao fundo da imagem também usam camisetas com a mesma estampa. Bem no fundo da imagem é possível ver que há somente três pessoas

${ }^{146}$ No primeiro ano pós transplante a visita aos médicos para acompanhamento e controle dos medicamentos é bastante frequente, chegando a ser semanal, o que impossibilita os pacientes de morarem distante do local do tratamento. 
dentro da água, as outras estão somente molhando os pés ou pernas e ficam na parte mais rasa da praia, o que pode indicar que o dia da visita não estava tão quente para a realização de banhos de mar ou as pessoas estavam apreensivas por terem pouca experiência com o mar.

Por conta da necessidade de continuar morando em Curitiba depois do segundo transplante ainda por praticamente um ano, vista a obrigatoriedade de visitas frequentes ao hospital, o $1^{\circ}$ ano do Ensino Médio do entrevistado foi realizado numa escola da cidade. No começo de 2004, ao voltar para Toledo, ele transfere a grade escolar para lá e finaliza o $2^{\circ}$ e $3^{\circ}$ ano do Ensino Médio em sua cidade natal, mesmo ainda fazendo acompanhamento pós transplante em Curitiba. Ao terminar o Ensino Médio, no início de 2006 ele começou a trabalhar na farmácia de um hospital de Toledo, sendo auxiliar de farmácia. Em 2007 prestou um concurso público, passou e começou a trabalhar como auxiliar administrativo também em Toledo ficando neste trabalho até 2008. Em 2009 ingressou na Universidade fazendo graduação em Enfermagem se formando em 2014.

Ele relata que teve dificuldades na sua graduação, pois vindo "de família humilde" tinha que estudar de manhã e trabalhar a tarde e noite para pagar a faculdade, pois esta era privada. Em junho de 2010, com dificuldades financeiras para cobrir os gastos com a mensalidade e com os materiais para conseguir acompanhar o curso, teve que trancar sua matrícula e ficou fora por seis meses, sendo que em conversas com a coordenadora do curso, esta sugeriu que ele fizesse o Exame Nacional do Ensino Médio (ENEM), para conseguir uma bolsa e pagar pelo menos a metade das mensalidades. Em novembro de 2010 ele fez o ENEM e em 2011 volta para a Universidade com uma bolsa de 100\%, por conta da nota do ENEM, ele foi bem na redação e nas disciplinas de Biologia, conseguindo nota suficiente para ter bolsa integral.

Não, já que eu ganhei uma bolsa integral eu posso estudar, voltar para o meu curso, que eu estava fazendo, que eu já conhecia os professores, conhecia os colegas. Eu posso voltar para a Universidade que eu estava fazendo e sem pagar! Eu vou aproveitar a oportunidade. (EX-ALUNO, 2018).

Em fevereiro de 2011 ele voltou a fazer graduação de Enfermagem, concluindo em dezembro de 2013, sendo que a colação de grau aconteceu em janeiro de 2014.

Como ele queria seguir na área da saúde, na enfermagem, mas era concursado na área administrativa, pede exoneração do emprego público de auxiliar administrativo 
em Toledo e em fevereiro de 2014 presta a prova para residência de enfermagem ${ }^{147}$ no Hospital Universitário de Cascavel ${ }^{148}$, passa e em março de 2014 inicia os estudos na residência de enfermagem como bolsista, como enfermeiro residente. Então, faz a pós-graduação, a residência em enfermagem de março de 2014 a março de 2016 e já em abril deste mesmo ano entra no mestrado também como bolsista, concluindo o mestrado em abril de 2018. Paralelamente ao mestrado, em dezembro de 2017 ingressa no hospital onde fez residência em Cascavel como enfermeiro assistencial, não mais como graduando, mas sim como enfermeiro. Então, desde dezembro de 2017 exerce a profissão de enfermeiro assistencial. "Depois que eu entrei na graduação eu emendei, fiz graduação, pós graduação e mestrado já na sequência"149.

Ao ser questionado se essas aulas que ele recebeu no hospital o ajudaram ele responde que "Demais. Demais". O entrevistado comentou que já falou para a professora que o atendia no hospital que se ele não tivesse tido aquela professora para lhe incentivar a continuar os estudos ele não teria o título de mestre, além de destacar que "não existe mestre que não passou pelo Ensino Fundamental". Ele esclareceu que o incentivo da professora foi fundamental.

Foi ali que tudo começou, foi o incentivo da pedagogia escolar ali com o trabalho que a [professora] fez comigo que deu todo o pontapé para eu seguir meus estudos e estar onde eu estou hoje, de ter o título que eu tenho hoje. Se não fosse aquelas aulas, se não fosse aquele momento de estudo, se eu tivesse talvez, pensado: "Não, eu vou parar, não vou estudar, vou esperar voltar para casa para retomar", eu não sei se eu retomaria, talvez não... (EXALUNO, 2018).

Ele continua justificando seu posicionamento informando que depois do transplante ficou ainda mais um ano em Curitiba na recuperação pós-operatória, neste período não podia fazer muito esforço, ainda assim, fez o $1^{\circ}$ ano do Ensino Médio tendo ainda o suporte do pessoal da Educação Hospitalar. "Então, se não fosse isso, eu não sei se eu continuaria. Eu não sei se eu teria feito Ensino Médio, muito menos

\footnotetext{
147 O programa de residência de enfermagem é um programa de especialização que dá bolsas de estudos. (Informação verbal Ex-aluno 1).

${ }^{148}$ Cascavel fica a $52 \mathrm{~km}$ de Toledo. Disponível em https://www.google.com.br/maps/dir/ Acesso em 27/05/2018.

${ }^{149}$ Entrevista concedida pelo EX-ALUNO. Entrevista I. [abril. 2018]. Entrevistador: Claudinéia Maria Vischi Avanzini. Curitiba, 2018. 1 arquivo.mp3 (41min.27seg.). A entrevista na íntegra encontra-se transcrita nos Apêndices D e K desta tese.
} 
graduação, residência nem pensar e mestrado era um sonho impossível se não fosse isso" 150 .

Ele ainda destacou que a dinâmica das aulas que ele recebia dentro do hospital o marcou bastante,

[...] o ensino principalmente da Ciência era muito lúdico, falava de algumas coisas que não tinha nada a ver com a Ciência, mas que ao mesmo tempo trabalhava Ciência [...]. Ela sabia chamar a atenção para a gente se concentrar mesmo estando ali conectado a uma máquina, [...] ela conseguia fazer com que a gente não ficasse preocupado com as intercorrências e prendia a minha atenção naquele conteúdo que estava sendo explicado, a Matemática mesmo era trabalhado com questões de remédios, eu lembro até hoje, quando ela falava: "Que horas você tem que tomar o remédio? Se você tomar o remédio ao meio dia e depois tomar o remédio às quatro da tarde, quantas horas passou de intervalo?". Então, o trabalho lúdico dela e trazendo para a minha realidade daquele momento foi algo que me marcou. Hoje eu fico pensando: "Meu Deus, como ela era boa, não é!? Para me prender". Eu não tinha essa destreza, essa habilidade, esse feeling mesmo, que acho que só quem é da pedagogia mesmo para aprender isso! Hoje eu fico imaginando: "Gente, como é que ela conseguia?" (EX-ALUNO, 2018).

As aulas eram tão interessantes, segundo o entrevistado, que conseguia desfocar a atenção dos alunos transferindo o foco de preocupação para os conteúdos escolares e não mais o tratamento que estava sendo feito. Ele destacou que em alguns momentos, eles nem percebiam que o tratamento tinha acabado e só viam quando a enfermeira chegava dizendo que era hora de encerrar, sendo que eles ou a professora até pediam para esperar um pouco, pois estavam terminando a atividade, ou iam ler até o final de determinado capítulo de algum livro. Segundo o entrevistado isso acontecia porque era algo que os distraia, a professora "conseguira prender realmente a atenção para aquilo que estava sendo passado" e hoje ele até pensa que a professora era bastante boa, pois "no meio de todo aquele contexto clínico ali, de saúde, doença, ela chamava a atenção para questão escolar e educacional"151.

O ex-aluno considera imprescindível esse tipo de atendimento educacional de professores no hospital, porque faz com que "o paciente não fique tão preocupado com sua condição clínica, propriamente dita", afinal o acompanhamento pedagógico hospitalar normalmente é oferecido quando o paciente fica um longo período em atendimento hospitalar. Segundo o ex-aluno, quando o período do tratamento for

\footnotetext{
150 Entrevista concedida pelo EX-ALUNO. Entrevista I. [abril. 2018]. Entrevistador: Claudinéia Maria Vischi Avanzini. Curitiba, 2018. 1 arquivo.mp3 (41min.27seg.). A entrevista na íntegra encontra-se transcrita nos Apêndices $\mathrm{D}$ e $\mathrm{K}$ desta tese.

151 Entrevista concedida pelo EX-ALUNO. Entrevista I. [abril. 2018]. Entrevistador: Claudinéia Maria Vischi Avanzini. Curitiba, 2018. 1 arquivo.mp3 (41min.27seg.). A entrevista na íntegra encontra-se transcrita nos Apêndices D e K desta tese.
} 
menor que dois dias, não é necessário receber o acompanhamento da professora do hospital, que provavelmente só conhecerá o paciente e este não terá acompanhamento pedagógico. Entretanto, se for uma pessoa que ficará muito tempo no hospital, é importante que tenha profissionais que o atendam nas questões médicas e também por outras questões, para que este paciente possa pensar em outras questões que não seja só a doença. A Educação Hospitalar inserida no contexto hospitalar, ajuda a distanciar da questão da doença e traz outros universos, outras discussões como o estudo dos dinossauros, no caso da Matemática, pizza, cortes de pizzas, para o estudo de frações. E isso é extremamente importante e necessário segundo o posicionamento do ex-aluno entrevistado.

O ex-aluno ainda lembrou dos momentos de descontração das aulas, pois havia momentos em que eles não queriam mais fazer atividades escolares, pois estavam cansados ou com dor de cabeça e a professora propunha que eles assistissem desenhos. Nestas situações, eles largavam todo o material de lado e assistiam desenho e isso também era interessante por parte da professora, pois ela percebia que os alunos estavam saturados, cansados, e continuavam na tentativa de distanciamento do tratamento levando-os ao universo da televisão, o que segundo ele era bem gostoso. A professora comentava o seguinte: Aí, também cansei, quer saber, não vamos mais estudar isso, vamos assistir desenho"152.

Ao finalizar a entrevista ele comentou que tem contato com professora que 0 atendeu no hospital e os dois estão trabalhando na produção de um artigo científico para contarem essa história dos dois. A intenção é escrever como foi a participação da professora na formação escolar do ex-aluno, como ocorreram as vivências dele enquanto paciente e também aluno de uma professora dentro do hospital. Segundo ele, isso é algo que considera válido para as crianças de hoje e que estão na hemodiálise, para que elas não acreditem que só o fato de estarem na hemodiálise vai acabar a vida para elas, que não verão mais os amigos da escola, não vão mais frequentar os bailes, não vão fazer mais nada, nem ver mais seus professores, sendo

\footnotetext{
152 Entrevista concedida pelo EX-ALUNO. Entrevista I. [abril. 2018]. Entrevistador: Claudinéia Maria Vischi Avanzini. Curitiba, 2018. 1 arquivo.mp3 (41min.27seg.). A entrevista na íntegra encontra-se transcrita nos Apêndices D e K desta tese.
} 
que não "é bem assim, a escola pode ir até ele, e é o que acontece"153 e aconteceu com ele durante o período de seu internamento.

\subsubsection{O olhar da família da criança internada para a Educação Hospitalar}

Com relação à família das crianças que receberam a Educação Hospitalar no hospital entre 1988 e 2012 foi possível entrevistar a mãe de uma ex-aluna do Hospital e que fazia tratamento com a equipe de nefrologistas, porque ela tinha problema de insuficiência renal crônica, sendo que a filha desta senhora frequentou o hospital infantil em Curitiba por aproximadamente 7 anos, entre 1991 e 2001, a menina perdeu o rim transplantado em 25 de agosto de 1993. Essa ex-paciente nasceu em 28 de fevereiro de 1982 e entre os anos de 1991 e 1993 ficou fazendo tratamento de hemodiálise no hospital, frequentou a Escola Estadual Miguel Kruger no Bairro Portão em Curitiba desde a pré-escola até a 4⿳亠丷a série do Ensino Fundamental.

A mãe informou que logo que a filha nasceu o médico que a atendeu solicitou que ela procurasse um bom pediatra. Com essa recomendação, a mãe acredita que o médico em questão observou algo diferente com a criança desde o seu nascimento, mas ela, na época se considerava bastante simples, "do interior" 154 , acabou indo para o atendimento de saúde público e solicitou um bom pediatra, ao que lhe indicaram Dr. Dario, um pediatra que já trabalhava na área há 8 anos e inicialmente ela o considerou um bom médico, pois sua filha "amava aquele pediatra"155. A mãe relatou que a filha tinha infecções muito frequentes e o médico sempre falava "Mãezinha, quando ela tiver 6 ou 7 anos ela vai criar defesa [...] e essas infecções ela não vai ter mais"156. Mesmo sendo simples, como ela destacou, um dia ela questionou o médico com relação ao grande número de antibióticos que a filha ingeria, se isso não iria fazer algum mal para ela, ao que o médico garantiu que não, entretanto, segundo a mãe, foram os antibióticos que destruíram a função renal de sua filha que com 7 anos, no final de $1989^{157}$, já estava praticamente com os rins destruídos, ocasionando a perda

\footnotetext{
153 Entrevista concedida pelo EX-ALUNO. Entrevista I. [abril. 2018]. Entrevistador: Claudinéia Maria Vischi Avanzini. Curitiba, 2018. 1 arquivo.mp3 (41min.27seg.). A entrevista na íntegra encontra-se transcrita nos Apêndices $\mathrm{D}$ e $\mathrm{K}$ desta tese.

${ }^{154}$ Comentário da mãe em entrevista. Grifo meu.

155 Comentário da mãe em entrevista. Grifo meu.

${ }^{156}$ Entrevista concedida pela MÃE. Entrevista I. [nov. 2016]. Entrevistador: Claudinéia Maria Vischi Avanzini. Curitiba, 2016. 1 arquivo.mp3 (28min.21seg.). A entrevista na íntegra encontra-se transcrita nos Apêndices $\mathrm{E}$ e $\mathrm{J}$ desta tese.

${ }^{157} \mathrm{Na}$ entrevista ela confunde os anos e diz que a filha tinha 7 anos no final do ano de 1990, mas como ela nasceu no dia 8 de fevereiro de 1982, em 1990 ela já teria 8 anos.
} 
total da função renal. Somando-se a isso, neste mesmo ano, a filha teve caxumba, varicela, e várias outras doenças. Em decorrência, acabou procurando outro pediatra que informou que a sua filha estava com uma doença renal crônica, essa informação acabou desestruturando totalmente a mãe, que, em três momentos distintos ao tentar fazer a fístula na filha para começar o tratamento dialítico, acabou fugindo com ela do hospital. "Hoje, é nossa, não pode, né! Mas eu era louca, eu fiquei completamente louca, louca, louca. Eu não aceitava!"158.

Essa reação de negação e fuga descrita pela mãe entrevistada não necessariamente é considerada loucura, na verdade ela ocorre em alguns casos por conta do acometimento de doenças crônicas gerando reações psicológicas no próprio doente ou em sua família. Com base na teoria de Kübler-Ross ${ }^{159}$ que propõe cinco estágios pelo qual as pessoas passam ao lidar com o luto e a possibilidade da aplicação destes estágios para qualquer forma de perda pessoal catastrófica, no caso a perda da saúde, essa reação descrita pela mãe entrevistada seria uma reação considerada dentro da normalidade.

Apesar de não significar que as pessoas passem por todas as cinco fases de luto descrita por Elisabeth Kübler-Ross, estas são consideradas úteis como sistemas de categorias para conceituar as nuances do modo como se administra o luto. Segundo Kübler-Ross negação, raiva, negociação, depressão e aceitação são as cinco fases do luto. Entretanto, no artigo de Spitz (1997) sobre as reações psicológicas à doença e ao adoecer são descritas quatro fases: regressão, depressão, negação e aceitação.

A negação é considerada "uma defesa contra a tomada de consciência da enfermidade, que consiste na recusa parcial ou total da percepção do fato de se estar doente" (SPITZ, 1997, p. 5). Essa negação é um mecanismo de urgência contra a angústia, sendo observada nas fases iniciais das doenças agudas ou de prognóstico grave. Com o passar do tempo, a negação costuma diminuir e a pessoa entra na fase da depressão. A depressão representa uma consequência psíquica quase inevitável

\footnotetext{
158 Entrevista concedida pela MÃE. Entrevista I. [nov. 2016]. Entrevistador: Claudinéia Maria Vischi Avanzini. Curitiba, 2016. 1 arquivo.mp3 (28min.21seg.). A entrevista na íntegra encontra-se transcrita nos Apêndices E e J desta tese.

159 Elisabeth Kübler-Ross foi uma psiquiatra suíço-americana, nascida em 1926, que se especializou em cuidados paliativos e em situações próximas da morte. Depois de trabalhar durante anos em contato com pacientes em estado terminal, desenvolveu o modelo Kubler-Ross, em que estabeleceu as cinco fases do luto. (PSICONLINEWS, 2017). Disponível em http://www.psiconlinews.com/2017/07/luto-as5-fases-de-elisabeth-kubler-ross.html. Acesso em 01/07/2018.
} 
do adoecimento, onde se observa os mais diversos estados mentais, mas é importante não confundir os sentimentos de preocupação, desesperança e tristeza relacionados à doença e à internação com quadros depressivos de maior intensidade (SPITZ, 1997, p. 3).

A raiva é a segunda etapa apontada o Kübler-Ross, mas não descrita no artigo de Spitz. Ela aparece como resultado da frustração que acomete as pessoas ao perceber a finitude da vida. Na raiva a pessoa reage com muita irritação ao compreender seu estado real e as consequências da doença e começa a questionar o porquê de isso acontecer com ela.

De acordo Spitz (1997, p. 02), a regressão é um mecanismo quase universal caracterizado com o aparecimento de um comportamento infantil de dependência e egocentrismo. No início da doença esse comportamento é considerado necessário e útil, pois o paciente passa a aceitar a ajuda e o apoio da equipe médica e do grupo social a que pertence, renunciando temporariamente suas atividades habituais.

A fase da negociação é o começo da aceitação da realidade mediante barganhas e onde a pessoa tem maior aproximação com a espiritualidade. Neste momento o paciente admite a existência da doença e pode tentar negociar em busca da cura. Finalmente, a adaptação ou aceitação ${ }^{160}$ é a superação dos outros estágios, entretanto, não significa uma submissão à doença ou aceitação passiva dela, é um processo permanente e dinâmico de convívio, onde a pessoa compreende que a doença é inevitável e acaba por aceitar seu destino, "por meio de um trabalho emocional complexo e doloroso de elaboração da profunda ferida narcísica representada pela enfermidade" (SPITZ, 1997, p. 5).

Apesar de Kübler-Ross alegar que os estágios nem sempre ocorrem numa determinada ordem e não serem todos experimentados por todas as pessoas, cada uma apresentará sempre pelo menos dois deles. No caso da entrevistada, é evidente a fase da negação e da raiva que motivaram a fuga dela em três momentos onde a filha teria que realizar um procedimento cirúrgico para iniciar o tratamento.

A filha da entrevistada, que segundo ela, estaria com 3 meses de idade, período em que ela não apresentava nenhum tipo de comprometimento de saúde, com exceção das múltiplas infecções, que ocasionaram o problema renal e a levaria a receber $\mathrm{o}$ atendimento pedagógico junto ao hospitalar, pode ser observada na figura

160 PARA FRASEAR, 2011. Disponível em: http://www.parafrasear.net/2011/02/o-modelo-de-kublerross.html. Acesso em: 01/07/2018. 
22. A imagem mostra uma criança bem grande e robusta, parecendo ter mais que 3 meses, até por conta do posicionamento das mãos que parecem estar bem firmes. Além disso, ela parece estar tranquila repousando no que parece ser uma cama, com alguns bichos de pelúcia ao redor. Como ela se encontrava com os olhos fechados, talvez estivesse dormindo.

Figura 22: Fotografia da filha da entrevistada com 3 meses.

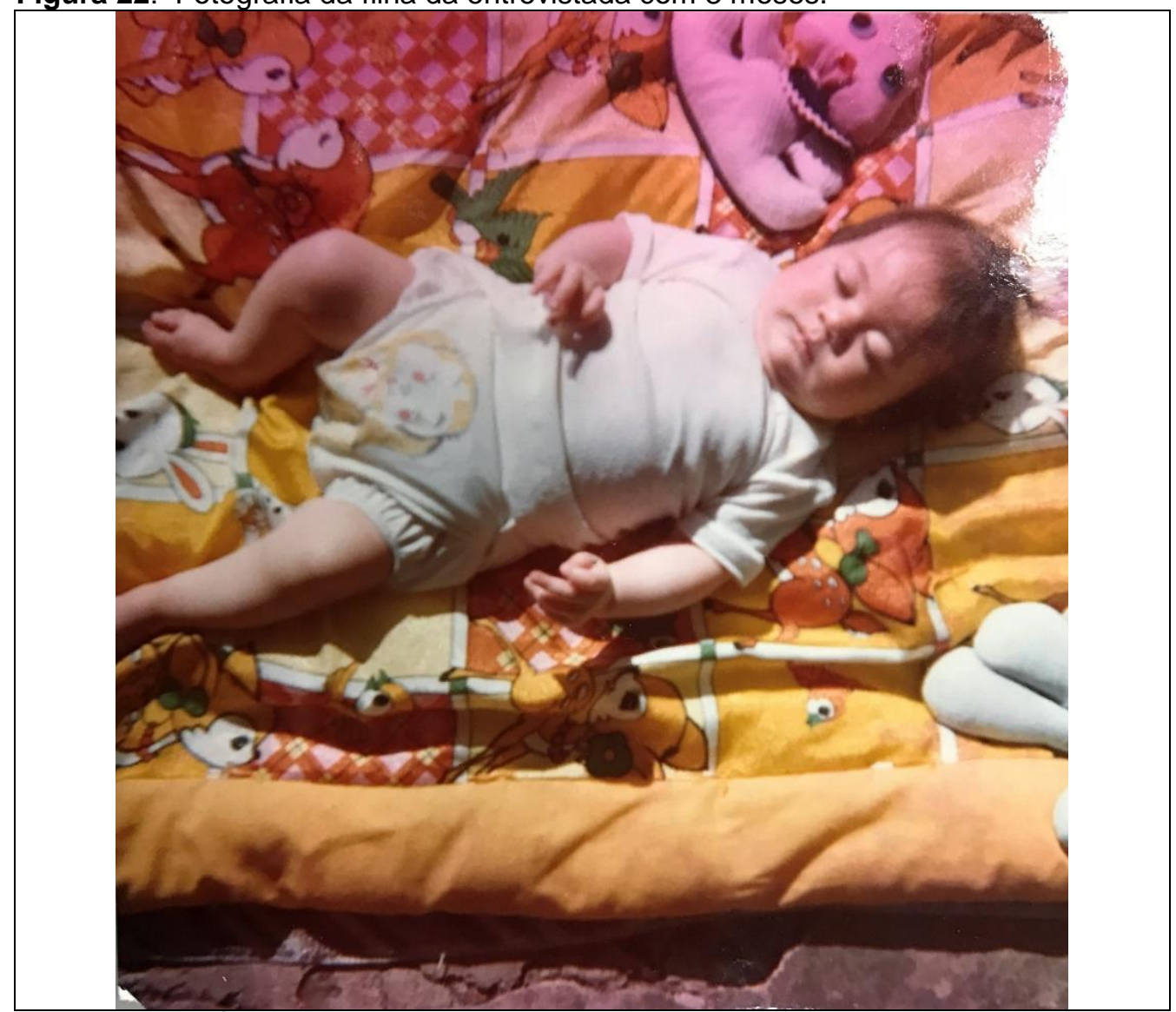

Fonte: Acervo Álbum de Família. (Junho/1982).

Kossoy indica que "a imagem fotográfica pode e deve ser utilizada como fonte histórica". Entretanto, precisamos levar em consideração que o registro

mostra apenas um fragmento da realidade, um e só um enfoque da realidade passada: um aspecto determinado. Não é demais enfatizar que este conteúdo é o resultado final de uma seleção de possibilidades de ver, optar e fixar um certo aspecto da realidade primeira (KOSSOY, 2014, p.121).

Complementando essa perspectiva, Sontag sustenta que "embora em certo sentido a câmera de fato capture a realidade, e não apenas a interprete, as fotos são 
uma interpretação do mundo" 161 , e ainda "a representação da realidade pela câmera deve sempre ocultar mais do que revela". (SONTAG, 2004, p.17, 34).

Neste sentido, apesar da mãe indicar que a fotografia foi tirada no mês de junho, o fato da criança estar descoberta e com uma roupa que indicava não ser um dia frio, pois ela estava vestindo um tipo de shorts e as mangas da blusa encontravamse arregaçadas, levanto a hipótese de a imagem ter sido registrada em meses mais quentes e, portanto, quando a criança era um pouco mais velha.

Figura 23: Fotografia da filha da entrevistada com 4 anos numa Festa Junina.

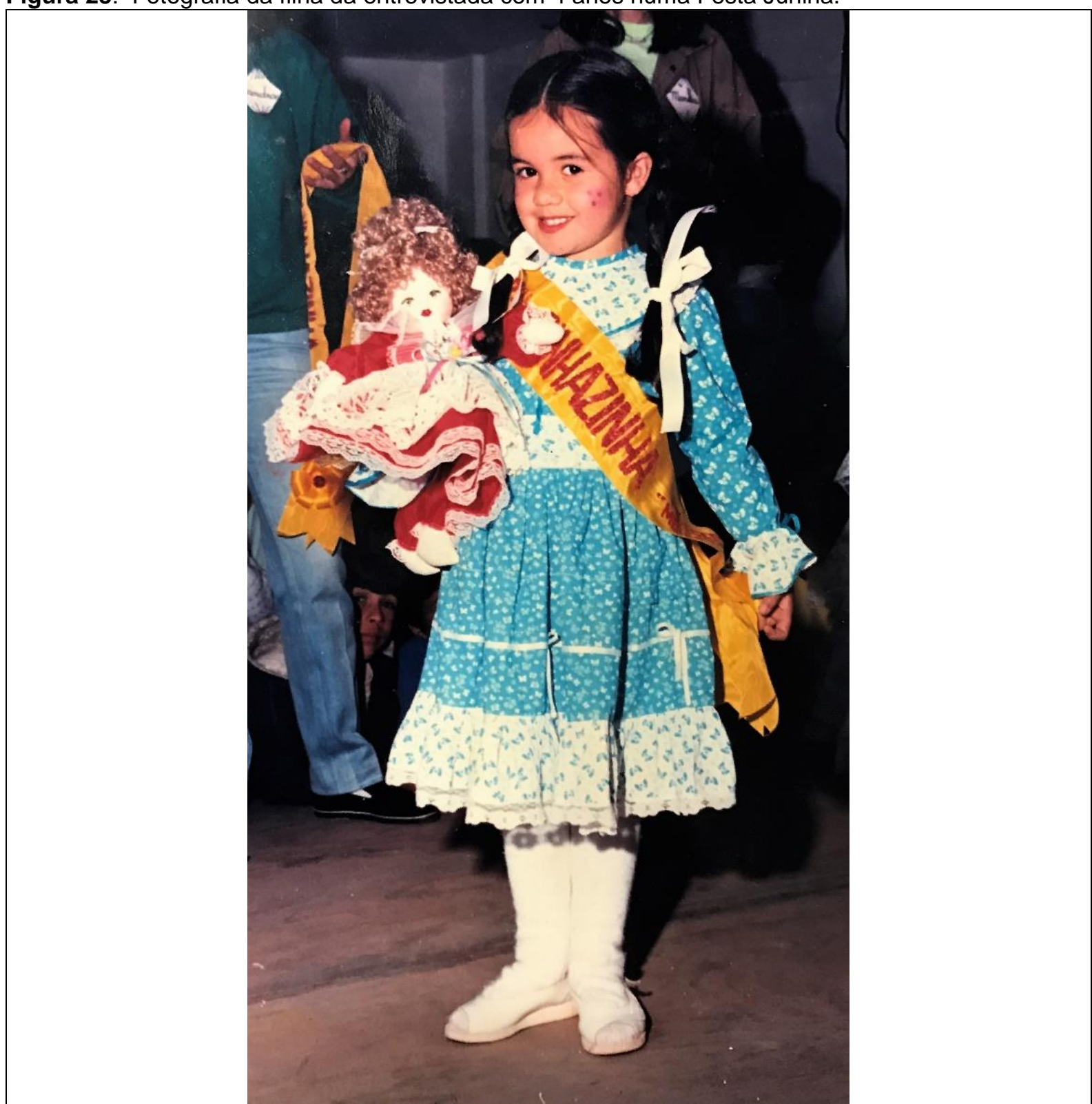

Fonte: Acervo Álbum de Família. (Junho/1986).

161 Para mais informações sobre crítica da fonte fotográfica, consultar: BURKE, Peter. Como confiar em fotografias. Folha de S. Paulo, 4 fev. 2001, Caderno Mais!, p.13. Marco Antonio Stancik, 464. Revista Brasileira de História, vol. 29, ㄲo 58. 
Registros da filha em situações escolares são apresentados na maioria das vezes em algum tipo de comemoração, como pode ser observado na figura 23 registrada em junho de 1986 numa Festa Junina da escola onde a filha da entrevistada estudava, quando tinha 4 anos. Na imagem ela aparece com um vestido típico de festa junina azul e branco de mangas longas e estampa de borboletinhas, está ainda com uma faixa amarela escrita Sinhazinha em vermelho, fitas brancas finalizando as tranças, rosto maquiado com pintinhas pretas na bochecha e segurando uma boneca com vestido vermelho e branco ao colo. As roupas de todos que aparecem na fotografia, inclusive da filha da entrevistada, que está com uma meia calça branca bastante grossa e um sapatinho branco nos pés evidencia que o registro aconteceu realmente na metade do ano, período de inverno bastante intenso em Curitiba.

Em 1986, ano do registro da fotografia, a filha da entrevistada estudava na Educação Infantil fazendo pré-escola e ainda não havia iniciado o tratamento de hemodiálise no hospital, somente fazia acompanhamentos médicos por conta das infecções repetitivas que tinha. Somente depois que o tratamento começou, entre 1991 e 1993, a filha dela começou a ter aula com a Professora 1 que trabalhava no hospital. Segundo a mãe, a professora auxiliava sua filha nas tarefas que ela tinha dificuldade. Esse atendimento começou porque a menina não conseguia acompanhar as aulas na escola e tinha que levar as tarefas e dúvidas para serem esclarecidas junto à família em casa. A mãe relata que tentava ensinar a filha, mas havia conteúdos que não conseguia e então, acabou pedindo auxílio para a Professora 1 que trabalhava no hospital.

Havia diversos problemas que as crianças que realizavam tratamento de saúde frequentemente enfrentavam, e isso não foi diferente com a filha da entrevistada. Ela relata que sua filha

[...] passava o maior tempo no hospital, porque tinha exame e a manhã inteira ela passava no hospital e ela levava o caderninho dela, só que muitas vezes ela não conseguia fazer as lições. Aí, ela chegava na sala de aula e a professora tinha aquele jeito dela, chamava fila por fila para entregar o caderno e a minha filha já ia tremendinho com o caderno, com a lição pela metade, daí quando a professora via que ela não tinha feito a lição, simplesmente ela pegava o caderno da minha filha e jogava no final da sala, e a minha filha ia pegava o caderno, vinha chorando, e um dia a tarde eu fui buscar ela na escola ela me contou a história. Ela falou: mamãe, me tira daquela escola senão eu vou ficar louca. Daí eu falei: Mas por quê? Ela disse assim: Não mamãe, eu não quero mais estudar lá. E daí de tanto eu incentivar ela, ela me contou a história, o que a professora fazia. Daí eu fui conversei com a Professora 1 tudo o que estava acontecendo e daí ela foi, conversou com o pessoal da Secretaria da Educação e tomou as medidas necessárias. 
Daí, daquele ponto, a professora até pediu para mim tirar ela da sala da escola, porque ela não acompanhava e ela tinha várias dificuldades, principalmente na matemática. E daí até ela falava: Mãe, você ensina de um jeito, a professora ensina de outro, e eu estou ficando louca! Daí eu conversei com a Professora 1 e falei: Olha Professora, eu não sei, eu aprendi o processo longo, ela disse que a professora ensina o processo curto e então você veja o que você faz. Daí ela foi e conseguiu passar de ano com a ajuda da professora. E daí ela auxiliou também na quarta série (Informação verbal Mãe) ${ }^{162}$.

Esse relato da mãe explicita a realidade pela qual algumas crianças que realizavam tratamento de saúde e estavam em idade escolar eram submetidas na década de 1990 no Paraná. Por conta do tratamento, a aprendizagem acabava ficando prejudicada, principalmente porque a criança não conseguia acompanhar as aulas devido ao grande número de faltas e a dificuldade de concentração causada pelos medicamentos, dores ou mal-estar. Essas ausências, por sua vez, prejudicavam o acompanhamento das explicações e os alunos começavam a se sentir perdidos, não dando conta da realização completa das atividades solicitadas e da pressão que o universo escolar e professoras exerciam em suas vidas acadêmicas, neste sentido, tanto professora, como aluna cogitaram a possibilidade de exclusão da escola por conta dessas dificuldades.

A professora da escola parecia não compreender o processo de tratamento pelo qual a criança estava sendo submetida e acabava agindo de forma bastante complicada chegando a jogar o caderno incompleto da criança no fundo da sala. Essas atitudes levam a entrevistada a procurar a professora da Educação Hospitalar para relatar o que acontecia na escola da criança e solicitar ajuda. Mesmo após a Professora 1 informar sobre o ocorrido para a Secretaria de Educação e o comportamento da professora melhorar, ela continuou sugerindo que a criança fosse retirada da turma. Neste ponto, fica nítido a importância do atendimento pedagógico da professora do hospital, pois segundo a entrevistada, foi essa ajuda que fez com que sua filha conseguisse passar para a $4^{2}$ série, que foi realizada na mesma escola, mas com outra professora.

Segundo a mãe, a professora da escola regular era uma professora bem rígida que já havia se posicionado indicando que por sua filha estar doente deveria ficar em casa, ela passava os conteúdos de Ciências, Língua Portuguesa, Matemática da

\footnotetext{
162 Entrevista concedida pela MÃE. Entrevista I. [nov. 2016]. Entrevistador: Claudinéia Maria Vischi Avanzini. Curitiba, 2016. 1 arquivo.mp3 (28min.21seg.). A entrevista na íntegra encontra-se transcrita nos Apêndices $\mathrm{E}$ e $\mathrm{J}$ desta tese.
} 
seguinte forma: "Ela enchia o quadro, ela não queria nem saber, era pergunta (...) era muita, muita coisa e problema bastante, ela enchia o caderno... "163, por conta disto, a mãe já levava os materiais da filha para que ela recebesse esclarecimentos com a professora do hospital, pois, segundo ela, havia coisas que ela não conseguia ensinar, que precisavam da professora. Esse comportamento da professora da escola regular foi amenizado somente após a interferência da professora do hospital, que teve uma conversa com ela e com os responsáveis da Secretaria de Educação, que também interviu fazendo com que a professora mudasse esse comportamento. A professora da escola regular acabou entendendo que a aluna realmente tinha dificuldade por conta do problema de saúde dela e que sua aprendizagem seria bem lenta.

$\mathrm{Na}$ metade da $4^{\underline{a}}$ série a aluna teve peritonite e perdeu o peritônio, pois neste período ela fazia diálise peritoneal. Por conta disso, ficou no hospital praticamente a metade do ano, segundo a mãe, ficou 29 dias correndo risco de morte, o que acabou impossibilitando inicialmente até o trabalho da professora que não conseguia realizar as atividades com ela. Entretanto, com a melhora da aluna, a mãe relatou que pegava as atividade e conteúdos na escola, levava para o hospital e a professora se dirigia a sua filha, conversava com ela e a auxiliava na realização das tarefas. Depois, com o trabalho realizado, a própria mãe devolvia para a escola que avaliava para que a filha não perdesse o ano escolar. Assim, ela terminou o ano letivo sem prejuízo, sendo que conseguiu fazer até a formatura no final do ano.

O momento em que a filha da entrevistada está entrando para a formatura da 4ª série do Ensino Fundamental é o registro da figura 24. Na imagem há alunos sentados nos dois lados de uma escada, que, pela arquitetura e janela ao fundo, é da própria escola onde as crianças estudavam. No lado direito da fotografia há nove alunos sentados e dois em pé e no canto inferior esquerdo é possível observar mais dois, que estão de costas para o fotógrafo e olhando na direção dos alunos que estão descendo a escada. Ao lado dos alunos que estão em pé há um homem adulto que parece estar ali para organizar a descida dos formandos que descem a escada entrando de dois em dois, sendo que entre os formandos, todos os meninos estão vestidos com camisetas brancas e calças pretas e as meninas com vestidos brancos, um tipo de uniforme para a formatura. Os dois primeiros meninos que entram fazem

163 Entrevista concedida pela MÃE. Entrevista I. [nov. 2016]. Entrevistador: Claudinéia Maria Vischi Avanzini. Curitiba, 2016. 1 arquivo.mp3 (28min.21seg.). A entrevista na íntegra encontra-se transcrita nos Apêndices E e J desta tese. 
pose com um capelo e um jabô cada um, símbolos de roupas apropriadas para formaturas. Como nenhum outro aluno da fila tem esses adereços, provavelmente esses, que estavam sendo utilizados pelos dois primeiros da fila, eram repassados a cada um dos alunos na hora do registro fotográfico, sendo que a filha da entrevistada seria a próxima a ser fotografada na entrada da formatura. Ela está no segundo degrau da escada, que por sua vez tem um tapete vermelho por onde eles pisam, de mãos dadas com um menino, possivelmente um colega de turma.

Figura 24: Formatura do Ensino Fundamental da filha da entrevistada com 10 anos.

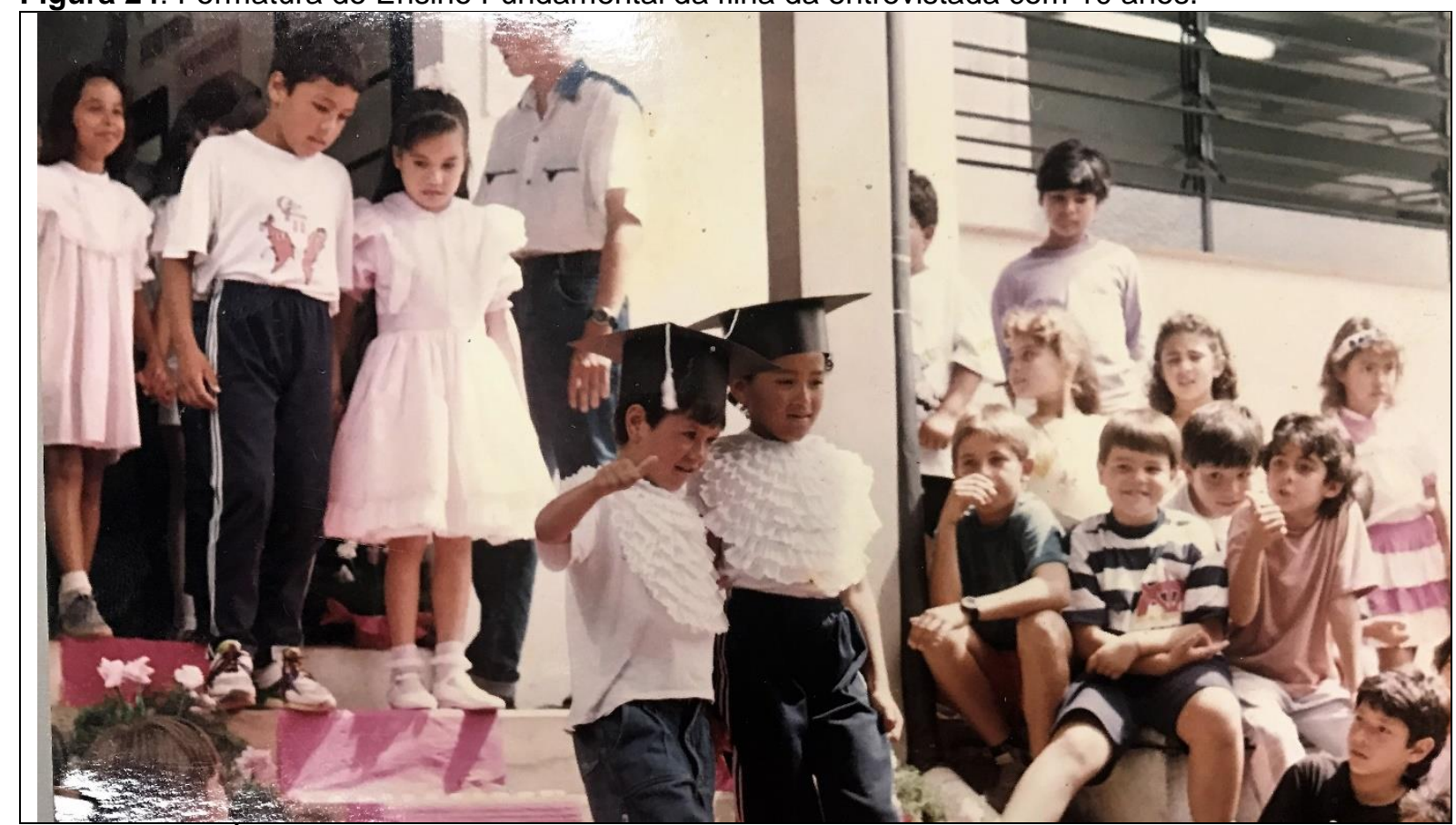

Fonte: Acervo Álbum de Família. (Dezembro/1992).

$\mathrm{Na}$ imagem, a filha da entrevistada aparece com um vestido com babados, de manga bufante, na altura do joelho, as meias são curtas e dobradas no meio da perna, finas com babadinho e as sapatilhas são do tipo boneca. Ela está com o cabelo preso no alto da cabeça e parece que amarrado com uma florzinha branca. Apesar de estar bastante arrumada, parece estar triste ou preocupada, pois não esboça nenhum sorriso e está olhando para o lado esquerdo da fotografia e para baixo, enquanto que a aluna que está logo atrás dela aparece com um sorriso tímido no rosto e olhando para frente.

Com o final das séries iniciais em 1992, a filha da entrevistada precisou mudar de escola ${ }^{164}$, sendo que ela passa a estudar na Colégio Estadual Professor Lysímaco

\footnotetext{
${ }^{164}$ Por conta da municipalização (discutida no capítulo 2), a partir da 5ª série, os alunos passam a ser atendidos por escolas estaduais.
} 
Ferreira da Costa. Entretanto, em agosto deste ano, ela fez o transplante, mas por estar na 5 série ela deixou de ser acompanhada pela professora que atendia somente alunos até a $4^{\text {a }}$ série, por conta de sua formação pedagógica e orientações da secretaria que a liberava para trabalhar na Educação Hospitalar ${ }^{165}$. A partir disto, a mãe passa a solicitar somente para a escola as atividades para a filha, que tem que as resolver sozinha.

Efetivamente, as aulas ministradas pela professora no hospital para a filha da entrevistada ocorreram até o ano de 1992, afinal em 1993, ela já se encontrava na 5a série do Ensino Fundamental. Segundo a mãe, essas aulas ofertadas no hospital para sua filha eram muitas vezes realizadas durante o tempo que ela estava esperando para consulta ou algum exame demorado. A professora chegava, dava as aulas e ajudava no que a filha tinha de tarefas, porque na maior parte das manhãs, quase todos os dias, elas ficavam no hospital para realização de vários tipos de exames e sabendo desta dinâmica do tratamento, ela já levava seus cadernos escolares com as tarefas que a professora de sua turma na escola regular passava. A professora do hospital ajudava a estudante na realização dessas tarefas escolares tirando suas dúvidas.

Ao ser questionada se sua filha gostava de ter aulas no hospital ela comentou que gostava e também gostava da professora, porque ela era bem carinhosa, era uma aula bem diferente com joguinhos, desenhos para pintar, isto era o que ela mais gostava de fazer, pois, segundo a mãe, desenhar era o foco dela. Essas aulas que sua filha teve no hospital ajudou na continuidade dos estudos dela posteriormente. $A$ mãe ainda considerou o atendimento educacional oferecido pelas professoras para crianças internadas no hospital muito importante e útil.

É, porque eles estão ali a maior parte do tempo, principalmente em hemodiálise, né, que 4 horas naquela máquina ali, então é muito interessante a professora está ali, dando, principalmente jogos, a minha filha gostava de desenhar, ela deu, me lembro, que ela deu um caderno de desenho que tinha aquelas folhas finas [...]. E a minha filha além de passar por aquilo ela [a professora] também ensinava as outras crianças. Ela ensinava, ela estava ali não é assim, ela dava força também, ajudava. E muitos que estavam na época ali junto com ela, nem para a escola iam. Porque não queriam estudar, a mãe tirava da escola, e ela não, eu sempre incentivei ela, eu também ajudei, porque eu acho que os pais têm que ajudar. (MÃE, 2016).

165 Maiores informações sobre esse assunto foram trabalhadas no Cap. 3. 
Além disto, a mãe comentou que podia perceber muitos progressos na aprendizagem da filha com esses atendimentos da Educação Hospitalar, pois o único ano que a filha reprovou foi o $3^{\circ}$ ano da Formação Docente que foi um período em que ela já não tinha mais o acompanhamento pedagógico no hospital, estava na adolescência e portanto, numa fase mais "rebelde"166. Segundo a mãe, sua filha havia pego implicância com uma professora, ela comentava que não aguentava a aula daquela professora, chegava na escola e dormia, ou nem chegava a ir para a aula, pois a mãe saia de casa às 6h20min. da manhã para trabalhar, deixava a filha tomando café e ela nem ia para aula. Ao ser questionada pela mãe sobre as atividades da escola, sua filha respondia que fazia tudo em sala de aula, entretanto, em outubro a mãe desconfiada foi para a escola falar com coordenadora, que lhe informou que já estava a muito tempo tentando falar com ela, pois sua filha estava com mais de 100 faltas e já se encontrava reprovada por conta do número excessivo de ausências à aula. Então, ela constatou junto à filha que os recados/bilhetes encaminhados para a mãe eram todos rasgados e jogados fora pela filha. A mãe considerou aquilo bem complicado e informou que era um erro da escola, pois eles deveriam ter the comunicado com antecedência, afinal ela trabalhava numa escola e sabia como funcionavam essas questões de ausências na aula. Contudo, não houve mais o que fazer e a filha realmente ficou reprovada no 3ํano do Ensino Médio. Destaco também o percurso escolar da filha da entrevista ter acontecido em sua grande parte na escola pública, com exceção da Educação Infantil que ela estudou numa instituição privada.

Essa postura favorável à escolarização por parte da mãe também ajudou que sua filha continuasse os estudos até o Ensino Médio, Formação Docente no Colégio Estadual Prof. Lysímaco Ferreira da Costa, terminando em 2001. Esse período da formação dela pode ser observado na figura 25, que traz um grupo de alunos numa aula externa plantando flores no jardim que fica na frente do colégio estadual onde a filha da entrevistada fez a Formação de Docentes.

O estudo do meio também tem sido uma das denominações e proposta de
aula em campo para as disciplinas escolares. Em escrito intitulado O conceito
de estudo do meio transforma-se..., Nídia Nacib Pontuschka (2004) mostra
como as metamorfoses fundamentais desse conceito acompanham os
contextos históricos pelos quais passaram as escolas e, assim, o ensino. Cita
como um dos exemplos as Escolas Anarquistas que, nas primeiras décadas
do século XX, entendiam o estudo do meio como instrumento de formação

${ }^{166}$ Entrevista concedida pela MÃE. Entrevista I. [nov. 2016]. Entrevistador: Claudinéia Maria Vischi Avanzini. Curitiba, 2016. 1 arquivo.mp3 (28min.21seg.). A entrevista na íntegra encontra-se transcrita nos Apêndices $\mathrm{E}$ e $\mathrm{J}$ desta tese. 
humana na criação da capacidade de crítica à vida de submissão. (OLIVEIRA e ASSIS, 2009, p. 202).

A placa com o nome do colégio pendurada logo acima da entrada do prédio comprova o local do registro da imagem, onde há dezesseis alunos fotografados e a professora de jaleco branco ao centro. Algumas alunas estão com as mudas de plantas nas mãos, outras mudas já estão plantadas e o único menino retratado está com a pá utilizada para fazer os buracos do plantio na mão direita. Todos estão em pé, com exceção de uma aluna que está agachada ao lado de uma muda recémplantada, o buraco parece ainda estar sem-terra, não é possível observar o rosto de duas alunas que estão atrás de colegas.

Figura 25: Fotografia da turma de Formação de Docentes do CE Prof. Lysímaco Ferreira da Costa onde estudava a filha da entrevistada [entre 1997 e 2001].

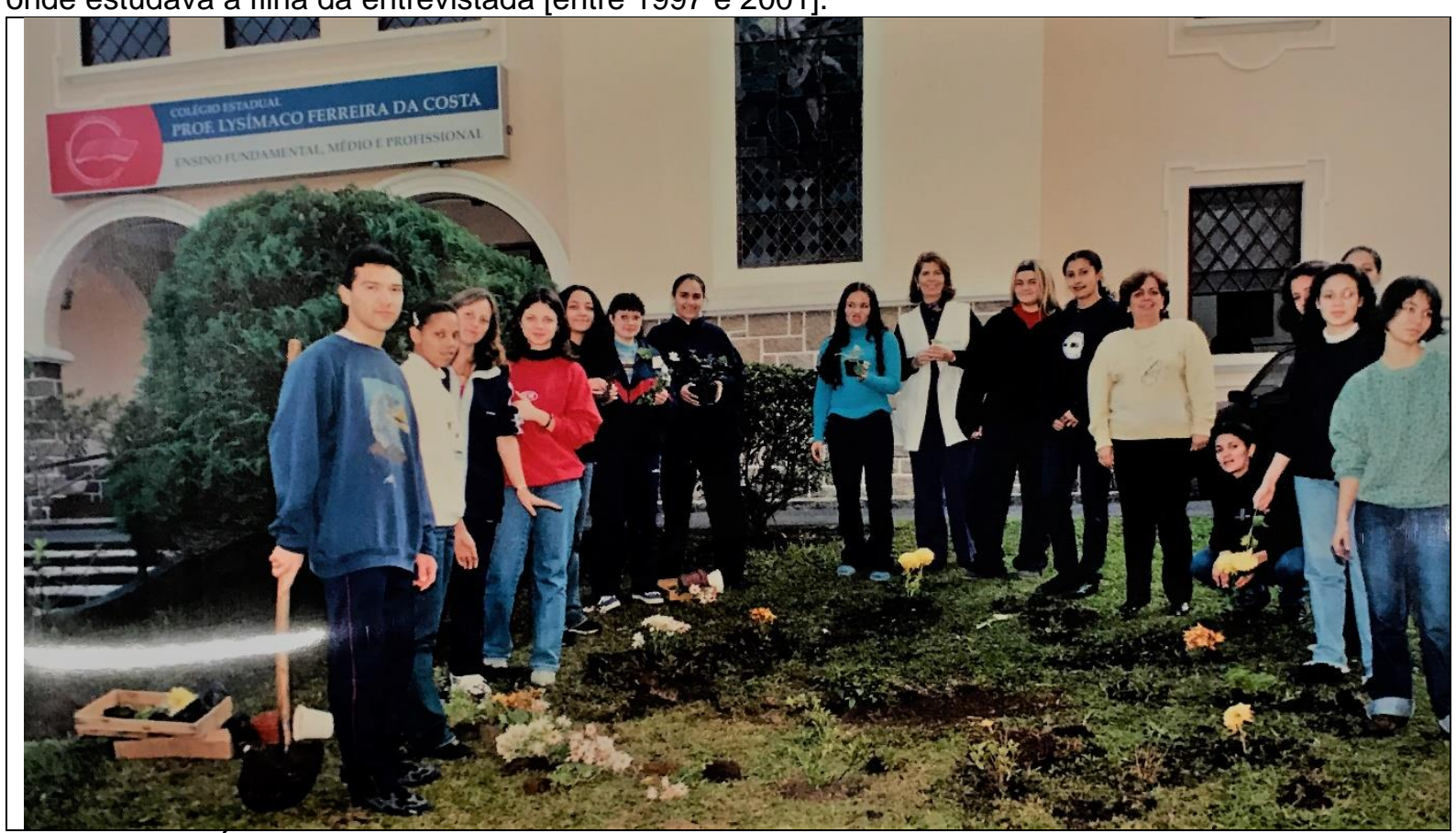

Fonte: Acervo Álbum de Família. [Entre 1997 a 2001].

Ao que parece, a filha da entrevistada é a aluna de blusa azul com uma muda de planta nas mãos ao lado da professora, pela sua expressão facial, ela está falando alguma coisa com alguém no momento do registro da imagem. Não é possível saber o ano exato do registro, mas foi entre 1997 e 2001, período em que ela estudou neste local.

Finalmente a duas últimas fotografias selecionadas para compor este capítulo são de dezembro de 2001, a formatura do curso de Formação de Docentes realizado pela filha da entrevistada. Nesta figura 26, ela posa para a fotografia que compõe o álbum de registro deste momento marcante em sua vida escolar, a finalização de um 
ciclo escolar, no caso o Ensino Médio realizado concomitantemente ao curso profissionalizante em Formação de Docentes, que a formou para exercer uma profissão, que, segundo informações da mãe entrevistada, nunca foi desempenhada pela filha. O principal elemento que demonstra ser este o registro da formatura é o vestuário da estudante, uma beca preta com babado branco em seu peito. Ela está com os cabelos soltos, penteados e divididos bem no centro da cabeça, não usa nenhum tipo de maquiagem, sua postura é formal com o rosto sério, sem esboçar nenhum tipo de sorriso nos lábios e seus olhos estão fixos na fotografia.

Figura 26: Fotografia da formatura da Formação de Docentes da filha da entrevistada.

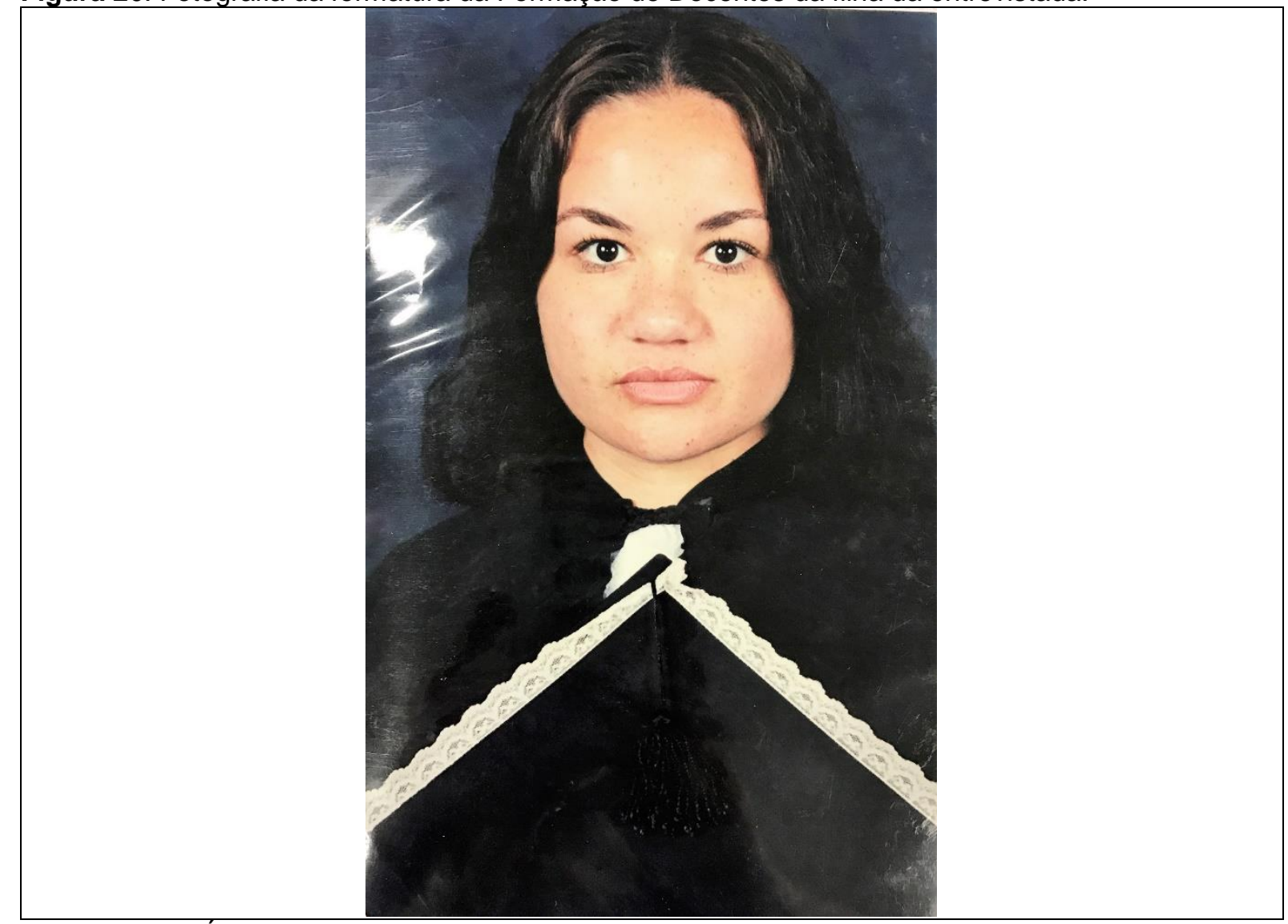

Fonte: Acervo Álbum de Família. (Dezembro/2001).

A cerimônia da formatura pode ser observada na figura 27 que apresenta um grupo grande de formandos, todos vestidos com becas pretas, jabôs brancos e faixas verde amarradas na cintura, cor do curso de Formação de Docentes. O registro ocorre num local bem grande, há cinco colunas imitando arquitetura grega e duas estátuas entre as colunas e prostradas no fundo do palco atrás dos formandos, que estão em pé olhando na direção da mesa diretiva que conta com sete pessoas, que também estão em pé, em posição de sentido, o que parece indicar que estão cantando hinos. 
Entre a mesa diretiva e o palco há arranjos de flores logo abaixo dos pés dos formandos. Com relação aos convidados, os poucos que estão retratados estão em pé, voltados e olhando em direção ao palco e aos formandos. No canto direito da imagem há um púlpito com um homem em pé, muito provavelmente o cerimonialista do evento. Sob a mesa diretiva há alguns copos de água e um bloco de caixinhas amarela, que poderiam ser o certificado de conclusão do curso, ou ainda uma pequena lembrança dos professores ou da escola para os formandos, algo bastante comum nas formaturas daquele período.

Figura 27: Fotografia da formatura da Formação de Docentes da filha da entrevistada.

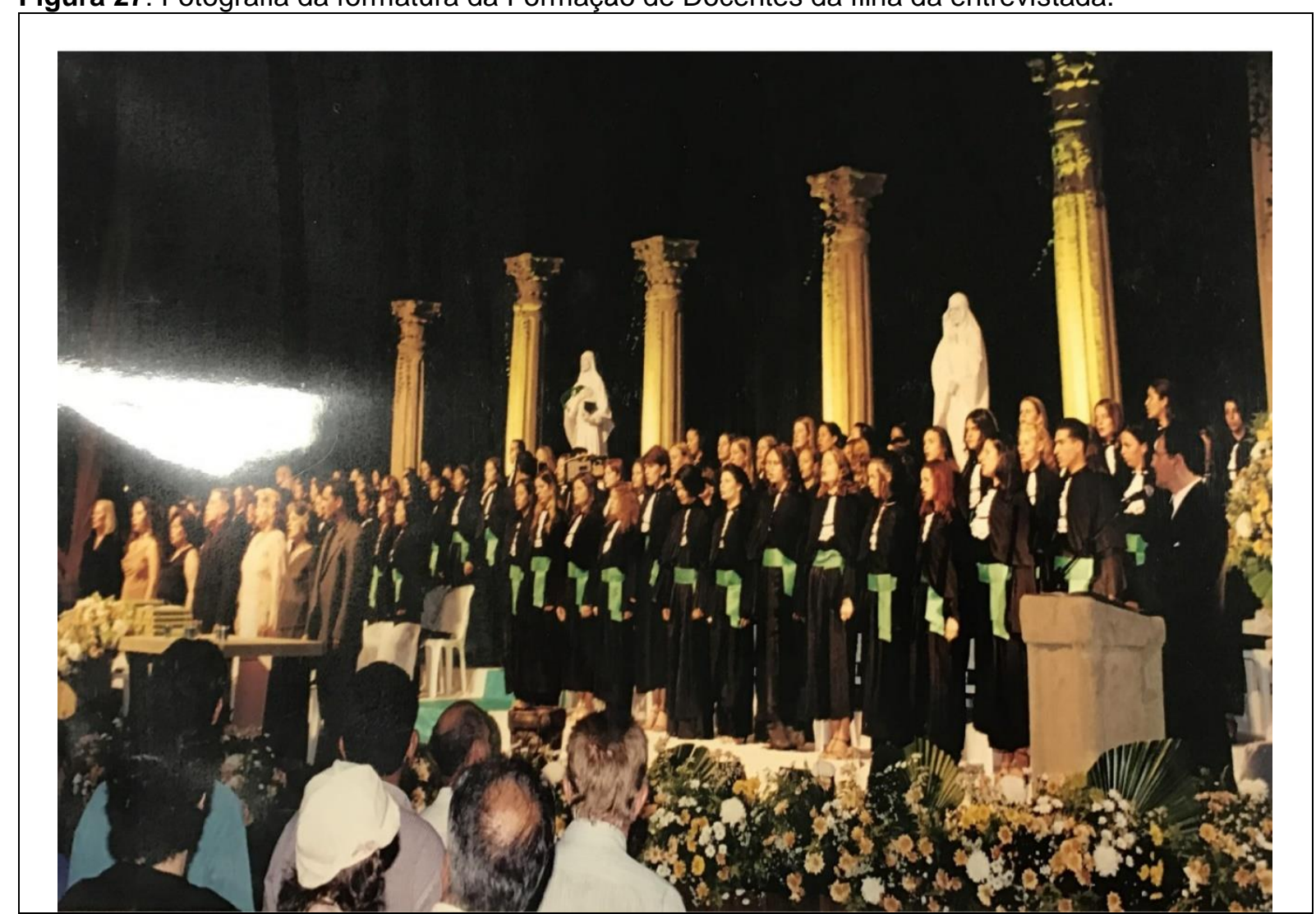

Fonte: Acervo Álbum de Família. (Dezembro/2001).

Apesar da imagem retratar um momento feliz que foi a formatura da filha da entrevistada, ela relembra que logo após esse momento, a filha acabou perdendo o rim transplantado e teve que voltar a fazer hemodiálise e mesmo depois que isso aconteceu se casou em 2007.

A apresentação dos registros iconográficos da formatura da filha pela entrevistada destaca implicitamente o entendimento das famílias com relação aos atendimentos pedagógicos recebidos pelas crianças ou adolescente no hospital ou em momentos de tratamentos prolongados, afinal para muitos familiares, o momento 
da formatura é o ápice do universo escolar e isso só acontece caso os alunos tenham êxito e sucesso em sua vida escolar. Esse sucesso escolar, para as crianças ou adolescentes em tratamento de saúde, algumas vezes somente será possível se ele receber um suporte como a Educação Hospitalar oferece. Corroborando com essa ideia, a mãe entrevistada considerou fundamental destacar que esses atendimentos são excelentes, que ela acredita que é preciso ter essa ajuda para as crianças que ficam no hospital, "porque muitas vezes os pais não incentivam, então é melhor a professora estar ali incentivando para eles ter um futuro"167. Ela lembrou que além de sua filha, outras crianças foram atendidas pela professora no hospital e tiveram continuidade em seus estudos, sendo que lembrou de um colega da filha que se formou em Matemática.

Com relação a filha, ela comentou que após a finalização de seus estudos formais, ela passou a fazer trabalhos manuais com biscuit. Aprendeu o ofício de artesã já adulta, com o objetivo de ganhar um dinheiro extra num período em que o marido estava desempregado. Na ocasião, fez uma semana de aula com uma professora de trabalhos manuais aprendendo o básico para iniciar os trabalhos e foi ampliando os conhecimentos sobre o ofício com a prática, tendo hoje até uma página na rede social onde apresenta seus trabalhos.

Ela é muito criativa! Muito caprichosa! A casa dela mesmo é um brinco! Sabe!? É uma cozinheira de mão cheia! Você vê, o marido dela era seco, hoje ele está gordo!! De coisas gostosas! Mas é, ela é uma batalhadora. Ela é uma guerreira! Nossa! Eu tiro o chapéu por ela. (MÃE, 2016).

Essas informações prestadas pela mãe de uma ex-aluna do atendimento hospitalar de Curitiba, se somando as informações prestadas pelo ex-aluno entrevistado e os depoimentos das duas professoras e da assistente social que trabalharam com a educação hospitalar auxilia no entendimento sobre quem eram esses alunos e demais sujeitos envolvidos com a Educação Hospitalar deste período estudado e quais as experiências que suas famílias tiveram em relação à Educação Hospitalar que os filhos frequentam nos período de internamento ou do tratamento que acaba oportunizando que esse trabalho apresente essa informação que até então não havia sido disseminada cientificamente no universo educacional.

167 Entrevista concedida pela MÃE. Entrevista I. [nov. 2016]. Entrevistador: Claudinéia Maria Vischi Avanzini. Curitiba, 2016. 1 arquivo.mp3 (28min.21seg.). A entrevista na íntegra encontra-se transcrita nos Apêndices E e J desta tese. 


\title{
CAPÍTULO 4 - A EXPERIÊNCIA PARANAENSE EM EDUCAÇÃO HOSPITALAR: CAMINHOS E DESCAMINHOS
}

\author{
perguntas \\ tem uma lista de perguntas \\ que quero mas nunca vou fazer \\ tem uma lista de perguntas \\ que reviro na cabeça \\ sempre que fico sozinha \\ e meu pensamento não se segura e te procura \\ tem uma lista de perguntas que quero fazer \\ então se estiver ouvindo de algum lugar \\ eu vim perguntar \\ (KAUR, 2018, p. 45).
}

O objetivo do capítulo é apresentar a experiência paranaense em Educação Hospitalar, caminhos e descaminhos, levando em consideração a característica do atendimento no âmbito estadual e municipal e as rupturas e descaminhos no atendimento da Educação Hospitalar. Essas questões são encontradas em diferentes fontes, como no próprio "Projeto Mirim de Hospitalização Humanizada", publicações no diário oficial e em diferentes jornais diários, em livros memorialísticos, em documentos oficiais da Associação Hospitalar de Proteção à Infância Dr. Raul Carneiro, das Secretarias Estadual e Municipal de Educação, como os Processos Administrativos, convênios e relatórios de atividades das professoras municipais que estavam cedidas para trabalhar na Associação Hospitalar de Proteção à Infância Dr. Raul Carneiro e nas entrevistas fornecidas, principalmente pela primeira professora que oficialmente assumiu o trabalho de Educação Hospitalar no Paraná, pela professora municipal que atuou no hospital até agosto de 2005. Além disto, apresentase o seguinte recorte temporal: de 1988 a 2000.

A análise da experiência paranaense em Educação Hospitalar, caminhos e descaminhos foi orientada pela perspectiva da história problema, sendo que dela surgiram muitas perguntas que me inquietavam, as quais destaco: De que modo a experiência paranaense em Educação Hospitalar se inicia e quais os descaminhos que percorre, em que medida e como se inicia a implantação do projeto "Hospitalização Escolarizada" no Paraná, como se apresentam as diferenças do atendimento no âmbito estadual e municipal, quais as especificidades destes atendimentos na Educação Hospitalar, de que maneira se observam as rupturas e descaminhos no atendimento da Educação Hospitalar paranaense e de que modo se apresentam os progressos no atendimento da Educação Hospitalar paranaense. 
O capítulo foi dividido em duas partes, sendo que a primeira trabalha a questão da característica do atendimento no âmbito estadual paranaense e municipal na cidade de Curitiba e a segunda parte deste capítulo trata das rupturas e descaminhos no atendimento da Educação Hospitalar finalizando a discussão sobre a Educação Hospitalar do Paraná.

\subsection{A CARACTERÍSTICA DO ATENDIMENTO NO ÂMBITO ESTADUAL E MUNICIPAL}

Apesar das fontes propagarem amplamente a informação de que a Secretaria de Estado da Educação inicia o atendimento no hospital em Curitiba, os depoimentos das professoras entrevistadas e algumas documentações encontradas que tratam do assunto, indicam que a diferença de tempo entre o envolvimento das Secretarias de Estado e do Município no atendimento educacional hospitalar na capital do Paraná é bem próximo.

A professora 1, que se declara oficialmente a primeira professora liberada pela Secretaria de Estado da Educação do Paraná para atuar na Educação Hospitalar por meio do Termo de Convênio, ao ser questionada na entrevista cedida para essa pesquisa sobre com quais outros profissionais ela trabalhou no hospital, destacou que ao ingressar no hospital em 1990 havia uma professora da Secretaria Municipal de Educação de Curitiba que já trabalhava no hospital e acabaram trabalhando juntas durante o restante daquele ano. Em 1991, com a saída desta professora entraram outras duas professoras municipais enquanto ela era a única cedida pela Secretaria de Estado da Educação, e assim ficou até 1999, quando ela é convocada a voltar para a escola regular e desligada do serviço de Educação Hospitalar ${ }^{168}$.

De acordo com Pacheco (2017, p. 34), essas professoras citadas pelo Professora 1 faziam parte do convênio de cooperação técnica entre a Prefeitura Municipal de Curitiba e os Hospitais Pequeno Príncipe e César Pernetta celebrado entre os anos de 1989 a 2015 que cedia "professoras de docência I para atender crianças da Educação Infantil e Ensino Fundamental I. Ainda segundo a autora, em 1988, a referida prefeitura já havia cedido "quatro professoras para atuar como

168 Entrevista concedida pela PROFESSORA 1. Entrevista I. [ago. 2016]. Entrevistador: Claudinéia Maria Vischi Avanzini. Curitiba, 2016. 1 arquivo.mp3 (60min.). A entrevista na íntegra encontra-se transcrita nos Apêndices C e H desta tese e PACHECO, 2017, p. 36. 
recreacionistas" nos Hospitais Pequeno Príncipe, César Pernetta, Erasto Gaertner e Hospital de Clínicas em Curitiba.

Essa discussão sobre os reais desbravadores do trabalho de Educação Hospitalar em Curitiba continua se reproduzindo por anos, sendo que uma matéria publicada no jornal diário Gazeta do Povo em 2008 intitulada "Escolas em hospitais fazem mais do que ensinar" aborda num trecho da reportagem que o impulso para 0 ensino no hospital se deu em 1987 com a dissertação de mestrado que apresentou a necessidade de apoio pedagógico para as crianças impossibilitadas de frequentar a escola e atendidas no hospital em Curitiba e que impulsionou logo no ano seguinte "a primeira parceria entre a prefeitura de Curitiba e o Hospital Pequeno Príncipe, para o acompanhamento escolar de $1^{\mathrm{a}}$ à $4^{\mathrm{a}}$ série". (DUARTE, 2008, p. 12).

Contudo, segundo Pacheco (2017, p. 36), o convênio com a Prefeitura Municipal de Curitiba efetivamente foi implantado com a cedência das professoras em 1989, um ano antes do início dos trabalhos da professora estadual cedida em convênio ao hospital. Apesar disto, é o convênio com o Estado do Paraná o mais conclamado como o primeiro efetivado, acredito que isso ocorra porque o Secretário de Estado da Educação liberou, mesmo sem convênio, uma professora para atuar em forma de experiência no hospital. De acordo com a publicação no jornal diário Gazeta do Povo de 1990 que informava que a experiência da Educação Hospitalar observada durante três meses de 1987 "conseguiu aprovação para vários alunos hospitalizados" estava consolidado e fomentava o "interesse nas outras unidades de saúde e educação". (GAZETA DO POVO, 01/11/1990, p. 56). Apesar da matéria e Pacheco (2017, p. 36) indicarem que nesses 4 meses em 1987 esta professora liberada experimentalmente ser estadual, destaquei anteriormente que possivelmente isso não possa ser confirmado somente por essas duas publicações em jornais de 1990 e na dissertação em questão, afinal os outros jornais de 1988 não evidenciam tal argumento.

Segundo a Professora 1, a SEED aceitou fazer o convênio para implantar o Projeto Mirim de Hospitalização Escolarizada antes do município por conta da grande preocupação da superintendente, Hôda Salamuni, para que houvesse um atendimento com qualidade, seriedade e dedicação. Afinal, isso foi solicitado pela própria superintende à professora estadual, principalmente por conta do problema causado pela professora designada anteriormente, e que segundo as duas professoras entrevistadas teria se intitulado autora do projeto e causado um mal-estar 
entre a Secretaria de Estado da Educação e a Associação de Proteção à Infância Dr. Raul Carneiro, mantenedora dos dois hospitais onde as professoras atuavam. (PROFESSORA 1, 2016; PROFESSORA 2, 2017).

Porque tinha ocorrido aquele problema anterior à matéria no jornal na qual a professora que lá atuava, teria se intitulado como autora da teoria do trabalho ou algo que pudesse indicar que o projeto teria sido elaborado por ela e isso não foi verdade, tanto é que me foi esclarecido na ocasião que a [Assistente Social] havia registrado em cartório o referido projeto para que nada mais fosse desvinculado do nome dela. O foco do trabalho, porque quem desenvolvia não era elaborador, era sim parte do desenvolvimento. (PROFESSORA 1, 2016).

Após o início do trabalho das professoras na Educação Hospitalar e de acordo com os relatórios de atividades desenvolvidas na Associação Hospitalar de Proteção à Infância Dr. Raul Carneiro pelas professoras da Secretaria Municipal de Educação - SME e informações colhidas na entrevista com a Professoras 1 da Secretaria de Estado da Educação, os atendimentos eram divididos entre elas, ficando cada uma responsável por determinadas clínicas. O objetivo dessas divisões seria para que cada profissional tivesse um maior envolvimento e atuação pedagógica junto às crianças internadas e não atendessem duplicadamente a mesma criança deixando outras sem atendimento. (PROFESSORA 1, 2016; PRADO, 1991b, p. 1; PACHECO, 2017, p. 167).

Entretanto, a informação das clínicas atendidas pelas professoras, diverge nos diferentes relatórios e depoimento. Segundo a Professora 1 (2016) ao ingressar no hospital, "a professora que lá já atuava, ocupava-se da Clínica Cirúrgica e Cardiologia, por sua escolha", assim, a professora estadual ficou responsável pela Nefrologia e Ortopedia. Contudo, em períodos que a Clínica Cirúrgica ficava com um número grande de paciente, a Professora 1 também atuava naquele lugar após uma divisão entre as duas professoras das crianças ali internadas.

Não dividíamos o mesmo aluno, havia sim, dentro de uma clínica a divisão por volume de alunos. $O$ aluno não era atendido paralelamente por duas professoras, havia sempre uma professora que acompanhava o caso daquela criança por conhecer especificamente a condição. (Informação verbal Professora 1).

Todavia, segundo informações prestadas por Prado nos relatórios de atividades desenvolvidas na Associação Hospitalar, os atendimentos da professora pertencente à SME do ano de 1990 aconteceram nas Clínicas Cirúrgica, de Cardiologia, Nefrologia e Ortopedia e nos ambulatórios de Hematologia e Reumática. 
(PRADO, 1990d, p. 1; PACHECO, 2017, p. 161). No relatório de 1991 há uma nova delimitação da área de trabalho de cada profissional junto às clínicas ficando a professora da prefeitura com as Clínicas de Cardiologia, Ortopedia e Hematologia e a professora do Estado na Nefrologia e Cirúrgica ${ }^{169}$. (PRADO, 1991b, p. 1; PACHECO, 2017, p. 167).

A informação sobre as séries atendidas pelas professoras surge em várias fontes e diverge algumas vezes. Segundo Prado, tanto no relatório de atividades desenvolvidas na Associação Hospitalar de outubro de 1990, como no de janeiro de 1992, a professora municipal atendia crianças 1a a $8^{\underline{a}}$ séries das diversas escolas, municipais ou estaduais, informação confirmada em algumas publicações nos jornais diários e no Relatório de Renovação de convênio da Associação Hospitalar de Proteção à Infância Dr. Raul Carneiro do dia 28 de janeiro de 1992.

\begin{abstract}
A Associação Hospitalar de Proteção à Infância Dr. Raul Carneiro conta com uma professora da Rede Municipal de Ensino que tem como função: ministrar aulas a nível de $1^{\circ}$ grau ( $1^{\text {a }}$ a $8^{\text {a }}$ séries $)$ às crianças internadas nos hospitais César Pernetta e Pequeno Príncipe, atividade esta relativa ao Projeto Mirim de Hospitalização Escolarizada. (PRADO, 1992, p. 1).
\end{abstract}

Com relação à função dos professores estaduais, o relatório destaca que eles "têm como atribuição as mesmas funções da professora da Rede Municipal de Ensino", ministrar aulas da $1^{a}$ a $8^{a}$ séries para as crianças internadas nos hospitais César Pernetta e Pequeno Príncipe. Apesar do contrato de trabalho da Professora 1 com a Secretaria de Estado da Educação do Paraná celebrado em 1990 a contratar para trabalhar como Professora de $5^{\text {a }}$ a $8^{\text {a }}$ séries no Projeto Hospitalar Pequeno Príncipe (PARANÁ, 1990), ela informa em sua entrevista que atendia todas as séries iniciais do Ensino Fundamental, na época, 1a a $4^{\underline{a}}$ séries, assim como as outras professoras do hospital que também atendiam essas mesmas turmas. Segundo a Professora 1 "não havia distinção alguma" entre o trabalho delas. Pacheco (2017, p. 34) e matéria publicada por Tatiana Duarte (2008, p. 12) validam essa informação da Professora 1 ao descrever que o atendimento da Prefeitura Municipal de Curitiba entre 1989 até 2015 era realizado com professoras de docência I que atendiam a Educação Infantil e o Ensino Fundamental I, no caso, as séries iniciais.

Comecei a trabalhar em 1989 na SEED. Após um ano de trabalho em sala de aula fui convidada pela Superintendência da Secretaria Estadual de

169 Essa informação não pode ser confirmada na entrevista da Professora 1, pois ela fala em momento algum dessa alteração de local de atuação. 
Educação a atuar como professora no ensino de $1^{\text {a }}$ à $4^{\underline{a}}$ série do Hospital Pequeno Príncipe, devido a necessidade de uma profissional que se adaptasse ao projeto que estava em andamento naquele hospital. O projeto tinha como nome "Projeto Mirim de Hospitalização Escolarizada". (Informação verbal Professora 1).

A Professora 2 destaca em sua entrevista que o município também deveria atender do $1^{\circ}$ ao $5^{\circ}$ ano ${ }^{170}$, entretanto quando ela começa a trabalhar na hemodiálise do hospital percebeu que muitas crianças evadiram da escola por conta do tratamento e deixaram de estudar, principalmente as séries finais do Ensino Fundamental. Então, ela procurou uma instituição que atendia a Educação de Jovens e Adultos (EJA) pertencente ao governo do Estado próxima ao Hospital onde trabalhava e fez a matrícula desses estudantes para concluírem seus estudos nas séries finais do Ensino Fundamental. Ela relata que "naquela época o supletivo era de você pegar as apostilas e estudar em casa", então ela pegava as apostilas e estudava com os alunos no hospital e eles iam fazer somente a prova na instituição, sendo que algumas vezes ela os levava no dia da avaliação e outras vezes, a instituição, por confiar no trabalho de educação desenvolvido dentro do hospital, entregavam as provas para a professora aplicar dentro do próprio hospital. Sendo que em uma ocasião foi autorizado pelo hospital que uma professora da instituição de EJA fosse aplicar a prova dentro da hemodiálise, esse fato serviu também para que a professora conhecesse o ambiente hospitalar ao qual esses alunos pertenciam.

Diversos pacientes de $5^{\mathrm{a}}$ a $8^{\mathrm{a}}$ séries, os quais não estavam frequentando a escola, estão atualmente estudando junto ao Centro de Ensino Supletivo (CES), tendo em vista as inúmeras vantagens que tal método de ensino (o aluno estudar em casa) oferece, eis que devemos levar em conta as particularidades de nossos alunos apresentam.

No Centro de Ensino Supletivo os alunos da Associação Criança Renal estão isentos de qualquer contribuição para compra das apostilas, estudam em casa e durante o tratamento hemodialítico e, quando têm qualquer dúvida em relação algum conteúdo, são prontamente por nós atendidos. (BLEY; PACHECO, 1999, p. 03 e 04; PACHECO, 2017, p. 51, 178 e 179).

A Professora 2 confirmou novamente em sua entrevista que sua atuação era específica até a $4^{a}$ série, que quando os estudantes tinham dúvidas de conteúdos mais complexos, como os de Física, Química ou Matemática, precisavam de um

\footnotetext{
170 Nomenclatura dada para a $1^{\text {a }}$ a $4^{\underline{a}}$ série após a reformulação da Lei de Diretrizes e Bases da Educação Nacional com a promulgação da Lei no 11.274/2006 que regulamenta o Ensino Fundamental de nove anos. Disponível em: http://www.planalto.gov.br/ccivil 03/ ato2004-2006/2006/lei//11274.htm Acesso em: 21/04/2019.
} 
professor da $5^{\text {a }}$ à $8^{\text {a }}$ série e portanto, tinham que tirar dúvidas dentro da instituição de EJA, pois ela não conseguia dar conta de esclarecer esses conteúdos, no máximo ajudava em Língua Portuguesa, História, Geografia porque poderia, nestes casos, ler o texto e compreender, mas as disciplinas da área de exatas ela não conseguia auxiliar. Segundo suas informações ela conseguiu, no período que trabalhou na hemodiálise, resgatar a escolarização de aproximadamente 12 adolescentes até a $8^{\text {a }}$ série e ainda uns 3 ou 4 pais na EJA de Ensino Médio e um na 8a série do Ensino Fundamental. Como esses pais ficavam aguardando durante todo o tratamento dos filhos, aproveitaram também para estudar nesse período com a professora. (PROFESSORA 2, 2017).

A Educação Infantil aparece "em fase de organização e montagem do planejamento" no Relatório de Prado (1990a, p. 2) de 17 de maio, por conta da necessidade considerada urgente, constatada pela "solicitação das próprias crianças e também do hospital" e, no Relatório de 31 de maio de 1991 onde aparece a indicação da existência de um Projeto da Pré-escola no trecho que trata do atendimento da professora municipal a três crianças da Clínica de Ortopedia e que, por razão da idade cronológica superior ao nível pré-escolar ao qual estavam inseridas, foram incluídas pela professora hospitalar no processo de Alfabetização. (PRADO, 1990b, p. 2; PACHECO, 2017, p. 166 e 171).

O local de atendimento pedagógico ocorria com ambas as professoras no leito e na sala da Hospitalização Escolarizada durante o período de sua existência para os alunos que poderiam sair das clínicas ou enfermarias. Porém, seu uso era organizado, porque as professoras não conseguiam atender criança de séries diferentes ao mesmo tempo e no mesmo ambiente, principalmente porque isso interferia e atrapalhava o desenvolvimento das atividades, por exemplo de uma criança de $4^{\underline{a}}$ série com uma professora e outra de $1^{\underline{a}}$ série com outra professora. Por conta disso, elas combinavam o período de tempo que cada uma utilizaria a sala com as crianças. Os atendimentos das crianças no leito também eram organizados por meio de um cronograma, com aproximadamente uma ou duas horas reservada de atividades pedagógicas para cada criança. O atendimento era praticamente individualizado, apesar de duas crianças poderem ser atendidas juntas da seguinte forma:

Eu explicava a atividade, enquanto um aluno estava desenvolvendo sua atividade eu me dirigia até outra criança, eu alternava as explicações, eu dava um tempo para cada criança, sozinha, fazer as tentativas de desenvolvimento, de resolução da atividade, depois retornava para conferir e 
corrigir. Se havia mais de uma criança na enfermaria, eu conseguia atender até duas crianças ao mesmo tempo. [...] Eu tinha um cronograma, tinha uma divisão que eu previa os atendimentos para equilibrar isso, e deixar justo. (Informação verbal Professora 1).

Com relação ao trabalho realizado dentro da hemodiálise, a Professora 2 (2017) da SME descreve em sua entrevista que seu local de trabalho era ao lado da criança na máquina, onde era colocado um banquinho de plástico. Suas atividades práticas eram quase sempre realizadas em prancheta, adequada à posição da criança e à falta de mesa de apoio, ou com o uso de material concreto ${ }^{171}$.

Nos relatórios encontrados que tratam das ações e funções das professoras municipais é possível perceber que elas realizavam um levantamento constante junto às clínicas" para verificar "as reais condições físicas de cada criança" para avaliar sobre a inserção ou não delas no projeto. Além disto, era realizado contato com os familiares e com as escolas de origem dos estudantes, com o objetivo de coletar dados para "um maior conhecimento e entrosamento quanto aos aspectos educacionais, sociais e afetivos que envolvem a criança em atendimento". (PRADO, 1991b, p. 1; PACHECO, 2017, p. 167).

A relação de disciplinas e conteúdos efetivamente trabalhado também era descrito nos relatórios com destaque para as séries das crianças atendidas e a clínica onde pertenciam, o que indicava que o trabalho era realmente pedagógico e voltado aos conteúdos escolares.

Atendimento escolar propriamente dito:

a) a 3 crianças de $4^{\underline{a}}$ série do 1ํgrau onde foram ministrados os conteúdos de: Português, Matemática, Estudo Sociais, Ciências e Educação Moral e Cívica, internadas na clínica de Cardiologia. [...]

d) a duas crianças da clínica de Nefrologia: com a $1^{\underline{a}}$ criança foram trabalhados conteúdos específicos de Português e Matemática, pois era aluna da $1^{\underline{a}}$ série do $1^{\circ}$ grau;

e) a segunda criança, é aluno da $6^{a}$ série do $1^{\circ}$ grau, onde foram trabalhados conteúdos de: Português, Matemática, Ciências, Geografia, História em Inglês, todos referentes ao 20 Bimestre [...].

Português: a) pronomes pessoais no caso reto e oblíquo.

b) Ortografia: uso dos porquês, mas/mais, trás/traz, mal/mau, grafia junto e separada, palavras com e/i, emprego de s/z, etc.

c) Uso do eu ou mim.

d) Cópia de textos em interpretações.

e) Redação.

f) Leitura de um livro.

g) Preposições.

h) Vários exercícios de expressão escrita, do livro.

i) Pára (verbo) e para (preposição).

j) trabalho: Elaboração de um jornal.

Matemática: Expressões numéricas (números inteiros)

${ }^{171}$ A discussão aprofundada desses materiais encontra-se no Capítulo 4. 
Todas as operações dentro das expressões.

\author{
Ciências: a) Celenterados \\ b) Platelmintos \\ c) Nematelmintos \\ d) Anelídeos \\ e) Moluscos \\ f) Artrópodes.
} Inglês: Lesson 1, 2 e 3.

História: 1) O Período Regencial

- O período das regências.

- Revoltas durante o período regencial.

2) O Segundo Reinado e a Política interna

- O segundo reinado.

- O imp. sufocando as últimas revoltas.

3) Política externa do Segundo Reinado

- a questão Christie e a questão Platina.

Geografia:

- A Guerra do Paraguai.

BRASIL

1) Meio ambiente brasileiro

- relevo

- hidrografia

- clima

- vegetação

2) População e a economia brasileira

- migrações

- população rural e urbana

- etnia

3) Trabalho em grupos. POPULAÇÃO BRASILEIRA

setor agrário

- plantações permanentes e temporários

- extração vegetal

- eletricidade no Brasil

- comunicações

- Indústria Comércio

- meio ambiente. (PRADO, 1990d, p. 2; PACHECO, 2017, p. 162).

Nessa descrição no Relatório de 25 de outubro de 1990, a professora cita os atendimentos indicando oito estudantes atendidos, três de $4^{\text {a }}$ série da Clínica Cardiológica, três da Ortopedia, sendo dois de $3^{\underline{a}}$ série e um de alfabetização e duas da Nefrologia, sendo um de $1 \stackrel{a}{\underline{a}}$ série e um da $6 \underline{\underline{a}}$ série. É interessante perceber que ela cita somente as disciplinas trabalhadas com os estudantes das séries iniciais, entretanto, com relação ao estudante da 6ª série são relatados todos os conteúdos trabalhados em cada uma das disciplinas. O porquê disso ocorrer não é explícito, entretanto elenco algumas possibilidades para essa descrição mais detalhada: pode ter acontecido por conta da 6 a série não ser uma das turmas que frequentemente era atendida pelas professoras, pois a especificidade de atendimento pedagógico relatado nas entrevistas das professoras que colaboraram com a pesquisa era até a 4aㅗ série e portanto, fora do padrão de atendimentos e a quantidade de conteúdo ser muito maior do que normalmente é realizado com os estudantes pode ser outra possibilidade de 
descrição mais detalhada. Apesar destas hipóteses, não foi possível identificar o real motivo desta diferença de registro.

A professora da SME apresenta ainda no Relatório de 17 de maio de 1990 algumas "inovações" necessárias "para a evolução e a expansão do projeto", dentre essas inovações, ela indica que está "em fase de planejamento a organização e montagem de apostilas de $1^{a}$ a $8^{\text {a }}$ série do $1^{\circ}$ grau, indispensável e imprescindível frente às atividades desenvolvidas diante do projeto". Nessas apostilas haveria a relação dos "conteúdos programáticas de acordo com cada série com anexos de exercícios de fixação para utilização e atividades práticas". (PRADO, 1990a, p.2; PACHECO, 2017, p. 171).

O relatório do dia 21 de junho de 1999 das professoras que atendiam na Associação Criança Renal também traz a relação de conteúdos trabalhados em Língua Portuguesa e Matemática nas séries iniciais do Ensino Fundamental, sendo que no caso dos alunos de $3^{a}$ e $4^{a}$ séries elas descrevem os seguintes conteúdos trabalhados entre abril/junho de 1999:

\footnotetext{
Língua Portuguesa:

- Estabeleceu relações interdiscursivas (através de leituras e produções escritas);

- A presença de intertextualidade (remessa a outros textos) pelo tipo de texto e temática

- Ampliação e sistematização do sistema de numeração decimal;

- Introdução a numeração romana em comparação com a numeração indoarábica;

- Operações: adição, subtração, multiplicação e divisão através de situações problemas. (BLEY; PACHECO, 1999 p. 03; PACHECO, 2017, p. 178).
}

Com esses registros é impossível não questionar sobre as reais razões do atendimento, pois parece que existia uma preocupação grande dos professores em deixar explícito seu trabalho relacionado aos conteúdos escolares, o que poderia funcionar como evidência para a continuidade da liberação delas para o trabalho com os alunos hospitalizados. Corroborando com esse argumento da efetivação do trabalho, em entrevista, a professora da SEED destacou que baseava seu trabalho nos planejamentos da própria Secretaria de Educação e que a partir deles selecionava os conteúdos para cada série.

Eu seguia um roteiro como se fosse em uma escola, como se fosse em uma sala de aula. Eu sabia que aquela criança, se estivesse em sala de aula, estaria estudando alguns conteúdos pertinentes ao nível, a série e ao bimestre na qual estava. Quando havia a possibilidade eu entrava em contato 
com a escola e a escola me fornecia essa orientação, essa programação, esse planejamento. (Informação verbal Professora 1).

Com base nos planejamentos fornecidos a professora organizava as atividades para desenvolver junto às crianças, que assim que recebiam alta levavam todo o material e atividades realizadas no hospital para a escola de origem onde suas professoras pudessem elaborar avaliações partindo dos conteúdos que foram trabalhados na Educação Hospitalar.

"É uma verdadeira escola dentro do hospital ", define Rosana, professora que
ajuda atender todas as crianças em idade escolar. Muitas ficar pouco tempo,
mas algumas ali permanecem um mês, dois e até mais e são procedentes
inclusive de outros estados como Mato Grosso do Sul em Santa Catarina. "O
atendimento é igual ao da escola". As professoras torno acesso aos
conteúdos e após conhecer do médico a situação do paciente, realizar um
planejamento para que a criança não perco ano. (GAZETA DO POVO,
$01 / 11 / 90$, p. 56).

Em âmbito municipal o trabalho pedagógico tinha por base as diretrizes do município e os documentos municipais. Segundo a Professora 2 (2017), muitas das crianças atendidas pertenciam às escolas do município de Curitiba, algumas eram do interior do Estado e residiam em Curitiba durante o período do tratamento e acabavam sendo transferidas para as escolas do município para facilitar por conta da proximidade e por fazerem parte da mesma realidade. Entretanto, quando a criança era de fora de Curitiba, ela trabalhava com os conteúdos das escolas de origem, principalmente porque se esperava que a criança retornasse a esse universo, além de se levar em consideração as especificidades regionais.

Por exemplo, uma coisa que eu costumo falar para as professoras: "Que adianta eu trabalhar a importância do pinhão para uma criança que mora no Nordeste?" Não vai fazer sentido nenhum. Eu vou ter que adequar a minha prática com os conteúdos deles, a geografia deles, a parte da região. (Informação verbal Professora 2).

De acordo com o Relatório de Renovação de convênio entre a Associação Hospitalar de Proteção à Infância Dr. Raul Carneiro e a Secretaria Municipal de Educação, as atividades relativas ao Projeto Mirim de Hospitalização Escolarizada era "um trabalho de natureza individualizada e multidisciplinar realizado junto a pacientes escolares internados em situação de longa permanência hospitalar". (PRADO, 1992, p. 1; GAZETA DO POVO, 02/12/1990, p. 26; PACHECO, 2017, p. 164).

Apesar dessa proposta estar descrita no relatório de 1992, as duas professoras entrevistadas descrevem que ao ingressarem na Educação Hospitalar os modelos 
educacionais direcionados ao atendimento das crianças e dos adolescentes nos hospitais infantis de Curitiba era o método tradicional, pois "se alfabetizava pelo método da silabação, já se falava na época em ciclos, "ventilava" a teoria da Emília Ferreiro, já se estudava em torno disso, mas era no método tradicional" que elas utilizavam. (PROFESSORA 1, 2016; PROFESSORA 2, 2017).

\begin{abstract}
Então, as crianças eram atendidas de acordo com a possibilidade do dia, da possibilidade do estado clínico e nós seguíamos o mesmo roteiro, o mesmo planejamento tradicional das escolas. Os trabalhos eram planejados em torno da programação bimestral, nós fazíamos um roteiro e procurávamos seguir aquilo que era tradicionalmente desenvolvido na época. (Informação verbal Professora 1).
\end{abstract}

Apesar deste discurso se repetir na entrevista das duas professoras, elas também destacam que os atendimentos pedagógicos aos estudantes variavam segundo as especificidades do quadro clínico, da individualidade e das necessidades pedagógicas dos estudantes. A Professora 2 (2017) comentou que acreditava que essas escolhas eram influenciadas pela sensibilidade delas em "perceber como é que funciona, qual o canal que você atinge essa criança". O foco do trabalho pedagógico das professoras dentro do hospital não era a recreação, mas sim o trabalho com conteúdo escolar que poderia ser explorado de forma lúdica, mas sempre com intencionalidade pedagógica. (PROFESSORA 2, 2017).

No discurso de ambas as professoras, tanto a estadual como a municipal, que atenderam durante toda a década de 1990 no Hospital, há um alinhamento de ideias com relação ao seu objeto de trabalho, que são os conteúdos escolares. Elas repetem mais de uma vez em suas entrevistas que a função delas dentro do hospital era pedagógica e não recreacionista. Talvez essa preocupação se deva ao fato da divulgação do trabalho realizado por elas não estar claro, nem difundido socialmente até mesmo para a coordenação ligada à Secretaria Municipal de Educação de Curitiba que em 2008, numa entrevista ao jornal diário Gazeta do Povo informa que

\footnotetext{
"Até 1998 o trabalho era mesmo mais recreativo. Depois passou a ganhar um caráter pedagógico", ressalta uma das coordenadoras do atendimento hospitalar da prefeitura, Fabiana Neves Rego Barbosa. Atualmente, se a criança ou o adolescente passar mais de 15 dias internado num desses hospitais, uma comunicação é feita a escola, que repassa conteúdos e avaliações que podem ser trabalhados pelos professores que vai atender um aluno. (DUARTE, 2008, p. 12).
}

Por mais de uma vez, as professoras informaram em suas entrevistas e, o que também pode ser observado nos seus relatórios entregues à própria Secretaria 
Municipal de Educação na década de 90, que elas trabalhavam com os conteúdos escolares, bem como o contato com as escolas de origem dos estudantes para coletar informações, atividades ou até mesmo avaliações já acontecia desde a implantação do Projeto Mirim de Hospitalização Escolarizada em 1988.

Ainda com relação ao trabalho prático das professoras, inicialmente bastante tradicional, este foi sendo alterado por conta de elas perceberem que haveria um jeito diferente de realizar suas aulas, sem uma obrigatoriedade das instâncias superiores, no caso as Secretarias de Educação, mas muito mais por conta da realidade educacional sugerir que a forma de trabalho tinha que ser diferente, tinha que, principalmente respeitar a individualidade de cada estudante. Então, as próprias professoras foram se questionando sobre o método tradicional de ensino e se este era realmente o mais adequado a ser implantado junto às crianças hospitalizadas e que recebiam o acompanhamento pedagógico delas.

Vamos pensar num modelo tradicional de ensino, eu fazia a caligrafia. Que caligrafia se ele estava numa máquina de hemodiálise, olha se tem sentido eu fazer caligrafia. A escola me cobrava a caligrafia, mas que sentido que teria isso para aquela criança? (Informação verbal Professora 2).

Neste caso, a professora tinha razão ao questionar a orientação da escola em oportunizar atividades de caligrafia para o aluno, pois não fazia sentido algum desenvolver uma letra redonda e bonita se a criança não conseguiria nem se comunicar, nem escrever nada por conta da imobilização a que estava acometida durante o tratamento. As professoras iam trabalhando e modificando sua prática de acordo com as experiências empíricas observadas nos atendimentos pedagógicos junto aos estudantes hospitalizados, afinal a realidade mostrava o que funcionava ou não nos atendimentos da Educação Hospitalar.

Dentre os resultados obtidos e descritos no Relatório de 21 de junho de 1999 com relação ao atendimento da hemodiálise pelas professoras municipais liberadas, destaco que

No momento em que a criança está na máquina de hemodiálise, o atendimento pedagógico facilita que a mesma fique com a suas atividades escolares em dia, podendo conciliar perfeitamente o tratamento com a aprendizagem.

Depois de dois anos de celebração do convênio com Associação Criança Renal, os resultados já podem ser percebidos [...]. No início do trabalho, havia diversas crianças fora da escola, sendo a grande maioria analfabeta. Hoje, tais crianças já estão todas alfabetizadas, não havendo nenhuma fora dos bancos escolares. (BLEY; PACHECO, 1999, p. 04; PACHECO, 2017, p. 179). 
Esses registros comprovam que a atuação das professoras auxiliava a vida escolar dos estudantes oportunizando a aprendizagem, a realização das atividades escolares durante o tempo de seu tratamento hospitalar, como também o resgate de estudantes evadidos do universo escolar, pois após somente dois anos, as professoras informaram no relatório que todas as crianças em tratamento estavam inseridas nos "bancos escolares" e mais nenhuma era analfabeta como foram encontradas no início do convênio.

Ainda segundo o relatório enviado à SME, outra ação desempenhada pelas professoras municipais liberadas para trabalhar na Associação Hospitalar de Proteção à Infância Dr. Raul Carneiro era o assessoramento pedagógico a profissionais de outras unidades hospitalares com o objetivo de esclarecer a proposta e o alcance do Projeto de Hospitalização Escolarizada explicitando a teoria e a prática do mesmo para a implantação do projeto naquelas instituições, esse assessoramento aconteceu junto "à profissional competente e responsável (professora) do Hospital Erasto Gaertner" em 1990 e "à profissional do Hospital de Clínicas de Curitiba (assistente social)" em 1991. (PRADO, 1990a, p. 2; PRADO, 1991a, p. 1; PACHECO, 2017, p. 171 e 175).

Enfim, essas são algumas das especificidades do atendimento na Educação Hospitalar no âmbito estadual e municipal na cidade de Curitiba Paraná na década de 90. Pela análise realizada para a construção do capítulo foi possível perceber que algumas delas se diferenciam, outras seguem um mesmo padrão. Além destas, outras podem ser observadas e ampliam o espectro do atendimento e das ações desenvolvidas pelo viés da educação dentro do hospital, entretanto não foram trabalhadas por conta da opção deste trabalho se restringir ao atendimento educacional ofertado pelas professoras estaduais e municipais. A ampliação da análise para a especificidade do atendimento das estagiárias, dos voluntários ou de outras pessoas vinculadas à instituição e que possam ter realizado algum tipo de trabalho educacional junto às crianças internadas ou em tratamento de saúde nos hospitais pesquisados pode ser abordada em outra pesquisa voltada para essas questões. 


\subsection{RUPTURAS E DESCAMINHOS NO ATENDIMENTO DA EDUCAÇÃO HOSPITALAR}

Para uma análise que vai além das especificidades do atendimento na Educação Hospitalar, discuto, a partir daqui as rupturas e descaminhos observados no atendimento da Educação Hospitalar. Pretendo apresentar algumas dessas rupturas e descaminhos numa ordem cronológica de acontecimentos e tentarei entender de que maneira eles aconteceram ou se refletiram no atendimento da Educação Hospitalar paranaense.

A primeira ruptura que percebo de forma bem evidente nas fontes pesquisadas é a disponibilidade da sala de aula que no início da implantação do "Projeto Mirim de Hospitalização Humanizada" existia e logo no começo da década de 90 é incorporada ao hospital durante uma reforma. Consigo perceber que no início as professoras ficam animadas com a possibilidade da reforma e melhoria do ambiente de trabalho, mas com o tempo esses anseios acabam não se efetivando, pois durante o período da pesquisa, essa sala de aula não fez mais parte da realidade hospitalar.

\footnotetext{
Inicialmente havia uma sala para as crianças que poderiam se locomover, com o passar do tempo aquele espaço deixou de existir. Os atendimentos eram na sala de aula ou eram no leito ao lado da criança. Com o passar do tempo os atendimentos passaram a ser nas enfermarias, ao lado da cama/leito da criança. (Informação verbal Professora 1).
}

A sala somente retorna anos mais tarde, no final de 2008, depois que o hospital passa por mais uma reforma e são construídos outros quatro andares totalizando 3.800 metros quadrados no prédio do Pequeno Príncipe. Segundo informações do site oficial do hospital, dois destes andares são exclusivamente para apartamentos, outro somente leitos de UTI "e no último andar foram instalados dois auditórios, um espaço ecumênico, biblioteca, sala para educação e cultura, setor de psicologia e serviços de apoio."172 (CARRIEL, 2008, Caderno Vida e Cidadania).

A demora na liberação oficial da professora estadual para a efetivação do Escolarização Hospitalizada é outro ponto que pode ser considerado uma ruptura no trabalho. Afinal, desde 1988 aparecem informações nos jornais e em diversas outras

\footnotetext{
172 Nos dois pavimentos com apartamentos "foram implantados 80 leitos", passando a ser disponibilizado 390 leitos que "poderá atender seis mil crianças e adolescentes a mais, por ano, nas alas de internação. Disponível em: http://pequenoprincipe.org.br/hospital/noticia/hospital-pequenoprincipe-inaugura-a-sua-ampliacao/ Acesso em 24/04/2019.
} 
fontes que esse atendimento já vinha acontecendo desde 1987 e oficialmente a professora somente começa a trabalhar no hospital no ano de 1990.

Segundo Pacheco (2017, p. 36) e as entrevistas das duas professoras, tanto a estadual como a municipal, houve uma professora que atuou de forma experimental antes da efetivação do convênio com o Estado em 1990. Além disso, a Professora 1, liberada pela Secretaria de Estado da Educação, comenta sobre uma preocupação da Secretaria com relação ao seu trabalho, por conta da professora designada anteriormente para esse serviço ter se apropriado da autoria do Projeto do hospital numa matéria publicada no jornal num período em que a Assistente Social, responsável pelo Projeto estava afastada por causa de um acidente. "[...] a professora que lá atuava, teria se intitulado como autora da teoria do trabalho ou algo que pudesse indicar que o projeto teria sido elaborado por ela e isso não foi verdade". Então, quando a professora 1 é convidada para atuar na Escolarização Hospitalizada, a Secretaria esclareceu que a autoria teórica do Projeto era da Assistente Social, que inclusive havia o registrado em cartório e que o foco de seu trabalho era 0 desenvolvimento prático. (PROFESSORA 1, 2016).

Então a preocupação era muito grande com a seriedade do trabalho, com o desenvolvimento dele. E ela deixou muito claro para mim, na época, que eu iria desenvolver a prática de um projeto, mas a teoria dele já havia, já tinha essa base, [...] quando a [Assistente Social] passa a escrever um livro sobre a pedagogia hospitalar [...] toda a base pedagógica eu subsidiei com informações também. Isso porque, elas tinham a base teórica da pesquisa, a teoria, mas as questões pedagógicas do como fazer, a prática não. (PROFESSORA 1, 2016).

Neste recorte da entrevista da Professora 1, há indicação do principal objetivo de seu trabalho o desenvolvimento prático do projeto. Essa informação ainda é complementada por conta da ajuda que ela ofereceu para a escrita de um livro da Assistente Social nas informações a respeito da parte pedagógica do atendimento prático da Educação dentro do hospital. Com esse depoimento, a Professora 1 reconhece o valor da produção teórica da Assistente Social, mas demonstra também a importância de sua elaboração e conhecimento prático do trabalho educacional desenvolvido no hospital, o que acaba sendo suporte inclusive para a produção do livro da Assistente Social. Há neste discurso uma certa ambiguidade que ao mesmo tempo que concorda e destaca o trabalho da Assistente Social, mas ao mesmo tempo afirmar e reconhece a importância criativa de seu próprio trabalho docente. 
Com relação à cedência experimental de uma professora estadual que atuou em 1987, me parece um pouco complicado assumir essa informação como verdadeira, pois a conversa com o Secretário de Estado da Educação do Paraná tratando do convênio aconteceu somente em 1988 e, em algumas publicações dos jornais sobre o assunto, ele se posiciona favoravelmente à assinatura do convênio e fica animado com as informações prestadas sobre a atuação de uma professora auxiliada por seis estagiárias do curso de magistério que atuou em 1987. (O ESTADO DO PARANÁ, 01/11/1990 p. 7; GAZETA DO POVO, 01/11/90 p. 56; PACHECO, 2017, p. 36). Sendo que não há qualquer referência nesses jornais do vínculo dessa professora. Na reportagem do Jornal Tribuna do Paraná (22/04/1988, p.2) é publicada a informação de que "todo o trabalho, inclusive de montagem das carteiras especiais foi organizado pela assistente social [...] e pelo diretor clínico" com recursos do próprio hospital. Como poderia esta professora de 1987 ser uma professora estadual, se o Secretário se compromete com a assinatura do convênio somente no dia 21/04/1988? (GAZETA DO POVO, 22/04/1988, p. 40). Além disto, a Professora 1, oficialmente a primeira liberada pelo estado, começa a trabalhar somente no início do ano 1990, tendo um lapso de praticamente dois anos entre a conversa inicial do Secretário de Estado da Educação com a Assistente Social e as possibilidades temporais de atendimento educacional hospitalar pela professora cedida pelo estado e que causou um certo constrangimento ao estado. Acredito que esta professora experimental de 1987 possa não ter sido a mesma que foi cedida inicialmente pelo Estado do Paraná, suponho que possa ter sido alguma voluntária com formação em educação que tenha orientado as estagiárias e subsidiado os dados para a conversa com as secretarias estaduais e municipais de educação.

A liberação de professoras municipais para fazer recreação é outra ruptura e descaminho que observo no atendimento da Educação Hospitalar no Paraná. De acordo com a Professora 2, como o governo de estado demora para efetivar o convênio e o hospital fica sem professor entre os anos de 1988 e 1989, a Assistente Social procura a Secretaria Municipal de Educação - SME para firmar um convênio com este órgão em 1988. Por meio deste convênio firmado com o Departamento de Educação Física, que, todavia, não tinha vínculo com o Departamento de Ensino, foram cedidas duas professoras ligadas à SME que realizavam projetos voltados à Educação Física em praças com atividades de recreação. Com o convênio, elas 
realizavam atividades na Praça Osvaldo Cruz, do Hospital Pequeno Príncipe. (PROFESSORA 2, 2017).

Considero atividades recreativas tão importante quanto as atividades de assistência escolar, até porque este é também um dos direitos garantidos às crianças hospitalizadas pela Resolução no 41/1995 do Conselho Nacional dos Direitos da Criança e do Adolescente que trata dos Direitos da Criança e do Adolescente Hospitalizados. O item 9 da resolução determina às crianças hospitalizadas o direito de "desfrutar de alguma forma de recreação, programas de educação para a saúde, acompanhamento do curriculum escolar, durante sua permanência hospitalar". (BRASIL, 1995). Entretanto, o que não pode acontecer é um direito se sobrepor a outro, ambos precisam ser respeitados e efetivados. Entretanto, o que as fontes acabam indicando é que antes da implantação do Projeto Mirim de Escolarização Hospitalizada em 1989 o que havia nos hospitais para as crianças internadas era somente atendimentos na perspectiva de recreação.

Então, em 06 de setembro de 1989, é assinado o Termo de Cooperação Técnica entre o Município de Curitiba e a Associação Hospitalar de Proteção à Infância "Doutor Raul Carneiro" que tinha o objetivo de "promover assistência escolar às crianças internadas nos Hospitais Pequeno Príncipe e Cezar Perneta, oferecendo atendimento individualizado, mantendo entrosamento com a escola a que pertencer a criança" (CURITIBA, 1989, p. 01), informação que pode ser confirmada no relatório de Prado em que ela destaca que começou a trabalhar na Associação Hospitalar no dia 11 de outubro de 1989 (PACHECO, 2017, p. 116) e portanto, é cedida uma professora municipal com objetivo específico de trabalhar com a questão da escolarização formal. (Informação verbal Professora 2; PACHECO, 2017, p. 115).

O atendimento improvisado, sem apoio institucional, tanto do estado como do município, no início dos atendimentos das professoras entrevistadas, a falta de direcionamento das Secretarias de Educação, assim como a diferença de liberação das professoras que eram totalmente cedidas para a instituição de saúde podem ser considerados rupturas e descaminhos observados no atendimento da Educação Hospitalar.

Com relação ao improviso no atendimento, a Professora 1 destaca que existia o projeto, a pesquisa, a teoria, entretanto "não havia uma sistematização, uma metodologia para o desenvolvimento daquele projeto", ou mesmo um direcionamento mais específico da SEED. Não havia informações de como deveria acontecer os 
atendimentos pedagógicos diretamente com os estudantes hospitalizados, então, no início, os atendimentos aconteciam de maneira improvisada, de acordo com as possibilidades e necessidades de cada estudante e de acordo com o que a professora considerava importante.

\begin{abstract}
Aprendi a trabalhar, trabalhando, aprendi a fazer, fazendo. Então, não havia material específico. Eu criei uma base de consulta, busquei livros nas editoras, tinha meu acervo dentro de um armário no serviço social, onde eu pesquisava atividades e selecionava para as crianças. Não havia nenhum referencial, não tinha de onde tirar atividades. Eu tinha que buscar, tinha que pesquisar, tinha que elaborar. (Informação verbal Professora 1).
\end{abstract}

Neste mesmo sentido, a Professora 2 informou que ao ser liberada pelo município para trabalhar no hospital foi cedida para a instituição, que era responsável por delinear todo o trabalho desenvolvido por ela. O município não intervia, somente Ihe informou no momento de sua liberação, as duas cláusulas do convênio que era "manter entrosamento com a escola de origem do aluno e trabalhar conteúdo escolar". Além disto, nada mais foi Ihe repassado, segundo ela, o que fazia no hospital era realizar a sua função como professora, desenvolvendo os conteúdos escolares com os estudantes atendidos na hemodiálise. (PROFESSORA 2, 2017).

Essa realidade é modificada na SME somente em 2005, quando a secretaria se dá conta da existência de professores dentro do hospital, justamente no momento "em que o município começa a abrir o leque para outras coisas, para as outras práticas, no momento que eles começam a ler Capra, que eles percebem que eles podiam ter uma visão mais holística". Então o Departamento de Ensino Fundamental da SME identifica essas professoras e se aproxima delas "para entender o que elas faziam" e percebem que ela realizavam "uma prática diferenciada"173.

No âmbito estadual, essa alteração vai acontecer somente em 2007, quando o Serviço de Atendimento a Rede de Escolarização Hospitalar - SAREH é implantado no hospital e então o projeto de educação hospitalar, seus professores, alunos e atendimentos se efetiva no universo paranaense por meio de uma estrutura específica para ele. (PARANÁ, 2007a, MENEZES, 2010, p. 20).

A fragilidade dentro das próprias Secretarias de Educação com relação a liberação das professoras se apresenta como um outro descaminho da Educação Hospitalar. Segundo a Professora 2, até 2005, o convênio de liberação delas pertencia

173 Entrevista concedida pela PROFESSORA 2. Entrevista I. [ago. 2017]. Entrevistador: Claudinéia Maria Vischi Avanzini. Curitiba, 2016. 1 arquivo.mp3 (1h35min.41seg.). A entrevista na íntegra encontra-se transcrita nos Apêndices C e I desta tese. 
ao Setor Jurídico da Secretaria Municipal de Educação, e não era ligando a departamentos pedagógicos como o Ensino Fundamental ou Educação Especial, por conta disto elas não eram convidadas a participar dos cursos ofertados pela secretaria, até porque os departamentos responsáveis pelas formações continuadas não sabiam da existência delas nos hospitais.

Por muitos anos as professoras atuaram de maneira isolada, trabalhavam com os alunos sem uma supervisão pedagógica, sem uma formação continuada, sem até mesmo manterem uma relação de contato entre si. (PACHECO, 2017, p. 80).

Além disto, outra ruptura e descaminho que observo no atendimento da Educação Hospitalar era a falta de conhecimento e apoio das instituições educacionais de origem das crianças e as dificuldades de contato com as escolas de fora da capital, Curitiba.

Apesar do relatório de 1990 descrever que entre os serviços prestados pelas professoras está o "contato com as escolas" de origem das crianças por meio de cartas ou telefonemas, com o objetivo de obter dados relativos à vida escolar dos estudantes, afinal esse contato com o professor regentes das crianças era essencial para adquirir os "conteúdos programáticos a serem trabalhados durante o período de internamento" (PRADO, 1990a, p. 1; PACHECO, 2017, p, 159), segundo as professoras entrevistadas, essa era uma realidade que implicava uma certa dificuldade para se concretizar. As professoras entravam em contato com as escolas de origem dos estudantes, explicavam a importância do trabalho e como era desenvolvido. Entretanto, no começo dos atendimentos, as escolas não compreendiam como essa educação no hospital acontecia e não se posicionavam favoráveis a encaminhar qualquer conteúdo ou atividade. A Professora 2 comentou que em alguns contatos tinha até que ser bastante incisiva e chegar a indicar que informaria a responsável pelas escolas na Secretaria Municipal de Educação para que a escola se envolvesse no caso e encaminhasse as atividades necessárias para as crianças internadas.

As escolas não entendiam, e hoje a gente ainda percebe que algumas escolas não compreendem muito esse caminho. Eu estou com essa criança agora, essa criança não é minha, a criança continua pertencendo à escola. Ela é da escola, não é porque a criança não está lá, não está frequentando que ela não é. "Ela é sua e eu estou para lhe auxiliar, fazer o que for possível para melhorar essa criança". (Informação verbal Professora 2). 
A Professora 1 comentou que sempre que era possível ela "entrava em contato com a escola" e esta encaminhava orientação, programação ou o planejamento para que ela organizasse as atividades para trabalhar com as crianças. Entretanto, isso era mais simples quando as escolas se localizavam em Curitiba, pois em alguns casos a professora visitava essas escolas, mantinha contato com as professoras e buscava os materiais para trabalhar com a criança hospitalizada, sendo que frequentemente conseguia trabalhar com os próprios materiais da escola das crianças separados e fornecidos pelas próprias escolas, comentou que algumas vezes os próprios profissionais da escola iam até o hospital levar as atividades e conteúdos.

Como não era sistematizado, não havia obrigatoriedade de nada. Algumas escolas se empenhavam mais, houve até caso de visitação de diretor, na época de orientador educacional ou supervisor, que hoje denominamos como pedagogos. Então, era muito relativo, assim como profissionais da escola foram até o hospital fazer visita à criança e levar atividades, eu também em alguns momentos, fui até a escola buscar subsídios para trabalhar com as crianças, quando eram da capital. (Informação verbal Professora 1).

Entretanto, ela relata que em alguns casos encontrou uma certa resistência no contato, pois as escolas se posicionavam negativamente à opção de encaminhar as atividades e conteúdos e argumentavam que ofertariam as atividades necessárias na própria escola quando o aluno retornasse do tratamento, afinal ele estaria "amparada por lei com atestado médico" 174 e poderia realizar as atividades depois que finalizasse o tratamento de saúde.

Com as crianças de outras cidades ela também tentava localizar a escola, por meio de uma relação das escolas públicas do Estado do Paraná ofertada pela Secretaria de Estado da Educação. Esses contatos eram por telefone ou cartas, sendo que "a escola às vezes dava retorno, às vezes não e, às vezes, quando chegava algum material, a criança também já estava recebendo alta"175. Apesar de acontecer de forma mais improvisada, com os conteúdos e atividades que a própria professora planejava de acordo com seus conhecimentos sobre as diretrizes estaduais, as crianças de outras cidades, mesmo sem uma sistematização mais efetiva oferecida pelas suas escolas de origem, também recebiam atendimento pedagógico.

\footnotetext{
174 Entrevista concedida pela PROFESSORA 1. Entrevista I. [ago. 2016]. Entrevistador: Claudinéia Maria Vischi Avanzini. Curitiba, 2016. 1 arquivo.mp3 (60min.). A entrevista na íntegra encontra-se transcrita nos Apêndices $\mathrm{C}$ e H desta tese.

175 Entrevista concedida pela PROFESSORA 1. Entrevista I. [ago. 2016]. Entrevistador: Claudinéia Maria Vischi Avanzini. Curitiba, 2016. 1 arquivo.mp3 (60min.). A entrevista na íntegra encontra-se transcrita nos Apêndices $\mathrm{C}$ e H desta tese.
} 
Além de toda essa problemática do envio das atividades pelas escolas que era possível entrar em contato, havia aquelas com as quais as professoras não conseguiam se comunicar.

$\mathrm{Na}$ época, o grande problema era o contato, porque as crianças oriundas do interior, muitas escolas não possuíam telefone, as crianças não conseguiam dizer exatamente onde estudavam. Não tínhamos internet como hoje, para entrar em contato com as escolas era algo difícil, através de cartas, era demorado, via telefone, às vezes a criança estudava num período e eu trabalhava em outro, para entrar em contato com a professora. O contato era o maior desafio. (Informação verbal Professora 1).

Mesmo com essa dificuldade de contato, a professora informou que trabalhava independente dele, segundo ela, o contato era secundário para ela e quando ele se efetivava, "as escolas quase sempre recebiam isso muito bem, com raras exceções". Todavia, "o projeto era pouco conhecido, pouco divulgado, era algo incomum para a época", soando como algo raro, sem muita expressividade naquele período. (Informação verbal Professora 1).

Além destas rupturas apontadas, considero a ruptura do atendimento das crianças que tinham alta umas das rupturas mais frequentes. Segundo a Professora 2, na maioria das vezes, as atividades propostas para as crianças hospitalizadas precisam ser planejadas para finalizar no mesmo dia, pois o tratamento ou o procedimento da criança pode acabar a qualquer momento e ela pode ser liberada com alta hospitalar.

Então, a flexibilidade das professoras na organização das atividades trabalhadas com os estudantes é essencial, principalmente com as crianças que ficam nos ambulatórios ou na clínica cirúrgica, pois algumas vezes a professora pode encontrar a mesma criança mais vezes, como também pode acontecer de a criança fazer uma cirurgia e rapidamente receber alta e nunca mais ser vista pela professora. Assim, é necessário que a professora esteja preparada para "trabalhar uma atividade pontual com essa criança e pronto, não tem, como você desenvolver um plano"176 específico e criar expectativas de continuidade do atendimento pedagógico com crianças que vão ao hospital para realizar procedimentos mais rápidos como cirurgias de apendicite ou amídalas, por exemplo.

176 Entrevista concedida pela PROFESSORA 2. Entrevista I. [ago. 2017]. Entrevistador: Claudinéia Maria Vischi Avanzini. Curitiba, 2016. 1 arquivo.mp3 (1h35min.41seg.). A entrevista na íntegra encontra-se transcrita nos Apêndices C e I desta tese. 
A Professora 1 (2016) destacou em sua entrevista que até mesmo as atividades solicitadas pelas escolas dessas crianças, algumas vezes não conseguiam ser aplicadas, porque quando o material chegava a criança já estava sendo liberada com alta.

Além da ruptura por alta hospitalar as professoras e a mãe entrevistadas destacaram a ruptura do atendimento na Educação Hospitalar das crianças que passavam para outro plano, que faleciam. Segundo a Professora 1, durante o período em que atuou na Educação Hospitalar, tudo era "muito flexível, não se tinha certeza alguma, nem mesmo da continuidade do trabalho". Ela relatou que em alguns momentos, ao chegar para atender alguma criança era informada que esta "não estava mais lá, não porque recebeu alta, mas porque não resistiu ao tratamento"177.

Com relação a essa questão, a mãe entrevistada comenta que a filha tinha um colega de tratamento, que ao fazer transplante acabou não resistindo e o grande questionamento da filha foi com relação a tudo o que ele passou e as experiências educacionais deste colega. A mãe comentou que sua filha não foi a única criança que recebeu esse acompanhamento pedagógico durante o tratamento. Houve o caso desse colega da filha que se formou em Matemática e, segundo a mãe entrevistada, ficou fazendo o tratamento de hemodiálise por 13 ou 14 anos e após o transplante teve uma intercorrência na bexiga e não resistiu. Isso levou sua filha a comentar: "Ele também teve acompanhamento com a professora. Ele sofreu tanto. Ele se formou, mãe"178. Segundo a mãe, houve vários casos assim, que durante o tratamento de sua filha, recebiam o acompanhamento pedagógico das professoras e muitos não resistiram. Essa questão acompanhava o trabalho das professoras que, com certeza, precisavam de um acompanhamento psicológico ou uma predisposição própria para lidar com essa situação.

Havia também a ruptura do atendimento na Educação Hospitalar das crianças que passavam para a 5ª série ou para o Ensino Médio.

De acordo com a mãe entrevistada, quando sua filha foi para a 5a série deixou de receber o acompanhamento da professora hospitalar que atendia somente até a

177 Entrevista concedida pela PROFESSORA 2. Entrevista I. [ago. 2017]. Entrevistador: Claudinéia Maria Vischi Avanzini. Curitiba, 2016. 1 arquivo.mp3 (1h35min.41seg.). A entrevista na íntegra encontra-se transcrita nos Apêndices $\mathrm{C}$ e I desta tese.

178 Entrevista concedida pela MÃE. Entrevista I. [nov. 2016]. Entrevistador: Claudinéia Maria Vischi Avanzini. Curitiba, 2016. 1 arquivo.mp3 (28min.21seg.). A entrevista na íntegra encontra-se transcrita nos Apêndices $\mathrm{E}$ e $\mathrm{J}$ desta tese. 
4a série. Assim como teve dificuldades no $3^{\text {o }}$ ano do Ensino Médio, chegando a reprovar por faltas, por não se adaptar a uma das professoras da turma. Segundo a mãe, "ela já não tinha ajuda do hospital", talvez se continuasse tendo esse acompanhamento da Educação Hospitalar, essa reprovação poderia ter sido evitada. Essa afirmação pode ser justificada com o comentário da mãe ao destacar que na época do hospital ela não reprovou, apesar de ter uma professora bastante complicada na 3a série do Ensino Fundamental, pois a filha recebia, na época, o acompanhamento com a professora no hospital, o que ajudou nesse período complicado com a professora do Ensino Fundamental. (Informação verbal Mãe).

A Professora 1 comentou que no atendimento a outra aluna que ficou muito tempo em tratamento no hospital, o atendimento educacional hospitalar acabou também não dando mais conta da parte pedagógica, pois a professora não conseguia mais atender a estudante na totalidade. Então, conseguiram uma bolsa de estudos no Colégio Sagrado Coração de Jesus, por conta de a estudante ser carente economicamente. No Colégio Sagrado, a estudante realizou a Formação de Docentes e conseguiu finalizar o Ensino Médio indo em um período do dia para a hemodiálise e no outro para a escola. (Informação verbal Professora 1).

Finalmente, a grande ruptura ou descaminho do atendimento da Educação Hospitalar foi a interrupção do convênio que liberava a professora para atuar no hospital realizado pelo governo do estado do Paraná em 1999.

A minha saída do hospital deu-se em janeiro de 99, por uma determinação
da Secretária de Educação na época, Alcione Saliba. Tendo em vista que
havia um déficit de professores, uma defasagem, havia a necessidade de
professores nas escolas e o governo não tinha feito concurso, foi determinado
que todos os professores em convênio retornassem para as salas de aula,
para suas funções de origem e que cada convênio seria analisado
individualmente e que se houvesse a necessidade, seria reativado o Termo
de Cooperação Técnico e haveria o chamamento posterior. (Informação
verbal Professora 1).

A professora deduz que durante alguns anos o convênio ficou interrompido, porque a SEED não julgou necessária a atuação de professores na área hospitalar, visto que esse foi o argumento para que ela voltasse a trabalhar nas escolas regulares no início de 1999. Essa análise posterior prometida para a professora não aconteceu na gestão da Secretária Alcione Saliba, que descontinuou o convênio, nem na gestão de sua sucessora, Sueli Conceição Moraes Seixas pertencentes ao mesmo governo estadual. A Educação Hospitalar estadual somente foi retomada sete anos mais tarde, em junho de 2007, quando um outro governo assume e o Secretário de Educação 
Maurício Requião de Mello e Silva apresenta outra proposta de Educação Hospitalar e implanta o SAREH ${ }^{179}$. (PARANÁ, 2007a; DUARTE, 2008, p. 12; CURSO...,2009180; MENEZES, 2010, p. 20; PARANÁ, 2019b; PARANÁ, 2019c).

Entretanto, como a prática de educação dentro de um hospital se desdobra na década de 90 ? Quem eram esses professores que atuavam dentro do nosocômio? Como o atendimento educacional acontecia efetivamente? Outra parte da história do Hospital Pequeno Príncipe e César Pernetta de Curitiba que vale a pena ser investigada e que será descrita e analisada no próximo capítulo deste trabalho. 


\section{CONSIDERAÇÕES FINAIS}

De tudo, ficaram três coisas: a certeza de que ele estava sempre começando, a certeza de que era preciso continuar e a certeza de que seria interrompido antes de terminar. Fazer da interrupção um caminho novo. Fazer da queda um passo de dança, do medo uma escada, do sono uma ponte, da procura um encontro. (SABINO, Fernando, 1981, p. 154).

Chegar ao final da escrita chega a ser assustador, perceber que nunca estará bom, que sempre é possível ampliar, melhorar e continuar enriquecendo o que por mais de quatro anos foi o objeto de desejo, de sonhos, de angústias e de prazer é algo que me faz entender o que Fernando Sabino quis dizer com as "três coisas" que ficaram, que estarei sempre começando, continuando e a interrompendo antes de terminar. Esse é o fim desse percurso da escrita da tese, mas com certeza essa interrupção está me mostrando que novos caminhos ficarão abertos e por eles, eu como outros pesquisadores, poderão criar outros passos de dança, subir novas escadas, criar outras pontes para encontrarmos outras teorias, conceitos e temáticas.

Esta análise das discussões e empreendimentos que resultaram na estruturação da Educação Hospitalar em dois hospitais em Curitiba, no Estado do Paraná indicou que as principais ações que contribuíram para a implantação da educação hospitalar para crianças em Curitiba no final do século XX foi de ordem legal e jurídica, observada na obrigatoriedade constitucional da Educação, sendo que a importância da educação considera as necessidades básicas e fundamentais das crianças e adolescentes enquanto sujeitos de direito nesse processo de efetivação dos atendimentos educacionais hospitalar às crianças curitibanas.

No resultado da pesquisa foi possível perceber que a Educação Hospitalar implantada em Curitiba no Paraná em 1988 não foi uma experiência inovadora ou pioneira no país, como algumas das entrevistadas insistiam em conclamar nas entrevistas, pois outros exemplos de Educação Hospitalar puderam ser encontrados em pleno funcionamento no início e meados do século XX nas cidades de São Paulo e Rio de Janeiro sucessivamente, assim como em outros lugares do mundo. Entretanto, se pensarmos exclusivamente no Estado do Paraná, se conclui que a Educação implantada nos hospitais César Pernetta e Pequeno Príncipe mantidos pela Associação Hospitalar de Proteção à Infância Dr. Raul Carneiro foi inovadora para o Estado, sendo inspiração para outras implantações em diversos hospitais, inicialmente da cidade e depois no próprio Estado do Paraná. 
Com relação a esses dados dos atendimentos na cidade, até 2002 tínhamos a Educação Hospitalar implantada no Hospital Infantil Cesar Pernetta, Hospital Pequeno Príncipe, Associação Criança Renal, Hospital de Clínicas, Hospital Erasto Gaertner, Hospital Universitário Evangélico e Associação de Hemofílicos com professores liberados tanto pela Secretaria Municipal de Educação de Curitiba como pela Secretaria de Estado da Educação do Paraná (PACHECO, 2017, p. 154). Após 2002 foi implantada a Educação Hospitalar na Associação Paranaense de Apoio à Criança com Neoplasia (APACN), no Hospital do Trabalhador, no Centro de Reabilitação Ana Carolina Moura Xavier e no Hospital Cajuru pela Secretaria de Estado da Educação que também conta com atendimentos pedagógico em outras unidades hospitalares ou de atendimento de saúde espalhadas pelo Estado como no Hospital Infantil Dr. Waldemar Monastier em Campo Largo, no Hospital Universitário do Oeste do Paraná e no Hospital do Câncer UOPECCAN em Cascavel, no Lar Dom Bosco em Campo Mourão, no Hospital Universitário Regional do Norte do Paraná e no Hospital do Câncer de Londrina, no Hospital Universitário Regional de Maringá nesta cidade, no Hospital Regional do Litoral em Paranaguá, na Clínica HJ em União da Vitória, na Comunidade Terapêutica Melhor Viver e na Comunidade Terapêutica Rosa Mística em Ponta Grossa. (PARANÁ, 2019a).

A respeito dos convênios da Secretaria de Estado da Educação do Paraná, a maioria destas unidades hospitalares passam a ofertar a Educação Hospitalar depois do segundo convênio disponibilizado pelo SAREH a partir de 2007, sendo que as únicas unidades hospitalares conveniadas ao Estado por meio do primeiro convênio implantado e efetivado durante a década de 90 do novecentos eram o Hospital Infantil Cesar Pernetta, Hospital Pequeno Príncipe, Associação Criança Renal, Hospital de Clínicas, Hospital Erasto Gaertner e a APACN, maioria deles interrompido no final da década de 90, como aconteceu nos hospitais da Associação Hospitalar de Proteção à Infância Dr. Raul Carneiro, somente retomando suas atividades educacionais com os convênios de 2007.

A interrupção do convênio com o Estado do Paraná e os hospitais pesquisados ocorreu efetivamente em janeiro de 1999, quando a Professora 1 foi comunicada pela Secretaria de Estado da Educação, que por conta da falta de professores nas escolas, causada principalmente pelas ausências de concursos públicos naquele período, todos os professores cedidos em convênio deveriam retornar para as suas funções de origem nas salas de aula. A promessa, entretanto, foi que "o convênio seria 
analisado individualmente e que se houvesse a necessidade, seria reativado o Termo de Cooperação Técnico" (PROFESSORA 1, 2016). Como o convênio não foi reativado elenco duas possibilidades para essa decisão, ou a necessidade da retomada do convênio nunca foi analisado individualmente, como prometido, ou a Secretaria de Educação o considerou desnecessário comparado às outras necessidades do estado que se mostraram mais importantes para o governo da época. Ambas as decisões causam um certo desconforto e indicam que a Educação Hospitalar não era valorizada como deveria, não era uma pauta prioritária e por isso passível de ser excluída das políticas de governo, contudo elenco a falta de garantia na efetivação ao direito à educação para um grande número de crianças que continuaram internadas ou em tratamento de saúde durante esse período que o Estado do Paraná se omite com relação a oferta da Educação Hospitalar e não libera os professores para efetivamente atender pedagogicamente essas crianças.

Lembrando que os atendimentos ofertados, o interesse em ampliações da Educação Hospitalar no Estado denota a preocupação com a educação das crianças garantindo-Ihes seus direitos constitucionais e legais. Afinal, de acordo com o art. 205 da Constituição e o art. 246 do Código Penal, nenhuma criança pode ficar fora da escola sem que o estado e seus pais sejam responsabilizados por crime tipificado como abandono intelectual. (BRASIL, 1940; 1988).

De acordo com os estudos deste trabalho foi possível ainda identificar que na década de 1990 do século XX, a Educação Hospitalar pode ser considerada um espaço de escolarização "formal" e experiencial ${ }^{181}$, assim como um espaço que favorece a socialização da criança com o universo hospitalar e o entretenimento, estes dois últimos principalmente nos casos de internamentos com tempo mais reduzido. Somando-se a isso, em Curitiba, as professoras entrevistadas repetiram em seus relatos orais que o objetivo do atendimento sempre foi a escolarização de conteúdos, sendo observadas as especificidades individuais de cada estudante e considerando as informações divididas com as escolas de origem dos atendidos na Educação Hospitalar. A experiência de vida tanto das crianças e adolescentes internados nos hospitais, quanto dos professores hospitalares, ocorre num ambiente que não é o escolar e, portanto, é demarcado por questões de saúde, medicação e conhecimentos do corpo humano. Além disto, as práticas educacionais dos próprios professores não

181 Cf. CAVACO, 2003. 
parte da totalidade, mas sim de alguns modelos de educação e nestes não está descrita a realidade e as experiências da hospitalização adquiridas pelos estudantes.

Com relação aos modelos educacionais observados na Educação hospitalar percebo ser essencial defender alguns princípios a serem vislumbrados para a melhoria da oferta e atendimento da escolarização em hospitais, como por exemplo a descentralização, autonomia, igualdade, inclusão, pensar nos estudantes como o centro do ensino, ter uma atenção redobrada para as fases iniciais de ensino, favorecer currículos integrados e organizar o tempo e espaços para a efetivação da Educação Hospitalar.

"É uma verdadeira escola dentro do hospital", define Rosana, professora que
ajuda atender todas as crianças em idade escolar. Muitas ficam pouco tempo,
mas algumas ali permanecem um mês, dois e até mais e são procedentes
inclusive de outros estados como Mato Grosso do Sul e Santa Catarina. "O
atendimento é igual ao da escola". As professoras tomam acesso aos
conteúdos e após conhecer do médico a situação do paciente, realiza um
planejamento para que a criança não perco ano. (GAZETA DO POVO,
$01 / 11 / 90$, p. 56).

Com relação aos desdobramentos observados na ampliação da Educação Hospitalar, a professora estadual ao ser questionada em que medida o projeto de educação hospitalar, seus professores, alunos e atendimentos se efetivou no universo paranaense responde que nos dias atuais há "uma estrutura específica para esse projeto", que, por sua vez, tem reconhecimento e é difundido entre "todos os profissionais dentro da área hospitalar" sem distinção entre profissionais do município ou do estado, bem diferente do momento em que ela trabalhou na Educação Hospitalar na década de 90 do novecentos, quando os profissionais do hospital nem sabiam que o projeto existia, só tomando conhecimento quando se deparavam com a professora trabalhando com as crianças. E ainda, segundo ela isso acontecia, não somente por falta de reconhecimento, mas também pela ausência de regulamentação e formalidade. (PROFESSORA 1, 2016). Medidas que só se efetivaram depois dos anos 2000 com regulamentações específicas sobre o assunto tanto do CNE como da SEED.

Neste sentido, o atendimento da Educação Hospitalar nos hospitais da Associação Hospitalar de Proteção à Infância inicia com a coordenação da Assistência Social em 1988, entretanto em 2002, com a criação do Setor de Educação e Cultura essa responsabilidade se dividiu na parte administrativa e teórica, sendo que, segundo a Assistente Social entrevistada, a parte administrativa era de responsabilidade do 
Setor recém-criado e a parte mais técnica era suprida pela própria Assistente Social. Ainda seguindo seu relato oral, ela acompanhou a Educação Hospitalar da Associação até o ano de 2012, quando se aposentou. (ASSISTENTE SOCIAL, 2016).

O Setor de Educação e Cultura criado em março de 2002 e instalado numa sala pequena do Hospital César Pernetta, além de se integrar à política nacional de humanização iniciada em $2003^{182}$, tinha por intuito "fortalecer e ampliar o trabalho de acompanhamento escolar" realizado até aquele momento, pelo Setor de Serviço Social do hospital (CARREIRA, 2016, p. 40). Segundo a autora o setor "passa a coordenar e promover ações voltadas não só para as crianças e adolescentes hospitalizados, mas também aos familiares e colaboradores do Pequeno Príncipe", o que amplia os sujeitos atendidos pela escolarização no hospital. Além disso, passou a realizar um planejamento mais sistemático, organizou o plano pedagógico do hospital, estruturou o registro das atividades desenvolvidas, organizou um cronograma de reuniões da equipe, concomitantemente à garantia da oferta de "atendimento individualizado à educação formal, com a manutenção do contato com a escola de origem" e a instituição do projeto "Jogos de todo o Mundo" para estimular "a prática de jogos de culturas de todo o planeta, com especial destaque [àqueles] que desenvolvem o raciocínio lógico, a expressão verbal e as habilidades cognitivas e psicomotoras". Com relação às profissionais do Setor de Educação e Cultura disponibilizadas no período de sua implantação, estas eram as professoras cedidas pela Secretaria Municipal de Educação de Curitiba e uma estagiária de pedagogia contratada pelo próprio hospital.

O espaço do Setor de Educação e Cultura foi ampliado no final de 2008, depois de uma reforma e construção de quatro novos andares no Hospital Pequeno Príncipe. (CARRIEL, 27/10/2008, Caderno Vida e Cidadania). O setor fica no sexto andar e conta com uma sala de atividades e reuniões equipada com um projetor e três

182 A Política Nacional de Humanização (PNH) iniciada em 2003 efetiva os princípios do SUS no cotidiano das práticas de atenção e gestão, qualificando a saúde pública no Brasil e incentivando trocas solidárias entre gestores, trabalhadores e usuários. A humanização é a valorização de todos esses envolvidos no processo de produção de saúde. Valorizar os sujeitos é oportunizar uma maior autonomia, a ampliação da sua capacidade de transformar a realidade em que vivem, através da responsabilidade compartilhada, da criação de vínculos solidários, da participação coletiva nos processos de gestão e de produção de saúde. Disponível em: http://portalms.saude.gov.br/saude-dea-z/projeto-lean-nas-emergencias/693-acoes-e-programas/40038-humanizasus Acesso em: 24/05/2019. No Hospital Pequeno Príncipe a Educação e Cultura, a sensibilização, capacitação e educação permanente das equipes, o oferecimento de momentos lúdicos o direito à informação e participação nas decisões são consideradas algumas das diretrizes de humanização do hospital. (FORTE; SATO, 2016, p. 24). 
computadores "aparelhados com o programas de iniciação às ciências, direcionados à aprendizagem de crianças de 3 a 6 anos", uma sala para a coordenação, uma sala de leitura nomeada Ruth Rocha, preferencialmente "destinada para as crianças de até 6 anos de idade", principalmente por conta da necessidade de fomentar "a atenção às crianças de 0 a 6 anos pela importância dessa etapa de desenvolvimento" e uma biblioteca com sala de leitura no quinto andar para as crianças e adolescentes. (CARREIRA, 2016, p. 49).

A paulatina ampliação dos atendimentos pedagógicos hospitalares, da complexidade das ações prestadas pela Educação Hospitalar nos nosocômios de Curitiba pesquisados, assim como nos outros hospitais paranaenses, sinalizam outros rumos plurais para a Educação Hospitalar das crianças e adolescentes no Paraná. A possibilidade de tentar descobrir como estas outras práticas de educação dentro de hospitais se desdobram. Quem eram os sujeitos (estudantes e famílias) que continuaram a ser atendidos pela educação hospitalar. E finalmente, quem eram os professores que atuavam dentro dos nosocômios desses novos convênios são algumas das novas possibilidades de uma outra parte da história da Educação Hospitalar que pode ser utilizada como temática e questionamentos para outros estudos futuros. 


\section{REFERÊNCIAS}

ALVES, Cássia Ferrazza e SIQUEIRA, Aline Cardoso. Perspectiva de adolescentes sobre seus direitos e deveres. Psicologia \& Sociedade. 2014, vol.26, n.3, p.583-593. Disponível em:_http://www.scielo.br/pdf/psoc/v26n3/a07v26n3.pdf Acesso em: 03/11/2018.

AMARAL e SILVA, A. F. Estatuto da criança e do adolescente: avaliação histórica. Educar em Revista, v. 15 n. 15, p. 13-15, Curitiba - PR, 1999. Disponível em: https://revistas.ufpr.br/educar/article/view/2049/1701 Acesso em: 28/10/2018.

ARAÚJO, Camila Camilozzi Alves Costa de Albuquerque. Atendimento escolar em ambiente hospitalar: um estudo de caso do estado de São Paulo. São Paulo, 2017. Fundação João Pinheiro, Escola de Governo Professor Paulo Neves de Carvalho. Dissertação (Mestrado em Administração Pública).

ARIÈS, Philippe. História social da criança e da família. 2a edição. Rio de Janeiro: Zahar, 1981.

AROSA, Armando de Castro; SCHILKE, Ana Lúcia. Reflexões sobre a escola no hospital. In: AROSA, A. de C.; SCHILKE, A. L. A escola no hospital: espaço de experiências emancipadoras. Niterói, RJ: Intertexto, 2007.

AVANZINI, C.M.V. As origens do Hospital de Crianças. Saúde e educação em Curitiba, (1917-1932). Curitiba, 2011. Setor de Educação, Universidade Federal do Paraná. Mestrado (Dissertação em Educação).

BARROS, A.S.S. A prática pedagógica em uma enfermaria pediátrica: contribuições da classe hospitalar à inclusão desse alunado. Revista brasileira de educação, Rio de Janeiro, n. 12, p. 84-93, 1999.

Escolas hospitalares como espaço de intervenção e de pesquisa. Presente! Revista de Educação/Centro de Estudos e Assessoria Pedagógica. Ano XVI, no. 61, jul./ago. 2008. Salvador: CEAP, 2008, p.33-37.

. Panorama da classe hospitalar no mundo. In: DÍAS, F., et al., orgs. Educação Inclusiva, deficiência e contexto social: questões contemporâneas [online]. Salvador. EDUFBA, 2009, p.279-288. Disponível em: http://books.scielo.org/id/rp6gk/26. Acesso em 15/11/2016.

Notas sócio-históricas e antropológicas sobre a escolarização em hospitais. In. SCHILKE, A.L.; NUNES, L.B.; AROSA, A.C. (org.) Atendimento escolar hospitalar: saberes e fazeres. Niterói: Intertexto, 2011, p. 19-28.

BAZÍLIO, Luiz Cavalieri. Avaliando a implantação do Estatuto da Criança e do Adolescente. In: Revista do Programa de Mestrado em Serviço Social da PUCRio. "O Social em Questão - violência e direitos". Rio de Janeiro, ano V, v.06, n 06, $2^{\circ}$ semestre/2001, p. 17 a 25. 
BELLINGHAUSEN, Ingrid B. De mãos dadas - às crianças de toda parte do mundo. São Paulo: DCL, 2003.

BERTUCCI, Liane Maria. Para a saúde da criança. A educação do trabalhador nas teses médicas e nos jornais operários (São Paulo, início do século XX). Revista Mundos do Trabalho, vol. 7, n. 13, janeiro-junho de 2015, p. 27-42. Disponível em: https://periodicos.ufsc.br/index.php/mundosdotrabalho/article/view/1984-

9222.2015v7n13p27 Acesso em: 15/05/2019.

BORGES, Maria Eliza Linhares. História \& Fotografia. Belo Horizonte: Autêntica, 2003.

BURKE, Peter. Como confiar em fotografias. Folha de S. Paulo, 4/02/2001, Caderno Mais!, p. 13. Marco Antonio Stancik, 464. Revista Brasileira de História, vol. 29, no 58.

. Introdução. Fotografias e retratos. In: . Testemunha ocular. História e Imagem. Bauru: Edusc, p. 11-41, 2004.

CAIADO, K. R. M. O trabalho pedagógico no ambiente hospitalar: um espaço em construção. In: RIBEIRO, M. L. S. e BAUMEL, R. C. R. C. Educação especial do querer ao fazer. Campinas: Ed. AVERCAMP, 2003.

CAMARA, Sônia. História da criança no Brasil. 2a edição. São Paulo: Contexto, 2000

CAMPOS, Maria M. Malta. Pré escola: entre a educação e o assistencialismo. 1985. In: ROSEMBERG, Fúlvia (Org.) Creche. Fundação Carlos Chagas: Cortez, 1994, p.11-19.

. A educação da criança de 0 a 6 anos na legislação. 1986. In: ROSEMBERG, Fúlvia (Org.) Creche. Fundação Carlos Chagas: Cortez, 1994, p.236-251.

CAPRA, Fritjof. Biografia Fritjof Capra. Disponível em: https://brasilescola.uol.com.br/biografia/fritjof-capra.htm Acesso em: 11/07/2018.

CARRIEL, Paola. Pequeno Príncipe ganha quatro andares e mais 80 leitos. Gazeta do Povo, 27/10/2008. Caderno Vida e Cidadania. Disponível em: https://www.gazetadopovo.com.br/vida-e-cidadania/pequeno-principe-ganha-quatroandares-e-mais-80-leitos-b8xomnkmv6924kfsi9u6ygaj2/ Acesso em: 24/04/2019.

CARREIRA, Denise. O Direito à Educação e à Cultura em Hospitais: Caminhos e Aprendizagens do Pequeno Príncipe. Associação Hospitalar de Proteção à Infância Dr. Raul Carneiro. Curitiba - PR, 2016.

CARSTENS, L.E. Teachers' experience of teaching in a Hospital School. South África, 2004. Faculty of Education and Nursing. Rand Afrikaans University. (Magister Educations).

CAVACO, Cármen. Fora da escola também se aprende. Percursos de formação 
experiencial. Educação, Sociedade \& Cultura. Porto - PT, no 20, 2003, p.125-147. Disponível em: https://www.fpce.up.pt/ciie/revistaesc/ESC20/20-5.pdf Acesso em: 10/05/2019.

CECCIM, R.B. Classe hospitalar: encontros da educação e da saúde no ambiente hospitalar. Pátio, revista pedagógica, Porto Alegre, n.10, p.41-44, 1999.

CERTEAU, Michel de. A escrita da história. Rio de Janeiro: Forense-Universitária, 1982.

A operação histórica. In: LE GOFF, Jacques (comp.). História: novos problemas. 3를 Ed. Rio de Janeiro: Francisco Alves Editora, 1988, p. 17-48.

A história, ciência e ficção; Psicanálise e história e $\mathrm{O}$ "romance" psicanalítico. História e literatura. In: e ficção. Belo Horizonte: Autêntica, 2011, p. 45-117.

História e psicanálise: entre ciência

CHARTIER, Roger. A História Cultural. Entre Práticas e Representações. Lisboa, Bertrand Brasil, 1993a.

. Le regard d'un historien moderniste. In: INSTITUT d'Histoire du Temps Présent. Ecrire l'histoire du temps présent. Paris, CNRS Editions, 1993b.

Estrategias y tácticas. De Certeau y las "artes de hacer". In: CHARTIER, Roger. Escribir las prácticas. Foucault, de Certeau, Marin. Buenos Aires: Manantial, 1996a, p. 55-72.

2010.

A história ou a leitura do tempo. $2^{2}$ ed. Belo Horizonte: Autêntica Editora,

CHOW, Susan. Que é peritonite? News Medical Life Sciences. 23/08/2018. Disponível em: https://www.news-medical.net/health/What-is-Peritonitis(Portuguese).aspx. Acesso em: 29/04/2019.

CIRQUEIRA, Angelica Pimenta. Violência física intrafamiliar: as percepções dos adolescentes dos Programa Sentinela de Itaboraí sobre a violência sofrida. Rio de Janeiro - RJ, 2007. Dissertação (Mestrado em Serviço Social) Pontifícia Universidade Católica do Rio de Janeiro.

CNBB - Conferência Nacional dos Bispos do Brasil. Pastoral do Menor Nacional, Princípios, Diretrizes e Organização, Artigo 12, 2014. Disponível em: Cf. https://www.pastoraldomenor.com.br/ Acesso em: 09/02/21019.

COLÉGIO SAGRADO CORAÇÃO DE JESUS. Sagrado - Rede de Educação. Disponível em: http://www.redesagradosul.com.br/ Acesso 11/04/2019.

CONANDA. Conselho Nacional dos Direitos da Criança e do Adolescente. Ministério da Justiça. Ministério Público do Paraná. Curitiba - PR, 2010. Disponível em: http://www.crianca.mppr.mp.br/modules/conteudo/conteudo.php?conteudo=1564 Acesso em: 24/04/2019. 
COMPLEXO PEQUENO PRÍNCIPE. Dr. Ivan é homenageado no lançamento da nova edição de "Um Hospital de Crianças". Curitiba - PR, 13/11/2012. Disponível em: http://pequenoprincipe.org.br/noticia/dr-ivan-e-homenageado-no-lancamento-deum-hospital-de-criancas/ Acesso em: 28/01/2017.

COSTA, Ana Luiza Jesus da. O educar-se das classes populares oitocentistas no Rio de Janeiro entre a escolarização e a experiência. São Paulo, 2012. Setor de Educação, Universidade de São Paulo. Doutorado (Tese em Educação).

COSTA, V.A.A. Boletim Casa Romário Martins. Memória da Rede Municipal de Ensino de Curitiba 1983-1998. Curitiba: Fundação Cultural de Curitiba, v. 33, n. 143, 2010.

COVIC, A.N. Atendimento pedagógico hospitalar: convalidando uma experiência e sugerindo ideias para a formação de educadores. São Paulo, 2003. Setor de Educação, Pontifícia Universidade Católica de São Paulo. Mestrado (Dissertação em Educação).

Aprendizagem da docência: um estudo a partir do atendimento escolar hospitalar. São Paulo, 2008. Setor de Educação, Pontifícia Universidade Católica de São Paulo. Doutorado (Tese em Educação).

CUNHA, Luiz Antônio. Educação, Estado e democracia no Brasil. São Paulo: Cortez, 1991.

DARELA, C.M.V. Classe Hospitalar e escola regular: tecendo encontros. Florianópolis, 2007. Centro de Ciências da Educação, da Universidade Federal de Santa Catarina. Mestrado (Dissertação em Educação).

DEL PRIORE, Mary (org.). História da criança no Brasil. 2a edição. São Paulo: Contexto, 2000.

DOSSE, François. A história. Tradução: Roberto Leal Ferreira. 1a ed. São Paulo: UNESP, 2012.

DOMINICÉ, Pierre. O Processo de Formação e Alguns dos seus Componentes Relacionais. In: NÓVOA, António; FINGER, Mathias (Orgs.) O Método (Auto) Biográfico e a Formação. Lisboa: Ministério da Saúde, 1988, p. 53-61.

DRAUZIO. Pielonefrite. Disponível em: https://drauziovarella.uol.com.br/doencas-esintomas/pielonefrite/ Acesso em: 12/05/2018.

DUTRA, Eliana de Freitas. (org.) O Brasil em dois tempos: história, pensamento social e tempo presente. $1^{\underline{a}}$ ed. Belo Horizonte: Autêntica, 2013.

EVANGELISTA, Olinda; SCHMIDT, Maria Auxiliadora. Relação Estado/Município no Paraná: construção ou desconstrução da escola pública de qualidade. In:

Estado e educação. Campinas, SP, Papirus: Cedes: São Paulo: Ande: Anped, 1992, p. 279 -297, (coletânea C.B.E.). 
FARIA FILHO, Luciano Mendes. O processo de escolarização em Minas Gerais: questões teórico-metodológicas e perspectivas de análise. In: VEIGA, Cynthia Greive; FONSECA, Thais Nívia de Lima e. História e Historiografia da Educação no Brasil. Belo Horizonte: Autêntica, 2003, p.77-97.

Fazer História da Educação com E. P. Thompson: trajetórias de um aprendizado. In: (Org.). Pensadores sociais e história da educação. Belo Horizonte: Autêntica, 2011, p. 247-264.

FARIA, Lina. Saúde e política. Rio de Janeiro: Ed. Fiocruz, 2007.

FÁVERO, Osmar. Tipologia da educação extra-escolar. Rio de Janeiro: Instituto de Estudos Avançados da Fundação Getúlio Vargas, 1980.

FERREIRA, Antonio Celso.; BEZERRA, Holien Gonçalvez.; LUCA, Tania Regina de. O historiador e seu tempo. São Paulo: UNESP: ANPUH, 2008.

FERREIRA, J. de L. Formação Continuada Online para o desenvolvimento profissional dos professores que atuam no atendimento pedagógico ao escolar em tratamento de saúde. Curitiba, 2015. Setor de Educação, Pontifícia Universidade Católica do Paraná. Doutorado (Tese em Educação).

FERREIRA, Marieta de Moraes. História do tempo presente: desafios. PetrópolisRJ: Cultura Vozes, v. 94, no 3, maio/jun., 2000, p.111-124. Disponível em: http://bibliotecadigital.fgv.br/dspace/themes/Mirage2/pages/pdfjs/web/viewer.html?file =http://bibliotecadigital.fgv.br/dspace/bitstream/handle/10438/6842/517.pdf?sequenc $\mathrm{e}=1$ \&isAllowed=y Acesso em: 22/05/2019.

FIBGE/UNICEF. Perfil estatístico de crianças e mães no Brasil: aspectos nutricionais 1974-75, Rio de Janeiro, 1982.

FICO, Carlos. História do Tempo Presente, eventos traumáticos e documentos sensíveis. O caso brasileiro. Revista Varia História, Belo Horizonte, vol. 28, № 47, jan/jun. 2012, p. 43-59. Disponivel em: http://www.scielo.br/pdf/vh/v28n47/03.pdf Acesso em: 22/05/2019.

FONSECA, E.S. A situação brasileira do Atendimento Pedagógico-Educacional Hospitalar. Revista Educação e Pesquisa. São Paulo, jan./jul. 1999a, Vol. 25, nº. 1, p.117-129.

Atendimento pedagógico-educacional para crianças e jovens hospitalizados: realidade nacional. Brasília: Instituto Nacional de Estudos e Pesquisas Educacionais, 1999b.

Classe hospitalar: ação sistemática na atenção às necessidades pedagógico-educacionais de crianças e adolescentes hospitalizados. Temas sobre Desenvolvimento, v.8, n.44, p.32-37,1999c.

- Implantação e implementação de espaço escolar para crianças hospitalizadas. Revista Brasileira de Educação Especial. Marília, jul./dez. 2002, Vol. 
8 n‥ 2, p.205-222.

2003.

. Atendimento escolar no ambiente hospitalar. São Paulo: Memnom,

O Brasil e suas escolas hospitalares e domiciliares. In. SCHILKE, A.L.; NUNES, L.B.; AROSA, A.C. (org.) Atendimento escolar hospitalar: saberes e fazeres. Niterói: Intertexto, 2011, p. 81-90.

FONTES, R.S. A classe hospitalar e a inclusão da criança enferma na sala de aula regular. Revista Brasileira Educação Especial, Marília-SP, v. 8, n.1, p.45-54, 2002.

FORTE, Luiza Tatiana; SATO, Cristina Miyuki. Programa Família Participante do Hospital Pequeno Príncipe: a humanização hospitalar como resgate da dignidade, exercício da cidadania e transformação da gestão hospitalar. Curitiba - PR: Associação Hospitalar de Proteção à Infância Dr. Raul Carneiro, 2016.

FRANCO, Maria Aparecida Ciavatta. Lidando pobremente com a pobreza análise de uma tendência no atendimento a crianças "carente" de 0 a 6 anos de idade. 1984. In: ROSEMBERG, Fúlvia (Org.) Creche. Fundação Carlos Chagas: Cortez, 1994, p.179216.

FREIRE, M.M. de L. 'Ser mãe é uma ciência': mulheres, médicos e a construção da maternidade científica na década de 1920. História, Ciência, Saúde - Manguinhos. Vol. 15, suplemento, jun. 2008, p. 153-171.

FREIRE, Paulo. A importância do ato de ler. São Paulo: Cortez, 39å edição, 2000.

FREITAS, S.N. et al. Inteligências múltiplas: desenvolvendo potencialidades em classe hospitalar. Educação, Porto Alegre- RS, v. 1, n. 55, p. 101-115, 2005.

FREUD, Sigmund. Sobre o narcisismo - Uma introdução, vol. XIV, 2014.

FRIGOTTO, G. Anos 1980 e 1990: A relação entre o estrutural e o conjuntural e as políticas de educação tecnológica e profissional. In: FRIGOTTO, G. e CIAVATTA, M. (orgs.). A formação do cidadão produtivo: a cultura de mercado no ensino médio técnico. Brasília: INEP, 2006.

FUNDAÇÃO FÉ E ALEGRIA. Educação Popular e Promoção Social na construção de sociedades justas e fraternas. Disponível em: https://fealegria.org.br/ Acesso em: 09/02/21019.

FUNGHETTO, S.S.; SOARES, M.S. Formação de professores na perspectiva inclusiva: uma ação pedagógica em classe hospitalar no setor de pediatria do Hospital Universitário de Brasília. Linhas Críticas, Brasília, v.9, n.16, p.141-154, 2003.

GARCÉS, E.R. Pedagogia Hospitalaria. Chile - Espana - Centro América. Enero, p.1-47, 2008. Disponível em http://www.cerelepe.faced.ufba.br/arquivos/fotos/103/chilespanhacentroamerica.pdf Acesso em 15/11/2016. 
GELPI, Ettore. Quelques propos politiques sur l'éducation expérientielle. Education Permanente. 1989, p. 91-96.

. Nouveaux savoirs, nouvelles luttes. In: COURTOIS, Bernadette; PINEAU, Gaston. La Formation expérientielle des adultes. Paris: La Documentation Française, 1991, p. 67-72.

GONDRA, J. G. "Modificar com brandura e prevenir com cautela". Racionalidade médica e higienização da infância. In: FREITAS, M.C.; KULHMANN JR, M. (org). Os intelectuais na História da Infância. São Paulo: Cortez, p. 289-318, 2002.

GOUVÊA, Maria Cristina Soares. A escolarização da "meninice" nas Minas oitocentistas: a individualização do aluno. In: VEIGA, Cynthia Greive; FONSECA, Thais Nívia de Lima e. História e Historiografia da Educação no Brasil. Belo Horizonte: Autêntica, 2003, p.189-225.

HALL, M. M. "História oral: os riscos da inocência". O direito à memória. São Paulo: Departamento do Patrimônio Histórico, 1992, p. 157-160.

HALBWACHS, M. Les cadres sociaux de la mémoire. Paris: Albin Michel, 1994.

. La mémoire collective. Paris: PUF/Albin Michel, 1997.

HEYWOOD, Colin. Uma história da infância. Porto Alegre: Artmed, 2004.

HOBSBAWM, E. Era dos extremos: O breve século XX. Tradução de Marcos Santarrita. São Paulo: Companhia das Letras. 1995.

. O sentido do passado; A volta da narrativa. In:

Sobre história.

São Paulo: Companhia das Letras, p. 22-35; 201-206, 1998.

HOCHMAN, Gilberto. A era do saneamento. São Paulo: Hucitec, 1998.

HOLANDA, E. R.; COLLET, N. As dificuldades da escolarização da criança com doença crônica no contexto hospitalar. Rev. esc. enferm. USP, São Paulo, v. 45, n. 2, 2011. Disponível em: http://www.scielo.br/pdf/reeusp/v45n2/v45n2a11.pdf Acesso em: 12/05/2019.

HOSPITAL PEQUENO PRÍNCIPE. Enfermagem. Disponível em: http://pequenoprincipe.org.br/hospital/enfermagem/ Acesso 11/04/2019.

HOSPITAL PEQUENO PRÍNCIPE, HPP. História. O começo da mobilização social. Disponível em http://pequenoprincipe.org.br/hospital/historia/ Acesso em 12/08/2018.

HOSPITAL PEQUENO PRÍNCIPE, HPP. Política de Humanização. Curitiba - PR. Disponível em: http://pequenoprincipe.org.br/hospital/politicas-de-humanizacao/. Acesso em: 27/07/2018.

HOSPITAL PEQUENO PRÍNCIPE, HPP. Voluntários. Curitiba - PR. Disponível em: http://pequenoprincipe.org.br/hospital/voluntarios/. Acesso em: 27/07/2018. 
HOSPITAL PEQUENO PRÍNCIPE, HPP. Pacientes do Hospital Pequeno Príncipe são surpreendidos com a visita do BOPE. Curitiba - PR, 04/10/2016. Disponível em: $\quad$ http://pequenoprincipe.org.br/noticia/pacientes-do-hospital-pequeno-principesao-surpreendidos-com-visita-do-bope/ Acesso em: 24/06/2018.

HOSPITAL SÍRIO LIBANES. Refluxo vesico uretral. São Paulo - SP. Disponível em: https://www.hospitalsiriolibanes.org.br/hospital/especialidades/nucleo-avancadourologia/Paginas/refluxo-vesicoureteral.aspx. Acesso em: 12/05/2018.

HUMANIZASUS. Ministério da Saúde. Política Nacional de Humanização. Brasília, 2003. Disponível em: http://portalms.saude.gov.br/saude-de-a-z/projeto-lean-nasemergencias/693-acoes-e-programas/40038-humanizasus Acesso em: 24/05/2019.

IBARRA, A.C.R.; GUIMARÃES, F.M.; DIAS, V.L.C. O atendimento em classe hospitalar: trajetória e perspectivas. Anais do XII Encontro Latino Americano de Iniciação Científica e VIII Encontro Latino Americano de Pós-Graduação Universidade do Vale do Paraíba. São José dos Campos - SP, 2008. Disponível em: http://www.inicepg.univap.br/cd/INIC_2008/anais/arquivosINIC/INIC0970_01_A.pdf . Acesso em 15/11/2016.

IBGE - INSTITUTO BRASILEIRO DE GEOGRAFIA E ESTATÍSTICA. Censo Demográfico 1872, 1890, 1900, 1920,1940, 1950, 1960,1970, 1980,1991, 2000 e 2010. Rio de Janeiro: IBGE, 2010. Disponível em: https://censo2010.ibge.gov.br/sinopse/index.php?dados $=4 \& u f=00$ Acesso em: $31 / 03 / 2019$.

INFOMIDI. O que é Nefrectomia? 2016. Disponível em: http://infomidi.com.br/noticia/5921/o-que-e-nefrectomia. Acesso em: 14/01/2017.

INVERNIZZI, L.; VAZ, A.F. Educação Física nos primeiros anos do ensino fundamental: uma pesquisa sobre sua organização pedagógica em classe hospitalar. Movimento, Porto Alegre, v.14, n.2, p.115-132, 2008.

JANUZZI, G. M. A educação do deficiente no Brasil: dos primórdios ao início do século XXI. Campinas: Autores Associados, 2004.

KAUR, Rupi. O que o sol faz com as flores. São Paulo: Planeta do Brasil, 2018.

KOSSOY, Boris. Fotografia e memória: reconstituição por meio da fotografia. In: SAMAIN, E. (Org.). O Fotográfico. São Paulo, Editora Hucitec, 1998, p. 41- 47.

Fotografia e história. 5.ed. rev. São Paulo: Ateliê Editorial, 2014.

KRAMER, Sonia. O papel social da pré-escola. 1985. In: ROSEMBERG, Fúlvia (Org.) Creche. Fundação Carlos Chagas: Cortez, 1994, p.20-27.

KRIEGER, Leonard. Ranke: The meaning of History. Chicago: The University of Chicago Press, 1977. 
KUHLMANN JR, M; FERNANDES, R. Sobre a história da infância. In FARIA FILHO, L.M. (Org). A Infância e sua educação: materiais, práticas e representações. (Portugal e Brasil). Belo Horizonte: Autêntica, 2004, p. 15-33.

LACERDA, A. C. de et al. Economia brasileira. 4. ed. São Paulo: Saraiva, 2010.

LAZAROTTO, Gislei Domingas Romanzini. e NASCIMENTO, Maria Lívia do. Infância e Cidade: inventar espaços e modos de viver. Fractal: Revista de Psicologia, v. 28, no 2, p. 257-265, maio-ago. 2016. Disponível em: http://www.scielo.br/pdf/fractal/v28n2/1984-0292-fractal-28-2-0257.pdf Acesso em: 28/10/2018.

LBA - Legião Brasileira de Assistência. Acervo Arquivístico da Universidade Federal de Santa Maria, Rio Grande do Sul. Disponível em: http://fonte.ufsm.br/index.php/legiao-brasileira-de-assistencia-lba Acesso em: 02/05/21019.

LEITE, Miriam Moreira. Retratos de família: leitura da fotografia histórica. 3.ed. São Paulo: Edusp, 2001. p.78, 87, 95.

LEVY, I.C. A trajetória de Moncorvo Filho: puericultura e filantropia num projeto de assistência à infância (1901-1922). Dissertação de Mestrado. UFRJ, 1996.

LEVY, M. L. Os Direitos da Criança Hospitalizada. Revista Acta Pediátrica Portuguesa. Lisboa, $1996 . \quad$ Disponível em: actapediatrica.spp.pt/article/download/5818/4580

LIMA, Antonio Bosco de., VIRIATO, Edaguimar Orquizas. As políticas de descentralização, participação e autonomia: desestatizando a educação pública. In: 23a reunião anual da ANPED, 2000, Caxambu. CD Room - Educação não é privilégio, 2000.

LIMA, Elvira Cristina de Souza. Algumas questões sobre o desenvolvimento do ser humano e a aquisição de conhecimentos na escola. In: PARANÁ, Secretaria de Estado da Educação. Currículo Básico para a escola pública do Paraná. Curitiba, 1992. p. 19-23.

LIZASOÁIN RUMEU, O; OCHOA LINACERO, B.; SOBRINO MORRÁS, A. LOS paciente pediátricos y la pedagogia hospitalaria en europa. Acta Pediatrica Española, vol. 57, no 7, 1999, p. 364-372.

LOBO, L. F. Os infames da história: pobres, escravos e deficientes no Brasil. Rio de Janeiro: FAPERJ: Lamparina, 2008.

LOCCO, Leila de Almeida; ZABOT, Nircélio. Política de municipalização do ensino de 10. grau no Paraná. Curitiba, s/d. (mimeo).

LOPES, K.R.; MENDES, R.P.M; FARIA, V.L.B. de (org.) Livro de Estudo. Coleção Pró Infantil Unidade 3. Brasília: MEC. Secretaria de Educação Básica. Secretaria de Educação a Distância, 2005. 
MATOS, Elizete Lucia Moreira; MUGIATTI, Margarida Maria Teixeira de Freitas. Pedagogia Hospitalar. A Humanização Integrando Educação e Saúde. 1. ed. Petrópolis - RJ: Vozes, 2006.

MARANHO, Daniel Augusto Carvalho e VOLPON, José Batista. Pé torto congênito. Acta Ortopédica Brasileira. [Online]. 2011;19(3):163-9. Disponível em: http://www.scielo.br/pdf/aob/v19n3/a10v19n3.pdf. Acesso em: 13/05/2018.

MARCÍLIO, M.L. História Social da Criança Abandonada. 2ª Edição. São Paulo: HUCITEC, 2006.

MARINHO, Maria Gabriela S.M.C. Elites em negociação. Bragança: Ed. USF, 2003.

MARQUES, V.R.B. A medicalização da raça: médicos, educadores e discurso eugênico. Campinas: UNICAMP, 1994.

MARTINS, A.P.V. Vamos criar seu filho: os médicos puericultores e a pedagogia materna no século XX. História, Ciência, Saúde - Manguinhos. Vol. 15, n‥ 1, p. 135-154, jan.-mar., 2008.

MAUAD, Ana Maria. Dimensões do presente; palavras e imagens de um acontecimento, os atentados ao world Trade Center e ao pentágono em 11 de setembro de 2001. In: PÔRTO JR, Gilson (org). História do tempo presente. Bauru -SP: Edusc, 2007.

Fotografia e História - possibilidades de análise. In: CIAVATTA, M.; ALVES, N. (Orgs.). A leitura de imagens na pesquisa social: história, comunicação e educação. São Paulo, Editora Cortez, 2004, pp. 19- 36.

MAZZOTTA, Marcos J.S. Educação Especial no Brasil: História e Políticas Públicas. São Paulo Cortez, 2003.

MELO, M.M.R; CARDOSO, T.M. Classe hospitalar e escola regular: estreitando laços. Ponto de Vista, Florianópolis-SC, n.9, p.113-130, 2007.

MENEZES, Cinthya Vernizi Adachi de. Serviço de Atendimento à Rede de Escolarização Hospitalar: o caráter inovador na construção de uma política pública no Estado do Paraná IN: PARANÁ. Secretaria de Estado da Educação. Superintendência de Educação. Diretoria de Políticas e Programas Educacionais. Núcleo de Apoio ao Sareh. Serviço de Atendimento à Rede de Escolarização Hospitalar (Sareh). Curitiba: Seed-PR., 2010. (Cadernos temáticos). Disponível em: <http://www.educadores.diaadia.pr.gov.br/arquivos/File/cadernos_tematicos/tematico sareh.pdf>. Acesso em 14/11/2012.

. [...]: estudo comparado das políticas educacionais do Paraná/Brasil e da Galícia/Espanha. Curitiba, 2018. Setor de Educação, Universidade Federal do Paraná. Tese (Doutorado em Educação).

MÉXICO. Administración Federal de Servicios Educativos en el Distrito Federal. Apuntes de Pedagogía Hospitalaria. Colonia Santa Cruz Atoyac: Administración 
Federal de Servicios Educativos en el Distrito Federal, 2009.

MINHA SAÚDE. Mielomeningocele: sintomas, tratamentos e causas. Disponível em: http://www.minhavida.com.br/saude/temas/mielomeningocele Acesso em: 12/05/2018.

MOTA, A. Quem é bom já nasce feito: sanitarismo e eugenia no Brasil. Rio de Janeiro: DP\&A, 2003.

MORELLI, Ailton José. SILVESTRE, Eliana e GOMES, Telma Maranho. Desenho da política dos Direitos da Criança e do Adolescente. Psicologia em Estudo, $\mathrm{DPI} / \mathrm{CCH} / \mathrm{UEM}$. v. 5, no 1, 2000, p. 65-84. Disponível em: http://www.scielo.br/pdf/pe/v5n1/v5n1a05.pdf Acesso em: 28/10/2018.

NEGRÃO, A.M.M. Infância, educação e direitos sociais: "Asilo de Órfãs" (18701960). Campinas: Publicações CMU/UNICAMP, 2004.

NOGUEIRA, Francis M. G.. Políticas Educacionais do Paraná. In: Cadernos Fórum Paranaense em Defesa da Escola Pública Gratuita e Universal. 11 â sessão temática: Avaliação das políticas educacionais do Estado do Paraná. Maio de 1994. Toledo, Paraná.

NORA, M. Les lieux de mémoire. Paris: Gallimard, 1984.

OLANDA, Osterlina Fátima Jucá. O Currículo Em Uma Classe Hospitalar: Estudo De Caso No Albergue Pavilhão São José Da Santa Casa De Misericórdia Do Pará. Belém- Pará, 2006. Setor de Educação, Universidade Federal do Pará. Dissertação (Mestrado em Educação).

OLIVEIRA, A.S.S. Atendimento psicopedagógico e saúde: classe hospitalar e o uso dos serviços e ferramentas da Internet. Revista Educare - ISEIB, Montes ClarosMG, v.1, p. 1-6, 2005.

OLIVEIRA, Christian Dennys Monteiro de. e ASSIS, Raimundo Jucier Sousa de. Travessias da aula em campo na geografia escolar: a necessidade convertida para além da fábula. Educ. Pesqui. [online]. 2009, vol.35, n.1, pp.195-209. ISSN 15179702. http://dx.doi.org/10.1590/S1517-97022009000100013.

OLIVEIRA, D. de. Urbanização e industrialização no Paraná. Curitiba: SEED, 2001.

OLIVEIRA, Fabiana Aparecida de Melo. Projeto Pedagógico Hospitalar Escola Móvel - Aluno Específico: cultura escolar e debate acadêmico (1989-2008). Campinas - SP, 2010. Faculdade de Educação, Universidade Estadual de Campinas. Dissertação (Mestrado em Educação).

OLIVEIRA, J. P., et al. O atendimento educacional nos ambientes Hospitalares. Revista FACEVV. Vila Velha, no. 4, jan./jun. 2010, p.75-81. Disponível em: http://facevv.cnec.br/wp-content/uploads/sites/52/2015/10/O-ATENDIMENTOEDUCACIONAL-NOS-AMBIENTES-HOSPITALARES.pdf Acesso em 15/11/2016. 
OLIVEIRA, L.M.; SOUZA FILHO, V.C.; GONÇALVES, A.G. Classe hospitalar e a prática da pedagogia. Revista Científica Eletrônica de pedagogia, Graça- SP, v. 6, n.11, p. 1-5, 2008.

OLIVEIRA, T. C. História da classe/escola hospitalar: no Brasil e no mundo. Anais do IV Colóquio Internacional Educação, Cidadania e Exclusão: Didática e Avaliação, Rio de Janeiro, 2015. Disponível em: http://www.editorarealize.com.br/revistas/ceduce/trabalhos/TRABALHO EV047 MD1 SA5 ID143 05052015093744.pdf Acesso em 15/11/2016.

OLIVEIRA, T. C; CAVALCANTE, R. Classe Hospitalar: um direito para todas as crianças hospitalizadas? In. SCHILKE, A.L.; NUNES, L.B.; AROSA, A.C. (org.) Atendimento escolar hospitalar: saberes e fazeres. Niterói: Intertexto, 2011, p. 101 110.

OLIVEIRA, Walter Ferreira de. Educação social de rua: bases históricas, políticas e pedagógicas. História, Ciências, Saúde - Manguinhos, Rio de Janeiro, v. 14, n.1, p.135-158, jan.-mar. 2007. Disponível em: http://www.scielo.br/scielo.php?script=sci arttext\&pid=S0104$\underline{40602003000200012 \& \operatorname{lng}=e n \& n r m=i s o}$. Acesso em: 20 out. 2018.

O MOVIMENTO DE MULHERES NO BRASIL, Cadernos da Associação das Mulheres, $\mathrm{n}^{\circ}$ 3, ago. 1979.

ORTIZ, L.C.M. et al. A classe hospitalar como instrumento de participação política na construção coletiva da associação de pais e pacientes da hemato oncologia. Educação Revista, Belo Horizonte - MG, v.26, n.2, p. 317-335, 2010.

ORTIZ, L.C.M.; FREITAS, S.N. Classe hospitalar: um olhar sobre sua práxis educacional. Revista Brasileira de Estudos Pedagógicos, Brasília-DF, v.82, n.200/201/202, p.70-77, 2001.

PACHECO, Mirta Cristina Pereira. Escolarização hospitalar e a formação de professores na Secretaria Municipal de Educação de Curitiba no período de 1988 a 2015. Curitiba, 2017. Educação, Pontifícia Universidade Católica do Paraná. Mestrado (Dissertação em Educação).

PAIVA, Vanilda. Um século de educação republicana. Pro-Posições, [S.I.], v. 1, n. 2, Campinas, UNICAMP: Cortez, n.2, jul 1990, p. 7-18. ISSN 1982-6248. Disponível em: $<$ https://periodicos.sbu.unicamp.br/ojs/index.php/proposic/article/view/8644495>.

Acesso em: 13 out. 2018.

PANDINI, S. A Escola de Aprendizes Artífices do Paraná: "Viveiro de homens aptos e úteis" (1910-1928). Curitiba, 2006. Setor de Educação, Universidade Federal do Paraná. Mestrado (Dissertação em Educação).

PANSARDI, Bárbara. Mobilizar para garantir: 25 anos do ECA. Belo Horizonte MG, 2015. Disponível em: http://oficinadeimagens.org.br/mobilizar-para-garantir-25anos-do-eca/ Acesso em: 28/10/2018. 
PARA FRASEAR. O Modelo de Kübler-Ross. 13/02/2011. Disponível em: http://www.parafrasear.net/2011/02/o-modelo-de-kubler-ross.html. Acesso em: 01/07/2018.

PARANÁ. Secretaria de Estado da Educação. Edital no. 03/2019 - GS/SEED. Processo de seleção de professores do Quadro Próprio do Magistério da Secretaria de Estado da Educação para suprir e substituir professor e professor pedagogo no Serviço de Atendimento à Rede de Escolarização Hospitalar - SAREH. Curitiba, 2019a. Disponível em: http://www.educacao.pr.gov.br/arquivos/File/editais/2019/edital3 2019gsseed.pdf Acesso em: 31/03/2019.

Galeria de Secretários da Educação do Paraná. Disponível em: <http://www.educacao.pr.gov.br/modules/conteudo/conteudo.php?conteudo=1409>. Acesso em: 17 mar. 2019b.

Governadores do Estado Casa Civil. Disponível em: <http://www.casacivil.pr.gov.br/modules/conteudo/conteudo.php?conteudo=95> Acesso em: 18 mar. 2019c.

PAULA, E.M.A.T. de. História das escolas nos hospitais do Brasil: Políticas Públicas de Atendimento às Crianças e Adolescentes. In: VI Jornada Nacional do HISTEDBR: História, Sociedade e Educação no Brasil, 2005, Ponta Grossa - PR. Reconstrução histórica das instituições escolares no Brasil, 2005. p. 01-20. Disponível em: http://www.histedbr.fe.unicamp.br/acer histedbr/jornada/jornada6/trabalhos/1002/10 02.pdf Acesso em: 16/01/2017.

PEDIATRICS, A.A. Home, Hospital, and Others Non-School-based Instruction for Children and Adolescents Who are Medically Unable to Attend School. Committee on Scholl Health. Vol. 105, ㄲo 5. November, 2000, p.1154-1155.

PELICCIONI, M.C.F; PELICIONI, A.F. Educação e promoção da saúde: uma retrospectiva histórica. O Mundo da Saúde. São Paulo: 2007: jul/set 31(3):320-328. Disponível em: http://pesquisa.bvs.br/brasil/resource/pt/ses-8923 Acesso em 16/01/2017.

PINSKY, Carla Bassanezi; LUCA, Tania Regina de. O historiador e suas fontes. São Paulo: Contexto, 2015.

PIRES JÚNIOR, H. et al. A perspectiva de profissionais de saúde sobre o atendimento educacional em classe hospitalar. Didática, São Paulo, v.31, p.175-197,1997.

POLAINO-LORENTE, A; LIZASOAIN, O. La pedagogia hospitalaria em Europa: La História reciente de un movimiento pedagogico innovador. Psicothema, vol. 4 №. 1, p.49-67, 1992. Disponível em: http://www.psicothema.com/pdf/814.pdf Acesso em $15 / 11 / 2016$. 
PORTAL DA DIÁLISE. O que é diálise peritoneal. 10/07/2016. Disponível em: https://www.portaldadialise.com/portal/o-que-e-dialise-peritoneal Acesso em: 24/06/2018.

E depois do transplante? 12/11/2016. Disponível em: https://www.portaldadialise.com/articles/e-depois-do-transplante Acesso em: 24/06/2018.

PÔRTO JR, Gilson (org). História do tempo presente. Bauru, SP: EDUSC, 2007.

PONTUSCHKA, N. N. O conceito de estudo do meio transforma-se... em tempos diferentes, em escolas diferentes, com professores diferentes. In: VESENTINI, J. W. O ensino de geografia no século XXI. Campinas: Papirus, 2004. p. 249 -288.

PSICONLINEWS. Luto: As 5 fases de Elisabeth Kübler-Ross. 02/07/2017. Disponível em: $\quad$ http://www.psiconlinews.com/2017/07/luto-as-5-fases-de-elisabeth-kublerross.html. Acesso em: 01/07/2018.

REDE LATINOAMERICANA E DO CARIBE PELA EDUCAÇÃO DE CRIANÇAS E JOVENS HOSPITALIZADOS OU EM TRATAMENTO (REDLACEH). Disponível em: http://www.redlaceh.org/ Acesso em: 11/05/2019.

REDE MARISTA DE SOLIDARIEDADE. Fontes sobre a infância: diagnóstico de

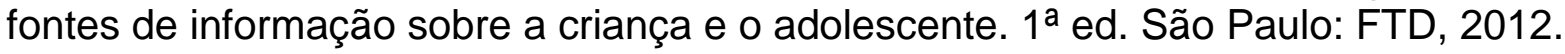

RELATÓRIO FINAL DA PESQUISA IMPLANTAÇÃO E IMPACTOS DO FUNDEF NO ESTADO DO PARANÁ., Gestão e Financiamento da Educação, Setor de Educação, UFPR, Núcleo de Política, Curitiba 2002 (mimeo).

ROCHA, S.M.; PASSEGGI, M.C. Classe hospitalar: um espaço de vivências educativas para crianças e adolescentes em tratamento de saúde. Revista@ambienteeducação, São Paulo, v.2, p.113-121, 2010.

ROSA, K.M.; XAVIER, R.P. Inglês para classe hospitalar. Revista Eletrônica de Extensão, Florianópolis - SC, v.4, n.5, dez.2007.

ROSEMBERG, Fúlvia. O Movimento de Mulheres e abertura política no Brasil: o caso da creche. 1984. In: ROSEMBERG, Fúlvia (Org.) Creche. Fundação Carlos Chagas: Cortez, 1994, p.90-103.

Fúlvia. Creches Domiciliares: argumentos ou falácias. 1986. In: ROSEMBERG, Fúlvia (Org.) Creche. Fundação Carlos Chagas: Cortez, 1994, p.217235.

SABINO, Fernando Tavares. O encontro marcado. 34 ${ }^{\mathrm{a}}$ Ed. Rio de Janeiro: Record, 1981.

SALDANHA, G.M.M.M; SIMÕES, R.R. Educação Escolar Hospitalar: o que mostram as pesquisas? Revista Brasileira de Educação Especial. Marília, jul./set. 2013, Vol. 19 ํo. 3, p.447-464. 
SALDANHA, G.M.M.M. A Educação Escolar Hospitalar: práticas pedagógicas docentes com crianças em tratamento oncológico no Hospital Ophir Loyola em Belém - PA. Belém, 2012. Instituto de Ciências da Educação, Universidade Federal do Pará. Dissertação (Mestrado em Educação).

SANDRONI, G.A. Classe hospitalar: um recurso a mais para a inclusão educacional de crianças jovens. Cadernos da Pedagogia, São Paulo, v.2, n.3, p. 1-13, 2008.

SANTA CASA DE MISERICÓRDIA DE SÃO PAULO. Irmandade da Santa Casa de Misericórdia de São Paulo: excelência na assistência, ensino e pesquisa. Disponível em: https://www.santacasasp.org.br/portal/site/quemsomos/historico Acesso em: 06/05/2019.

SANTOS, Jussara Maria T. Puglielli. As políticas governamentais para o ensino fundamental no Estado do Paraná diante dos preceitos da Constituição. São Paulo, 1998, Tese (Doutorado em Educação) Faculdade de Educação da Universidade de São Paulo.

. O processo de municipalização no estado do Paraná. Educ. rev. [online]. 2003, n.22, $\quad$ p. 257-279. em:http://www.scielo.br/scielo.php?script=sci arttext\&pid=S0104$40602003000200012 \& \operatorname{lng}=$ en\&nrm=iso. Acesso em: 07 out. 2018.

SANTOS, Jussara Maria T. Puglielli; NUNES, Odilon Carlos. Ensino de 1. Grau: elementar e fundamental. In: PARANÁ, Secretaria de Estado da Educação. Currículo Básico para a escola pública do Paraná. Curitiba, 1992. p. 15-18.

SANTOS, R.O. dos. Rock e quadrinhos nas páginas da Revista Chiclete com Banana (1985-1990). Curitiba, 2014. Setor de Ciências Humanas Letras e Artes, Universidade Federal do Paraná. Doutorado (Tese em História).

SÃO PAULO. Universidade de São Paulo. Resolução n 4.871 de 22/10/2001. Código de Ética da Universidade de São Paulo. 2001. Disponível em: http://www.leginf.usp.br/?resolucao=resolucao-no-4871-de-22-de-outubro-de-2001 Acesso em: 22/04/2017.

SARAMAGO, José. O caderno. São Paulo: Companhia das Letras, 2009.

SAVIANI, Dermeval. História do tempo e tempo da história: estudos de historiografia e história da educação. Campinas, SP: Autores Associados, 2015.

SILVA, Heloise Peratello e Silva. A Formação dos corpos: representações sobre corpo e alimentação, no Brasil, nas décadas de 1970 e 1980. Curitiba, 2011. Setor de Ciências Humanas Letras e Artes, Universidade Federal do Paraná. Mestrado (Dissertação em História).

SILVA, S. C. H. P. da. De órfãos da gripe a trabalhadores. O Asilo São Luiz de Curitiba, 1918-1937. Curitiba, 2010. Setor de Educação, Universidade Federal do Paraná. Mestrado (Dissertação em Educação). 
SOCIEDADE BRASILEIRA DE NEFROLOGIA. Hemodiálise. 2017. Disponível em: http://sbn.org.br/publico/tratatamentos/hemodialise/ Acesso em 14/01/2017.

Fístula arteriovenosa. 2017. Disponível em: http://sbn.org.br/publico/tratatamentos/hemodialise/ Acesso em 14/01/2017.

Cateter. 2017. Disponível em: http://sbn.org.br/publico/tratatamentos/hemodialise/ Acesso em 14/01/2017.

SONTAG, Susan. Sobre fotografia. São Paulo: Companhia das Letras, 2004.

SOUZA, Valéria F. M. As faces da menoridade: uma leitura do $1^{\circ}$ Congresso Brasileiro de Proteção à Infância - 1922 e do Código dos Menores - 1927. Dissertação apresentada ao Programa de Pós-Graduação em Sociologia, Setor de Ciências Humanas, Letras e Artes da Universidade Federal do Paraná. Curitiba, setembro de 1998.

SPITZ, Lucia. As reações psicológicas à doença e ao adoecer. Saúde Mental no Hospital Geral. Cadernos do IPUB, no 6, Instituto de Psiquiatria/UFRJ, 1997. Disponível em http://tcead.nutes.ufri.br/vivencias/recursos/891As Rea es Psicol gicas Doen a e ao Adoecer Profa. Lucia Spitz.pdf. Acesso em 01/07/2018.

STANCIK, Marco Antonio. Entre flores e canhões na Grande Guerra (1914-1918): o final da Belle Époque e o começo do "breve século XX" em um álbum de retratos fotográficos. Rev. Bras. Hist. [online]. 2009, vol.29, n.58, pp.443-465. ISSN 01020188. http://dx.doi.org/10.1590/S0102-01882009000200009.

TELAROLLI JR., R. Imigração e epidemias no estado de São Paulo. História, Ciências, Saúde - Manguinhos. Vol. III, nº. 2, p.265-283 jul.-out. 1996.

THIECKER, Gabriele Daiana. Resenha: História do tempo presente. Revista Eletrônica História em Reflexão, vol. 2, n. 3 - UFGD - Dourados Jan/Jun 2008. Disponível

em: http://ojs.ufgd.edu.br/index.php/historiaemreflexao/article/view/279/241 Acesso em: 22/05/2019.

THOMPSON, E.P. A miséria da Teoria ou um planetário de erros - uma crítica ao pensamento de Althusser. Editora Zahar, Rio de Janeiro, 1981.

Tradición, revuelta y consciencia de clase. $2^{a}$ ed. Barcelona: Crítica/Grijalbo, 1984.

Senhores e caçadores: a origem da lei negra. Tradução de Denise Bottmann. Rio de Janeiro: Paz e Terra, 1987.

Brasileira, 2002.

Os Românticos. A Inglaterra na Era Revolucionária. RJ, Civilização

TRINTIN, Jaime Graciano. História e desenvolvimento da economia paranaense: da 
década de trinta a meados da década de noventa do século XX. In: Segundas Jornadas de História Regional Comparadas, 2005, Porto Alegre. Segundas Jornadas de História Regional Comparadas, 2005.

TUA SAÚDE. O que é bexiga neurogênica e principais tipos. Disponível em: https://www.tuasaude.com/bexiga-neurogenical. Acesso em: 12/05/2018.

TURINA, K.F.R. Escola Maternal: história, assistência e escolarização da infância em Curitiba (1928-1944). Curitiba, 2010. Setor de Educação, Universidade Federal do Paraná. Mestrado (Dissertação em Educação).

VASCONCELOS, Sandra Maia Farias. Intervenção escolar em hospitais para crianças internadas: a formação alternativa re-socializadora. In: Congresso Internacional De Pedagogia Social, 1., 2006, São Paulo. Anais... São Paulo: Faculdade de Educação da Universidade de São Paulo, Universidade Presbiteriana Mackenzie e Centro Universitário UniFMU, 2006.

VENÂNCIO, Renato Pinto (org.). Uma história social do abandono de crianças. São Paulo: Alameda, 2010.

VIDAL, Diana Gonçalves. De Heródoto ao gravador: histórias da história oral. Resgate: Revista Interdisciplinar de Cultura. (UNICAMP), Campinas, v. 1,1990, p. 77-82.

Michel de Certeau e a difícil arte de fazer história das práticas. In: FARIA

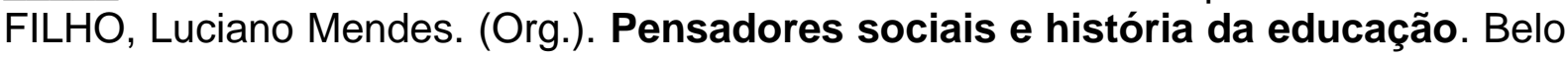
Horizonte: Autêntica, 2011, p. 265-292.

VIDAL, Diana Gonçalves; BICCAS, Maurilane de Souza. As múltiplas estratégias de escolarização do social em São Paulo (1770-1970). Cultura e prática escolares. In: VIDAL, Diana Gonçalves. Educação e Reforma: O Rio de Janeiro nos anos 19201930. Belo Horizonte, MG: Argvmentum; São Paulo: CNPq: USP, Núcleo Interdisciplinar de Estudos e Pesquisas em História da Educação, 2008, p.19-44.

VIEIRA, C.E. Jornal diário como fonte e como tema para a pesquisa em História da educação: um estudo da relação entre imprensa, intelectuais e modernidade dos anos de 1920. In: OLIVEIRA, Marcus, A. T. (org.) Cinco estudos em história e historiografia da educação. Belo Horizonte: Autêntica, 2007, p. 11-40.

VINCENT, Guy.; LAHIRE, Bernard; THIN, Daniel. Sobre a história e a teoria da forma escolar. Educação em Revista, Belo Horizonte, n.33, jun. 2001, p.7-48.

WADSWORTH, J. E. Moncorvo Filho e o problema da infância: modelos institucionais e ideológicos da assistência à infância no Brasil. Revista Brasileira de História. Vol.19, №. 37, set. 1999.

ZANARDINI, Isaura Monica Souza. A ideologia da pós-modernidade e a política de gestão educacional brasileira. Tese de Doutorado. UNICAMP/ Campinas-SP, 2006.

ZANARDINI, Isaura Monica Souza, BLUM, Marcia Sabina Rosa e MICHELLON, 
Edimor Antonio. Uma Análise das Políticas de Gestão Escolar no Paraná e no Brasil entre os anos de 1980 e 2006. Revista Educação e Fronteiras On-Line, Dourados/MS, v.3, n.7, p.117-139, jan./abr. 2013. Disponível em: http://www.histedbr.fe.unicamp.br/acer histedbr/jornada/jornada7/ GT2\%20PDF/UM A\%20AN\%C1LISE\%20DAS\%20POL\%CDTICAS\%20DE\%20GEST\%C30\%20ESCO LAR\%20NO\%20PARAN\%C1\%20E\%20NO\%20BRASIL.pdf Acesso em: 07 out. 2018.

ZAPATA, Sandra Julieth; ARBOLEDA, Gloria María Lópes; BUSTAMANTE, Alexander Rodríguez. Intervención psicopedagógica en aulas hospitalarias: hacia una pedagogía incluyente en contextos adversos. Infancias Imágenes, Bogotá (colômbia), n. 13, v. 2, julio-diciembre 2014, pp. 56-63. Disponível em: . Acesso em: 02 abr. 2017.

ZARDO, S.P. et al. O trabalho por projetos pedagógicos em classe hospitalar: transformando ações e concepções educacionais. Revista Teoria e Prática da Educação, Maringá-PR, v.7, n.1, p.91-96, 2004.

ZARDO, S.P.; FREITAS, S.N. Educação em classes hospitalares: transformando ações e concepções à luz da teoria da complexidade. Educar, Curitiba-PR, n.30, p.185-196, 2007.

ZOMBINI, E.V. Classe hospitalar: uma estratégia para a promoção da saúde da criança. São Paulo, 2011. Setor de Saúde Pública, Universidade de São Paulo. Mestrado (Dissertação em Saúde Pública). 


\section{FONTES}

\section{Anais de Congresso}

Anais do 1․ Encontro Nacional sobre o Atendimento Escolar Hospitalar - Rio de Janeiro, 19 e 21 de julho de 2000. Teatro Noel Rosa da Universidade do Estado do Rio de Janeiro - RJ Disponível em: http://www.escolahospitalar.uerj.br/anais.htm Acesso em 16/01/2017.

CECCIM, R.B.; FONSECA, E.S. da. Classes hospitalares: onde, quantas e por quê? Anais do 1․ Encontro Nacional sobre o Atendimento Escolar Hospitalar - Rio de Janeiro, 19 e 21 de julho de 2000. Teatro Noel Rosa da Universidade do Estado do Rio de Janeiro - RJ Disponível em: http://www.escolahospitalar.ueri.br/anais.htm Acesso em 16/01/2017.

MATOS, E.L.M. e MUGGIATI, M.M. T. de F. Pedagogia hospitalar (Hospital Infantil Pequeno Príncipe - PR). Anais do 1‥ Encontro Nacional sobre o Atendimento Escolar Hospitalar - Rio de Janeiro, 19 e 21 de julho de 2000. Teatro Noel Rosa da Universidade do Estado do Rio de Janeiro - RJ Disponível em: http://www.escolahospitalar.uerj.br/anais.htm Acesso em 16/01/2017.

RITTMEYER, Lecy; SILVA, Rachel Perrone da; IMBROSIO, Leila Ozon. Classe Hospitalar Jesus: trajetória do jubileu de ouro (1950-2000). Anais do 1‥ Encontro Nacional sobre o Atendimento Escolar Hospitalar - Rio de Janeiro, 19 e 21 de julho de 2000. Teatro Noel Rosa da Universidade do Estado do Rio de Janeiro - RJ Disponível em: http://www.escolahospitalar.uerj.br/anais.htm Acesso em 16/01/2017.

\section{Correspondência}

Raquel, pessoa da Universidade de Cascavel - PR.

\section{Dissertação}

MUGGIATI, Margarida Maria Teixeira de Freitas. Hospitalização Escolarizada: uma nova alternativa para o escolar-doente. Porto Alegre, 1989. Serviço Social, Pontifícia Universidade Católica do Rio Grande do Sul. Mestrado (Dissertação em Serviço Social).

\section{Documentos oficiais}

PARANÁ. Caderno de Gestão Escolar Caminhos para a Gestão Compartilhada. Curitiba,1995.

\section{Entrevistas}

ASSISTENTE SOCIAL. Entrevista I. [ago. 2010]. Entrevistador: Claudinéia Maria Vischi Avanzini. Curitiba, 2010. 1 arquivo.mp3 (14min.19seg). A entrevista na íntegra encontra-se transcrita nos Apêndices A e F desta tese. 
ASSISTENTE SOCIAL. Entrevista II. [ago. 2016]. Entrevistador: Claudinéia Maria Vischi Avanzini. Curitiba, 2016. 1 arquivo.mp3 (60 min.). A entrevista na íntegra encontra-se transcrita nos Apêndices B e G desta tese.

PROFESSORA 1. Entrevista I. [ago. 2016]. Entrevistador: Claudinéia Maria Vischi Avanzini. Curitiba, 2016. 1 arquivo.mp3 (60 min.). A entrevista na íntegra encontra-se transcrita nos Apêndices $\mathrm{C}$ e $\mathrm{H}$ desta tese.

PROFESSORA 2. Entrevista I. [jan. 2017]. Entrevistador: Claudinéia Maria Vischi Avanzini. Curitiba, 2017. 1 arquivo.mp3 (60 min.). A entrevista na íntegra encontra-se transcrita nos Apêndices C e I desta tese.

MÃE. Entrevista I. [dez. 2016]. Entrevistador: Claudinéia Maria Vischi Avanzini. Curitiba, 2016. 1 arquivo.mp3 (60 min.). A entrevista na íntegra encontra-se transcrita nos Apêndices E e J desta tese.

EX-ALUNO. Entrevista I. [abril. 2018]. Entrevistador: Claudinéia Maria Vischi Avanzini. Curitiba, 2018. 1 arquivo.mp3 (41min.27seg.). A entrevista na íntegra encontra-se transcrita nos Apêndices D e K desta tese.

\section{Folhetos e Históricos}

HOSPITAL INFANTIL. Histórico do Hospital de Crianças - Resumo de 1922 a 1987. Curitiba, (mimeo), 1987. (Biblioteca Hospital Pequeno Príncipe).

MEIRA, Deyler Goulart. Hospital Jesus: subsídios à sua história. Gráfica Editora Laemmert S.A. Rio de Janeiro, 1971.

Jornais

DIÁRIO DO PARANÁ, PR - 1961 (Hemeroteca Biblioteca Nacional).

GAZETA DO POVO, Curitiba, 1988, 1991, 1990 e 2007. (Biblioteca Pública do Paraná e Museu Paranaense).

FOLHA DE LONDRINA, Londrina, PR - 1988. (Biblioteca Pública do Paraná).

O ESTADO DO PARANÁ, PR - 1988, 1990. (Biblioteca Pública do Paraná).

TRIBUNA DO PARANÁ, PR - 2003. (Biblioteca Pública do Paraná).

ÚLTIMA HORA, RJ - 1961 (Hemeroteca Biblioteca Nacional).

\section{Leis e Decretos}

BRASIL. Decreto-lei n. 2.848, de 7 de dezembro de 1940. Código Penal. Disponível em: http://www.planalto.gov.br/ccivil 03/decreto-lei/del2848compilado.htm Acesso em: 24/05/2019. 
Decreto-Lei no 5.452/43. Aprova a Consolidação das Leis do Trabalho. Brasília, 1943. Disponível em: http://www.planalto.gov.br/ccivil 03/DecretoLei/Del5452.htm Acesso 07/04/2019.

. Decreto-Lei n. 1.044/69. Dispõe sobre tratamento excepcional para os alunos portadores das afecções. Brasília, 1969. Disponível em: http://www.planalto.gov.br/ccivil 03/Decreto-Lei/Del1044.htm Acesso em: 28/10/2018.

Lei n. 6.202, de 17 de abril de 1975. Atribui a estudante em estado de gestação o regime de exercícios domiciliares instituído pelo Decreto-Lei no 1.044 , de 1969, Brasília, 1975. Disponível em: https://www2.camara.leg.br/legin/fed/lei/19701979/lei-6202-17-abril-1975-357541-publicacaooriginal-1-pl.html Acesso em 31/03/2019.

. MEC/SEEC. Sinopse estatística da educação pré-escolar. Brasília, 1980.

. Constituição da República Federativa do Brasil. Brasília, MEC, 1988.

. Lei n. 8.069, de 13 de julho de 1990. Estatuto da Criança e do Adolescente, Brasília, 1990. Disponível em http://www.planalto.gov.br/ccivil 03/LEIS/L8069.htm Acesso em: 06/04/2019.

1993.

. Ministério da Educação. Plano Decenal de Educação. Brasília, DF: MEC,

- Ministério da Educação e do Desporto. Secretaria de Educação Especial. Política Nacional de Educação Especial. Brasília, MEC/SEESP, 1994, 66 p.

. Conselho Nacional dos Direitos da Criança e do Adolescente. Resolução $\mathbf{n}^{\circ}$ 41, de 13 outubro de 1995 (DOU 17/10/95). Disponível em: https://www.ufrgs.br/bioetica/conanda.htm Acesso em: 04/04/2019.

. Lei n. 9.394, de 20 de dezembro de 1996. Lei de Diretrizes e Bases da Educação Nacional. Brasília, MEC, 1996. Disponível em: http://www.mec.gov.br. Acesso em 13/01/2009.

. Ministério da Educação - MEC. Balanço do Primeiro ano do FUNDEF. Brasília: MEC, 1999.

Ministério da Educação, Secretaria de Educação Especial. Projeto Escola Viva - Garantindo o acesso e permanência de todos os alunos na escola - Alunos com necessidades educacionais especiais. Adaptações Curriculares de Grande Porte. Vol. 5, Brasília, 2000a. Disponível em: <http://portal.mec.gov.br/escola-de-gestoresda-educacao-basica/192-secretarias-112877938/seesp-esducacao-especial2091755988/12658-projeto-escola-viva>. Acesso em: 16 jul. 2016.

- Ministério da Educação, Secretaria de Educação Especial. Projeto Escola Viva - Garantindo o acesso e permanência de todos os alunos na escola - Alunos com necessidades educacionais especiais. Adaptações Curriculares de Pequeno Porte. 
Vol. 6, Brasília, 2000b. Disponível em: <http://portal.mec.gov.br/escola-de-gestoresda-educacao-basica/192-secretarias-112877938/seesp-esducacao-especial2091755988/12658-projeto-escola-viva>. Acesso em: 16 jul. 2016.

. Conselho Nacional de Educação. Resolução CNE/CEB n. 02, de setembro de 2001. Institui as Diretrizes Nacionais para a Educação Especial na Educação Básica. Brasília: MEC/SEESP, 2001.

Ministério da Educação. Classe hospitalar e atendimento pedagógico domiciliar: estratégias e orientações. Secretaria de Educação Especial. Brasília, MEC/SEESP, $\quad 2002, \quad 35 \quad$ p. $\quad 3$ Disponível em: <http://portal.mec.gov.br/seesp/arquivos/pdf/diretrizes.pdf>. Acesso em: 28/08/2015.

Lei $\mathrm{n}^{\circ}$ 11.274, de 06 de fevereiro de 2006. Regulamenta o Ensino Fundamental de nove anos. Brasília, 2006. Disponível em: http://www.planalto.gov.br/ccivil 03/ ato2004-2006/2006/lei//11274.htm Acesso em: 21/04/2019.

ONU Assembleia Geral. Declaração Universal dos Direitos Humanos. Paris, 1948. Disponível em: <http://www.ohchr.org/EN/UDHR/Documents/UDHR_Translations/por.pdf>. Acesso em 15/01/2017.

Assembleia Geral. Declaração Universal dos Direitos da Criança. Paris, 1959. Disponível em: <http://www.dhnet.org.br/direitos/sip/onu/c_a/lex41.htm>. Acesso em 15/01/2017.

PARANÁ. Secretaria de Estado da Educação. Currículo Básico para a escola pública do Paraná. Curitiba, 1992.

Secretaria de Estado da Educação. Inovando nas Escolas do Paraná. Brasília: Instituto Nacional de Estudos e Pesquisas Educacionais, 1994.

Lei no 13.116, 8 de março de 2001, Paraná, 2001. Disponível em: http://leisestaduais.com.br/pr/lei-ordinaria-n-13116-2001-parana-dispoe-sobre-adestinacao-da-quota-estadual-do-salario-educacao-de-que-trata-o-art-15-1-inciso-iida-lei-federal-n-9424-de-24-de-dezembro-de-1996-e-sobre-a-redistribuicao-de-50da-mesma-ao-estado-e-municipios Acesso em: 14 out. 2018.

Disponível

Conselho Estadual de Educação. Deliberação no 02/03. Curitiba, 2003. http://celepar7cta.pr.gov.br/seed/deliberacoes.nsf/7b2a997ca37239c3032569ed005f b978/93946370948cd82903256d5700606b9e?OpenDocument>. Acesso em: 28/08/2015.

Disponível

Secretaria de Estado da Educação. Resolução no 2527/07. Curitiba, 2007. https://www.legislacao.pr.gov.br/legislacao/pesquisarAto.do?action=exibir\&codAto=1 24390\&indice=1\&totalRegistros=1 Acesso em: 31/03/2019. 


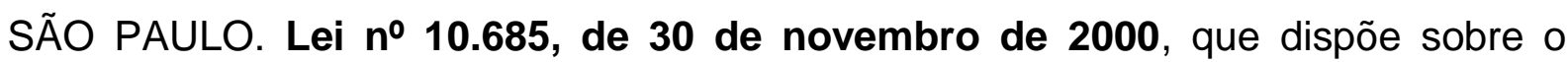
acompanhamento educacional da criança e do adolescente internados para tratamento de saúde. São Paulo, 2000. Disponível em: https://www.al.sp.gov.br/repositorio/legislacao/lei/2000/lei-10685-30.11.2000.html Acesso em: 12/05/2019.

UNESCO. Conferência Mundial Sobre Educação Para Todos, 1990, Tailândia. Declaração mundial sobre educação para todos. Jomtien, Tailândia, 1998. Disponível em: < https://www.unicef.org/brazil/pt/resources_10230.htm> Acesso em 15/01/2017.

UNESCO. Declaração Universal dos Direitos Humanos, 1948. Disponível em: https://www.unicef.org/brazil/pt/resources 10133.htm Acesso em: 21/10/2018.

UNICEF - Declaração universal dos Direitos das Crianças. Unicef, 1959. Disponível em: http://www.dhnet.org.br/direitos/sip/onu/c a/lex41.htm Acesso em: 21/10/2018.

UNICEF - Declaração mundial sobre educação para todos e plano de ação para satisfazer as necessidades básicas de aprendizagem. Brasília: Unicef, 1991.

Livro

KNAPIK, Márcia Carneiro. (Org.) Movimento Popular de Mulheres no Paraná: 10 anos construindo vida. Curitiba: Gráfica Popular: CEFURIA, 2005.

MUGGIATI, Margarida Maria Teixeira de Freitas. Serviço Social. Relatos autobiográficos e memorialísticos de uma Assistente Social. Editora Associação Hospitalar de Proteção à Infância Dr. Raul Carneiro. Curitiba, 2012.

VALLAURI, Mara. Movimento Nacional de Meninos e Meninas de Rua. Curitiba: Gráfica Popular, 2007.

Revista

VIDA UNIVERSITÁRIA, Pontifícia Universidade Católica, 1988. 


\section{Apêndice A - Entrevista I Assistente Social (2010)}

1. Qual ano que a sra. começou a trabalhar aqui no hospital?

2. E qual o seu serviço na época. Como que a sra. começou a trabalhar aqui no hospital?

3. Como era o hospital quando a sra. começou a trabalhar?

4. Qual a faixa etária dos atendimentos quando a sra. começou a trabalhar, as crianças?

5. E, nos primeiros anos do hospital? De 1930 a 32, a sra. sabe se também era até 12 anos?

6. Era possível ter alguma informação das profissões dos pais das crianças atendidas?

7. Havia mudado muito desde a fundação do hospital? Mudou isso ou era muito parecido com o começo?

8. É possível ter noção da condição financeira das famílias das crianças atendidas?

9. E como que a sra. identificaria o grupo que mais procurou os hospitais nos primeiros anos de funcionamento?

10. Quais as doenças mais tratadas no hospital quando a sra. começou a trabalhar?

11. Sabe quais as moléstias mais atendidas nos primeiros anos do hospital?

12. Havia atendimento de acidentado?

13. E havia especialidades nos atendimentos realizados no hospital quando a sra. começou a trabalhar?

14. Quando começaram as especialidades? Será que no começo do hospital já tinha especialidade ou eles eram só pediatra?

15. Quem trazia as crianças para ser atendida no hospital no tempo em que a sra. começou a trabalhar? Quem mais que acompanhava a criança para a consulta e internações, assim?

16. Será que houve mudança desde 1930 e 32 ? Será que também eram os pais? Também eram os pais em $30 / 32$ que traziam as crianças para o hospital?

17. Será que eram mais pai ou mãe?

18. Essas pessoas, essas mães, esses pais que acompanhavam as crianças, recebiam algum tipo de instrução para a saúde? Ensinavam pra elas a cuidar das crianças?

19. Se sim, pode destacar o grupo que mais recebeu essa instrução?

20. Quando a sra. começou a trabalhar no hospital existia algum tipo de instrução para as crianças? Ou desde 1930? Quando que começou essa instrução para as crianças no hospital? 


\section{Apêndice B - Entrevista II Assistente Social (2016)}

1. Quando a sra. começou a trabalhar no hospital como assistente social?

2. Como surgiu a ideia em criar um serviço de escolarização para as crianças internadas?

3. Quando foi implantado a "Hospitalização escolarizada" no hospital que a sra. trabalhava?

4. Como esse serviço foi implantado?

5. Como era esse serviço da "Hospitalização escolarizada"?

6. Sra. saberia me dizer se havia algum convênio realizado entre o hospital e o Estado ou prefeitura que disponibilizavam as professoras para a efetivação da "Hospitalização escolarizada"? Se sim, onde posso encontrar cópias destes documentos?

7. A sra. encontrou alguma dificuldade para efetivar essa implantação do serviço de escolarização? Se sim, quais foram essas dificuldades?

8. Encontrou facilidade para efetivar essa implantação do serviço de escolarização? Se sim, quais foram essas facilidades?

9. Quem Ihe ajudou inicialmente nesta implantação?

10. Quem foram as primeiras professoras que se dispuseram a realizar este serviço?

De onde elas vinham?

11. O que as professoras faziam no hospital?

12. Qual era a rotina das professoras?

13. Onde elas atendiam?

14. Como eram os atendimentos das professoras aos alunos internados?

15. Como essas professoras trabalhavam? Qual era a frequência delas no hospital?

16. O que os alunos achavam destas aulas?

17. Como essas aulas eram vistas pelos pais ou responsáveis pelas crianças?

18. Essas professoras mantinham contato com as escolas das crianças?

19. Tem alguma informação do que as escolas achavam destes atendimentos das professoras oferecido às crianças no hospital?

20. E os médicos e demais funcionários do hospital, aceitavam essas aulas?

21. Qual era a reação dos médicos e demais funcionários do hospital ao fato de haver professoras trabalhando no hospital e dando aula para as crianças?

22. Até quando a sra. acompanhou este trabalho?

23. Depois da implantação da "Hospitalização escolarizada", a sra. pode observar melhoras nas crianças? Se sim, em que sentido?

24. Quais as melhores recordações que tem deste período?

25. Gostaria de falar mais alguma coisa? Fique à vontade! 


\section{Apêndice C - Entrevista Professores}

1. Qual a sua formação?

2. A quanto tempo trabalha no magistério?

3. Qual seu vínculo de trabalho (particular, estadual ou municipal)?

4. Quando você começou a trabalhar no Hospital como professora?

5. Até quando trabalhou no hospital? Gostaria de contar por que saiu do hospital?

6. Como surgiu essa possibilidade de trabalho num hospital infantil?

7. Que motivos a levaram a iniciar esse trabalho?

8. Foi a primeira professora a trabalhar no hospital ou houve alguma outra antes de você? Se sim, saberia me dizer quem seria essa ou essas professoras? (Gostaria de também entrar em contato com ela (as) para incluí-las na pesquisa.)

9. Você tem conhecimento de algum projeto ou convênio realizado entre o hospital onde foi trabalhar e sua mantenedora? Se sim, saberia dizer onde posso encontrar cópias destes documentos?

10. Qual era a sua função no hospital?

11. Com quais outros profissionais você trabalhava no hospital? Existia um trabalho da equipe multidisciplinar na Educação Hospitalar no hospital infantil de Curitiba? Caso positivo, como é o trabalho desta equipe multidisciplinar? Quais as relações e entrelaçamentos entre seus diferentes membros?

12. Havia outros professores que trabalhavam com você? Se sim, como era a divisão de trabalho entre vocês? Quem eram esses professores? Qual o vínculo empregatício deles?

13. Quais as séries das crianças que você atendia?

14. Quem eram os alunos da Educação Hospitalar deste período estudado e quais as experiências que eles relatam com relação à Educação Hospitalar na qual tiveram aula nos períodos de internamento?

15. Quais as ações efetivas que desencadearam na Educação Hospitalar paranaense?

16. Em que medida o projeto de Educação Hospitalar, seus professores, alunos e atendimentos se efetiva no universo paranaense?

17. Como eram esse atendimento?

18. Você tem registros destes atendimentos? Se sim, poderia me emprestar para utilizar na pesquisa?

19. Como era o seu planejamento de trabalho? Tem registros destes planejamentos? Se sim, poderia me emprestar para utilizar na pesquisa?

20. Onde você atendia? Que setores do hospital eram liberados para que você trabalhasse com as crianças?

21. Havia um lugar específico para fazer os atendimentos/aulas? Como era esse local? Poderia me contar como aconteciam os atendimentos ali ou em cada um destes locais (se eram em diferentes locais e diferentes possibilidades de atendimento)? Havia material pedagógico ou físico específico para estes atendimentos?

22. Havia algum registro ou relatório das suas atividades no hospital? Se havia, você tinha que encaminhar para algum lugar esses registros? Teria cópias para me emprestar para que eu possa ver e utilizar na pesquisa?

23. Como era a avaliação das crianças atendidas?

24. Havia algum contato com a escola de origem destas crianças? Ou um retorno sobre as atividades realizadas por eles junto à escola quando o aluno tinha alta? 
25. Você tem algum registro de atividades, caderno de planejamento, caderno de atividades, caderno de alunos, listagem de alunos ou qualquer outro tipo de registros de quando atendia no hospital? Se sim, poderia me emprestar para utilizar na pesquisa?

26. Quais os materiais educacionais e pedagógicos utilizados no hospital infantil de Curitiba na Educação Hospitalar?

27. Lembra-se de algum aluno ou alunos que tenha ou tenham the marcado no tempo que trabalhou no hospital? Gostaria de contar o que foi marcante para você?

28. Em que medida o projeto de Educação Hospitalar, seus professores, alunos e atendimentos se efetiva no universo paranaense?

29. Como a Assistente Social que implantou o projeto da "Escolarização Hospitalizada" efetivou essa implantação?

30. Quais os modelos educacionais direcionados ao atendimento das crianças e dos adolescentes que podem ser observados nos atendimentos da Escolarização Hospitalar no hospital infantil de Curitiba?

31. De que modo se apresenta os progressos no atendimento da Escolarização Hospitalar no hospital infantil de Curitiba?

32. Quais as questões político pedagógicas podem ser observadas. Poderia me indicar alunos que tenha atendido para que eu possa entrar em contato com eles e solicitar a participação nesta pesquisa?

33. Como foi uma das pioneiras ou talvez a pioneira neste trabalho tão diversificado, teria alguma consideração a fazer sobre as dificuldades que encontrou neste novo ambiente de trabalho que se delineou nos seus dias profissionais?

34. Você acredita que esse período de trabalho no hospital the acrescentou alguma coisa em sua vida pessoal ou profissional? Se sim, poderia me dizer o que foi?

35. Você trabalhou somente neste hospital ou também chegou a trabalhar em outros hospitais?

36. Tem interesse em voltar a trabalhar em hospitais como professora?

37. Quais as melhores recordações que tem deste período?

38. Gostaria de falar mais alguma coisa? Fique à vontade! 


\section{Apêndice D - Entrevista Aluno}

1. Gostaria de me dizer por que fazia tratamento no hospital quando era criança?

2. Durante quanto tempo frequentou o hospital de crianças?

3. Poderia me dizer de que ano até que ano frequentou o hospital quando criança?

4. Nesse período você já frequentava a escola regular?

5. Lembra em qual série ou séries estava? E escola, se lembra onde estudava?

6. Nesse período chegou a ter aulas com as professoras que trabalhavam no hospital?

7. Durante quanto tempo teve aulas no hospital?

8. Como eram essas aulas no hospital?

9. Você gostava de ter aulas no hospital? Por quê?

10. Essas aulas o ajudaram a continuar seus estudos normais?

11. Você se lembra quem eram as professoras no hospital?

12. Como era as aulas desta (as) professoras?

13. Lembra de algo que tenha lhe marcado durante as aulas que recebia no hospital?

14. Você considera importante esse tipo de atendimento de professores no hospital? Por quê?

15. Tem algum tipo de material/caderno deste período com as tarefas do hospital? Se sim, poderia me emprestar para que possa utilizar na pesquisa?

16. Tem fotos deste período? Se sim, poderia me mostrar?

17. Quais as melhores recordações que tem deste período?

18. Gostaria de falar mais alguma coisa? Fique à vontade! 


\section{Apêndice E - Entrevista Família}

1. Gostaria de me dizer por que sua filha fazia tratamento no hospital quando era criança?

2. Durante quanto tempo frequentou o hospital infantil em Curitiba com sua filha?

3. Nesse período sua filha já frequentava a escola regular?

4. Lembra em qual série ou séries sua filha estava neste período? E escola, se lembra onde ela estudava?

5. Nesse período sua filha chegou a ter aulas com as professoras que trabalhavam no hospital?

6. Você se lembra quem era/eram a(s) professora(s) no hospital?

7. Como começou esse atendimento pedagógico? Quais os motivos que levaram a sua filha a ter essas aulas no hospital?

8. Durante quanto tempo sua filha teve aulas no hospital?

9. Você se lembra como eram essas aulas no hospital ofertadas para sua filha? O que a professora fazia nas aulas de sua filha?

10. sua filha gostava de ter aulas no hospital? Por quê?

11. Essas aulas ajudaram sua filha a continuar os estudos normais?

12. Como era as aulas desta(as) professora(s) de sua filha?

13. Lembra de algo que tenha lhe marcado durante as aulas que sua filha recebia no hospital?

14. Você considera importante esse tipo de atendimento de professores para crianças internadas no hospital? Por quê?

15. Tem algum tipo de material/caderno de sua filha deste período com as tarefas do hospital? Se sim, poderia me emprestar para que possa utilizar na pesquisa?

16. Tem fotos deste período? Se sim, poderia me mostrar e/ou emprestar para compor um álbum a ser utilizado na pesquisa?

17. Você conseguia ver progressos na aprendizagem de sua filha com o(s) atendimento(s) da Escolarização Hospitalar?

18. Lembra quais eram os materiais educacionais e pedagógicos utilizados pela professora nas aulas dadas para sua filha no hospital infantil?

18. Gostaria de falar mais alguma coisa? Fique à vontade! 


\section{Apêndice F - Transcrição Entrevista I Assistente Social (AS)}

Eu - Gravando agora.... Qual ano que a sra. começou a trabalhar aqui no hospital? AS - 1974. Agosto de 74. Houve um convite para eu vir trabalhar aqui e já com supervisão à duas alunas que estavam fazendo um trabalho de TCC.

Eu - Ah, sei...

AS - Da Escola de Serviço Social da PUC...

Eu - Certo! E qual o seu serviço na época. Como que a sra. começou a trabalhar aqui no hospital?

AS - Já foi como chefe de setor. (Sorri)

Eu - Ah! Já foi?!?

AS - Já. Como chefe de setor. Naquele tempo o diretor aqui era o Dr. Sobania. Que não sei se você conhece?

Eu - Não...

AS - Ele era chefe também do serviço de ortopedia aqui dentro. E eu vim conversar com ele, mas a convite também foi da direção do hospital e essas alunas estavam precisando de supervisão aqui dentro. E eu então, acabei aceitando. Gostei do trabalho e continuo até hoje.

Eu - Continua até hoje (sorrindo).

AS - Olha, sinceramente eu já estou até aposentada, mas eu vou esticando.

$\mathrm{Eu}-\mathrm{Ah}$, sim. A gente nunca consegue se desligar, não é?!

AS - A minha família, meus filhos, não entendem.

Eu - risos

AS - Agora é tempo de você estar passeando e tudo o mais. E eu digo: que nada! Mas olhe o serviço vai crescendo e precisando da gente sempre mais, sabe?

Eu - É, verdade...

AS - Então eu sou chefe de setor. Continuo como chefe de setor aqui e tenho uma equipe muito boa.

$\mathrm{Eu}-\mathrm{Ai}$, que bom, não é?!

AS - Uma equipe excelente, viu! De qualidade! Tudo isso eu falo aqui.

$\mathrm{Eu}-\mathrm{Ai}$, que bom!

AS - No trabalho.

Eu - Como que era o hospital quando a sra. começou a trabalhar?

AS - Bom! O meu contrato se fez no hospital pelo Cesar Perneta. Sim, no Hospital de Crianças.

Eu - Ahã!

AS - Não! Não é bem isso. Havia uma ligação entre Cesar Perneta e

Pequeno Príncipe e depois eles fizeram um comodato unindo os dois hospitais e eu era AS de ambos os hospitais.

Eu - Sim.

AS - Em 74 eu trabalhava na parte clínica e administrativa também! Hoje estou mais na parte clínica, porque não a gente dá conta mesmo!

Eu - Sim. É verdade! Qual a faixa etária dos atendimentos quando a sra. começou a trabalhar, as crianças?

AS - Naquele tempo era até 12 anos. Depois ele foi estendido aos adolescentes até 18 anos. Hoje, até 18 anos.

Eu - Ãhh... E, nos primeiros anos do hospital? De 1930 a 32, a sra. sabe se também era até 12 anos? 
AS - Possivelmente... Agora isso eu não tenho bem certeza, porque quando eu entrei aqui era até 12 anos.

Eu - Até 12 anos.

AS - Precisava buscar, assim... documentos que comprovassem isso...

Eu - Que comprovasse que tinha 12 anos?!

AS - Eu tenho até monografias antigas, que quando eu cheguei já estavam aqui na biblioteca que possivelmente possa ter essas informações.

Eu - As respostas, não é? Ahã! E era possível ter alguma informação das profissões dos pais das crianças atendidas?

AS - Quando eu entrei aqui sim!

Eu - Dava para saber?

AS - Dava para saber!

Eu - A maioria assim?

AS - Domésticas, pedreiros, carpinteiros, pessoal de uma renda mais baixa.

Eu - Mais baixa?

AS - É. E também, depois que a gente teve a possibilidade de estar aqui, a gente entendeu que podia ter atendimentos de convênio e também particulares. Não só internamentos como ambulatórios.

Eu - E pelo que a sra. ouvia, havia mudado muito desde a fundação do hospital? Mudou isso ou era muito parecido com o começo?

AS - Sabe! Eu acho que foi gradativo, o começo, a partir do Grêmio das Violetas, o atendimento foi uma forma gradativa, assumindo qualidade.

$\mathrm{Eu}-\mathrm{Ah}$ !

AS - De acordo com a evolução do próprio hospital, os conhecimentos, né!

Eu - Sim. Verdade! É possível ter noção da condição financeira das famílias das crianças atendidas? Bom, isso a sra. já falou, né?

AS - Olha, nos documentos que a gente tem aqui, de TCCs antigos dá para ver isso aí. Tem que fazer uma análise. Depois eu vou te mostrar alguns TCCs que os alunos procuravam pesquisar isso aí também.

Eu - Certo!

AS - Eu não tenho bem certeza, mas, como eu te falei, pessoal de baixa renda, principalmente eles faziam atendimento a pessoas assim, com poucos recursos financeiros! E hoje, nós temos também particulares aqui.

$\mathrm{Eu}$ - E como que a sra. identificaria o grupo que mais procurou os hospitais nos primeiros anos de funcionamento?

AS - Precisava olhar os documentos! Esses eu não tenho.

Eu - Esses documentos então na biblioteca? A sra. acha que tem?

AS - Eu tenho aqui TCCs, Trabalho de Conclusão de Curso.

$\mathrm{Eu}-\mathrm{Sim}$.

AS - Em que os alunos, pesquisavam isso aí.

Eu - Certo!

AS - Então aparece nos TCCS. Eu vou te mostrar isso aí.

Eu - Então está bom! Quais as doenças mais tratadas no hospital quando a sra. começou a trabalhar?

AS - Olha... Desnutrição infantil, e também aquela doença que a criança perde o líquido do organismo... Como que é o nome?

Eu - Diarreia, será?

AS - A diarreia é, é uma das causas. Eu tenho até trabalhos de TCCs sobre isso aí.

Eu - Sobre essa doença?

AS - Mas eu já te falo. É desidratação! 
$\mathrm{Eu}-\mathrm{Ah}$ !

AS - Desidratação! Tinha muito, bastante!

Eu - É... Sabe quais as moléstias mais atendidas nos primeiros anos do hospital?

AS - Nos primeiros anos? Isso eu vou ter que dar uma pesquisada (sorri)

Eu - Havia atendimento de acidentado?

AS - Sim! Sempre! Aqui sempre foi assim, um hospital de emergência.

$\mathrm{Eu}$ - Ah! E havia especialidades nos atendimentos realizados no hospital quando a sra. começou a trabalhar?

AS - Especialidades?

Eu - É! Os médicos já tinham especialidade em alguma coisa?

AS - Já tinham! Sobre desnutrição. Principalmente sobre desnutrição infantil. E também Nefrologia, Ortopedia, isso desde o começo.

Eu - Desde o começo?

AS - Ortopedia, Cardiologia.

Eu - E quando? Desde o começo que a sra. começou ou desde o começo do hospital?

Será que no começo do hospital já tinha especialidade ou eles eram só pediatra?

AS - Bom, eles eram Pediatras... Logo no comecinho, de uma forma generalista.

Eu - Ahhh!!!

AS - Atendiam tudo! Aí depois foi definindo separações.

Eu - Foi separando!

AS - É! Foi separando!

Eu - Foi se especializando...

AS - Mas no começo eles praticamente eram médicos da família.

$\mathrm{Eu}-\mathrm{Ah}$ !

AS - Atendiam de tudo. Então, interessante... Começaram como médicos generalistas...

Eu - Aham...

AS - Mas chegou num ponto que eles precisaram, tiveram necessidade de separar, mas a separação chegou num tal ponto que bateu, porque era assim, médico da mão, médico do dedo...

Eu - Era muita coisa...

AS - Muita especialidade, porque de repente eles têm necessidade agora de enxergar de uma forma holística!

Eu - O todo... Aham!

AS - O todo novamente! Então estão, bateu aqui, estão voltando para essa visão holística, mais geral do fato!

Eu - Aah! Interessante!

AS - Isso é muito interessante!

Eu - É! No tempo que a sra. começou a trabalhar no hospital quem levava as crianças para serem atendidas? Quem que trazia as crianças para ser atendida no hospital? Quem mais que acompanhava a criança para a consulta e internações, assim?

AS - De um modo geral os próprios pais. Quando viam que situação estava, se estava agravando eles corriam ao hospital.

Eu - Ah, então os pais que traziam? Será que outros... (interrompida).

AS - E tinha também os postos de saúde.

$\mathrm{Eu}-\mathrm{Ah}$ !

AS - Os postos! Eles vão aos postos e os postos encaminham, não é! Muitas vezes ele vem diretamente para o hospital.

Eu - Será que houve mudança desde 1930 e 32? Será que também eram os pais? Também eram os pais em $30 / 32$ que traziam as crianças para ... 
AS - Não...

Eu - Será que eram mais pai ou mãe?

AS - Mais mãe.

Eu - Mais mãe!

AS - É. Mais mãe. Os pais trabalham, não é! E a mãe que traz. Trazia.

Eu - É verdade!

AS - Mas isso ainda até hoje continua...

Eu - Continua?

AS - É! Mas é que não sei se naquele tempo ainda tem a questão, também dos maus tratos.

Eu - É que hoje tem, não é?

AS - Hoje tem no mundo inteiro e nós aqui estamos na fase hospitalar, porque a obrigação é que haja a denúncia.

Eu - Sim! Mas como não há a denúncia...

AS - A denúncia, hoje há! Para a rede.

Eu - Sei.

AS - A rede de proteção! E o hospital aqui já está numa estância, já...

Eu - Superior até, não é? Porque já está atendendo... (interrompida).

AS - Superior, porque dentro do hospital... Não quando a coisa já se torna mais grave... Às vezes é fratura e tudo o mais... Quer ver uma história que eu presenciei? Não! Que eu soube aqui no hospital? Secretamente de brigas do casal

Eu - Ai que dó!

AS - Maus tratos! E eles, digamos assim, agridem a criança, porque afetando a criança ela é filho do outro...

Eu-É!

AS - Eles se agridem mutuamente.

Eu - É como se eles se agredissem... É!

AS - E olha um caso que eu escutei aqui, foi assim, uma criança recém-nascida, o pai querendo se vingar da mãe, jogou a criança contra a parede.

Eu - Uuuhiii!!!

AS - Matou a criança!

Eu - Que dó!!!

AS - Matou a criança! (Falou sussurrando)

$\mathrm{Eu}-\mathrm{Ai}$, que horror, né?! (Falei horrorizada!)

$A S$ - E mais coisas incríveis que acontecem hoje de pais, assim...

Eu - A gente nem imagina, não é?!

AS - Você não pode nem calcular! Você quer saber? Uma vez, mas isso dentro do serviço social, diz uma mãe assim: "Essa criança é tão endiabrada, que um dia não tive dúvida, tirei a calcinha dele e sentei no formigueiro"!

Eu - Ai que dó, gente!!!! (Falei mais horrorizada ainda!)

AS - Isso para coisas mais graves ainda...

Eu - Ahã!!!! Nossa, é muito chocante, né?!

AS - É muito chocante!!!

Eu - E, as pessoas, essas mães, esses pais que acompanhavam as crianças, elas recebiam algum tipo de instrução para a saúde? Ensinavam para elas a cuidar das crianças?

AS - Bom! Eu já logo quando entrei aqui, eu senti essa necessidade. Aí, o que eu fazia. Porque era assim. As visitas, isso para as crianças internadas, mas a gente também convidava pessoas que traziam para os ambulatórios os internamentos, para os internamentos havia visita só duas vezes por semana, naquele tempo. Então o que 
eu fiz? Eu inventei algumas sessões... E para os dias de visitas, eu, a gente convidava, punha as estagiárias a convidar os pais. A gente procurava e eu tinha sempre reservado, ou melhor, um dos ambulatórios aqui dentro, não é ambulatório, auditório. Eu - Sei...

AS - Então a gente juntava todo mundo lá dentro do auditório...

Eu - Aham!

AS - E eu, eu abria sessões. Bom, mas eu trazia sempre um médico para falar de alguma coisa.

Eu - Sei!

AS - Então, um falava do soro que é da hidratação, desnutrição... Ah, e ainda eu trazia gente da Secretaria Municipal da Saúde, que vinham. Eles adoravam! Porque passavam filmezinho sobre saneamento básico, sobre desnutrição, sobre desidratação! Sobre tudo isso aí! Sabe?

Eu - Sei!

AS - Eles amavam, porque era o cineminha da época! (Fala e sorri!)

$\mathrm{Eu}-$ (Ri junto com ela!)

AS - Eu trazia o pessoal todo e passava o cinema para eles, é filmes, né?! E para eles era extremamente. Não é?! Essas sessões.

$\mathrm{Eu}-\mathrm{E}$ a sra. pode destacar o grupo que mais recebeu essa instrução?

AS - Olha, de um modo geral, os pais que tinham os filhos internados aqui.

$\mathrm{Eu}-\mathrm{Ah}$ !

AS - Mas eu acho que sobre a desidratação, naquele tempo, era a doença que mais aparecia. Nós tínhamos uma enfermaria só de desidratação.

Eu - Humm?!

AS - Hoje não tem mais.

Eu - Isso quando a sra. começou a trabalhar?

AS - Comecei a trabalhar!

Eu - Antes da sra. vir, a sra. sabe se tinha alguma coisa nesse sentido?

AS - Não!

Eu - Faziam formação para os pais?

AS - Não sei!

Eu - Não sabe?

AS - Não, não sei!

Eu - A gente não tem como descobrir isso...

AS - Tem nos documentos aí que eu vou mostrar para você!

Eu - Ah! Então depois a gente vê... E existia algum tipo de instrução para as crianças? Quando a sra. começou? Ou, assim, desde 1930? Quando, né, que teve?

AS - Olha, só olhando nos documentos alí, porque eu tenho monografias que contam historicamente estas coisas, mas eu vou te mostrar. Quer ver? Eu posso até já começar a mostrar. Espere aí! (Para de falar comigo e vai procurar os documentos que me falou num armário que ficava atrás dela) 


\section{Apêndice G - Transcrição Entrevista II Assistente Social (AS)}

Eu - Quando a Sra. começou a trabalhar no hospital como assistente social?

AS - Em 1974.

Eu - Como surgiu a ideia em criar um serviço de escolarização para as crianças internadas?

AS - Pela incompatibilidade do tratamento e da escola.

Eu - Quando foi implantado a "Hospitalização escolarizada" no hospital que a Sra. trabalhava?

AS - Em 1988.

Eu - Como esse serviço foi implantado?

AS - Conversei com a direção do hospital e começamos o trabalho.

Eu - Como era esse serviço da "Hospitalização escolarizada"?

AS - A escola... a frequência à escola e ao mesmo tempo o tratamento...

Eu - Aaahhh! Aí começou a ficar compatível o tratamento do hospital e a frequência à escola! Mas elas frequentavam a escola ou elas frequentavam a escola no hospital? (Silêncio). As crianças?

AS - Elas faziam tudo ao mesmo tempo.

$\mathrm{Eu}$ - Ah, enquanto elas estavam no hospital elas iam fazendo a escolarização delas.

AS - Logicamente!

Eu - Havia algum convênio entre o hospital e a Prefeitura?

AS - (Silêncio prolongado) Olha, esse convênio havia sim, porque imediatamente eu fui conversar com a direção do hospital e também com o secretário da educação e ao mesmo tempo ele... ele... ele achava que era possível sim... essa estadualização ao mesmo tempo do tratamento.

Eu - Quem era esse secretário?

AS - Doutor Valverde Jobim (não consegue se lembrar do nome completo do secretário).

Eu - Era do Estado ou da prefeitura?

AS - Estado.

Eu - Ah, certo! Ééé... a Sra. saberia me dizer se tem cópias desse, desse convênio em algum lugar?

AS - Deve ter na secretaria de educação.

Eu - Certo! Ãhhh... voltando a falar agora do trabalho. Quando a sra. foi implantar, não tinha nada disso no hospital? Não tinha professora trabalhando dentro do hospital?

AS - Não.

Eu - A sra. encontrou alguma dificuldade para implantar esse serviço?

AS - Olha... eu não encontrei dificuldade nenhuma, porque os médicos queriam o projeto, ao mesmo tempo que a direção do hospital também!

Eu - Huhum. E a secretaria também apoiou, quando a sra. foi conversar com o secretário?

AS - Sim!

Eu - Então a Sra. encontrou facilidade para efetivar esse projeto?

AS - Eu acho que encontrei facilidade de implantar esse projeto!

Eu - A sra. saberia me dizer quais foram essas facilidades?

AS - Olha... As professoras da escola mandavam os projetos para o hospital e ao mesmo tempo eu fazia as provas para os alunos... E passava para as professoras. A nota é dada pelas professoras.

$\mathrm{Eu}$ - As professoras que trabalhavam no hospital? Ou pela da escola? 
AS - Da escola!

Eu - Aaahhh! A escola que dava a nota! Então..., deixa ver se eu entendi. A escola passava as provas, a Sra. repassava para as professoras que trabalhavam no hospital, essas professoras davam para os alunos e devolviam para a escola colocar a nota?

AS - Huhum.

Eu-É?

AS - (balança a cabeça afirmativamente)

Eu - Quem ajudou a Sra. inicialmente nesta implantação? Teve algumas pessoas? Teve uma pessoa? Ou foi um trabalho mais assim a Sra. mesmo que foi atrás?

AS - Eu acho que o dr. Ivan que ajudou muito. Dr. Ivan... (fica em silêncio tentando lembrar o nome dele) Você se lembra o nome dele?

Eu - Não lembro o nome dele. Eu sei quem é o dr. Ivan! Eu conversei com ele.

AS - Ahãm.

Eu - Ele está aposentado agora, né?!

AS - Huhum.

Eu - Ele é da sociedade de pediatria, não é? O Dr. Ivan?

AS - É!

Eu - Eu conversei com ele lá na sociedade de pediatria. E quem foram as primeiras professoras que se dispuseram a realizar este serviço no? A Sra. lembra quem eram? AS - (Silêncio prolongado) ... Professora... Eu não posso dizer... Eu posso afirmar isso depois que eu me lembrar.

Eu - De onde elas vinham? Era prefeitura, estado?

AS - Estado

Eu - Inicialmente era do Estado?

AS - Huhum.

Eu - O que essas professoras faziam no hospital? A Sra. já falou que elas davam as provas. Além disto, o que mais elas faziam?

AS - Elas ajudavam as crianças... esclarecia os termos... e daí as crianças entregavam paras as professoras e as professoras levavam para a escola.

Eu - Qual era a rotina das professoras?

AS - Huum?

Eu - Qual era a rotina delas professoras lá no hospital?

AS - Olha, as professoras chegavam às 8h. Elas ficavam lá até a hora do almoço. $E$ depois... olha..., eu não me lembro bem... Elas vinham em rotina alternadas. Às vezes elas eram de manhã, outras à tarde.

Eu - Ah! Entendi! (Pausa). E elas chegavam e iam primeiro para onde? Já iam direto atender as crianças ou passavam em algum lugar?

AS - (Pausa grande, pensando). Eu acho que elas passavam primeiro na secretaria... para dar a presença delas!

Eu - Ah, sei! E onde que elas atendiam as crianças? Tinham uma sala para ter aula?

AS - Olha, uma sala especial. Depois, ela atendia no leito.

$\mathrm{Eu}$ - Ah, certo! De todo o hospital ou elas tinham só alguns lugares que elas podiam atender?

AS - Olha. Nem sempre as salas podiam, podiam ser reservadas para esse tipo de trabalho.

Eu - Sim.

AS - Era mais o leito!

$\mathrm{Eu}-\mathrm{E}$ como que eram os atendimentos das professoras aos alunos internados? $\mathrm{O}$ que elas faziam? 
AS - Olha... elas faziam... (Pausa grande) Como é que eu posso dizer... Elas faziam as provas, aliás, as perguntas e as crianças respondiam...

Eu - Mais alguma coisa que a Sra. lembra que elas faziam?

(Pausa grande).

AS - Havia também os quadros negros.

$\mathrm{Eu}$ - Elas usavam esse quadro negro para ensinar?

AS - Sim!

Eu - Como que essas professoras trabalhavam? Como era a frequência delas no hospital?

AS - (Pausa). Elas iam todos os dias.

Eu - De segunda a sexta?

AS - De segunda a sexta.

Eu - Final de semana elas não iam?

AS - Olha, eu agora não estou lembrando se elas iam no final de semana...

Eu - Acho que não, né?! E o que que os alunos achavam destas aulas?

AS - Gostavam!

Eu - Gostavam?

AS - Eles torciam para que, que passasse o dia rápido para eles terem as aulas.

Eu - Para as professoras chegarem?

AS - Huhum!

Eu - E os pais? Como essas aulas eram vistas pelos pais ou responsáveis pelas crianças?

AS - Os pais davam graças a Deus! Porque sempre eles encontravam essa incompatibilidade do tratamento com a escola, a frequência à escola.

Eu - Sim.

AS - E não é brincadeira isso! Ou a escola, ou o tratamento.

Eu - Huhum. E essas professoras? Então elas mantinham contato com as escolas das crianças? Com as escolas que as crianças estudavam?

AS - Huhum

Eu - Como elas faziam esse contato?

AS - Através do serviço social também... e elas próprias iam às escolas.

Eu - Ah! Certo! A Sra. tem alguma informação do que as escolas achavam destes atendimentos das professoras? Que elas faziam no hospital?

AS - Olha, eu tenho até uma carta muito interessante aplaudindo a ideia!

Eu - Então as escolas gostavam, apoiavam?

AS - Apoiavam e elas diziam assim, que a criança nem parecia que estava em tratamento, porque ela ficava internada.

$\mathrm{Eu}$ - Huhum. Porque quando ela voltava para a escola era como se ela nem tivesse ficado internada? Era isso?

AS - Ahãm!

Eu - Ah! E os médicos e demais funcionários do hospital, eles aceitavam essas aulas?

O que eles pensavam dessas aulas dentro do hospital?

AS - Eles aplaudiam as aulas.

Eu - Ah, é?

AS - Eles ficavam agradecidos, porque o aluno colaborava com o tratamento.

Eu - Ah! Como assim? Como que ele colaborava? Quando ele começou a ter aula ele colaborava mais com o tratamento?

AS - Huhum!

Eu - Ele aceitava? Tomava remédio? 
AS - Ele aceitava o tratamento. É! E ao mesmo tempo eles... eles... como eu falei, aceitavam mais o tratamento.

Eu - Sei! Qual era a reação dos médicos e demais funcionários do hospital ao fato de haver professoras trabalhando no hospital e dando aula para as crianças? A hora que ele chegava e encontrava a professora dando aula, qual era a reação deles?

AS - Eles colaboravam!

$\mathrm{Eu}-\mathrm{Ah}$ !

AS - Eles sempre diziam assim, que a hora que precisar, eles estavam à disposição!

$\mathrm{Eu}$ - Entendi! E até quando a sra. acompanhou este trabalho?

AS - Olha, até 2012..., quando eu me aposentei. Em 2002, quando criaram o Setor de Educação e Cultura a responsabilidade ficou dividida.

Eu - Como foi essa divisão?

AS - Ele cuidava da parte administrativa e eu cuidava mais da parte técnica.

Eu - Ah! Então, todo o tempo que a sra. trabalhou no hospital a sra. acompanhou o trabalho... depois que ele foi implantado!

AS - Huhum!

Eu - Depois da implantação da "Hospitalização escolarizada", a sra. pode observar melhoras na criança? Se sim, em que sentido?

AS - Ahãm!

Eu - As crianças passaram a melhorar, então?

AS - Huhum! Elas passaram a melhorar e colaboravam com o tratamento.

Eu - Ah! Certo! E quais as melhores recordações que tem deste período?

AS - Olha, vau dizer uma coisa, eu contribui... Eu sou feliz, porque eu contribui com alguma coisa para a escolarização da criança. É!

Eu - Gostaria de falar mais alguma coisa? Fique à vontade!

AS - Vou te dizer uma coisa..., hoje eu estou realizada, em parte também por, pelo projeto.

Eu-É?

AS - Eu estou realizada!

Eu - Que bom! Que bom! E a gente fica muito feliz da sra. ter implantado essa inovação que foi a escolarização.

AS - Eles achavam o projeto muito importante... E a mídia veio ao hospital e fez entrevistas... Eles diziam assim, que o projeto era importantíssimo para a criança.

Eu - Ah! E era mesmo!

AS - Vou te dizer uma coisa, me realizei!

Eu - Que bom! Muito bom! Bom, obrigada pelas informações. Foram muito boas, muito importantes e vai me ajudar bastante!

AS - Eu vou dizer uma coisa..., como assistente social, isso fez parte de minha realização..., porque eu contribui com alguma coisa e algo assim, importantíssimo!

Eu - É mesmo!

AS - E eu vou te dizer uma coisa, estou realizada!

Eu - Que bom! Muito bom!

(Toca a campainha e a empregada vem para abrir a porta). 


\section{Apêndice H - Transcrição Entrevista Professora 1}

Eu - Bom, vou fazer a entrevista agora com a professora [estadual] para pesquisa $A$ EDUCAÇÃO DE CRIANÇAS EM HOSPITAIS: A experiência da cidade de Curitiba, Estado do Paraná num Hospital Infantil, 1988 - 2002. Você pode falar o seu nome completo?

Professora: Meu nome é Professora $1^{183}$, tenho atualmente 27 anos de trabalho dentro da rede estadual de educação do Paraná. Sou formada na disciplina de Língua Portuguesa. Leciono Português e Literatura atualmente, tenho especialização em Interdisciplinaridade na Educação Básica, atuei como professora no Hospital Infantil Pequeno Príncipe durante 9 anos, entre os anos de 1990 e 1998. Atualmente trabalho com a EJA. Sou, QPM no Estado, tenho vínculo desde o início, ou seja, há 27 anos. Eu - Pode me explicar o que é QPM?

Prof. - Sou estatutária, sou concursada, tenho estabilidade dentro do Quadro Próprio do Magistério. QPM significa do Quadro Próprio do Magistério da Secretaria de Estado da Educação do Paraná - SEED.

Eu - Está bom. Então como professora, quando que você começou a trabalhar?

Prof. - Comecei a trabalhar em 1989 na SEED. Após um ano de trabalho em sala de aula fui convidada pela Superintendência da Secretaria Estadual de Educação a atuar como professora no ensino de $1^{\underline{a}}$ a $4^{\underline{a}}$ série do Hospital Pequeno Príncipe, devido a necessidade de uma profissional que se adaptasse ao projeto que estava em andamento naquele hospital. O projeto tinha como nome "Projeto Mirim de Hospitalização Escolarizada", de autoria da [Assistente Social], que na ocasião era assistente social do Hospital Pequeno Príncipe e professora da Pontifícia Universidade Católica no Curso de Serviço Social. Ela no decorrer do período de sua atuação como assistente social no hospital e pesquisadora na universidade, percebeu que havia uma lacuna entre o tratamento de saúde das crianças internadas naquele hospital e a defasagem que o tratamento gerava em relação à escolarização daquelas crianças. Elas ficavam em um vácuo durante o período de tratamento e isso gerava nas famílias e nas próprias crianças uma instabilidade emocional, porque elas chegavam muitas vezes de outras cidades e deixavam de lado o estudo, em virtude do tratamento. Isso gerava uma desestrutura emocional porque para que elas garantissem o tratamento, deixavam de estudar e isso também era um problema para as famílias, então a [Assistente Social], como pesquisadora percebeu que havia a possibilidade de conciliar o tratamento de saúde com a escolarização desde que houvesse a implantação de um projeto. Foi então que ela, em pesquisa fez uma tese de mestrado baseada numa obra de um autor espanhol. Ela leu pesquisas de trabalhos na Espanha e elaborou um trabalho que foi inédito na época, não havia nada parecido no Brasil e sugeriu à direção do Hospital Pequeno Príncipe que fosse implantado o projeto, então isso foi aceito. No primeiro momento soube que uma professora da Secretaria de Educação, designada pela Secretaria de Educação esteve desenvolvendo esse trabalho, mas que em algum momento tinha havido algum problema no que diz respeito à questão de divulgação da autoria do projeto, houve ali uma confusão na questão de desenvolver o projeto e assumir a autoria. Então, a Secretaria de Educação, por um período, que eu não sei especificar quanto tempo, deixou o hospital sem profissional e sem o convênio que foi interrompido em virtude

183 Para preservar a identidade da professora, no lugar de seu nome optei por deixar Professora 1 por ela ter sido a primeira professora a ceder a entrevista para a pesquisa. 
dessa necessidade de esclarecimento, pois quem estava desenvolvendo o projeto (que foi previamente escrito) não tinha sobre ele, quaisquer interferências ou autoria. Eu - No caso essa professora?

Prof. - A professora anterior a mim.

Eu - Certo!

Prof. - Quando fui convidada pela Superintendente da Educação da SEED, me foi esclarecido que o projeto já havia, já era algo construído, defendido em forma de tese na Pontifícia Universidade Católica de Porto Alegre, se eu não estiver enganada, mas que eu iria desenvolvê-lo sem ter sobre ele quaisquer responsabilidades de base, porque ele já estava pronto e acabado. Cabia a mim, sim, desenvolvê-lo dentro dos padrões e sempre que necessário fosse, levar quaisquer tipos de dúvidas à [Assistente Social], que seria eu a responsável pelo desenvolvimento. A [Assistente Social] foi minha supervisora e chefe imediata durante todos os anos que estive no Pequeno Príncipe. Então, quaisquer dúvidas que houvessem em relação ao projeto era com ela, ela tinha plena responsabilidade, assinava, eu apenas desenvolvia, cumpria a parte pedagógica. Então, quando iniciei minha atuação me foi esclarecido isso, que eu não teria coparticipação e coautoria. Não poderia falar em nome do projeto sem citar a origem dele, que era da [Assistente Social].

Eu - Claro!

Prof. - Porque tinha ocorrido aquele problema anterior a matéria no jornal na qual a professora que lá atuava, teria se intitulado como autora da teoria do trabalho ou algo que pudesse indicar que o projeto teria sido elaborado por ela e isso não foi verdade, tanto é que me foi esclarecido na ocasião que a [Assistente Social] havia registrado em cartório o referido projeto para que nada mais fosse desvinculado do nome dela. O foco do trabalho, porque quem desenvolvia não era elaborador, era sim parte do desenvolvimento.

Eu - Certo! Você gostaria de contar por que saiu do hospital?

Prof. - A minha saída do hospital deu-se em janeiro de 99, por uma determinação da Secretária de Educação na época, Alcione Saliba. Tendo em vista que havia um déficit de professores, uma defasagem, havia a necessidade de professores nas escolas e o governo não tinha feito concurso, foi determinado que todos os professores em convênio retornassem para as salas de aula, para suas funções de origem e que cada convênio seria analisado individualmente e que se houvesse a necessidade, seria reativado o Termo de Cooperação Técnico e haveria o chamamento posterior. Não sei por quanto tempo, mas parece que por alguns anos o convênio ficou interrompido devido a SEED não julgar necessária a atuação de professores na área hospitalar. Foi uma determinação da SEED, não uma escolha própria, minha saída do Hospital Infantil Pequeno Príncipe.

Eu - Entendi! E que motivos a levaram a iniciar esse trabalho? Você disse que você entrou no estado em 89 e um ano depois você foi convidada, mas o que lhe fez aceitar ir para o hospital?

Prof. - Fui chamada pela superintendente, houve uma indicação, pelo meu perfil, através da diretora com quem trabalhei no ano de 1989, identificaram em mim algumas características e julgaram na época, que eu poderia desenvolver o trabalho de uma maneira coerente, acharam que eu tinha perfil para atuar com essas crianças. Então fui convidada, inicialmente foi uma surpresa. Eu não tinha nem ideia de que existia aquele projeto e que já tinha sido implantado. Não tinha conhecimento algum do projeto. Então, quando fui convidada inicialmente precisei de um tempo para refletir e pensar se realmente poderia corresponder ao trabalho e depois de algum tempo aceitei e fui designada para o referido convênio no Hospital Pequeno Príncipe. 
Eu - Certo! Então, você já falou que não foi a primeira professora a trabalhar ali no hospital, que antes de você havia uma outra professora que também era professora do Estado.

Prof. - Sim, porém, oficialmente, acredito que eu tenha sido a primeira professora, porque a professora anterior foi para o hospital de uma maneira experimental. Pareceme que a atuação dela ficou no nível da recreação, porque nada foi oficial durante o período que ela esteve lá, nem mesmo os relatórios, não havia nenhuma anotação, não havia nada que configurasse um trabalho efetivamente pedagógico.

Eu - Entendi! Você saberia me dizer quem era essa professora?

Prof. - Eu não tenho o nome completo dela, sei que se chamava Maria Augusta. Quem pode esclarecer esses fatos com mais especificidade é a [Assistente Social], porque foi através dela que houve a interrupção da disponibilidade funcional da referida professora. Ela retornou para a Secretaria da Educação, e o que foi feito com ela eu não sei dizer.

Eu - Certo!

Prof. - A [Assistente Social] sofreu um acidente e durante o período em que ficou afastada do hospital tratando da saúde houve essa situação de divulgação indevida do projeto, se eu não estiver enganada, foi através do jornal Gazeta do Povo, houve uma matéria bem extensa, mas naquela matéria, não houve a citação do nome da [Assistente Social], houve apenas a citação do nome da professora em questão, MA $^{184}$ e isso gerou um problema de autoria. Houve quase que uma questão de plágio na época, foi assim, que a SEED entendeu.

Eu - Foi publicado então no jornal? Uma entrevista que a Maria Augusta deu?

Prof. - Foi publicado no jornal, uma matéria. Eu não a tenho, pode ser que a [Assistente Social] tenha esse histórico, o que me foi informado na época, é que eu deveria ter todo o cuidado ao falar do projeto, que sempre deveria evidenciar que aquele projeto era de autoria da [Assistente Social] e eu apenas atuava como professora. Que não poderia ficar obscuro a autoria do projeto.

Eu - Ou implícito que você também tinha participação por isso?

Prof. - Sim. Eu sempre tinha que deixar claro que só desenvolvia o projeto, que foi elaborado antes do início, da minha atuação como professora.

Eu - Certo! Você conhece o projeto. Você já viu o projeto! E o convênio? Havia um convênio?

Prof. - Sim. Havia um convênio documentado, porque eu o assinava. Desde o primeiro momento, eu já entrei no hospital com esse convênio assinado. O Termo de Cooperação Técnica ficava no Departamento Jurídico da SEED e na diretoria do Hospital Infantil Pequeno Príncipe, do hospital quem o assinava eram os diretores, o diretor clínico, quando eu entrei, era o diretor Dr. Ivan Fontoura, Dona Ety Forte. Eles assinaram a parte do...

Eu - Do hospital (cortando a fala da entrevistada).

Prof. - Da Associação Hospitalar de Proteção à Infância Dr. Raul Carneiro, era assim que vinha como parte e a outra parte era a Secretaria da Educação. Esse convênio sempre era elaborado pelo departamento jurídico da SEED. Então, houve um documento oficial desde o primeiro momento que fui para o hospital.

Eu - Certo!

Prof. - Inclusive, o que me foi deixado claro pela superintendente, professora Hôda Salamuni na época, que eu não teria nenhuma implicação trabalhista fora do magistério em relação ao que eu iria fazer, que contaria como trabalho efetivo em sala

${ }^{184}$ Para preservar a identidade da professora, optei por utilizar somente as iniciais no lugar de seu nome. 
de aula, muito embora, fosse em um hospital, mas que na minha carreira trabalhista, isso não acarretaria, não configuraria afastamento de sala de aula e sim, trabalho pedagógico.

Entrevista $2^{\circ}$ dia

Eu - Bom, Hoje é dia 08, não é?

Prof. - Nove, 9 de março.

Eu - 9 de março de 2017 e a gente vai continuar a entrevista com a professora [estadual], para pesquisa A EDUCAÇÃO DE CRIANÇAS EM HOSPITAIS: A experiência da cidade de Curitiba, Estado do Paraná num Hospital Infantil, 1988 2002.

Você pode me contar como surgiu essa possibilidade de trabalho num hospital infantil?

Prof. - No ano de 1990, fui convidada pela superintendente da SEED, Hôda Salamuni a atuar no Hospital Infantil Pequeno Príncipe - HIPP, como professora. No momento em que houve o convite, achei muito desafiador, não me julgava capaz de trabalhar com crianças hospitalizadas, mas já respondendo aqui a questão número 7 , que motivos me levaram a iniciar esse trabalho? Foi a confiança que me foi depositada pela professora Hôda Salamuni, na época Superintendente de Educação, ao me selecionar para atuar como professora no HIPP e sua insistência para que eu aceitasse o convite, ela havia identificado em mim um perfil que correspondia ao que a instituição hospitalar necessitava para o trabalho com as crianças internadas. A superintendente já tinha referências em relação ao meu trabalho pedagógico, ela havia feito um levantamento de dados a respeito da minha atuação como professora. Acabei aceitando em caráter experimental aquela experiência no hospital e com o tempo acabei me identificando, me adaptando e fiquei então por 9 anos trabalhando lá.

Eu - Você foi a primeira professora a trabalhar no hospital ou houve alguma outra professora antes de você?

Prof. - Existe sim, um levantamento que uma professora anterior a mim, da Secretaria Estadual de Educação, atuou lá por algum tempo, eu não a conheci, ela foi afastada na época por ter se apropriado indevidamente da proposta, do projeto de hospitalização escolarizada e ter feito, juntamente, com um jornal local, uma matéria onde ela intitulou-se a grande responsável pelo projeto e permitiu que o jornal, de certa forma, apresentasse a matéria como sendo ela a grande pensadora, a pessoa que teria implantado isso no hospital, o que não foi verdade, ela apenas desenvolvia o projeto, ela não era a autora. Ela havia sido afastada por esse equívoco, por essa situação.

Eu - Então, havia um projeto inicial da [Assistente Social], é isso?

Prof. - A [Assistente Social em questão] era chefe do Serviço Social no Hospital Pequeno Príncipe e professora do curso de Serviço Social da Pontifícia Universidade Católica, por essa atuação no Serviço Social do Hospital e na área de pesquisa da Pontifícia Universidade Católica ela percebeu essa necessidade de implantar um projeto dentro do hospital, projeto esse que foi a tese de mestrado dela, onde ela propõe o atendimento pedagógico às crianças hospitalizadas. Então o projeto inicial existe, é algo registrado em cartório, existe toda a fundamentação, a base de tudo é esse projeto.

Eu - E desse projeto que saiu o convênio com o Estado?

Prof. - Sim, ela propôs junto à Secretaria Estadual de Educação, bem como à Secretaria Municipal de Educação um convênio para que ambas as secretarias 
cedessem profissionais, no caso professoras para atuarem dentro do Hospital Pequeno Príncipe.

Eu - Qual era a sua função no hospital?

Prof. - Eu era professora, eu fazia atendimentos às crianças, quando possível numa sala que havia no início. Inicialmente havia uma sala para as crianças que poderiam se locomover, com o passar do tempo aquele espaço deixou de existir. Os atendimentos eram na sala de aula ou eram no leito ao lado da criança. Com o passar do tempo os atendimentos passaram a ser nas enfermarias, ao lado da cama/leito da criança.

Eu - Com quais outros profissionais você trabalhava no hospital?

Prof. - Quando eu ingressei em 1990 havia lá uma professora da Rede Municipal de Educação, professora Vânia, ela trabalhou comigo no ano de 1990, após isso em 1991 entrou a professora Flávia e em seguida a professora Yara, todas da Rede Municipal, da Rede Estadual, apenas eu.

Eu - Essa professora Vânia já estava quando você começou ou começou depois de você?

Prof. - A professora Vânia já estava, ela fazia parte do convênio com a Secretaria Municipal de Educação - SME.

Eu - Existe uma equipe multidisciplinar na educação hospitalar no hospital infantil em Curitiba? Que você relatou que você trabalhava com outras professoras, além das professoras, quem mais atuava? Tinha uma equipe, assim?

Prof. - Durante minha atuação como professora, mantive contato frequente com os profissionais da área Médica, Enfermagem, Serviço Social e Psicologia. Mais especificamente trabalhei em equipe multidisciplinar na clínica de Nefrologia, onde a dinâmica de atendimento previa aqueles encontros mensais, após as consultas dos pacientes, quando os profissionais das áreas citadas se reuniam para falar de cada caso e avaliar a condição do paciente/aluno, então naquele momento eu como professora participava das reuniões, porque era um atendimento mais global onde havia a possibilidade de planejamento de atuação, se havia a necessidade de visita domiciliar por parte do assistente social, se o psicólogo percebia que havia a necessidade de um acompanhamento mais específico e de minha parte se havia a necessidade de visita, de acompanhamento junto à escola.

Eu - Você comentou dos professores da SME, vocês trabalhavam juntos?

Prof. - Não, houve sempre uma divisão.

Eu - Como era essa divisão?

Prof. - No Hospital Pequeno Príncipe havia sempre uma professora da Rede Municipal e uma da Rede Estadual de Educação, a divisão era feita por clínica, cada profissional ficava responsável por suas respectivas clínicas de atendimento e crianças/estudantes ali internado. Eu atuava na Nefrologia e na Ortopedia, também em alguns momentos dividíamos as crianças e da Clínica Cirúrgica, quando havia um número elevado, mas era sempre feita uma divisão. Nós não dividíamos alunos, dividíamos clínicas.

Eu - Ah! Certo!

Prof. - Não dividíamos o mesmo aluno, havia sim, dentro de uma clínica a divisão por volume de alunos. O aluno não era atendido paralelamente por duas professoras, havia sempre uma professora que acompanhava o caso daquela criança por conhecer especificamente a condição.

Eu - Que séries essas crianças que você atendia estavam?

Prof. - Todas as séries do ensino primário, na época, 1aa a $4^{a}$ séries.

$\mathrm{Eu}$ - As outras professoras também atendiam essa faixa etária? 
Prof. - Sim, era a mesma faixa etária. Não havia distinção alguma.

Eu - Quem eram esses alunos da Educação Hospitalar deste período? Quais as experiências que eles relatam com relação à Educação Hospitalar na qual eles tiveram aula no período do internamento? Você lembra? Assim, pra me dizer? Tinha um padrão de aluno?

Prof. - Devido ao tempo que se passou, não tenho mais contato com os alunos da época, porém existe uma aluna com a qual mantive contato recentemente, a $\mathrm{CL}^{185}$, com quem podemos vir a conversar posteriormente, mas o que se percebia na época através das crianças é que o atendimento gerava um grande conforto emocional para elas, só o fato de saberem que estavam amparadas pedagogicamente gerava um conforto para elas e consecutivamente para as famílias.

$\mathrm{Eu}$ - Quais as ações efetivas que desencadearam na Educação Hospitalar Paranaense?

Prof. - A base de todo o trabalho hospitalar é a tese, o projeto da Prof ${ }^{a}$./Assistente Social [...]. Não existe outra referência, se não houvesse uma cabeça pensante que percebesse aquela lacuna existente, e que havia a necessidade de implantar aquele trabalho, ele não teria surgido. A base toda é o projeto.

Eu - Você comentou da professora da SME que já estava lá quando você começou. Você sabe de quando é o convênio da prefeitura? Ou não teve convênio, também foi uma negociação com eles?

Prof. - Eu não tenho essa informação de forma precisa. Penso que a [Assistente Social] buscou esse termo de cooperação técnica ao mesmo tempo, no mesmo momento, a concessão de profissionais é que talvez tenha sido em datas diferentes. Não tenho esses dados mais precisos.

Eu - A professora Mirta, recentemente em sua qualificação de mestrado na PUC/PR, comentou algo sobre isso.

Prof. - Acredito que ela tenha dados bem precisos através da pesquisa que fez, porque ela é da Rede Municipal de Educação e especificou a atuação das professoras da SME.

Eu-É.

Prof. - Dentro da Rede Municipal de Educação quem poderia responder isso precisamente seria a [professora municipal ${ }^{186}$ ]. De minha parte, posso me responsabilizar pelos dados que lhe apresentei pelos meus contratos.

Eu - Sim.

Prof. - Na SEED tenho as informações desde 90. A professora que citei, anterior a mim, não sei dizer exatamente a data de concessão dela, a data de sua saída. Isso teria ficado registrado no jurídico da Secretaria de Educação, porque quando eu ingressei, quando comecei a trabalhar todos os contratos, e toda a documentação eram guardados no departamento jurídico, era lá que eu ia para assinar, para entregar, para retirar, porque eu mesma fazia isso. Eu retirava na secretaria, levava para os diretores do hospital assinarem, devolvia a documentação, mas não tenho como precisar datas.

Eu - Estou te questionando, porque até nas publicações dos jornais tudo começa em 1988 e tudo com a indicação dos professores do Estado. A prefeitura só vai aparecer depois de 90.

Prof. - Eu creio que a SEED tenha aceitado a ideia da [Assistente Social] antes do município, justamente por eu ter percebido na época que fui convidada, isso no ano

185 Para preservar a identidade da estudante, optei por utilizar somente as iniciais no lugar de seu nome. 186 Para preservar a identidade da professora, no lugar do nome optei por deixar professora municipal ou Professora 2 por ela ter sido a segunda professora a ceder a entrevista para a pesquisa. 
de 90, a grande preocupação da superintendente, Hôda Salamuni. A preocupação dela era grande para que houvesse esse atendimento com qualidade, com dedicação, que era o que ela me pedia e achava que eu correspondia. $E$ justamente a preocupação dela também era proveniente do acontecimento anterior que foi justamente a professora ter sido designada para desenvolver o projeto de autoria da [Assistente Social] e ter se intitulado autora desse projeto. Então a preocupação era muito grande com a seriedade do trabalho, com o desenvolvimento dele. E ela deixou muito claro para mim, na época, que eu iria desenvolver a prática de um projeto, mas a teoria dele já havia, já tinha essa base, que eu não iria colaborar na parte de desenvolvimento, tanto é que, posteriormente, quando a [Assistente Social] passa a escrever um livro sobre a pedagogia hospitalar junto com a professora Elizete Matos, toda a base pedagógica eu subsidiei com informações também. Isso porque, elas tinham a base teórica da pesquisa, a teoria, mas as questões pedagógicas do como fazer, a prática não. Então houve também uma pesquisa de campo no hospital.

Eu - Interessante. Bom, em que medida o projeto de educação hospitalar, seus professores, alunos e atendimentos se efetiva no universo paranaense?

Prof. - Atualmente existe uma estrutura específica para esse projeto, tanto no município (SME) como no estado (SEED). Ele é reconhecido, é de conhecimento de todos os profissionais dentro da área hospitalar que ele existe. Isso tanto com profissionais da SME, quanto com profissionais da SEED. Então, todos os profissionais que atuam dentro dos hospitais onde esse projeto é desenvolvido, sabem da existência do projeto. Na época que iniciei havia profissionais de dentro do hospital que nem sabiam que aquele projeto existia. Eles só tomavam conhecimento quando me viam, quando viam a atuação das estagiárias, trabalhando com as crianças. Não era algo regulamentado, não era algo tão formal, não havia o reconhecimento. Hoje sim.

Eu - Já que você comentou das estagiárias, você quer falar como que era esse trabalho das estagiárias, antes da gente continuar com a 17?

Prof. - Podemos sim começar a 17 - Como eram esses atendimentos? No início os atendimentos se davam de maneira improvisada, de acordo com as necessidades e possibilidades de cada aluno.

Eu - Sei

Prof. - A atuação das estagiárias dentro do Hospital Pequeno Príncipe ocorreu quando, por parte do Colégio Sagrado Coração de Jesus, a então Coordenadora do Magistério, que na época era a professora $\mathrm{MSB}^{187}$, nos procurou. Inicialmente procurou a [Assistente Social], por ser ela a chefe do Serviço Social, pedindo o espaço do Hospital Pequeno Príncipe como campo de estágio para as estudantes do Magistério. Então, a [Assistente Social] me chamou e perguntou sobre minha disponibilidade para supervisionar o estágio dentro do hospital, tendo em vista que a minha função era professora e não supervisora, que isso ficaria a meu critério, tendo em vista que não haveria vínculo empregatício, não haveria remuneração para aquela função, mas me propus na época a fazê-lo, a supervisionar o estágio por acreditar que aquilo iria contribuir muito no cotidiano das crianças, porque daria uma abertura maior, uma possibilidade maior quanto ao volume de atendimento. E mesmo que o trabalho não ficasse efetivamente no campo pedagógico, haveria sim, uma estimulação, não ficaria no campo da recreação, mas entraria como um estímulo para as crianças, por mais que as atividades não fossem tão pedagógicas na época, sistematizadas de acordo com os conteúdos, isso eu trabalhava com as crianças, eu selecionava as

187 Para preservar a identidade da professora, optei por utilizar somente as iniciais no lugar de seu nome. 
atividades e distribuía o que era possível para as estagiárias. Elas não elaboravam nada, elas apenas aplicavam, eu separava as atividades e elas aplicavam e trabalhavam com as crianças.

Eu - Elas iam quantas vezes na semana? Você lembra?

Prof. - Duas vezes por semana, porém a carga horária que elas desenvolveram, isso não lembro, só lembro que eram duas vezes na semana porque eu organizava meus horários de acordo com aquela necessidade.

Eu - Quantas estagiárias iam mais ou menos, você lembra?

Prof. - Os grupos eram de 10, mais ou menos.

Eu - Por dia que elas iam?

Prof. - Por período. Elas faziam magistério pela manhã e iam à tarde ao hospital.

Eu - Um grupo significativo. lam umas 20, então na semana?

Prof. - Não.

Eu - Umas 10 repetiam as duas vezes.

Prof. - Repetiam, eu creio que mais ou menos o grupo de 10 havia rodízio. Elas faziam estágio, cumpriam a carga horária e depois elas abriam espaço para outro grupo. Quem poderia responder melhor como foi essa organização é a própria professora Maria Silvia, porque lembro que eu controlava a frequência delas e depois repassava os meus apontamentos em relação as atitudes, em relação a atuação, em relação as reações emocionais, porque algumas se alteravam muito emocionalmente, por se depararem com situações adversas, a condição de cada criança. E quanto a isso eu já estava preparada porque eu já atuava ali há mais tempo, era um choque para elas em alguns momentos. Elas passavam mal, elas queriam desistir do estágio. Então, tudo isso eu relatava e ajustava com a professora Maria Silvia, nós nos encontrávamos, tínhamos as nossas reuniões quando uma passava para a outra as informações, as intervenções necessárias em relação à cada estagiária e como resolver aquilo.

Eu - Com relação ao atendimento, você disse que no início era improvisado. Como assim improvisado? Como que você descreveria isso?

Prof. - O improvisado?

Eu-É.

Prof. - Havia um projeto, a parte de pesquisa, mas não havia uma sistematização, uma metodologia para o desenvolvimento daquele projeto. Havia o projeto em si, porém como ele aconteceria, quanto a isso não havia nada escrito. Aprendi a trabalhar, trabalhando, aprendi a fazer, fazendo. Então, não havia material específico. Eu criei uma base de consulta, busquei livros nas editoras, tinha meu acervo dentro de um armário no serviço social, onde eu pesquisava atividades e selecionava para as crianças. Não havia nenhum referencial, não tinha de onde tirar atividades. Eu tinha que buscar, tinha que pesquisar, tinha que elaborar.

Eu - Sim. E como você decidia que tipo de atividade você ia dar para um aluno, qual atividade ia dar para um aluno? Como que vocês sabia? Como que você preparava esse material?

Prof. - Baseada nos planejamentos da própria Secretaria de Educação que separava os conteúdos para cada série. Então eu seguia um roteiro como se fosse em uma escola, como se fosse em uma sala de aula. Eu sabia que aquela criança, se estivesse em sala de aula, estaria estudando alguns conteúdos pertinentes ao nível, a série e ao bimestre na qual estava. Quando havia a possibilidade eu entrava em contato com a escola e a escola me fornecia essa orientação, essa programação, esse planejamento. O planejamento somente, porém não as atividades. As atividades eram escolhidas e selecionadas por mim para que as crianças atuassem. Eu fazia isso. Eu 
levava os livros para as enfermarias, mostrava figuras nos livros, as ilustrações, dava as explicações e as crianças desenvolviam atividades. Quando eram crianças que ficavam internadas em longa permanência eu preparava um caderno e as atividades ficavam no caderno. Quando eram de internamento de curta duração eu fazia em folhas separadas, sempre arquivava isso em envelopes e quando as crianças voltavam para as escolas, elas levavam as produções, por isso não ficavam no hospital. Raramente ficava uma ou outra produção de criança. As crianças voltavam e mostravam para as professoras de origem, para as escolas de origem o que elas produziram enquanto estiveram internadas. Até para que as professoras pudessem sim, elaborar avaliações partindo dos conteúdos que foram trabalhados.

Eu - Então você acabou respondendo o 18, você tem registros desses atendimentos? Prof. - No meu acervo pessoal, nada. Tudo o que foi desenvolvido, trabalhado dentro do Hospital Pequeno Príncipe durante minha atuação, de 90 a 98, ficaram no hospital. Nunca retirei nada, nem relatórios. O que era necessário retirar foi para levar para a SEED por algum momento por solicitação. Tudo ficou lá.

Eu - E você comentou que você foi no hospital, na Assistência Social e não tem nada guardado lá. É isso?

Prof. - Não, não existe nada registrado, nada guardado. Até porque hoje, o trabalho dentro do Pequeno Príncipe, não é mais do comando do Serviço Social. Existe lá, de maneira estruturada, um setor; Educação e Cultura que tem outro encaminhamento, uma outra proposta.

Eu - Bom, planejamentos então também não ficaram com você. Você planejava em cima daquilo que o Estado Ihe passava? Você já tinha esse conhecimento dos planejamentos gerais, do currículo do Estado.

Prof. - Sim, do currículo sim.

$\mathrm{Eu}-\mathrm{E}$ a partir disso você realizava as atividades.

Prof. - Sim, porque quando eu ingressei no hospital eu já tinha uma bagagem como professora. Eu já havia sido estagiária da SEED por dois anos, em 87 e 88, eu já atuava em escolas estaduais como estagiária de 1a a $4^{a}$ série, então já tinha uma bagagem. E no ano de 89 eu fui professora regente numa escola da Rede Estadual. Então eu já tinha esse contato, já sabia como funcionava e na época não havia essa flexibilidade de conteúdos que hoje a nossa educação propõe, era uma sistematização e era algo mais rígido. Não havia muita variação de conteúdo. Sabia-se o que o primeiro ano iria trabalhar no decorrer do ano, os conteúdos eram separados em bimestres, sabia-se o que era conteúdo de $2^{\underline{a}}$ série, de $3^{\underline{a}}$ e de $4^{\underline{a}}$. Na realidade eu seguia roteiros. Buscava atividades dentro dos livros, mas seguia roteiros preestabelecidos pela própria Secretaria de Educação.

$\mathrm{Eu}$ - Certo! Onde que você atendia? Você comentou que atendia as vezes no leito e as vezes na sala.

Prof. - No ano de 1990 havia sim uma sala pequena com uma mesa e quatro cadeiras, onde de maneira agendada nós poderíamos levar crianças para o atendimento, porém isso tinha que ser feito de uma maneira organizada, porque eu não poderia atender uma criança de $4^{\underline{a}}$ série e a minha colega de trabalho atender uma criança de $1^{\underline{a}}$ série, onde ela estaria alfabetizando no mesmo momento que eu estaria trabalhando outro conteúdo, isso iria interferir e atrapalhar no desenvolvimento das atividades. Então nós combinávamos um período de tempo para que cada qual fizesse uso da sala com as crianças, para os alunos que poderiam sair das enfermarias. Isso era benéfico emocionalmente, as crianças se locomoviam, saiam da cama e não se sentiam tão aprisionadas ao leito. Então isso era bom pra crianças que podiam. As crianças que não podiam sair do leito, os atendimentos eram feitos também dentro de uma 
organização, havia um cronograma de atendimento. E mais ou menos em um período de uma ou duas horas para cada criança, no próprio leito. Depois de 1990, essa sala deixou de existir por uma questão de reforma e não mais a resgatamos, passamos sim a planejar e fazer a nossa organização junto ao Serviço Social, na mesma sala e atendimento somente nas enfermarias.

Eu - Os setores, você disse que atendia a Nefrologia e a clínica Ortopedia?

Prof. - Quando ingressei no HIPP, a professora que lá já atuava, ocupava-se da Clínica Cirúrgica e Cardiologia, por sua escolha. Fiquei então, responsável pela Nefrologia e Ortopedia. Em alguns momentos, quando a Clínica Cirúrgica ficava sobrecarregada, havia uma divisão, então eu atuava lá, também.

$\mathrm{Eu}$ - E o atendimento era praticamente individual, de criança para criança?

Prof. - Individualizado. Eu explicava a atividade, enquanto um aluno estava desenvolvendo sua atividade eu me dirigia até outra criança, eu alternava as explicações, eu dava um tempo para cada criança, sozinha, fazer as tentativas de desenvolvimento, de resolução da atividade, depois retornava para conferir e corrigir. Se havia mais de uma criança na enfermaria, eu conseguia atender até duas crianças ao mesmo tempo. Então me organizava para ficar metade do período na Nefrologia, metade do período na Ortopedia, por exemplo na segunda-feira, na terça-feira eu invertia, eu atendia um pouco na Nefrologia, um pouco na Ortopedia, eu alternava. Eu tinha um cronograma, tinha uma divisão que eu previa os atendimentos para equilibrar isso, e deixar justo.

Eu - O lugar específico você já comentou da salinha e depois nos leitos. O material pedagógico ou físico específico para esse atendimento. Quando você começou a fazer o atendimento no leito, eu vi pelo jornal que tinha uma...

Prof. - Uma caixinha.

Eu - Isso, uma caixinha

Prof. - Adaptada.

Eu - Isso. Você pode falar desses materiais que você tinha lá?

Prof. - Essa caixinha, uma carteira adaptada foi uma iniciativa da [Assistente Social], creio que tenha sido uma invenção dela com o diretor do hospital na época, Dr. Ivan Fontoura. Porque as carteiras já existiam, elas já haviam sido confeccionadas e pintadas com tinta a óleo, que permitia que fossem higienizadas, que fosse feita a assepsia, passavam álcool sempre que nós a levávamos para o leito eram higienizadas pelas enfermeiras para que nós pudéssemos colocar sobre a cama da criança. Tinha, também uma prancheta para que pudessem escrever. Essas caixinhas eram muito utilizadas, principalmente na Ortopedia, onde as crianças ficavam no leito, elas não se locomoviam. Então essas carteiras foram de iniciativa da [Assistente Social]. Ela não só escreveu o projeto, como achou a solução para essas crianças.

Eu - Era como se fosse uma pequena carteira escolar?

Prof. - Era uma carteira que se adaptava ao corpo e tinha uma pranchetinha. Então, ali a criança conseguia colocar a atividade, escrever, bem como servia de suporte para um livro, para uma leitura.

Eu - Certo. Além disso, então, ela tinha essa caixinha e o material que você levava depois. A folha, o livro...

Prof. - Isso, os lápis de cor, o lápis, o apontador, eu levava dentro de uma outra caixa organizadora, um volume de atividades, o que eu poderia necessitar naquele dia.

$\mathrm{Eu}$ - Havia algum registro ou relatório das suas atividades no hospital? Se teria cópias? Você também respondeu que não ficou nenhum registro...

Prof. - Havia sim, relatórios, em linhas bem gerais, nada específico do que eram os conteúdos, isso a SEED não tinha necessidade de verificar, somente solicitava o 
volume de crianças que haviam sido atendidas nos períodos, anualmente ou semestralmente para que se justificasse a concessão da profissional, para manter o Termo de Cooperação Técnica (TCT).

$\mathrm{Eu}$ - O termo era renovado anualmente?

Prof. - Sim. Anualmente.

Eu - Aí eu até vi em alguns desses processos a relação de crianças que vocês atendiam.

Prof. - Essa relação de crianças sempre saia do Hospital Pequeno Príncipe supervisionada pelo Serviço Social. Isso tudo era feito em conjunto com a [Assistente Social]. Ela enquanto chefe do Serviço Social assinava e supervisionava todo e qualquer documento.

Eu - Como era a avaliação das crianças atendidas?

Prof. - A avaliação não ficava a cargo do projeto. Nós não avaliávamos. Nós apenas dávamos suporte no desenvolvimento de atividades pedagógicas. A avaliação ficava a cargo da escola, quando a criança retornava. Ou em alguns momentos, se a escola solicitasse e enviasse a avaliação, nós aplicávamos, porém não corrigíamos, mandávamos para a escola. A questão da avaliação específica, nota, esse controle ficava por conta das escolas.

Eu - Havia algum contato com a escola de origem destas crianças? Ou um retorno sobre as atividades realizadas por eles junto à escola quando o aluno tinha alta? Como que era esse... Na verdade, você já comentou que algumas escolas você entrava em contato, eles passavam. Agora você falou que algumas escolas mandavam avaliação, vocês aplicavam e devolviam.

Prof. - Quando as escolas eram da própria capital, em Curitiba, tornava-se mais fácil. Em alguns momentos cheguei a fazer visita às escolas, tive contato com as professoras, fui até a escola, buscar material. Em alguns casos trabalhei com as crianças, com os próprios materiais da escola, quando a escola fornecia e se predispunha a separar isso para mim. Tudo era muito relativo. Como não era sistematizado, não havia obrigatoriedade de nada. Algumas escolas se empenhavam mais, houve até caso de visitação de diretor, na época de orientador educacional ou supervisor, que hoje denominamos como pedagogos. Então, era muito relativo, assim como profissionais da escola foram até o hospital fazer visita à criança e levar atividades, eu também em alguns momentos, fui até a escola buscar subsídios para trabalhar com as crianças, quando eram da capital. Quando não havia reciprocidade no contato, porque também houve isso, momentos em que a escola dizia: "não, quando o aluno voltar, daremos conta aqui". Porque ela estava amparada por lei com atestado médico. Então havia isso também de não haver reciprocidade por parte da escola. Quando eram crianças oriundas de outras cidades, havia inicialmente a tentativa de localização da escola, eu tinha uma relação das escolas públicas do Estado do Paraná, que consegui através da Secretaria de Educação. Eu tentava contato telefônico, correspondência, que também saia com envelope e timbre do hospital, sempre assinado pela [Assistente Social], eu elaborava o texto, ela enviava, porque como eu estava lá para desenvolver o projeto e ela era a grande responsável, sempre passava por ela e a escola às vezes dava retorno, às vezes não, às vezes, quando chegava algum material a criança também já estava recebendo alta, mas nem por isso ela ficava sem atendimento, sempre atendimento havia, nunca uma criança permaneceu no hospital sem algum tipo de atendimento pedagógico, por isso era improvisado, porque não havia essa sistematização.

Eu - Certo. Quais os materiais educacionais e pedagógicos utilizados no Hospital Infantil de Curitiba na Educação Hospitalar? 
Prof. - Quais os materiais? Você quer que eu fale especificamente?

Eu - No caso, você comentou já dos livros, das atividades que você fazia...

Prof. - Eu buscava esses livros nas editoras. Eu buscava volumes para ter como base, mas não tinha livros para distribuir para as crianças, até porque, cada criança tinha uma escola diferente com escolhas de materiais pedagógicos também distintos. Então eu tinha no meu acervo, o material básico, folhas, lápis, borracha, apontador, cadernos e livros nos quais eu buscava atividades.

Eu - Tinha livros paradidáticos?

Prof. - Sim.

$\mathrm{Eu}$ - Jogos?

Prof. - Na época, jogos... Bem poucos, porque naquele período não havia nem produção. Hoje se tem uma gama muito intensa de materiais, hoje se faz isso, trabalha-se jogos dentro da sala de aula, isso faz parte da rotina do professor, na época isso era algo inacessível, poucas pessoas tinham acesso a isso e não se tinha na ocasião conhecimento que jogos fosse algo tão importante, se usava jogos mais no campo da recreação.

Eu - Lembra-se de algum aluno ou alunos que tenha ou tenham the marcado no tempo que trabalhou no hospital? Gostaria de contar o que foi marcante para você? Você comentou da $\mathrm{CL}$ que você...

Prof. - Encontrei recentemente

$\mathrm{Eu}-\ldots$ encontrou recentemente. Você quer comentar alguma coisa sobre ela?

Prof. - Sim, podemos falar sobre ela, porque é um referencial vivo, um referencial que poderemos depois consolidar as informações, dentre tantos alunos que passaram por lá, alunos que atendi e que me marcaram, porque existe sim um trabalho no qual os conteúdos pedagógicos são trabalhados, porém existe uma afetividade que envolve todo esse trabalho, porque se não houver afetividade você não atinge a criança. $A$ área hospitalar acima de tudo sugere que o profissional tenha uma percepção do que fazer, como fazer e quando fazer, mas isso não estava registrado em lugar nenhum, era puramente percepção. Quando eu chegava e via o estado da criança, o que ela tinha para oferecer naquele momento de acordo com o estado clínico dela, de acordo com o exame que ela tinha feito, de acordo com o estado emocional dela. O que fazer, como fazer e quando fazer era uma questão de percepção, por isso não poderia ser qualquer pessoa, porque não era um trabalho comum. A aluna, $C L$ era uma paciente da Nefrologia, ela fazia Hemodiálise duas ou três vezes por semana, ela tinha vindo de um outro estado, do Estado de Santa Catarina, porque lá não havia um atendimento específico para o caso dela, ela havia perdido a audição com o passar do tempo por excesso de medicamentos, por não terem conseguido diagnosticar especificamente a questão da insuficiência renal dela, ela tornou-se uma insuficiente renal crônica, ela passou por transplante, e ficou muito tempo em tratamento dentro do hospital, com o passar do tempo ela acabou estudando no Colégio Sagrado Coração de Jesus através da concessão de uma bolsa de estudos, porque precisava desse atendimento, era uma criança muito carente economicamente, a mãe teve que alugar uma casa em Curitiba para ficar aqui mantendo esse atendimento de saúde. $O$ atendimento hospitalar já não dava mais conta da parte pedagógica, eu não conseguia atendê-la na totalidade, então conseguimos uma bolsa de estudos. Ela ia num período para a hemodiálise, ao sair da hemodiálise, se alimentava no hospital e ia para a escola. Foram muitos casos que marcaram, porém esse, mais especificamente posso relatar por se tratar de uma criança que hoje é adulta e que também pode dar subsídios, elementos para esta pesquisa. 
Eu - Ela, você atendeu? Nesses períodos de internamento dela, você chegou a atendê-la enquanto professora?

Prof. - Eu atendi, e depois a [professora municipal] também a atendeu.

Eu - E hoje ela trabalha?

Prof. - Trabalha. Ela trabalha, acabou ficando no próprio hospital como funcionária. Trabalha no Hospital Pequeno Príncipe. Conseguiu concluir o Ensino Médio. Ela está buscando hoje uma área, gostaria de fazer curso superior, mas tem muita dificuldade financeira.

Eu - E ela é transplantada hoje?

Prof. - Sim.

Eu - Não faz mais tratamento?

Prof. - Não, não faz mais tratamento.

Eu - Não o que ela fazia.

Prof. - Não, não da mesma forma. Não posso especificar qual o nível de tratamento que ela faz.

Eu - Você lembra de ter atendido essa menina enquanto ela fazia hemodiálise lá no hospital?

Prof. - Sim. Eu a atendia durante o período de hemodiálise, enquanto ela ficava na máquina, eu ao lado, fazia atendimento.

Eu - Bom, em que medida o projeto de Educação Hospitalar, seus professores, alunos e atendimento se efetiva no universo paranaense?

Prof. - Hoje o projeto é estruturado, hoje existem mais profissionais designados, em vários hospitais, em Curitiba especificamente, eu creio que são 8 hospitais que possuem esse atendimento, já no Estado do Paraná, não tenho essa informação de quais hospitais adotaram a hospitalização...

Eu - Como que a assistente social que implantou o projeto de escolarização hospitalizada efetivou essa implantação?

Prof. - Inicialmente a [Assistente Social] fez a tese, e a defendeu, logo após ela apresentou isso para ambas as secretarias, de Estado e do Município, havendo o termo de cooperação técnica, o convênio, a escolarização estava implantada dentro do Hospital Pequeno Príncipe de forma embrionária, de forma experimental. Foi assim que aconteceu.

Eu acho que hoje, acho que paramos agora. Paramos na 29?

Eu - Isso. Vamos parar aqui?

Prof. - Paramos para. A gente faz mais um encontro e daí conclui?

Eu - Pode ser.

Prof. - Até lá, porque agora eu tenho que ir para a sala de aula.

Eu - Era isso que eu estava preocupada. 9:20 é seu horário? Então tá, a gente continua num outro dia.

Entrevista $3^{\circ}$ dia

Eu - Hoje é dia 29 de agosto de 2017 e a gente vai continuar a entrevista com a professora [estadual] a partir da questão 29: Como a Assistente Social que implantou o projeto da Escolarização Escolarizada efetivou essa implantação?

Prof. - No momento em que eu fui convidada para atuar no Hospital Pequeno Príncipe toda a parte de implantação já havia sido feita. O Termo de Cooperação Técnica, então só fui designada e a partir daquele momento, eu prestava serviço mensalmente, assinava o ponto e levava minha folha ponto à SEED ou ao NRE, mas toda a documentação, toda a implantação já havia sido feita anteriormente, pois outra professora, anterior a mim já tinha atuado no hospital, ela havia sido afastada, mas o Convênio já estava no Departamento Jurídico. 
Eu - Certo. Quais os modelos educacionais direcionados ao atendimento das crianças e dos adolescentes que podem ser observados nos atendimentos da Escolarização Hospitalar no hospital infantil de Curitiba?

Prof. - Quando ingressei no hospital infantil em 1990, a forma de trabalho, o método ainda era tradicional, se alfabetizava pelo método da silabação, já se falava na época em ciclos, "ventilava" a teoria da Emília Ferreiro, já se estudava em torno disso, mas era no método tradicional. Então, as crianças eram atendidas de acordo com a possibilidade do dia, da possibilidade do estado clínico e nós seguíamos o mesmo roteiro, o mesmo planejamento tradicional das escolas. Os trabalhos eram planejados em torno da programação bimestral, nós fazíamos um roteiro e procurávamos seguir aquilo que era tradicionalmente desenvolvido na época.

Eu - De que modo se apresenta os progressos no atendimento da Escolarização Hospitalar no hospital infantil de Curitiba? Você conseguia ver progressos?

Prof. - Nós avançávamos

à medida que todo o corpo clínico ia tomando conhecimento do que estava acontecendo, percebia a importância do trabalho e permitia uma abertura maior para a atuação, não havia mais uma resistência por parte dos médicos. Nós tínhamos mais liberdade para trabalhar com as crianças. Pouco a pouco eles foram permitindo o uso de aparelho que produzisse som, os lápis coloridos para pintura, eles foram dando um pouco mais de abertura por perceberem que as crianças demonstravam interesse, se animavam. As psicólogas também, em reuniões manifestavam que aquilo produzia nas crianças uma segurança, um bem-estar. Então o corpo clínico foi aceitando mais a atuação do projeto, de quem trabalhava no projeto, no caso eu e uma outra professora. Isso foi um progresso muito grande, a aceitação por parte do corpo clínico. Eu - Você conseguia ver progresso também nas crianças que eram atendidas?

Prof. - Sim, as crianças manifestavam o quanto para elas era importante serem atendidas, quando eu chegava nas enfermarias, isso lembro bem, elas estavam aguardando minha chegada. A aula, para elas, fazia parte do tratamento hospitalar, elas aguardavam o momento de serem atendidas. $\mathrm{O}$ atendimento da professora para elas era muito importante. Isso eu lembro!

Eu - Quais as questões político pedagógicas podem ser observadas. Poderia me indicar... Bom, ali é a questão da indicação de alunos. Mas que questões político pedagógicas você conseguia perceber? Tinha isso?

Prof. - Mais especificamente como? Acho que eu não compreendi essa pergunta.

Eu - A questão assim, você falou um pouco do interesse dos médicos. O interesse da administração do hospital? A questão pedagógica: as escolas. Havia interesse, as escolas começaram a perceber a importância do atendimento?

Prof. - Sempre que houve a possibilidade de entrar em contato com as escolas, quase sempre isso foi muito bem visto, houve muita aceitação. Na época, o grande problema era o contato, porque as crianças oriundas do interior, muitas escolas não possuíam telefone, as crianças não conseguiam dizer exatamente onde estudavam. Não tínhamos internet como hoje, para entrar em contato com as escolas era algo difícil, através de cartas, era demorado, via telefone, às vezes a criança estudava num período e eu trabalhava em outro, para entrar em contato com a professora. $O$ contato era o maior desafio. Então eu trabalhava independente do contato. O contato era secundário para mim, porém quando havia a efetivação desse contato, as escolas quase sempre recebiam isso muito bem, com raras exceções. Só que o projeto era pouco conhecido, pouco divulgado, era algo incomum para a época, sempre isso soava como algo raro. Então, a valorização do trabalho havia, mas de uma maneira muito discreta. Não era expressiva na época. 
Eu - A questão política da Secretaria. Havia interesse que o....

Prof. - O projeto se mantivesse. Sim. Atuei lá os 9 anos e nunca se pensou em não ceder, não haver essa parceria. Houve o desinteresse por parte da mantenedora SEED quando na ocasião da gestão do Governador Jaime Lerner, quem assumiu a Secretaria foi uma profissional, especificamente Secretária Alcione Saliba, que não viu relevância naquele projeto, naquele Termo de Cooperação Técnica. Ela não julgou o trabalho relevante me reabsorvendo e me pedindo que voltasse para a sala de aula. O meu retorno para a sala de aula foi por determinação da Secretaria de Educação, mais especificamente da Secretária que não viu importância naquele trabalho. Ela não avaliou aquilo como algo relevante, por isso houve a interrupção do trabalho, que anos mais tarde retornou mais institucionalizado como o SAREH.

Eu - Você poderia me indicar alunos que tenham sido atendidos para que eu possa entrar em contato com eles e solicitar a participação nesta pesquisa?

Prof. - Eu só tenho hoje uma única indicação, que o resgate dessa aluna foi por intermédio da [professora municipal], através do trabalho dela eu reencontrei uma aluna no momento da qualificação da Mirta e poderia indicá-la sem nenhum problema. $\mathrm{Eu}$ - Como foi uma das pioneiras ou talvez a pioneira neste trabalho tão diversificado, teria alguma consideração a fazer sobre as dificuldades que encontrou neste novo ambiente de trabalho que se delineou nos seus dias profissionais?

Prof. - Na ocasião da minha atuação lá?

Eu - Sim.

Prof. - O maior desafio para mim foi atuar como professora na área hospitalar sem nenhum preparo, porque eu não passei por nenhum curso, por nenhuma disciplina, por nenhuma capacitação. Então eu aprendi a fazer, fazendo. Eu não tive sequer orientação de uma profissional, porque na época isso não era conhecido, para isso não havia uma preparação, então o que eu tenho como forte em mim foi minha superação, porque no início, eu sequer aceitei o convite, eu não queria atuar no Pequeno Príncipe por me julgar despreparada para aquele ambiente e inexperiente para me deparar com situações nas quais e com as quais eu nunca havia pensado. Hoje, quem ingressa na área hospitalar entra preparado teoricamente, vai por vontade, é uma escolha, e sabe que tem essa inclinação. Eu percebi a minha inclinação depois, fui percebida antes, e me dei conta de que aquilo realmente era algo para o qual eu tinha uma sensibilidade ao trabalhar com as crianças no período em que já estava atuando, mas de início tive resistência, porque era um desafio muito grande, era um ambiente alheio ao ambiente escolar. Quando estudei para ser professora, minha formação foi para trabalhar dentro de uma sala de aula, dentro de um "quadradinho", era tudo muito tradicional. E ali, durante os anos que atuei, era tudo muito flexível, não se tinha certeza alguma, nem mesmo da continuidade do trabalho, porque durante algumas vezes, eu cheguei para trabalhar com uma criança e me disseram que ela não estava mais lá, não porque recebeu alta, mas porque não resistiu ao tratamento.

Eu - Você acredita que esse período de trabalho no hospital lhe acrescentou alguma coisa em sua vida pessoal ou profissional? Se sim, poderia me dizer o que foi?

Prof. - Profissionalmente aprendi muito, trago isso para minha vida até hoje, essa flexibilidade na questão do trabalho, justamente pelo que o ambiente sugeria e exigia e para a vida pessoal foi uma lapidação de alma, porque trabalhar como professora com aquelas crianças naquela época era algo que eu nunca havia imaginado na minha vida e aprendi muito, porque uma criança já nos ensina, mas uma criança num momento de doença apresenta uma condição muito diferente. Ela não tem consciência do que está acontecendo e, talvez por isso não se abata tanto, mesmo 
em situações tão graves, mas o exemplo de superação que essas crianças me deram foi sempre muito tocante ver o progresso delas na questão de saúde e na vontade que elas tinham de trabalhar as questões pedagógicas, porque elas tinham sempre muita vontade, elas pediam, mesmo quando não era o dia, o horário, o momento delas.

Eu - Você trabalhou somente neste hospital ou também chegou a trabalhar em outros hospitais?

Prof. - Por um período curto, alguns meses no ano de 2003, trabalhei no Hospital Evangélico. Fui suprir uma vaga. Houve um convite, foi uma oportunidade, pois lá eu tive contato com uma outra clínica que até então eu não havia trabalhado, a Clínica dos Queimados. Dentro do Pequeno Príncipe não havia o atendimento aos queimados e dentro do Hospital Evangélico era um atendimento específico. Durante aquele Período atuei com os queimados e na Clínica Cirúrgica.

Eu - Você tem interesse em voltar a trabalhar em hospitais como professora?

Prof. - Se um dia houver um convite e isso vier ao encontro das possibilidades? Foi algo que gostei muito de fazer e talvez, se isso ainda estiver no meu caminho, no meu trajeto profissional. Por que não?

Eu - Quais as melhores recordações que tem deste período?

Prof. - As crianças recebendo alta e levando seus envelopinhos para casa. Levando os envelopes das atividades que executaram durante o período que estiveram lá e recebendo alta e bem de saúde. Essa era a melhor parte do trabalho!

$\mathrm{Eu}$ - Eu queria que você falasse para mim, contasse de novo como era, descrever como era o...

Prof. - O espaço físico?

Eu - Não o espaço, a carteira!

Prof. - A carteira. Quando comecei a trabalhar no Pequeno Príncipe, a [Assistente Social] tinha mandado confeccionar algumas carteiras. Como já falei, penso que o Engenheiro que a desenhou foi seu filho, se eu não estiver enganada. Nós tínhamos aquelas carteiras adaptáveis. Eram de um material fino, uma espécie de MDF, não sei especificar, eram de madeira leve, elas foram recortadas, uma espécie de caixotes que se encaixavam ao corpo, uma mesinha que se encaixava ao corpo das crianças nas laterais e uma prancheta que dava para encaixar algo na altura do rosto. E nelas, apoiando o material as crianças escreviam, principalmente as crianças da clínica de Ortopedia, elas ficavam imóveis, não podiam se mexer, não podiam sair das enfermarias, não saiam nem da cama. Então, pensando naquelas crianças, principalmente, foi que a [Assistente Social] conseguiu encontrar a solução para assegurar o atendimento. Quando cheguei elas já estavam lá. E realmente eram grandes, mas eu as levava uma a uma para as enfermarias e era com elas que eu trabalhava. Elas não podiam ficar nas enfermarias, tinham que voltar para a sala, eram pintadas de branco, com tinta à base de óleo, porque precisavam ser higienizadas depois, era necessário passar um pano para fazer a assepsia. Então aquelas carteiras já estavam lá. E depois disso, nada mais sugestivo foi inventado. Nós usávamos também, pranchetas normais, levávamos dentro de uma caixa os materiais: lápis, lápis de cor, as folhas destacadas, os cadernos, os livros que nós tirávamos as atividades para as crianças olharem, alguns livrinhos de historinha. Enfim, isso tinha uma caixa. Era um transporte constante, na época não havia ainda cestinha de supermercado, carrinho, hoje seria bem mais fácil transportar, na época não, perdia-se algum tempo, perdia-se ou ganhava-se levando esses materiais para as enfermarias. Mas também posso falar da sala um pouquinho?

Eu - Pode. 
Prof. - No período também curto quando eu entrei no Pequeno Príncipe havia uma sala pequena. Ela tinha uma mesa, umas 4 cadeiras, uma mesa de professor, uma mesa de escritório, um telefone, um armário. Inicialmente era uma sala só para as professoras, mas isso não perdurou por muito tempo, porque o hospital estava sempre em reformas e modificações e houve a necessidade de absorver aquela sala para algum setor. Então logo após o uso daquela sala, ela foi absorvida, nunca mais nós obtivemos um espaço específico para levar as crianças. Aí sim, o atendimento era só nas enfermarias. Foi um período bem curto, um ano mais ou menos

Eu - Que teve a sala?

Prof. - É, que nós tivemos a sala.

Eu - Você gostaria de falar mais alguma coisa? Fique à vontade.

Prof. - Só tenho a agradecer a oportunidade de dar essas informações sobre um trabalho que tanto me acrescentou e estou à disposição para quaisquer outras que possam esclarecer a etapa inicial sobre um projeto de tamanha relevância para a educação.

Eu - Ah eu que agradeço!

Eu - Eu que agradeço a contribuição está sendo super valiosa, a sua memória é muito viva. Então, eu agradeço imensamente a sua disponibilidade.

Prof. - Lamento que eu só tenha a oferecer fatos que guardei na memória, porque a parte documental, a parte do acervo do trabalho especificamente, isso percebi que não existe mais. Houve mudanças, houve toda uma reformulação do trabalho, hoje ele tem outra consistência, uma nova formatação. Houve uma abertura muito grande, percebe-se que atualmente o trabalho de escolarização dentro do hospital é bem abrangente. Na realidade, a escolarização quase se fundiu com o trabalho do setor de Educação e Cultura. Então hoje, o que existe dentro do hospital é bem mais organizado, é bem mais estruturado, pensa-se no trabalho efetivamente. $\mathrm{Na}$ época não, como dizia a [Assistente Social], "nós estamos numa fase embrionária". Ela sempre usava essa expressão nas reuniões: a fase era embrionária. Então nós tínhamos que superar aquela fase para que efetivamente o trabalho nascesse. Acredito que essa gestação, essa fase embrionária demorou um longo período, mas efetivamente o trabalho nasceu e está crescendo, muito embora ele tenha outras características, outros contornos, talvez não se mantenha na originalidade do nome, mas a base foi inegavelmente a que relatei. A base é essa! Quem de alguma forma quiser dizer que inovou, é verdade, mas não dá para rejeitar a essência do trabalho que vem da proposta de autoria da [Assistente Social].

Eu - Obrigada! 


\section{Apêndice I - Transcrição Entrevista Professora 2}

Eu - A gente vai começar a entrevista com o tema: A EDUCAÇÃO DE CRIANÇAS EM HOSPITAIS: A experiência da cidade de Curitiba, Estado do Paraná num Hospital Infantil, de 1988 a 2002. Hoje é dia 22 de agosto de 2017. Você pode dizer seu nome completo, por favor?

Prof. - Professora $2^{188}$.

Eu - Qual é a sua formação?

Prof. - Normal Superior, depois especialista em Educação Especial, Educação Especial Inclusiva com ênfase em Avaliação Diagnóstica Escolar, mestre em educação

Eu - A quanto tempo trabalha no magistério?

Prof. - Nossa, que pergunta difícil!

Eu - Aproximadamente. Você começou quando?

$\mathrm{Eu}-88,89$. Acho que 87, alguma coisa assim.

Eu - Qual seu vínculo de trabalho (estadual ou municipal)?

Prof. - Desde 96, municipal.

Prof. - Quando você começou a trabalhar no Hospital como professora?

$\mathrm{Eu}-98$

Prof. - Até quando trabalhou no hospital?

Eu - Até o ano passado, 2016.

Prof. - Gostaria de contar por que saiu do hospital?

Eu - Por conta do Mestrado.

Eu - E no Pequeno Príncipe?

Prof. - Eu não trabalhei no Pequeno Príncipe. Eu trabalhei num espaço que era arrendado para a Associação Criança Renal e que ficava dentro do Hospital Pequeno Príncipe. O nosso convênio com o município que eu trabalhava era com a Associação Criança Renal que depois virou Fundação Criança Renal.

Eu - Que ano você começou nesse trabalho? Você ficou de que ano a que ano ali na Fundação?

Prof. - Na Associação Criança Renal que depois Fundação, de 98 a 2005, agosto de 2005.

Eu - Como que surgiu essa possibilidade de trabalho na Fundação?

Prof. - Fui para um remanejamento, porque tinha poucos anos de rede e me mandaram, na seleção, para uma escola muito longe de casa, tinha dois filhos pequenos, que estavam em torno 2 anos e meio falei que não teria condições de ir para um lugar tão longe. Daí uma pessoa da Secretária me falou: "Tem esse convênio, se você quiser, é próximo da sua casa". Quando eu falei que morava no Santa Quitéria, ela me falou: "é perto do Atlético. Se você quiser." Eu falei: "Quero, é claro." Não sabia nem do que se tratava. E quando cheguei no endereço que me deram era de um consultório médico. Pensei na hora, até comentei com meu marido: "Acho que me deram o endereço errado, porque não tem escola aqui, não tem nada". Aí meu marido disse: "Então bata no consultório para ver o que é, e aí você volta na Secretaria". Quando fui falar com a pessoa desse consultório, ela me disse: "Não, é pra cá mesmo", eu falei: "como assim?" Ela falou: “É pra você trabalhar, é um convênio que nós temos com o município. O município cede professora. Era cessão de um profissional para trabalhar dentro do setor de hemodiálise, que ficava no Hospital

188 Para preservar a identidade da professora, no lugar de seu nome optei por deixar Professora 2 por ela ter sido a segunda professora a ceder a entrevista para a pesquisa. 
Pequeno Príncipe, era um convênio com a Associação Criança Renal junto com a prefeitura. Foi assim que surgiu.

Eu - Que motivos a levaram a iniciar esse trabalho?

Prof. - Quando iniciei minha vida profissional, iniciei na Educação Especial, sempre tive um pé na Educação Especial e senti que aquilo era um trabalho diferenciado, não a Educação Especial que eu estava acostumada. A Educação Especial que eu estava acostumada era com Deficiente Mental severo e chamávamos na época de Distúrbio de Comportamento Severo, eram esquizofrênicos, que não se utilizava esse nome na época, o autista já se utilizava e algumas síndromes, depois trabalhei com a Deficiência Visual. Eu achei que era uma educação diferenciada, não via como Educação Especial, porque naquela época a gente achava que Especial era a criança com deficiência e ali não tinha nenhuma, elas estavam passando por um momento diferente, momento especial de vida. Então eu fui, por ser um desafio novo, pra mim era mais fácil, porque ia estar próximo da minha casa e dos meus filhos, podendo deixá-los na escola. Foi uma experiência assim. Foi mais ou menos isso.

$\mathrm{Eu}$ - Você foi a primeira professora a trabalhar ali na hemodiálise do hospital ou houve outras antes de você?

Prof. - O convênio tinha começado em 96. Eu comecei em 98. O convênio começou em 96 e era uma professora no período da manhã e uma professora no período da tarde. A professora do período da tarde, não houve adaptação dela, da profissional. $\mathrm{E}$ aí a Associação solicitou a troca desse profissional. Então eu fui a terceira. O convênio teve início acho que foi lá por setembro, alguma coisa assim. Eu acredito que na dissertação tenha as datas mais precisas, porque eu de cabeça realmente não lembro. Tinha uma professora no período da manhã e eu trabalhava a tarde.

Eu - A dissertação que você se referiu agora é a dissertação que você defendeu na PUCPR em 2015?

Prof. - 2017. Ela é de 2016 e foi defendida em fevereiro de 2017.

Eu - Ali na dissertação você cita essas professoras?

Prof. - Sim, todas.

Eu - Ou você diz quem são elas?

Prof. - Sim, o nome delas.

Eu - Certo! Você tem conhecimento de algum projeto ou convênio realizado entre o hospital onde foi trabalhar e sua mantenedora? Você me disse que você era professora municipal. Então tinha nesse momento não era um convênio. Que você era cedida.

Prof. - Era convênio, mas hoje a gente tem convênios que as professoras são disponibilizadas. Qual é a diferença que eu entendo? Quando a professora era cedida naquela ocasião, ela era cedida mesmo para a instituição, e a instituição cuidava dessa professora. Hoje elas são, de alguns anos para cá, mais ou menos a partir de 2005, é mais uma disponibilidade, porque o município intervém junto a essas professoras, e naquela época não. O município cedia e a professora ficava dentro da instituição. A instituição que, mais ou menos, delineava o trabalho desse profissional. O município mandava a gente no convênio. O convênio tinha duas cláusulas: Manter entrosamento com a escola de origem do aluno e trabalhar conteúdo escolar. Eu fui para o hospital com duas coisas que o município me disse: Você vai trabalhar conteúdo da escola, manter entrosamento com a escola do aluno. Era esse o termo, entrosamento com a escola de origem. Foram essas duas questões que me passaram: entrosamento com escola de origem e conteúdo escolar. Só! Era isso que o município passava. E o resto a gente fazia, porque minha função enquanto professora, era trabalhar conteúdo escolar. 
Eu - E você teve acesso a esse convênio que você acabou fazendo parte?

Prof. - A gente tinha, porque o convênio acho que a cada dois anos era renovado e quando eu comecei a trabalhar em fevereiro de 1998, a professora que trabalhava no período da manhã me disse que existia uma professora dentro do hospital, que era um convênio do hospital. Daí a gente conversava em questão de acertar a questão de férias, a gente fazia muito parecido, parecido não, a gente fazia exatamente como as escolas faziam. Então a gente tinha um pouco de acesso a essa profissional. Eu tinha menos, porque essa profissional trabalhava no período da manhã. As duas eram no período da manhã. Professora [...] que era a professora do Estado e a professora [...] que era a professora do município. Então eu tinha muito pouco acesso a elas porque eu trabalhava no período da tarde. Durante o ano de 1998 eu devo ter tido umas duas ou três reuniões com elas e daí eu conhecia a professora [...], que era do município e a professora [...] que era do governo do Estado.

Eu - Você tem cópia deste convênio?

Prof. - Eu tenho. Tenho porque eu tive acesso a todos os documentos por conta da dissertação.

Eu - E você colocou cópia nos anexos da dissertação ou não?

Prof. - Não. Acho que não. Não lembro.

Eu - Será que você consegue uma cópia para mim?

Prof. - Acho que capaz que tem na dissertação. Tem o Projeto Mirim. Acho que o convênio mesmo não tem! Acho que tem mais o projeto que foi escrito pela [Assistente Social], que data de 89.

Eu - Esse é um dos relatórios.

Prof. - Relatórios. Eu acho que os convênios eu não coloquei porque acho que fiquei com um pouco de receio de usar um documento, eu tive acesso aos arquivos, no arquivo da educação tinham os relatórios, mas a questão de documentos de convênio, ele fica num outro arquivo do município, que é o arquivo público, que foi lá que eu consegui. Então eu fiquei com receio de utilizar esses convênios dentro da minha dissertação, mas eles ficam no arquivo público. Então provavelmente você tenha acesso. No arquivo público todo mundo tem acesso.

Eu - Sim. Qual era a sua função no hospital?

Prof. - Professora.

Eu - Com quais outros profissionais você trabalhava no hospital?

Prof. - Enfermeiros, médicos, psicólogos. Dentro do setor tinham enfermeiros, auxiliares de enfermagem, médicos, assistente social a gente se comunicava bastante e com a psicologia.

Eu - Existia um trabalho da equipe multidisciplinar na Educação Hospitalar no setor que vocês estava?

Prof. - De início não, porque eles reconheciam que a parte mais importante para a criança era a saúde e que a escola podia ficar em segundo plano. No momento em que a gente começou a mostrar a evolução dessas crianças pedagogicamente eles nos incluíram na equipe e daí a gente começou a participar até de reuniões deles. Às vezes, na consulta com a médica, ela nos chamava para conversar sobre a escola com a família.

Eu - Então havia uma relação, um entrelaçamento dos diferentes profissionais depois de um certo período?

Prof. - Sim.

Eu - Quanto tempo seria isso? Você consegue lembrar?

Prof. - Acho que no próprio ano.

$\mathrm{Eu}$ - No primeiro ano? 
Prof. - É. Dentro do prontuário médico da criança, a última página do prontuário era como se tivesse um histórico escolar. Era na última folha, então quando o médico fazia a consulta ele olhava a última folha e dizia: Ah, você estuda em tal escola, está fazendo tal ano. Como é que está a escola? Está indo ou não está? Está dando certo? Então a gente mantinha isso dentro do prontuário, na última página do prontuário. Ficavam lá a página desse acompanhamento pedagógico.

Eu - Então vocês eram chamadas para as consultas?

Prof. - Algumas vezes sim.

$\mathrm{Eu}$ - Eram chamadas para algumas reuniões e também eram chamadas para preencher essa documentação?

Prof. - A gente tinha uma documentação nossa, que nós desenvolvemos e ficava dentro do prontuário. Qualquer modificação, por exemplo, no começo do ano a criança foi do $1^{\circ}$ para $02^{\circ}$ ano, a gente atualizava. Quando elas mudavam da escola, ou alguma coisa, a gente atualizava também.

Eu - Havia outros professores que trabalhavam com você? Bom, você já falou que tinham uma durante a manhã e outra à tarde.

Prof. - Isso, uma de manhã e eu a tarde no convênio da Associação dentro do setor de hemodiálise, não era dentro do hospital inteiro, mas dentro do hospital tinha uma do município e uma do governo do estado.

Eu - Bom, então vocês dividiam o trabalho entre manhã e tarde?

Prof. - Sim, porque as crianças da manhã faziam hemodiálise no período da manhã e eram atendidas por essa outra profissional e os do período da tarde eram por mim.

Eu - Quem eram essa professora da manhã que trabalhava com você?

Prof. - Professora Juliana.

Eu - A que continua lá?

Prof. - Não. É outra. A professora Juliana ficava no período da manhã e eu ficava no período da tarde. A professora Juliana é advogada. Então de manhã ela trabalhava com a professora da prefeitura e no período da tarde ela era advogada.

Eu - Certo.

Prof. - Eu saí da Fundação Criança Renal em 2005. Depois não lembro bem a data a Fundação fechou e entregou o Setor de Hemodiálise para o hospital. Então essas duas professoras (a que ficou no meu lugar e a Juliana) que estavam disponibilizadas para a Fundação, como a Fundação fechou, elas foram para o hospital, fazer parte do convênio do hospital. Juliana foi, ficou um período no hospital e depois ela saiu e foi para um outro departamento do município.

Eu - Entendi. Então o vínculo dela também municipal?

Prof. - Municipal.

Eu - Quais as séries das crianças que você atendia?

Prof. - O município tem a característica de ser do $1^{\circ}$ ao $5^{\circ}$ ano, mas quando cheguei lá, percebi muitas crianças que tinham desistido da escola por conta da hemodiálise. Você conhece bem o que é um processo de hemodiálise. Você sabe do que eu estou falando. Não é? Uma sessão de hemodiálise corresponde a uma maratona, você sai muito cansado. Então, muitas crianças desistiram da escola. Eu percebia assim, que até $04^{\circ}$ Ano os pais conseguiam manter as crianças na escola, mas quando elas entram na adolescência apresentavam certa rebeldia e acabavam desistindo. Então, quando eu cheguei lá percebi que algumas crianças da tarde e algumas da manhã que não eram meus alunos, eles acabaram desistindo da escola. Então, na época, como a gente não tinha uma, digamos assim, uma fiscalização, não é bem esse o termo, mas uma coordenação do trabalho, e a gente tinha uma certa liberdade para trabalhar, eu fui atrás de um supletivo do governo do Estado, o CEEBJA Paulo Freire 
que era na Rua Doutor Pedrosa, ali perto da Praça Rui Barbosa, na época tinha uma diretora chamada Terezinha e expliquei a ela que tinha algumas crianças, alguns adolescentes. E ela disse: "Traga para cá que a gente dá um jeito". Então naquela época o supletivo era de você pegar as apostilas e estudar em casa. Então o que a gente fazia? Pegava as apostilas e estudava no hospital. Daí eu consegui envolver algumas crianças da manhã e da tarde. A gente fez um resgate escolar destas crianças com o supletivo, com o CEEBJA Paulo Freire, com a Diretora Terezinha na época, e a gente conseguiu formar naquele período que eu fiquei, acho que foram em torno de uns 12 adolescentes até a $8^{a}$ série. E eu propunha o seguinte para eles: "Nós vamos fazer o supletivo até a $8^{a}$ e daí o segundo grau, que era chamado na ocasião, vocês vão fazer na escola. Combinado? Combinado". Então a gente colocava esses adolescentes para estudarem até a $8^{\underline{a}}$ série. $E$ alguns pais no supletivo de Ensino Médio também, porque os pais ficavam, enquanto as crianças ficavam na hemodiálise, segunda, quarta e sexta, à tarde, por exemplo, eles ficavam lá fora na sala de espera esperando o filho. E eu falei: "Em vez de vocês ficarem esperando, vamos fazer alguma coisa". E eu coloquei eles para estudar. Se não me engano, de pais, acho que foram 3 ou 4 que a gente formou no Ensino Médio. $E$ teve um pai que também fez até a $8^{\underline{a}}$ série. E quando chegou uma pessoa da secretaria, em 2005 mais ou menos que ela foi conversar conosco, eu contei para ela isso, porque eu era professora de $1^{\underline{a}}$ a $4^{\text {a }}$ série, então foi um risco pessoal, e que eu fiz, porque eu achava que como pessoa eu tinha que fazer. Fiz a formatura dessas pessoas, fiz até a $8^{\underline{a}}$ série e eles estudaram e depois eles continuaram suas vidas, alguns infelizmente foram a óbito, mas a gente fez esse serviço e esse serviço infelizmente não contemplavam em nossos relatórios. Os relatórios eram até a $4^{a}$ série.

Eu - Você comentou que você também atendeu uns alunos da manhã, você era professora da tarde. De vez em quando você ia de manhã também ou a professora que estava de manhã fazia?

Prof. - Ela fazia. A gente intermediava isso. O supletivo nos fornecia a apostila, algumas vezes a gente levava, eu principalmente levava as crianças fazer prova, colocava as crianças dentro do meu carro, levava. A professora Juliana não tinha tanta disponibilidade como eu, porque ela trabalhava no hospital de manhã e no período da tarde ela tinha outro emprego. Eu como trabalhava só no período da tarde, de vez em quando eu pegava algumas crianças, quer dizer, adolescentes dela e ia de manhã fazer prova com eles, porque era uma disposição minha, pessoal. Não tinha nada a ver com a secretaria, até porque a secretaria nem sabia que eu fazia isso. Fazia mesmo por conta de trabalhar para essas crianças. Então, obviamente que em momento algum eu peguei uma apostila de História, História não, digo, de Física, de Química, Matemática, porque eu não tinha pé para isso, eu era professora até a $4^{a}$ série. Então, quando eram conteúdos mais elaborados para um professor do 6ำ ao 9을 da $5^{\underline{a}}$ série até a $8^{\mathrm{a}}$ que era na época, eles iam tirar dúvidas dentro do CEEBJA, porque Língua Portuguesa, História, Geografia você podia arranhar, ler o texto e compreender, mas as disciplinas mais exatas eu não me arriscava, porque eu não tinha pé pra isso, então eles iam e os professores do supletivo atendiam, eles iam assistir algumas aulas ou recebiam orientações, porque naquela época você podiam assistir aula ou você podia tirar dúvida com o professor. Então, muitas vezes, eu levava esses alunos para tirarem dúvidas dentro do supletivo, algumas provas eles iam no supletivo, eu levava eles até o supletivo para eles fazerem as provas ou a gente aplicava dentro do setor, ou eu ou essa outra professora. O pessoal do Supletivo confiava no trabalho da gente, sabiam que era um trabalho sério, que a gente jamais ia ajudar numa prova, ajudava sim a ler a questão e só, interpretação e a questão da 
prova mesmo o aluno fazia sozinho, mas eles tinham, a diretora Terezinha, na época, tinha plena confiança, porque ela sabia que a gente agia como profissional, não ia, em momento algum, facilitar a vida desses alunos, porque a gente fazia eles estudarem para aprenderem o conteúdo. Teve uma vez que uma professora foi dentro do setor, foi autorizado, lógico, pela Fundação, a gente solicitou primeiro a autorização dela e ela foi aplicar a prova para ver como que era o ambiente. Foi um trabalho muito legal que a gente conseguiu fazer com essas crianças.

Eu - Que legal mesmo! Quem eram os alunos da Educação Hospitalar deste período, de 88 a 2002?

Prof. - 2005.

Eu - Isso. De 88 a 2005, que é o seu período.

Prof. - Não, meu período foi 98

Eu - 97 a 2005.

Prof. - 98 a 2005 dentro do Setor de Hemodiálise.

Eu - Quem eram esses alunos da Hemodiálise? Quais as experiências que eles relatam com relação à Educação Hospitalar na qual tiveram aula nos períodos de internamento?

Prof. - Eram crianças, muitas delas, eram do interior, mas a partir do momento que você inicia um tratamento de hemodiálise você tem que morar na cidade, porque você vai estar de 3 a 4 vezes por semana na capital, no local onde se fazia, então muitos deles eram do interior. Então a gente procurava trazer os menores, até a 4⿳a série, em alguns momentos eu vou me atrapalhar em falar em $5^{\circ}$ ano, mas é que era a nomenclatura que se usava era série naquela época. Teve uma época que era ano também, mas era até $4^{\circ}$ ano ou $4^{\text {a }}$ série.

Eu - Isso.

Prof. - Então essas crianças menores até o $4^{0}$ ano, até a 4⿳a série, que era o nosso foco, a gente procurava trazer eles da escola de lá para os matricular numa escola do município, para que ficasse mais próximo e que falasse a mesma realidade nossa. Enquanto a gente, como professoras do município, a gente tinha que trabalhar com as diretrizes do município, afinal de contas, nós éramos professora do município, a gente tinha que trabalhar com documentos do município. Então a gente trazia muitas dessas crianças para a realidade de Curitiba, para a cidade de Curitiba e escolas do município, mas muitas eram do interior do estado, mas acabavam residindo aqui, então a gente procurava colocar nas escolas do município. Era isso que você tinha perguntado?

Eu - Era. Quem eram os alunos?

Prof. - Muitos deles eram do interior, mas acabavam ficando morando aqui, por conta do tratamento.

Eu - Quais as ações efetivas que desencadearam na Educação Hospitalar paranaense?

Prof. - Eu percebo assim, que quando eu entrei dentro do Setor de Hemodiálise a própria saúde valorizava muito a questão da saúde. A questão da escolarização não era tão valorizada, porque no momento que você tem uma doença de um filho, a gente enquanto mãe, a gente percebe que a gente quer focar na doença mesmo, que a criança tem a cura, no caso, que vá para um transplante, que fique..., não dependa da máquina, então se focava muito na saúde, na doença, na questão do problema de saúde mesmo e no momento em que a gente começa a aparecer com essa possibilidade de uma escola, a gente percebe que o foco não ficava só na doença, porque tinha um outro viés que parecia que era da educação e que se tornava importante para as crianças, para as famílias, o resgate dessa escola para a família, 
muitas vezes a gente percebia que quando chega de início eles tem um certo: "não, agora não. A gente vai pensar no transplante, vamos pensar no problema de saúde", mas à medida que eles vão vendo que a coisa acontece, que de repente esse transplante pode ser que não seja tão rápido assim, ele pode demorar um pouco mais, não vai sair em 6 meses, em 1 ano... as vezes demora mais tempo, no caso ali do setor ele dependia de um transplante ou de um doador da própria família que fosse compatível, ou de um rim de cadáver, então às vezes essa espera de meses passase anos. Então tá... E a gente vai ficar esperando, esperando a vida passar? E era uma coisa que eu colocava muito para as famílias, eu dizia: "vamos aproveitar o tempo, enquanto está tratando a doença vamos focar em outras coisas, porque, de repente ele vai sair daqui e daí? Se a coisa demorar um pouco mais para passar. $\mathrm{O}$ que que eu vou fazer da minha vida agora?" Com os adolescentes foi nesse sentido que eu consegui resgatar a escola, eu dizia: "Tá, vocês vão transplantar e daí? O que vai ser sua vida? Você não estudou. Você esqueceu disso. Você foi vivendo a sua hemodiálise. Você ficou doente, vivendo um tratamento..." Claro que a gente ia colocando em outra linguagem, tentando mostrar didaticamente, pedagogicamente de uma outra maneira. "Mas o que vai ser da sua vida a hora que você transplantar, porque sua vida é casa, hemodiálise, casa, hemodiálise. $E$ a hora que transplantar. $O$ que vai ser? Ah, é né! É, então vamos estudar". Então a gente vinha com essa questão da educação e ela caminhava muito bem e a gente percebia que o foco não ficava só na doença, se focava em outras coisas também. Tem se relatos, de crianças que foram meus alunos crianças e que hoje, um deles está fazendo mestrado, estão fazendo faculdade, estão se virando na vida. Seguiram. Eles dizem: "Puxa vida, ainda bem que você apareceu e que eu não fiquei parado esperando as coisas acontecerem". Então, é legal, quando você vê essas histórias assim de que no momento da doença a gente tem uma outra questão que a gente pode ver também, que a gente não fica parado pensando que é só doença, porque a coisa acontece de focar muito na doença, no momento que você tira o foco também tem uma questão de que a vida é mais do que só doença, tem outras coisas que a gente pode viver.

Eu - Em que medida o projeto de Educação Hospitalar, seus professores, alunos e atendimentos se efetiva no universo paranaense?

Prof. - Eu percebo que pra nós enquanto município, em 2005 quando eles percebem que existia um professor dentro do hospital e que a Secretaria de Educação... porque na verdade assim, os nossos convênios pertenciam à Secretaria de Educação, mas ele era vinculado a um Departamento, que depois você pode até ver na minha dissertação, que vai estar lá escrito direitinho, mas ele era uma questão que ficava na parte do jurídico e que ele não chegava num Ensino Fundamental, numa Educação Especial, ele ficava no jurídico. E no momento em que o município começa a abrir o leque para outras coisas, para as outras práticas, no momento que eles começam a ler Capra, que eles percebem que eles podiam ter uma visão mais holística disso, eles percebem que tinham professores deste convênio, "como assim, a gente tem professores cedidos no hospital? O que esses professores fazem lá?" Então em 2005, quando uma pessoa do Ensino Fundamental percebe que tinham esses professores, eles se aproximam dessas profissionais, na época eram 14, 2 da Fundação Criança Renal, 5 no Pequeno Príncipe, 3 no HC, 1 no Erasto Gaertner, 1 na Associação dos Hemofílicos, 2 no Evangélico, na verdade poderia-se dizer que eram 16, pois 2 delas 1 no $\mathrm{HC}$ e outra no HEG trabalhavam os 2 períodos (2 matriculas). Eles se aproximam dessas profissionais para entender o que elas faziam. Então eu acho que a partir de 2005 se dá o grande passo no momento em que o Ensino Fundamental junto com o jurídico pega essas professoras e vai ver o que está acontecendo. Então acho que 
uma coisa legal que aconteceu foi em 2005 quando eles percebem esses professores que estavam fazendo uma prática diferenciada.

Eu - Como eram esse atendimento?

Prof. - A gente sempre... O Setor de Hemodiálise é um pouco diferenciado. Cada instituição, hoje eu percebo, nessa minha caminhada de praticamente 20 anos, 19 anos, dentro de um mesmo convênio, de um mesmo local, você tem realidades diferentes. Então na hemodiálise você consegue trabalhar e fazer um desenvolvimento com a criança, porque elas sempre serão as mesmas, segunda, quarta e sexta você terá a criança $A, B, C, D, E \ldots$ no período da manhã e $H, I, J, K \ldots$ a tarde. Na terça e quinta $L, M, N, \ldots$ de manhã e $O, P, Q, R \ldots$ a tarde, portanto serão sempre as mesmas... Então você conseguia fazer um trabalho, conseguia dar uma sequência. Hoje, segunda-feira eu trabalho com o aluno $A$ tal conteúdo, na quarta consigo dar a continuidade. Já em outros hospitais, em outras clínicas não acontece isso, por exemplo, dentro do ambulatório você tem que fazer a coisa muito rápida, vai ver aquela criança, de repente, uma vez por mês, uma vez por semana, e ela fica ali, meia hora, 40 minutos enquanto está esperando a consulta, enquanto está aguardando um exame. A criança da oncologia, por exemplo, você vai ficar com essa criança, em torno de... quando eu trabalhava no Erasto, fui pra lá em 2006, o tratamento do câncer durava em torno de 2 anos, então você tinha aquela criança mais próxima, não tanto quanto a hemodiálise, na oncologia, você tem um número $X$ de crianças que vão fazer um tratamento em torno de dois anos e que você acaba encontrando novamente as crianças no momento em que ela interna e você tem que começar a atividade, na maioria das vezes, você tem que iniciar uma atividade no dia e terminar no mesmo dia, porque de repente, o tratamento dela é que ela ficou para fazer determinado procedimento que vai demorar 4 dias e de repente o procedimento acaba sendo em 2 , então, de repente você vai chegar no $3^{\circ}$ dia e se você se programar para trabalhar 4 com ela, não vai render 4 , porque de repente ela pode ter alta antes. Então a característica é de se trabalhar o conteúdo no mesmo dia. Outras clínicas, como eu falei para vocês, no ambulatório, você vai ver, conforme for o ambulatório oncológico, você vai ver, às vezes, algumas vezes a mesma criança. Já uma clínica de procedimento cirúrgico, por exemplo, vai a criança A fazer uma cirurgia de adenoide que você nunca mais vai ver, então você vai trabalhar uma atividade pontual com essa criança e pronto, não tem, como você desenvolver um plano com essa criança. Então, são realidades diferentes.

Eu - Você tem registros desses atendimentos? Se sim, poderia me emprestar para utilizar na pesquisa?

Prof. - Eu acredito que eu tenho, preciso dar uma olhada assim...

Eu - Caderno de planejamento, atividades...

Prof. - Eu preciso olhar, é capaz que eu tenha.

Eu - Diferentes atividades que você fazia...

Prof. - Eu acho que eu tenho. Naquela época da hemodiálise, eu fiquei até 2005, talvez eu não tenha, posso dar uma olhada lá em casa se eu tiver, talvez tenha, é que a gente, na medida em que a gente vai estudando e de repente, a gente não vai usar mais aquilo, você acaba...

Eu - Como era o seu planejamento de trabalho? Tem registros destes planejamentos? Se sim, poderia me emprestar para utilizar na pesquisa?

Prof. - A gente trabalhava dentro dos documentos do município, sempre pautada nas diretrizes do município e, às vezes, quando a criança era de fora a gente costumava trabalhar com conteúdos das escolas delas, já na experiência do Erasto, isso era mais forte com o planejamento da escola de origem da criança, você trabalha com o 
conteúdo de lá, porque no meu entendimento é que essa criança vai retornar. Por exemplo, uma coisa que eu costumo falar para as professoras: "Que adianta eu trabalhar a importância do pinhão para uma criança que mora no Nordeste?" Não vai fazer sentido nenhum. Eu vou ter que adequar a minha prática com os conteúdos deles, a geografia deles, a parte da região.

Eu - Onde você atendia? Que setores do hospital eram liberados para que você trabalhasse com as crianças?

Prof. - Na hemodiálise, porque a Nefrologia, por exemplo de internamento, era um setor do hospital, não era um setor da Fundação Associação Criança Renal. Então a gente trabalhava só dentro do Setor de Hemodiálise.

Eu - Havia um lugar específico para fazer os atendimentos/aulas? Como era a hemodiálise, era no ambiente da Hemodiálise? Não havia uma sala? Eles não saiam da máquina para fazer na sala?

Prof. - Não. Dentro do setor, a gente sentava num banquinho do lado.

Eu - Como era esse local? Conte para mim como acontecia o atendimento ali.

Prof. - A gente ficava do lado da criança na máquina. Colocava um banquinho de plástico do lado da máquina e atuava ali. Então o que eu procurava adequar na minha prática era: as atividades eram sempre feitas em pranchetas, por conta da posição da criança, porque não tinha uma mesa. E uma coisa que eu utilizei e que achava bem legal na época, eu fui num Calheiro e pedi para ele fazer uma placa de zinco um pouquinho maior que o A4, utilizava alfabeto móvel, figuras, atividades que eu colocava aquelas plaquinhas de imã. Hoje se acha isso para vender, mas antigamente não tinha. Então a gente utilizava aqueles imãs de propaganda de gás, da panificadora... Quando ia fazer uma atividade com o alfabeto móvel ou qualquer outra atividade, eu colava o imã nestes materiais para utilizar nessa placa. Assim conseguia trabalhar no concreto.

Eu - Fora esse material, você se lembra de algum outro que você usava para estes atendimentos?

Prof. - Quando eu comecei em 98, os materiais que a gente utilizava era a própria instituição que nos dava, que era a Associação Criança Renal. A partir de 2005, o município começou a mandar material também... Lápis, borracha, as próprias pranchetas, livros, jogos pedagógicos, material dourado, que tinha uma época que o município começou a usar muito. Então, eles nos davam esses materiais para a gente trabalhar com as crianças. Dentro da sala da hemodiálise, tinha um armário onde a gente guardava todo o nosso material. Também tínhamos as fichas das crianças, onde fazíamos todos os relatos das crianças, dos atendimentos, tudo, os dados da escola, com quem falávamos na escola, porque a gente fazia o papel do professor, do pedagogo, do diretor, a gente fazia tudo sozinha. A gente entrava em contato com as escolas, explicava a importância do trabalho, como acontecia. No início as escolas não entendiam muito bem como era isso, e às vezes colocavam: "Ah, tá, vamos ver de mandar", e às vezes eu era um pouco incisiva, me lembro até em algumas situações eu dizia para algumas escolas do município que não entendiam, não sabiam o que era aquilo e a pedagoga dizia: "Ah, não sei". Eu me lembro que teve uma das pedagogas que começou: manda, não manda e eu liguei um dia para ela e falei: "A sua chefia é do Ensino Fundamental, não é?" E ela: "É." Eu falei: "Fulana de tal é sua chefia, né?" Ela disse: "Sim". E eu disse: "É a mesma da minha e ela sabe o trabalho que eu faço aqui dentro, então, para bom entendedor, meia palavra basta, se você não me auxiliar, porque eu estou querendo fazer um benefício para sua criança, se você não me auxiliar e me mandar o que vocês estão trabalhando na escola vai dificultar para você mesmo, então, se você não colaborar a gente vai para outra 
instância". E a partir desse momento a coisa mudou! Então a gente teve que chegar um pouco junto no início. As escolas não entendiam, e hoje a gente ainda percebe que algumas escolas não compreendem muito esse caminho. Eu estou com essa criança agora, essa criança não é minha, a criança continua pertencendo à escola. Ela é da escola, não é porque a criança não está lá, não está frequentando que ela não é. "Ela é sua e eu estou para lhe auxiliar, fazer o que for possível para melhorar essa criança".

Eu - Havia algum registro ou relatório das suas atividades no hospital?

Prof. - Sim. Mesmo que a gente fosse cedida, como no meu caso a partir de 98, nós tínhamos que mandar relatório semestral para a secretaria para dar conta do nosso trabalho. A gente tinha um plano anual de trabalho, que a gente tinha que mandar para SME. Na renovação do convênio a gente tinha que mandar o plano, não era anual, era de dois em dois anos, se não me engano... Então a gente fazia um plano para os dois anos de trabalho e a cada seis meses a gente tinha que mandar um relatório de atendimento, depois passou a ser trimestral. Mesmo que a gente não tinha uma coordenação do trabalho, nós tínhamos que mandar relatório, justificando esses profissionais que estavam, a gente não era totalmente largada, a gente era cedida sim para a instituição, mas éramos cobrados. O foco era: "trabalhem conteúdo em entrosamento com a escola de origem, conteúdo escolar e nos mandem relatórios".

$\mathrm{Eu}$ - Você tem cópia desses relatórios que você encaminhava? Ou desse plano de dois em dois anos que você fazia?

Prof. - Eu devo ter em casa. E no arquivo do município tem algumas coisas. Quando eu fui fazer a minha pesquisa, agora do mestrado, eu me bati um pouco, porque eu percebi que tinham muitos documentos que deveriam estar lá e eu não localizei.

Eu - Por isso que eu estou lhe perguntando, porque como é um arquivo pessoal teu, se você tiver como me disponibilizar, eu consigo utilizar, olhar, ver o que dá para utilizar no trabalho. Como é uma pesquisa histórica, é um pouco diferente do tipo de pesquisa que você fez.

Prof. - Tenho. A minha pesquisa, na verdade era de formação de professores, mas ela acabou entrando num viés histórico, por mais que não fosse, porque ela relata 0 histórico do município, então ela acaba entrando um pouco naquela parte histórica. A minha dissertação foi uma coisa um pouco meio diferente.

Eu - Como era a avaliação das crianças atendidas?

Prof. - Naquela época era muito... a gente lidava muito com prova mesmo. A escola mandava provas, não é aquela avaliação que hoje a gente faz, uma avaliação formativa que dá para utilizar atividades da criança, que você pode avaliar o conhecimento...

Eu - Então você aplicava as provas da escola, quando a escola mandava?

Prof. - Sim. Até hoje a gente ainda aplica. Se a gente tem crianças que sejam das escolas particulares e a escola trabalha com prova, a gente aplica a prova, sim.

Eu - Havia algum contato com a escola de origem destas crianças? Ou um retorno sobre as atividades realizadas por eles junto à escola quando o aluno tinha alta?

Prof. - Sim. Sempre. Como era hemodiálise, a gente sempre tinha um contato constante com a escola, porque a cláusula primeira do convênio era o entrosamento com a escola de origem, então a gente tinha muito contato com a escola sim.

Eu - Você tem algum registro de atividades, caderno de planejamento, caderno de atividades, caderno de alunos, listagem de alunos ou qualquer outro tipo de registros de quando atendia no setor do hospital?

Prof. - Eu devo ter. Eu vou dar uma olhada lá em casa, mas eu acho que eu tenho. Eu - Se tiver, vocês separam para me emprestar, por favor? 
Prof. - Eu sou bem "lixentinha". Na verdade, não é uma pessoa "lixentinha", é uma questão de histórico, de registro.

Eu - Eu também sou... É de registro do trabalho da gente, não é?!.

Prof. - Eu percebia, acho que por isso fiz muita questão na dissertação, de que as pessoas não fazem registro da história, de você perceber, por exemplo, quando fui para o Erasto, o Hospital Erasto Gaertner, cheguei em abril de 2006, porque saí da Fundação em agosto de 2005, fui para o HC e fiquei de agosto de 2005 a abril de 2006 no HC, quando fui para o Erasto em abril de 2006 percebi que existia uma pessoa que trabalhou lá por 15 anos, de 88 a 2003, quando se aposentou. Quer dizer, tinha um trabalho pedagógico em um local dentro do hospital e alguns profissionais que não conheciam que aquilo existia. Eu dizia: "Você sabia que tinha uma escola dentro do hospital? Não. Tem?" Então eu pensava: "Meu Deus, é um local que existia desde 88 e que as pessoas não percebem que existiu!" Então fiz um resgate histórico do Erasto. Fiz o resgate histórico da Fundação também, fiz o Normal Superior, enquanto trabalhava na hemodiálise, meu trabalho de final de curso foi dentro da hemodiálise. Fiz o resgate da hemodiálise do meu tempo. Então assim, você acaba guardando os documentos porque são registros, são históricos. Então eu devo ter alguma coisa lá em casa da Fundação por conta disso, vou dar uma olhada, quase certeza que tenho.

Eu - Está ótimo. Qualquer coisa me passa depois, me empresta, por favor.

Prof. - Tá.

Eu - Você se lembra de algum aluno ou alunos que tenha ou tenham lhe marcado no tempo que trabalhou ali? Gostaria de contar o que foi marcante para você?

Prof. - Olha Claudinéia. Tem muita história marcante, porque cada um que passa pela vida da gente deixa um pouco, leva um pouco da gente. São muitas histórias assim que te marcam. Uma história que... Como nosso foco era do 1a a $4^{a}$ série, para o de $5^{\circ}$ a $8^{\circ}$ você dava um auxílio. Então, os pequenos da Educação Infantil, a gente não atendia, porque para nós, pra mim, no meu caso, era muito claro que eu tinha que trabalhar conteúdo escolar e entrosamento com a escola de origem, então a parte lúdica, eu sei o quanto isso é importante, mas eu deixava isso para o voluntário. A minha função era professora, então eu vou trabalhar o conteúdo escolar. Isso eu bati muito, sempre bati em cima dessa tecla, mas tinha uma criança de uns 3, 4 anos me lembro que de vez em quando ele me chamava: "Professora, professora, professora". E um dia ele chegou e estava muito espoleta naquele dia e eu falei para ele: "O que você tem hoje fulano, que você está", eu lembro o nome, mas não vou citar, "o que você tem hoje que você tá tão assim, né, pulando ai que está tão feliz?", ele disse pra mim: "eu vou tirar o cateter, eu vou parar de tomar banho de gato". Aquilo foi assim, muito marcante para mim, porque eu entro embaixo do chuveiro e eu tomo meu banho e pronto, mas ele tomava banho de gato, porque ele não podia molhar o cateter. Então isso me marcou. Tinha um outro que era um aluno mesmo, ele fazia o primeiro aninho e ele era muito de participar, ele gostava, o prazer dele era que a gente ficasse trabalhando com ele o dia inteiro, a tarde inteira e esquecesse dos outros. E um dia ele estava e ficava: "Professora, professora, professora...!" e eu já tinha trabalhado com ele, e ele dizia: "Professora, professora, professora..." e eu falei assim para ele: "Espere um pouco, a professora vai terminar de trabalhar com fulano e a professora volta para trabalhar com você se der tempo, mas a gente já trabalhou hoje. Eu tenho que atender o fulano..." Eu falei para ele: "Fulano", também não vou citar o nome, "seja um pouco mais paciente", e ele disse para mim: "Eu sou paciente da doutora X". Então é uma coisa que foi muito engraçada com o que ele disse, ele era paciente, então, quer dizer, não era paciente da paciência, era paciente. Eles têm um vocabulário muito 
próprio. Quando você falar para uma criança de 3, 4 anos sem cateter, isso não significa nada para ele, mas para aquela criança significava, o banho de gato e para esse outro, a paciência, o paciente não significava o paciente, o paciente para ele era o paciente do médico. Então, eram assim, histórias que marcavam. Teve um outro menino que chegou no meio do ano e estava fazendo a $7^{\text {a }}$ série e eu falei para ele: "Fulano". E ele disse: "Pois é professora, eu tive que parar". Ele era do interior do estado, "eu tive que parar, porque agora eu vim para cá, morar aqui", acho que na casa de parente, alguma coisa assim, e eu vi que ele tinha potencial, que ele gostava de estudar, e eu dizia para ele: "Então vamos fazer o seguinte, vamos terminar essa $7^{a}$ série agora de agosto até o final?", porque, por conta de vir para Curitiba, ele não tinha terminado o $1^{\circ}$ semestre, ele tinha feito parte do $1^{\circ}$ semestre da $7^{a}$ série. Eu falei: "Vamos fazer um supletivo da $7^{a}$ série e daí a $8^{a}$ você estuda numa escola. Combinado?" "Combinado". E eu fiz o supletivo com ele naqueles 6 meses da $7^{a}$ série e no ano seguinte e se matriculou numa escola próxima da residência. Ele fez a $8^{a}$, porque ele tinha, mais ou menos era compatível a idade, porque eu percebia nos adolescentes que eles iam... o adolescente já tem toda aquela característica, então ele estar dentro de uma escola da $5^{\underline{a}}$ a $8^{\underline{a}}$ série numa idade que não era compatível com os colegas não era legal! Então por isso eu insistia tanto para eles fazerem o supletivo. Se eles fossem para um segundo grau acima da idade, não tem problema, porque no $2^{\circ}$ grau tem todas as idades, mas de $5^{\underline{a}}$ a $8^{\underline{a}}$ tinha a idade característica e ele tinha, mais ou menos a idade compatível com a série. Falei: "Então fulano, a gente faz a $7^{\underline{a}}$ no supletivo e a $8^{\underline{a}}$ série você vai estudar na escola perto da tua casa. Combinado?" "Combinado" e ele foi, terminou, era um menino muito estudioso, gostava de se dedicar ao estudo e a gente fez o supletivo naquele ano e no ano seguinte a família matriculou ele na $8^{a}$ série, próximo de casa. Então nos dias que ele fazia hemodiálise, a hemodiálise já tinha uma característica de adequar a hemodiálise conforme a escola, coisa que no início, quando a gente começou o primeiro ano, não se pensava nisso, depois a característica é adequar de acordo com a escola, adequar a fístula de acordo com a mão que escreve, porque antes se fazia no braço e pronto, a partir do momento que se tem uma professora trabalhando, vamos fazer a fístula no braço esquerdo se ele escreve com a mão direita, se escreve com a mão esquerda, fístula do lado direito. Quer dizer, a equipe já fazia essa dinâmica. Ele vai, faz a $8^{\text {a }}$ série, depois de um tempo faz o $1^{\circ}$ ano do Ensino Médio, faz o transplante, volta para a cidade dele e depois, você tem a grata surpresa, hoje com a tecnologia a gente acaba encontrando essas pessoas, o menino começou a fazer enfermagem e depois: "Puxa, ai que legal!" E ele disse para mim: "Puxa, [Professora]! Foi por tua conta isso. Você que me fez voltar a estudar. Você me deu a oportunidade para isso". Depois você encontra, ele terminou enfermagem e daí no ano seguinte eu estava no mestrado, no $1^{\circ}$ ano do mestrado e ele disse para mim: "Ah, eu vou fazer residência de enfermagem no hospital". E eu falei para ele: "Fulano, por que você não faz um mestrado?" Ele falou: "Eu quero ir para a academia depois de eu ir para a prática". Ele fez a residência na parte de enfermagem no ano de 2015 e o ano passado ele entrou no mestrado. Então, até eu tive a oportunidade de encontrá-lo, acho que um mês atrás e conversando com ele como mestrando.

Eu - Que legal, não é?

Prof. - É! Então assim, foi muito legal, porque a gente foi fazer um lanche, ele veio para um congresso aqui em Curitiba e quando eu soube que ele veio, sempre quando ele aparece por aqui ele me avisa: "Olha, [Professora]...", porque hoje já não é mais aluno, é amigo. "[Professora], vou para Curitiba. Vamos se encontrar?" "Tá, vamos". Ele é transplantado, então tem a possibilidade de ele tomar refrigerante, de comer, 
porque é outra vida, não mais um processo de hemodiálise, porque ainda tem algumas crianças daquelas, que hoje estão com 30 anos, ainda estão fazendo hemodiálise, porque não teve o transplante ou que fizeram o transplante e perderam e que estão em hemodiálise. Eu tenho contato com dois deles que continuam fazendo hemodiálise e mais 5 ou 6 que já estão transplantados, estão seguindo a vida. E daí a gente sentou e conversou e foi muito legal, porque a gente sentou e conversando da academia, ele contando coisas do mestrado. Então é assim, é bem legal! São coisas que te marcam e que você vê que você acaba fazendo a diferença. E uma coisa que eu sempre comento com as pessoas é a importância que tem um professor. Você pode fazer o que quiser com eles. Então a gente tem que tomar muito cuidado com o que a gente faz, com as ações, com a palavra, com o que você faz, porque você pode pegar essa pessoa e levar que ela melhore tanto a auto estima dela e levá-la lá para cima, e se você fizer uma ação, uma palavra você pode derrubar. Então a gente tem que tomar muito cuidado dentro da ação, e hoje, enquanto secretaria, eu converso muito em relação a isso com as professoras do hospital e principalmente, a do domiciliar, que é uma característica muito diferente, da importância de se cuidar ao que se fala, da sua ação, com ética em primeiro lugar, porque você pode fazer o que você quiser com essa pessoa.

Eu - Exatamente!

Prof. - Nós temos um poder muito grande nas nossas mãos, então a gente tem que tomar muito cuidado. Então, são histórias assim, que você vai guardando na tua caixinha e que quando você vê, você pensa: "Puxa que legal! Hoje ele está fazendo enfermagem". Esse menino que está no mestrado é um menino muito dedicado! Eu achei muito legal a história dele. Ele falou assim: "Eu quero ir para a academia, mas eu quero ter a prática, eu não quero ficar na academia ficar falando por falar. Eu quero ter a prática, porque eu não quero que seja uma fala vazia. Eu quero estar falando de uma coisa que eu vivi e que eu sei como que é dentro de um hospital". Assim, esse menino é super, nossa ele... Eu digo para ele: "Nossa, você é meu orgulho". Eu digo para ele, quando a gente se encontra eu falo: "Nossa, você me orgulha!" e ele disse para mim: "Você faz parte disso! Você me ajudou." Então são coisas, que você vê. Às vezes você encontra. Dentro da hemodiálise eles tinham uma característica de chamar os próprios enfermeiros, os médicos não, eles tinham mais receio, mas as enfermeiras, os auxiliares eles chamavam de Tia fulana, Tio fulano, então eu era a Tia [...], até hoje alguns deles me chamam de Tia [...]. Chega a ser engraçado. Em momento algum eu dizia: "Ai, eu não sou sua parente." Não, era a característica do local se chamar de tia. Então, Tia ficou e a gente foi caminhando. São histórias que você tem, que guarda em sua memória que você vê o quanto pode fazer a diferença na vida dessas pessoas. E percebo que esse professor dentro do hospital pode fazer muita diferença.

$\mathrm{Eu}$ - Como a Assistente Social que implantou o projeto da "Escolarização Hospitalizada" efetivou essa implantação? Você saberia me dizer rapidamente?

Prof. - Ela começou, ela relata muito na dissertação dela, que percebia que muitas crianças, ou deixavam a escola por conta do tratamento e alguns deixavam o tratamento por conta da escola. Tem relatos disso dela, que a criança deixava o tratamento por conta da escola ou deixava a escola por conta do tratamento. Ela dizia: "Puxa, não é possível que a criança não estuda por conta do tratamento", daí ela faz a dissertação dela, vai em busca dessa pesquisa e em, não vou saber te precisar bem as datas, acho que foi em 88,87 , quando ela escreve esse documento, ela vai atrás do governo do estado por conta de uma parceria, porque ela queria implantar esse projeto que chamava na época, Projeto Mirim de Hospitalização Escolarização. Esse 
era o nome que a [Assistente Social] utilizava, Projeto Mirim. Ela vai atrás do governo do estado para pôr um professor dentro do hospital e o governo do estado, na época o secretário ele empresta, ele dá uma professora para a [Assistente Social], para que essa professora desenvolvesse todo um trabalho dentro do hospital, porque era uma coisa que era viável. Essa professora fica por 3 meses dentro do hospital, acho que foi $97 \ldots$

Eu -87.

Prof. - 87, isso, desculpa! Ele cede, ele dá essa professora por 3 meses, sem convênio, as coisas eram muito diferentes a 30 anos atrás. Ele dá essa professora para o hospital, essa professora fica 3 meses para desenvolver o projeto e depois acontece algumas questões que essa professora é devolvida novamente ao governo do estado, o hospital fica sem professor, isso dentro do Pequeno Príncipe, fica sem professor e daí em 88 a [Assistente Social] vai atrás do município para já firmar convênio. Daí em 88 se firma convênio com o hospital, mas inicialmente, discutia-se, se falava muito que esse convênio em 88 já começou com o viés da escolarização. $E$ agora na minha pesquisa eu descobri que não, foram cedidas duas professoras que participavam de projetos voltados à Educação Física. Elas eram professoras da Secretaria de Educação, na época se chamava Gerência de Ensino, uma coisa assim... Na dissertação eu cito isso, o nome correto. Elas trabalhavam como professoras em praças com atividades de recreação. Elas trabalhavam ali na praça... Osvaldo Cruz é aquela praça do Pequeno Príncipe? Elas trabalhavam nuns lugares assim, elas trabalhavam a recreação. E daí o governo do município faz o primeiro convênio em 88 com o Pequeno Príncipe e são disponibilizadas, cedidas duas professoras para trabalhar a recreação. Aí depois de um tempo, acho que no ano seguinte, vem uma professora para trabalhar a parte da escolarização mesmo. As datas assim...

Eu - Do município mesmo?

Prof. - Do município. Isso em 88. Daí o governo do estado fica afastado um tempo, por conta daquela professora ser emprestado sem convênio por três meses. Aí, eu descobri dentro dos documentos do arquivo público que em 89 o governo do estado faz o primeiro convênio com o hospital e que daí é cedida a professora [estadual], que acho que é a pessoa que você fez contato que começa em 89.

$\mathrm{Eu}$ - Sim. Quais os modelos educacionais direcionados ao atendimento das crianças e dos adolescentes que podem ser observados nos atendimentos da Escolarização Hospitalar no hospital infantil de Curitiba no Setor que você trabalhava? Que modelo de educação que é implantado ali naquele início que você ficou?

Prof. - Ah! Era bem tradicional mesmo, a gente trabalhava bem como eram as escolas, aquela coisa tradicional mesmo. A alfabetização, toda a parte bem tradicional.

$\mathrm{Eu}$ - De que modo se apresenta os progressos no atendimento da Escolarização Hospitalar ali no setor do hospital infantil de Curitiba?

Prof. - Existia a quase 10 anos na época. A gente seguia os documentos do município. Então o que acontece, quando eu entro no município... não, eu entrei na Fundação em 98, não foi em 97. Iniciou o convênio com a Associação Criança Renal em 97, eu entro em 98. Quando eu entrei no município em 96 eu vinha de uma Escola Especial. Então, meu foco era a Educação Especial, quando eu entro em 96 no município, eles estavam mudando a questão da alfabetização e eu fui para uma 1a série, na época, acho que era $1^{\circ}$ ano naquela época, eles estavam mudando o método de alfabetização, porque eles trabalhavam com o método tradicional e eles começam a modificar, que vem aquela coisa do texto, de alfabetizar pelo texto, não era mais 
aquela coisa do $\mathrm{BA}-\mathrm{BE}-\mathrm{BI} .$. não, é pelo texto. Então eu entro em $96 \mathrm{com}$ um $1^{\circ}$ ano e a alfabetização estava mudando, o município estava passando por um processo de mudança. Eu fico só dois anos na escola regular, o primeiro ano de município com $1^{\circ}$ ano mesmo, $1^{\mathfrak{a}}$ série, e no ano seguinte vou para Educação Artística. Então, eles estavam modificando todas as diretrizes e a gente caminhava e ia naquela onda junto, sem entender muito bem o que estava acontecendo, porque era tudo muito novo. Quando eu vou para o hospital em 98 o município não dava o assessoramento para esses professores, então a gente caminhava como dava, como você achava que deveria alfabetizar, como você achava que deveria trabalhar do $1^{\circ}$ ao $4^{\circ}$ ano, que era nosso foco maior. Então, a gente ia fazendo como... ia caminhando. $E$ coincidentemente eu fiquei dentro do Setor de 98 a 2005, fora dos cursos do município. Então, toda aquela parte pedagógica que estava sendo trabalhado no município, a parte de atualizações pedagógicas a gente não tinha, porque a gente não participava de curso. Então, você ia meio no escuro, vou fazendo como dava certo, vai acontecendo, era muito mais uma visão do que dá certo com Fulano, com o aluno $A$, e o que dá certo com o aluno $B$, vamos indo no escuro, porque a gente não tinha uma orientação até 2005. 2005 sim, daí o município pega essas professoras, começa a ter reuniões pedagógicas. A partir de 2005 a gente consegue seguir uma linha pedagógica e ir compreendendo o que acontece, mas de 98 até 2005 eu fiz como eu achava que tinha que ser e como funcionava. Se você fosse trabalhar alfabetização e você visse que tinha que trabalhar com o $\mathrm{BA}-\mathrm{BE}-\mathrm{BI}$ - BO - BU você ia trabalhar com o $\mathrm{BA}-\mathrm{BE}-\mathrm{BI}-\mathrm{BO}$ - BU, se você via que dava para começar a trabalhar com a articulação dentro de um texto, você ia fazendo. Então, era meio que nas escuras. $\mathrm{Eu}$ - Quais as questões político pedagógicas que podem ser observadas nesse período?

Prof. - Puxa, não sei te precisar mesmo como é que era, porque a gente ficava afastada. A gente trabalhava meio que no modelo tradicional, era o material que a gente conseguia e que a gente ia... A gente estava afastada disso, nós éramos afastadas, a gente não fazia curso, a gente ficava a margem, você ia trabalhando com o que você achava e eu como uma professora que não era a professora que trabalhava com a questão de você ter orientações pedagógicas de como você trabalhar, você fazia as coisas meio que pelo escuro, se lia, pegava os documentos do município e ia adaptando, ia organizando, mas era o modelo mais tradicional mesmo.

Eu - Você poderia me indicar alunos que tenha atendido para que eu possa entrar em contato com eles e solicitar a participação nesta pesquisa?

Prof. - Eu acho que esse menino do mestrado, de repente dê para você entrevistar. Tem alguns que dá pra ver, falar com eles. Tem uma que está fazendo enfermagem. Tem umas outras história que é bem legal que é de uma aluna que era deficiente auditiva, e a gente fazia um acompanhamento meio que a parte, porque ela já era de $5^{\underline{a}}$ a $8^{a}$ série e ela estudava numa escola, primeiro que não era nosso foco, de $5^{\underline{a}}$ a $8^{\text {a }}$, então a gente não podia se meter muito na questão, e ela estudava numa escola que era para surdos. Ela perdeu a audição por conta do problema renal e um dia ela chegou, terminou a $8^{a}$ série e ela queria fazer $2^{\circ}$ grau e ela disse para mim: "[Professora], se eu fizer magistério, você deixa eu fazer estágio aqui dentro da hemodiálise?" Eu falei: "Deixo", porque a gente queria que eles estudassem, você quer que evoluam, que vá para a frente. Daí eu disse para ela: "Eu deixo". E falei: "Tem o fulano de tal, que era uma outra criança que era também deficiente auditivo, e eu tenho uma certa dificuldade, dentro da Educação Especial meu foco maior, antes de entrar na prefeitura, foi o mental e depois o visual, mas o auditivo eu sempre tive 
uma certa dificuldade, o auditivo talvez, porque eu fale demais e seja muito italiana e use muito o gestual então, eu nunca trabalhei, eu tinha uma certa dificuldade, e esse menino, era uma criança da $1^{\underline{a}}$ a $4^{\text {a }}$ série, e eu tinha uma certa dificuldade de trabalhar com ele, porque ele era deficiente auditivo. E eu falei para ela: "Pode, você vem fazer estágio e você vai dar aula para fulano", que era o deficiente auditivo. E ela disse: "Ah, legal!" E eu disse: "Beleza". Entrei em contato com a Fundação, naquele momento já era a Fundação na época e conversei com a presidente e falei: "Olha, a fulana vai fazer magistério e tem intenção de fazer o estágio aqui dentro, mas pra gente não ter algum problema, na questão trabalhista mesmo, entrei em contato com o Hospital Pequeno Príncipe, com o voluntariado e conversei com a Patrícia e a Rita que eram funcionárias do hospital e falei: "Fulana quer fazer o estágio do magistério dentro do setor. Tem como a gente colocá-la como voluntária do hospital?", e elas falaram: "Tem". Então, a gente fez através do voluntariado, ela como voluntária era minha auxiliar dentro do setor. Eu assinava as fichas de estágio, ela fazia magistério no Instituto de Educação. Eu assinava as fichas do estágio dela, ela preenchia as fichas do que ela trabalhava com o aluno, mas era vinculado ao voluntariado do hospital. Depois de um tempo ela foi trabalhar no hospital, ela trabalhou no hospital até esse ano. Agora ela saiu do hospital esse ano, mas ela ficou um tempo trabalhando em outras funções dentro do hospital, até porque ela nem terminou o magistério, acabou indo fazer o $2^{\circ}$ grau em outra área, acho que a parte administrativa, não me lembro, mas ela trabalhou no hospital até esse ano.

Eu - Ela saiu do hospital então?

Prof. - Sim. É transplantada, mas ela não chegou a fazer ensino superior, fez só Ensino Médio, que é uma menina bacana assim, que dá para falar.

Eu - Depois então eu pego o contato dela. Como foi uma das pioneiras ou talvez a pioneira neste trabalho tão diversificado, teria alguma consideração a fazer sobre as dificuldades que encontrou neste novo ambiente de trabalho que se delineou nos seus dias profissionais, nos seus primeiros dias profissionais aqui na prefeitura, porque você ficou dois anos na escola regular e já foi para o hospital?

Prof. - É. Foi muito rápido, eu não tive muita experiência não na rede. Uma questão que eu acho super importante é que antes de ir para um ambiente deste, você passe pela escola. Meu tempo de escola foi pequeno, mas foi importante. Importante que esse professor passe pela escola. Em alguns momentos eu brinco e digo, professor para ele estar dentro da sala de aula tem que passar pelo hospital, porque no momento que você tem um trabalho deste, a tua visão muda, você não consegue mais entender que os 30 alunos são todos iguais, você consegue entender que cada um é único, que cada um você tem que trabalhar de uma maneira diferente, não tem como você trabalhar todos de um mesmo jeito e todo mundo vai entender e aprender do mesmo jeito, por mais que a gente tentasse trabalhar num modelo tradicional dentro do hospital ali que era o que eu fazia naqueles 7 anos e meio, você acaba modificando a prática, porque você percebia que esse entendia mais de uma maneira e esse, 0 canal de aprendizagem dele era um, do outro era outro. Então era muito a questão da sua sensibilidade. O professor que está dentro do ambiente, tem que ter um perfil diferenciado, ele tem que ser uma pessoa sensível, mas ele não pode ser mole. Ele tem que ter a sensibilidade, mas ele não pode ser uma pessoa... tem que ser firme, tem que ser flexível, mas tem que ser firme. E eu me lembro de uma coisa que me marcou muito dentro do setor que tinha enfermeira e eu fui falar para ela quando eu comecei: "Fulana..." era uma situação assim: a criança da $1^{a}$ a $4^{a}$ série estudava a tarde e a criança da $5^{\text {a }}$ a $8^{\text {a }}$ estudava de manhã e essa criança fazia hemodiálise a tarde, comigo que era um período e ele ia mudar de escola e no ano seguinte ele teria 
que estudar de manhã, um coisa assim, ia mudar de turno e eu cheguei para ela e falei: "Fulana, eu queria ver com você se tem condições de agora para o próximo ano passar o fulano para a manhã na hemodiálise, por conta da escola." Ela foi muito dura comigo, me disse: "Aqui, primeiro é a saúde, depois a gente vê isso da escola". Depois, quer dizer, é transplante e depois a gente vê como fica... "Vai ficar no período da tarde". Foi assim um "baque", o primeiro "baque" que eu levei. E falei: "Hum, tá bom né!" E depois você vê que essa mesma profissional em algum momento em que a criança não ia para a escola ela vinha e dizia: "[Professora], o fulano não está indo para a escola, hoje ele passou pela consulta da Dr. Fulana (antes da gente começar a participar as vezes das consultas) hoje ele participou da consulta com a Dr. Fulana e ele não está indo para a escola. Você veja o que está acontecendo!" Quer dizer, à medida que você começa a mostrar a prática, que a coisa funciona e é um outro olhar, que essa criança consegue viver a questão da saúde e que também pode viver as outras questões da vida. Você vê quanto isso é legal, quanto isso é diferente. Foi uma coisa que me marcou muito isso de ouvir ela dizendo que primeiro a saúde e depois a escola a gente tem que ver e eu engoli em seco, mas depois isso mudou. Essa mesma pessoa me cobrava: "Fulano não está indo para a escola veja lá o que está acontecendo... Falou para a médica que não foi para a aula..." Então, era uma coisa que me marcou muito. Não sei se te respondi.

Eu - Não, era como esse novo trabalho se delineou na sua vida...

Prof. - Eu acho que passa muito pela sensibilidade da gente perceber como é que funciona, qual o canal que você atinge essa criança. A gente dentro do hospital não trabalha... ah não e não vou trabalhar recreação, eu vou trabalhar o conteúdo escolar, mas eu não posso chegar para ele e falar: "Ah não, é só isso aqui". Eu posso passar conteúdo assim, eu posso passar por esse caminho, mas sempre com intencionalidade pedagógica.

Eu - E trabalhar o conteúdo de forma lúdica, também. Principalmente porque eles são crianças, brincando eles vão aprendendo...

Prof. - Posso. Eu não vou ler uma história por uma história, não vou fazer um jogo pelo jogo, eu tenho uma intencionalidade com isso. Então, eu vou trabalhar sempre amarrando com o pedagógico escolar. $E$ eu acho que a gente tem que aliar, eu vejo que dá resultado isso, o quanto é importante, o quanto essas crianças... Você tira ela daquela coisa da doença, só daquele mundo que ela está vivendo da doença, você consegue mostrar outros caminhos, outras vertentes de vida para ela.

$\mathrm{Eu}$ - Eu estou percebendo que você está falando que o trabalho inicialmente era bastante tradicional e aí você foi percebendo que não... que esse tradicional... o trabalho derrubou por terra toda essa questão tradicional, te mostrou que era um jeito diferente de realizar o trabalho, sem uma obrigatoriedade superior, porque você não tinha acesso às formações, mas a realidade te mostrava que a forma de trabalho tinha que ser diferente, que tinha que respeitar a individualidade de cada um.

Prof. - Sim. É, porque você ia fazendo.... Não tinha como eu pegar uma... Vamos pensar num modelo tradicional de ensino, eu fazia a caligrafia. Que caligrafia se ele estava numa máquina de hemodiálise, olha se tem sentido eu fazer caligrafia. A escola me cobrava a caligrafia, mas que sentido que teria isso para aquela criança? Que sentido teria isso? Então, vamos procurar como dar. Vamos ver por esse lado.

Eu - Para que ter uma letra super bonitinha, redonda, se ela não consegue nem se comunicar, nem escrever nada, não é.

Prof. - Pois é! Então, a gente ia caminhando como as coisas iam mostrando, a gente, meio que ia fazendo as coisas às cegas mesmo.

$\mathrm{Eu}$ - Mas a realidade ia te mostrando aquilo que funcionava ou não. 
Prof. - É.

Eu - Você acredita que esse período de trabalho no hospital lhe acrescentou alguma coisa em sua vida pessoal ou profissional? Se sim, poderia me dizer o que foi?

Prof. - Eu acho que a gente procura... a gente sempre diz: "Ah, o profissional é o profissional, o pessoal é o pessoal" e a gente procura ter muito isso claro, porque você não vai misturar, mas não tem como, é muito difícil você ver a realidade, você saber separar de que eu tenho, por exemplo, uma criança de 5, 6 anos fazendo hemodiálise, 7, na época que os meus filhos eram da Educação Infantil, eu via que eu tinha duas crianças perfeitas em casa e que às vezes faziam birra por umas coisinhas bobas, porque não era suco era coca cola e saber que tinha mesma criança passando por um tratamento que muitas vezes não podia tomar água, coca cola muito menos e nem pensar. Então, não tem como você fazer a separação disso, não tem como você não mudar. Então, uma das mensagens que eu sempre dou quando eu vou dar palestra, sempre que a gente chega nesse ponto, desta fala, eu digo para as pessoas assim, se surge essa possibilidade e pelo viés da palestra que você está dando e você percebe que as perguntas dos estudantes, que a gente acaba dando palestra nos cursos de Pedagogia, partem muito para esta questão do emocional, eu finalizo muito com um aprendizado que eu tive: Não durma brigado com ninguém, não brigue por causa de um tomate, você não sabe o amanhã. Então, isso eu levei muito para minha vida profissional, eu não durmo brigada com ninguém, eu não discuto por qualquer besteira, eu não discuto por causa de um lápis, não, a vida é muito mais que isso. Então, não tem como você dizer que não teve aprendizado na sua vida. A minha vida mudou muito, muito. Hoje eu dou valor para algumas coisas que eu... A questão desta criança que eu te falei do banho. Gente, banho você entra embaixo do chuveiro, você toma banho e pronto. Não, para ele não era entrar embaixo do chuveiro e pronto. Eu nas minhas férias de dezembro, fui para a praia, ele não vai para a praia, ele vai ficar, porque ele tem que fazer hemodiálise no dia 24 , e depois no dia 26 , é um dia sim, um dia não. Ah, tem Natal? Pode ser que o Setor consiga adaptar e fazer hemodiálise um pouco... consiga organizar para que eles tenham o dia 25 livre, às vezes não... Então, para o tratamento você tem que estar três vezes na semana, sim. Tinha que estar e tem que estar. Não tem como você ficar: "Ah, nas minhas férias eu vou para a praia e fico um mês". Não, não vai ficar. "Ah, eu vou para minha família visitar, vou lá para minha cidade ficar duas semanas". Gente, você tem que pegar o teu material da hemodiálise, mandar para aquela cidade, para aquele hospital te atender naquele período, porque você precisa ir e isso não é liberado sempre. É toda uma dinâmica totalmente diferente de vida. Então, não tem como você não mudar com isso, não perceber que a vida é muito mais do que isso. Não tem! Então, por isso que de vez em quando eu brinco que todo professor antes de ir para a sala de aula tinha que passar pelo hospital para entender toda essa dinâmica, o que é essa vida. Então, não tem como não te mudar. É impossível, é impossível você continuar vendo a vida e os alunos, principalmente na questão pedagógica, todos eles iguais. Impossível!

Eu - Hoje você trabalha na Secretaria de Educação.

Prof. - Sim.

Eu -Você tem interesse em voltar a trabalhar algum dia como professora no hospital? Prof. - Mas é o que eu mais amo! É o chão da minha fábrica!!!! (Risos) A gente tem uma Diretora do nosso Departamento, esse ano ela entra num governo novo, e a proposta dela é que eu acompanhe, que eu dê assessoramento para as professoras toda semana no hospital. Então, eu estou nos hospitais toda semana. Então, eu dou aula toda semana no hospital. Eu dou aula no Pequeno Príncipe como professora uma semana, eu dou aula no Erasto Gaertner como uma professora, eu dou aula na 
APACN como professora, eu dou aula no $\mathrm{HC}$ como professora. Então, em vez de estar em um hospital, estou em todos, eu estou em todas as unidades. Num dia eu vou num hospital e fico na parte oncológica, no outro dia fico na Clínica Pediátrica, no outro eu vou no ambulatório. Então, eu estou em todas.

Eu - Ampliou então?

Prof. - Ficou mais legal!

Eu - Ficou mais legal! Quais as melhores recordações que tem deste período lá na hemodiálise no Pequeno Príncipe?

Prof. - Aí foi assim, era um trabalho muito legal! Você vê assim a evolução, você vê pai e mãe que voltaram a estudar, sabe?! Eu acho que a gente enquanto educador, a gente não consegue tirar isso da vida. Não é?! Você está numa roda de amigos e a hora que você vê você já está falando: "E daí, está estudando, o que você está fazendo? Ah! Vai fazer? Nossa, mas você parou de estudar? Vai atrás de um supletivo". Está no seu sangue. De vez em quando... Nestes dias minha irmã me ligou e disse: "Ah, sabe, tem um rapaz aqui tão legal, está trabalhando aqui no escritório, não sei que, veio não sei de onde..." E eu falei: “Tá, mas não está estudando?" E ela: "Não, não está..." E eu falei: "Vai atrás de um supletivo". Daí ela falou: "Mas onde que tem? Será aqui?" Porque ela não é da Educação. Ai eu falei: "Ah, eu já vejo pra você!". Eu estava indo trabalhar, eu parei meu carro e peguei no celular, já puxei qual era o supletivo que tinha perto da onde ele estava morando, porque eu já perguntei para a meu irmão onde ele morava, já mandei e falei: "Olha, vai..." Liguei no supletivo para ver se tinha vaga. Tudo assim, porque a gente quer que a pessoa esteja incluída, siga a vida, vá fazer curso técnico, vá fazer supletivo, vá fazer faculdade. Você quer que vá para a frente, não é! É muito difícil você tirar isso de você! Você quer que as pessoas evoluam, evoluam, evoluam academicamente. Então, eu acho que ver dentro da hemodiálise algumas pessoas que saíram, que foram.... Tem um deles que não mora mais em Curitiba, que trabalha como socorrista. Esse menino mesmo do mestrado ele foi para a área renal.

Eu - É. Ficou no sangue, não é?!

Prof. - É. Então, eu acho que a gente, enquanto educador, enquanto professor não consegue separar muito isso da vida. Assim, as lembranças que eu tenho da hemodiálise são muitas e até hoje, quando eu vou lá, até semana passada, eu fui e conversei com uma pessoa que trabalhou, que era enfermeira, essa enfermeira da hemodiálise não trabalha mais na hemodiálise, ela trabalha numa outra parte renal, eu não sei qual o setor que ela trabalha, mas eu acho que ela trabalha na... não sei se é com os transplantados, não sei... realmente eu não sei, mas ela trabalha dentro da Nefrologia, e eu fui lá pra ela esses dias, porque eu estou com uma criança de atendimento domiciliar, ele faz tratamento no Pequeno Príncipe, mas ele não faz hemodiálise, ele faz consulta, e eu fui e falei para ela: "Fulana, você sabe me dizer do fulano, da criança?" Aí ela disse para mim: "Puxa [Professora], a situação dele está meio complexa, talvez ele venha para a hemodiálise". E eu falei: "Pois é, porque ele está em atendimento domiciliar e agora vai vencer por seis meses e eu gostaria muito que ele voltasse para a escola, porque eu percebo que há uma característica da mãe". A mãe estava superprotegendo e insistindo no domiciliar. Eu falei: "Poxa seria tão importante que essa criança voltasse para a escola, tivesse o convívio social, a rotina". $\mathrm{E}$ eu fui conversar com essa enfermeira em relação à essa criança. Por estar dentro da secretaria eu tenho essa possibilidade. E ela disse assim para mim: "Olha [Professora], nós temos reunião da equipe uma vez por semana, venha para a reunião". Eu falei para ela: "Fulana, como é que eu vou vir para a reunião?" "[Professora], você trabalhou um monte, tempo junto com a gente, você é de casa. 
Venha para a reunião falar com a Doutora que daí você pode expor isso no grupo, na reunião de médicos e ver se realmente, se ele tiver condições, veja com a médica para ele retornar para a escola". Daí eu fiquei meio acanhada de ir na reunião. Ah, Eu não vou na reunião, chegar assim, fica meio esquisito. Depois eu liguei para ela e falei: "Fulana, não vou na reunião". "Anote aí o celular da médica, e liga para ela". Falei: "Fulana, como é que eu vou ligar para a médica?" Ela falou: "[Professora], pode ligar. Dra. Fulana é muito legal, pode ligar"' E eu realmente, me deu um certo receio, porque os médicos têm uma postura diferente, alguns a gente tem mais facilidade para conversar, mas outros não. "Puxa vida, vou ligar para a médica". E eu liguei para a médica e falei: "Doutora Fulana, a enfermeira $X$ deu o seu telefone, a senhora desculpa, mas eu gostaria de conversar a respeito do fulano, porque... Daí foi muito legal, porque a médica foi bem aberta comigo e ela disse: "O momento dele está sendo este, este e este" e eu falei: "Sim, a professora do domiciliar me passou isso, que o momento dele é esse, que está acontecendo assim". Ela disse para mim: "Olha, talvez ele tenha que, por conta do tratamento dele, ir para a hemodiálise, então, acho que por conta da questão, eu acho melhor a gente manter um pouco mais". Eu falei: "A senhora que manda. Vamos manter, então!" Por conta de você ter ficado tanto tempo dentro de um hospital, no setor, o setor ainda está incorporado, não é! Muitos médicos e enfermeiros daquele tempo ainda estão lá. Então, tem uma criança também que eu estava com atendimento domiciliar e eu fui falar com o médico. "Ah, fale com o dr. Fulano, essa enfermeira me falou, fale com o dr. Fulano". E eu fui e falei: "Doutor, o atendimento domiciliar foi..." E ele: "Mas como que funciona isso, a mãe me disse que o atendimento domiciliar é assim, assim, assim..." Eu falei: "Não doutor, não é bem assim, o atendimento domiciliar é assim, assim, assim". Aí ele ficou Humm... Eu falei: "Seria tão importante se ele voltasse para a escola, eu estou percebendo um pouco da mãe uma superproteção, porque a gente sabe que a hemodiálise, a questão do cateter, tem algumas questões..." E daí ele falou: "Vamos ver, então!" Eu falei: "Seria muito legal se ele voltasse para escola". Ele falou: "Vamos estudar isso então, em vez de domiciliar a gente tentar incluir na escola". Porque é importante a rotina, expliquei para o médico a importância da rotina, a importância do convívio com outras crianças, de toda aquela dinâmica. O atendimento domiciliar é uma coisa muito interessante, muito bacana que você trabalha o conteúdo específico com aquela criança, que vai ser diferente de uma sala de aula, mas a questão escolar, quanto é importante toda essa rotina, esse convívio. Aí ele disse assim: "Vamos dar uma pensada então, se a gente mantém esse domiciliar". Então assim, eu estou conseguindo ter dentro do setor por eu ter saído de lá a mais de 10 anos, eu ainda consigo... eles conseguem enxergar que eu trabalho dentro do setor, porque é um trabalho tão legal e eles acreditam tanto nisso que eles ainda me têm como uma pessoa que é parceira e que a gente possa fazer. Eu ainda tenho acesso, a hemodiálise não pertence mais à Fundação, pertence ao hospital, mas eu ainda consigo ter acesso a isso. Eu acho que é muito legal, porque aí você vê que o trabalho que você fez, que você conseguiu desenvolver, foi válido e eles reconhecem isso até hoje. De vez em quando, muitos profissionais dentro do setor de hemodiálise trabalham em outros hospitais, de vez em quando eu encontro eles nas minhas caminhadas pelos hospitais, esses dias eu estava lá no ambulatório da APACN e a médica me olhou assim no corredor, era uma médica que trabalhou na hemodiálise, e ela disse para mim: "O que você está fazendo aí, [Professora]?" E eu falei para ela: "O que que a senhora está fazendo aqui na oncologia, brinquei com ela". E ela: "Ah, também estou trabalhando no HC. Ai que legal, você está trabalhando aqui!!!" E eu: "Não, não estou". Ela: "Ah! Não acredito que você não está! Saudade de você!" Eu falei: "Ah, eu dou umas trabalhadas", brinquei com ela e expliquei e ela falou: 
"Ai, que legal, você está na secretaria! Que bacana!" Então, o momento que eu vou para o Erasto eu encontro médicos, no momento que eu vou HC eu encontro médicos. Então, você acaba circulando e acaba conhecendo as pessoas e te trazem recordações, assim que.... Porque não tem como você não levar isso para sua vida. É impossível!

Eu - A gente está acabando aqui. Você gostaria de falar mais alguma coisa? Fique à vontade.

Prof. - Acho que eu já falei bastante! Eu estou aí disposta para o que você precisar, não sei se contribui muito, não é!

Eu - Contribuiu bastante.

Prof. - O meu histórico não é dentro do Hospital Pequeno Príncipe, eu gosto muito de frisar isso. Eu acho que é muito importante que o hospital tenha criado um setor e eu peguei uma parte dessa criação desse setor. E eu gosto de frisar muito que eu não trabalhava no Hospital Pequeno Príncipe, eu trabalhava na Associação, sempre deixei isso muito claro, porque era um convênio com a Associação.

Eu - Esse Setor foi criado em 2015. É isso? Ou 2002?

Prof. - 2002

Eu - 2002. É quando eu vou encerrar a minha pesquisa, o marco de quando eu encerro a minha pesquisa. Você comentou do arquivo público. É o municipal ou estadual?

Prof. - Municipal.

Eu - Onde que fica esse arquivo público?

Prof. - Eu acho que o nome daquela rua é a Peri Moreira, se não me engano ou o Prédio é Peri Moreira. Tem a prefeitura, a Cândido de Abreu, é uma quadra para cima, tem a Assembleia ali, é uma ruazinha.

Eu - Para fazer pesquisa lá tem que marcar horário? Como que faz?

Prof. - Eu acho que dá para você ligar ou ir lá mesmo. Você solicita o documento e eles conseguem os documentos para vocês.

Eu - Você também comentou sobre as diretrizes municipais da década de 90 . Será que na biblioteca pública tem esse documento?

Prof. - Nós temos a biblioteca do município.

Eu - E onde fica essa biblioteca?

Prof. - Então, a prefeitura tinha o Centro de Formação, que ficava na Dr. Faivre, na frente da Federal, mas agora, com a mudança de gestão, ele foi devolvido, o prédio.

$\mathrm{Eu}-\mathrm{Ah}$ !

Prof. - E aí ficava a biblioteca do município, porque tem os Faróis do Saber, as bibliotecas das escolas e a biblioteca da educação.

Eu - Da Educação, do professor.

Prof. - É, do professor. As diretrizes, todos estes documentos ficam nessa biblioteca.

Ele era ali na Dr. Faivre. Eu não tenho certeza absoluta, mas parece-me que ele foi para a Escola Batel, porque estava em reforma a própria escola e eles iriam fazer a modificação toda de prédio, mas parece-me, eu posso me certificar onde está para você, posso ver, mas eu tenho quase certeza que estão lá.

Eu - Você acha que ali e posso encontrar essas diretrizes da década de 90.

Prof. - Sim. No meu, acho que no terceiro capítulo da dissertação eu trabalho um pouco, porque eu peguei essas diretrizes, obviamente que eu não as li inteiras, mas eu pego todos esses documentos do município, porque eu queria ver em que momento que ele fala da escolarização. Eu falei, não, não é possível, em algum momento ele vai ter que entrar e vai falar alguma coisa da escolarização. Então eu pego alguns documentos. Tem a professora Elisabeth e acho que a professora Albani 
da PUC, que elas fazem algumas pesquisas históricas, que elas pesquisam as diretrizes. Então, se você procurar dentro da minha dissertação tem documentos delas, onde elas pesquisaram como que era a questão pedagógica do município. Elas fizeram alguns artigos, algumas dissertações que elas pesquisaram essa faixa na escola, mas lá na biblioteca tem esses documentos. $E$ daí ele vai mostrando assim que o município caminhava, era bem engatinhando mesmo. Bem engatinhando. Deixa ver se eu acho aqui (folheando a dissertação). Aqui não está afinal, porque essa era da qualificação, mas ali no seu, a que mandei para você, arquivo vai ter. A professora Elisabeth, a professora Beth, a famosa professora Bethinha da PUC e a professora Albani. É, não está aqui mesmo nesta. Acho que está sim. Acho que está. Eu peguei a parte do site. Eu sou ruim para nome. Aqui, Miguel, professora Bethinha Miguel e a professora Vieira é a professora Albani, As Políticas Educacionais da Rede Municipais de Educação de Curitiba, implantação. Se você jogar na internet você vai achar algumas coisas. E esses documentos tem lá no nosso arquivo.

Eu - Legal.

Prof. - Professora Maria Elizabeth, que é a professora Bethinha e a professora Albani. Então, foram alguns documentos que eu pesquisei delas e lá no arquivo tem, no arquivo não, na biblioteca do município você vai achar essas diretrizes. Só me lembre para eu procurar, ver para você onde que está.

Eu - Para onde que foi a Biblioteca.

Prof. - Eu acho que algumas coisas foram para o Colégio Brandão, Professor Brandão que é ali perto do Delta e algumas coisas foram para a Escola Batel, eu tenho quase certeza que a biblioteca do... que eles estavam em reforma, a biblioteca foi lá para a Escola Batel, que era o antigo 19 de novembro.

Eu - Ah!

Prof. - Sabe qual é, onde que é, não é?

Eu - Sei.

Prof. - Ele é ali pertinho do Pequeno Príncipe. É o antigo 19 que agora é a Escola Municipal Batel.

Eu - Só precisa me passar o contato dos alunos.

Prof. - Está.

Eu - Obrigada, agradeço muitíssimo, ajudou bastante.

Prof. - Imagina. 


\section{Apêndice $\mathrm{J}$ - Transcrição Entrevista Mãe}

Eu - Aqui é Claudinéia Maria Vischi Avanzini que está fazendo a pesquisa "A EDUCAÇÃO DE CRIANÇAS EM HOSPITAIS: A experiência da cidade de Curitiba, PR num Hospital Infantil, 1988 - 2002"

Eu - Qual o nome da Sra.?

Mãe - ESB ${ }^{189}$.

Eu - A Sra. é mãe de uma ex-aluna do Hospital que ficou nesse período lá, não é? Mãe - Sim.

Eu - A Sra. Gostaria de me dizer por que que sua filha fazia tratamento no hospital quando era criança?

Mãe - Do?

Eu - É. Por que ela ia para o hospital?

Mãe - Fazendo tratamento com a equipe de nefrologistas, porque ela tinha problema de insuficiência renal crônica.

Eu - Está. Durante quanto tempo a Sra., a filha da Sra. frequentou o hospital infantil em Curitiba?

Mãe - Acho que uns 7 anos mais ou menos.

Eu - Nesse período... A Sra. Lembra de que ano até que ano, mais ou menos?

Mãe - Ela começou o tratamento em 91, 1991 e daí ficou até 2001, que ela perdeu o rim novamente.

Eu - Quando que ela fez o transplante?

Mãe - Ela fez no ano de 25 de agosto de 1993.

Eu - Certo. E nesse período, que foi de 91 até 93 que ela ficou fazendo a hemodiálise no hospital.

Mãe - Exatamente.

Eu - Nesse período de 91 a 93 ela já ia para a escola regular?

Mãe - Sim

Eu - Que série que ela estava?

Mãe - Ela começou no prézinho e foi até a quarta série.

Eu - Nesse tempo todo ela também estava no hospital

Mãe - Nesse tempo. Sim!

Eu - Ela estava no hospital desde o pré até a quarta série?

Mãe - Sim, desde o pré até a quarta série no ensino regular.

Eu - Que escola que ela estudava? A Sra. Lembra?

Mãe - Escola Miguel Kruger. Escola Estadual Miguel Kruger.

Eu - Em Curitiba?

Mãe - Em Curitiba, Portão.

Eu - Nesse período, a sua filha chegou a ter aula com as professoras que trabalhava no hospital?

Mãe - Sim.

Eu - Como que foi. A Sra. lembra como que eram essas professoras?

Mãe - Era a professora [estadual] na época. Ela auxiliava ela nas tarefas que ela tinha dificuldade.

Eu - Como que começou esse atendimento? Qual o motivo que levou a sua filha a ter essas aulas no hospital?

189 Para preservar a identidade da mãe, optei por utilizar somente as iniciais no lugar de seu nome. 
Mãe - Porque ela não conseguia acompanhar as aulas na sala de aula. As dificuldades ela levava para casa. O que eu podia ensinar eu ensinava e o que eu não podia, ela pedia auxilio para a professora [estadual].

Eu - A Sra. quer me contar como que foi aquele problema com a professora na sala de aula?

Mãe - Sim! Porque ela não tinha... ela passava o maior tempo no hospital, porque tinha exame e a manhã inteira ela passava no hospital e ela levava o caderninho dela, só que muitas vezes ela não conseguia fazer as lições. Aí, ela chegava na sala de aula e a professora tinha aquele jeito dela, chamava fila por fila para entregar 0 caderno e a minha filha já ia tremendinho com o caderno, com a lição pela metade, daí quando a professora via que ela não tinha feito a lição, simplesmente ela pegava o caderno da minha filha e jogava no final da sala, e a minha filha ia pegava o caderno, vinha chorando, e um dia a tarde eu fui buscar ela na escola ela me contou a história. Ela falou: mamãe, me tira daquela escola senão eu vou ficar louca. Daí eu falei: Mas por quê? Ela disse assim: Não mamãe, eu não quero mais estudar lá. $E$ daí de tanto eu incentivar ela, ela me contou a história, o que a professora fazia. Daí eu fui conversei com a professora [estadual] tudo o que estava acontecendo e daí ela foi, conversou com o pessoal da Secretaria da Educação e tomou as medidas necessárias. Daí, daquele ponto, a professora até pediu para mim tirar ela da sala da escola, porque ela não acompanhava e ela tinha várias dificuldades, principalmente na matemática. E daí até ela falava: Mãe, você ensina de um jeito, a professora ensina de outro, e eu estou ficando louca! Daí eu conversei com a professora [estadual] e falei: Olha [Professora], eu não sei, eu aprendi o processo longo, ela disse que a professora ensina o processo curto e então você veja o que você faz. Daí ela foi e conseguiu passar de ano com a ajuda da professora. E daí ela auxiliou também na quarta série.

Eu - A professora que estava no hospital?

Mãe - A professora do hospital.

Eu - Ela estava na 3a. série nessa época?

Mãe - 3 ${ }^{a}$. série que aconteceu.

Eu - Que aconteceu esse problema com a professora?

Mãe - É! Com a professora.

Eu - Daí ela tinha...

Mãe - Daí na 4ํ․ Série...

Eu - Ela tinha quantos anos na $3^{\underline{a}}$ série?

Mãe - Nessa época ela estava com 8 anos.

Eu - Nossa!

Mãe - 8 aninhos.

Eu - E aí na $4^{\text {a }}$ série ela continuou na mesma escola?

Mãe - Aí ela continuou, só com outra professora.

Eu - Sim!

Mãe - Daí na metade do ano ela pegou uma peritonite e veio a perder o peritoneu.

Eu - Ela fazia hemodiálise peritoneal, nessa época?

Mãe - Exatamente. Daí ela praticamente, a metade quase do ano, ela ficou no hospital, porque ela ficou 29 dias entre a vida e morte. Então neste período, até a [professora estadual ${ }^{190}$ ] ia lá e ela não conseguiu. Pegava atividade na escola, eu levava e daí a [Professora] com carinho ia e conversava com ela, até que a gente pegava o conteúdo, trabalhinho e a gente levava para ela não perder o ano. Tipo

190 Para preservar a identidade da professora, no lugar do nome optei por deixar professora estadual ou Professora 1 por ela ter sido a primeira professora a ceder a entrevista para a pesquisa. 
assim, que nem ali na escola também a direção, que na época era a coordenadora, não tinha nem... acho, sei lá se tinha pedagogo. E daí eu levava o trabalhinho dela e daí dava notas para ela e ela terminou o ano.

$\mathrm{Eu}-\mathrm{E}$ conseguiu fazer formatura no final do ano!

Mãe - Conseguiu fazer.

Eu - Que são aquelas fotos que a Sra. mostrou.

Mãe - E ela foi para o Lysímaco. Daí na metade do ano, que foi agosto, ela fez o transplante.

Eu - No ano seguinte? Quando ela foi para o $5^{\circ}$ ano?

Mãe - No ano seguinte. Sim. Daí também o mesmo dilema, a gente ia na escola, só que ela não tinha mais o acompanhamento com a [Professora], que foi até a 4⿳亠丷a série. $\mathrm{Eu}$ - Ah! A [professora estadual] não atendia quando ia para o $5^{\circ}$ ?

Mãe - Não. Não. Foi só até o Ensino...

Eu - Fundamental, fim das séries iniciais?

Mãe - Fundamental! Exatamente!

Eu - Durante quanto tempo sua filha teve aulas no hospital? Então foi até 93, não é?

Foi quando...

Mãe - Até 90.... Não, 92.

Eu - Que aí em 93 ela foi para o 5a ano.

Mãe - É! Até 92.

Eu - Certo! A Sra. se lembra como eram essas aulas no hospital, que eram dadas para sua filha? O que a professora fazia nas aulas de sua filha?

Mãe - É, porque durante o tempo que ela estava lá esperando para consulta, um exame demorado, ela chegava ali e dava as aulas, ajudar no que ela tinha, porque na maior parte da manhã era os dias a gente estava lá, era exame para isso, exame para aquilo.

Eu - Então sua filha já levava os cadernos?

Mãe - Já levava os caderninhos dela.

Eu - As tarefinhas. E a professora ajudava ela a fazer?

Mãe - Exatamente.

Eu - Tirava as dúvidas?

Mãe - E tirava as dúvidas, porque a professora, ela é.... não sei, era o jeito dela, ela fazia, era Ciência, Português, Matemática, então era atividade assim... Ela enchia o quadro, ela não queria nem saber, era pergunta, então eu já levava o caderninho dela, já levava a mochilinha dela e o livro e tinha coisa que eu não sabia, porque tinha que ser a professora para ensinar. Então ela levava e o que ela podia, porque era muita, muita coisa e problema bastante, ela enchia o caderno...

Eu - A professora da sala dela, da turma?

Mãe - Da sala. Da turma dela. Então tinha profes., porque ela era uma professora mesmo bem rígida, né! Era uma... assim uma alemã, bem rígida, daquelas, mas só que no final assim, que ela viu que depois que eu fui conversar, a professora foi lá conversar com ela, e daí recebeu também ligação da secretaria, e daí ela mudou o comportamento, que ela viu que não era bem assim, que ela tinha mesmo dificuldade e mesmo por causa do problema dela ela era meia... né... devagar, já digo, bem devagar.

Eu - Está! A sua filha gostava de ter aulas no hospital?

Mãe - Gostava. Ela gostava da professora.

Eu - E por que que ela gostava da professora do hospital?

Mãe - A professora era bem carinhosa. Bem carinhosa! Dava joguinhos para ela. Dava as coisas para ela pintar, que ela amava pintar. Desenhar era o foco dela. 
Eu - Era uma aula diferente?

Mãe - Era uma aula diferente!

Eu - Essas aulas que ela teve no hospital ajudaram a sua filha a continuar os estudos normais depois?

Mãe - Sim. Ajudaram! Deram bastante força para ela. Foi muito interessante, né!

Eu - Como que eram as aulas desta professora da sua filha? Bom a Sra. já explicou, dava joguinhos, desenhos... Lembra de algo que tenha lhe marcado durante as aulas que sua filha recebia no hospital? Uma coisa diferente que aconteceu algum dia?

Mãe - Olha, assim eu não me lembro. Sabe, não me lembro, assim...

Eu - Ela só teve aula com a [professora estadual]?

Mãe - Só com a [professora estadual].

Eu - Não teve aula com outras professoras?

Mãe - Não! Só com ela!

$\mathrm{Eu}$ - A Sra. considera importante esse tipo de atendimento das professoras para crianças internadas no hospital?

Mãe - Sim! Com certeza é muito útil!

Eu - Por que que a Sra. acha que é útil?

Mãe - É, porque eles estão ali a maior parte do tempo, principalmente em hemodiálise, né, que 4 horas naquela máquina ali, então é muito interessante a professora está ali, dando, principalmente jogos, a minha filha gostava de desenhar, ela deu, me lembro, que ela deu um caderno de desenho que tinha aquelas folhas finas, e daí ela... só de olhar assim, ela começava olhar um gibi ela desenhava o desenho, então ela era muito criativa, minha filha era... E a minha filha além de passar por aquilo ela também ensinava as outras crianças.

$\mathrm{Eu}$ - Ah, que legal!

Mãe - Ela ensinava, ela estava ali não é assim, ela dava força também, ajudava. E muitos que estavam na época ali junto com ela, nem para a escola iam. Porque não queriam estudar, a mãe tirava da escola, e ela não, eu sempre incentivei ela, eu também ajudei, porque eu acho que os pais têm que ajudar.

Eu - É!

Mãe - Da força, dizer, não filha, você vai vencer. Principalmente porque se eu fosse uma mãe que, nem a professora 'você tem que tirar ela, você tem que procurar outra escola', eu falei não, a minha filha é igual aos outros que estão aqui, a minha filha, ela não é, tipo, ela tem um problema de saúde que pode ser resolvido. Agora porque a minha filha? A minha filha, então ela achava que minha filha era doente e doente tinha que ficar em casa e eu falei não! Eu desconsidero o que você pensa! Eu acho que minha filha tem que ser tratada igual aos outros. Né! Então na minha cabeça, no meu ver, eu acho que tinha que ser assim!

Eu - Por um acaso, a Sra. tem algum tipo de material de caderno de sua filha deste período com as tarefas do hospital?

Mãe - Menina, eu até fucei para ver se eu achava. Eu tinha uns trabalhos lindos dela! Mas eu acho que eu joguei fora!

Eu - Se Sra. achar, Sra. me avisa, me traz para eu poder ver!

Mãe - Eu tinha uma pasta de dobradura dela, menina, pois eu não sei, eu até fui nesse final de semana na casa dela para ver seu encontrava, porque teve coisas que eu dei para ela guardar. Daí ela tinha também uma pastinha também com os desenhos dela que eu falava, eu vou jogar, não, eu vou guardar, e eu não sei, menina, fucei, mas era muito interessante.

Eu - É! Eu gostaria de ver sabe, assim os trabalhinhos que ela fazia. Se a Sra. encontrar a Sra. me passa. 
Mãe - Ai, meu Deus do céu! Então!

Eu - Bom! As fotos que a Sra. me trouxe. Tem a foto de bebe dela, a Sra. lembra mais ou menos que idade que ela tinha naquela foto?

Mãe - De bebe?

Eu - É!

Mãe - Ela estava com 3 meses.

Eu - 3 meses. Depois tem uma foto dela em uma festa junina.

Mãe -4 anos.

Eu - 4 anos. Aí tem a foto da formatura do 4ano. Ela já estava com 9?

Mãe - Não! 10 anos. 10 anos.

$\mathrm{Eu}-\mathrm{E}$ aí tem aquela outra foto que ela está em 91.

Mãe - Eu acho que 9 anos. Ali ela está com 10, que foi na 4⿳a série. É, 10 anos.

Eu - Aí tem as fotos da formatura do magistério. Ela fez magistério depois?

Mãe - Ela fez magistério, ela terminou em 2000... Ai gente! (Procurando no álbum).

Aqui... 2001. Recordação do magistério. 2001.

Eu - Sim! Ela terminou o magistério! Foi a formatura eu acho, não é?

Mãe - Foi a formatura! Ah é, foi! Porque daí logo em seguida ela perdeu o rim.

Eu - Foi depois da formatura que ela perdeu o rim?

Mãe - Foi depois da formatura.

Eu - Ela fez magistério em que colégio?

Mãe - No Colégio Estadual Lysímaco Ferreira da Costa.

Eu - Ah, tá! Ela foi no 5ํano para o Lysímaco e lá ficou até o Ensino Médio?

Mãe - Até a formatura do Magistério.

Eu - E depois o casamento dela?

Mãe - Depois o casamento dela.

Eu - Quando ela casou?

Mãe - Ela casou em 2007.

Eu - Tá!

Mãe - 2007!

Eu - Quando ela nasceu? Quando é o aniversário dela?

Mãe - 28 de fevereiro de 1982.

Eu - Legal!

Mãe - 82.

Eu - Deixa ver aqui...

Mãe - Porque engraçado professora, que quando ela nasceu, eu não sei, o p... o meu médico pegou e falou assim: mãezinha, pega um pediatra bom! Então eu acho assim, que ele já viu algo ali.

Eu - Sim.

Mãe - Mas eu, na época assim, uma mãe, já digo, que vim lá do interior, né! $E$ eu cheguei, pedi um pediatra bom, e ela falou, não, o dr. Dario é um pediatra bom, já faz 8 anos que ele é médico, e eu me apeguei com ele, com ela também, ela amava aquele pediatra, mas eu não sei, professora, daí aquelas infecções, né... muito frequentes... Mãezinha, quando ela tiver 6, 7 anos ela vai criar defesa, né. Ela vai criar defesa e ela vai, essas infecções ela não vai ter mais. E um dia eu olhei para ele e disse, mas dr. esses antibióticos não vão fazer mal para minha filha? E ele, não mãezinha... E foram eles que foi destruindo a função renal, né... E daí com 8, 7 anos mesmo ela estava praticamente com os rins destruídos...

$\mathrm{Eu}$ - Pararam os rins delas quando?

Mãe - Pararam.

Eu - Com quantos anos? Quantos anos ela tinha? 
Mãe - Ela estava com 7 anos.

$\mathrm{Eu}-7$ anos.

Mãe - Que foi no ano de 90,90 que a gente começou, final de 90 que a gente começou, aí deu tudo... Deu caxumba, deu varicela, deu tudo...

$\mathrm{Eu}-\mathrm{E}$, porque a imunidade, acho que já estava baixa, né...

Mãe - Sabe! E daí que depois que a gente foi, daí uma pediatra olhou bem falou, mãezinha, não quero te assustar mãezinha, mas a sua filha está com uma doença renal. E eu falei: Dra., pelo amor de Deus, tantos anos que minha filha e eu vivo essas infecções. Deus ajude que não esteja crônico. Maldita hora que eu abri minha boca... Eu - Nossa!

Mãe - Daí foi a Dra. Denise Coller Menezes, Dra. Regiane, uma médica assim, que foi muito dura comigo, quando foi para ela fazer a fístula, eu fugi com ela 3 vezes do hospital. Hoje, é nossa, não pode, né! Mas eu era louca, eu fiquei completamente louca, louca, louca. Eu não aceitava!

Eu - Mas desestrutura tudo mesmo...

Mãe - Nossa! Meu Deus do céu!

Eu - É muito complicado...

Mãe - E daí, estamos aí, não é?!

Eu - A Sra. conseguia ver progressos na aprendizagem da filha da Sra. com esses atendimentos da Escolarização Hospitalar?

Mãe - Sim! E muito.

Eu - Ela reprovou algum ano?

Mãe - Só quando ela estava no $3^{\circ}$ ano do magistério, que ela pegou implicância com a professora, e ela chegava e dormia na sala. Ela falava, professora eu não aguento a tua aula e ela dormia. E quando ela não ia para a aula para dormir eu saia de casa 6:20 da manhã, deixava ela tomando café. Ela odiou tanto aquela professora...

Eu - Que ela nem ia?

Mãe - Que ela não ia. E daí quando foi no mês de agos... eu chegava em casa e eu dizia: filha, cadê as tuas atividades? E ela: eu faço na sala de aula. Eu falei: Não, você não me engana. $E$ eu em outubro, falei assim....

Eu - Ela estava bem adolescente. Normal!

Mãe - Sim. E eu falei para a diretora, era a prof. Vera, eu falei assim: Vera, vou lá no Lysímaco agora. E ela falou, tá bom! Eu estou preocupada. E eu cheguei lá e daí a prof. Madalena na época coordenadora: Mãezinha, ainda bem que você chegou aqui, eu mando recado, mando bilhete, ela rasgava e jogava, eu falei: Meu Deus, a tua filha está reprovada por falta!

Eu - Meu Deus!

Mãe - Eu falei: eu não acredito. Ela estava com 100 e poucas faltas.

Eu - Meus Deus, quase não foi para a aula o ano inteiro.

Mãe - Aí eu falei assim, mas gente erro de vocês, vocês tinham que me comunicar, eu trabalho numa escola, eu sei como funciona. Daí ela falou assim: Ela está reprovada por falta. Daí eu falei: Filha! Você reprovou. Mãe, eu odeio aquela professora. E foi, por causa de falta.

Eu - Mas aí já era $3^{\circ}$ ano.

Mãe $-3^{\circ}$ ano.

Eu - Ela já não tinha ajuda do hospital.

Mãe - Não, não tinha ajuda. Ela já era rebelde!

Eu - Mas na época do hospital ela não reprovou, apesar de ter aquela professora chata da $3^{\mathrm{a}}$ série, ela não reprovou?

Mãe - Não. Não reprovou! 
Eu - A Sra. acha que as aulas do hospital a ajudavam a acompanhar?

Mãe - Sim! Ajudaram! Ajudaram! E ela tinha as notas boas. Eu até procurei o boletim dela e não consegui achar, que eu queria mostrar as notas que ela tinha durante todo esse período que ela estava com a professora ajudando ela, as notas dela eram excelentes!

Eu - Ela sempre estudou em escola estadual?

Mãe - Sempre! Era só o prézinho dela que eu fiz particular.

Eu - Vou tentar levantar o histórico dela no Lysímaco.

Mãe - Só! [...] É mesmo! Né?

Eu - É! Posso ir lá e pedir!

Mãe - E na escola

Eu - Aí se eu conseguir eu trago para a Sra.

Mãe - Exatamente. E na escola ali, Miguel Kruger, não sei, porque passaram muitos anos, né!

Eu - É, mas quando ela sai de uma escola e vai para outra, a documentação vai para a outra escola.

Mãe - Isso, vai

Eu - É!

Mãe - Verdade! Eu lembro!

Eu - Fica na última escola. A última escola dela foi o Lysímaco?

Mãe - O Lysímaco.

Eu - É! Então está no Lysímaco.

Mãe - É mesmo! Deve estar lá! Aí vai estar lá a nota das rebeldias dela! Porque ela já estava rebelde, né!

Eu - É! Não, mas tem todas, todas desde o começo. É bem legal, ter o histórico, né?! Mãe - Exatamente! É verdade, né!

Eu - A Sra. lembra quais eram os materiais educacionais e pedagógicos utilizados pela professora nas aulas dadas para sua filha? A Sra. já falou que ela usava desenhos, jogos...

Mãe - Desenho, jogos...

Eu - Os cadernos que ela levava, os livros ela levava, tinha mais alguma coisa ou era isso mesmo

Mãe - Ahãm! Não, era somente isso! Só.

Eu - A Sra. quer falar mais alguma coisa?

Mãe - Não. Eu acho assim que está... Né, foi muito excelente! Eu acho que sempre tem que ter essa ajuda com as crianças que ficam lá, porque muitas vezes os pais não incentivam então é melhor a professora estar ali incentivando para eles ter um futuro.

Eu - É!

Mãe - Não é? Porque na época dela teve, não foi só minha filha, teve um que né, foi formado em Matemática, né! Nossa, foi um herói aquele menino, só que daí ele ficou anos, anos em hemodiálise, acho que ele fez, acho, 13 ou 14 anos de hemodiálise, porque é assim, eles não fazem xixi, né! Então a bexiga, ela...

Eu - Retrai.

Mãe - Exatamente! O que que o médico tinha que ter feito, sei lá, acho que tinha... fez o transplante, só que não viu a bexiga, só que a bexiga estava cheia de pedrinha, né! Eu - Nossa!!!

Mãe - Empedrou! E você acredita que a minha filha, daí a minha filha foi na UTI ver ele com 3 dias de transplantado e ele estava para ela, e falou assim, Nay, pegou na mão dele, a Nayla pegou na mão dele e falou assim: Você vai vencer, ele falou assim: 
Ore por mim, eu estou com muita dor, muita dor, eu não vou aguentar. A bexiga dele estourou!

Eu - Nossa!

Mãe - Estourou!

Eu - Coitado!

Mãe - Para você ver, que nem a minha filha falou. Mãe, ele sofreu tanto. Ele também teve acompanhamento com a professora. Ele sofreu tanto. Ele se formou, mãe. Não pôde aproveitar. Então teve, teve vários, é que eu não me lembro da época dela, das crianças, mas a maioria, a maioria deles já faleceram. Já faleceram. Então, raros. Daquela época dela mesmo, de 91,92 aquelas crianças já faleceram. E a minha filha é uma guerreira que está até hoje comigo.

Eu - Está né!?

Mãe - O dia, eu não sei se eu vou estar preparada, já digo, porque a gente tem que estar preparada, né?!?

Eu - É!

Mãe - Porque hoje, hoje mesmo, que nem ela falou: Mãe, eu vivo o hoje, amanhã, Deus proverá minha vida!

Eu - Exatamente!

Mãe - Então, e ela mesma ali hoje, ela ali, no hospital de adulto, ela falou assim: Mãe, eu sinto muita falta, que nem no Pequeno Príncipe, ali tinha, ia voluntário, já digo, tinha acompanhamento, Psicóloga chegava ali e conversava, ali na clínica adulta a gente é abandonado. Não aparece ninguém, então as 4 horas é uma tortura, mesmo que ela leva um livro, né! Mas é uma tortura, porque não aparece ninguém. Eu acho que eles também tinham que fazer um trabalho assim, com o adulto!

Eu-É!

Mãe - Tipo assim, não... Porque ali também tem jovem, tem adolescente. Ali também tem!

Eu - É, verdade!

Mãe - Tem uns que não estudam, não trabalham. Eles vivem de um auxílio.

Eu - Uhum!

Mãe - Que nem ela falou: Mãe, eu acho muita falta, muita falta disso aí, porque tem que ter, sei lá. A vida da gente ali é tão...

Eu - Hoje ela está fazendo hemodiálise de novo, porque o transplante parou de funcionar?

Mãe - Parou. Em 2001 ele perdeu o rim e ela está até hoje.

Eu - Mas ela trabalha também?

Mãe - Ela faz os trabalhos dela, né! Que nem eu falo para ela: Filha, você é uma guerreira, é uma artesã! Porque ela pegou, acho que uma semana de aula com a professora Madalena, ali na Beija Flor. Que um dia ela estava assim, e falou: Não, eu vou ter que fazer alguma coisa. Daí ela pegou, o marido dela não conseguia emprego e ela falou: Eu vou ter que fazer alguma coisa para ganhar um dinheirinho extra. Daí até fui eu que dei o dinheiro para ela. Porque ela tem uma mente assim, ela grava as coisas, sabe?! Ela teve uma semana com a professora Madalena e ela aprendeu ali o básico, já digo. E ela foi fazendo, e hoje ela é uma artesã de primeira. É só você pegar a página dela que você vai ver.

Eu - Ela faz biscuit, não é?

Mãe - Ela faz biscuits. Ahãm. Tudo o que pedem para ela!

Eu - Ela é bem caprichosa! Eu já olhei! Eu já vi a página dela. 
Mãe - É, então! Ela é muito criativa! Muito caprichosa! A casa dela mesmo é um brinco! Sabe!? É uma cozinheira de mão cheia! Você vê, o marido dela era seco, hoje ele está gordo!!!

Eu - (rindo)

Mãe - De coisas gostosas! Mas é, ela é uma batalhadora. Ela é uma guerreira!

Eu - É mesmo!

Mãe - Nossa! Eu tiro o chapéu por ela.

Eu - Mas tem muito da criação da Sra. nisso também!

Mãe - Sim! Ela... Para dizer assim, desde quando ela era pequena assim, se ela foi revoltada? Eu estou mentindo. Ela sempre aceitou assim, digamos, que nem eu falava, eu falava assim: Filha, eu não sei o que eu falhei, no que eu falhei para receber, sei lá, se lá se é castigo ou o quê, né?! Daí ela falava assim: Mãezinha, não. Não se lamente, o que Deus traçou na minha vida, eu vou e eu preciso de sua ajuda e você vai me ajudar e eu vou vencer! E eu sempre fui uma mãe que sempre dei força para ela e continuo dando força!

Eu - Parabéns para a Sra. Viu! Porque, com certeza, tem muito da Sra. nessa força dela.

Mãe - Tem né?! Tem!

Eu - Tem! Muito obrigada pela entrevista! 


\section{Apêndice K - Transcrição Entrevista Aluno 1}

Eu - Hoje é dia 28/04/2018, estou fazendo a entrevista com um ex-aluno do hospital, que fez tratamento no hospital de 1988 a 2002 para a pesquisa de doutorado da Universidade de São Paulo: "A Educação de crianças em hospitais: A experiência da cidade de Curitiba, Estado do Paraná num Hospital Infantil, de 1988 a 2002. Você pode dizer seu nome completo?

Ex-aluno - Meu nome é dos RPS ${ }^{191}$, eu nasci em 87 na cidade de Toledo, interior aqui do Paraná e desde 90 eu faço acompanhamento com nefrologista, por conta de doença renal.

Eu - Você fazia então, tratamento no hospital por conta da doença renal. Como era inicialmente esse tratamento?

Ex-aluno - Então, na verdade é assim, eu não nasci com problema renal, eu nasci com um problema neurológico de acometimento da espinha, eu nasci com mielomeningocele, que é a espinha bífida, espinha aberta, popularmente conhecida como espinha aberta. A mielomeningocele me deu um problema neurológico de bexiga, que é a bexiga neurogênica. A bexiga neurogênica, por sua vez, me deu um problema de refluxo vesico urinário. O refluxo vesico urinário me deu muitas infecções, muitas infecções repetidas me deram pielonefrite e a pielonefrite acabou com meu rim. Então, esse percurso todo foi de três anos, do meu nascimento até os 3 anos de idade, por não descobrirem que eu tinha bexiga neurogênica em decorrência da mielomeningocele, eu fiquei vagando de médico a médico até eles tentaram fechar um diagnóstico, quando eles fecharam um diagnóstico, eu tinha perdido um rim e estava com $60 \%$ de funcionamento do outro e foi quando eu tinha 3 anos de idade. Aí foi então que eu comecei o tratamento com o nefropediatra.

Eu - E você já começou com hemodiálise?

Ex-aluno - Não, não, não. Já aos três anos eu entrei, mais ou menos no Hospital Pequeno Príncipe em junho/julho de 1990 e eu fazia aniversário de três anos em agosto daquele mesmo ano. Daí eu entrei, fiz já uma cirurgia, passei na verdade por várias cirurgias para correção do problema na bexiga, eu fiz ampliação de bexiga para corrigir o problema da bexiga neurogênica, daí também fiz uma outra cirurgia, porque além disso, além do problema da bexiga, a mielomeningocele fez com que eu nascesse com os pés tortos, o pé equinovaros bilateral, então eu tinha dos dois pés tortos e mais o problema da bexiga, tudo em decorrência do problema da mielomeningocele. Quando eu entrei no Pequeno Príncipe, no início dos anos 90, eu já fiz a cirurgia de correção ortopédica nos pés, fiz a correção dos pés e também fiz ampliação na bexiga e daí eu iniciei o tratamento com o nefrologista pediátrico no Pequeno Príncipe. A partir do momento que eu fiz essa ampliação da bexiga e que se identificou qual era o problema que estava causando o problema renal, foi tratado 0 problema da bexiga, mas aí o problema renal continuou, como eu já tinha perdido o rim, eu fiz uma cirurgia para retirar um rim que não estava funcionando e fiquei em acompanhamento com o que eles chamam de tratamento conservador, fiquei em acompanhamento para ver a função, monitorar a função do outro rim.

Eu - E esse tratamento durou quanto tempo?

Ex-aluno - Esse tratamento conservador durou de 90, junho de 1990, em 1990 eu entrei no hospital e durou até o ano 2000. Foi quando eu não consegui mais, meu rim entrou em falência renal total e eu necessitei fazer diálise. No ano 2000, no início do

191 Para preservar a identidade do ex-aluno, optei por utilizar somente as iniciais no lugar de seu nome. 
ano 2000 eu perdi, então realmente toda a função renal basal que eu tinha do único rim e eu fui para a diálise peritoneal. Como o tratamento do Pequeno Príncipe é aqui na capital do Paraná, a gente está em Curitiba, e eu sou do interior, morava em Toledo, de início se cogitou a possibilidade de eu fazer a diálise peritoneal, que daí eu poderia ir para casa, não precisava morar aqui em Curitiba. Aí então, no ano 2000, no início do ano 2000 eu perdi o rim, retirei ele e fiquei no tratamento dialítico, por meio da diálise peritoneal. Fiquei internado um tempão, colocando cateter, tirando cateter, porque daí eu tive que fazer três colocações de cateteres, três procedimentos cirúrgicos para colocação do cateter, que dava rejeição, ou dava infecção, ou meu peritônio era inviável, segundo colocação médica, daí fiz, três cirurgias para colocar e retirar cateter, até que um cateter deu certo, o terceiro cateter deu certo, a cirurgia para colocação de cateter deu certo, já tinham treinado a minha mãe para dialisar, de início a gente começou com a diálise manual, depois foi me disponibilizado a máquina de diálise para fazer uma diálise automática, eu ganhei alta e fui para casa. Nesse momento que eu ganhei alta e fui para casa, eu fiquei 8 meses, 8 meses exatos do momento que eu iniciei a diálise ao momento que me deu infecção peritoneal, eu peguei peritonite, que foi uma peritonite por infecção fúngica, eu peguei cândida, foi extremamente severa, foi o único momento ao longo dos meus 30 anos que eu achei que eu realmente ia morrer, eu fazia picos de 40, 41, 42 graus de febre, e assim, parado eu tremia, tremia, tremia, tremia, muito. Então, com 8 meses de diálise, eu peguei essa peritonite, contraí essa infecção fúngica, necessitei vir para o hospital de novo, retirar o cateter, tratar a infecção fúngica e daí, não teve jeito, iniciei o tratamento hemodialítico, fui para a hemodiálise, isso já em final do ano 2000. Entrei na hemodiálise em dezembro do ano 2000 , então eu fui do mês 4 , mais ou menos abril de 2000 até dezembro de 2000 em diálise peritoneal, quando eu peguei infecção, tratei a infecção e em dezembro eu iniciei a hemodiálise, em dezembro de 2000 . Em dezembro eu iniciei a hemodiálise já iniciando os exames para o transplante renal, pois a minha mãe ia ser a doadora. Detalhe importante, era uma pessoa, eu sou inclusive até hoje uma pessoa que sou adotivo, sou filho adotivo dos meus pais que moram comigo. Lá em Toledo mesmo, quando eu tinha 3 meses de idade, a minha mãe biológica me colocou numa creche domiciliar, que existia naquela época, as casas, as chamadas creches domiciliares, ela me colocou numa dessas creches domiciliar quando eu tinha 3 meses de idade e me deixou lá. Veio embora, hoje eu sei que ela veio embora para Curitiba, mas na época ninguém sabia o paradeiro dela, me deixou naquela creche por 3 anos, ou seja, me abandonou literalmente na creche. Então, nesse período que eu fiquei lá, dos 3 meses até os 3 anos de idade, que foi o período que eu mais sofri por conta dos meus problemas de saúde, eu não estava com minha mãe biológica, quem fez todo esse processo foram meus pais adotivos, aí para fazer viagens para vir para Curitiba, para poder se apresentar como pais perante os serviços médicos, a gente teve que fazer processo de adoção. Eles fizeram todo o procedimento legal para adoção, eu fui registrado no nome deles e eles que me acompanharam. Depois de muitos anos, depois que eu, acho que eu estava com uns 10 anos de idade, a minha mãe biológica apareceu. "Oi, tudo bem? Eu sou sua mãe". Eu - Meu Deus!

Ex-aluno - Meu Deus digo eu. Eu disse: "Não, minha mãe está aqui do meu lado, sempre esteve, essa é minha mãe, esse é meu pai e vão continuar sendo, você pode ser a pessoa que me colocou no mundo, mas não se apresente como minha mãe, porque tu não é, pode ser qualquer outra pessoa, talvez no máximo quem me colocou no mundo, ou qualquer outra coisa que tu queiras, menos ser minha mãe, porque minha mãe é essa que está aqui do meu lado e esteve todos os meus anos de vida". 
Mas enfim, como eu precisei ir para a hemodiálise, porque eu tinha perdido o cateter da diálise peritoneal, e já assim, teve uma aproximação da minha mãe biológica, ela se disponibilizou, eu não falei em nenhum momento, eu nunca digo, com certeza, ela se disponibilizou a doar o rim. Ela falou: "Como eu já te abandonei lá atrás, por questões adversas", que depois ela tentou dar a sua versão, mas enfim... Ela disse: "Então eu vou doar o rim para você, vou te trazer a vida novamente. " Palavras dela. E eu: "Nooossa! Que lindo, né?! Que lindo! Muito obrigado! Tá bom, se você quer. Eu não estou te pedindo, mas já que você quer, vamos lá". Então em dezembro de 2000, quando eu perdi o rim que fui para a hemodiálise, eu entrei na hemodiálise já com minha mãe biológica fazendo toda a bateria de exames, de histocompatibilidade para nós transplantamos. Então, a ideia de quando eu entrei na hemodiálise era assim, foi me dito: "RPS, você vai ficar na hemodiálise até concluir todos os exames e estiver tudo ok para o transplante. "Fiz hemodiálise dezembro, janeiro e fevereiro eu transplantei com o rim da minha mãe biológica. Os exames tudo pronto, tudo certinho, compatibilidade ok, de acordo com o necessário, tudo certinho. Vamos para o centro cirúrgico transplantar. A diálise era só um período de transição, a hemodiálise só um período de transição, tem rim, tem doador, tem compatibilidade, vamos transplantar. Enfim, mas não é fácil assim, não é?! Deus já deixa as coisas todas certinhas, não basta você querer e aparecer 10 anos de novo e depois dizer: "Oi, eu sou sua mãe e vou lhe trazer a vida. " Deus já sabe como funciona as coisas e ele faz caminhos certos por linhas tortas, como dizem. Rejeitei o rim. "Não te quero, rim, porque tu não faz parte de mim, nunca fez e não vai ser agora. " Rejeitei o rim. O que aconteceu? A explicação médica, eles não viram, nenhum exame mostrou que a minha mãe tinha uma artéria a mais e no momento de fazer essa ligação desta segunda artéria na artéria o meu rim houve um rompimento da artéria, então houve um sangramento moderado no momento do rim, que foi controlado e que depois, quando eles fizeram a ligação da artéria tudo certinha, não ia sangue suficiente. Então meu rim estava hipoperfundido, hipooxigenado e essa hipoxigenação, essa hipoperfusão acabou fazendo com que eu tivesse uma rejeição aguda imediata, não durou uma semana, meu rim estava necrosado. Então, é o que eu digo, não basta você querer consertar o inconsertável. Não teve jeito, rejeitei o rim, sofri um monte, transplantei em fevereiro sai em abril do hospital, ou seja, fiquei 2 meses ali sofrendo, indo para o centro cirúrgico revisando o rim, fazendo enxurrada de volume, muito soro, muito soro, muito soro e o soro não saia, porque o rim não estava funcionando, o líquido entrava, mas não saia, então eu ia inchando, a pressão ia aumentando, até que o médico um dia falou para mim, eu fiz o transplante, se não me engano, se não me falha a memória, foi dia 3 de fevereiro, dia 20 de março o médico falou para mim: "Ou nós tiramos esse rim, ou ele acaba com a vida do seu filho." Falou para minha mãe, que eu considero como mãe, e falou para a pessoa que doou, que é a minha mãe biológica também. "Não teve jeito, ou nós tiramos ou ele morre, porque ele está ficando inchado, está ficando com a pressão alta, o rim está necrosando e vai necrosar os outros órgãos do abdômen, então não dá, nós vamos ter que tirar". "Tá, e tirar e daí fazer o quê?" "Não tem o que fazer, é o que você já sabe, é tirar e voltar para a hemodiálise". Aí falei: "Ah, não, está com zoação com a minha cara". "Não, não estou brincando, nós vamos tirar e você vai voltar para a hemodiálise". Aí teve todo aquele momento de negação, porque é cinco fases do luto, não é?! Foi literalmente um momento de luto, aí vencemos todo aquele momento tenebroso, horrível, mas enfim, tá bom, né! Antes sem um rim vivo e com um rim morto. Então, vamos tirar o rim. Tiramos o rim e eu fiquei melhor. Então, não teve... aquilo não fazia parte de mim e nunca fez e não ia ser naquele momento. Tiramos o rim, foi passando os dias e eu fui melhorando 
clinicamente, aí saí do hospital, mas já saí do hospital dialisando, hemodialisando, fazendo hemodiálise, isso já era março de 2001, então março de 2001 eu já comecei a hemodiálise e fiquei até dezembro de 2002 na hemodiálise. Então, eu fiquei uma média de um ano e 9 meses em hemodiálise exclusivamente, 8 meses em diálise peritoneal e 1 ano e 9 meses em hemodiálise. E foi nesse período de 1 ano e 9 meses, de abril, março/abril que sai do hospital de 2001 a dezembro de 2002 que a pedagogia escolar me acolheu, porque tá, agora não tem jeito, agora você tem que vir para Curitiba, você tem que largar sua vida, você tem que largar seus amigos, você tem que largar sua família e inclusive a sua escola lá na sua cidade e vir para Curitiba cuidar da sua saúde, porque sem vida não existe mais nada, ou você está bem, você tem saúde para viver todo o resto, gozar da vida, ou você não tem mais nada, do que adianta você estudar, querer viver com sua família, seus amigos, se você não tem vida. Então, largamos tudo lá, viemos eu e minha mãe para Curitiba, vamos mudar para cá. Mudar como, de que jeito? O único lugar que, eu que era criança, a minha mãe é analfabeta, não sabe ler nem escrever, ela escreve o primeiro e o segundo nome, porque aprendeu em casa com a mãe dela, mas aí ela vai tudo por cor, ela sabe... a gente cria...

Eu - mecanismos

Ex-aluno - mecanismos secundários para se virar. Mas enfim, foi difícil igual, porque a gente teria que morar em Curitiba, é diferente de você vir para fazer um tratamento e voltar. Então, tinha toda aquela questão de adaptação de cidade também, alugar casa, nós somos de família humilde, e assim, duas famílias para cuidar, porque viemos para Curitiba eu e minha mãe apenas, mas tinha o resto da família lá em casa. Meu pai era assalariado, funcionário público de Ensino Médio, ganhava somente aquele salário, meus irmãos mais velhos trabalhavam na lavoura, eram o que chamavam naquela época de boias-frias e daí foi o que aconteceu. A gente largou tudo lá e viemos eu e minha mãe morar em Curitiba para iniciar a hemodiálise no Pequeno Príncipe, no momento que eu ganhei alta em março/abril de 2001 até dezembro de 2002. Então, 2001 foi um ano de hospital, mais nada, não teve um ano escolar, eu já não tinha iniciado por conta que eu vim antes, em dezembro, quando iniciei a hemodiálise e já iniciei os exames para transplantar, eu já vim para começar os exames e fiquei mais aqui. Então o início do ano letivo de 2001 não existiu, e depois então, menos ainda, porque 2001 foi um ano de adaptação, de morar em Curitiba, de se adaptar a hemodiálise e de reconstituir uma vida de acordo com o que a gente tinha naquele momento.

Eu - Nesse período, você abandonou a escola então?

Ex-aluno - Sim, 2001 foi um ano que eu não frequentei a escola.

Eu - Até 2001 você frequentava a escola em Toledo?

Ex-aluno - Até $2001 \mathrm{sim}$.

Eu - Que série era essa? Você se lembra?

Ex-aluno - Em 2001 eu estava, se não me engano, 2001 eu ia para o $7^{0}$ ano. 2001 é o $7^{\circ}$ ano.

Eu - Você fez todas as séries iniciais, tudo?

Ex-aluno - Sim, até o 6o ano eu estudava lá.

Eu - Fazendo tratamento aqui e voltando para lá e continuando na própria escola que você estudava.

Ex-aluno - Isso.

Eu - Aí 2001, que foi esse período da mudança, você ficou fora do colégio só voltando em 2002.

Ex-aluno - Só voltando em 2002. 
Eu - O seu tratamento terminou em 2002 ou continuou depois?

Ex-aluno - O meu tratamento na hemodiálise terminou em 2002, em dezembro de 2002.

Eu - Você fez um outro transplante, é isso?

Ex-aluno - Eu fiz um outro transplante de um doador cadáver.

Eu - Entendi.

Ex-aluno - Ai Deus me abençoou com um doador cadáver em dezembro de 2002, 11 de dezembro de 2002, uma data de nascimento, de renascimento. 11 de dezembro de 2002 eu fiz um segundo transplante e estou com ele, graças a Deus, até hoje, 2018. Vivendo lindo e maravilhoso, belo e feliz, estudando.

Eu - Que bom!!! Ah, então, estudando. Me diga, eu até deixei como uma pergunta final, fala então de seu histórico escolar. Você acabou de falar que em 2001 você estava no $7^{\circ}$ ano.

Ex-aluno - Isso, eu ia iniciar o $7^{\circ}$ ano.

Eu - Em 2002, então você concluiu o $7^{\circ}$ ano, porque aí você voltou a fazer o $7^{\circ}$ ano em 2002?

Ex-aluno - É, então, o que que aconteceu? Em 2002, quando eu... Em 2001 eu já fui para a diálise, que eu saí do hospital. Eu saí em março/abril e já sai da diálise em 2001, para a hemodiálise. Em 2001 mesmo, depois de passar todos aqueles meses de adaptação, final de 2001 eu fui abordado pela professora que trabalhava a questão da pedagogia hospitalar, na época a professora [municipal]. Ela veio me conhecer, porque ela fazia um trabalho de conhecer todos os pacientes novos que entravam na hemodiálise, coletar o histórico escolar, saber como estava, como que era a vivência escolar e fazia um acompanhamento dali em diante. Daí, no final de 2001 a [professora municipal] veio conversar comigo, veio se apresentou, disse que trabalhava a pedagogia hospitalar e ela queria sabem em que série que eu estava, o que estava fazendo, como era o meu estudo, se eu estava estudando ou não e foi aí que a gente conversou sobre isso. Aí nós acordamos que "em 2001, agora nós estamos no finalzinho, então em 2002 você vai fazer CEEBJA, você vai concluir o Ensino Fundamental, por meio do supletivo, você vai fazer um ano de CEEBJA e concluir $7^{\circ}$ e $8^{\circ}$ ano, e depois em 2003, se você estiver conosco ainda, você já vai para uma escola de Ensino Médio normal e eu Ihe acompanho aqui na hemodiálise, 2003 vamos aguardar para ver" Foi o que ela me disse. "Vamos esperar para chegar, mas agora como você parou no Ensino Fundamental, vamos concluir o seu Ensino Fundamental por meio do CEEBJA. Eu falei: "Então, está bom, mas agora eu não entro, agora eu não tenho condições para continuar". "Tudo bem, no início de 2002 eu converso contigo de novo e aí, quando for para eu conversar com você de novo vai ser para dizer que você já está matriculado". Já foi meio que um desafio, sabe, o que a [Professora] falou. Eu falei: "Tá, não é! Vamos tentar, vamos tentar, se eu estiver bem clinicamente, a gente vai tentar". E deu tudo certo. Deu certo e eu comecei em 2001 a hemodiálise, início de 2002 eu estava ainda em hemodiálise, fazia hemodiálise três vezes na semana, três horas por vez e então já iniciei no início do ano de 2002 o supletivo para concluir o Ensino Fundamental. Aí eu fiz CEEBJA, em um ano eu fiz o $7^{\circ}$ e o $8^{\circ}$ ano no ano de 2002.

Eu - E como eram essas aulas do CEEBJA? Você ia no CEEBJA ou a [Professora] pegava as atividades e trazia para você? Me explica como que você estudava?

Ex-aluno - Isso, isso. Ela que correu atrás, dos trâmites burocráticos, ligou na minha escola lá em Toledo, viu como que era, o que precisava de documentação... A parte escolar burocrática ela que resolveu, já veio me dizer que você já está matriculado, está tudo ok, nós só demos a informação e as fontes, os contatos com quem ela 
precisava falar, mas ela que fez todo os contatos, ligou e foi atrás de documentação. Aí, quando eu entrei no CEEBJA aqui, ela que também ia até lá, buscava no CEEBJA os materiais, os conteúdos escolares para eu estudar e trabalhava na hemodiálise, eu ia para o CEEBJA somente para fazer as provas.

Eu - Ah, você ia para fazer as provas. Você não fazia as provas ali na hemodiálise.

Ex-aluno - Eu ia para fazer as provas. Não.

Eu - Você ia lá no CEEBJA fazer as provas?

Ex-aluno - A gente estudava o conteúdo ali na hemodiálise com a [Professora] e em casa também.

Eu - Sim, para dar conta de tudo.

Ex-aluno - E depois eu ia para o CEEBJA para fazer as provas.

Eu - Nos dias das provas você ia fazer lá?

Ex-aluno - Isso, eu agendava as provas no CEEBJA e fazia as provas lá.

$\mathrm{Eu}$ - E você gostava dessas aulas que você tinha? O que você achava dessas aulas com a [Professora], lá indo fazer no CEEBJA.

Ex-aluno - Olha, para ser bem sincero, no começo eu não estava tão animado assim, porque ainda existia toda a questão psicológica, eu não queria, eu já tinha toda uma vida escolar, os meus amigos de escola lá em Toledo. Então eu falava: "Não, quando eu acabar aqui, se Deus quiser isso vai ser rápido, quando eu acabar eu volto e continuo lá, mas a insistência dela foi tão grande: "Não, vamos, porque quando acabar você pode voltar e continuar lá, mas aí você não perdeu". E eu falei: "Não, eu não vou perder, eu estou querendo me tratar agora". Ela: "Não, não, vamos vamos!"

Eu - É, porque ia dar certinho, os seus colegas estavam no $7^{\circ}$ ano em $2001 \ldots$

Ex-aluno - Sim, eu não fiz.

Eu - Você já não ia estar com eles assim que voltasse. Em 2002 eles já estariam no 8ํe e aí você, se você fizesse o $7^{\circ}$ em 2002 ainda chegaria depois atrasado. Então, fazendo o CEEBJA, você conseguiu juntar as duas num só e a hora que você voltou, não sei se você voltou depois para lá, mas se você voltou, voltaria junto com sua turma, não é!?

Ex-aluno - Isso, sim! Detalhe né, só que quando a gente entra na hemodiálise, depois que você já fez um transplante, que você só precisa de um rim de cadáver, é você entrar e botar nas mãos de Deus, a gente não tem certo assim: "final de 2002 você vai terminar e vai transplantar e vai vir um rim e tudo. Não!" Isso é um planejamento mental, mas a gente não sabia...

Eu - Não é um planejamento da gente.

Ex-aluno - Não é um planejamento da gente, tanto que quando a gente começou as aulas do CEEBJA, no início eu estava bem desanimado, porque eu falava: "Ai, meu Deus, até quando isso vai?" É uma coisa que a gente não sabe quanto tempo vai durar, então, daí você fala: "Meu, se eu entro nisso aí eu vou ficar pelo resto da vida nessa vida?! Não, eu não quero". Daí, foi muita insistência dela. "Vamos estudar". E eu: "Tudo bem! Vamos". As aulas eram boas, sabe! Ela tinha...

Eu - Dava uma distraída.

Ex-aluno - Isso! Ela tinha uma didática pedagógica bacana, que daí assim, ela aguardava eles me conectarem na máquina, eu era pulsionado, tinha fístula, ela aguardava eu me conectar na máquina e eu vendo que estava tudo bem, que não tinha passado mal, nem nada, aí ela vinha com o conteúdo, cada dia de diálise, cada sessão nós trabalhávamos uma coisa. Numa sessão da segunda-feira nós vamos trabalhar Ciências, na sessão da quarta a gente pega Matemática, na sessão da sexta-feira vamos ver Geografia, ah, mas se você tem prova de Geografia na outra segunda, então nas três sessões de diálise vamos trabalhar só Geografia, porque na 
semana que vem você vai ter prova. Então o conteúdo era trabalhado, mais ou menos dessa forma. Ela trabalhava o conteúdo de prova na semana anterior comigo nas diálises, mas sem dizer... "Olha, em casa você estuda as outras disciplinas, as outras matérias". E era assim que a gente ia levando.

Eu - No começo estava chato, mas depois você foi vendo que estava ajudando.

Ex-aluno - No começo eu não estava muito a fim, estava meio que desanimado e falava: "Meu Deus do céu, eu não quero isso, porque se eu entrar eu não vou sair mais". Esse era o meu pensamento.

Eu - O seu medo.

Ex-aluno - O meu medo, ahãm.

Eu - E essas aulas te ajudaram a continuar seus estudos normais?

Ex-aluno - Sim, ajudaram e muito, hein! E muito mesmo, porque daí em 2001 eu não estudei, mas eu estudei em 2002 os dois anos ao mesmo tempo. Até eu tenho fotos aqui, registros da minha formatura do Ensino Médio.

Eu - Ai, que legal!

Ex-aluno - Que foi todo assim... Ai tenho que dizer mesmo, foi toda organizada e promovida pelo pessoal da Nefrologia Pediátrica do Pequeno Príncipe.

Eu - Ai, que bonitinho!

Ex-aluno - Eles promoveram todo, porque tinha eu e mais outros colegas também que estavam no mesmo ano, na mesma série de estudo e nós fizemos uma formatura de Ensino Médio. A gente terminou ali em 2002 o Ensino Fundamental concluído via CEEBJA, $7^{\circ}$ e $8^{\circ}$ ano e fizemos a formatura. Aí em dezembro de 2002 , graças a Deus veio um rim para mim, eu transplantei, em 2003 eu já comecei o Ensino Médio numa escola.

Eu - Regular?

Ex-aluno - Regular, 2003 eu já fui para o $1^{\circ}$ ano do Ensino Médio numa escola regular. Eu - Aqui em Curitiba ainda?

Ex-aluno - Aqui em Curitiba ainda, porque assim, eu transplantei em dezembro de 2002, mas eu fiquei em acompanhamento aqui em Curitiba ainda até 2008.

Eu - Você morou aqui até 2008?

Ex-aluno - Não. Eu fui e ganhei alta, fui para casa no final de 2003, que eu terminei 2002 transplantado, em 2003 inteiro eu fiquei aqui ainda, que foi quando eu fiz o $1^{\circ}$ ano do Ensino Médio. O 1ำ ano do Ensino Médio eu fiz aqui. No começo de 2004 eu voltei para minha cidade Toledo e transferi a grade escolar para lá. Daí o $2^{\circ}$ e $3^{\circ}$ ano do Ensino Médio eu fiz lá em Toledo, mas ainda fazia acompanhamento aqui, pós transplante em Curitiba.

Eu - Você vinha nas consultas médicas.

Ex-aluno - Nas consultas médicas. Até 2002 eu fiquei em acompanhamento médico nas consultas médicas, mas daí em 2003 eu fiz o 1ํano do Ensino Médio aqui em Curitiba em 2004 eu já fiz em Toledo. 2004 e 2005 eu fiz em Toledo.

Eu - Depois que você terminou o Ensino Médio, o que você fez?

Ex-aluno - Depois que eu terminei o Ensino Médio, terminei o Ensino Médio em 2005, em 2006, no começo de 2006, Deus me abençoou com um emprego, fui trabalhar.

Eu - Aí que bom!

Ex-aluno - Eu fui trabalhar numa farmácia de um hospital. Fui ser auxiliar de farmácia, era um hospital da minha cidade, daí eu trabalhei no hospital em 2006. Em 2007, como eu já tinha Ensino Médio, em 2007 eu prestei um concurso público e passei e entrei como auxiliar administrativo no município da minha cidade como concursado, trabalhei 2006, 2007, 2008 em 2009 eu ingressei na Universidade. Em 2009 eu 
ingressei na Faculdade de Enfermagem, e eu fiz Universidade, fiz graduação em Enfermagem em 2009.

Eu - Se formou quando?

Ex-aluno - Eu me formei em 2014. Como eu venho de família humilde, em 2009 eu ingressei na Universidade, mas assim, eu estudava de manhã e trabalhava tarde e noite para pagar a faculdade, porque eu ingressei numa Universidade particular, uma Universidade privada. Então, eu ingressei em 2009 na Universidade privada, estudando de manhã, trabalhando tarde e noite. Em 2010 eu não consegui levar financeiramente, porque daí eu tinha gasto para ir para a Universidade, gasto com as mensalidades da Universidade, com os materiais para conseguir acompanhar o curso, então em 2010 eu tive que trancar minha Universidade. 2010 eu tranquei, em junho de 2010 eu tranquei a Universidade, parei de estudar. Daí eu conversei com a coordenadora do curso, falei que não dava mais por questões financeiras, ela se lamentou tudo, mas entendeu e em junho de 2010, quando eu tranquei o curso ela falou: "Olha, vai ter ENEM, faça ENEM, quem sabe você consegue uma bolsa para você pagar pelo menos a metade. Se você deixar de pagar metade, já te ajuda?" E eu falei: "Claro, me ajuda pra caramba! Daí eu, com certeza, concluo o curso". Aí foi assim que nós fizemos. Eu tranquei a graduação em junho de 2010, no final de ano, se não me engano, foi em novembro que foi o ENEM naquele ano, em novembro de $2010 \mathrm{eu}$ prestei o ENEM, fiz a prova do ENEM e em 2011 eu voltei para a Universidade com uma bolsa $100 \%$, por conta da nota do ENEM, que eu fui bem na redação do ENEM e nas disciplinas de Biologia, por incrível que pareça! Nas disciplinas de Biologia do ENEM eu fui bem e mais na redação e eu consegui nota suficiente para ter o custo pago 100\% pelo governo e eu ganhei uma bolsa integral.

Eu - Que legal!!!! Que bom!

Ex-aluno - Ahãm! Aí eu falei: "Não, já que eu ganhei uma bolsa integral eu posso estudar, voltar para o meu curso, que eu estava fazendo, que eu já conhecia os professores, conhecia os colegas. Eu posso voltar para a Universidade que eu estava fazendo e sem pagar!" Eu falei: "Eu vou aproveitar a oportunidade". Então, em fevereiro de 2011 eu voltei para a Universidade de Enfermagem, voltei a fazer a graduação de Enfermagem, continuar o curso. Aí eu destranquei e continuei como aluno bolsista integral. Fiz 2011 e concluí em dezembro de 2013, em 2014 foi a minha colação de grau, janeiro de 2014 eu concluí a graduação. Então foi de 2009 a 2014, tendo esse meio ano ali de recesso, por questões financeiras eu tive que trancar.

Eu - Você trabalha com enfermagem ou não? Você continua como Auxiliar Administrativo?

Ex-aluno - Não, não. Eu trabalho com enfermagem. Como eu falei, eu entrei no emprego público como Auxiliar Administrativo em 2007, em 2014 eu pedi exoneração para sair do emprego público, porque em janeiro de 2014 eu colei grau da graduação e em fevereiro eu prestei prova para residência de enfermagem e passei. Como a prova de residência de enfermagem, o programa de residência de enfermagem é um programa de especialização que dá bolsas de estudos também, então eu saí. Como eu queria seguir na área da saúde, seguir na área de enfermagem e eu era concursado numa área administrativa, eu pedi exoneração em fevereiro de 2014 e em março de 2014 eu iniciei os estudos na residência de enfermagem como bolsista, enfermeiro residente. Então, fiz a pós-graduação, a residência de enfermagem de março de 2014 a março de 2016, como bolsista, ganhando e estudando. Terminei a residência em março de 2016. Em abril de 2016 entrei no mestrado também como bolsista, porque eu fui bem na prova.

Eu - Que bom! 
Ex-aluno - Em abril de 2016 eu entrei como bolsista no mestrado e conclui o mestrado agora em abril de 2018. Só que antes disso, antes de concluir o mestrado, que terminava agora em abril, em dezembro eu ingressei no hospital que eu fiz residência como enfermeiro assistencial, não mais como estudante, não mais como graduando, mas sim como enfermeiro. Então, estou desde de dezembro de 2017 exercendo a profissão de enfermeiro assistencial no hospital que eu fiz a residência e em abril deste ano agora em 2018 eu concluí o mestrado. Depois que eu entrei na graduação eu emendei, fiz graduação, pós-graduação e mestrado já na sequência.

Eu - É um hospital lá em Toledo?

Ex-aluno - É um hospital em Cascavel, que eu morava em Toledo até o final da graduação e no início de 2014 eu prestei essa prova para residência num hospital universitário de Cascavel.

Eu - No Hospital Universitário de Cascavel?

Ex-aluno - Isso, no Universitário de Cascavel. Eu saí de Toledo, pedi a conta do hospital, falei para a Mãe: "Tô indo". Aí fui para Cascavel, morar em Cascavel. Eu estou agora em Cascavel. Atualmente em Cascavel, fui em 2014 para Cascavel e estou até hoje, daí fiz residência, fiz mestrado e agora estou trabalhando lá, tudo no hospital.

Eu - Que legal!

Ex-aluno - Hoje eu estou morando em Cascavel.

Eu - Então essas aulas lhe ajudaram?

Ex-aluno - Demais. Demais.

Eu - A chegar no que você conquistou hoje.

Ex-aluno - Até ontem eu estava conversando com a [professora municipal] e eu mandei uma foto para ela do dia da minha formatura do Ensino Fundamental, que a gente está junto. Eu mandei a foto e falei para ela: "Lembra desse dia?" E ela: "Ai, que lindo! Você ainda tem?" E eu: "Claro! Se eu não tivesse ali você para me dar aquele incentivo de continuar meus estudos..." Eu falei para ela: "Hoje eu tenho o título de mestre, mas não existe mestre que não passou pelo Ensino Fundamental. Então, seu incentivo foi literalmente fundamental". Foi ali que tudo começou, foi o incentivo da pedagogia escolar ali com o trabalho que a [Professora] fez comigo que deu todo 0 pontapé para eu seguir meus estudos e estar onde eu estou hoje, de ter o título que eu tenho hoje. Se não fosse aquelas aulas, se não fosse aquele momento de estudo, se eu tivesse talvez, pensado: "Não, eu vou parar, não vou estudar, vou esperar voltar para casa para retomar", eu não sei se eu retomaria, talvez não... Como eu falei, depois do transplante eu fiquei ainda mais um ano ali meio que em recuperação pósoperatória, que eu não poderia fazer muita coisa de esforço. Então, ainda assim, que eu estava aqui, eu fiz o $1^{\circ}$ ano aqui eu ainda tive muito suporte de $1^{\circ}$ ano deles, sabe, do pessoal da pedagogia escolar. Então, se não fosse isso, eu não sei se eu continuaria. Eu não sei se eu teria feito Ensino Médio, muito menos graduação, residência nem pensar e mestrado era um sonho impossível se não fosse isso.

Eu - Bom da [Professora] você falou, as aulas você já explicou com era, algo que tenha lhe marcado durante as aulas que recebia no hospital?

Ex-aluno - Eu acho que a dinâmica, o ensino principalmente da Ciência era muito lúdico, falava de algumas coisas que não tinha nada a ver com a Ciência, mas que ao mesmo tempo trabalhava Ciência, eu acho que isso foi algo que me marcou. Ela sabia chamar a atenção para a gente se concentrar mesmo estando ali conectado a uma máquina, que a qualquer momento poderia tirar um pouco mais de sangue ou deixar de tirar sangue e você passar mal, poderia te dar enjoo, poderia ter hipotensão, todas as intercorrências de quem faz hemodiálise e ainda assim, ela conseguia fazer com 
que a gente não ficasse preocupado com as intercorrências e prendia a minha atenção naquele conteúdo que estava sendo explicado, a Matemática mesmo era trabalhado com questões de remédios, eu lembro até hoje, quando ela falava: "Que horas você tem que tomar o remédio? Se você tomar o remédio ao meio dia e depois tomar o remédio às quatro da tarde, quantas horas passou de intervalo?". Então, o trabalho lúdico dela e trazendo para a minha realidade daquele momento foi algo que me marcou. Hoje eu fico pensando: "Meu Deus, como ela era boa, não é!? Pra me prender". Eu não tinha essa destreza, essa habilidade, esse feeling mesmo, que acho que só quem é da pedagogia mesmo para aprender isso! Hoje eu fico imaginando: "Gente, como é que ela conseguia?" E ia mesmo, a gente se desvencilhava, se desligava totalmente, estava ali com o braço ligado, mas assim o conteúdo era aqui que a gente estava trabalhando. Até quando chegavam as tias da hemodiálise, que a gente chamava de tias: "Olha, já acabou seu tempo". Tinha momentos que a gente nem tinha terminado a atividade. "Não, espera aí, vamos terminar só isso". Ou então: "Leia até o finalzinho esse capítulo desse livro para a gente". Porque era uma coisa que distraia, sabe. Ela conseguira prender realmente a atenção para aquilo que estava sendo passado. Eu acho que isso foi algo que me marcou, porque hoje eu fico pensando: "Meu, aquela mulher era boa, não é!?" No meio de todo aquele contexto clínico ali, de saúde, doença, ela chamava a atenção para questão escolar e educacional.

Eu - Verdade! Você considera importante esse tipo de atendimento de professores no hospital?

Ex-aluno - Demais.

Eu - Por quê?

Ex-aluno - Na verdade eu considero imprescindível. Primeiro porque você faz com que o aluno não fique ali tão... o paciente não fique tão preocupado com sua condição clínica, propriamente dita. Se é uma pessoa, se é um paciente que precisa de um acompanhamento pedagógico hospitalar, é uma pessoa que vai precisar de um período hospitalar grande, porque se você vai para um hospital para ficar dois dias no hospital, você não é acompanhado por uma professora de hospital. Talvez ela vá te conhecer, mas não tem um acompanhamento. Então, se é uma pessoa que vai ficar ali muito tempo dentro do hospital é importante que ele tenha profissionais que venham trabalhar questões que não são médicas, que não são de hospital, que tire ele daquele mundo de doença, daquele mundo de passar mal. Então, é nesse ponto que eu acho interessante, imprescindível que a pedagogia hospitalar esteja inserida no contexto hospitalar, que é o papel de vocês. Vocês vão lá e falam: "Não, hoje não vamos falar de doença, não vamos falar de nada. Hoje nós vamos falar de... dinossauros, por exemplo. Para estudar Matemática, hoje nós vamos falar de pizza, vamos cortar pizzas, por exemplo". Então eu acho isso aí é extremamente importante e necessário.

Eu - Dá uma distanciada do problema, não é?

Ex-aluno - Dá uma distanciada do problema! Isso.

Eu - Você tem algum tipo de material/caderno deste período como as tarefas, atividade? Você guardou ou não guardou nada?

Ex-aluno - Então, cadernos e atividades eu tenho, mas eu não trouxe comigo, está lá na minha casa em Toledo. O que eu trouxe comigo são fotos, daquele momento inclusive tem fotos do dia da formatura, que eu tenho aqui comigo.

Eu - Eu vou olhar todas elas, quero pedir permissão para você de fazer fotos delas, reproduzir, tem aqui a autorização de uso de imagem para que eu possa usar na tese. 
A gente tem até ideia de fazer um álbum de fotos e deixar disponível para futuros pesquisadores que queiram pesquisar.

Ex-aluno - Que legal!

Eu - Então, por isso que tem até ali a solicitação de autorização de imagem. Eu quero fazer foto de todas elas depois. Só assim, para a gente finalizar. Quais as recordações que tem deste período?

Ex-aluno - Olha, essa era uma outra professora também que trabalhava junto com a [Professora que sempre me atendia] no hospital.

Eu - Qual era o nome dela? Ela trabalhou comigo também lá... Juliana

Ex-aluno - Não lembro qual era o nome dela...

Eu - Eu vou lembrar e daqui a pouco vou lhe falar....

Ex-aluno - Não sei se era Juliana...

Eu - Juliana, isso!

Ex-aluno - Acho que era Juliana.

Eu - A Ju. Nossa, ela está novinha... Ela tem filhas gêmeas hoje.

Ex-aluno - Sério! Que legal! Mostrar essa foto para ela para ver se as filhas são parecidas?

Eu - Ahãm!!!

Ex-aluno - Que bacana!

Eu - Me diga então. Você tem alguma outra recordação que você lembre?

Ex-aluno - Olha, eu lembro também de nossos momentos de descontração, porque tinha momento que a gente falava: "Não, para. Eu não quero mais. Eu estou cansado, com dor de cabeça". "Ah, então beleza! Tudo bem, vamos assistir desenhos. Não vou mais estudar!" A gente largava literalmente o material de lado e ia assistir desenho. "Vamos ver Frajola na TV, vamos assistir Cartoon Network". Então, isso também era uma coisa que era bacana delas, de falar: "Não, ele está saturado, está cansado, vamos levar para outro mundo". Isso acho que era uma coisa bem legal também, que eu gostava muito.

Eu - As próprias professoras faziam isso?

Ex-aluno - As próprias professoras, justamente. Elas falavam: "Aí, também cansei, quer saber, não vamos mais estudar isso, vamos assistir desenho". E eu falava: "Boa prof. Vamos ver desenho!"

Eu - Ai que legal!!! Você gostaria de falar mais alguma coisa?

Ex-aluno - Olha, eu acho que é isso. Como eu falei, hoje e tenho contato, inclusive até hoje eu tenho contato com a [professora municipal]. A gente já está trabalhando na produção de um artigo científico para nós contarmos, inclusive de novo em forma de artigo essa história. Como foi a participação dela na minha formação escolar? Como foi o meu vivenciamento enquanto paciente e também aluno de uma professora dentro do hospital? Então, ainda tenho esse contato com ela e a gente está também trabalhando nesta questão de montar esse artigo científico.

Eu - Ah, legal!

Ex-aluno - Que é uma coisa que eu acho que é válido para as crianças de hoje em dia, que às vezes fala: "Ah, não, eu vou entrar na hemodiálise e vai acabar tudo para mim, não vou ver mais meus amigos da escola, não vou mais frequentar os bailes, não vou mais... Não vou fazer mais nada... Não vou ver mais profs. Mas não é bem assim, a escola pode ir até ele, e é o que acontece.

Eu - Que legal! Bem legal!!!! Olha, muito obrigada!

Ex-aluno - Imagina, eu que agradeço.

Eu - Eu vou fazer a cópia das fotos agora. Obrigada mesmo!

Ex-aluno - Imagina, eu que agradeço. 


\section{Legenda da transcrição}

Eu - Pesquisadora

AS - Assistente Social

Prof. - Professoras

... - todas as vezes que aparece reticências significa que alguém dá pausa na fala. Quando as palavras se repetem é momentos que os participantes da pesquisa gaguejam e acabam repetindo a mesma palavra algumas vezes... 


\section{Apêndice L - Exemplos de Educação Hospitalar depois de 2002}

Com relação ao Norte do Brasil, em 2003, foi implantada a primeira classe hospitalar em Belém do Pará no Hospital Ophir Loyola ${ }^{192}$, tinha por objetivo dar continuidade à escolarização das crianças de 0 a 14 anos hospitalizadas em tratamento oncológico. Eram responsáveis por este trabalho duas pedagogas da Secretaria de Educação do Pará (SEDUC). O desdobramento deste projeto motivou a criação de um projeto chamado "Prosseguir", que, no dia 06 de março de 2006 inaugurou a sala de aula e a brinquedoteca, inclusive com espaço de leitura na ala de Quimioterapia do hospital. (OLANDA, 2006, p. 58; SALDANHA, 2012, p. 17).

Em 2004, o Albergue Pavilhão São José, localizado na Santa Casa de Misericórdia do Pará ${ }^{193}$, começou a realizar atendimento pedagógico às crianças em tratamentos especializados de saúde, sendo que

As crianças albergadas são atendidas de forma educativo-pedagógica pelas professoras do NEP-UEPA na sala de Atendimento Psicológico situada no $1^{\circ}$ andar. Esse atendimento pedagógico tem como base o Projeto de Ensino Educação Básica: inclusão social e escolar; [...] As atividades ocorrem às segundas, quartas e quintas-feiras das 15 às 17 horas. (OLANDA, 2006, p. 82).

Os estudantes desse atendimento pertenciam ao ensino fundamental, estavam em processo de alfabetização, ou, ainda excluídos do sistema educacional, principalmente por conta dos problemas de saúde que os acometiam, como "fibrose hepática congênita, distúrbios neurológicos, paralisia cerebral, alterações cardíacas". Estavam albergados por residirem nos mais distantes municípios como "Parauapebas, Canaã dos Carajás, Tailândia, Ponta de Pedras, Rondon do Pará, Paragominas, Altamira, Eldorado dos Carajás, Breves e Castanhal". (OLANDA, 20065, p. 82).

A proposta do NEP para o Albergue Pavilhão São José segue a mesma linha
metodológica do trabalho pedagógico do NEP-UEPA na AVAO. Apresenta
respaldo na filosofia educacional de Paulo Freire, que visa desenvolver a
formação ético-política por meio de diálogos críticos e estímulo à convivência
e a participação coletiva, utilizando temas geradores contextualizados na
realidade do aluno através das artes e expressão corporal, passeios culturais,

192 Hospital Ophir Loyola é um hospital de referência em câncer no Estado do Pará. (OLANDA, 2006, p. 58; SALDANHA, 2012, p. 30).

${ }^{193}$ A Fundação Santa Casa de Misericórdia do Pará foi fundada em 24 de fevereiro de 1650, em Belém, e desenvolve um trabalho de atenção à saúde da população do estado do Pará. No início do século XX, após a instalação da Faculdade de Medicina e Cirurgia do Pará, se tornou hospital de ensino, sendo responsável pela formação de diversas gerações de médicos paraenses. Em 1990, passou à Fundação Pública Estadual vinculada à Secretaria Especial de Promoção Social (SEEPS) e começou a prestar serviços à população usuária do Sistema Único de Saúde (SUS). (OLANDA, 2006, p. 75). 
desenhos, pinturas, dinâmicas de socialização, teatro, contos e recontos, com um sentido pedagógico. Como objetivos específicos, estão expressos nessa proposta curricular [...]: agendar datas comemorativas e das programações do Pavilhão como temas geradores; planejar jogos, brincadeiras que possam ser realizadas no contexto hospitalar e desenvolvam habilidades motoras, estéticas, envolvendo a criatividade e a expressividade; reconhecer e estruturar o espaço físico destinado às atividades educativo pedagógicas; aplicar questionários de pesquisa sócio-antropológica com as mães, com o intuito de construir uma rede temática que, junto com as datas comemorativas, deve nortear a prática pedagógica. (OLANDA, 2006, p. 83).

A ação educacional da classe hospitalar do Pavilhão São José, diferente da maioria das classes hospitalares brasileiras, não é vinculada à escola de origem dos estudantes, nem aos seus conteúdos, mas baseia seu processo educativo em elementos de um currículo multicultural de "caráter híbrido das identidades culturais; [com] a associação de elementos cognitivos e afetivos na prática pedagógica; a sensibilização para a diversidade cultural e sua influência no processo educativo e a problematização dos conteúdos”. (OLANDA, 2006, p. 86). Enfim, o currículo é dinâmico e considera o espaço e o tempo no desenvolvimento do processo educacional.

A partir do ano de 2007, há informações sobre atividades com Educação em Hospitais em outros países da América Latina, como Costa Rica, Guatemala e em EI Salvador.

No caso da Costa Rica, havia uma única escola no Hospital Nacional da Criança Dr. Carlos Saenz Herrera, na cidade de San José, e que estava ligada diretamente ao Ministério da Educação. Entre seus principais objetivos estavam: promover oportunidades iguais para crianças e adolescentes hospitalizados por meio de programas de apoio educacional adaptados para as necessidades educacionais especiais, facilitar o contato da criança e do adolescente hospitalizados com a instituição de origem e com o processo educacional desenvolvido junto à Educação Hospitalar e gerar a interação entre diferentes profissionais de saúde e educação envolvidos no atendimento dessas crianças/estudantes. Com relação aos espaços específicos de atendimento, estes eram realizados no quarto de internamento, onde os estudantes eram atendidos no leito ou na sala de aula hospitalar, o espaço destinado ao programa da Educação Hospitalar, era um ambiente descontraído e agradável, onde os estudantes tinham acesso a recursos didáticos e audiovisuais para o desenvolvimento de conteúdos pedagógicos. O trabalho foi organizado de acordo com os períodos de hospitalização, divididos em: a) longa estadia de mais de 30 dias, 
b) estadia média entre 15 e 30 dias e c) período de estadia curta inferior a 15 dias (GARCÉS, 2008, p. 37 e 38).

Neste mesmo ano, a Guatemala contava com atendimento em três hospitais: Hospitales Roosevelt, San Juan de Dios y de Infectología y Rehabilitación, que ficam na capital do país. De acordo com o diagnóstico apresentado pelas três salas de aula ao Ministério da Educação, indicava a necessidade de estabelecer a organização e o funcionamento pedagógico das Escolas Hospitalares. Indicou ainda, entre os principais objetivos manter a continuidade da escolaridade e treinamento de crianças hospitalizadas, visando contribuir para a melhoria da qualidade de vida, reincorporar o estudante à vida social e escolar no momento de sua alta e incentivar uma estadia agradável para crianças/estudantes no hospital. A metodologia de trabalho nos hospitais dependia de cada professor, sendo que o método utilizado no Hospital Roosevelt era o multissensorial, baseado nos fundamentos de uma educação personalizada e com atividades de arte, lúdicas e cívica.

No San Juan de Dios, devido a um problema de espaço, o trabalho educacional, que era personalizado, realizado por meio de fichas ou guias, era essencialmente feito nos quartos/enfermarias ou em um corredor personalizado. A sala de aula que havia no hospital era muito pequena e sem mobiliário adequado para desenvolver as atividades propostas. No Hospital de Infectologia e Reabilitação o trabalho era baseado em uma metodologia global, método de palavras geradoras, com uso de didática especial personalizada com uso de meios audiovisuais, pratos, músicas e muito trabalho manual (GARCÉS, 2008, p. 39).

Em 2007, El Salvador contava somente com uma escola especial no Hospital de Niños Benjamín Bloom, escola essa ligada ao departamento de Educação Especial, do Ministério da Educação do país e financiada por algumas ONGs e empresas. Dentre seus objetivos, se destacavam apoiar as crianças no seu ingresso no hospital, oferecendo artes, música e pintura, assim como em seu retorno às escolas de origem nos momentos de alta. Além disso, eram realizados também festivais e concursos com estudantes que frequentavam a escola hospitalar. Entretanto, as atividades da Educação Hospitalar acabavam sendo prejudicadas e reduzidas por conta de os espaços disponíveis serem pequenos, bem como as salas da Educação Hospitalar e dos auditórios, além dos mesmos serem usados de forma compartilhada para a realização de cursos de treinamento para funcionários. (GARCÉS, 2008, p. 39). 
Em Honduras, neste mesmo ano de 2007, havia duas experiências em educação hospitalar em Tegucigalpa e em San Pedro Sula, respectivamente no Hospitales Materno Infantil, onde se localizava a escola especial "Sonrisa Infantil" e no Hospital San Felipe, onde ficava o Jardín de niños y escuela "Vida Infantil", ambos na capital do país. As duas escolas eram reconhecidas pelo Ministério, estando vinculadas ao departamento de Ajuda Externa e ao de Educação Especial. As aulas do Hospital Materno Infantil tinham por objetivo compensar os atrasos acadêmicos dos alunos, muitos deles oriundos da zona rural, atender os aspectos biopsicossociais das crianças, pois muitos eram alunos "com carências cultural, higiênica e social", e orientar os pais, com palestras sobre higiene e sobre a importância da continuidade dos estudos no hospital.

As aulas no Hospital San Felipe focavam na integração dos alunos em tratamento com os alunos externos, que eram encaminhados por conta de algum problema de aprendizagem ou de linguagem, para realização das atividades curriculares nas diferentes áreas das classes hospitalares. Esse atendimento tinha o intuito de auxiliar os alunos a não atrasarem sua aprendizagem. Nesses casos observamos que as crianças com problema de aprendizagem passaram a ser consideradas problemas médicos, o que se reflete tanto para as que estão internadas com problemas de saúde, quanto para as que estão em escola regular que iam para um hospital para melhorar a aprendizagem ou os problemas de linguagem, e, possivelmente estas seriam somente dificuldades de alfabetização. Isso indica que a escola hospitalar do Hospital San Felipe atendia as crianças que são especiais nas escolas regulares, que não são doentes, mas que não conseguem efetivar a aprendizagem no mesmo ritmo dos outros alunos.

Os espaços destinados à Educação Hospitalar eram diferenciados em cada um dos hospitais, sendo que no Hospital Materno Infantil, havia uma sala adequada onde os estudantes tinham estações de aprendizagem. Entretanto, as atividades pedagógicas aconteciam também na Ortopedia, na Oncologia e na Cirurgia Pediátrica. A escola do Hospital San Felipe contava com um setor dividido em dois quartos, um para a Educação Infantil e outro para o Ensino Fundamental. O trabalho de escolarização era mais constante neste hospital, pois a permanência das crianças era maior, além de receberem estudantes externos, que não eram hospitalizados, mas como tinham problemas de aprendizagem relacionados à linguagem também realizavam atividades pedagógicas nessas mesmas salas. O método utilizado era 0 
Montessori com uso de guia de aprendizagem, trabalhos em grupos e individuais (GARCÉS, 2008, p. 40). 


\section{Anexos 1 - Lista de Governadores e respectivos Secretários da Educação do Paraná.}

\begin{tabular}{|c|c|}
\hline Governadores do Paraná & $\begin{array}{c}\text { Secretários da Educação do } \\
\text { Paraná }\end{array}$ \\
\hline $\begin{array}{l}\text { Ratinho Junior } \\
01 / 01 / 19\end{array}$ & $\begin{array}{l}\text { Renato Feder } \\
01 / 01 / 19\end{array}$ \\
\hline $\begin{array}{l}\text { Maria Aparecida Borghetti } \\
06 / 04 / 18 \text { a } 31 / 12 / 18\end{array}$ & $\begin{array}{l}\text { Lucia Aparecida Cortez Martins } \\
\text { 10/04/18 a } 31 / 12 / 18\end{array}$ \\
\hline \multirow{2}{*}{$\begin{array}{l}\text { Carlos Alberto Richa (reeleito) } \\
01 / 01 / 2015 \text { a 06/04/2018 }\end{array}$} & $\begin{array}{l}\text { Ana Seres Trento Comin } \\
06 / 05 / 2015 \text { a } 10 / 04 / 2018\end{array}$ \\
\hline & $\begin{array}{l}\text { Fernando Xavier Ferreira } \\
01 / 01 / 2015 \text { a 06/05/2015 }\end{array}$ \\
\hline \multirow{2}{*}{$\begin{array}{l}\text { Carlos Alberto Richa } \\
01 / 01 / 2011 \text { a } 31 / 12 / 2014\end{array}$} & $\begin{array}{l}\text { Paulo Afonso Schmidt } \\
\text { 03/04/2014 a 31/12/2014 }\end{array}$ \\
\hline & $\begin{array}{l}\text { Flávio José Arns } \\
\text { 01/01/2011 a 02/04/2014 }\end{array}$ \\
\hline \multirow{2}{*}{$\begin{array}{l}\text { Orlando Pessuti } \\
01 / 04 / 2010 \text { a 01/01/2011 }\end{array}$} & $\begin{array}{l}\text { Altevir Rocha de Andrade } \\
19 / 11 / 2010 \text { a 29/12/2010 }\end{array}$ \\
\hline & $\begin{array}{l}\text { Yvelise Freitas de Souza Arco-Verde } \\
\text { 10/07/2008 a 19/11/2010 }\end{array}$ \\
\hline $\begin{array}{l}\text { Roberto Requião de Mello e Silva } \\
\text { 01/01/2007 a 01/04/2010 }\end{array}$ & $\begin{array}{l}\text { Maurício Requião de Mello e Silva } \\
\text { 01/01/2003 a 10/07/2008 }\end{array}$ \\
\hline \multirow{2}{*}{$\begin{array}{l}\text { Jaime Lerner (reeleito) } \\
01 / 01 / 1999 \text { a 01/01/2003 }\end{array}$} & $\begin{array}{l}\text { Sueli Conceição Moraes Seixas } \\
02 / 09 / 2002 \text { a 02/01/2003 }\end{array}$ \\
\hline & $\begin{array}{l}\text { Alcyone Vasconcelos Rebouças } \\
\text { Saliba } \\
01 / 01 / 1999 \text { a 02/09/2002 }\end{array}$ \\
\hline $\begin{array}{l}\text { Jaime Lerner } \\
01 / 01 / 1995 \text { a 01/01/1999 }\end{array}$ & \begin{tabular}{|l} 
Ramiro Wahrhaftig \\
$02 / 01 / 1995$ a 30/12/1998
\end{tabular} \\
\hline $\begin{array}{l}\text { Mário Pereira } \\
\text { 02/04/1994 a 01/01/1995 }\end{array}$ & $\begin{array}{l}\text { João Olivir Gabardo } \\
\text { 02/04/1994 a 30/12/1994 }\end{array}$ \\
\hline
\end{tabular}




\begin{tabular}{|c|c|}
\hline $\begin{array}{l}\text { Roberto Requião de Mello e Silva } \\
\text { 15/03/1991 a 02/04/1994 }\end{array}$ & $\begin{array}{l}\text { Elias Abrahão } \\
\text { 15/03/1991 a 31/03/1994 }\end{array}$ \\
\hline $\begin{array}{l}\text { Álvaro Fernandes Dias } \\
\text { 15/03/1987 a 15/03/1991 }\end{array}$ & $\begin{array}{l}\text { Gilda Poli Rocha Loures } \\
11 / 01 / 1989 \text { a 15/03/1991 }\end{array}$ \\
\hline $\begin{array}{l}\text { João Elísio Ferraz de Campos } \\
\text { 09/05/1986 a 15/03/1987 }\end{array}$ & $\begin{array}{l}\text { Belmiro Valverde Jobim Castor } \\
16 / 03 / 1987 \text { a } 09 / 01 / 1989\end{array}$ \\
\hline $\begin{array}{l}\text { José Richa } \\
\text { 15/03/1983 a 09/05/1986 }\end{array}$ & $\begin{array}{l}\text { Gilda Poli Rocha Loures } \\
\text { 16/03/1983 a 13/03/1987 }\end{array}$ \\
\hline $\begin{array}{l}\text { José Hosken de Novaes } \\
14 / 05 / 1982 \text { a } 15 / 03 / 1983\end{array}$ & $\begin{array}{l}\text { Iran Martin Sanches } \\
14 / 05 / 1982 \text { a } 14 / 03 / 1983\end{array}$ \\
\hline $\begin{array}{l}\text { Ney Aminthas de Barros Braga } \\
15 / 03 / 1979 \text { a } 14 / 05 / 1982\end{array}$ & $\begin{array}{l}\text { Edson Machado de Souza } \\
15 / 03 / 1979 \text { a } 12 / 05 / 1982\end{array}$ \\
\hline \multirow{2}{*}{$\begin{array}{l}\text { Jayme Canet Júnior } \\
15 / 03 / 1975 \text { a 15/03/1979 }\end{array}$} & $\begin{array}{l}\text { Eleutério Dallazem } \\
\text { 08/08/1978 a 15/03/1979 }\end{array}$ \\
\hline & $\begin{array}{l}\text { Francisco Borsari Netto } \\
15 / 03 / 1975 \text { a 08/08/1978 }\end{array}$ \\
\hline $\begin{array}{l}\text { Emilio Hoffmann Gomes } \\
11 / 08 / 1973 \text { a } 15 / 03 / 1975\end{array}$ & $\begin{array}{l}\text { Cândido Manuel Martins de Oliveira } \\
\text { 20/08/1973 a 14/03/1975 }\end{array}$ \\
\hline \multirow{2}{*}{$\begin{array}{l}\text { Pedro Viriato Parigot de Souza } \\
\text { 13/03/1971 a 11/07/1973 }\end{array}$} & $\begin{array}{l}\text { Luiz Gabriel Sampaio } \\
\text { 16/04/1973 a 19/08/1973 }\end{array}$ \\
\hline & $\begin{array}{l}\text { Roberto Linhares da Costa } \\
\text { 09/12/1971 a 11/04/1973 }\end{array}$ \\
\hline $\begin{array}{l}\text { Haroldo Leon Peres } \\
\text { 15/03/1971 a 23/11/1971 }\end{array}$ & $\begin{array}{l}\text { Cel. Haroldo Souto Carvalhido } \\
\text { 15/03/1971 a 09/12/1971 }\end{array}$ \\
\hline \multirow{3}{*}{$\begin{array}{l}\text { Paulo Cruz Pimentel } \\
31 / 01 / 1966 \text { a 15/03/1971 }\end{array}$} & $\begin{array}{l}\text { Nelson Luiz Silva Fanaya } \\
31 / 03 / 1970 \text { a } 15 / 03 / 1971\end{array}$ \\
\hline & $\begin{array}{l}\text { Cândido Manuel Martins de Oliveira } \\
\text { 04/12/1968 a 30/03/1970 }\end{array}$ \\
\hline & $\begin{array}{l}\text { Cândido Manuel Martins de Oliveira } \\
04 / 12 / 1968 \text { a 30/03/1970 }\end{array}$ \\
\hline
\end{tabular}




\begin{tabular}{|c|c|}
\hline & $\begin{array}{l}\text { Carlos Alberto Moro } \\
\text { 28/07/1966 a 03/12/1968 }\end{array}$ \\
\hline $\begin{array}{l}\text { Algacir Guimarães } \\
20 / 11 / 1965 \text { a 31/01/1966 }\end{array}$ & \begin{tabular}{|l} 
Lauro Rêgo Barros \\
05/05/1965 a 27/07/1966
\end{tabular} \\
\hline \multirow{3}{*}{$\begin{array}{l}\text { Ney Aminthas de Barros Braga } \\
31 / 01 / 1961 \text { a } 17 / 11 / 1965\end{array}$} & $\begin{array}{l}\text { Vespero Mendes } \\
\text { 20/04/1964 a 05/05/1965 }\end{array}$ \\
\hline & $\begin{array}{l}\text { Jucundino Furtado } \\
\text { 01/03/1962 a 20/04/1964 }\end{array}$ \\
\hline & $\begin{array}{l}\text { Mário Braga Ramos } \\
\text { 31/01/1961 a 01/03/1962 }\end{array}$ \\
\hline \multirow{2}{*}{$\begin{array}{l}\text { Moysés Lupion } \\
31 / 01 / 1956 \text { a 31/01/1961 }\end{array}$} & $\begin{array}{l}\text { Nivon Weigert } \\
24 / 07 / 1958 \text { a 30/01/1961 }\end{array}$ \\
\hline & \begin{tabular}{|l} 
Vidal Vanhoni \\
$31 / 01 / 1956$ a 23/07/1958
\end{tabular} \\
\hline $\begin{array}{l}\text { Adolpho de Oliveira Franco } \\
01 / 05 / 1955 \text { a 31/01/1956 }\end{array}$ & $\begin{array}{l}\text { Nilson Batista Ribas } \\
\text { 02/05/1955 a 30/01/1956 }\end{array}$ \\
\hline \multirow{4}{*}{$\begin{array}{l}\text { Bento Munhoz da Rocha Netto } \\
31 / 01 / 1951 \text { a 03/04/1955 }\end{array}$} & $\begin{array}{l}\text { Joaquim de Mattos Barreto } \\
\text { 26/06/1954 a 30/04/1955 }\end{array}$ \\
\hline & $\begin{array}{l}\text { Dep. Lauro C. P. Tavares } \\
21 / 08 / 1953 \text { a 25/06/1954 }\end{array}$ \\
\hline & $\begin{array}{l}\text { João Xavier Vianna } \\
\text { 17/04/1952 a 21/08/1953 }\end{array}$ \\
\hline & $\begin{array}{l}\text { Newton Carneiro } \\
31 / 01 / 1951 \text { a } 17 / 04 / 1952\end{array}$ \\
\hline $\begin{array}{l}\text { Guataçara Borba Carneiro } \\
\text { (Substituto) } \\
25 / 07 / 1949 \text { a } 31 / 10 / 1949\end{array}$ & $\begin{array}{l}\text { Erasmo Piloto } \\
03 / 01 / 1949 \text { a 29/01/1951 }\end{array}$ \\
\hline $\begin{array}{l}\text { Moysés Lupion } \\
\text { 12/03/1947 a 31/01/1951 }\end{array}$ & $\begin{array}{l}\text { José Loureiro Fernandes } \\
\text { 28/02/1948 a 03/01/1949 }\end{array}$ \\
\hline $\begin{array}{l}\text { Antonio A. de Carvalho Chaves } \\
06 / 02 / 1947 \text { a } 12 / 03 / 1947\end{array}$ & $\begin{array}{l}\text { Gaspar Duarte Veloso } \\
13 / 05 / 1947 \text { a } 22 / 12 / 1947\end{array}$ \\
\hline
\end{tabular}

Fonte: Casa Civil e Secretaria de Estado da Educação, 2019b/c. 


\title{
Anexos 2 - PARECER CONSUBSTANCIADO DO CEP
}

\author{
INSTITUTO DE PSICOLOGIA \\ DA UNIVERSIDADE DE SÃO
}

\section{PARECER CONSUBSTANCIADO DO CEP}

\section{DADOS DA EMENDA}

Título da Pesquisa: A EDUCAÇÄO DE CRIANÇAS NO HOSPITAL PEQUENO PRÍNCIPE, 1988 - 2007

Pesquisador: Claudinéia Maria Vischi Avanzini

Área Temática:

Versäo: 2

CAAE: 54847715.0.0000.5561

Instituição Proponente: UNIVERSIDADE DE SAO PAULO

Patrocinador Principal: UNIVERSIDADE DE SAO PAULO

Financiamento Próprio

\section{DADOS DO PARECER}

Número do Parecer: 1.681.077

\section{Apresentação do Projeto:}

Projeto de doutorado que pretende analisar aspectos do processo social e cultural que resultou na estruturação do atendimento educacional hospitalar no Hospital de Crianças de Curitiba nas últimas décadas do Novecentos a luz da teoria de E. P. Thompson e Certeau. A opçäo pelo estudo das ideias e ações que resultaram na organização deste atendimento no Hospital (micro) acaba por auxiliar o entendimento do macrocosmo (sociedade curitibana) e, por sua vez, auxilia a compreensäo da forma como as crianças, principalmente as mais pobres, eram percebidas no século XX na capital do estado do Paraná.

\section{Objetivo da Pesquisa:}

Os objetivos da pesquisas säo investigar. as motivaçöes para a constituição de convênio entre a Secretaria de Educação de Curitiba e o Hospital infantil (1988-2007): a importância da educação para crianças internadas; como acontecia a educação dentro do hospital; quem eram os professores e como trabalhavam na assistência às crianças.

Avaliação dos Riscos e Benefícios:

É possível ocorrência de lembranças eventualmente traumáticas e/ou desagradáveis para os professores que lá atuaram, funcionários e ex-alunos (hoje adultos). A pesquisadora deve informa que, como providências nestes casos, irá interromper a pesquisa e a exclusão total ou parcial das

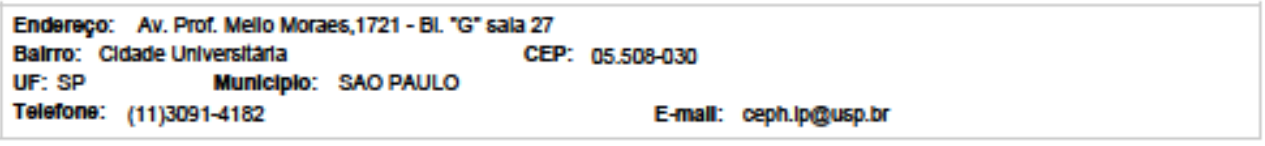




\section{INSTITUTO DE PSICOLOGIA DA UNIVERSIDADE DE SÃO}

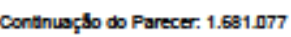

informaçöes prestadas pelo participante.

Comentários e Consideraçōes sobre a Pesquisa:

Projeto bem estruturado com desenho de pesquisa claro e objetivo.

Considerações sobre os Termos de apresentação obrigatória:

TCLE bem formulado, tendo sido esclarecido quais as providências a serem tomadas em caso de eventuais desconfortos como os mencionados; quando a pesquisadora declara também seu telefone para ser encontrada, para "recebimento de orientaçäo e/ou atendimento".

\section{Recomendaçöes:}

Sem recomendações.

Conclusões ou Pendências e Lista de Inadequaçöes:

Sem pendências ou inadequações.

Consideraçöes Finais a critério do CEP:

Se o projeto prevê aplicaçäo de TCLE, todas as páginas do documento deveräo ser rubricadas pelo pesquisador e pelo voluntário e a última página assinada por ambos, conforme Carta Circular no 003/2011 da CONEPICNS.

Salientamos que o pesquisador deve desenvolver a pesquisa conforme delineada no protocolo aprovado.

Eventuais modificações ou emendas ao protocolo devem ser apresentadas ao CEPH de forma clara e sucinta, identificando a parte do protocolo a ser modificada e suas justificativas. Lembramos que esta modificaçäo necessitará de aprovaçäo ética do CEPH antes de ser implementada. De acordo com a Res. CNS 466/12, o pesquisador deve apresentar a este CEP/SMS o relatório final do projeto desenvolvido, conforme preenchimento de Protocolo disponível na página do Comitè de Ética em Pesquisa com Seres Humanos do IPUSP, do site do IPUSP. Em seguida, o protocolo preenchido deverá ser enviado ao CEPH pela Plataforma Brasil, ícone Notificação, logo que o mesmo estiver concluído.

Este parecer foi elaborado baseado nos documentos abaixo relacionados:

\begin{tabular}{|l|l|c|c|c|}
\hline \multicolumn{1}{|c|}{ Tipo Documento } & Arquivo & Postagem & Autor & Situaçäo \\
\hline $\begin{array}{l}\text { Informaçóes Básicas } \\
\text { do Projeto }\end{array}$ & $\begin{array}{l}\text { PB_INFORMAÇŌES_BÁSICAS_718753 } \\
01 / 06 / 2016 \\
\text { E1_pdf }\end{array}$ & & Aceito \\
\hline
\end{tabular}

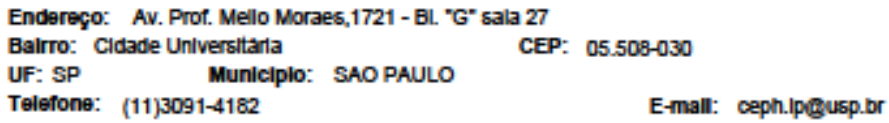


INSTITUTO DE PSICOLOGIA

DA UNIVERSIDADE DE SÃO

Platoforma

Brasil

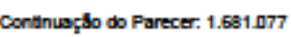

\begin{tabular}{|l|l|c|l|c|}
\hline $\begin{array}{l}\text { TCLE / Termos de } \\
\text { Assentimento I } \\
\text { Justificativa de } \\
\text { Auséncia }\end{array}$ & TCLE.pdf & $\begin{array}{c}01 / 06 / 2016 \\
14: 45: 26\end{array}$ & $\begin{array}{l}\text { Claudinéia Maria } \\
\text { Vischi Avanzini }\end{array}$ & Aceito \\
\hline Folha de Rosto & Folha_Rosto.pdf & $\begin{array}{c}04 / 04 / 2016 \\
19: 49: 40\end{array}$ & $\begin{array}{l}\text { Claudinéia Maria } \\
\text { Vischi Avanzini }\end{array}$ & Aceito \\
\hline $\begin{array}{l}\text { Projeto Detalhado / } \\
\text { Brochura } \\
\text { Investigador }\end{array}$ & Projeto.docx & $\begin{array}{c}22 / 03 / 2016 \\
16: 36: 40\end{array}$ & $\begin{array}{l}\text { Claudinéia Maria } \\
\text { Vischi Avanzini }\end{array}$ & Aceito \\
\hline $\begin{array}{l}\text { Declaraçäo de } \\
\text { Instituiçấo e } \\
\text { Infraestrutura }\end{array}$ & Declaracao_Estado.pdf & $\begin{array}{c}15 / 03 / 2016 \\
12: 47: 56\end{array}$ & $\begin{array}{l}\text { Claudinéia Maria } \\
\text { Vischi Avanzini }\end{array}$ & Aceito \\
\hline $\begin{array}{l}\text { Declaraçäo de } \\
\text { Pesquisadores }\end{array}$ & Declaracao.pdf & $\begin{array}{c}22 / 11 / 2015 \\
22: 03: 21\end{array}$ & $\begin{array}{l}\text { Claudinéia Maria } \\
\text { Vischi Avanzini }\end{array}$ & Aceito \\
\hline
\end{tabular}

Situação do Parecer:

Aprovado

Necessita Apreciaçäo da CONEP:

Näo

SAO PAULO, 16 de Agosto de 2016

Assinado por:

Helena Rinaldi Rosa

(Coordenador)

Endereço: Av. Prof. Mello Moraes,1721 - Bl. "G" sala 27

Bairro: Cldade Universitarla

CEP: $05.508-030$

Telefone: (11)3091-4182

E-mall: ceph.Ipgusp.br 